\author{
UNIVERSIDADE DE SÃO PAULO \\ FACULDADE DE FILOSOFIA, LETRAS E CIÊNCIAS HUMANAS \\ DEPARTAMENTO DE ANTROPOLOGIA \\ PROGRAMA DE PÓS-GRADUAÇÃO EM ANTROPOLOGIA SOCIAL
}

EDSON TOSTA MATAREZIO FILHO

\begin{abstract}
A Festa da Moça Nova
Ritual de iniciação feminina dos índios Ticuna
\end{abstract}

(Versão Corrigida)

São Paulo,

junho de 2015 


\author{
UNIVERSIDADE DE SÃO PAULO \\ FACULDADE DE FILOSOFIA, LETRAS E CIÊNCIAS HUMANAS \\ DEPARTAMENTO DE ANTROPOLOGIA \\ PROGRAMA DE PÓS-GRADUAÇÃO EM ANTROPOLOGIA SOCIAL
}

\title{
A Festa da Moça Nova \\ Ritual de iniciação feminina dos índios Ticuna
}

EDSON TOSTA MATAREZIO FILHO

Tese apresentada ao Programa de PósGraduação em Antropologia Social do Departamento de Antropologia da Faculdade de Filosofia, Letras e Ciências Humanas da Universidade de São Paulo, para a obtenção do título de Doutor em Antropologia.

Orientador: Prof. Dr. Marcio Ferreira da Silva

\author{
(Versão Corrigida) \\ São Paulo, \\ junho de 2015
}


TÍTULO - A Festa da Moça Nova - ritual de iniciação feminina dos índios Ticuna RESUMO

Esta tese tem como foco principal a descrição e análise do ritual de iniciação pelo qual passam as moças ticuna, a chamada Festa da Moça Nova. Os Ticuna são um povo de língua isolada, habitantes, em sua maior parte, do Alto Rio Solimões (AM), distribuídos entre Brasil, Peru e Colômbia. Por ocasião da menarca, as meninas são colocadas em reclusão e é organizado o ritual. Para compreendermos esta Festa, que marca a saída das moças da reclusão, exponho suas relações com outras dimensões da vida ticuna: organização social e parentesco, mitologia, cosmologia, corpo e xamanismo. A etnografia e a análise se concentram principalmente nas canções, instrumentos musicais e narrativas míticas relacionados à Festa e seu processo ritual.

Palavras-chave: Ticuna, ritual de iniciação, parentesco, mitologia, canções, instrumentos musicais.

TITLE - The Moça Nova Festival - Female initiation ritual of the Ticuna indigenous people

\section{ABSTRACT}

This thesis mainly focuses on the description and analysis of the Moça Nova Festival, the initiation ritual through which Ticuna young women go through. The Ticuna people speak an isolated language and inhabit, for the most part, the Upper Solimões River (Amazonas, Brazil), spread across Brazil, Peru and Colombia. At the time of the menarche, girls are secluded and the ritual is organized. In order to understand this festival, which marks the moment when girls leave seclusion, I present how it relates to other dimensions of Ticuna life: social organization and kinship, mythology, cosmology, body and shamanism. Both the ethnography and the analysis concentrate primarily on the songs, musical instruments and mythic narratives related to the festival and its ritual process.

Key-words: Ticuna, initiation ritual, kinship, mythology, songs, musical instruments. 
Para Caetano

Para Ondino e Hilda 


\section{Agradecimentos}

Estou na USP desde 2002, quando ingressei no curso de Ciências Sociais. Na época nem sonhava que chegaria tão longe. E o trajeto é longo $(45 \mathrm{~km})$, morando no outro extremo de São Paulo - "Terra de arranha-céu/ A garoa rasga a carne/ É a Torre de Babel” -, de São Miguel Paulista, na Zona Leste, eu nem sabia onde ficava o Butantã. Graças ao empenho infinito dos meus pais, Edson e Sirlei, durante ao ano de 2001 consegui ficar um ano inteiro sem trabalhar, só me dedicando ao curso pré-vestibular. Desde então, passei, sem paradas, pela graduação, licenciatura, mestrado e, agora, doutorado, que durou exatos quatro anos. Longo trajeto e ao longo do qual tive o apoio de muita gente.

Durante todos estes anos na USP, aprendi muito e tenho muito a agradecer aos professores. Paula Monteiro, a quem tenho muita admiração, possui um raciocínio preciso para questões de método e um ouvido atento para as colocações dos alunos. José Guilherme Magnani, cuja paixão pela Antropologia contagia a todos, em especial pelos incentivos para seus alunos irem a campo. Beatriz Perrone-Moisés, que me ensinou a ler as Mitológicas. Dominique Gallois, pelo interesse em minhas pesquisas e pelos debates. Sylvia Caiuby Novaes e Rose Satiko Gitirana Hikiji, por me ensinarem a pensar as imagens e por me abrirem as portas do LISA (Laboratório de Imagem e Som em Antropologia - USP) para que eu realizasse meus filmes. Ainda no LISA, agradeço aos funcionários do Laboratório, Leo Fuzer, Ricardo Dionísio, Paula Morgado e Mariana Vanzolini, por todo o apoio. Gostaria de agradecer aos professores que participaram do meu exame de qualificação, Renato Sztutman e Marta Amoroso. Ambos são etnólogos de mão cheia, espero ter feito jus a toda a dedicação de vocês.

As professoras Marta e Sylvia compuseram a banca da defesa desta tese, junto com os professores Márnio Teixeira-Pinto e Cesar Gordon. Agradeço a eles pela paciência em ler a tese, todos os comentário e sugestões. Tentei incorporar parte deles na correção final do texto.

Meu grande orientador, Marcio Ferreira da Silva, esta tese fecha um longo ciclo. São nada menos que dez anos de parceria na pesquisa antropológica, desde que comecei minha primeira iniciação científica em 2005. Agradeço pelo bom humor, pela paciência, pelos debates sobre antropologia e pela amizade. 
Agradeço ao corpo docente da UFSC, especialmente ao professor Rafael José de Menezes Bastos, pelas aulas de etnomusiologia e pelas trocas de ideias. Ao meu amigo, que me acolheu em sua casa na ilha, professor Gabriel Coutinho Barbosa, agradeço também pelas aulas de surf, pela generosidade imensa e pela boa companhia.

Subindo para o Amazonas, Leopoldo Dias, amigo de longa data, que tive a felicidade de reencontrar na FUNAI de Tabatinga, virou meu irmão (tchauene). Se não fosse você, essa pesquisa precisaria de mais uns dez anos para ser concluída. Agradeço a Mislene Mendes e todos os funcionários da FUNAI do Alto Rio Solimões. Aos camaradas de Manaus, que sempre me receberam com muita amizade, Gilton e Carlão.

Agradeço a Jamille Pinheiro por ter traduzido o resumo desta tese em cima da hora.

Minha família sempre me apoiou em minha escolha em ser pesquisador. Agradeço aos meus irmãos, Juliana e Rafael, e meus pais, Edson e Sirlei. A minha companheira, Inayara, pelo amor e pela paciência durante todos estes anos juntos. Ao Daruê, por me ensinar a jogar basquete, futebol e a andar de skate. Agradeço a Maria Lucia, sempre com muita generosidade ajudando com as crianças. A meu filho, Caetano, que nasceu no meio do doutorado, e tornou minha vida ainda mais feliz.

Aos Ticuna também só tenho a agradecer. Por todas comunidades onde passei sempre fui recebido com extrema gentileza e generosidade: Nossa Senhora de Nazaré, Santa Clara, Porto Lima, Vendaval, Belém do Solimões, Campo Alegre, Vila Independente, Umariaçu I e II. Devo um agradecimento especial aos que participaram mais diretamente da pesquisa: Danilo Macário, Ondino Casimiro, Hilda Tomás do Carmo e seus filhos, Adélia Luis Bintencout, Francisco Alexandre Filho, Severino Alexandre Gomes, Cirineu, meu compadre Gabriel, Firmario Olesio Macário, Luscita Bibiano Ezequiel, Nailson Pissango Salvador, Reinaldo, Malvina, Clarícia, Darciano Manduca Bibiano.

Agradeço à FAPESP pelos quatro anos de bolsa. 


\section{Índice}

Lista de Figuras

Introdução.

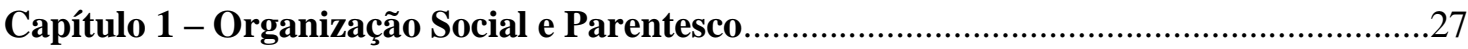

1.1 - Magüta - A Origem dos Ticuna..........................................................................27

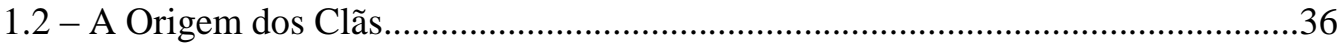

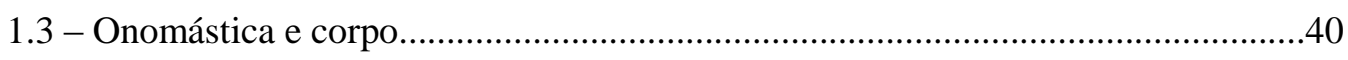

1.3.1 - Nomes de Casas.................................................................................43

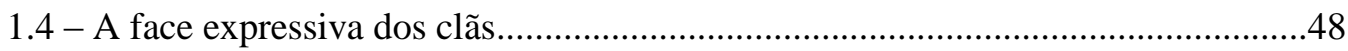

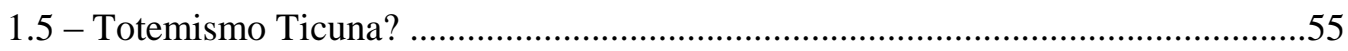

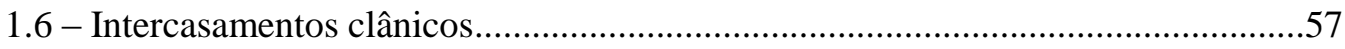

1.7 - Hierarquia clânica, política e residência....................................................................63

1.8 - Residência, casas, famílias e GUDD.....................................................................66

1.9 - Clãs e Chefia - equilíbrio político....................................................................

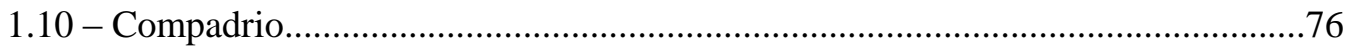

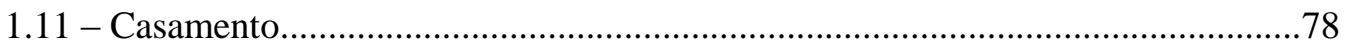

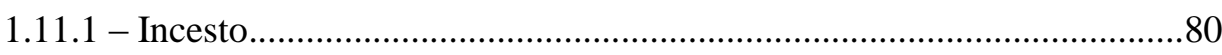

1.11.2 - O casamento obliquo composto dos Ticuna.........................................84

1.11.3 - Terminologia de parentesco e cálculo de cruzamento...........................86

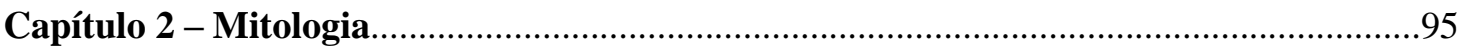

2.1 - A passagem para a América do Norte...................................................................95

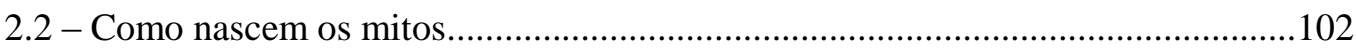

2.3 - O homem grávido - a questão de gênero como primeiro evento mítico................105

2.4 - To 'oena, a primeira moça nova...........................................................................111

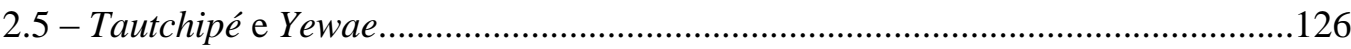

2.6 - Monmaneki - O Don Juan hiperbólico............................................................133

2.7 - Metare - O bom partido....................................................................................139

2.8 - Atualização do mito - notas sobre o messianismo ticuna....................................149

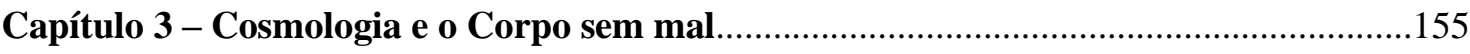

3.1 - Imortais ou encantados (

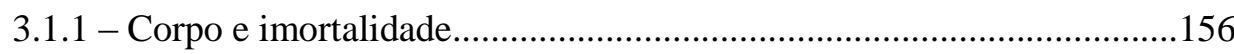


3.1.2 - O lugar dos imortais - as idas e vindas da imortalidade. .158

3.1.3 - Processos para tornar-se imortal....... 167

3.1.4 - Festa e imortalidade. 173

3.1.5 - O corpo em formação e o mundo verde...................................................176

3.1.6 - Pensamento-Ação.........................................................................179

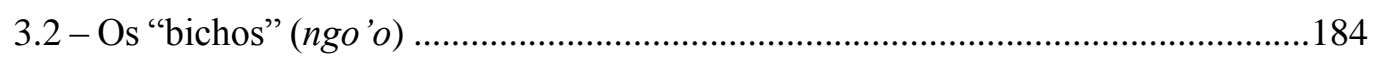

3.2.1 - Vampiros (nütchi'i) ........................................................................190

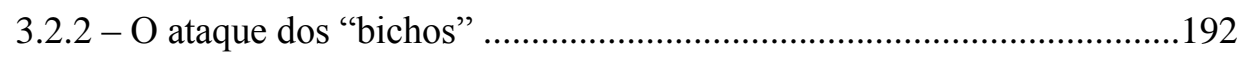

3.2.3 - Ulisses, o homem que foi levado pelo demônio.......................................195

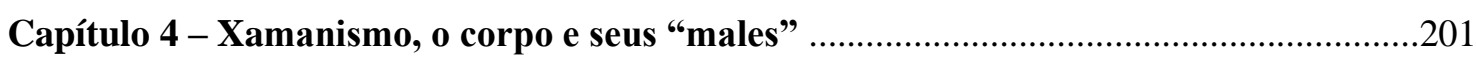

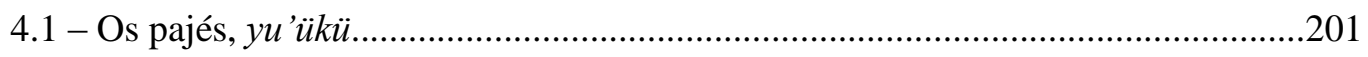

4.1.1 - Tipos de Pajé ..................................................................................202

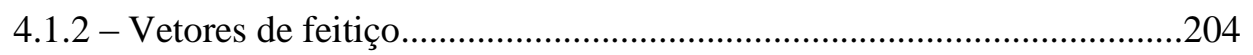

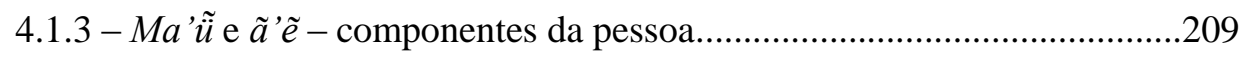

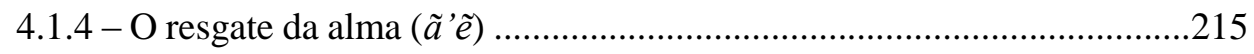

4.1.5 - Waia, a origem do feitiço, do pajé e sua formação..................................223

4.1.6 - História do pajé Augusto - a execução do feiticeiro..............................228

4.1.7 - O estranhamento dos nativos ou a descoberta de que eu não era um

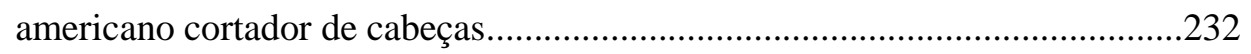

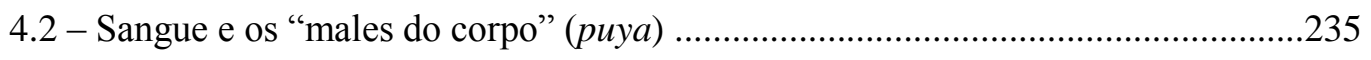

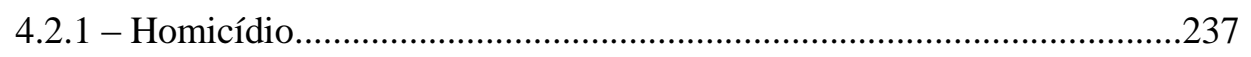

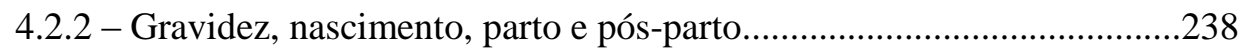

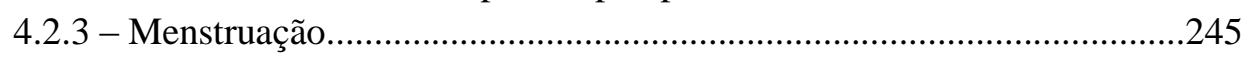

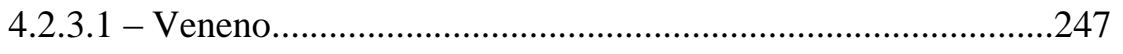

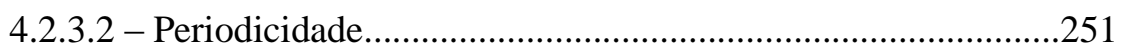

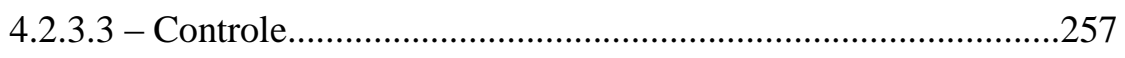

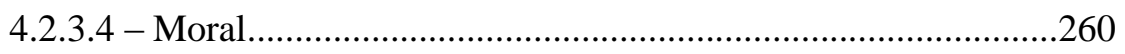

4.2.3.5 - Fertilidade...................................................................261

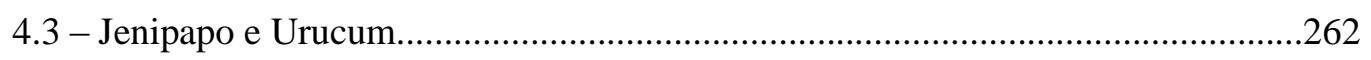

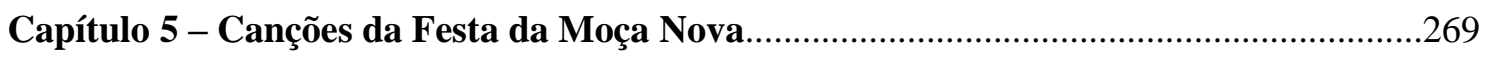

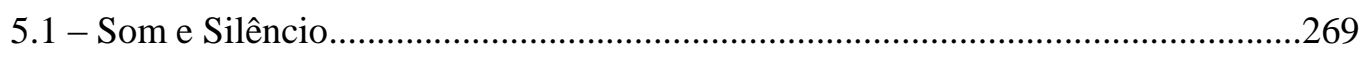

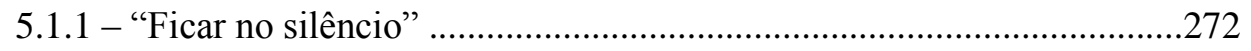

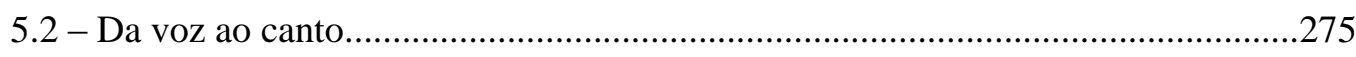




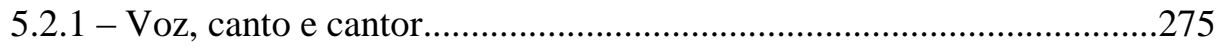

5.2.2 - Falsete e gênero - o "travestismo vocal” ..........................................282

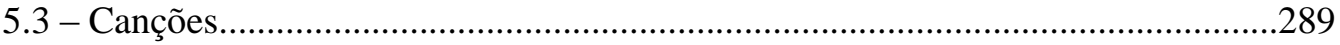

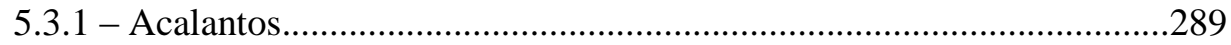

5.3.2 - Canções da Festa da Moça Nova...........................................................292

5.3.2.1 - A canção dos imortais.........................................................294

5.3.2.2 - Canções de aconselhamento..................................................304

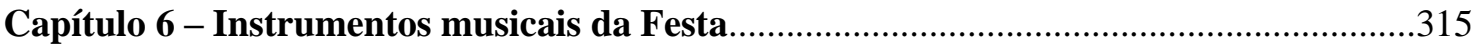

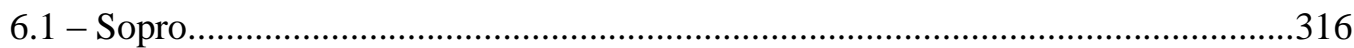

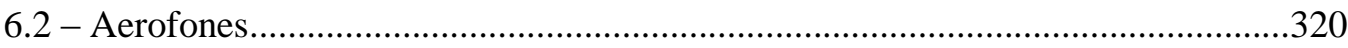

6.2.1 - Batizado e Nomes dos trompetes.........................................................329

6.2.2 - Rapé, iniciação aos trompetes..............................................................340

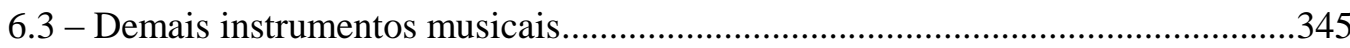

Capítulo 7 - A Festa da Moça Nova

7.1 - Preparativos, menarca e início da reclusão..............................................................363

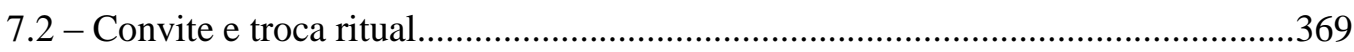

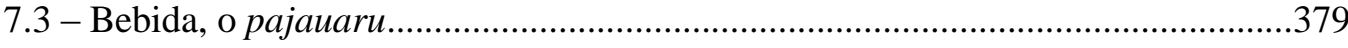

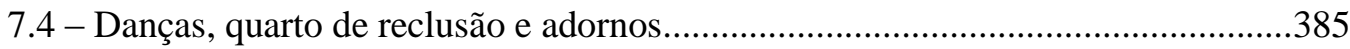

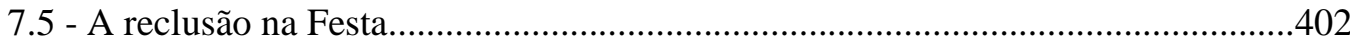

7.6 - Madrugada adentro - Trompete de Bambu, Jenipapo e Tururi.............................407

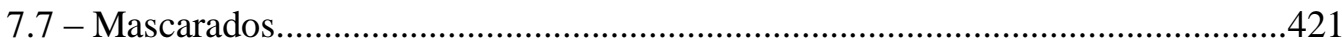

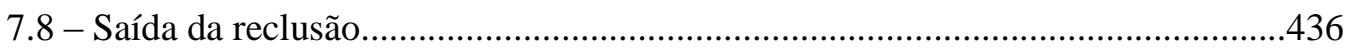

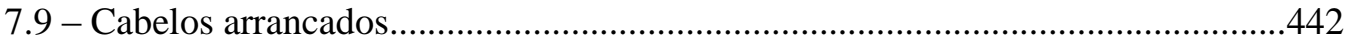

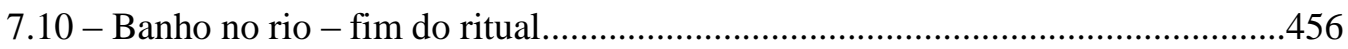

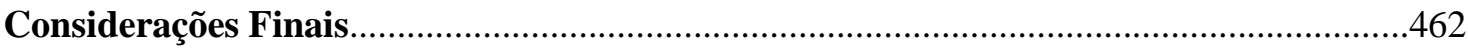

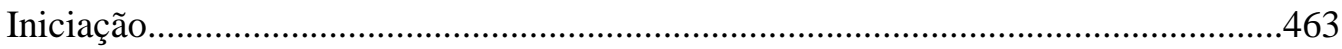

Por que os cabelos da moça são arrancados? …………………………………............472

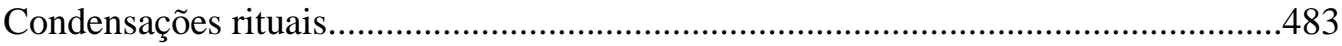

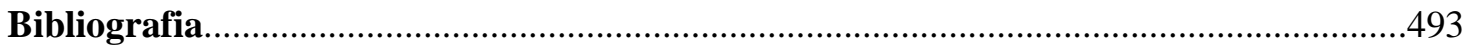

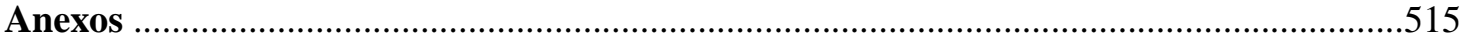




\section{Lista de Figuras}

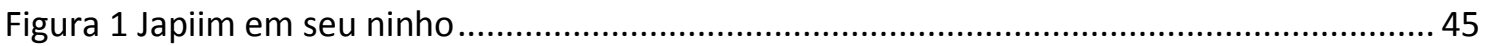

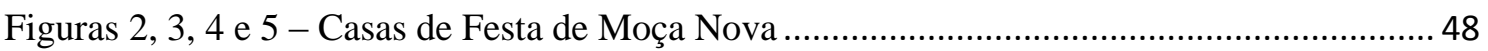

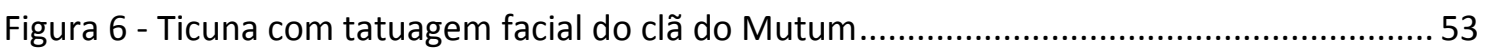

Figura 7 - Alguns exemplos de pintura facial (desenhos de Inayara Samuel Silva) .................... 54

Figura 8-O esquema aqui esboça duas metades contendo seus clãs. As linhas são as

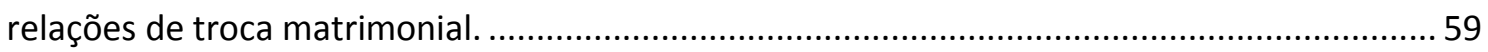

Figura 9 - Aqui as duas metades desaparecem e temos pares de clãs trocando entre si. .......... 59

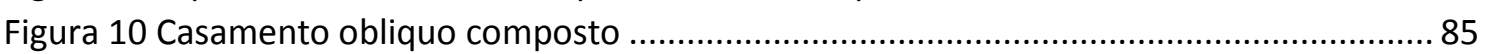

Figura 11 - Relação de contrariedade $(-)$, relação de contradição $(\rightarrow)$ e relação de implicação

$(\leftrightarrow)$

Figura 12 - Foto da serpente arco-íris (Epicrates cenchria).................................................... 120

Figura 13 - Tori próximo ao telhado da casa, onde é deixado no intervalo das danças. Esta

proximidade com o teto remete à morte do sogro canibal Tütchuru.

Figura 14 - Gráfico de velocidade do vento gerado a partir da estação meteorológica de

Benjamin Constant (AM). Site http://www.inmet.gov.br/portal/index.php?r=home2/index.... 319

Figura 15 - Primeiro, a casca da arvore é cuidadosamente retirada, dividida ao meio num corte

que acompanha a altura do tronco e (Figura 16) enrolada para o transporte.

Figura 17 - Num segundo momento, uma metade da casca é enrolada, iniciando com a medida de um dedo para a largura do bocal do trompete. Figura 18 - Ao terminar de enrolar a primeira parte da casca, emenda-se a outra metade para estender o tamanho do instrumento.

Figura 19 e figura 20 - Para dar sustentabilidade ao trompete, a casca enrolada é amarrada a uma vara. Durante os rituais os trompetes são apoiados em forquilhas fixadas no chão. Como estávamos na escola da comunidade, improvisamos com as carteiras para experimentarmos o som.

Figura 21 - Extensão de notas do iburi tocado no CD Magüta arü wiyaegü - Cantos Tikuna, faixa 11 (Pereira et al, 2009). C.T indica o centro tonal (dó sustenido) das melodias tocadas no instrumento.

Figura 22 - Extensão de notas do iburi construído durante meu trabalho de campo. C.T. indica o centro tonal (nota ré) das melodias deste instrumento.

Figura 23 - Raízes aéreas da paxiúba, palmeira utilizada na fabricação da trompa to 'cü. Figura

24 - Francisco desbastando as raízes da paxiúba em torno da raiz central.

Figura 25 - Tronco da paxiúba já desbastado sendo levado para o igarapé. Figura 26 - Ele ficará

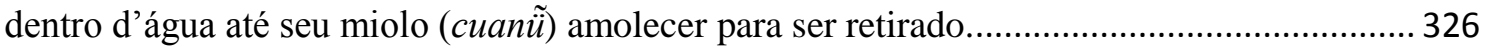

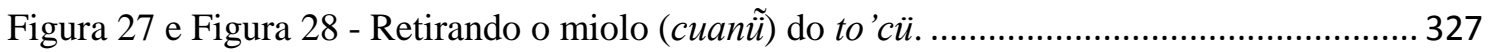

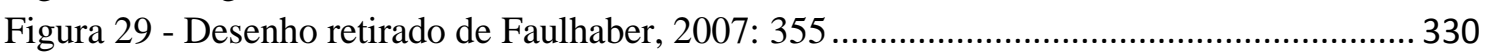

Figuras 30, 31 e 32 - Trompetes de bambu (coĩri) e flautas pan (tchecü) ................................. 347

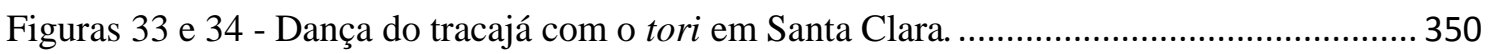

Figura 35 - Desenho do ba'ma retirado de Gruber, 1999: 25 .................................................. 354

Figura 36 - Bastão de ritmo (aru) tocado ao lado de mulher espremendo massa de jenipapo .. 357

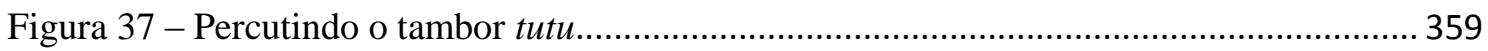

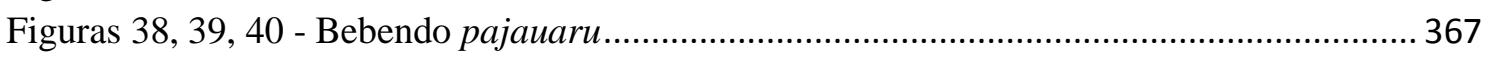

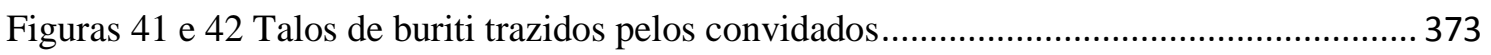

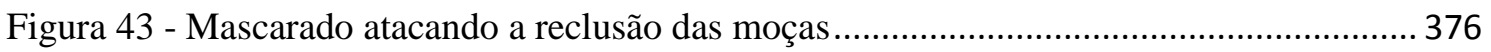

Figura 44, 45, 46 - Retirando a carne moqueada do jirau para entregar aos mascarados .......... 377

Figura 47 - Mascarado recebendo bebida de madrugada ............................................................ 377

Figura 48 - Gravura retirada do livro Um Naturalista no Rio Amazonas de Henry Bates.......... 379

Figuras 49, 50, 51, 52, 53, 54, 55, 56 - Processo de preparo do pajauaru. ............................. 381

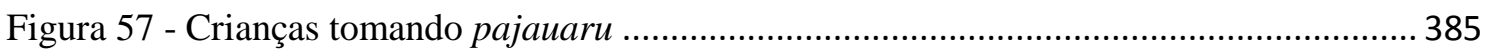




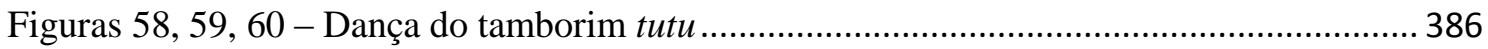

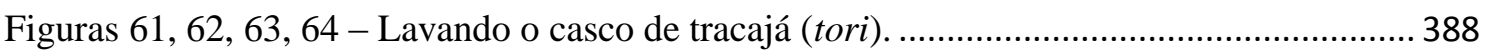

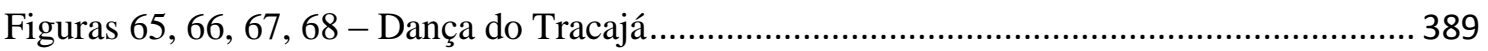

Figuras $69,70,71,72,73,74,75,76,77$ - Construção do quarto de reclusão (turi). Os adornos

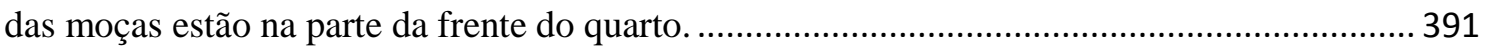

Figuras 78, 79, 80, 81, 82 - Fazendo a esteira para as moças novas........................................ 392

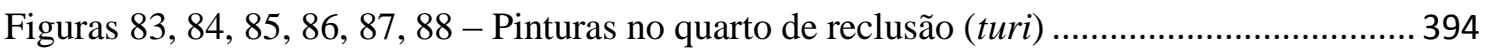

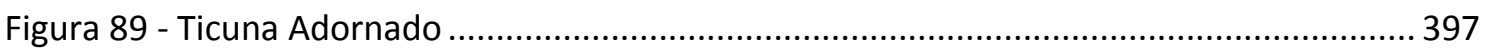

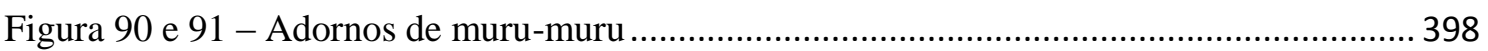

Figura 92, 93, 94, 95 - Adornos de olho de buriti ............................................................... 400

Figura 96 - No "Retrato de um índio Ticuna", gravura feita por Marcoy (2001[1869]: 29) em

sua passagem pelo Alto Rio Solimões em 1847, podemos ver os antigos braceletes ticuna... 400

Figuras 97 e 98 - Adornos na parte da frente do quarto de reclusão .......................................... 401

Figuras 99, 100, 101, 102 e 103 - Moças entrando no quarto de reclusão ................................. 403

Figuras 104, 105, 106, 107, 108 e 109 - Buscando a carne moqueada...................................... 404

Figuras 110 e 111 - Jirau próximo ao teto da casa de Festa ....................................................... 406

Figuras 112, 113, 114, 115, 116, 117, 118, 119, 120, 121, 122, 123, 124, 125, 126 e 127 -

Benzimento dos trompetes de bambu e "queixadas" bebendo pajauaru e morrendo ................ 411

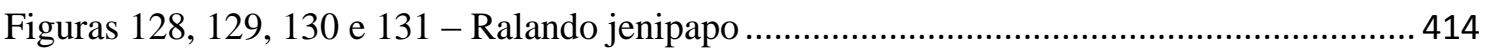

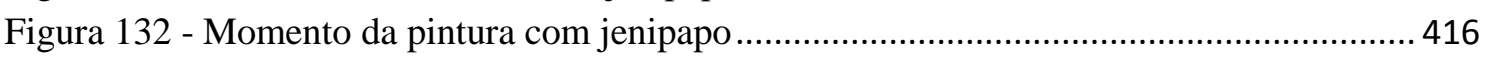

Figuras 133, 134, 135 e 136 - Adornamento das moças e abanação com taperebá................... 419

Figuras 137, 138, 139, 140 e 141 - Confecção do cocar e apresentação dos adornos das moças

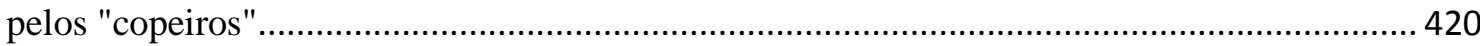

Figura 142 - Alguns mascarados na gravura feita por Spix (Spix \& Martius, 1981[1831]),

"Préstito Festivo dos Tecunas", entre 1819 e 1820, quando esteve no Alto Rio Solimões. Ver

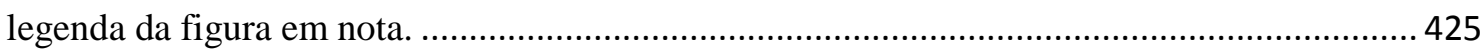

Figura 143 - Mascarados Mawü dançando com a moça nova, desenho de Adélia Luis Bitencourt

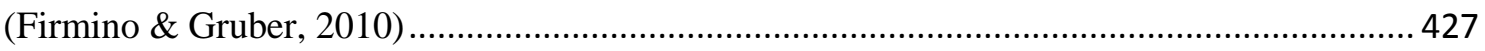

Figuras 144, 145, 146, 147, 148, 149, 150, 151, 152, 153, 154, 155, 156, 157 e 158 -

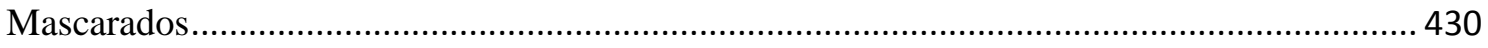

Figura 159 - Mascarados Tchoreruma e Yotchiruma, desenho de Hilda Tomás do Carmo

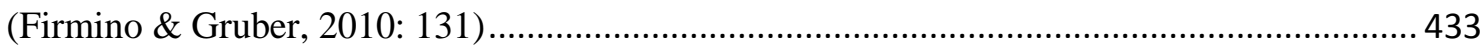

Figuras 160, 161, 162 e 163 - Fotografias de escudos (tchine) retiradas de Valenzuela (2010:

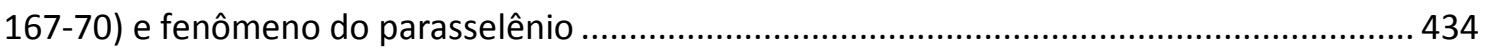

Figuras 164, 165, 166, 167, 168, 169 e 170 - Saída do quarto de reclusão ............................... 439

Figuras 171, 172, 173 e 174 - Jogando o tição no tronco do taperebá ...................................... 441

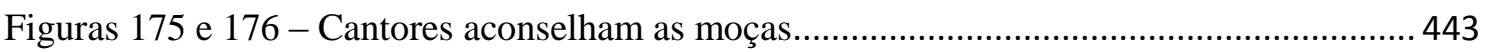

Figuras 177, 178 e 179 - Beru, desenhos de Adélia Luiz Bitencourt (Firmino \& Gruber, 2010)

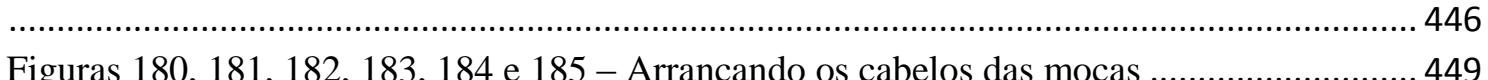

Figuras 186, 187, 188, 189 e 190 - Crianças adornadas na Festa............................................ 457

Figuras 191, 192, 193, 194, 195 e 196 - Corte do "cabelo" da casa de Festas .......................... 458

Figuras 197, 198, 199 e 200 - Levando as moças e o "lixo" para o rio ....................................... 460 


\section{Introdução}

"É ingênuo sugerir que virar nativo é a única maneira de alguém "aprender" efetivamente outra cultura, pois isso exigiria abrir mão da sua própria cultura. Assim sendo, já que todo esforço para conhecer outra cultura deve no mínimo começar por um ato de invenção, o aspirante a nativo só conseguiria ingressar num mundo criado por ele mesmo, como faria um esquizofrênico ou aquele apócrifo pintor chinês que, perseguido por credores, pintou um ganso na parede, montou nele e fugiu voando!" (Roy Wagner, A invenção da Cultura, p. 37)

O ritual que o leitor acompanhará a descrição e análise nesta tese foi inventado por mim. Com toda minha experiência de trabalho de campo, minhas leituras em "ticunologia", as quatro Festas de Moça Nova de que participei, as inúmeras conversas com meus colaboradores Ticuna e meu esforço para "aprender" sua cultura, o que consegui, no final das contas, foi inventar um ritual. Apesar de ser o mais próximo possível do que penso ser uma Festa de Moça Nova, se o leitor presenciar uma Festa destas, terá uma percepção diferente do que apresento na tese. Alguns eventos, que no ritual são prática e propositalmente imperceptíveis, ganham grandes dimensões no texto. Outros acontecimentos, como as danças, p.ex., que se repetem preenchendo boa parte da Festa, ganham um espaço menor na descrição e análise. Tudo isso exige algumas breves considerações que podem servir para a descrição e análise de outros rituais.

Nesta medida, compus a Festa que inventei com a seguinte fórmula: 1) observação e participação, 2) etnografias de terceiros, e 3) relatos e exegeses. Temos aqui três elementos que colaboraram para a descrição e análise que veremos, mas que isoladamente não são confiáveis. Vejamos cada um destes pontos.

1) A observação de um ritual tem seus limites, por mais que o etnógrafo participe de um número grande deles. Muitas vezes acontece eventos simultâneos, o que torna impossível acompanhar um ritual integralmente. Os acontecimentos, mesmo que descritos minuciosamente, carecem de sentido se não há uma explicação. E, o mais importante, a fronteira entre descrição e o início da análise é muito tênue. É difícil saber o quanto a descrição de uma determinada ação ritual é suficiente para o leitor ter uma boa imagem do que se quer mostrar. O recurso às imagens, sejam desenhos ou fotografias, ajuda bastante. Por um lado, se a descrição estiver excessivamente sucinta, a análise não 
será inteligível. Por outro lado, uma descrição interminável - como costumam ser os próprios rituais - pode transformar a leitura do texto numa tortura.

2) etnografias de terceiros são datadas e apresentam um determinado ponto de vista. Por mais que eu não seja o primeiro a etnografar a Festa da Moça Nova dos Ticuna - e são notáveis os trabalhos de Nimuendaju (1952) e Valenzuela (2010), por exemplo sempre encontrava lacunas que exigiam mais campo da minha parte. Os rituais se transformam ao longo do tempo também. Alguns elementos que Nimuendaju menciona já não existem mais, novidades que não existiam começam a aparecer na Festa, novas interpretações nativas são formuladas.

3) relatos, exegeses, a etnografia das outras esferas da vida ticuna, o recurso a tudo o que está fora do evento ritual, mas que são imprescindíveis para a sua compreensão. Para tanto, recorri a diversos temas de estudos consagrados dentro da Antropologia. Minha análise da Festa da Moça Nova não prescinde de um entendimento da organização social, parentesco, mitologia, xamanismo, cosmologia, música, organologia, etc., dos Ticuna. Cada capítulo apresenta um aprofundando destes temas, mas o leitor é conduzido, assim espero, a reter o necessário para a compreensão do maior foco da tese, a Festa da Moça Nova. Tentei deixar claro também quando se trata de alguma dedução minha ou de um comentário nativo. Estes últimos são fundamentais para se ter uma dimensão do que os nativos pensam sobre a ação ritual, por mais que a análise mostre algo diferente do que é explicado nas exegeses.

Existem recursos que podem ajudar no estudo dos rituais. Primeiro, o registro em áudio e vídeo de tudo o que parecer importante. Durante as Festa de Moça Nova ticuna foram poucas coisas que consegui perguntar "no calor da hora". Depois, numa ocasião mais tranquila, quando isso era possível, eu assistia aos vídeos ou ouvia os registros em áudio com meus colaboradores. Outro recurso importante é conversar sobre os rituais com as pessoas fora do contexto do ritual. Obtive muitas explicação e descrições da Festa enquanto traduzia mitos e canções com os Ticuna.

Mesmo que permaneça muito tempo em campo, o etnógrafo de rituais pode ter o azar de não presenciar muitas celebrações, ou mesmo assistir somente a um ritual no qual ele está focando seus estudos. O rito em foco pode ser daquele tipo de celebração que acontece com intervalos de muitos anos. Além disso, um ritual é um momento compacto do que é a limitação de uma etnografia de uma forma geral. Em qualquer etnografia, 
conseguimos registrar apenas uma pequena parte do que estamos presenciando, quando damos sorte de registrar boa parte do que é relevante.

Há uma dificuldade também com relação à escrita da descrição do ritual. Em um ritual como a Festa da Moça Nova, podem acontecer diversos eventos ao mesmo tempo. Muitas vezes um pequeno conjunto de gestos, realizado em poucos minutos, condensa mais significados do que horas de danças ininterruptas. Esta sobreposição de eventos deve se transformar numa escrita linear, o que exige idas e vindas aos diversos momentos que compõem a Festa. Desta maneira, apesar de o ritual ser descrito no Capítulo 7, muito do que acontece na Festa já é apresentado nos capítulos anteriores. Trata-se de mostrar não só o que fundamenta aquelas ações que estão em curso, mas também outras ações que correm paralelamente e contribuem para a compreensão do evento principal.

Antes de abordarmos os Ticuna, gostaria ainda de ressaltar que as centenas de páginas que compõem esta tese não pretendem esgotar o estudo da Festa da Moça Nova dos Ticuna. Outros pontos de vista são possíveis (e desejáveis) de serem descritos. Tratase de um ritual tão rico e complexo que percebo que apenar organizei algumas ideias e elaborei hipóteses sobre esta festa, muito há para se fazer ainda. Tanto na descrição quanto na análise, faço minhas as palavras de Hugh-Jones.

"A lo largo de todo este libro he evitado hacer interpretaciones unilaterales de los ritos de Yuruparí de los Barasana, porque no creo que exista algo que pueda erigirse como la verdadera y privilegiada interpretación de esta o cualquiera otra totalidad ritual. Este punto fue establecido hace mucho tiempo por Richards (1956) en su análisis de la iniciación femenina entre los Bemba.” (2011[1979]: 314).

Os Ticuna conformam uma população atual de mais de 50 mil pessoas distribuídas entre Brasil, Colômbia e Peru (Goulard, 2009: 15). No Brasil, constituem o mais numeroso grupo indígena, contando com mais de 46 mil indivíduos (2010, IBGE) ${ }^{1}$, falantes de uma língua tonal e isolada ${ }^{2}$. Estão distribuídos ao longo da bacia do Rio

\footnotetext{
${ }^{1}$ Os Ticuna também são a etnia de maior população da Amazonia colombiana: "La etnia Tikuna es el grupo indígena de mayor población que habita las selvas de la Amazonia colombiana." (Valenzuela, 2010: 28).

${ }^{2}$ A língua ticuna foi, por muito tempo, considerada uma ramificação do tronco Tucano (Nimuendaju, 1952; Lévi-Strauss 2004[1967]). Antes disto, Rivet chegou a considerá-la "um dialeto arawak muito corrompido" (1912). Atualmente, a maior parte dos lingüistas que estudaram a língua ticuna a consideram "isolada" (Montes Rodríguez, 2000; Soares, 2000). Outros estudos mostram que ela poderia estar filiada a um tronco denominado Macro-Daha, que encamparia as línguas da família Sáliba (Sáliba e Piaroa), a língua
} 
Solimões (AM), com sua maior concentração no alto curso deste rio e apresentando também uma forte presença em cidades amazônicas.

Alguns pesquisadores dos Ticuna fizeram uma pesquisa histórica consistente. Em geral, estes estudos se debruçaram sobre as relações entre os índios e a sociedade nacional, privilegiando a conceitos como "fricção interétnica" (Cardoso de Oliveira, 1964) ou "integração social”" (Oliveira Filho, 1988). Os Ticuna eram índios da terra-firme, viviam próximos das cabeceiras dos igarapés (Oliveira Filho, 1988, 2000; Goulard, 2009). Conforme os confrontos com os brancos foram dizimando os Omágua (Cambeba), estes inimigos tradicionais dos Ticuna foram cedendo espaço para estes últimos se aproximarem das margens dos grandes rios.

As levas de migrantes cearenses se estabeleceram na região nas últimas décadas do sec. XIX (Oliveira Filho, 2000: 288). Nestes primeiros anos de migração, o foco da produção era a seringa (Cardoso de Oliveira, 1964; Oliveira Filho 1988). "No correr do primeiro quartel deste século $[\mathrm{XX}]$, as malocas das diferentes "nações" [clãs] foram derrubadas e os índios distribuídos em famílias nucleares nas "colocações” dos seringais (...) Da última década do século passado até o início da década de 40, por mais de cinquenta anos, os "patrões" seringalistas exerceram um domínio completo sobre o Alto Solimões, aí incluída também a população não-indígena e as instituições políticoadministrativas e religiosas lá localizadas." (Oliveira Filho, 2000: 288). Os descendentes destes primeiros "patrões" estão presentes até hoje no Alto Solimões e, ao menos em São Paulo de Olivença, destacam-se entre a oligarquia local.

Esta mesma elite dos "patrões" teria sido a responsável por uma das "mortes" de Nimuendaju ${ }^{3}$. A insistência deste etnógrafo em continuar seu trabalho resultou na primeira monografia sobre os Ticuna, The Tukuna (1952). Segundo Robert Lowie (1952: v) - organizador da publicação póstuma, composta por manuscritos em português

\footnotetext{
Hoti, a língua Andoque e a língua Ticuna (Jolkesky, 2009). Para uma apreciação mais atual sobre esta língua, ver Goulard \& Montes Rodríguez, 2013.

${ }^{3}$ O texto "A morte e as mortes de Nimuendajú", de Laraia (1988), aposta que esta é uma das "mortes" mais improváveis de Curt Nimuendaju, que morreu entre os Ticuna em dezembro de 1945. Ele provavelmente foi vítima de sua saúde frágil. Em carta a Herbert Baldus datada de 10 de novembro e 1943, Nimuendaju relatava que "os médicos chegaram a conclusão que o meu estado sanitário era tal que eu devia abandonar de uma vez e para sempre a minha vida de sertão e de convivência com os índios." (idem: 7).
} 
traduzidos para o inglês -, Nimuendaju teve seu primeiro contato com os Ticuna em 1929, passando apenas quinze dias entre eles (ver Nimuendaju, 1982[1929]). Muitos anos depois, o etnógrafo alemão despende um tempo maior entre estes índios, seis meses em 1941 e cinco meses em 1942. A monografia, fruto destes períodos de campo será de importância fundamental para as análises dos mitos ameríndios empreendida por LéviStraus nas Mitológicas. Os dados fornecidos por Nimuendaju nos acompanharão ao longo de toda esta tese.

Outros estudos sobre os Ticuna se farão presentes também. Jussara Gruber possui uma extensa experiência com os Ticuna. Morou durante muitos anos no Alto Solimões, trabalhando principalmente com a educação destes índios. Fez diversas incursões a campo entre os anos de 1978 e 1995 (Gruber, 1999: 2, nota 1). Tive a felicidade de conversar com um de seus ex-colaboradores, o Sr. Manuel Pereira Ângelo, mais conhecido como Manuel Rita. Com ele aprendi muitas coisas sobre os trompetes ticuna, como veremos. Mas, principalmente, os professores Ondino e Hilda.

Jean-Pierre Goulard fez uma primorosa etnografia dos Ticuna habitantes do Peru e da Colômbia. Sem seus avanços no detalhamento de muitos termos e elementos da vida ticuna minhas análises não teriam rendido tanto. Procurei evidenciar quanto notei diferenças entre as descrições deste etnólogo e minhas observações sobre os Ticuna residentes no Brasil. Com relação a definição da maioria dos termos, no entanto, encontrei mais semelhanças do que diferenças. Os trabalhos de Oliveira Filho e Cardoso de Oliveira, apesar de tratarem mais de temas do contato com os brancos, também foram importantes para esta tese. Retomo principalmente as análises deste último sobre o sistema de parentesco ticuna para atualizar sua discussão desenvolvida nos anos 1960.

Ao longo desta pesquisa de doutorado, realizei quatro períodos de trabalho de campo, com durações distintas. Ao todo foram cerca de cinco meses convivendo com os Ticuna. Iniciei meu trabalho de campo entre os Ticuna em janeiro e fevereiro de 2012. Durante este período tive meus primeiros contatos com os Ticuna, povo que ainda não conhecia pessoalmente. O objetivo principal era solicitar junto aos índios e a FUNAI uma autorização de permanência em campo para minha pesquisa. Contudo, o rendimento etnográfico foi bem grande, o que me surpreendeu por se tratar de uma primeira ida a campo. 
Como os Ticuna estão localizados nos mais diversos municípios da calha do Rio Solimões, principalmente no alto curso deste rio, passei pelos três municípios mais povoados por estes índios. A intenção era sondar qual seria o local ideal para iniciar minha pesquisa de campo. Depois de um rápido encontro com alguns ticuna residentes em Manaus, tive a oportunidade, então, de passar por Tabatinga, Benjamin Constant, São Paulo de Olivença e conversar com os moradores ticuna destas cidades ${ }^{4}$.

Em Manaus foi onde encontrei com os primeiros ticuna. Por indicação de amigos, cheguei ao bairro Cidade de Deus, onde é registrada a maior concentração de índios ticuna desta cidade. Junto a estes índios, me informei sobre as primeiras indicações de pessoas a quem procurar no Alto Rio Solimões, cantores e conhecedores do ritual da moça nova, que poderiam me ajudar com minha pesquisa.

Fui ao encontro dos Ticuna localizados no Alto Rio Solimões, onde pretendia desde o princípio realizar minha pesquisa, e a primeira cidade a visitar foi Tabatinga. A cidade foi escolhida como primeiro porto de parada, pois lá está localizada a Coordenação Regional da FUNAI do Alto Rio Solimões, onde, aliás, trabalham muitos ticuna. Em Tabatinga conheci indígenas principalmente moradores das comunidades próximas da cidade, como Umariaçu I e II. Ao ficarem sabendo que eu tinha interesse nas festas de moça nova, não demorou muito para me convidarem a participar de uma. Por intermédio de uma ticuna, Mislene Mendes, na época mestranda em antropologia pela UFAM e moradora de Benjamin Constant, fui convidado para um ritual na comunidade de Porto Lima, localizada neste mesmo município. Nos dias 21 e 22 de janeiro de 2012 presenciei minha primeira Festa de Moça Nova com os Ticuna. Não permaneci muito em Benjamin Constant, voltei para Tabatinga e, de lá, segui para São Paulo de Olivença.

Esta foi a cidade escolhida para despender a maior parte de meu trabalho de campo. Desde meus primeiros contatos em Manaus, todos me diziam que no igarapé Camatiã se localizavam os maiores cantores e especialistas nos rituais ticuna. Além disso, quando perguntava porque o Camatiã tinha as melhores Festas, me diziam que lá se produziam os melhores "artesanatos", se referindo às conhecidas máscaras de Festa e aos

\footnotetext{
4 Este primeiro trabalho de campo teve as passagens aéreas custeadas pelo projeto "Paisagens Ameríndias. Habilidades, Mobilidade e Socialidade nos Rios e Cidades da Amazônia", PROCAD/CAPES, um projeto de parceria entre a USP e a UFAM.
} 
adornos da moça nova. Logo que cheguei à cidade, entrei em contato com Danilo Macário, ticuna vice-presidente da ACISPO (Associação de Caciques de São Paulo de Olivença), que não poupou esforços para me ajudar no que precisasse. Ao saberem de meu interesse pelos rituais de passagem ticuna, mais uma vez fui convidado para a segunda Festa de Moça Nova da qual participei. Desta vez, na comunidade de Santa Clara, nas margens do Rio Solimões.

No retorno para a cidade, eu sabia que o próximo destino seria o igarapé Camatiã, mas não tinha qualquer contato com os moradores de lá. Atracamos o barco num flutuante, um tipo de estabelecimento comercial bastante comum nas beiras de rio amazônicas, onde paramos para comprar gasolina. Quando descemos do barco, Danilo olhou para mim e falou, "você não está procurando o professor Ondino? Olha ele ali! ". Este foi meu primeiro contato com Ondino, quem se tornaria um dos meus maiores colaboradores. Comentei com ele que era pesquisador e que gostaria de aprender a cantar em ticuna. Meio ressabiado, ele disse que eu seria muito bem-vindo à comunidade dele. No dia seguinte, num final de tarde, eu estava chegando com toda a minha bagagem na pequena aldeia de Nossa Senhora de Nazaré.

Neste local, me estabeleci na casa de Ondino e passei o restante de meus dias deste primeiro período de campo. Em Nazaré fiz um levantamento genealógico de cerca de 450 indivíduos; participei das atividades cotidianas, como, pescarias, trabalho na roça - onde as pessoas falavam mais abertamente sobre feitiçaria -, os momentos de refeição, as conversas ao anoitecer. Com Ondino, Francisco e Severino coletei uma infinidade de canções, mitos, vocabulário, informações sobre a Festa da Moça Nova e, principalmente, sobre os instrumentos musicais da Festa.

Meu segundo período de trabalho de campo aconteceu nos meses de outubro, novembro e dezembro de 2012, principalmente na cidade de São Paulo de Olivença. Este período pode ser dividido em duas partes, uma de intensa imersão na floresta e outra mais urbana. O que eu esperava, no entanto, não iria acontecer. Naquele período não haveria Festa de Moça Nova na região do igarapé Camatiã. A não ser que eu fosse para alguma grande comunidade. Mas isto implicaria em começar do zero, com pessoas desconhecidas. Achei melhor voltar para Nazaré. Mais uma vez, fui muito bem recebido e, de fato, a intimidade me deu acesso a informações que um novato não teria. Até então eu não havia conhecido nenhum dos pajés da comunidade. Nesta segunda viagem pude acompanhar diversas seções de pajelança, para os mais variados fins. Desde benzimentos 
de recém-nascidos, algo bastante corriqueiro, até seções xamânicas que varavam a noite para buscar a alma (ã'ê) de um sujeito que tinha se isolado na mata. No dia 13 de novembro fui levado por Valdenei, o agente de saúde de Nazaré, para a cidade, pois havia contraído uma grave infecção intestinal. Chegando lá fui medicado e internado por uma noite no hospital de São Paulo de Olivença. Isto interrompeu minha pesquisa em Nazaré, contudo, descortinou uma outra oportunidade que me foi bastante frutífera também.

Chegamos, então, à parte urbana deste período de campo. Apesar desta mudança de planos forçada, desde que cheguei a São Paulo de Olivença eu já pensava em passar um tempo na cidade fazendo traduções com os professores ticuna locais. Em meu primeiro trabalho de campo, me caiu às mãos os três volumes da Coleção Eware, intitulados “Ore i nисӥтаӥgü̈̈: Histórias Antigas”, publicados em 2010 (Firmino \& Gruber). Os livros são uma publicação dos mitos coletados pela ticuna Lucinda Santiago Firmino (Metchirena) diretamente da boca de seu pai, Ernesto Alberto Santiago (Tchüreecü), e sua mãe, Romualda Joaquim Costódio (Ücürana). Ao todo, são 26 mitos distribuídos em três livros de quase 200 páginas cada. Contudo, estão escritos em língua ticuna e, apesar de muitos ticuna lerem o português, pouquíssimos sabem ler no próprio idioma. Além disso, um tradutor ideal para este tipo de histórias teria que, além de ler muito bem em seu idioma materno, conhecer os mitos, tê-los ouvido muitas vezes na vida, pois o texto estava registrado exatamente como o narrador os contou.

Depois de muitas tentativas e erros com alguns tradutores ticuna, estava prestes a voltar para Nazaré para continuar com meu campo "mais clássico". Foi então que conheci a professora Hilda Tomás do Carmo (Mutchique'ena) e acabei encontrando uma tradutora tão boa quanto Ondino era para mim quando traduzíamos as canções e histórias. Tornamo-nos grandes amigos, passávamos o dia fazendo traduções. Hilda tinha gosto pela leitura, gostava de aperfeiçoá-la e, enquanto ela lia e comentava, eu gravava e fazia anotações em meu caderno de campo. Seguimos esta rotina durante dias e, neste ritmo, traduzimos todos os três volumes de histórias, com exceção de alguns poucos mitos.

Em meu terceiro período de campo, entre julho e início de agosto de 2013, pude conhecer algumas comunidades ticuna de grande porte do Alto Rio Solimões: Belém do Solimões, Vendaval e Campo Alegre. Na primeira, pude presenciar um Festival de música e cultura ticuna, que não aparece nesta tese, mas que muito me impressionou pela grande estrutura de palco e equipamento de som, além da grande quantidade de ticunas que vieram de diversas comunidades. Acabei despendendo mais tempo em Vendaval, 
local que já ouvira a fama de ter Festas de Moça Nova "toda semana". De fato, nos dois finais de semana que permaneci na comunidade ocorreram iniciações das meninas. Vendaval possui a quantidade espantosa de cinco casas de Festa de Moça Nova, um número desproporcional em relação às outras comunidades. Na sexta-feira que saí de Vendaval, indo para Campo Alegre, estavam preparando mais uma Festa. Além da etnografia dos rituais, em Vendaval contei com a colaboração de muitos professores ticuna.

Fiz ainda uma última incursão a campo em julho de 2014. Como havia registrado uma grande quantidade de material em língua ticuna, neste último campo me dediquei a fazer traduções e resolver questões pontuais. Desta vez permaneci em Umariaçu I, comunidade vizinha a cidade de Tabatinga. Aproveitei uma estada da professora Hilda nesta comunidade para continuarmos nossas traduções.

Muitos foram os ticuna que me ajudaram com a pesquisa. Alguns nomes serão muito recorrentes ao longo do texto. Em geral, mencionarei apenas o primeiro nome ${ }^{5}$ : Ondino Casimiro (Doctürécurügõecü), Hilda Tomás do Carmo (Mutchique'ena), Adélia Luis Bintencourt (Dütanüna), Francisco Alexandre (Üpetücürüngütchiãcü), Severino Alexandre Gomes (Tõetükü). Trabalhei mais ou menos com todos eles em algum momento da pesquisa de campo. Posso dizer que, além da leitura das etnografias, aprendi muita coisa sobre os Ticuna com estas pessoas. Mas o contrário também aconteceu. Todos eles sempre me perguntavam coisas, conversávamos muito, e a pesquisa se construiu desta maneira, numa troca de saberes.

Todas as traduções do ticuna para o português foram feitas por mim e por meus colaboradores ticuna. São traduções livres, ou seja, não houve consulta a dicionários. Até porque não conheço dicionários publicados que traduzam o ticuna para o português, existem apenas alguns glossários não publicados. Junto com Hilda e Ondino fiz a leitura de boa parte das histórias registradas nos livros da Coleção Eware. As traduções são praticamente recriações do texto original, já que não foram feitas com o rigor linguístico necessário. Fui gravando as leituras destes tradutores, o que incluía explicações, comentários, exegeses dos mitos e, muitas vezes, discordâncias que nos levavam ao relato

\footnotetext{
${ }^{5}$ Fiz o mesmo com relação ao nome em português do ritual que apresentarei. Para evitar referir-me sempre ao ritual de iniciação feminina ticuna como Festa da Moça Nova, escrevo a palavra Festa em maiúscula me referindo sempre a este ritual.
} 
de outras versões. Seria difícil precisar onde termina a tradução do texto e onde começam as intervenções dos leitores. Os textos de outros pesquisadores citados que não estavam em português ou espanhol eu mesmo fiz a tradução para o português. Consta na bibliografia as referências originais para consulta.

Antes de apresentar de que tratam os capítulos desta tese e de adentrarmos ao pequeno universo das comunidades ticuna, cumpre ampliar um pouco o foco e relatar brevemente sobre a cidade onde permaneci boa parte do trabalho de campo. São Paulo de Olivença é uma cidade indígena. Possui o segundo maior contingente de índios do Brasil (14.974, censo IBGE 2010) ${ }^{6}$, perdendo apenas para São Gabriel da Cachoeira (29.017) e seguida por Tabatinga (14.855), que também apresenta uma considerável presença ticuna.

Os Ticuna de Nazaré vão com frequência à cidade. Alguns vão quase toda semana, outros em média duas vezes por mês, alguns preferem não sair da comunidade. Muitas vezes eu os acompanhava na viagem até o centro urbano de São Paulo de Olivença. Desembarcávamos numa mercearia flutuante as margens do Solimões, lá todos trocavam suas roupas entre os tanques de gasolina e um pequeno depósito. Os homens tiravam suas roupas de trabalho, já gastas e sujas, e colocavam calças, tênis, sapatos, camisas, bermudas, tudo impecavelmente novo e limpo. As senhoras colocavam vestidos vistosos e levavam cada qual sua bolsa. As crianças também eram vestidas com roupas de visitar a cidade, as mesmas roupas que são usadas nas festas ou na missa de domingo.

Depois da peregrinação burocrática pelo fórum, correio, bancos, etc., almoçávamos num restaurante em que o dono "trata bem os Ticuna". A preferência é pela carne de boi, que raramente chega à comunidade, guaraná Baré ou cerveja. Nestas idas à cidade, os Ticuna aproveitam para saciar a vontade de alimentos industrializados. As crianças, e muitos adultos também, aproveitam para se fartar de doces, sorvete, biscoito, refrigerante, muitas balas. Os homens adultos tomam cerveja, compram o que estão precisando para a casa: sabão, vela, gasolina, shampoo, açúcar, sal, arroz, fumo, cachaça, etc.

\footnotetext{
${ }^{6}$ Os dados demográficos que apresento estão baseados no último levantamento censitário feito pelo IBGE, 2010 e foram retirados no dia 19 de fevereiro de 2015, do site http://indigenas.ibge.gov.br/graficose-tabelas-2
} 
Ir para a cidade é também um momento de encontrar conhecidos, conversar na praça central e nas ruas, buscar quem chega de longe ou quem está esperando uma carona para voltar para alguma comunidade do igarapé Camatiã. São Paulo de Olivença é uma cidade em que se ouve as pessoas conversando em ticuna pelas ruas, principalmente no período de recebimento de benefícios (aposentadoria, bolsa família, salários em geral) do mês. Nesta época, além dos Ticuna que habitam e circulam pela cidade, diversos outros chegam para receber e fazer suas compras.

As relações dos Ticuna com os brancos moradores das cidades, no entanto, nem sempre foram pacíficas. Os relatos de abusos por parte dos brancos são inúmeros. Seria necessária uma pesquisa histórica mais detalhada para compreendermos como se deu esta apropriação ticuna da cidade. Atualmente estes índios contam com vereadores eleitos e pessoas trabalhando em diversas instâncias nos cargos administrativos das cidades do Alto Rio Solimões.

Esta tese está dividida em sete capítulos. Como o leitor perceberá, parto de um escopo mais amplo, comparando mitos ticuna com os de outros povos, e o foco da análise vai se estreitando para, então, descrever e analisar o processo ritual da Festa. Todos os capítulos contribuem, em maior ou menor medida, para o entendimento do que se passa neste ritual. Vejamos um panorama do que o leitor encontrará nas páginas que seguem.

O primeiro capítulo se inicia com a própria origem dos Ticuna. Procuro, na exposição deste mito de origem, já indicar algumas comparações com a mitologia dos índios norte-americanos, o que será mais detalhado no capítulo seguinte. A intensão nesta primeira abordagem do mito de origem é principalmente apresentar como os Ticuna se diferenciaram dos outros povos e dos animais de caça. Os mitos serão abordados mais extensamente no Capítulo 2. Começo o primeiro capítulo com o mito de origem principalmente para mostrar como ele é homólogo ao mito de origem dos clãs, este sim mais estreitamente relacionado ao tema do capítulo inicial: organização social e parentesco dos Ticuna. As considerações sobre os clãs ticuna se estendem ainda em suas relações com a onomástica, as metades exogâmicas, chefia, hierarquia e, finalmente, o casamento. Este é analisado em suas duas faces complementares, a genealogia e a grade terminológica. O tema do casamento reaparecerá no capítulo seguinte, mas 
principalmente, na própria Festa, na medida em que o ritual prepara a moça nova para o casamento.

O segundo capítulo, talvez por uma exigência da própria análise estrutural dos mitos, exige um trabalho comparativo que extrapola o que quer que possamos considerar as fronteiras étnicas dos Ticuna. A principal inspiração e base de comparação aqui são as Mitológicas, escritas por Lévi-Strauss. Após uma passagem pela América do Norte numa tentativa de demonstração da hipótese lévi-straussiana de que a mitologia ticuna articularia as narrativas míticas dos dois continentes - o capítulo apresenta alguns personagens míticos que possuem relações com a Festa. $\mathrm{O}$ homem primordial dos mitos ticuna, Ngutapa, é também o primeiro a gestar pessoas em seu corpo. A presença de um homem grávido na mitologia de um povo cujo principal ritual é um rito de iniciação feminina dá o que pensar. Há, nesse sentido, uma relação peculiar dos Ticuna com o gênero que nos acompanhará ao longo de toda a tese. As narrativas sobre To'oena se justificam pelo fato de ser ela a primeira moça nova. Os mitos que tratam das cobras Tautchipé e Yewae nos mostram reflexões sobre as transformações do corpo, tema central para compreendermos as transformações que ocorrem no corpo das moças reclusas. Estas narrativas se apoiam principalmente na capacidade transformativa, especialmente rejuvenescedora, operada por meio da troca de pele, própria das cobras. Tento mostrar também que os heróis Monmaneki e Metare são opostos em suas relações com o casamento, tema fundamental para a análise da Festa. Fecho o Capítulo 2 com algumas notas sobre a relação entre messianismo e mitologia. É importante ressaltar ainda que a mitologia ticuna não se restringirá às páginas deste capítulo. Abro o primeiro capítulo com ela e teremos idas e vindas das narrativas sempre que for necessário recorrer a elas.

O terceiro capítulo apresenta alguns "personagens" que serão centrais na Festa. Além dos convidados que vêm para o festejo, deste ritual também participam muitos outros habitantes do cosmos. Alguns deles são considerados extremamente nocivos, os "bichos" (ngo'o), personificados nas figuras dos mascarados, são aguardados com todas as precauções. Outros, que já alcançaram o estado de imortais (ü'üne), são esperados com a intenção de trazerem sabedoria e levarem os festeiros para a imortalidade. A Festa, portanto, não é somente frequentada por humanos. Todos os habitantes do cosmos contribuem, de alguma maneira, para a "formação" das jovens ticuna.

Apresentados estes seres e estados benéficos e nocivos, o quarto capítulo inicia com uma descrição do responsável por lidar com estes "personagens" que participam da 
Festa. Examinaremos o xamanismo ticuna para além do ritual, em suas relações com os estados de saúde e doença, os duplos e componentes do corpo, a formação dos pajés, a perigosa relação com o feitiço e os rumores que circulam pela tríplice fronteira do Brasil sobre americanos cortadores de cabeças. Começo a introduzir os temas relativos ao corpo, que ganharão grandes proporções durante a Festa. Em especial, a noção ticuna de "sangue" e os chamados "males" ( menstruação das moças, esta modificação corporal mais importante para o início do ritual, será examinada em seus vários desdobramentos na vida ticuna. Encerro o capítulo com o poderoso antídoto dos "males", a pintura com o sumo do jenipapo, adorno central na Festa da Moça Nova.

Os quinto e sexto capítulos formam um conjunto sobre a música ticuna. No quinto capítulo, abordo as canções deste povo entoadas durante a Festa. Passei boa parte de meu trabalho de campo traduzindo e ouvindo explicações sobre estas canções. Parto de noções musicais mais elementares, como, "som", "ruído", passando pela voz dos(as) cantores(as), até chegarmos a um detalhamento das letras e dos tipos de canções presentes no ritual. Passo a um exame dos instrumentos musicais da Festa no sexto capítulo. O destaque está nos aerofones, principalmente os grandes trompetes construídos pelos Ticuna. Instrumentos estes que também são considerados "gente" ( $d u$ ' $\ddot{)})$, recebem bebida durante o ritual e aconselham as moças reclusas. Outros instrumentos desta rica organologia são apresentados no final do capítulo e reaparecerão na descrição da Festa, no Capítulo 7.

O sétimo capítulo é uma etnografia das Festas que presenciei, sem prescindir de outros relatos etnográficos e de comentários e lembranças dos Ticunas com quem conversei. Este capítulo mostra um processo ritual da iniciação feminina ticuna, como disse, que eu inventei, compondo-o de maneira peculiar. Tentei não apenas encadear os eventos, mas também dar o tom das emoções, sentimentos, angustias, tensões, relaxamentos, gargalhadas, choros, expectativas, vinculadas às ações que conformam o ritual da moça nova. As descrições e as imagens das Festas são muitas. Deixei as análises mais longas para as Considerações Finais da tese. Neste epílogo, faço uma consideração geral sobre rituais, em especial, rituais de iniciação à vida adulta ou de saída da infância; elaboro uma hipótese explicativa de porque os cabelos das moças são arrancados ao final do ritual; e, por fim, delineio, também a título de hipóteses, o que seriam algumas 
"condensações rituais" que acontecem na Festa e que nos ajudam a compreender certas ações e eventos presentes neste ritual.

Para finalizar esta Introdução, gostaria ainda de fazer duas ressalvas. Alguns temas são bastante delicados para serem etnografados e analisados pelo antropólogo. Como seria uma tese em que um etnólogo tivesse necessariamente que abordar o tema do infanticídio indígena? O tema que abordo não é menos difícil de lidar. Abordei a mesma questão da violência dos rituais de passagem em minha dissertação de mestrado (Matarezio Filho 2014[2010]). Neste texto analisei o ritual de iniciação masculina dos índios Waimiri-Atroari, em que os meninos, de cerca de 5 a 10 anos, passam por muitos sofrimentos: desde a exposição pública, passando por picadas de formigas e culminando com o açoitamento final.

Confesso que até pouco tempo este tipo de violência, tão difundida nos diversos rituais de passagem pelo mundo, me era ininteligível. Não conseguia ver o porquê da necessidade das crianças passarem por estas provações físicas e psicológicas. Eis que um dia me encontro numa sala de vacinação com meu filho no colo e finalmente, num exercício de simetrização antropológica feito num posto de saúde, compreendo a necessidade inescapável do sofrimento.

Algo que também gostaria de deixar bem claro de saída nesta tese é o fato de os ameríndios lidarem com o amadurecimento dos corpos, das mulheres em especial, de maneira radicalmente oposta ao modo como lidamos com isto. Em nossa sociedade, o evento da menarca para as moças, quando não se dá de forma traumática ${ }^{7}$ e despreparada, certamente acontece de maneira privada. Para os ameríndios, de maneira geral, o primeiro sangramento menstrual de uma moça é um evento que diz respeito não somente à toda a comunidade em que ela vive, mas pode até mesmo alterar a ordem cósmica (Lévi-Strauss, 2006 [1968]: 199, Belaunde, 2006). Para os Ticuna, em particular, a periodicidade cósmica e a relação com todos os outros seres que habitam o universo dependem de um bom andamento nas primeiras regras das mulheres. Não bastasse isso, a menarca da moça

\footnotetext{
${ }^{7}$ Em estudo realizado em 3 escolas Estaduais de Ensino Fundamental e Médio da região de Santo Eduardo, município de Embu das Artes, São Paulo (SP), os autores concluíram que "[p]ara as adolescentes entrevistadas, a menarca foi relatada como uma experiência negativa, relacionada a sentimentos de medo e angustia. Atribui-se essa visão às construções sociais, históricas e culturais que não valorizam o diálogo e às questões referentes ao corpo." (Brêtas et al. 2012: 249, eu grifo).
} 
ticuna é ocasião para o mais importante ritual realizado por estes índios, a Festa da Moça Nova. É no sentido de compreendermos este ritual que desenvolvo os capítulos desta tese. 


\section{Capítulo 1 - Organização Social e Parentesco}

\section{1 - Magüta - A Origem dos Ticuna}

"PEIXE SOLÚVEL, não serei eu o peixe solúvel, nasci sob o signo de Peixes e o homem é solúvel em seu pensamento! A fauna e a flora do surrealismo são inconfessáveis. ',

André Breton, Manifesto do Surrealismo

Os mitos que contam as aventuras dos gêmeos Yoi e Ipi são os mais conhecidos entre os Ticuna e foram bastante registrados ${ }^{8}$. O final da saga dos dois irmãos narra a origem do povo ticuna. Neste mito, Yoi - o herói cultural - manda Ipi - o enganador buscar jenipapo para pintar o filho do último, que acabara de nascer. Ipi só encontra árvores sem fruta. Yoi o manda "voltar e subir na árvore bem no alto. Subiu, mas só viu dois frutos" (Oliveira Filho, 1988:100). Yoi diz para ele pegar um só. "Mas toda vez que Ipi tentava alcançar a fruta, Yoi fazia a árvore crescer mais e mais". Este último, então, manda crescer uma orelha-de-pau (Polyporus sanguineus ou Pycnoporus sanguineu) ${ }^{9}$ no tronco para impedi-lo de subir mais. Ipi se transforma em tucandeira e diminui o jenipapo para poder descer. "Lá embaixo se transformou em gente de novo" (idem:102).

No mito de origem ticuna, portanto, diferente do desaninhador de pássaros ${ }^{10}$, seja bororo ou norte-americano, Ipi sobe na árvore para apanhar a fruta de jenipapo. Vejamos

\footnotetext{
${ }^{8}$ Ver Nimuendaju, 1952; Goulard, 2009; Oliveira Filho, 1988; dentre outros.

${ }^{9}$ De modo geral, coloquei as referências de nomes de animais e plantas na seguinte sequência: "nome em português" ("nome em ticuna", "nome científico"). Pode faltar algum deste itens na referência, nestes casos eles dificilmente se confundem.

${ }^{10}$ Lévi-Strauss abre o primeiro volume das Mitológicas, O Cru e o Cozido, com a "Ária do desaninhador de pássaros", este motivo será recorrente também ao longo dos outros volumes.
} 
um trecho de $\mathrm{O}$ Homem $\mathrm{Nu}$ que pode esclarecer estas inversões ticuna do desaninhador de pássaros:

"Pois bem, havíamos mostrado em $O$ cru e o cozido e lembrando resumidamente em Do mel às cinzas (:24-28) que o ciclo sul-americano do desaninhador de pássaros pertence a um vasto grupo de transformações que permite passar da invenção do fogo de cozinha para a da carne, de um lado, e para a dos adornos e acessórios, do outro" (2011 [1971]: 50, eu grifo)

Ou seja, o grupo de transformações a que pertence o clássico mito do desaninhador relata a origem tanto da carne de caça como dos adornos. Veremos, no capítulo seguinte, que a origem de alguns adornos também se encontra no mito origem dos Ticuna, o que o conecta a algumas versões norte-ameríndias. Deste modo, temos as duas principais "invenções" do referido "vasto grupo de transformações" em uma única narrativa ticuna. Contudo, nos detenhamos na "invenção da carne" e sua relação com o surgimento dos magüta, de quem descendem os atuais Ticuna.

Com diferentes tipos de isca os diferentes povos foram pescados, isto influenciou o atual tom de pele destas pessoas. Juntamente com os povos, as caças também foram pescadas. Transcrevo abaixo o trecho do mito coletado por mim que narra estas diferentes origens.

"Ipi ralou a si próprio enquanto estava ralando o jenipapo e se espremeu. Sua mulher o ajudou. Yoi jogou o bagaço de jenipapo no rio Eware e cercou para não escapar. O bagaço foi jogado na água e virou piabinha (tonõniacü), uma piracema $\left(u^{\prime} u\right)$ deste peixe. Quando os peixinhos começaram a subir, Yoi foi pescá-los. Primeiro foram pescados os queixadas, com caroço de tucumã. Ele também usou macaxeira descascada para pescar os alemães, por isso que eles são tão brancos. Usou milho para pescar os americanos. Os Ticuna (magüta) foram pescados com macaxeira com casca. Por isso que eles têm a pele escura e por isso que os alemães e americanos têm a pele clara.

A onça foi pescada com carne crua. Ipi foi pescado sem isca. Yoi tentou pescá-lo, mas não conseguiu, só a mulher de Ipi conseguiu. Yoi falou: "está aqui o caniço para você pescar seu marido". Quando ela baixou o caniço, Ipi pulou e mordeu o anzol sem isca. Então Ipi tentou pescar, mas ele cacetava os peixes. O irmão dele o alertou, "não é assim, você está matando as pessoas". Então Ipi parou de cacetar e pescou os peruanos com casca de macaxeira também." 
Temos, portanto, um mito ticuna que narra a origem da carne - de caça e humana -, derivada da transformação de Ipi em jenipapo, sua ralação, transformação em peixe e pescaria subsequente. Esquematizando a narrativa, o mito apresenta as seguintes origens:

$I p i \rightarrow$ jenipapo ralado $\rightarrow$

Suco de jenipapo usado para pintar o bebê, a "moça nova" e o homicida.

Borra do jenipapo ralado jogada no rio $\rightarrow$ peixes/piracema $\rightarrow$

Queixada/porco do mato, pescados com caroço de tucumã

Alemães, pescados com macaxeira descascada

Americanos, pescados com milho

Os Ticuna (magüta), pescados com macaxeira com casca

Onça, pescada com carne crua

Ipi foi pescado sem isca por sua esposa $\rightarrow$ peruanos

Negros, pescados do resto da borra do jenipapo

Primeiro são pescadas as caças, com o caroço do tucumã. Um outro narrador nos explica que o caroço tem relação com a dentição forte dos queixadas e caititus: "Os queixadas e caititus têm os dentes fortes porque foram pescados com tucumã, que é duro. Os dentes das pessoas são mais fracos porque elas foram pescadas com isca de macaxeira, que é mole" ${ }^{\prime 11}$. Esta referência aos dentes não aparece nas outras versões que tenho deste mito. Ou seja, a isca diferente criou seres diversos, com dentições e tons de pele diversos. Mas, notemos bem, é como se o ser pescado já o fosse em potência o que a pescaria o transformará. Veremos em seguida que o mesmo se deu com as pessoas que provaram do caldo que criou os diversos clãs. Determinada isca era alvo de determinado ser, deste modo, o ser já possuía o paladar de seu devir futuro. Bastou que Yoi o estimulasse com a isca para a transformação se completar. Yoi fisga peixes com um paladar de queixada isto é, peixes que possuem uma qualidade trans-específica, um gosto pelo mesmo alimento que os queixadas e caititus -, mas a transformação se consuma ao puxar a pesca (pogüta). Ao saírem da água, puxados para a terra pelo caniço, os peixes que comem tucumã se transformam em queixadas e caititus.

\footnotetext{
${ }^{11}$ Trecho de mito retirado de um trabalho escolar, na escola estadual da comunidade de Vendaval.
} 
Após a pescaria da caça, os diferentes povos são pescados também. O mesmo motivo da diferenciação dos povos de acordo com a cor da pele aparece entre os povos do Sul da Califórnia. Os diferentes tipos humanos, classificados de acordo com a cor da pele emergem da exposição diferenciada ao sol da argila moldada ${ }^{12}$. Entre os Ticuna, o tom da pele é dado de acordo com a cor do alimento ou da casca do alimento, no caso da macaxeira, usada como isca para o peixe. Os Ticuna foram pescados com macaxeira com casca, por isso eles têm a pele escura. Ao contrário dos alemães, que tem a pele clara, pois foram pescados com macaxeira sem casca. Mas voltemos a figura do gêmeo Ipi, central nesta parte final do mito para compreendermos esta especiação.

Contudo, antes que Ipi jogasse a borra de jenipapo no rio, foi preciso que ele copulasse com sua cunhada. Voltemos um pouco na ordem da narrativa para este trecho do mito, conhecido como a "Filha do umari" ou a "moça do umari". O trecho que nos interessa da versão do mito coletada por Nimuendaju é o seguinte:

"Yoi e Ipi foram participar da festa da puberdade de sua sobrinha, a filha do esquilo [quatipuruzinho], Ta'üne, que havia se casado com sua irmã Aiküna (...). Ipi não reconheceu seu cunhado e, enquanto os irmãos estavam voltando da celebração, ele repetidamente perguntou quem tinha sido o anfitrião, mas Yoi sempre respondia que não sabia. Na festa tinha sido arranjado para que Yoi, não Ipi, ficasse com a garota. No entanto, Ipi insistiu que ele queria casar com ela e para este propósito queria voltar para casa de Ta 'üne, mas ele não conseguia mais encontrar o caminho".

"Enquanto isso, a menina já havia chegado à casa dos irmãos. No quintal havia uma grande árvore de umari ${ }^{13}[\mathrm{~T}$., të tchi]. A moça se transformou em uma fruta umari, a única na árvore, de onde seu nome të'tchi-arü-ngui ["Garota do Umari”]. Assim que ele viu, Ipi quis pegar a fruta, mas Yoi o

\footnotetext{
12 “Acredita-se na Califórnia do Sul - à mesopotamiana, poderíamos dizer - que os primeiros humanos foram feitos de argila. O demiurgo Mukat, precisam os Cahuilla, modelou-os cuidadosamente, e em seguida colocou-os ao sol. Segundo o grau de cozimento, uns ficaram negros, outros vermelhos, e os que ficaram expostos por pouco tempo ficaram brancos; assim se formaram as raças humanas. Wiyot, o herói cultural luiseño, ensinou aos humanos, entre outras artes, a cerâmica" (Lévi-Strauss,1986: 189). No trecho seguinte, o autor relata a relação de transformação entre os mitos ticuna e do norte da Califórnia. “Também em L'Homme nu (PP. 36-40) comparei os mitos tukuna a mitos provenientes de regiões ao norte da Califórnia, que os reproduzem quase que literalmente" (idem: 227).

${ }^{13}$ Geoffroea spinosa
} 
proibiu. Então Ipi varreu o chão limpando debaixo da árvore, a fim de encontrar a fruta assim que ela caísse, e esperou a sua hora."

"Yoi foi caçar, matou muitos pássaros, e voltou, cansado e manchado de sangue. Depois de dar os pássaros para Ipi limpar e depenar, ele saiu para tomar banho. Enquanto isso, a fruta umari caiu. A menina assumiu novamente a forma humana e esperou Yoi, que logo se juntou a ela. Ele rolou ela entre as palmas das mãos, reduzindo seu tamanho até que foi capaz de esconde-la dentro de sua flauta de osso. Muito mais tarde, Ipi terminou seus trabalhos e, voltando para casa, viu imediatamente que a fruta não estava mais sobre a árvore, nem no chão. Ele acusou o irmão de ter comido ou escondido, mas Yoi respondeu que provavelmente alguma cutia tinha levado embora."

"Durante quatro dias Yoi foi à noite levar a menina para sua rede, brincando com ela em silêncio. Sempre um pouco antes do amanhecer, ele a escondia mais uma vez em sua flauta de osso. Na quinta noite, ela riu com ele e os sinos feitos de conchas de pequenos caracóis em suas braçadeiras tilintou. "Meu irmão", perguntou imediatamente Ipi, "com quem você está rindo?" "Nada”, respondeu Yoi. “A vassoura riu porque eu fazia cócegas nela!” Então Ipi levantou, pegou uma vassoura com um sino de concha de caracol amarrado, deitou-se com ela em sua rede, e começou a fazer cócegas na vassoura". "Irmão", reclamou ele, “a vassoura não ri!". "Pois", respondeu Yoi, "a minha sim!”. Quando, na noite seguinte, Ipi voltou a ouvir o riso da moça, ele começou a perguntar quem estava com Yoi, e este respondeu que estava brincando com o quiriká $^{14}$, Ipi imediatamente levantou-se para trazer um quiriká para a sua rede e começou a fazer cócegas nele. No entanto, ele não riu."

“Të'tchi-arü-ngui era agora esposa de Yoi, mas ele continuou a escondê-la na flauta de osso todos os dias antes do amanhecer, para Ipi não a ver. No entanto, este último estava convencido de que seu irmão tinha uma esposa e ele procurou por toda a parte. Um dia, quando Yoi tinha ido caçar, Ipi tomou seu arco e flechas e pegou uma grande quantidade de peixes pequenos $\left[a i^{n} k e\right]$ no igapó. Ele trouxe para casa, onde derramou-os em um vaso de barro grande, que ele colocou sobre o fogo. Quando o calor da cerâmica aumentou os peixes ainda vivos começaram a pular sobre ele. Então Ipi puxou seu pênis para fora de seu cinto peniano e dançou ao redor da fogueira, cantando: "Tchau

\footnotetext{
${ }^{14}$ Peça de madeira em forma de meia lua, usada para amassar a mandioca.
} 
tarakunyë'-nyë'-nyë'"com isso, seu pênis começou a balançar para cima e para baixo." 15

“Të'tchi-arü-ngui viu isto de seu esconderijo e não pôde conter o riso. Ipi imediatamente parou e olhou ao redor, escutando atentamente, mas como ele não descobriu nada, ele continuou sua dança. Mais uma vez Të'tchi-arüngui teve que rir, e desta vez Ipi descobriu-a dentro da flauta. Ele a puxou para fora, fornicou com ela, e depois tentou colocá-la na flauta novamente, mas ele não poderia fazê-lo, pois ela já estava grande com criança [grávida]." (Nimuendaju, 1952: 127-28).

A narrativa segue como resumi acima, Yoi fica bem bravo e manda seu irmão buscar jenipapo para pintar a criança. Veremos no capítulo seguinte que a moça do umari é também To'oena, a primeira moça nova. Ou seja, a moça estava em reclusão quando a história começa e os planos eram que ela se casasse com Yoi. Este chega a ficar um tempo com a moça e a esconde em sua flauta para que seu irmão não a descubra. O motivo da criança escondida ou da mulher guardada em um recipiente - "cesto, caixa, flauta, casulo, fossa subterrânea, colmo do telhado etc." (Lévi-Strauss, 2011 [1971]: 39-40) - é encontrado tanto entre os Ticuna como entre os os Lilloet de língua salish da América do Norte. Lévi-Strauss mostrou que os relatos são tão próximos que basta justapor as versões para notar a semelhança. O fato de estar escondida remete, seguindo as pistas da mitologia ticuna, à própria reclusão da moça nova.

Uma das versões deste mito fornecida por Nimunedaju e analisada por LéviStrauss mostra um Ipi que poder ser equacionado a um sariguê, devido a forma como copula $^{16}$. Contudo, nas versões de Oliveira Filho (1988) e principalmente Goulard (2009), Ipi não se comporta como um sariguê, isto pode indicar uma inversão importante. Ao menos, com esta transformação, este mito perde seu parentesco com o "grupo jê da esposa celeste de um mortal", em que "Estrela é uma sarigüéia, que é violentada pelos cunhados".

\footnotetext{
${ }^{15}$ Segundo me explicaram ngawü (samotazinho) é o peixe que Ipi fritou no mito de origem dos Ticuna. Ele ficou pulando ao redor do forno com o pênis balançando e falando, "tchautaracünhẽ, tchautaracünhẽ, tchautaracünhẽ". Podemos fracionar esta palavra da seguinte forma: tchautara = meu pênis, cünhẽ pode ser traduzido como "choque", como o choque do peixe-elétrico, ou quando se toma uma pancada. Ele dizia isso para sua cunhada dar risada e denunciar onde estava escondida.

${ }^{16}$ Esta é a segunda versão do mito, coletada em 1929 por Nimuendaju. O trecho da cópula é o seguinte: “Soprando sobre isso, ele forçou Të'tchi-arü-ngui para fora e teve o coito com ela até que seu esperma exalou de sua boca e narinas" (1952: 128)
} 
O que se inverte agora não é mais a "função sariguê" dos mitos jê, mas, como veremos, a função desaninhador destes mitos. A cunhada de Ipi continua descendo a terra - como a estrela dos mitos jê -, pois cai como uma fruta umari da árvore, mas não é mais violentada. Além disso, o mais importante, Ipi não é um desaninhador de pássaros, mas sim um apanhador de fruta.

Por que o irmão mais velho dos gêmeos míticos escondeu sua esposa dentro de uma flauta? Que tipo de flauta se trata? Interessante notar que o informante de Goulard chama as flautas feitas dos tornozelos do demônio (ngo'o) Machi'i de tururi. Veremos que este nome designa a entrecasca de que são construídas as máscaras ticuna. Então, porque uma flauta recebe o nome de uma entrecasca. Ora, esta mesma flauta será utilizada para "vestir" e esconder a cunhada de Ipi: "Yoi havia deixado sua mulher em sua flauta. Havia soprado e a havia posto ali" (2009: 402). Ao perceber que sua cunhada estava dentro do tururi, Ipi diz: "eu ouvi aqui a voz da minha cunhada dentro do tururi" (idem: 403). E depois de ter relações com Ipi, sua cunhada diz a ele: "Com o teu irmão, cada vez, ele me amassa/esfrega e assim me coloca em seu tururi" (idem:404). Examinemos mais de perto o recurso da flauta como um esconderijo da cunhada de Ipi e o fato da flauta também ser chamada de tururi.

Existem evidências de que as máscaras e a flauta onde a esposa de Yo’i - que veremos ser uma variação de To'oena, a primeira moça nova - foi escondida são identificáveis. A começar pela alusão que o esconderijo faz à reclusão da moça nova. Além disso, Ipi é como o mascarado que provoca a moça com seu pênis e no mito ele obtém êxito ${ }^{17}$. A moça do umari sai da sua "reclusão" sucumbindo à provocação de Ipi. O termo tururi - notoriamente usado para se referir à casca de árvore com que se confecciona as máscaras -, em uma variação do mito de origem ticuna transcrito por Goulard e mencionada acima, equaciona terminologicamente a flauta de Yo'i e a casca de árvore. Ipi escuta a voz de sua cunhada dando risada dele balançar o pênis em cima dos peixes (fam. Chicliés). Descobre que ela está dentro da flauta tururi, desamarrou a flauta, olhou dentro, não havia nada. Começou a bater na flauta e sua cunhada caiu parada ao seu lado $^{18}$. O nome da casca também é uma metonímia da própria máscara, muitas

\footnotetext{
17 Alguns mascarados chegam na Festa com um pênis à mostra. Isso será melhor examinado quando tratarmos das máscaras no ritual, Capítulo 7, tópico 7.7-Mascarados.

18 "Joi había dejado a su mujer en su flauta. Había soplado y la había puesto alli". " - Ahí está mi cuñada, dentro de su tururi" [disse Ipi ao ouvir a risada de sua cunhada] (Goulard, 2009: 403).
} 
vezes as máscaras são chamadas de tururi. O tururi, portanto, é a "pele" dos seres que vêm visitar a Festa, os próprios mascarados, muitos deles considerados “bichos" (ngo'o). Ou seja, o que quero ressaltar nesta análise é que este equacionamento terminológico que encontramos nesta versão do mito colhida por Goulard não é fortuita. Ao ser "guardada" dentro de uma flauta que é referida com o mesmo termo que a "pele" dos mascarados, a moça como que recebe uma nova pele ${ }^{19}$. O tururi - e o que ele suscita de confusão com uma pele verdadeira - é referido em outros mitos, como o de Torama, em que as pessoas confundem a pele verdadeira de uma onça que um rapaz vestia com uma máscara de onça $^{20}$. Partindo destas conexões, devemos considerar o quanto os trompetes - feitos de casca de árvore também - são “peles" dos ngo'o, de imortais e de To'oena, que soam dentro dos trompetes. Examinaremos isso oportunamente, quando formos tratar dos instrumentos do ritual ${ }^{21}$, mas principalmente das máscaras da Festa.

Após esta pequena fuga da rota que traçávamos - inescapável quando se está estudando mitos -, pelo motivo da mulher escondida, voltemos a nossa análise da origem do povo Magüta. Sobre dois termos fundamentais deste princípio não existe um consenso, são eles, pogüta e magüta. As informações de Goulard, por exemplo, apontam que pogüta seriam os primeiros humanos pescados por Yoi, com macaxeira (2009: 47 e 126). Segundo os dados de Goulard, haveria uma diferença temporal e qualitativa entre os seres pogüta e magüta. Os pogüta teriam sido pescados primeiro e, devido a suas relações incestuosas, teriam desaparecido num primeiro cataclismo. Somente com o estabelecimento dos clãs, realizado pelo gêmeo e herói cultural $Y o i$, e da estabilização do mundo (na'ãne) que ocorreu o povoamento pelas “diferentes clases de seres $d u$-ũgü [gentes]” (2012: 20). Os ticuna contemporâneos se identificariam como magüta. A análise de Goulard, portanto, leva a entender que os magüta, ticunas atuais, descendem dos pogüta, humanidade primeira que foi pescada.

Sem pretender refutar esta interpretação, gostaria de apresentar dados para enriquecer a definição destas palavras. Segundo o ticuna Francisco, as duas palavras se

\footnotetext{
${ }^{19}$ Estou adiantando aqui algo que será importante na análise do ritual propriamente, no Capítulo 7: a Festa opera uma troca de pele na moça nova, isso a rejuvenesce.

20 "Pensavam que era uma máscara de verdade. Onde ele aparecia, ninguém conhecia ele e pensavam que era a máscara da Torama." (Firmino \& Gruber, 2010, vol. 1).

${ }^{21}$ Capítulo 6, tópico $6.2-$ Aerofones.
} 
referem ao movimento do caniço quando se está pescando. Magüta significa o movimento de lançar a linha e a isca que estão amarradas na vara de pesca. Esta palavra tem um sentido geral de "arremesso", p. ex., quando se lança uma pedra com uma baladeira ${ }^{22}$, lançar uma flecha com o arco, a linha de pesca, jogar coisas em geral ${ }^{23}$. Tudo isso é magüta. Já pogüta é o movimento inverso, quando se puxa o caniço, trazendo o que se está pescando. Segundo Francisco, esta seria a melhor referência ao povo ticuna, pois indica que eles foram puxados para a terra pelo caniço de Yoi. Contudo, a expressão "povo magüta" é o mais aceito e difundido quando os Ticuna se referem a si mesmos. Outro termo bastante usado é $d u$ 'ügü, plural ( $g \ddot{u})$ de "gente" ( $d u$ ' $\tilde{u})$, atributo que muitos seres perderam no tempo do mito, mas que pode ser agenciado por outros seres quando tomam a forma humana. Trata-se, portanto, de um tipo de "pronome cosmológico", um ponto de vista no qual o sujeito se posiciona em relação a outros seres do cosmos (Viveiros de Castro, 2002a).

Para compreendermos os usos destes termos entre os Ticuna, um texto muito inspirador de Roy Wagner (2010[1974]) nos incita a buscar, antes de tudo, as formas "como os "nativos" fazem suas coletividades", o "modo "nativo" de fazer a sociedade" ou a "forma como as pessoas se criam socialmente" (idem: 244) na sociedade estudada. Neste sentido, devemos ter em mente que, ao longo da literatura que trata dos Ticuna, temos duas ficções que são constantes: 1) o próprio etnônimo destes índios e 2) as metades exogâmicas, de que trataremos abaixo. Não quero dizer aqui que os etnólogos que estudaram os Ticuna criaram absurdos conceituais que nada tem a ver com a vida deste povo. Contudo, tais noções devem ser tomadas como termos analíticos, com uma função heurística, mas que transcendem a forma como o ticuna faz, nos termos de Wagner, sua sociedade.

O etnônimo que atualmente os Ticuna assumiram para si é - como acontece com muitos povos ameríndios (cf. Viveiros de Castro, 2002a) - muito provavelmente, uma palavra estrangeira. Nimuendaju abre sua monografia sobre estes índios mencionando as

\footnotetext{
${ }^{22}$ No sul do país é conhecido como estilingue.

${ }^{23}$ Nimuendaju comenta este sentido da palavra magüta. "Esta primeira raça de homens que Yoi e Ipi pescaram é chamada magüta (a partir de magü, "jogar alguma coisa a partir da ponta de uma vara elástica", e ta, sufixo plural) ou üüne (os imortais). Eles não morrem como nós, seus descendentes, o yuna'tü (mortais), no entanto, vivem até hoje em um estado encantado na região onde eles foram criados, ou longe, a leste, com Yoi." (1952: 135).
} 
distintas grafias que os viajantes usaram para o nome da "tribo", "Tikuna (Tekuna) or Tukuna (Tokuna)" (1952:1). Contudo, o etnógrafo alemão não se atem a origem do nome. Para Barbosa Rodrigues, "nome Ticuna que tem a tribu é tirado do veneno que fabricam, chamados pelos Tapuyos ticuna ou urary" (1882: 52), o que faz bastante sentido, afinal o veneno fabricado pelos Ticuna era bastante conhecido na região.

O que une esta população e faz com que estas pessoas se considerem parte de uma mesma coletividade é o fato de compartilharem uma mesma narrativa de origem. É o mito dos gêmeos Yoi e Ipi, compartilhado pelas pessoas que acreditam que seus antepassados tiveram origem na pescaria de $Y o i$, o alicerce que $f a z$ a sociedade ticuna. Os Ticuna se auto identificam como povo magüta ou pogüta, palavras que remetem mais para ações - o ato de lançar o caniço ou puxá-lo, respectivamente - do que para categorias substantivas. Ou seja, se podemos pensar os Ticuna como uma sociedade, um grupo em que as pessoas possuem um certo grau de identificação entre si, devemos ter em mente que eles se pensam como pessoas originadas de um mesmo movimento executado durante a pescaria de Yoi, magüta e pogüta. São fruto desta passagem da água, quando eram peixes, para a terra, ao se transformarem em gente $(d u$ ' $\ddot{u})$. Neste sentido, assim como mostrarei que em alguns momentos a fronteira entre o pensamento e a ação, para os Ticuna, é borrada, termos como magüta e pogüta, quando usados como "etnônimos", tornam o ser e a ação intercambiáveis ${ }^{24}$.

\section{2 - A Origem dos Clãs}

A origem dos clãs segue esta mesma lógica da diferenciação entre os povos de cor de pele diferente, animais de caça e predadores. Assim como este tom de pele distinto foi originado das diferentes iscas usadas para pescá-los - ou seja, o alimento que distingue

\footnotetext{
${ }^{24}$ Me inspiro aqui na descrição de Sahlins sobre "a lógica cultural havaiana", que parece não estar muito longe do nosso horizonte comparativo. "Temos dificuldade em imaginar que ao nível do significado, que é o nível da cultura, ser e ação sejam intercambiáveis. (...) Verbos significam tanto e tão bem quanto substantivos, e a ordem estrutural pode ser trabalhada tão bem em uma direção quanto em outra. (...) tomada como um todo, a lógica cultural havaiana sugere que a oposição entre estado e processo ou substância e ação, entronizada nas nossas ciências sociais e históricas, não é pertinente - não importando o quanto essa distinção nos pareça uma condição necessária do pensamento." (Sahlins, 1990 [1987]: 46-47).
} 
as diferentes gentes habitantes do universo, tantos as pessoas quanto animais de caça e predadores - é o paladar que diferencia as pessoas pertencentes aos diversos clãs. Entretanto, a gênese clânica parte de um único caldo, um único alimento, mas cujo sabor é sentido de forma diferente, de acordo com o clã ao qual a pessoa pertence. Levando-se em conta o sistema de casamento ticuna de exogamia clânica, que examinaremos no próximo tópico, se levarmos este raciocínio que está no mito adiante, podemos definir a noção de tabu do incesto ticuna como a interdição de se casar com alguém que - ao menos no tempo mítico -, dado o mesmo alimento, sinta o mesmo sabor que você. Vejamos o trecho do mito que coletei e que conta esta origem:

"Quando Yoi terminou de pescar os magüta, ele foi procurar niri [comida antiga], que era um jacuriti [um jacaré com a cabeça vermelha e o corpo verde $]^{25}$. Ele cozinhou este jacarezinho e foi convidando as pessoas que ele pescou. De cada nação ${ }^{26}$ tinha apenas uma pessoa, elas ainda não tinham nação. Ele dava um pouquinho de caldo para cada uma, uma colherzinha para cada. Depois ele perguntava qual era o gosto do caldo. Se for amargo, a pessoa é da nação de avaí [Thevetia nerifolia ou Thevetia peruviana]. Outra pessoa experimentou o caldo e disse, "está meio queimoso [nai '̌̃, esta palavra referese a algo que queima, como uma ferrada de formiga saúva]", então era nação de saúva. Quem sentiu gosto pitiú ${ }^{27}$ (nanhaca) virou nação da onça. Outra pessoa falou que o caldo estava ruim (nguaca), então virou nação mutum. Por último ele chamou a nação de japó, este disse que o gosto parecia de cupuaçu (nãbaruaca). Desde então, os Ticuna casam com outra nação."

A concepção ticuna de clãs, portanto, evoca um aspecto sensível da pessoa que pertence a ele. O mito que narra a origem dos clãs, coletado por Goulard, começa com a seguinte frase: "Naquele tempo as pessoas não tinham sabor" (2009: 411). Um dos termos utilizados para se referir ao clã, além de _kü- $a^{28}$, é justamente_ãka, literalmente "pela

\footnotetext{
25 Nas diferentes versões o nome regional dado ao jacaré também varia: jacuraru e jacuruxy em Nimuendaju (1952: 129-30); jacuriti, jacururu, jacarerana. Não pude identificar estes jacarés, mas meu informante se referiu a eles como niri, "comida antiga". O ticuna Pedro Inácio estabelece uma distinção: “jacuraru vive na terra e a jacarerana vive na água, dentro do rio" (Faulhaber, 2000: 111).

${ }^{26}$ Os Ticuna do Brasil utilizam frequentemente o termo nação para se referirem aos seus clãs.

${ }^{27}$ Regionalismo, "tupi pïti'u 'cheiro desagradável, característico de peixe cru'” (dic. Houaiss).

${ }^{28}$ Nimuendaju (1952) utiliza a notação kia' e Cardoso de Oliveira (1983[1961], 1983[1964]) escreve kie para se referirem à mesma ideia.
} 
boca", expressando a noção de "gosto", "sabor" (idem: 94). A partir do momento em que Yoi obrigou as pessoas "sem sabor" a provarem um caldo, elas possuem "sabores", ou melhor, paladares distintos e pertencem a clãs distintos. Antes de serem separados desta forma, os Ticuna eram incestuosos e isto causava diversas catástrofes - dilúvios, terremotos - que extinguiam os primeiros seres (pogüta). Contudo, esta mudança corpórea, a ingestão do caldo do jacarezinho (niri), cria pessoas distintas, pessoas que tem paladar e que, por isso, obedecem a uma regra de casamento.

Incesto e sabor, portanto, estão intimamente relacionados no pensamento ticuna. Esta relação é detalhada por Goulard da seguinte forma: “A situação de incesto produz um estado amargo, da- $\ddot{u}$. Mas o amargor é uma expressão da imaturidade, de tudo o que ainda está verde, do- ̈̈̈ (não suave-amargo). Assim, no mito de origem, a terra estava verde, do- ̈̈, ela estava instável; somente o fim das relações incestuosas pela institucionalização dos clãs permitiu sua estabilidade." (2004: 89). Veremos mais de perto esta relação entre a imaturidade do mundo (na'ane) e dos corpos das pessoas no Capítulo 3, tópico 3.1.5 - O corpo em formação e o mundo verde. Por hora, cumpre ressaltar esta associação do amargor com o incesto. Conforme as pessoas adquirem "sabor", elas podem se casar de modo correto. Portanto, a regra matrimonial foi criada pelos sabores distintos sentidos pelas pessoas, mas, ao mesmo tempo, estes sabores podem ser alterados, amargados, em caso de quebra da regra. Podemos notar isso no exemplo dado por Bueno: "Uma pessoa que tenha esses hábitos condenáveis [desobediência às regras matrimoniais, dentre outros] pode até sentir outros sabores ao experimentar os alimentos, que ao invés de doces lhe pareçam amargos, por exemplo" (2014: 57)

O mito do surgimento dos clãs se mostra capaz de se moldar aos acontecimentos atuais, como mostrou Gow (2001) em relação aos mitos dos Piro. Ou melhor, a variação é uma das características dos mitos piro, e estas variações estão intimamente relacionadas às mudanças no mundo destes índios (idem: 79). Ao contrário de serem narrativas à prova da história, os mitos seriam atualizados constantemente ${ }^{29}$. Neste sentido, é possível se compreender a explicação de uma mulher ticuna com relação ao pertencimento clânico de seu marido mestiço. Questionada do porquê de ele pertencer ao clã da arara (ngo-ü), afirmou ela, “quizás antes un blanco ha robado un poco del caldo del caimán” (Goulard,

\footnotetext{
${ }^{29}$ Retomo esta ideia no Capítulo 2, tópico 2.2 - Como nascem os mitos.
} 
2009: 109$)^{30}$. O que possibilita uma afirmação como esta, se seguirmos o raciocínio de Gow, é o fato de que ninguém testemunhou o evento narrado no mito (idem: 82$)^{31}$. A mesma dinâmica entre mito e história ocorre com a estrutura clânica, com novos clãs que surgem - como o clã do boi (woca) ${ }^{32}$ ou da galinha, ao qual pertencem os brancos - ou clãs que desaparecem - como na história relatada por Cardoso de Oliveira, de um clã que foi derrotado e as pessoas assimiladas pelo clã vencedor, que relato em seguida. Segundo um informante de Goulard, o clã do anu-preto $(u-i)$ existira, mas seus membros "foram dizimados em tempos anteriores" (2009: 111).

Os clãs existem uns em relação aos outros. O nome pessoal, como veremos, é o elo que vincula um indivíduo ao seu clã, torna-o indivíduo de uma determinada "espécime" do clã, assim como o clã se define por um conjunto de seus "espécimes". Contudo, estas fronteiras entre “espécimes" não são intransponíveis. É possível se transformar num outro clã, num processo, muito provavelmente, análogo à metamorfose xamânica e às transformações que acontecem nos mitos, ou mesmo os possíveis casos de transformação de pessoas em outros seres. Nesse sentido, Cardoso de Oliveira relata uma transformação de um clã em outro que o derrotou numa guerra: "em tempos pretéritos os clãs $\tilde{n} u ? n \ddot{e}(n)$ (mutum cavalo) e 'e?ne (periquito) lutaram entre si, sendo o segundo derrotado pelo primeiro. Os sobreviventes foram recolhidos pelo clã vencedor e neles integrados. Em consequência de sua derrota, os ' $e$ ? ne tiveram de substituir seus nomes pelos de seus vencedores, consumando, por assim dizer, e no plano simbólico, a total destruição do clã (...) Constituiria um paradoxo alguém continuar a ser chamado por um nome denotativo da qualidade de um epônimo de um clã desintegrado e, ao mesmo tempo, estar assimilado a um outro clã simbolizado por um epônimo diferente" (Cardoso de Oliveira, 1983 [1964]: 92-3).

Assim como os mitos não existem fora de uma experiência vivida, a experiência de ter os ouvido sendo contados (Gow, 2001: 84), a existência e a distribuição dos clãs no território ticuna varia também de acordo com a experiência de cada um (Goulard,

\footnotetext{
30 Como mostrei acima, a informante se refere ao caldo de jacaré servido por Yoi, que deu "sabor" às pessoas e criou os clãs.

31 "myths are the least certain of all narratives (...) They are even more uncertain than rumours about distant events, for at least rumours emanate from living witnesses, albeit unknown ones" (Gow, 2001: 82).

32 Temos aqui certamente uma corruptela da palavra "vaca".
} 
2009: 111$)^{33}$. Assim afirma Goulard, numa frase muito semelhante ao que diz Gow sobre os mitos dos Piro. "De este modo, una posible repartición de los clanes tiene que ver con la experiencia de cada uno. Se construye un discurso fundado en lo que se conoce, pero se agregan los comentarios de otros, muchas veces reinterpretados, sobre todo cuando se refiere a clanes alejados o desaparecidos" (idem: 111). E o que é contado sobre os clãs envolve conflitos que ressaltam os temperamentos típicos das pessoas daquele clã. Um indígena questionado sobre a existência do clã do jenipapo, respondeu, "ellos vivían aquí (...) odiaban a la gente. Hoy dia no existen más" (idem: 110). Contudo, ressalta o autor que este clã se encontrava em outra parte do território. Este jeito pessoal de cada membro de determinado clã é o que trataremos a seguir, mas antes cabe examinar mais detidamente a relação entre o corpo, o nome e o clã.

\section{3 - Onomástica e corpo}

O nome de uma pessoa sempre remete ao clã ao qual ela pertence, sem mencionar, na maioria das vezes, o epônimo do clã. A referência é sempre feita a um hábito ou característica do animal ou planta ${ }^{34}$. Desse modo, ao enunciar seu nome, um indivíduo se posiciona num "sistema de classes encadeadas" (Cardoso de Oliveira, 1983 [1964]: 88), nome-qualidade-do-epônimo $\rightarrow$ clã $\rightarrow$ metade. Temos, então, uma "sistemática zoológica" codificando a organização social ticuna, o que responde à pergunta colocada no título do artigo de Cardoso de Oliveira (Totemismo Tukúna?).

Os nomes formam, portanto, um complexo sistema codificado. Segundo Goulard, "su función es transmitir una o varias señales, destinadas a representar o transmitir una información. Solo su decodificación permite dar sentido para establecer la comunicación social; es decir, las modalidades posibles de relación entre personas” (2009: 92). Este

\footnotetext{
${ }^{33}$ Levando-se em conta o que diz Carneiro da Cunha, não estamos muito longe do que é o próprio regime de conhecimento amazônico. A experiência pessoal de cada um é fundamental neste regime de conhecimento: “... na Amazônia, segundo vários autores, é a experiência direta que prevalece. O conhecimento se fundamenta no peso das experiências visuais, auditivas e perceptivas" (2009: 365).

34 Coletei inúmeros nomes entre os Ticuna, menciono apenas alguns exemplos: Doctürécurügõecü "aquele que tem rabo verde e voa" (clã do mutum), Nainputanarümeinputana - "dente da saúva brilhoso e bonito" (clã da saúva), Üpetücürüngütchiãcü - “japó pescando e fazendo ninho” (clã do japó), Tchaicütanüna = "descascado depois que o pássaro comeu" (clã do avaí).
} 
autor constrói a hipótese de uma "língua da espécie epônima" baseando-se numa possível cognação entre as palavras "nome" $(\mathrm{g} a)$ e o termo utilizado para se referir à "língua". Isto porque o morfema ga designaria também, de acordo com o contexto, a "língua", a “palavra', a "voz”, o “dito" (idem: 91-2). Este morfema seria um radical genérico para a "língua da espécie epônima". Desta maneira, ao dizer seu nome, a pessoa estaria utilizando a "língua" de sua espécie epônima, uma metalinguagem que envolve um profundo conhecimento da anatomia e da etiologia dos seres naturais (idem: 93).

Dizer que os clãs ticuna são de descendência patrilinear não quer dizer que eles reconheçam linhagens operando em seu sistema de parentesco. Uma linhagem implicaria a possibilidade de uma pessoa demonstrar, por meio de conexões genealógicas, sua descendência de um ancestral em comum com outros membros da linhagem. O que temos no caso dos clãs ticuna é o que Cardoso de Oliveira chama de "descendência "estipulada"” (1983 [1964]: 88), que está implícita na própria ideia do que é um clã: um grupo de pessoas descendentes de um ancestral mítico, ou seja, do qual não é possível demonstrar uma conexão genealógica. Assim, esse "parentesco" com o epônimo do clã deve ser pensado não como um elo genealógico demonstrável, mas no âmbito deste domínio de um idioma comum.

Apesar de não se inventarem novos nomes, sendo, portanto, o estoque de nomes finito, dificilmente os nomes são repetidos numa mesma comunidade. No dia seguinte ao nascimento de sua neta, Francisco me contou que teriam que mudar o nome que deram a ela. Perguntei qual o motivo de terem que trocar o nome. Ele me disse que já tinha uma criança com o mesmo nome na comunidade e não pode haver nomes iguais. Os nomes em português dos moradores de Nazaré também são todos diferentes.

Os nomes em ticuna raramente são usados como vocativos. Dentro da casa de Ondino, onde fiquei hospedado a maior parte do trabalho de campo, eu ouvia muito chamarem pelos nomes em português. Isto principalmente entre irmãos. Contudo, pude observar muitas vezes, Ondino e Francisco chamarem seus filhos (nẽ) pelo termo de parentesco. Possuo informações esparsas para algumas posições de parentesco também. Por exemplo, me disseram, que os tios (MB e FB) e avós devem ser chamados pelo termo de parentesco. Seus nomes não devem ser pronunciados, "senão a formiga tucandeira (Paraponera clavata) ferra a pessoa no mato", explica Ondino. Outros termos são usados para se chamar o parente de uma forma carinhosa ou respeitosa. Üna é uma palavra usada pela mãe chamar o filho ou filha carinhosamente, ela aparece, por exemplo, na canção do 
Wiwirutcha (Anexo-001). A palavra ta' $a$, usada para se referir à sobrinho(a) e neto(a) ${ }^{35}$, pode ser substituída no vocativo por rita, que é mais carinhoso. Maĩe é o termo que Ipi usa para chamar seu irmão, Yoi. É um equivalente a ene (irmão), mas conota um grande respeito.

O uso dos vocativos "mama" e "papa", respectivamente, para chamar a mãe e o pai são muito recorrentes no uso cotidiano. O termo "mama" é largamente usado como vocativo entre os ticuna. Um dos termos para se referir à mãe é õe. Contudo, um vocativo derivado deste termo é apenas $\tilde{o}$, como podemos notar na letra da canção da To'oena, primeira moça nova, que foi morta por Yoi. Ela usa a expressão "pa o...., a palavra " $p a "$ indica que o que vem em seguida é um vocativo ${ }^{36}$. Por isso que em muitas letras de canções da Festa da Moça Nova, ouve-se muito "pa worecü...”, ou de uma maneira mais floreada "Pa iri iri pa wowarecü". Isto porque as canções interpelam as meninas que estão na reclusão. Ambas as expressões estão chamando a atenção da moça nova.

De acordo com Montès Rodrígues (2004: 57), os nomes ${ }^{37}$ em ticuna se caracterizam, primeiramente e de forma mais global, pela oposição entre alienáveis e inalienáveis. Em consequência, a separação dos nomes nestas duas classes conforma, portanto, um critério que "separa dois tipos de referentes". "Os nomes inalienáveis sempre requerem prefixar um índice possessivo". Grosso modo, o referente do nome inalienável exige que "alguém" o possua, ele necessita de um "dono", enquanto que o referente do nome alienável não comporta esta exigência. Segundo a autora encontramos os termos inalienáveis nos seguintes domínios: os termos de parentesco, partes do corpo, partes de vegetais e do cosmos.

Contudo, no âmbito das partes do corpo e dos termos de parentesco existem exceções. Dentre as partes do corpo consideradas alienáveis estão ${ }^{38}$ a medula e os miolos (designados por um único termo, òtà), a língua (kónü), o estômago (tüe), o coração (mà:üne), os dentes molares (áï) e os caninos (kuaina) (os demais dentes são designados por nomes inalienáveis). Dos termos de parentesco, os considerados alienáveis são os pais

\footnotetext{
${ }^{35}$ Ver terminologia de parentesco ticuna no Anexo - 008.

${ }^{36}$ Uma das canções de To'oena aparecem no mito desta personagem, Anexo - 005. O mesmo termo, õ, podemos encontrar no mito do caçador Õtchi, que analisaremos no próximo capítulo.

37 Uso aqui o termo "nome" com um sentido mais amplo que simplesmente nome próprio.

${ }^{38}$ Utilizo aqui a grafia estabelecida por Montes Rodrìgues (2004) para os Ticuna da Colômbia.
} 
dos pais e o irmão da mãe. Ou seja, toda a geração acima dos pais de Ego, a geração dos avós, é formada por parentes designados por um termo alienável. Esta marca de alienabilidade que os termos usados para designar os avós carregam pode ser notada no uso destas palavras. Muitas vezes o sogro é chamado de vovô (oi). Ondino explica que é "porque Ticuna gosta de chamar assim o sogro". Ele me contou isso enquanto traduzíamos a História do Maũcütchametü ${ }^{39}$, em que a nora do personagem o chama de vovô (oi). Avô (oi) - ou vovô, como preferem traduzir muitos ticuna - é um modo de se referir a alguém mais velho e a quem se tem em boa consideração. O herói cultural Yoi é referido diversas vezes como "vovô" Yoi. Este tipo de uso dos termos para os avós (vovô e vovó) é bastante recorrente nos mitos, aparecendo quando o personagem deseja tratar a pessoa mais velha respeitosamente ou mesmo carinhosamente. Vemos, com isso, que ao utilizar estes termos não se está referindo necessariamente a um parente.

\subsection{1 - Nomes de Casas}

Antes de passarmos a uma consideração sobre como esta relação entre o nome e o corpo das pessoas se traduz no comportamento das pessoas, devemos atentar para o fato de que as casas de Festas novas também são batizadas pelos Ticuna. As casas recebem nomes - ou seja, pertencem a um clã - e suas partes mantém uma relação, como tantas outras coisas, com as partes do corpo humano ${ }^{40}$.

Os Ticuna ainda constroem suas casas em formato tradicional. Contudo, existem algumas modificações que foram feitas ao longo do tempo no modelo tradicional. As casas retangulares não são mais fechadas nas laterais com ripas de paxiuba. Segundo Nimuendaju, esta alteração na arquitetura das casas se deu em virtude da introdução dos mosquiteiros. "A introdução do mosquiteiro alterou completamente o estilo de habitação.

\footnotetext{
${ }^{39}$ Maũcütchametü, o homem que foi vivo para o céu. Voltaremos a falar dele quando formos descrever os imortais (ü’üne), no Capítulo 3, tópico 3.1.2 - O lugar dos imortais - as idas e vindas da imortalidade.

${ }^{40} \mathrm{O}$ ticuna Abel Santos comenta sobre as partes do corpo como parámetro para a nomeação de "qualquer elemento": "las partes de la casa, los espacios de la casa, y las partes de las cosas, de los seres, de cualquier elemento, también se nombran en relación con el cuerpo, de los árboles, del remo, la canoa, la flecha, todo tiene como forma de cuerpo humano, tiene cabeza, tronco, espalda, manos, pies, pecho" (Valenzuela, 2010: 55, nota 50, eu grifo). Para uma descrição mais pormenorizada da relação entre corpo e território, ver Angarita (2008: 112-126; 2013).
} 
Uma vez que já não eram necessárias para selar a casa hermeticamente, as paredes foram abandonadas, e hoje elas raramente são vistas.” (1952:12). De fato, apesar de serem numerosas nos locais onde as Festas acontecem bastante, não conheci nenhuma casa que possuísse as laterais fechadas. Uma consequência desta mudança para a Festa é a facilidade com que as pessoas circulam, entram e saem da casa. De acordo com os mais velhos, isso era bastante condenável antigamente. Todos deveriam permanecer dentro da casa durante a Festa.

Elas podem ser batizadas tanto no final da Festa, como presenciei em Porto Lima, quanto no começo da Festa, como me disseram que fazem em Nazaré. Em Porto Lima, ao final da Festa, uma mulher e um homem correram em torno da casa aparando seus "cabelos". As palhas irregulares do telhado, os "cabelos", eram cortados e guardados num cesto. Nimuendaju comenta como é feita a nomeação da casa: "Concluída a construção, o proprietário convida os vizinhos e amigos para uma "festa do corte de cabelo" (referese às pontas irregulares do novo telhado de palha), e nesta ocasião, ele anuncia o nome, escolhido livremente pelo próprio e não independentemente do clã, diferente de como é escolhido os nomes das pessoas" (1952: 13). Goulard também relata sobre o ritual de inauguração da casa nova, "[d]urante a inauguração de uma nova casa coletiva, o proprietário convida os futuros moradores [entrants] para uma celebração chamada "festa de arrumação [arrengement] da cabeleira", isto é, do telhado, com referência às folhas com bordas irregulares cujas pontas são então cortadas. Para os Tikuna, este procedimento é semelhante ao corte de pelos pubiano e não ao corte do cabelo que encerra outros rituais" (2010: 119). Retomaremos esta informação fornecida por Goulard, da relação entre os pelos pubianos e os "cabelos" da casa. Juntamente com o fato de a entrada da casa ser chamada "boca-vagina da casa", isso pode indicar que o que acontece lá dentro seja uma espécie de gestação. Atenhamo-nos, por enquanto, aos nomes dados às casas.

Goulard compara o anúncio do nome da casa nova pelo seu dono com o anúncio do nome de um recém-nascido pouco antes do corte do cordão umbilical. Nos dois casos, segundo Goulard, é a nominação que determina o ato do corte "por uma espécie de paralelo entre o "cabelo" da casa e do cordão umbilical de recém-nascido" (2010: 120) ${ }^{41}$. O nome pode remeter simplesmente às características do entorno da casa, como, Mẽẽgünẽ = "ao redor da casa é bonito". Mas o importante a se destacar é que, ao receber um nome,

\footnotetext{
${ }^{41}$ No Capítulo 4, tópico 4.2.2 - Gravidez, nascimento, parto e pós-parto mostro como é feito o batismo do bebê, junto com o corte do cordão umbilical.
} 
elas tornam-se membros de um clã. A casa de Nazaré, por exemplo, é de clã "de pena”, chama-se Tchügatchinẽrüyeegunẽ = "estava em um lugar e mudou, virou de cabeça para baixo e entrou no céu".

O começo deste nome é devido ao fato de que a casa estava localizada num extremo da comunidade e foi transferida para o outro extremo. Demorei, no entanto, a entender o sentido da palavra yeegunẽ, que aparece no final do nome transcrito acima. Os Ticuna possuem diversas palavras para descreverem as posições dos pássaros durante o

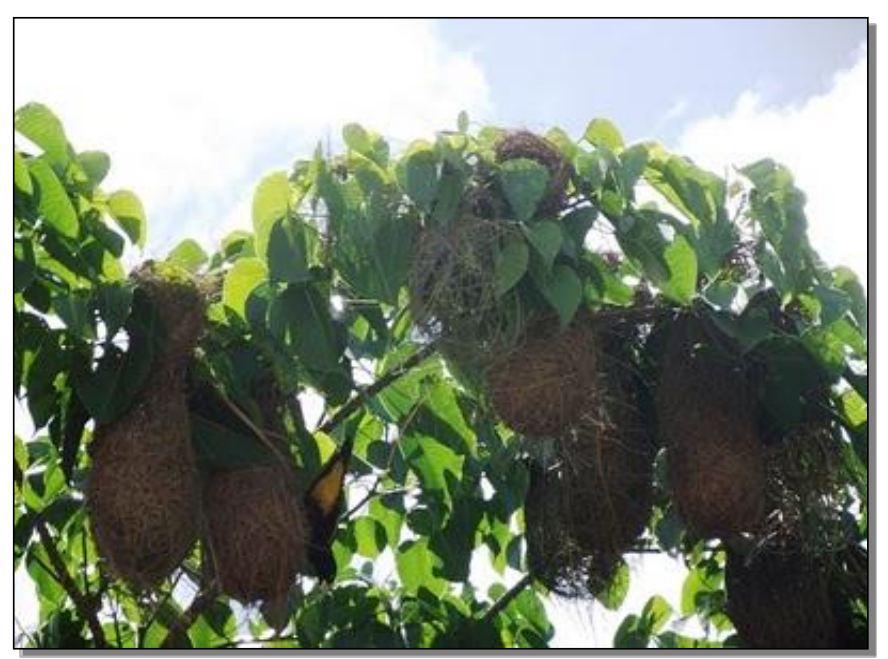

Figura 1 Japiim em seu ninho voo $^{42}$. Ondino me explicava ela dizendo, "quer dizer: vira de cabeça para baixo e some", descrevendo o movimento da casa que se encanta - torna-se encantada/imortal (ü'üne) com as pessoas que estão dentro. Desta forma abstrata fica difícil de decifrar o significado de yeegunẽ. Um dia Ondino falou: "é como o japiim entrando na casa dele", então tudo fez sentido. O japiim

(Cacicus cela) é um pássaro que faz ninhos que pendem do galho das árvores, como uma bolsa pendurada. O nome da casa, portanto, descreve o movimento que faz a casa ao entrar no céu - "virou de cabeça para baixo e entrou" -, da mesma forma que o japiim faz para entrar em seu ninho.

Outro exemplo de nome de casa com movimento de pássaro é Tchẽãtchinẽ = "pássaro no ar com as asas abertas". Existem também palavras para descrever o balançar de um pássaro durante um vendaval ou a formação de voo de um grupo de aves e estes termos costumam vir associados aos nomes pessoais e das casas. O termo totchima' $\tilde{u}$, que aparece neste trecho da canção do Tchowatü, rio localizado no primeiro patamar celeste:

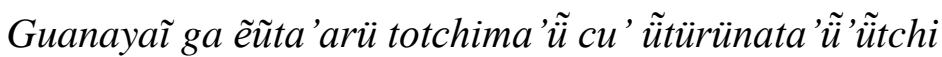

\footnotetext{
42 Analisei os desafios que a tradução de alguns termos ticuna impõem também em Matarezio Filho (2014b).
} 
"Você está como aquela sua gaivota lá, voando junto"

refere-se a formação de voo das gaivotas. Foi-me traduzido como "pássaros voando juntos”. A canção diz que a moça que está sendo iniciada no ritual está como esta gaivota em sua formação de voo. As moças novas, em geral, não são iniciadas sozinhas, ou seja, mais de uma moça fica recolhida no quarto de reclusão. Ao saírem da reclusão, elas ficam uma do lado da outra. Outro exemplo que aparece nesta mesma canção é e'egü = "parado no ar voando":

Tchowatüamã rü yacutüwa

"Lá do outro lado do rio Tchowatü"

Cucagata e'egü

"Parada no ar, voando, para você"

Ela descreve uma casa que está do outro lado do rio Tchowatü, "parada no ar e voando". A palavra yegutchigu - que aparece na canção do trompete coĩri, instrumento musical tocado nas Festas de Moça Nova -, me foi traduzida como: "quando está ventando muito e o urubu cambaleando". No entanto, esta palavra se refere ao movimento cambaleante do voo de qualquer ave.

No final da canção do rio Tchowatü, a música que estava sendo cantada para a moça nova é endereçada à "vovó, vovozinha". As vovós (noe), junto com as tias e tios paternos - pertencentes ao mesmo clã que a moça, diz a canção, "como eu (do mesmo clã), cantando" (tchamarü'ünta yautüma'ã) - são preferencialmente quem canta para ela dentro do quarto de reclusão. O trecho diz o seguinte:

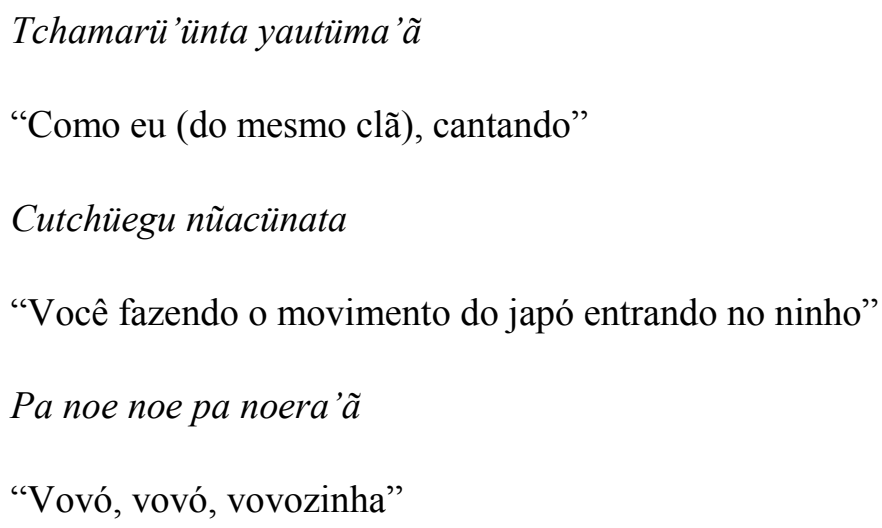

Tudo indica que este local, ao menos nesta canção, é comparado a um ninho de japuaçu (Psarocolius bifasciatus). O movimento dos cantores entrando e saindo do local 
de reclusão é comparado ao movimento da ave entrando e saindo de seu ninho para cuidar de sua prole. Com estes exemplos, podemos notar que os movimentos dos pássaros são uma das metáforas privilegiadas para falar sobre as pessoas que participam deste ritual ticuna.

Em uma língua muito diferente da nossa, muitas vezes nos deparamos com uma multiplicidade de termos sobre assuntos que interessam aos povos nativos. Entre os Ticuna podemos dizer que existe uma "proliferação conceitual" sobre as modalidades de formação de voo entre os pássaros. Com relação a esta "proliferação conceitual" e sua relação com a atenção e o interesse sobre o que se nomeia, Lévi-Strauss já comentava em 1962, em O Pensamento Selvagem. Diz este autor, que "[c]omo nas linguagens profissionais, a proliferação conceitual corresponde a uma atenção mais firme em relação às propriedades do real, a um interesse mais desperto para as distinções que aí possam ser introduzidas" (1989 [1962]: 17). A formação de voo das aves é um assunto de intenso debate entre os Ticuna, algo que para compreendermos devemos atentar para a organização social deste povo, especialmente sua divisão em clãs patrilineares e a relação destes clãs com a onomástica ticuna.

Mas qual a relação entre o voo dos pássaros e as casas de Festa de Moça Nova? Vejamos mais de perto alguns exemplos de nomes de casa fornecidos por Nimuendaju: "habitação engolida"; "para subir no ar"; pa'ru ou vaipü (nome da montanha que salvou uma população mítica da inundação) [1952:141]; "amarrados flutuando juntos"; e a última casa mencionada, chamada "casa tauari”, casa do herói $Y o{ }^{43}$. A segunda referência (“para subir no ar") é bem explicita quanto a uma das funções da casa durante a Festa, levar as pessoas voando para a morada dos imortais. O nome "amarrados flutuando juntos" também faz referência a este voo que se espera da casa e reforça a ideia de que todos devem estar juntos ("amarrados") dentro da casa. Já para compreendermos o nome "habitação engolida" é necessária a referência à metáfora do japiim entrando em seu ninho, que muitas vezes é utilizada para descrever o movimento da casa entrando no "céu" dos imortais. Assim como a montanha pa'ru ou vaipü, que salvou a família de ser afogada

43 “Alguns exemplos: tchi:'ru-güne (tchi:'ru, engolir; gü’ne, habitação); tche'üü’ne (tche'üü', para subir no ar); pa:'ru (o nome do uma serra mítica [pg. 141]); nhürë-güne (nhü, flutuando; rë, amarrados juntos); taive-gü'ne (taive, tauary, uma árvore [Couratari sp]), a casa do herói cultura Yoi"' (Nimuendaju, 1952: 13). 
pelo dilúvio ${ }^{44}$, a casa de Festas é mencionada muitas vezes como o único lugar de salvação para as pessoas. O nome "casa tauari", usado para se referir a casa de Yoi pode se relacionar com o uso regional do termo tauari para se referir a uma "pequena choupana"45.
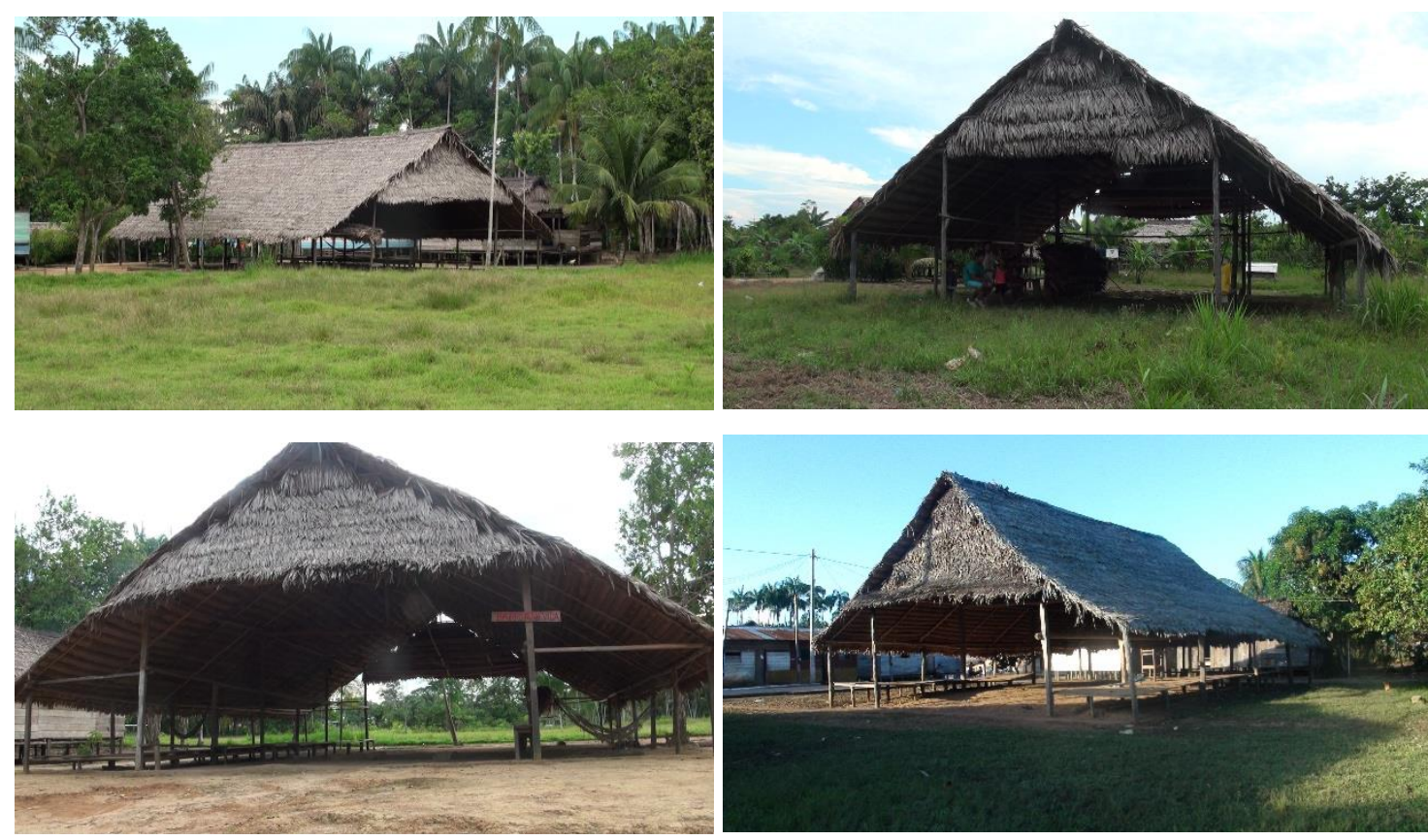

Figuras 2, 3, 4 e 5 - Casas de Festa de Moça Nova

\section{4 - A face expressiva dos clãs}

Este é um ponto em que não concentrei muita atenção durante meu trabalho de campo. Veremos que, com relação ao parentesco ticuna, me detive mais nas questões, digamos, mais estruturais e menos performáticas. O que apresento nesta seção, portanto, está calcado principalmente na literatura sobre os Ticuna. Este tópico trata, em síntese, do fato de que o pertencimento de uma pessoa à determinado clã acarreta em um comportamento ou, melhor dizendo, um habbitus ou devir (Viveiros de Castro, 2002),

\footnotetext{
44 "A crença em Yoi, Ipi e nos imortais está associada com as ideias de cataclismo, passado e futuro, e as Montanhas da Salvação, valpi' ou pa:'ru." (Nimuendaju, 1952: 141). Ver nesta mesma página referida o mito "O Dilúvio".

$45 \mathrm{O}$ dic. Houaiss dá o sentido a esta palavra no regionalismo amazônico, por metonímia da própria árvore tauari, de "pequena choupana encontrada em seringais, feitorias etc".
} 
correspondente ao epônimo do clã. Comecemos por uma passagem bastante esclarecedora de Cardoso de Oliveira:

"Durante os rituais genericamente denominados "Festas da moça nova" os participantes, devidamente paramentados com máscaras e vestimentas de líber, cuidam de interpretar a personalidade de seus epônimos. Nimuendaju menciona o depoimento de seu informante a propósito do comportamento imitativo dos membros de um determinado clã relativamente a seu epônimo. "Nino (um informante) disse-me certa vez - escreve Nimuendaju - que os membros do clã o'ta (galinha) podiam ser reconhecidos de longe, pois quando andavam, costumavam acenar com a cabeça como as galinhas, mas como esse clã não morava na localidade, ele não pode provar sua afirmativa com exemplos concretos" (Cf. Nimuendaju 1952: 58). Conversando com um dos meus informantes, o velho Moka, do clã Galinha, e residente em Mariuaçu, pude lhe dizer provocativamente que estranhava não vê-lo andar como as galinhas, ao que respondeu: "eu só ando assim nas brincadeiras" (...) parece claro que é na situação ritual que a identificação do indivíduo com seu epônimo ou "totem" tende a ser explicitada (...) A justificação de sua pequena estatura que um Tukúna fez a Nimuendaju (ibdem), referindo-se ao fato de seu epônimo ser pequeno ("'everu:= auaí pequeno), é mais uma ilustração desse procedimento metafórico e sintagmático (...) Esta, como outras, são maneiras de "sinalização" de um indivíduo num sistema global de referência como parecem ser os sistemas ditos "totêmicos"” (Cardoso de Oliveira, 1983[1964]: 91-2).

O próprio Nimuendaju é considerado como pertencendo provavelmente ao clã do Japiim (kaure), porque, como este pássaro, ele também possuía olhos azuis (1952: 58) Como este autor enfatiza, não se trata de um "parentesco místico" entre o epônimo do clã e as pessoas que compõem este clã ${ }^{47}$. Entretanto, existe algo para além de uma simples classificação social baseada nas descontinuidades impostas pelos ticuna ao mundo natural. É como uma espécie de metamorfose xamânica, digamos, em um grau menor. Como se as pessoas fossem compostas por determinadas qualidades, afetos do epônimo

\footnotetext{
46 "Em todo caso, a ideia de que algumas características do epônimo deve, ou pode, aparecer nos membros de um clã não é totalmente estranha aos Tukuna" (Nimuendaju, 1952: 58).

47 “Não há sequer um traço de crença em um parentesco místico comum aos membros de um clã e a respectiva árvore ou animal correlacionado com ele, nem essas correlações representam qualquer valor emocional" (Nimuendaju, 1952: 58).
} 
clânico - ao menos mostrando isto em momentos rituais -, mas não o suficiente para se tornarem parentes ou mesmo os próprios animais ou plantas.

Desse modo, alguns traços do epônimo são considerados característicos das pessoas do clã. O exemplo do clã do jaguar é bastante ilustrativo: "nadie se extraña de los enfrentamientos físicos entre personas del clan del jaguar porque "son malos", "peleadores", y se dice además que algunos "no se portan bien con las mujeres"” (Goulard, 2009: 107). Outros clãs também têm fama de serem belicosos, como seus epônimos, o do gavião real (dawü), do gralhão ou cancão-grande (ko-ü), do anu-preto (ui), etc. E existem aqueles cuja sociabilidade pode ser qualificada de positiva (idem:108), o clã do inhambu (nguga) e do mutum (ngunü), por exemplo. Os pertencentes ao clã da cascavel (aru), ao qual pertenciam todos os humanos antes de Yoi criar os demais clãs, possuem uma qualidade muito semelhante ao pensamento sobre as cobras entre os índios guianenses, a imortalidade ${ }^{48}$. Um informante de Goulard nos conta que "ellos han aumentado bastante ya que entre ellos casi nadie muere" (idem: 108).

As características físicas do epônimo também estão presentes entre os pertencentes ao clã. Os pertencentes ao clã da formiga (naiyu), por exemplo, dizem ter o cabelo loiro ou avermelhado, mesma cor da carapaça da formiga (idem: 108). Oliveira Filho diz ainda que os membros deste clã seriam avessos a água, devido ao perigo de se afogarem, como as formigas (1988: 109). As pessoas do clã do condor (echa) teriam uma tez clara e olhos azuis, como os brancos, por outro lado, as do clã do jenipapo $(e)$ tem a pele negra (Goulard, 2009: 108). Pelos exemplos que mostramos, podemos notar que as qualidades dos membros dos clãs são sempre qualidades atribuídas por terceiros, nunca reivindicadas pelas pessoas. Este é um traço notado por Goulard nos Ticuna do Peru e aparece nos Ticuna do Brasil também ${ }^{49}$.

Vimos acima, no trecho de Cardoso de Oliveira, sobre o clã da galinha, como os integrantes deste clã apresentam características do epônimo. Mas, vimos também, que estas qualidades são enfatizadas nas "brincadeiras", forma como os ticuna traduzem seus momentos rituais. Presumo que se trate da uma espécie de reificação das relações sociais

\footnotetext{
${ }^{48}$ Cf. Farage, 1986: 198, em nota também no Capítulo 2, tópico 2.4 - To'oena, a primeira moça nova.

49 “Estas qualidades ou 'modos de ser sociais ou morais dos clãs' nunca são reivindicados diretamente por membros do clã em causa, mas no discurso de terceiros para quem eles refletem sua realidade" (Goulard, 2004: 79).
} 
nestes momentos, como tentei mostrar para o caso do ritual de iniciação masculina dos Waimiri-Atroari (Matarezio Filho, 2014[2010]). Durante este ritual, classificações sociais que variam, não só de acordo com o sistema terminológico de tipo dravidiano, mas também em função da distância geográfica - uma característica fundamental do dravidianato concêntrico da América do Sul - são cristalizadas em paxira (afins distantes), os parceiros rituais que chegam para a festa, e yaska (consangüíneos coresidentes), os anfitriões da festa. Neste sentido, poderíamos dizer que se trata de uma performatização da cultura. É nestes momentos que a "cultura" clânica ticuna é dada a ver aos membros dos outros clãs, uma espécie de elaboração consciente da cultura (Carneiro da Cunha, 2009). Mas, como veremos, há uma inversão de papéis nesta performance, pois um clã executa o que é de propriedade de outro clã.

$\mathrm{O}$ que acontece com os ticuna me parece, portanto, algo semelhante ao que acontece nas festas waimiri-atroari. Durante as 'brincadeiras' as pessoas ressaltam mais as qualidades do epônimo de seu clã. Justamente para marcar com traços fortes as diferenças, neste momento surge uma "cultura" que em momentos ordinários da vida cotidiana é apenas cultura. O consumo de bebida fermentada durante os rituais faz com que se expressem as potencialidades do "princípio corporal” (ma’ũ) de cada um. Costuma-se dizer que uma pessoa do clã da serpente atape se torna violento, raivoso e briguento. Se pertence ao clã do jaguar, ela "salta por todas as partes, não sabe sentar-se", provocando os outros (Goulard, 2009: 129).

Para os Ticuna, todos os seres pertencem a um clã. Pertencer a um clã, diz Goulard, "humaniza" (2009: 90) ${ }^{50}$. Como vimos, o nome remete diretamente a um determinado clã. Este nome, além disso, constitui o que Goulard chama de "principio corporal" $\left(m a^{\prime} \tilde{u}\right)^{51}$ da pessoa. Ao ser nominada, a criança recebe este "princípio" $(\text { ibdem })^{52}$. Ou seja, existe uma conexão direta, via nomes, entre corpo e clã. E é este

\footnotetext{
50 "La ausencia de referencia clánica concierne a grupos étnicos enemigos a quienes se les considera como desposeídos de toda humanidad" (Goulard, 2009: 90).

51 “El ma-ü ['princlpio corporal'] funda y determina antes que nada la identidad personal” (Goulard, 2009: 89).

52 “La noción de ma-ü significa la forma y permanencia de los seres. Es el 'princ/pio corporal' que, con el 'princlpio vital' constituye la totalidad del Ser" (Gooulard, 2009: 113). O "Ser" ticuna, diz Goulard, é formado pelo ã'ẽ e pelo ma'ũ, que este etnógrafo traduz, respectivamente como "princípio vital" e "princípio corporal". Poderíamos traduzir estes termos também como "espírito" ou "alma", o que não melhoraria muito nossa compreensão deles. Mantenho em alguns momentos a tradução de Goulard.
} 
mesmo "princípio corporal" que torna um clã "parente" do outro. Por exemplo, os clãs do jaguar e da seringueira são considerados como possuindo um mesmo "princípio", pois

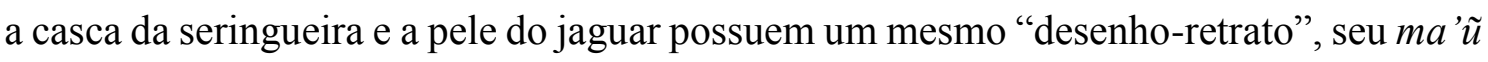
(idem: 113). O fruto avaí (Thevetia) também dividiria este "princípio" com o esquilo, por suas cores semelhantes, e a cabeça das serpentes atape e nawü. Podemos notar, por estes exemplos, que cada denominação clânica, nas palavras de um ticuna, expressa "variedades de formas: sabor, flor, fruto y de formas de vida, de comer, de gritar, de cantar" (idem: 112). A mesma palavra, ma'ũ, também é utilizada para designar toda espécie de fio que une. O xamã segue seu "fio" (ma'ũ) em suas viagens aos "pais" (natï) dos animais. O mesmo "fio" amarra uma canoa ao porto. A palavra para "caminho de caça” (fenemaü) (Soares, 1992-II: 59) também envolve a mesma ideia. Com base nisto, Goulard propõe que o "princípio" ma'ũ seria o "fio" metafórico que uniria o humano ao seu epônimo clânico. Assim, o nome, que é também o "princípio corporal” da pessoa, a conecta ao seu clã, e este, por sua vez, se conecta aos demais clãs "parentes" pelo mesmo "princípio".

Podemos dizer, portanto, que temos entre os indivíduos e os clãs uma diferença apenas de escala. Uma forma de pensarmos esta relação é o modelo da pessoa fractal, proposto primeiramente por Wagner (1991) em relação à noção de pessoa na Nova Guiné, mas que também mostra um bom rendimento entre os ameríndios (ver. Kelly, 2001 e Lima, 2005). Em poucas palavras, a pessoa fractal é caracterizada por apresentar uma mesma forma variando sua escala. Dessa maneira, a parte não se distingue do todo, a não ser pelo seu tamanho. O "princípio corporal" expressa um caráter fractal que vai da pessoa-como-indivíduo à pessoa-como-clã, isto é, a segunda sendo como a primeira, mas numa escala maior. Este pensamento é expresso na ideia de "sangue". Todas as pessoas de uma mesma metade - que reúne, portanto, diversos clãs “aparentados" por um mesmo "princípio corporal" - possuem o mesmo "sangue", por isso não podem casar entre si e devem casar-se com pessoas da metade oposta, de outro "sangue" 53.

\footnotetext{
Tratarei mais detidamente destes termos no Capítulo 4, tópico 4.1.3 - Ma'ũu e ã'ẽ - componentes da pessoa.

53 “... esta sustancia fundamenta el principio de asociación entre los clanes y el de la oposición entre las mitades" (Goulard, 2009: 117). Discutiremos a noção de sangue ticuna mais detidamente no Capítulo 4, tópico 4.2 - Sangue e os "males do corpo" (puya), para mostrar principalmente suas relações com a poluição menstrual (4.2.3 - Menstruação).
} 
Vimos acima, na história da assimilação de um clã pelo outro, um exemplo de pessoa fractal nos clãs e metades ticuna. As pessoas na escala dos indivíduos são obrigadas a mudar de nome, pois a pessoa na escala dos clãs foi assimilada por outro clã. Essa pessoa ampliada - clã do mutum cavalo - que guerreia com outra - clã do periquito -, ao vencê-la, modifica sua forma e modifica a forma de suas "partes". Agora as pessoas pertencentes ao extinto clã derrotado adquirirão outras qualidades do clã vencedor, algo que é evidenciado pela mudança de nome dos indivíduos, "nome-qualidade-do-epônimo" (Cardoso de Oliveira, 1983 [1964]: 92). A totalidade dos Ticuna poderia ser pensada como uma pessoa numa super escala. Digo isto pois o mesmo termo utilizado para designar o clã, kia' ou kie, é também a palavra que designa o conjunto de todos os ticunas 54 .

Nimuendaju nos dá outros exemplos de "performatização" da cultura de cada clã, uns em relação aos outros, ou seja, sua auto-reflexão enquanto diferente de outro clã e

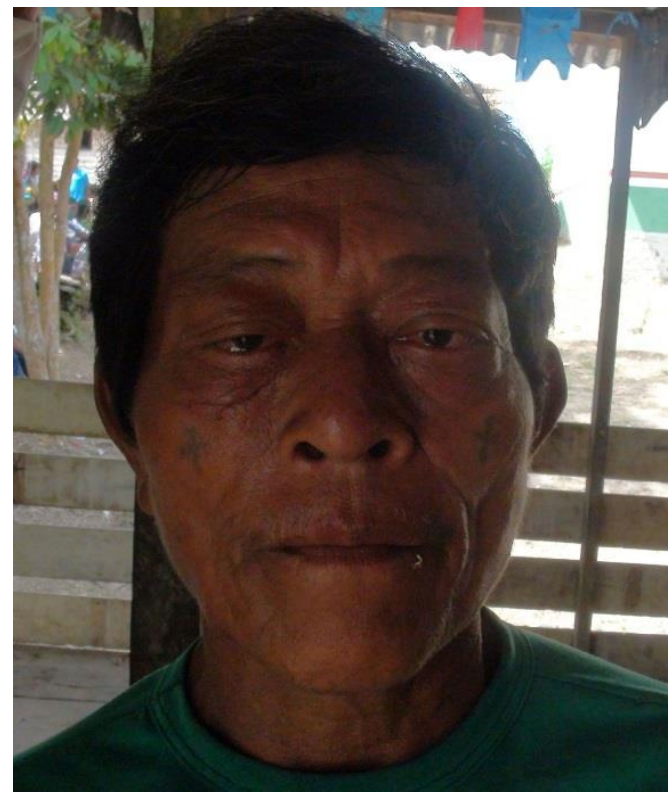

Figura 6 - Ticuna com tatuagem facial do clã do Mutum sua expressão na forma de uma certa "cultura". O etnógrafo nos diz que antigamente as pessoas do clã da arara usavam uma tatuagem facial semelhante à plumagem facial deste pássaro (1952: 57). Conheci dois ticunas, um homem e uma mulher, que ainda possuíam tatuagens faciais identificando seus clãs. O homem fotografado é do clã do mutum. Os desenhos faciais ainda são largamente utilizados pelos Ticuna nas Festas (idem: 39) e a intenção ainda é a mesma, distinguir os indivíduos dos diferentes clãs.

54 “The Tukuna language has only one word, kia', for both tribe and clan" (Nimuendaju, 1952: 56) 

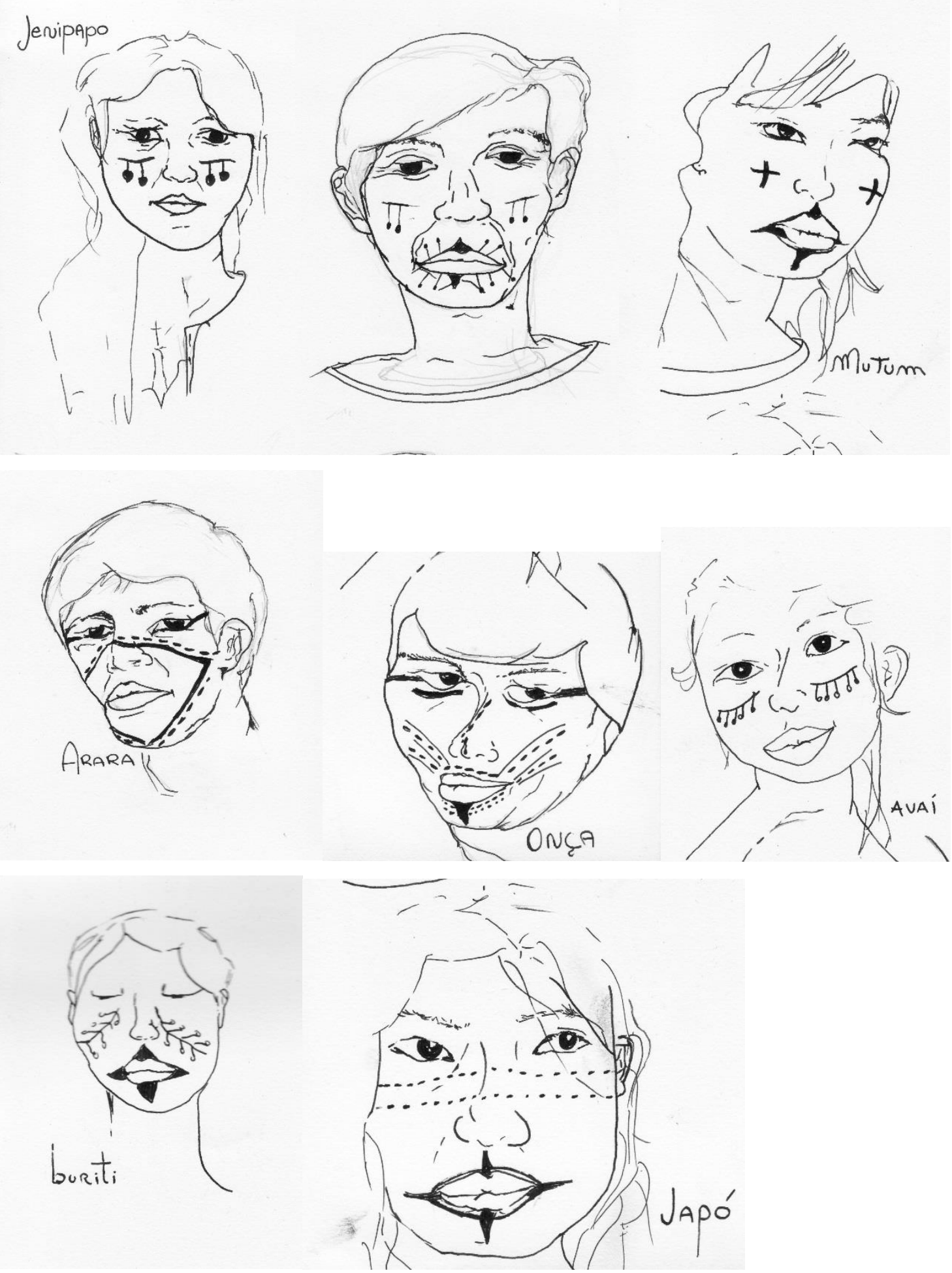

Figura 7 - Alguns exemplos de pintura facial (desenhos de Inayara Samuel Silva) 


\section{5 - Totemismo Ticuna?}

É de se considerar bastante louvável que Roberto Cardoso de Oliveira tenha encarado um problema confuso e espinhoso como o totemismo dos Ticuna. Em 1961, ele escrevia um artigo sobre a organização social e parentesco ticuna (1983[1961]). Neste trabalho o autor não só analisa a estrutura de clãs e metades dos ticunas dos igarapés Belém e Mariuaçu (Umariaçu), como transcreve a grade terminológica desse sistema de parentesco. Pode-se dizer que esta terminologia, mais de cinquenta anos após sua primeira publicação, é a mais completa descrição dos termos de parentesco ticuna. É a partir dela, por exemplo, que podemos inferir que o cruzamento desta terminologia é de tipo kuma (Viveiros de Castro, 1996: 62), e não dravidiano (Goulard \& Barry, 1998: 220) ou mesmo Dakota-Iroquês, como supõe o próprio Cardoso de Oliveira (1983 [1961]:63)

Ainda digna de nota é a pergunta que faz este autor no título de outro artigo seu, “Totemismo Tukúna?”. Ou seja, em 1964 - pouco tempo após a publicação dos dois livros de Lévi-Strauss que tratam do tema do totemismo ${ }^{55}$ - Cardoso de Oliveira arriscava, ainda que brevemente, analisar a organização clânica ticuna nos termos lévistraussianos. Contudo, este antropólogo chegou a um impasse devido ao seu foco exclusivo no parentesco ticuna, como veremos. Por hora, tracemos um esboço da organização social destes índios.

As etnografias são unanimes em dizer que os Ticuna estão segmentados em clãs patrilineares que estão distribuídos entre duas metades exogâmicas. Nimuendaju fala em aproximadamente trinta clãs no Brasil, mas afirma também que podem existir mais variedades no Peru e Colômbia. Goulard \& Barry (1998) falam em cerca de cinquenta no total. Goulard (2009: 100-101) faz um balanço de seu levantamento dos clãs em campo, junto com o Nimuendaju (1952), Oliveira Filho (1988) e os clãs que constam nos mitos. Ele apresenta um total de 50 clãs, distribuídos entre 29 da metade "com penas" e 21 da metade "sem penas". Em geral, as metades exogâmicas não são reconhecidas terminologicamente pelos ticuna ${ }^{56}$. Contudo, como também destaca Gruber (1999), é possível distinguir, nos termos ticuna, as duas metades, "com pena" (âtchiü) e "sem pena"

\footnotetext{
55 "O Totemismo Hoje" e "O Pensamento Selvagem", ambos de 1962, Cardoso de Oliveira (1983 [1964]). 56 “... enquanto o Clã é uma unidade genericamente conhecida por Kie e possuidora de um nome específico (Awaí, Maguari, Mutum, etc.), a Metade é anônima, não sendo designada por qualquer termo específico" (Cardoso de Oliveira, 1983[1961]: 55).
} 
(ngetchiï). Goulard também as chama de metades "com penas" e "sem penas", já que o primeiro grupo é composto exclusivamente de epônimos aves. A metade "sem penas" é composta por uma maioria de clãs com nomes de plantas, mas inclui também, por exemplo, onça, saúva, quatipuru etc.

Antes de aprofundarmos a relação dos clãs e sistema matrimonial ticuna, cumpre olharmos mais de perto para as metades exogâmicas e sua possível conexão com alguns termos de parentesco.

Amália e Altair moram em Nazaré há apenas dois anos ${ }^{57}$. Ele é branco, "civilizado" como dizem os Ticuna, e ela é ticuna. Três anos atrás, Altair comentara com Ondino que gostaria de ter um roçado, mas a vida na cidade o impossibilitava. Ondino sugeriu que o casal se mudasse para Nazaré e eles aceitaram. Plantaram roça, construíram uma casa e mudaram, mas sem abandonar a casa na cidade. Os filhos não quiseram vir, já estavam acostumados com a vida urbana, por isso, constantemente os pais vão para São Paulo de Olivença. Perguntei a Amália se ela tinha algum parente em Nazaré, ela me falou que era parente de Ondino, já que seu clã é japó e o de Ondino é mutum, ambos clãs “de pena". Cardoso de Oliveira também notou algo semelhante sobre a relação entre os clãs da mesma metade e fez um comentário que vai ao encontro desta colocação de Amália sobre a relação entre clãs de uma mesma metade. "A consciência dos membros de um Kie [clã] de estarem associados aos membros dos demais Kie detentores de qualidades da mesma natureza se expressa no tipo de tratamento que dão uns aos outros através do vocativo 'mai(n)e, que quer dizer irmão. Essa associação é tão significativa que os conduz a um sentimento de solidariedade, consubstanciado na defesa dos interesses e direitos da "fraternidade" e na ação eficaz e, às vezes, coletiva, contra aqueles que a ameaçam" (Cardoso de Oliveira, 1983[1961]: 55).

Além do termo mencionado por Cardoso de Oliveira, que relaciona os membros de uma mesma metade, a história de Amália e Altair ilustra algo que quero mostrar com relação à tradução da palavra "parente" que me foi apresentada muitas vezes. Uma possível tradução para "parente" é o termo magü ${ }^{58}$. Este termo corresponde às seguintes posições de parentesco, todas localizadas em G-1: BS, BD, FBSS, FBSD, MZSS,

\footnotetext{
57 Isso era em 2012.

58 Apesar da sugestiva semelhança, desconheço qualquer referência linguística que estabeleça alguma cognação entre as palavras magü e magüta, a autodenominação dos Ticuna.
} 
MZSD $^{59}$. Excetuando-se os termos para filho (nẽ) e filha $(a c u)$, temos apenas dois termos em G-1, que estão, em certo sentido, como veremos, em oposição. Penso que não é fortuito o fato de magü corresponder a parente, na medida em que ele se opõe, na geração dos sobrinhos e filhos, ao termo $t a$ ' $a$, que inclui todos os primos cruzados.

O que temos aqui, portanto, é uma noção metafórica de parentesco expressa na posição magü. A diferença entre os parentes magü e os afins ta'a é notada por Ego principalmente com relação aos filhos de seus irmãos e irmãs. Os primeiros, BS e BD, são considerados "parentes" (magü), pois são do mesmo clã de Ego. Os filhos da irmã são classificados como ta' $a$, pois pertencerão ao clã do marido da irmã. Contudo, olhando para o diagrama com a terminologia ticuna e sobrepondo-o ao diagrama que mostra os indivíduos pertencentes à metade de Ego e os que são da metade oposta (Anexo - 008), notamos que a oposição magü : ta'a :: parente (consanguíneo) : afim deve ser matizada. Percebe-se, por exemplo, que a posição $t a$ ' $a$ sobrepõe-se aos parentes da mesma metade nas posições: FZDS, FZDD, MBDD e MBDS. Ou seja, estes parentes, apesar de receberem um termo que designa um alguém casável, pertencem a mesma metade de Ego, não são desposáveis. Todos os demais classificados como ta' $a$ são desposáveis ${ }^{60}$.

\section{6 - Intercasamentos clânicos}

Explica Cardoso de Oliveira, baseando-se nas definiçõos de Lévi-Strauss, que "uma Metade não é mera soma de Clãs" (1983 [1964]: 57), deve ser pensada "menos como uma instituição identificável por traços precisos, do que como um método aplicável

\footnotetext{
${ }^{59}$ Ver terminologia de parentesco no Anexo - 008.

60 Outro termo que evoca um maior parentesco entre os membros da mesma metade é tanü, traduzido com "família". Não me lembro de ouvir referências a esta palavra em campo. Goulard diz o seguinte sobre este classificador: "No mito da origem de clãs, depois de ter proclamado em voz alta o gosto-cheiro da carne que é consumida, então cada um deve "ajunta-se aos seus" chigütanükü. Ou seja, tanü expressa uma noção de consolidação, acumulação, e, neste contexto, de um juntar-se em caráter familiar. Outro informante explica que por cha-utanü ele quer dizer "a minha família", "o meu grupo", "aqueles que têm a mesma característica". Assim, independentemente do contexto do enunciado, o termo tanü refere-se à metade, com referência ao clã, como se "cada metade da mesma família", disse o outro, "o clã, que é para reconhecer-se como uma família"." (2004: 88, eu grifo).
} 
à solução de problemas múltiplos" (Lévi-Strauss apud Cardoso de Oliveira, 1983[1964]: 57). O clã forneceria ao indivíduo uma regra negativa, a consciência de que ele não pode se casar dentro de seu próprio clã, devendo buscar seu cônjuge em algum dos $n$ outros clãs. As metades exogâmicas reduziriam os grupos a dois e forneceriam uma "determinação positiva" de casamento, então, “em lugar de se saber que não se pode casar dentro de um grupo, aprende-se que se deve casar num outro" (idem: 58).

Chegamos, aqui, ao ponto em que podemos expor a questão levantada por Cardoso de Oliveira em seus estudos sobre a organização social ticuna. Diz este autor que as metades exogâmicas ticuna, compostas de dezenas de clãs, são unidades que "asseguram, em última instância, a coesão tribal, afetada, é verdade, pela natureza peculiar da aliança interclânica" (1983[1961]: 71). Contudo, este antropólogo não encontrava solução para a questão da "coesão tribal", pelo "fato de as alianças interclânicas tenderem a unir dois (no máximo três) Kie [clãs], jamais criando uma rede de relações que abranja todos os Kie praticamente autossuficientes (enquanto pares de Metades Opostas) no que se refere à troca de mulheres e, consequentemente, à aliança interclânica" (idem: 72). De fato, a questão não poderia ser solucionada levando-se em conta, como diz o autor, que o comportamento destas unidades (clãs e metades) é regulamentado "por suas instituições básicas na estrutura social global: são elas o matrimônio e o parentesco" (idem: 71). O autor argumenta que só não acontece um "completo fracionamento" da sociedade Ticuna porque a regra de casamento não é estritamente observada, isto é, "devido à ação de mecanismos não-prescritivos de aliança" (Cardoso de Oliveira, 1983[1961]: 72). Assim, temos um raciocínio um tanto estranho. A regra social de casamento, destinada a manter a "coesão tribal”, é de fato efetiva porque não é estritamente cumprida. Acredito que a questão da "coesão tribal" ticuna deva ser colocada em outros termos.

A afirmação de Cardoso de Oliveira de que os clãs ticuna se relacionam matrimonialmente aos pares ("no máximo três") entre as metades - ou seja, um clã de uma metade tende a trocar cônjuges com apenas um ou dois clãs da metade oposta - nos coloca um problema, nos termos em que coloca este autor, de "coesão tribal" para os Ticuna. Se pensarmos que a troca de cônjuges é a única forma de relação entre os clãs, o que impediria uma organização social pensada nestes termos estritos do parentesco de se “desagregar". Isto é, passarmos de uma forma deste tipo: 


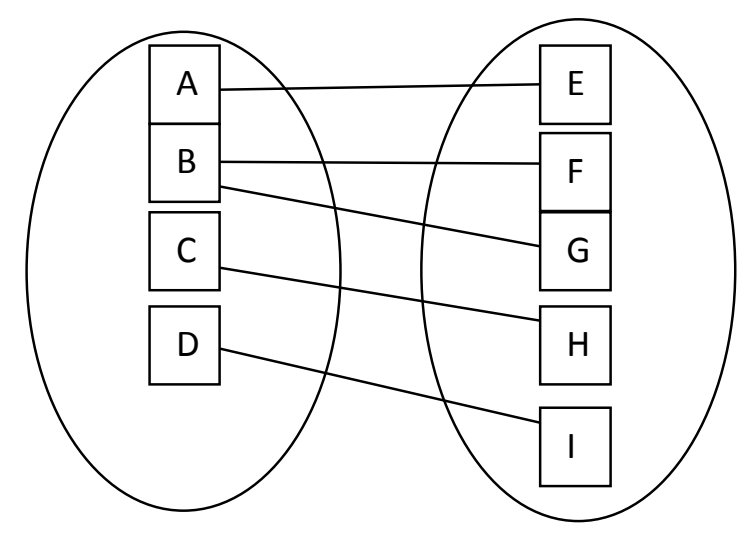

Figura 8 - 0 esquema aqui esboça duas metades contendo seus clãs. As linhas são as relações de troca matrimonial.

Para uma deste tipo:

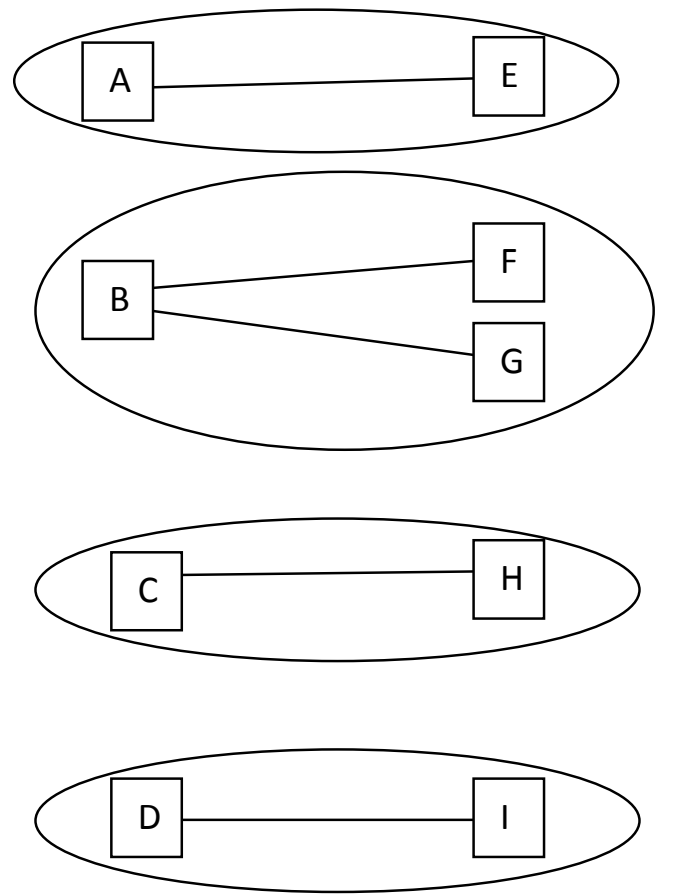

Figura 9 - Aqui as duas metades desaparecem e temos pares de clãs trocando entre si.

Tudo indica que o autor incorre no mesmo erro que levou Rivière a ver os "grupos locais" guianenses como unidades atomizadas (2001[1984]), um produto exclusivo do parentesco. O elo que une os clãs e metades pode ser buscado em outro lugar. Como mostrei para o caso Waimiri-Atroari, índios caribe-guianense, a relação entre os "grupos locais" era realizada especialmente durante as festas de iniciação masculina (Matarezio 
Filho, 2014[2010]). O mesmo afirma Seeger com relação aos "grupos cerimoniais baseados em nomes" dos Suyá, quando diz que estes grupos "fazem pouco mais do que cantar juntos" (1980: 103). Ainda acrescenta este autor, que a "estrutura da música, longe de ser um reflexo, é parte da criação e contínua recriação das características duais da sociedade Suyá" (ibdem).

Quando abordarmos a relação das Festas com a organização social ${ }^{61}$, veremos que há uma interdependência ritual entre os clãs, o que contribui também para a existência de variados clãs numa mesma comunidade. Contudo, em certo sentido, Cardoso de Oliveira tem razão, pois há uma forte tendência das comunidades Ticuna possuírem um par de clãs dominantes numérica e politicamente, que trocam cônjuges majoritariamente entre si. Através do tratamento computacional de duas genealogias coletadas por mim em campo pude confirmar a intuição de Cardoso de Oliveira. De fato, a tendência de intercasamentos exclusivos entre pares de clãs é muito presente entre os Ticuna, ao menos para esta amostragem significativa. Isso indica que as unidades trocadoras de cônjuges no sistema de parentesco ticuna, apesar de operar com metades, são alguns pares de clãs, como mostrarei, identificáveis ${ }^{62}$.

Uma ressalva, entretanto, deve ser feita. É importante frisar que a rede genealógica ticuna tem a peculiaridade de ser apenas um recorte, um fragmento de uma malha gigantesca para os padrões ameríndios. Alguns trabalhos recentes que se debruçaram sobre redes genealógicas possuem a característica de lidarem com populações pequenas, facilmente delimitadas, o que torna possível abranger toda a rede em estudo ${ }^{63}$. Deste modo, como temos em foco o maior grupo indígena do Brasil ${ }^{64}$, seria impraticável para um único etnógrafo, no período de campo de uma tese de doutorado, delinear toda a genealogia lembrada pelos Ticuna. Pretendo aqui fazer como um arqueólogo que, com

\footnotetext{
${ }^{61}$ Ver, por exemplo, no Capítulo 6, o tópico 6.3-Demais instrumentos musicais, sobre o pertencimento de alguns instrumentos musicais a certos clãs e metades.

62 "Quando a divisão em metades não regulamenta os casamentos, este papel é em geral assumido por outras formas de grupamento, quer se encontre uma nova bipartição do grupo, paralela ou perpendicular à anterior, quer as metades compreendam clãs, subclãs ou linhagens exogâmicas, quer, finalmente, as modalidades do casamento dependam de formações especializadas chamadas classes matrimoniais." (Lévi-Strauss, 1976 [1949]: 108).
}

\footnotetext{
${ }^{63}$ Ver os trabalhos de Bueno (2008), Maizza (2012), Silva (2012) e Florido (2013).

${ }^{64}$ Tal extensão de rede poderia ser comparável a dos Guarani Kaiowá, ver IBGE censo indígena 2010.
} 
um fragmento de tecido encontrado de uma população já extinta, nos explica como funcionava o processo de tecelagem desta população. O método utilizado, portando, é induzir a partir de um fragmento desta rede genealógica algumas proposições que considero possivelmente gerais para a o parentesco ticuna. Podemos observar nas tabelas abaixo que o número de repetições de um mesmo tipo de aliança é bastante recorrente.

Tabela 1 - Intercasamentos clânicos do igarapé Camatiã ${ }^{65}$

\begin{tabular}{|l|l|l|}
\hline Clã de Pena & Clã sem Pena & N. de Casamentos \\
\hline Mutum & Saúva & 24 \\
\hline Japó & Saúva & 15 \\
\hline Carará & Saúva & 12 \\
\hline Japó & Avaí & 6 \\
\hline Munãne & Saúva & 4 \\
\hline Carará & Avaí & 4 \\
\hline Mutum & Onça & 4 \\
\hline Japó & Onça & 3 \\
\hline Maguari & Saúva & 3 \\
\hline Mutum & Civilizado & 2 \\
\hline Civilizado & Saúva & 2 \\
\hline Mutum & Avaí & 2 \\
\hline Mutum & Jenipapo & 2 \\
\hline Cocama & Avaí & 1 \\
\hline Carará & Carará & 1 \\
\hline Carará & Japó & 1 \\
\hline Japó & Civilizado & 1 \\
\hline Japó & Cocama & 1 \\
\hline Japó & Jenipapo & 1 \\
\hline Mutum & Carará & 1 \\
\hline Mutum & Civilizado & 1 \\
\hline Civilizado & Saúva & 1 \\
\hline Saúva & Saúva & 1 \\
\hline Tuiuiu & Saúva & 1 \\
\hline TOTAL & & $\mathbf{9 4}$ \\
\hline
\end{tabular}

Tabela 2 - Intercasamentos clânicos de Vendaval

\begin{tabular}{|l|l|l|}
\hline Clãs de Pena & Clãs sem Pena & N. de Casamentos \\
\hline Mutum & Onça & 60 \\
\hline Arara & Onça & 51 \\
\hline Mutum & Avaí & 13 \\
\hline
\end{tabular}

\footnotetext{
${ }^{65}$ Os casos de casamentos internos às metades ou aos clãs (incestos) estão marcados em vermelho.
} 


\begin{tabular}{|l|l|l|}
\hline Arara & Avaí & 9 \\
\hline Arara & Buriti & 9 \\
\hline Arara Vermelha & Onça & 5 \\
\hline Avaí & Onça & 5 \\
\hline Mutum & Saúva & 5 \\
\hline Maguari & Onça & 5 \\
\hline Arara Vermelha & Onça & 3 \\
\hline Japó & Avaí & 3 \\
\hline Avaí & Saúva & 2 \\
\hline Avaí & Avaí & 2 \\
\hline Japó & Onça & 2 \\
\hline Maguari & Saúva & 2 \\
\hline Arara & Saúva & 2 \\
\hline Cambeba & Avaí & 2 \\
\hline Japó & Saúva & 2 \\
\hline Arara Vermelha & Saúva & 1 \\
\hline Mutum & Civilizado & 1 \\
\hline Arara & Maguari & 1 \\
\hline Arara & Boi & 1 \\
\hline Mutum & Boi & 1 \\
\hline Japó & Civilizado & 1 \\
\hline Civilizado & Onça & 1 \\
\hline Japó & Buriti & 1 \\
\hline TOTAL & & $\mathbf{1 9 0}$ \\
\hline
\end{tabular}

Temos acima duas tabelas que mostram os casamentos interclânicos que ocorrem em duas regiões Ticuna bem distintas, Igarapé Camatiã e Vendaval, dois locais onde fiz trabalho de campo. A primeira corresponde a uma genealogia de 442 indivíduos, em que aparecem 94 casamentos. Nazaré, contudo, é uma pequena comunidade, como é comum no igarapé Camatiã, não ultrapassa os 100 moradores. O que fiz foi perguntar sobre os parentes que moravam em outras comunidades e que tinham algum vínculo de parentesco com os moradores de Nazaré. Em geral, os indivíduos da genealogia são habitantes do igarapé Camatiã, o que mostra que esta região conforma uma rede de trocas matrimoniais e rituais, o que torna difícil o foco exclusivo numa comunidade quando se trata de rede genealógica. Assim que comecei a coletar os dados percebi que minha rede seria uma boa amostra dos casamentos de todo o igarapé. A rede, portanto, totaliza e extrapola a comunidade de Nazaré.

A segunda genealogia, que embasa a segunda tabela, é praticamente o contrário da primeira. Apesar de mais extensa que a primeira, já que está fundamentada numa rede 
de 765 indivíduos, não totaliza a comunidade de Vendaval, de onde foi coletada. Esta última comunidade está localizada no Rio Solimões e sua população é de cerca de 1.500 pessoas. Apesar de algumas exceções, a maior parte dos integrantes da rede são moradores de Vendaval. Deste modo, a genealogia não totaliza a comunidade, mas é uma amostra, ainda que bastante significativa, da população.

As implicações demográficas que um quadro como este nos mostra são evidentes. As comunidades possuem uma tendência a terem uma maioria populacional de pessoas pertencentes a um par de clãs. Existem também implicações políticas proporcionadas por esta assimetria dos casamentos interclânicos. Devido ao tipo de eleições nas quais são escolhidos os chefes atualmente, estes acabam sendo sempre dos clãs dominantes. É para esta assimetria entre os clãs que iremos olhar mais de perto no próximo tópico.

\section{7 - Hierarquia clânica, política e residência}

Outros pesquisadores notaram também esta hierarquia intracomunitária que existe entre os clãs ticuna ${ }^{66}$.

"En el caso ticuna, y a manera de hipótesis, puede plantearse que estas variaciones de carácter jerárquico existen dentro de la organización de mitades y clanes, y que se expresan, además, en un control territorial. (...) también se plantea como hipótesis que la importancia de los dueños de maloca se ha transferido al de la casa. Esta transferencia se ajusta a una nueva configuración espacial interna a de las aldeas, en donde se reconoce la predominancia de un clan y su control territorial, así como su jerarquía en el escenario global ticuna" (Oyuela-Caycedo \& Albarracin, 1999: 148, grifo meu).

O estudo de Fajardo (1986), relatado por Oyuela-Caycedo \& Albarracin, mostra que a população de San Martin de Amacayacu - localizada no trapézio amazônico, Colômbia - também expressa uma grande quantidade de intercasamentos entre dois clãs,

\footnotetext{
${ }^{66}$ Ao contrário do que nos informa Oliveira Filho: "não há qualquer hierarquia entre as nações [clãs], nem entre as metades" (1988: 116), também em Bueno (2014: 29).
} 
aru (avaí) e ngunü (mutum) ${ }^{67}$. A comunidade de San Sebastian de los Lagos, localizada próxima da cidade de Letícia, Colômbia, possuiria os mesmos dois clãs predominantes. (Gonzalez \& Rivas, 1990: 70-71 apud Oyuela-Caycedo \& Albarracin 1999: 151). A predominância de um ou dois clãs, que trocam preferencialmente cônjuges entre si, dentro de uma aldeia e em territórios adjacentes (aldeias vizinhas), como vimos, é algo que encontrei também em meus dados de campo.

O fato de um par de clãs ser predominante em uma comunidade e trocar muitos cônjuges colabora, como ressaltam Oyuela-Caycedo \& Albarracin $^{68}$, para uma baixa mobilidade interaldeã entre os Ticuna, ao menos para as pessoas pertencentes a estes clãs dominantes. Baixa mobilidade da população aldeã, ou seja, os Ticuna tendem a permanecer na mesma comunidade, não costumam casar "fora". Um comentário que ouvi sobre isso na comunidade de Vendaval era que nesta aldeia, durante muito tempo, as lideranças proibiram os moradores de casarem-se com pessoas de fora da comunidade. Vendaval tem a fama de ser uma comunidade que permaneceu por um longo período evitando relações com o mundo exterior, tanto com relação aos casamentos, mas também com relação ao estudo formal dos mais jovens. Segundo me foi relatado, enquanto os moradores de Campo Alegre enviavam seus filhos para a cidade para estudar, em Vendaval isso era proibido pelas lideranças. Devemos ter em mente também que Campo Alegre é uma comunidade sob forte influência da Igreja Batista, o que pode ter favorecido o letramento, mas, ao mesmo tempo, coibia a realização das Festas de Moça Nova ${ }^{69}$. Vendaval, apesar destes comentários de que o estudo formal teria sido proibido no passado, é conhecida pela abundância de Festas de Moça Nova.

\footnotetext{
67 "Del total de familias, 62,1\% eran matrimonios entre los clanes aru (cascabel) [avaí] y guduw (ngunü= paujil [=mutum]), con una tendencia a la matrilocalidad (Fajardo, 1986: 40-44)." (Oyuela-Caycedo \& Albarracin, 1999: 151).

68 "Retomando los patrones de residencia, 70,4\% nació en la misma área donde vive, lo que indica una baja movilidad; sólo $29,6 \%$ tiene un origen externo a la zona de influencia de la aldea y de este porcentaje 10,2\% son nacidos en los países vecinos (véase el cuadro 7)." (Oyuela-Caycedo \& Albarracin, 1999: 159).

${ }^{69}$ Bueno realizou a pesquisa de campo para sua tese de doutorado principalmente junto aos Ticuna de Campo Alegre. De acordo com a autora, baseada em Macedo (1996, 1999), "Campo Alegre foi fundada em 1959 por pastores norte-americanos da Association of Baptists for World Evangelism (...) A escola fundada pelos pastores servia a brancos e índios, onde se lecionava a língua portuguesa e os princípios da religião cristã. Tal escola formou a maioria das figuras de prestígio e os primeiros professores indígenas de Campo Alegre e instaurou uma nova forma de relacionamento com os brancos" (2014: 40-41).
} 
O quadro descrito por Oyuela-Caycedo \& Albarracin, para as comunidades da região do trapézio amazônico colombiano, é de uma maior frequência da patrilocalidade, "es normal que los hijos se casen y mantengan como residencia la vivienda del padre del esposo - residencia patrilocal." (1999: 158). A residência é patrilocal, mas isso não quer dizer que as mulheres tenham que sair da comunidade em que vivem. Os autores podem estar confundindo duas coisas distintas, casa e aldeia. Se a residência é patrilocal como eles afirmam, as mulheres deixam a casa de seus pais para ir morar na casa de seus sogros, ou seja, continuam morando na mesma comunidade - como atesta a baixa mobilidade entre aldeias demonstrada pelos mesmos autores. Esta provável confusão entre casa e aldeia é notada nos resultados que os autores apresentam: “... debería esperarse un bajo porcentaje de mujeres que vivan aun en la misma aldea donde nacieron, pero esto no ocurre." (idem: 161). Uma questão a ser verificada para comprovar a residência patrilocal seria se as mulheres de fato deixam a casa dos pais depois do casamento. Este cálculo deveria averiguar não somente as pessoas que tem "uma origem externa à zona de influência da aldeia", mas também os nascidos na mesma área onde vivem. Assim, partindo da constatação de que a mobilidade intercomunitária é baixa, podemos concordar com o autor quando ele afirma que "los ticuna ribereños del Amazonas colombiano tienden a la endogamia - casi $70 \%$ de los casos - y a la baja movilidad residencial" (ídem: $162)^{70}$. O que poderia haver, contudo, é a possível existência de uma exogamia de casas intra-aldeã: "la patrilocalidad puede darse en cuanto a la casa de residencia dentro de la aldea, mas no en relación con otras aldeas." (ibdem).

A pesquisa de Cardoso de Oliveira, realizada em fins dos anos 50 e início dos 60, mostra um quadro ligeiramente diferente com relação à residência dos ticuna após o casamento. Diz este etnólogo que "atualmente existe um relativo equilíbrio entre matrimônios virilocais e uxorilocais ${ }^{[71]}$, com ligeira inclinação para os primeiros: 58,53\% de uniões virilocais (Belém, 59,09\%; Mariuaçu, 57,89\%) contra 41,47\% de uxorilocais (Belém 40,91\%; Mariuaçu, 42,11\%). E quando se trata de neolocalidade, esta ocorre em regra sempre próxima à casa dos pais de um dos cônjuges, i. e., numa mesma área vicinal”

\footnotetext{
70 Os dados de Goulard sobre os Ticuna do Peru também apontam para as mesmas conclusões, os casamentos ticuna intracomunitário são prevalecentes. Entre os não evangélicos o percentual de casamentos internos à comunidade é de $60 \%$, enquanto numa comunidade evangélica este percentual chega a $90 \%$ (2012: 31-32).

${ }^{71}$ Apenas para ficar claro, já que esta terminologia varia bastante: virilocal = patrilocal, o casal vai morar com a família do marido; uxorilocal = matrilocal, o casal vai morar com a família da esposa.
} 
(1983[1961]: 62). O trecho final reforça o que havíamos constatado, os Ticuna tendem a permanecer na mesma comunidade em que nasceram. Contudo, a predominância da patrilocalidade é menor nos dados de Cardoso de Oliveira.

Não fiz nenhuma coleta de dados mais sistemática sobre localidade pós-marital com os Ticuna que trabalhei. Contudo, forneço dados que nos permitem olhar alguns casos mais de perto, saindo um pouco dos números estatísticos. Tenho minhas dúvidas se existe alguma regra rígida de moradia após o casamento entre os Ticuna. Notei apenas que é mais frequente o casal ir morar com o pai da esposa. Francisco, por exemplo, em 2012, estava com três genros morando em sua casa em Nazaré e todos queriam se mudar de lá. Cristovão veio passar uns tempos na casa do sogro, para ajudar Mariazinha, sua sogra, a fazer roça. Josineide mora na comunidade Torre da Missão, veio para Nazaré em virtude das festividades da padroeira, para tocar teclado nas festas. Arnaldo cogita em construir uma casa em Nazaré, porém também quer voltar para perto da casa de sua mãe, no município de Amaturá. Xisto, professor e antigo morador de Vendaval, me contou que o homem vai morar com o sogro para aprender a fazer canoa, remo, pescar, fazer roça, etc. "Só sai da casa do sogro quando dá problema, se não tiver problema continua morando com o sogro". O que percebi que acontece, de modo geral, é que os recémcasados ajudam os pais em suas roças até terem a sua própria, assim adquirem condições para construírem sua própria casa.

\section{8 - Residência, casas, famílias e GUDD}

Há algo recorrente nas etnográficas sobre os Ticuna e estreitamente relacionado ao tema da residência de que estamos tratando: as antigas malocas de um único clã. Comecemos por um comentário de Nimuendaju sobre estas malocas: "Eu tenho ouvido muitas vezes dos próprios índios que, em tal ou tal lugar já houve uma grande maloca deste ou daquele clã. Eu não sei como interpretar essa afirmação, pois, embora os clãs dos Tukuna sejam patrilineares, a família é mais matrilocal do que patrilocal, de modo que só em circunstâncias muito especiais poderiam todos os homens de uma maloca pertencerem ao mesmo clã." (1952: 11). Existe uma dificuldade em avaliar esta informação, pois há uma grande diferença em dizer que todos os moradores da casa são do mesmo clã ou que todos os homens o são. Em último caso, a matri ou patrilocalidade 
é o que decide a veracidade da informação. Se os Ticuna fossem patrilocais - isto é, o casal vai morar no mesmo local de origem do marido - existiria a possibilidade sociológica de os Ticuna possuírem malocas unilineares, mas somente de homens pertencentes ao mesmo clã, não todos os moradores. Contudo, se a matrilocalidade for predominante, como atesta Nimuendaju e algo que não posso inferir a partir de meus dados, as antigas malocas unilineares estão inviabilizadas.

Sigamos mais um pouco com Nimuendaju em seu comentário sobre a possibilidade de a residência patrilocal ter predominado no passado. "Se o Tukuna está certo em dizer que nos velhos tempos as malocas eram habitadas por famílias de apenas um clã, a residência deve, então, ter sido patrilocal. Hoje não existe uma regra fixa, mas há uma tendência bem estabelecida de os pais não deixarem uma filha fora da vista e livre de seu controle, mesmo depois do casamento. Compare com este conselho do tio para a worecü [moça nova]: "Nunca abandone a sua mãe, e procure por ela, mesmo depois do casamento" (p. 90); e a ameaça da sogra potencial ao pretendente que ela vai reivindicar sua filha se esta não for bem tratada (p. 94).” (1952: 96, grifo meu). Notemos que, apesar de ter afirmado que a regra era "mais matrilocal do que patrilocal", atualmente a regra não é tão fixa. Mas faço minhas as palavras de Nimuendaju quando me refiro aos Ticunas com quem convivi. Ao que parece, quando tem condições, os pais tendem a preferir que a filha fique próxima a eles depois do casamento, seja na mesma casa ou, ao menos, na mesma comunidade.

No livro de Oliveira Filho (1988: 114), o autor elaborou um mapa (idem: 115) onde indica a localização, levantada com informantes mais velhos, de 20 malocas de um único clã. Oliveira Filho sugere que este tipo de organização deve remontar ao primeiro quartel do século passado. Este autor não tem dúvidas quanto à existência real destas malocas. O que devemos enfatizar aqui é que este tipo de informação é sempre remetida a um passado, "houve uma grande maloca deste ou daquele clã" (Nimuendaju, 1952: 11). Acredito que há uma possibilidade para a saída deste impasse. Uma mudança histórica radical que alterou o padrão de residência ticuna. Com o fim das grandes casas comunais, onde predominava um único clã - nesta hipótese os Ticuna eram necessariamente patrilocais - as comunidades pulverizaram os clãs em casas familiares. Neste contexto, as comunidades se organizaram como vemos hoje, dois clãs trocadores dominantes para cada comunidade. Com isso, as famílias tendem a manter as filhas mais próximas de casa depois do casamento. A função que as antigas malocas patrilocais tinham antigamente - 
manter as jovens recém-casadas próximas das mães - é cumprida hoje, de forma menos rígida, com a tendência à uxorilocalidade. Outro autor já havia esboçado, mas em outros termos, esta questão da mudança social ocasionada com o fim das grandes malocas.

Quando estudou o parentesco ticuna, Cardoso de Oliveira notou algo que não estava registrado em Nimuendaju, o que poderia indicar, portanto, uma mudança importante na organização social destes índios. Por um lado, como vimos até aqui, a principal unidade do sistema de parentesco ticuna é o clã. Isso implica em um critério de descendência que não passa pelo "reconhecimento de "elos genealógicos"” (Cardoso de Oliveira, 1983[1961]: 54). Por outro lado, segundo este autor, estariam se formando entre os Ticuna "linhas de descendência" 72 , que ele denominou GUDD, Grupos Unilineares de Descendência Demonstrável, "unidade social até agora despercebida, e que merece ser considerada" (idem: 60).

Estes GUDD identificados por Cardoso de Oliveira são traduzidos pelos ticuna como "famílias" e, de acordo com o autor, eles seriam internos aos clãs. Na comunidade de Belém do Solimões, onde o estudo foi feito, podemos pinçar alguns exemplos, o clã da saúva seria composto de quatro GUDD: os Barra, os Raimundo, os Lourenço e os Pui; o clã da arara teria cinco GUDD: os Estevão, os Salustiano, os Surucuiu, os Gabriel e os Belém. Estas "linhas de descendência" internas aos clãs ocupariam áreas contíguas, formando "grupos vicinais". "Os grupos vicinais surgem com a associação de dois ou três GUDD pertencentes a clãs diversos de tal forma que sempre sejam vizinhos determinados Kie [clãs] de Metades opostas. Isso faz com que o matrimônio tenda a ocorrer duplamente, e não raro, triplamente, entre dois únicos GUDD” (Cardoso de Oliveira, 1983[1961]: 61). Os GUDD, portanto, seriam as unidades internas aos clãs que proporcionariam os redobramentos de casamentos entre os pares de clãs.

Mas qual o motivo para o surgimento destas "famílias" internas aos clãs ticuna? Segundo o mesmo autor, baseando-se em Nimuendaju, como vimos, as antigas residências ticuna - as grandes malocas - eram locais onde habitavam um único clã. Apenas para delinearmos melhor o argumento de Cardoso de Oliveira, cumpre dizer que com "a desagregação da grande residência clânica" haveria uma "perda considerável de controle da família de orientação sobre os seus membros masculinos e femininos, se a

\footnotetext{
72 "um arranjo de parentes de um indivíduo, que se pode demonstrar num diagrama de parentesco" (Radcliffe-Brown apud Cardoso de Oliveira, 1983[1961]:55).
} 
sociedade Tukúna não procurasse compensá-lo (como de fato o fez) com o fortalecimento de grupos unilineares de descendência "demonstrável” [GUDD] (...) assegurando, sobretudo, o controle sobre as filhas e filhos, genros e noras" (idem: 62). O controle, portanto, que a grande residência clânica exercia sobre as pessoas passou, com o fim destas residências, para a vicinalidade dos GUDD.

O que pude registrar em meu trabalho de campo, contudo, ao menos para as comunidades de Nazaré e Vendaval, não confirmam estas intuições de Cardoso de Oliveira. De fato, as "famílias" são facilmente identificáveis pelos sobrenomes das pessoas e a forma como são transmitidos estes sobrenomes, de modo geral, apontam para a construção de linhagens. É possível, através deles, demonstrar as relações genealógicas dos indivíduos de uma mesma família. Não descarto a hipótese de que na época em que Cardoso de Oliveira fez seu estudo, há mais de cinquenta anos, a organização social ticuna se dava deste modo. Entretanto, de acordo com meus dados, as famílias em Vendaval, por exemplo, não pertencem a um único clã. Se selecionarmos seis famílias da minha amostragem com número de indivíduos bastante expressivo, relacionando seus membros com seus clãs teremos os seguintes quadros:

Tabela 3 - Clãs e quantidade de indivíduos com o sobrenome Arapaço

\begin{tabular}{|l|l|}
\hline Clã & N. de indivíduos \\
\hline Arara & 45 \\
\hline Onça & 21 \\
\hline Arara vermelha & 17 \\
\hline Buriti & 9 \\
\hline Boi & 3 \\
\hline Mutum & 3 \\
\hline Saúva & 1 \\
\hline
\end{tabular}

Tabela 4 - Clãs e quantidade de indivíduos com o sobrenome Souza

\begin{tabular}{|l|l|}
\hline Clãs & N. de indivíduos \\
\hline Avaí & 29 \\
\hline Onça & 20 \\
\hline Mutum & 7 \\
\hline Arara & 1 \\
\hline Civilizado & 1 \\
\hline Saúva & 1 \\
\hline
\end{tabular}


Tabela 5 - Clãs e quantidade de indivíduos com o sobrenome Antônio

\begin{tabular}{|l|l|}
\hline Clã & N. de indivíduos \\
\hline Arara & 28 \\
\hline Buriti & 9 \\
\hline Onça & 6 \\
\hline Maguari & 1 \\
\hline
\end{tabular}

Tabela 6 - Clãs e quantidade de indivíduos com o sobrenome Inácio

\begin{tabular}{|l|l|}
\hline Clã & N. de indivíduos \\
\hline Onça & 23 \\
\hline Mutum & 10 \\
\hline Arara vermelha & 4 \\
\hline Avaí & 1 \\
\hline
\end{tabular}

Tabela 7 - Clãs e quantidade de indivíduos com o sobrenome Viturino

\begin{tabular}{|l|l|}
\hline Clãs & N. de indivíduos \\
\hline Arara & 19 \\
\hline Onça & 13 \\
\hline Mutum & 1 \\
\hline
\end{tabular}

Tabela 8 - Clãs e quantidade de indivíduos com o sobrenome Bonifácio

\begin{tabular}{|l|l|}
\hline Clã & N. de indivíduos \\
\hline Onça & 30 \\
\hline Arara & 5 \\
\hline Mutum & 2 \\
\hline
\end{tabular}

Estas tabelas mostram que as famílias, apesar de se concentrarem mais nos dois clãs mais numerosos de Vendaval, arara e onça, não se concentram em um único clã. Elas estão distribuídas em três ou mais clãs de ambas as metades. Além disso, nossas análises mostram também que não há qualquer preferência pela troca de cônjuges entre determinadas famílias, ao contrário do que acontece com os clãs dominantes, como vimos acima.

Estamos aqui num terreno em que a organização social, os casamentos e a política estão entremeados. Pelo que vimos até aqui seria quase impossível pensá-los separadamente. Os próximos dois pontos de que quero tratar, portanto, dão um maior 
acento às relações existentes entre 1) os clãs e o casamento e 2) os clãs e a chefia. Como o primeiro ponto é mais espinhoso e demorado, começo pelo segundo.

\section{9 - Clãs e Chefia - equilíbrio político}

Quando estive em campo pela primeira vez, entre janeiro e fevereiro de 2012, Julio (clã da saúva, metade "sem pena") era o cacique de Nazaré. Ele anunciara que deixaria seu posto em janeiro, mas quando deixei a comunidade ele ainda era cacique. Comentaram comigo que havia dois candidatos ao posto: Altair, um branco casado com uma ticuna, e Gabriel (clã do mutum, metade "com pena"), ticuna peruano que se casou em Nazaré há alguns anos. Ambos são compadres de Ondino (clã do mutum, metade "com pena"), mas este último disse que apoia a candidatura de Gabriel, pois sempre que este distribui sua caça, dá pedaços a Ondino. Um forte pré-requisito para ser cacique é ser um bom caçador e compartilhar a carne caçada. Ondino reclama que Julio não costuma lhe dar nada do que caça. Já Gabriel sempre lhe dá carne quando mata algum animal, muitas vezes com a arma e os cartuchos de Ondino. Por causa deste empréstimo, Ondino fica com a maior parte da caça ${ }^{73}$.

Durante a limpeza do cemitério para as cerimônias do dia de finados, o cacique Julio e Aldinha, sua esposa, assaram peixes num moquém armado no local mesmo. Os parentes mais próximos do cacique comeram com ele. Ondino e sua família continuou o trabalho, sequer foram convidados. A família de Cirineu (clã do japó, metade "com pena”) também não foi convidada. A principal crítica de Ondino a Julio, além de ele ter brigado com Gabriel por causa de Aldinha, é o fato de ele não lhe dar nada. Nunca lhe deu peixe ou caça, o que um cacique deveria fazer, como faz Gabriel. Por isso - apesar ser peruano e morar em Nazaré há apenas cinco anos -, este é vice-cacique e um forte candidato à chefia.

\footnotetext{
${ }^{73}$ A generosidade deve ser um atributo de quem pretende se envolver com a política municipal também. Ondino me disse que votou em Aurea (clã da saúva), única candidata de Nazaré para vereadora em São Paulo de Olivença, porque ela Ihe deu gasolina.
} 
Gabriel é um excelente caçador. Não raro, pessoas que estão de passagem por Nazaré deixam alguns cartuchos de espingarda com ele para pegarem a caça em outra ocasião. Esta facilidade com a caça e o fato de falar bem português e espanhol o torna um nome com chances para se tornar cacique ${ }^{74}$. Quando cheguei para minha segunda temporada de trabalho de campo, Gabriel comentou que infelizmente não tinha nenhum presente para me dar. Entretanto, ele é muito generoso comigo, sempre me dando peixe e comida quando vou a sua casa. Durante a festa da padroeira, diversas vezes ele me ofereceu aguardente.

Depois de uma certa idade, quando o cacique já não caça mais, em geral, suas filhas já estão casadas com bons caçadores. Isto aumenta a afluência de alimento para o chefe, mas ele continua a ser cobrado como um pródigo distribuidor de bens. Ouvi o cacique Miguel, da comunidade Santa Clara, fazer uma reclamação típica de chefe ameríndio. Ele disse que comprava muita coisa - neste caso ele estava se referindo ao café que tinha acabado -, mas as pessoas levavam tudo. Contudo, apesar de não o ter visto sair para pescar nenhum dia, não nos faltou peixe para comer. Seus genros se encarregavam de trazer peixes para ele.

Durante meu segundo período de trabalho de campo, pude presenciar a eleição de um cacique em Nazaré. Os nomes dos candidatos foram escritos no quadro da escola e foi aberta a votação. Diversos nomes estavam no pleito, contudo a disputa era entre a "facção" de Gabriel, atual vice-cacique do clã do mutum, ou seja, metade "com pena"; e a "facção" de Julio, atual cacique que estava apoiando a candidatura de seu irmão, Joseney, ambos do clã da saúva, portanto, metade "sem pena". Se a lógica desta eleição fosse cada um votar em seu clã ou metade, a vitória de Joseney seria certa. E, de fato, ele ganhou a eleição. Contudo, Ondino, cujo voto possui um peso político imenso, apesar de ser do clã do mutum e ter Gabriel como compadre e grande amigo, votou em Joseney. Este último obteve mais que o dobro de votos que Gabriel.

Nesta eleição, Laelsio (clã do avaí, metade "sem pena") foi um dos candidatos. Acredito que ele se candidatou porque é notoriamente um bom caçador. Seus cachorros são todos submetidos a um tratamento com ervas que ele esfrega no focinho deles para

\footnotetext{
${ }^{74}$ Para uma consideração sobre os atributos do chefe ameríndio de um modo geral, como a boa oratória e a generosidade na doação de bens, ver Clastres (2003[1962]). O privilégio da poliginia também é um terceiro atributo destacado por Clastres para os chefes.
} 
que fiquem mapiara. Ele me contou que, numa caçada, o cacique tem precedência para dar os primeiros tiros. Certo dia, ele foi caçar um bando de queixadas com o então cacique Julio. Segundo sua versão da história, quando avistaram o bando, este último deu oito tiros e errou os oito. Laelcio deu cinco tiros e foram cinco queixadas mortos. Uma derrota como esta para Julio representava uma possibilidade de ascensão política para Laelcio, que não achou nada mal seu nome ser escrito na lousa da escola junto com os demais candidatos.

Além de exigirem que o chefe seja um generoso provedor, ele também tem a responsabilidade de resolver brigas, representar a comunidade em reuniões políticas, providenciar documentos para os moradores da aldeia. Com relação às brigas, o cacique atual está com sua moral abalada. Em 2011, Aldinha, a esposa de Julio, acusou Gabriel de ter um caso com ela. Quando ficou sabendo, o cacique foi tirar satisfações, chegou furioso na casa de Gabriel e, pelo que me disseram, a briga foi feia. Isso aconteceu durante a festa da padroeira da comunidade, em 12 de outubro daquele ano. Nimuendaju menciona Tessmann sobre o ciúme dos Ticuna, em caso de adultério o marido briga com seu rival. Contudo, diferente das minhas observações e das de Tessmann, Nimuendaju diz não ter visto nenhuma briga por casa de ciúmes entre pessoas do mesmo sexo. "Por outro lado, entre os cônjuges ciúme provoca cenas violentas (ver p 51.), que podem levar à separação" (1952: 95).

Depois da briga, Gabriel se mudou para a casa de seu sogro, Severino, em Umariaçu I, município de Tabatinga. Contudo, ele e sua família não se adaptaram ao local. A caça, o peixe e o espaço para fazer roça eram escassos, então, Gabriel resolveu voltar para Nazaré. Com o ocorrido, Severino, na época, um dos moradores mais antigos de Nazaré, resolveu deixar a comunidade e se mudar de vez para Umariaçu I. Um dia antes da festa para a padroeira da comunidade, N.S. de Nazaré, Ondino convocou uma reunião com os líderes. Gabriel havia se tornado vice-cacique e estava pleiteando a posição de chefe principal. Durante a reunião, Ondino fez um apelo principalmente para que não houvesse briga na festa. O recado, evidentemente, era para os dois líderes que deveriam dar o exemplo para os demais moradores.

$\mathrm{O}$ fato do cacique e do vice-cacique de Nazaré pertencerem às metades opostas não me parece ser um mero acaso. Contudo, ao que tudo indica, o vice-cacicado dos Ticuna não tem nada a ver com nossa ideia de vice. Parece-me mais uma forma de conciliar duas "facções" opostas do que uma ideia de suplência ou de aliados políticos. 
Gabriel e Julio não são aliados, são opostos, inclusive pertencem à metades exogâmicas distintas. O vice-cacicado de Gabriel distribui o poder de Nazaré entre os dois clãs mais numerosos da comunidade (ver tabela abaixo), saúva e mutum, pertencentes às duas metades opostas, descentrando o poder das mãos de um único cacique. A chefia política em Nazaré, portanto, apresenta uma verdadeira intenção de equilibrar as desavenças entre as metades do parentesco. É para este tipo de composição da chefia que daremos atenção agora.

Tabela 9 - Distribuição dos indivíduos segundo seus clãs em Nazaré e Camatiã

\begin{tabular}{|l|l|}
\hline Clã & N. de Membros \\
\hline Saúva & 140 \\
\hline Mutum & 90 \\
\hline Japó & 60 \\
\hline Carará & 34 \\
\hline Avaí & 29 \\
\hline Onça & 19 \\
\hline Jenipapo & 9 \\
\hline Maguari & 7 \\
\hline Civilizado & 7 \\
\hline Tuiuiu & 5 \\
\hline Munãne & 3 \\
\hline Cocama & 3 \\
\hline
\end{tabular}

Para verificar se este tipo de equilíbrio é buscado intencionalmente entre os Ticuna, teríamos que ter uma amostragem maior de casos. Poderíamos analisar quais são as lideranças das demais comunidades e seus respectivos clãs, ou analisar as mudanças de caciques e vice-caciques de uma só comunidade no tempo. Possuo uma pequena 
amostragem dos clãs a que pertencem alguns caciques e vice-caciques que pode nos dar um panorama das composições políticas ticuna.

Recapitulando rapidamente, quando estive pela primeira vez em Nazaré, no início de 2012, Julio era o cacique e, em pouco tempo, Gabriel tornou-se vice. O primeiro é do clã da saúva e o segundo é do clã do mutum, os dois clãs com o maior número de intercasamentos (ver tabela acima). Contudo, o clã da saúva é dominante em número de membros, seguido do clã do mutum, o que acaba favorecendo Julio e seus parentes na hora da votação. O falecido irmão mais velho de Ondino, Abdon, era vice-cacique de Nazaré na época em que Severino era cacique. Este último é do clã da saúva, enquanto Abdon é mutum, ou seja, mais uma combinação das duas metades, "com pena" e "sem pena", na chefia da comunidade. Mais tarde, Abdon tornou-se cacique de Nazaré. Isso pode indicar, além de uma composição entre chefes das duas metades, uma alternância no tempo entre os clãs dominantes no cacicado e vice-cacicado.

Celso, o vice-cacique de Vendaval, do clã da arara, é explicitamente um opositor de Pedro Inácio, do clã de onça, antigo afamado chefe de Vendaval e considerado hoje como o chefe de todos os Ticuna. Provavelmente o atual cacique, Virgílio, do clã de onça, seja uma indicação deste último. Celso também não gosta do cacique. Um dado importante é que o clã de onça é numericamente dominante em Vendaval (ver tabela abaixo). Desta maneira, numa votação como as que acontecem atualmente para a escolha do cacique, dificilmente se elegeria como chefe alguém que não fosse desse clã. A chefia da comunidade de Campo Alegre também segue o mesmo padrão, o cacique Henrique Emílio Marques é do clã da arara enquanto o vice-cacique, Raimundo Macario, é do clã da saúva.

Tabela 10 - Distribuição dos indivíduos segundo seus clãs em Vendaval (parcial)

\begin{tabular}{|l|l|}
\hline Clãs & N. de membros \\
\hline Onça & 250 \\
\hline Mutum & 167 \\
\hline Arara & 152 \\
\hline Avaí & 66 \\
\hline Buriti & 24 \\
\hline Saúva & 22 \\
\hline Arara vermelha & 19 \\
\hline
\end{tabular}




\begin{tabular}{|l|l|}
\hline Japó & 13 \\
\hline Maguari & 12 \\
\hline Boi & 5 \\
\hline Civilizado & 4 \\
\hline Total & $\mathbf{7 3 4}$ \\
\hline
\end{tabular}

No entanto, apesar deste ser o provável quadro político mais recorrente, existem exemplos de composições em que cacique e vice-cacique são de uma única metade exogâmica. Numa conversa com Valdir, cacique de Umariaçu I, perguntei a ele se o cacique e o vice-cacique deveriam ser necessariamente de metades opostas. Valdir negou, disse que podem ser da mesma metade. Em Umariaçu I, segundo me informou, não é o caso. Ele é do clã do avaí e o vice-cacique é de clã "sem pena" também. Humberto, cacique da comunidade Cidade Nova, próxima de Belém do Solimões, é do clã do japó. O vice-cacique é do clã da arara. Ou seja, os dois são de clãs "com pena". Humberto me falou que na comunidade dele tem mais pessoas que pertencem a clãs de penas. "Avaí, por exemplo, tem pouquinho", me disse ele. Neste caso, o fato de os cargos não estarem distribuídos entre as duas metades, muito provavelmente tem a ver com a expressiva população de pessoa do clã "de pena”. Vila Independente, comunidade vizinha de Campo Alegre, é outro exemplo de chefia dominada pela metade "sem pena". O cacique Milton da Silva é do clã do avaí e o vice-cacique, Xisto Macário, é do clã da onça. Em síntese, a predominância do casamento entre pares de determinados clãs se reflete, portanto, não só na distribuição geográfica dos clãs pelas diversas comunidades, a liderança política também é afetada por este padrão de intercasamento.

\subsection{0 - Compadrio}

As relações entre os clãs, políticas e matrimoniais dos Ticuna tornam-se ainda mais complexas quando notamos que elas são também infletidas pelas relações de compadrio. Qualquer um pode cortar o cordão umbilical de uma criança tornando-se, deste modo, seu padrinho (paiãgawa) ou madrinha (mãiãgawa). A relação de compadrio é bastante relevante para os Ticuna que conheci. Ondino, p. ex., sempre se refere a algum 
compadre (pai ou cupá) ${ }^{75}$ seu colocando este termo antes do nome da pessoa, como: "compadre Gabriel" ou "compadre Cirineu".

Este é o batismo ticuna do recém-nascido. O batismo cristão é chamado "colocar água” na criança. Quando as enfermeiras perguntaram a Ondino o nome de seu filho, ele respondeu que já tinham "colocado água" nele, chamava-se Railson, pois tinha puxado à mãe, Raissa. Assisti ao batismo cristão de Railso. Seu padrinho, Orlando - um "civilizado" que veio para a festa da padroeira de Nazaré -, simplesmente pegou um raminho de folhas, molhou na água e repetiu várias vezes, “eu te batizo Railson”.

A relação de compadrio, seja cortando o cordão umbilical da criança ou pelo batismo e casamento cristão, amplia a rede de relações da pessoa. Um estudo do compadrio ticuna ainda está por ser feito e poderia revelar coisas interessantes. Descrevo abaixo os compadres e comadres de Ondino, uma pessoa que possui muitos deles, para termos uma noção de como pode ser extensa uma rede de compadrio.

Tabela 11 - Compadres e comadres de Ondino.

\begin{tabular}{|l|l|l|}
\hline Japó & $\begin{array}{l}\text { Homens: Francisco, Cirineu, Valdeney, Nilo } \\
\text { (irmão de Renato), Fidélio (irmão de Francisco) }\end{array}$ & Quantidade: 5 \\
\hline Mutum & $\begin{array}{l}\text { Mulheres: Madalena (esposa do compadre } \\
\text { Getúlio), Deusa (filha de Benedita) } \\
\text { Homens: Gabriel, Renato (irmão de Francisco, } \\
\text { mora em Nova Jerusalém) }\end{array}$ & $\begin{array}{l}\text { Quantidade: 2 } \\
\text { Total: 7 }\end{array}$ \\
\hline Carará & $\begin{array}{l}\text { Mulheres: Nazilda } \\
\text { (filho do Maduquinho), Argemiro (filho de seu } \\
\text { Manoel), Arcênio. }\end{array}$ & $\begin{array}{l}\text { Quantidade: 1 } \\
\text { Total: 3 }\end{array}$ \\
\hline & $\begin{array}{l}\text { Mulheres: Zelita (esposa de Roberto), Nazita, } \\
\text { Maria da Glória, }\end{array}$ & Quantidade: 3 \\
\hline & Total: 7 \\
\hline
\end{tabular}

75 Esta última palavra me parece uma corruptela de compadre. Penso o mesmo de "comadre", que é referida como cumari. 


\begin{tabular}{|c|c|c|}
\hline \multirow[t]{2}{*}{ Saúva } & $\begin{array}{l}\text { Homens: Roberto (pajé), Filadelfo (irmão de } \\
\text { Roberto), Valdemar, Altair (filho do finado } \\
\text { Joaquim, tio da esposa de Terêncio), Getúlio } \\
\text { (filho de Seu Pedro), Julio (ex-cacique). }\end{array}$ & Quantidade: 5 \\
\hline & $\begin{array}{l}\text { Mulheres: Zélia (esposa de Cirineu), Celina } \\
\text { (esposa de Gabriel), Amália (esposa de Manuel, } \\
\text { filha de Laureano), Clarisse (WZ de Ondino), } \\
\text { Mariazinha (esposa de Francisco), Áurea (irmã de } \\
\text { Mariazinha) }\end{array}$ & $\begin{array}{l}\text { Quantidade: } 6 \\
\text { Total: } 11\end{array}$ \\
\hline \multirow[t]{2}{*}{ Avaí } & Homens: Laelsio, Francisco (de Tchowariãpü) & Quantidade: 2 \\
\hline & Mulheres: & Total: 2 \\
\hline \multirow[t]{2}{*}{ Onça } & Cecília & $\begin{array}{l}\text { Quantidade: } 1 \\
\text { Total: } 1\end{array}$ \\
\hline & & Total clãs "sem pena": 14 \\
\hline \multirow[t]{2}{*}{ "Civilizado" } & Homens: Helio (peruano), Cristovão, Cleonaldo, & Quantidade: 3 \\
\hline & Mulheres: Lilia, Sebastiana, & $\begin{array}{l}\text { Quantidade: } 2 \\
\text { Total: } 5\end{array}$ \\
\hline
\end{tabular}

Os compadre e comadres de Ondino, dispostos na tabela acima, estão divididos em clãs "com penas" e clãs "sem penas". Em suma, temos uma distribuição razoavelmente uniforme dos aliados por compadrio, com uma leve preferência pelos de clãs "com penas", mesmo tipo de clã de Ondino, mutum. Enquanto o conjunto destes últimos conta com 17 pessoas, os de clãs "sem penas" contabilizam 14 indivíduos. Ao todo, somando os "civilizados", Ondino, que é do clã do mutum, "com pena", portanto, conta com 36 compadres e comadres.

\subsection{1 - Casamento}

O casamento é um divisor de águas na vida de um casal. Pode definir, por exemplo, o grau de maturidade da pessoa. De acordo com a descrição de Oliveira Filho, casar-se e ter filhos é um dos critérios que determinam se um rapaz se tornou de fato adulto. "Segundo a concepção dos Ticuna os rapazes se tornam efetivamente homens adultos, com uma esfera própria de responsabilidades e com poder de decisão, quando o 
seu casamento dá certo, isto é, quando já têm um ou dois filhos e podem vir a construir uma casa separada daquela de seu sogro. Antes disso, seja solteiro ou casado, ele vive com o pai ou o sogro, subordinado portanto à autoridade desses" (1988: 156).

Devido a esta importância do casamento para os Ticuna, a solteirice torna-se um problema. Os rapazes que ainda não se tornaram pai (ngetüücü = quando ainda não é pai, mas está na idade de casar) na comunidade de Nazaré são, em geral, bem jovens. Quando permanecem nesta situação por muito tempo, são alvo de gracejos dos demais homens da comunidade. Ulisses, irmão de Ondino, por exemplo, é frequentemente zombado por sua condição de solteiro. Um ticuna comentou comigo, em tom de zombaria, que Ulisses está esperando uma mulher virgem, por isso ainda não se casou. Gabriel, meu compadre, ficava tirando sarro de Ulisses sobre o tamanho de seu pênis, dizendo que era como o pênis do quati, por isso não arranjava mulher. Em Nazaré ele é o único homem de sua idade (53 anos) que não é casado e não tem filhos.

Com relação às mulheres, uma possível interpretação do termo worecü pode contribuir para o entendimento do início da fase casável da mulher. Worecü é o termo utilizado para se referir à moça nova, aquela que teve sua menarca há pouco tempo. Segundo a explicação de Abel Santos Angarita a Valenzuela, a palavra em questão indica uma maturidade do corpo da moça para ter relações sexuais. Vejamos o trecho em que Valenzuela explicita isso. "Worekü es el nombre en tikuna de la muchacha a la que se le realiza la fiesta. En adelante me referiré a ella de esta manera. Su significado profundo, alude a lo maduro: Wore: coito, kü: tercera persona, mujer madura, que ya puede coitar, y por eso hay que preparar el cuerpo para crear seres, el cuerpo del mundo se prepara para que pueda fecundarse y para que sea fértil" (Abel Santos com. pers.)" (2010: 141, nota 160). A maturidade sexual do corpo da moça, portanto, não é um assunto privado. Pelo contrário, é ocasião do maior evento ritual que acontece entre os Ticuna. 


\subsection{1 - Incesto}

Chegamos finalmente ao tópico referente à função que talvez os Ticuna percebam como a mais fundamental de seus clãs, a regulação dos casamentos ${ }^{76}$. Comecemos esta apreciação do sistema de parentesco ticuna, focada agora nas alianças matrimoniais, pelo seu negativo: o incesto. Veremos, no Capítulo 7, sobre a Festa da Moça Nova, que muitos elementos da Festa remetem ao incesto que aconteceu no mito. Mas, principalmente, estas referências ao incesto - tanto na vida cotidiana, como delinearei agora, como sua simbolização na Festa - estão intimamente entrelaçadas com uma educação para os bons modos da moça que está sendo iniciada.

Entre os Ticuna há um tipo de discurso muito difundido que existe também em outras culturas. Trata-se do que Sahlins chamou de "pessimismo sentimental", em poucas palavras, a ideia de que a cultura é um "objeto" em vias de extinção (1997). O "pessimismo sentimental" ticuna sempre insiste que as Festas eram mais frequentes e melhores no passado; a cultura, mais rica; os jovens, mais interessados; a língua, mais fiel aos costumes ticuna; etc. Contudo, além das Festas da Moça Nova, que "estão se acabando", dois elementos da cultura ticuna são eleitos como verdadeiros bastiões da "cultura": a língua - de fato, os casos de ticuna que não falam a língua materna são raríssimos - e o sistema de clãs.

Se há algo escandaloso e sujeito a severas sanções entre os Ticuna é o casamento errado ou Womatchi, casar-se dentro da própria metade. O problema deste tipo de casamento, dizem os Ticuna, é que mistura o mesmo "sangue". A imagem evocada para esta mistura é a da "carne torcida, pensamiento torcido" (Valenzuela, 2010: 92) ou “corpos com carnes trançada.” (Rosa, 2013: 82). Isto é, como nos explica Rosa, trata-se do "efeito da interação de corpos feitos com substâncias similares" (ibdem). As pessoas pertencentes a um mesmo clã são consideradas como possuindo um mesmo "sangue" (Goulard, 2004: 85; Rosa, 2013: 82). Este critério ou "o princípio causal como substância", portanto, identifica todos os clãs de uma mesma metade, de mesmo "sangue", e opõe as duas metades, de "sangue" diferente (Goulard, 2004: 88-89). O

\footnotetext{
76 “[A] função de um sistema de parentesco é gerar possibilidades e impossibilidades de matrimônios (...) ele age como um agente operador num sistema de trocas matrimoniais dentro da comunidade" (LéviStrauss, 1969[1965]: 127).
} 
casamento só é permitido entre pessoas de "sangue" diferente, o que está expresso na diferença entre clãs "com pena" e clãs "sem pena".

Devo lembrar que a moça é colocada em reclusão quando de seu primeiro sangramento, sua menarca. Portanto, mais adiante, principalmente no tópico 4.2 - Sangue e os "males do corpo" (puya) do Capítulo 4, desenvolveremos mais detidamente os desdobramentos da noção ticuna de "sangue", principalmente com relação à menstruação. Por hora, vejamos as origens e as consequências desta união de pessoas do mesmo "sangue", o próprio incesto (Womatchi).

O mito ticuna de origem do incesto não difere em nada do clássico pan-americano. Trata-se de uma narrativa “cuja difusão é pan-americana, já que se encontra desde o Brasil meridional e a Bolívia até o estreito de Bering (e mais além, na Ásia setentrional, no norte da Rússia e na Malásia), passando pela Amazônia e pela Guiana" (Lévi-Strauss, 2004 [1964]: 339). Em meu campo registrei algumas versões deste mito. A versão colhida por Nimuendaju e analisada por Lévi-Strauss (M358, 2006 [1968]: 35, 89-90 e passim) é a seguinte: um menino aproveitou-se da escuridão e do sono profundo de sua irmã e teve relações sexuais com ela.

\begin{abstract}
"Por fim, ela engravidou e teve um filho. Como era costume, ela ralou jenipapo para pintar a criança de negro, e à noite colocou o pote que contém a tintura próxima à sua rede (...). Quando, na escuridão, seu irmão voltou para se deitar com ela, ela enfiou a mão na tintura e esfregou-a sobre o rosto dele. Ele reconheceu o jenipapo pelo seu odor e imediatamente fugiu para a borda da floresta, onde pegou as folhas para enxugar o rosto. Assim que ele jogou fora uma folha suja ela se transformou em um forest turkey, um anum [Crotophaga menor, Gm.], ou algum outro pássaro preto. Então ele foi para o riacho e lavou o rosto. Por esta razão, o Igarapé de São Jerônimo está preto até estes dias. Ele nunca mais foi visto por ninguém, mas subiu para o céu, onde se tornou a lua" $(1952: 143)^{77}$.
\end{abstract}

Segundo Belaunde, este mito tão difundido nas Américas, teria uma função mnemônica do tabu do incesto, ou seja, sugere "que a estória do incesto de Lua seja um mito sobre como a memória torna possível que as mulheres separem irmão de cônjuge

\footnotetext{
77 Ouvi uma explicação deste mito que colocava o herói Ipi, irmão de Yoi, no lugar de Lua. Um ticuna assim me falou: "Na parte de Ipi tem problema, porque ele "mexeu" com a cunhada dele. A mancha da lua é a cara de Ipi. A cunhada dele pintou a cara dele de jenipapo".
} 
(...) o incesto primordial de Lua é a instância fundadora do parentesco humano, já que impõe o domínio da memória" (2006: 225-226). Um dos índices desta memória "fundadora do parentesco humano" é a própria periodicidade da Lua e seu correlato, a periodicidade do corpo feminino. Além da lua, presente nas pinturas no ritual, esta memória é agenciada também pelo fruto desta união incestuosa, a estrela da manhã, filho de Lua e de sua irmã. Um dos nomes do filho de Lua é Womatchi, o próprio termo ticuna usado para designar o incesto ${ }^{78}$.

Womatchi - assim como a Lua, motivos pictóricos recorrentes na Festa, como veremos - é o símbolo da relação com alguém excessivamente próximo. Este mito ticuna, diz Lévi-Strauss, se situa na outra extremidade do mesmo eixo em que está o mito de Monmaneki, que abordaremos no próximo capítulo. Enquanto Lua se relaciona com alguém próximo demais, sua própria irmã, “aquém do grupo social”, Monmaneki casa-se sucessivamente com múltiplas esposas situadas longe demais, "além da própria humanidade" (2006[1968]: 89). Podemos notar - e isso ficará ainda mais claro no próximo capítulo em que compararei a atitude de Monmaneki e do caçador Õtchi - que os Ticuna possuem uma série de mitos que comparam sistematicamente as atitudes dos esposos. Em uma sociedade em que o ritual de iniciação das moças é tão importante ritual este que prepara a moça para o casamento -, não é de se estranhar que o pensamento mítico também reflita esta preocupação. Como afirmei acima, as sanções sobre quem comete o incesto são terríveis e é para elas que olharemos agora.

Deuzenira é uma ticuna nascida na cidade de São Paulo de Olivença. Ela passou a maior parte de sua vida na cidade, morou muito pouco em comunidade, na floresta. Atualmente ela trabalha como técnica de enfermagem no posto de saúde indígena. Quando eu estava em trabalho de campo, no ano de 2012, Deuzenira morava com seu filho, sua mãe e irmãos, todos bastante habituados à vida na cidade. Nesta época, ela já estava separada do marido. Ela me ajudou bastante com algumas traduções de mitos e conversamos bastante sobre o modo de vida dos Ticuna e sobre sua vida também. Ela me disse que sofreu muito preconceito quando souberam que ela estava casada com um rapaz do mesmo clã que ela. Segundo me contou, o rapaz a enganou dizendo que era de um clã de pena, mas não era. Ela engravidou dele e foram morar juntos. Quando ficou sabendo,

78 "Três nomes para a mesma pessoa: Wora, Womatchi e Woremecuri, a estrela da manhã, o filho da lua." (Faulhaber, 2003: 42). 
sua mãe foi buscá-la à força em Tabatinga, onde ela estava morando com o esposo e seu filho havia oito meses. Passaram-se três anos e, desde então, o pai da criança nunca mais viu o filho. Deuzenira diz que seu ex-marido não podem sequer se aproximar. Ela diz que cometeu um grave pecado e que os Ticuna não admitem este tipo de atitude. Perguntei sobre que tipo de perigo um casamento como este pode trazer. Ela me contou que o sobrenatural, os “bichos” (ngo’o) podem pegar e, além disso, é pecado.

Quando estive pela primeira vez em Nazaré, me disseram que, antigamente, um homem havia sido levado por um "bicho" (ngo'o) em Mangueira, comunidade vizinha de Nazaré, porque se casou com uma moça do mesmo clã que ele. Em meu segundo período de campo, depois de quase um ano desaparecido na floresta, ele apareceu para Mariazinha no roçado. Nesta ocasião pude conhecer melhor a história de Ulisses e as diversas acusações que sofreu, uma delas, de cometer incesto ${ }^{79}$. Ouvi também sobre um caso em Santo Antonio do Iça de um rapaz que o "bicho" (ngo'o) levou porque namorava com a prima. Este tipo de histórias, de pessoas que foram levadas pelos "bichos" (ngo'ogü) porque cometeram incesto, se multiplicam entre os Ticuna, ouvi inúmeras delas. Este tipo de atitude é comentada pelos Ticuna como atitude de guariba, de cachorro, numa nítida remissão do ato à animalidade.

Existem alguns seres que são responsáveis por "vingar" a pessoa caso ela cometa incesto. Segundo Oliveira Filho, "[o crime de incesto clânico ou de metade], por sua especial gravidade, é o único em que Taé pode punir o culpado ainda em vida, dando-lhe a alma de um animal e conduzindo-o à loucura" (1988: 143). Ta'é é a deusa responsável por decidir quem passará ou não à morada dos imortais após a morte, "recuperando a condição de imortal (situação que ocorre somente se a pessoa não cometeu wamachi)." (Rosa, 2013: 82-83). O incesto pode levar, portanto, à duas sanções proporcionadas por $T a$ 'e: 1) a condenação a não participar da imortalidade e 2) a "loucura" ainda em vida.

Este estado de "loucura", no limite, conduz a pessoa ao suicídio. Quando um jovem tem seu desejo de casar com outro frustrado isso pode acarretar em suicídio. Ouvi um relato sobre isso em meu campo. Bueno relata a relação causal entre uma onda de suicídios acontecida na comunidade de Campo Alegre e os incestos que aconteciam no local.

\footnotetext{
${ }^{79}$ Faço um relato deste caso mais detalhadamente no Capítulo 3, tópico 3.2.3 - Ulisses, o homem que foi levado pelo demônio.
} 
"É preciso ressaltar que o diagnóstico xamânico de feitiçaria para o caso do suicídio é bastante complexo, no que se refere à proibição do incesto clânico (Womatchi). Isso porque se relacionar com um membro da mesma metade pode acarretar diversos males para as famílias e a comunidade inteira, conforme me foi relatado em diversos casos. Num deles, a informante me conta que encontrou um "bicho", ngo'o, no caminho de sua casa, do qual conseguiu escapar. Depois de um tempo, descobriu que sua irmã estava se relacionando com um membro da mesma nação que elas, o que explica o aparecimento daqueles seres em torno de sua casa. Muitos me afirmaram que a onda de suicídio no final de 2011 em Campo Alegre se deveu ao fato de vários incestos acontecendo na comunidade. "(2012: 23).

Os dois cunhados de Xisto, professor e antigo morador de Vendaval, se suicidaram. Um deles se enforcou. O outro era um pajé feiticeiro, se apaixonou por uma moça, mas o pai dela não quis entregá-la. A moça queria, mas o pai não deixava. Um dia ele tomou timbó e morreu. Filhos de compadre não podem se casar. Como o pai do pajé tinha cortado o umbigo da moça - ou seja, era seu padrinho -, eles não podiam se casar. Não poderia ser sogro e padrinho ao mesmo tempo. Hoje em dia essa regra não opera mais, segundo Xisto. Por fim, o suicídio também é punido pelo demônio Matchi'i. Após este monstro ser morto por Yoi e Ipi, sua alma foi para o “mundo superior. Lá ela ataca as almas incestuosas quando elas chegam. Quando isto acontece, ouve-se na terra o zumbido abafado das vespas de Matchi' $i$ '" (Nimuendaju, 1952: 125).

Feitas algumas considerações sobre o negativo das alianças matrimoniais entre os Ticuna, a noção nativa de incesto, voltemos nossa atenção para a face positiva destas alianças. Começarei por um tipo de aliança menos recorrente, mas que foi analisada em um importante artigo sobre parentesco ticuna.

\subsection{2 - O casamento obliquo composto dos Ticuna}

Apesar de afirmarem que o tipo mais frequente de casamento entre os Ticuna seja entre primos cruzados bilaterais, Goulard \& Barry - autores da última análise que possuo do parentesco ticuna - têm como foco em seu artigo um tipo de casamento bastante recorrente entre os povos ameríndios e da Índia do Sul, o chamado "casamento oblíquo" (1998: 219). Podemos pensar este tipo de casamento como uma união matrimonial intergeracional com algumas possibilidades combinatórias, como Goulard \& Barry atestam em nota. Casamento com a esposa do tio materno (MBW), a esposa do irmão mais velho 
(eBW) ou com a filha do irmão da esposa (WBD) (idem: 233, nota 1). Contudo, os autores estão interessados somente em um tipo de "casamento obliquo", aquele com a filha da irmã (ZD).

$\mathrm{O}$ artigo parte da seguinte premissa: os casamentos que ocorrem em uma determinada geração estão estreitamente relacionados aos casamentos que os precederam ${ }^{80}$. Assim, um modo de "composição de aliança" seria o seguinte, "la repetition entre generations consecutives du mariage MB/ZD aboutit in fine à une union avec la cousine croisee matrilaterale [MBD]" (ibdem). Esta aproximação entre o casamento obliquo e o casamento de primos cruzados não está limitada a uma construção teórica hipotética, dizem os autores. Os dados ticuna nos permitiriam perceber a inscrição do casamento obliquo na própria terminologia. Esta apontaria uma equivalência - "qui ne relèvent pas d'un strict modele dravidien" (idem: 226) - entre primos cruzados bilaterais e a filha da irmã $(\mathrm{FZCh}=\mathrm{MBCh}=\mathrm{ZCh})$, referidos pelo termo $t a-a$.

Contudo, para compreender esta equivalência, não podemos considerar uma única ocorrência isolada de um casamento obliquo e/ou um casamento de primos cruzados bilaterais. Devemos considerar a troca de irmãs $e$ um "casamento obliquo composto", isto é, dois casamentos oblíquos "encaixados" (enkystés, idem: 227):

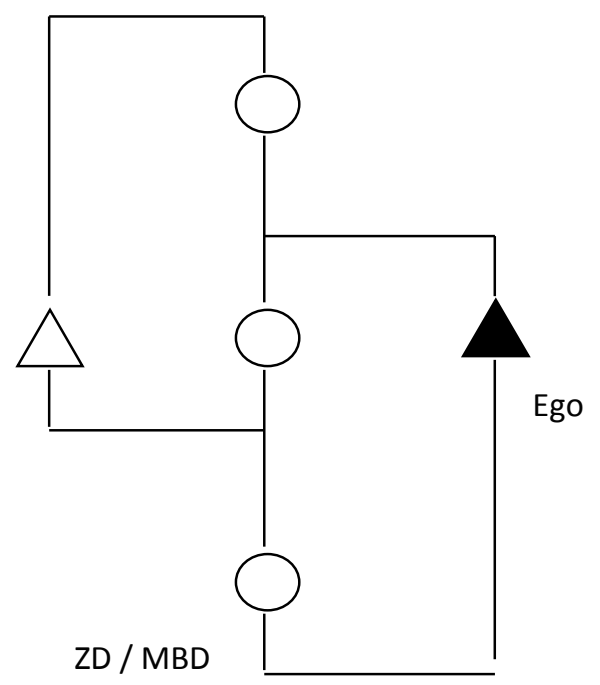

Figura 10 Casamento obliquo composto

\footnotetext{
${ }^{80}$ Goulard \& Barry chamam esta relação de "modo de composição de aliança" (1998: 219). A mesma relação também é apontada por Silva, como sendo um efeito de Hiper Tetris (2010: 192; cf. também Dal Poz \& Silva, 2009: 21), ou seja, o modo como as "peças do jogo" irão se posicionar depende do posicionamento das "peças" que caíram anteriormente.
} 
Nesta figura temos, portanto, uma equivalência entre uma ZD e uma MBD. Assim, esta troca pode ser pensada como a de uma $\mathrm{Z}$ por uma $\mathrm{ZD}$, ou uma troca de $\mathrm{Z}$ por uma MBD. E, segundo o modelo dravidiano, temos a seguinte equivalência $\mathrm{WB}=\mathrm{ZH}$. A figura acima, de um duplo casamento obliquo, também evoca a equivalência $\mathrm{DH}=\mathrm{WB}$. Assim, os autores desdobram as equivalências entre irmão da esposa, cunhado e genro (WB=ZH=DH). Contudo, tal equivalência apontada não encontra respaldo na terminologia. Enquanto WB, ZH são referidos como_ané, DH é chamado_até. Goulard $\&$ Barry argumentam que uma mesma raiz (a) uniria estes termos, mas indicam também, em nota, que as raízes dos termos de parentesco levantadas por eles careceriam de uma análise linguística mais aprofundada (1998: 233, nota 8).

Esboçado o tipo de casamento analisado por Goulard \& Barry, passemos a uma análise da terminologia de parentesco e o que ela pode nos informar sobre o tipo de cruzamento que podemos encontrar entre os Ticuna.

\subsection{3 - Terminologia de parentesco e cálculo de cruzamento}

De acordo com Goulard \& Barry, a terminologia de parentesco ticuna seria essencialmente "um modelo dravidiano, a terminologia de G+1 a G-1 exprimindo claramente a oposição entre consanguíneos e afins" (idem : 220). Contudo, os dados ${ }^{81}$ fornecidos pelos autores apenas nos permitem inferir algumas evidências. Por exemplo, podemos notar que se trata de uma terminologia de "fusão bifurcada" em G+1 para os parentes maternos, ou seja, a irmã da mãe (MZ) é assimilada terminologicamente à mãe $(\mathrm{M}, e ́)^{82}$. Desta forma, os filhos da irmã da mãe (MZ) serão também “irmãos" de Ego (ené $=\mathrm{B}, \mathrm{MZS}, \mathrm{FBS} ;$ eya $=\mathrm{Z}, \mathrm{FBD}, \mathrm{MZD})$. Contudo, isto não vale para o lado paterno, pelo qual Ego herda seu clã. Neste, o FB (népü) não é equacionado terminologicamente ao F (natii), mas as consequências - como podemos ver nas posições definidas pelos termos

\footnotetext{
${ }^{81}$ Ver diagrama no Anexo - 010.

82 Termo que inclui também a WM, isto é, minha "sogra" é, antes de tudo, uma 'mãe'. Acredito que isto deva ter alguma relação com o fato de minha WM ser da metade oposta a de minha W, portanto, da minha metade, possuindo, desta maneira, o mesmo 'sangue' que eu. No meu campo não encontrei esta equivalência de forma tão evidente. Os Ticuna do Brasil me informaram que a posição $\mathrm{MZ}$ corresponde ao termo "tia", do português mesmo. Contudo, não notei este termo sendo usado no cotidiano. Ao mesmo tempo, as consequências da equação $\mathrm{M}=\mathrm{MZ}$ se mantém para $\mathrm{G} 0$, já que os filhos de $\mathrm{MZ}$ são -ené e -eya, respectivamente, irmão e irmã classificatórios.
} 
ené e eya - são as mesmas de um sistema de "fusão bifurcada" para todos os indivíduos de G0, a geração de Ego. Melhor dizendo, mesmo que o irmão do pai não seja nomeado como "pai", seus filhos serão "irmãos" de Ego, da mesma maneira que os filhos da irmã da mãe. Por outro lado, todos os primos cruzados, filhos do irmão da mãe (MB = kuta / $o-e /-t a)$ e da irmã do pai $(\mathrm{FZ}=$ tükü ou kütükü), são classificados com o mesmo termo, ta-a. Mas também as posições em G-1 e G-2: ZS, ZD, SS, SD, DS, DD.

O problema, então, seria a afirmação de que o sistema ticuna é dravidiano. Acredito que para confirmar tal hipótese seriam necessários os termos para toda a geração G-1, para efeito de testar o cálculo de cruzamento dravidiano para esta geração, já que "as terminologias dravidianas e iroquesas classificam os primos de primeiro grau identicamente" (Viveiros de Castro, 1996: 51). Um teste como este poderia nos dar uma resposta segura de que se trata de um sistema dravidiano e não iroquês, já que a diferença entre os dois se dá justamente em G-1. Estes dados foram publicados somente por Cardoso de Oliveira (1983[1961]) e depois confirmados por mim no campo. Entretanto, antes de seguirmos com os cálculos que estes dados nos proporcionam, devemos testar outras hipóteses que podem se mostrar corretas futuramente.

Primeiramente, em ralação a declaração de Goulard \& Barry (1998) temos um impasse. Pois, se de um lado estes autores afirmam uma evidente grade terminológica dravidiana - definindo-a como um agrupamento dos primos cruzados numa categoria única de afins virtuais opondo-se a outra categoria, a dos primos paralelos e irmãos ${ }^{83}$-, Viveiros de Castro é bem categórico com relação à vinculação do dravidianato com metades ou seções, em diversas passagens de seu texto de $1996^{84}$. Levando em conta esta incompatibilidade, tudo leva a crer, então, que o caso ticuna é um tipo de cruzamento

\footnotetext{
83 “''inflexion dravidienne de la terminologie ticuna est, comme nous l'avons déjà souligne, evidente en première lecture: la classification des cousins croises dans une catégorie unique d'affins virtuels, laquelle s'oppose a une autre regroupant parallèles et germains, correspond bien it un tel modele" (1998:226, ênfase minha)

${ }^{84}$ Apenas para citar algumas delas: “... a terminologia dravidiana é inconsistente com metades e/ou sua subdivisão em seções; ela não mostra nem duas 'linhas' nem duas 'seções'; seus conjuntos recíprocos atestam que $\mathrm{F}$ e $\mathrm{M}$ são parente do mesmo tipo, opostos, como paralelos ou consanguíneos, a MB e FZ, ambos cruzados ou afins" (1996: 20), “... acho verossímil a tese de que os sistemas de seções são reificações de superclasses terminológicas (...) Mas tais reificações supõem que a terminologia seja organizada segundo princípios formalmente equivalentes a um cálculo sociocêntrico de 'classes' matrimoniais (...) As classificações do dravidianato, em troca, exprimem um 'método das relações' irredutível ao 'método das classes"” (idem: 23), "... oposição que os sistemas dravidianos não usam, aquela entre 'metades' ou seções paterna e materna" (idem: 24).
} 
iroquês, este sim compatível com metades, terminologia separada de afins ${ }^{85}$ e frequentemente considerado como "nada tendo a ver com regimes de aliança" (1996: 33). $\mathrm{O}$ que regularia o casamento ticuna, portanto, no caso de termos uma terminologia iroquesa, seriam as metades. É o que de fato acontece. O cruzamento iroquês serviria para que então?

Acredito que existam duas chaves para se concluir sobre o sistema ticuna de parentesco. Primeiro, deve-se testar o cálculo de cruzamento. Isto indicará se, de fato, se trata de um cruzamento dravidiano ou iroquês. Uma segunda chave seria compreender melhor a relação entre a terminologia, as metades/clãs e os casamentos. Já que o cálculo iroquês nada tem a ver com a aliança - deixando isso, presumo, a cargo do sistema metades/clãs - e o sistema dravidiano nada tem a ver com as metades.

Vejamos mais de perto a distinção feita por Trautmann (1981: 88) dos dois tipos em questão. "Trautmann explica tal diferença [entre as terminologias dravidianas (D) e iroquesas (I)] pela presença (D) ou ausência (I) de uma regra de casamento de primos cruzados, que se manifestaria na diferença entre os respectivos cálculos de cruzamento e na presença (I) ou ausência (D) de uma terminologia separada de afinidade" (Viveiros de Castro, 1996: 16-7 - grifo meu). Temos aqui, portanto, a indicação de uma aparente mistura de características dravidianas e iroquesas na terminologia ticuna. Ela apresenta, de acordo com as etnografias, uma regra de casamento entre primos cruzados, característica dos sistemas dravidianos ${ }^{86}$. Lembrando que estes são equacionados terminologicamente aos $\mathrm{ZCh}$, o que favorece o casamento avuncular. Contudo, a partir do casamento, Ego adotará toda uma nova terminologia para designar seus afins, característica dos sistemas iroqueses ${ }^{87}$. Se estamos lidando com uma terminologia iroquesa, como explicar, então, a predominância dos o casamento entre primos cruzados? E se tratasse de uma terminologia dravidiana, como ela se relaciona com estes dois traços "iroqueses" na terminologia ticuna: a terminologia para afins e o sistema de metades?

Parece-me que Scheffler (1971) consegue matizar a diferença dizendo que "há sistemas com cruzamento dravidiano e com termos separados de afinidade; e há sistemas

\footnotetext{
${ }^{85}$ Ver terminologia de afins ticuna no Anexo - 009.

86 “... le cas d'un mariage entre cousins croises bilateraux, la forme d'union la plus courante chez les Ticuna..." (Goulard \& Barry, 1998: 221).

87 “Il convient egalement de souligner un trait global que le vocabulaire ticuna partage d'ailleurs en commun avec un certain nombre d'autres groupes amerindiens, à savoir la primauté de l'expression de l'affinité réelle (beaux-parents) sur l'affinité virtuelle ("parents" croises)" (Goulard \& Barry, 1998: 221)
} 
iroqueses com algumas equivalências entre cruzados e afins" (apud Viveiros de Castro, 1996: 45). Mas qual seria o caso ticuna, o primeiro ou o segundo? Talvez não seja nem um nem outro e estejamos tratando de uma variante intermediária entre os dois ${ }^{88}$. Pode ser que estejamos tratando de uma mistura ou sobreposição dos dois tipos, mas com "uma base comum" (idem: 47). Um dado teórico importante é que o cruzamento na terminologia ticuna - seja ele dravidiano ou iroquês - tem uma estreita relação com o sistema de alianças ${ }^{89}$. Então, para que servem as metades se as possibilidades de aliança já estão definidas na terminologia? Conforme formos explicitando certas relações entre a organização social e o ritual, como o pertencimento clânico de alguns instrumentos musicais, veremos que a articulação entre as metades transcende a troca matrimonial, envolvendo diversas prerrogativas rituais recíprocas.

Oscilando entre estes dois tipos, portanto, teríamos duas opções. O sistema ticuna seria um sistema iroquês com uma terminologia que sugeriria uma "identificação entre cognação cruzada e afinidade" (1996: 50). Podemos notar, entretanto, que o tipo de equação $\mathrm{MB}=\mathrm{WF}$ não se encontra na terminologia ticuna. Seria isso uma evidência de que as trocas de irmãs não são repetidas em gerações consecutivas e, portanto, trata-se de um sistema iroquês (idem: 51)? Mas os primos cruzados de fato não 'funcionam' como cônjuges? Isso pode estar na regra de casamento, como afirmam Goulard \& Barry. Entretanto, as análises computacionais feitas sobre redes genealógicas mostram que a frequência de casamentos entre cognatos de qualquer tipo é muito baixa ${ }^{90}$ mesmo para sistemas dravidianos. Além disso, muitas posições de primos cruzados coincidem com indivíduos da mesma metade de $\mathrm{Ego}^{91}$, o que os coloca fora das possibilidades matrimoniais, pendendo o sistema para um tipo iroquês. Continua, desta maneira, o

\footnotetext{
88 “Existe além disso uma notável variedade interna aos dois tipos[, dravidiano e iroquês] (...), bem como uma quantidade de formas de transição registradas pela etnografia, o que sugere que estamos operando com modelos ainda excessivamente próximos de paradigmas empíricos arbitrariamente escolhidos como tipos-ideias" (Viveiros de Castro, 1996:47)

89 “... o 'cruzamento' deve ser visto como uma propriedade derivada de uma estrutura de aliança” (1996:48). Frase que faz eco a definição de Lévi-Strauss (1965) de para que serve um sistema de parentesco, identificar pessoas casáveis e não casáveis.

90 Ver Houseman \& White, 1998: 229, para uma análise das seguintes genealogias e sua frequência de casamentos cognatos: Makuna, Yanomami, Pakaa-Nova, Parakana, Trio, Waimiri-Atroari, Guahibo, Xavante e Suya. Para uma atualização da análise da rede Waimiri-Atroari, ver Matarezio Filho, 2014: 7987.

${ }^{91}$ Indiquei na terminologia de parentesco (Anexo - 008).
} 
problema da incompatibilidade da terminologia iroquesa com o (suposto) casamento de primos cruzados de primeiro grau (ibdem).

Estamos analisando, deste modo, um dravidianato com termos separados de afinidade? Segundo Viveiros de Castro (1996: 48), na Amazônia este tipo de combinação é até bastante comum. Seria um argumento que apoiaria a tese de Goulard \& Barry (1998), de que o sistema de parentesco ticuna é um dravidianato com termos separados de afinidade. Mas, e como ficam as metades neste sistema? Se há um impedimento formal de uma grade iroquesa operar com "o casamento de primos cruzados de primeiro grau" (idem: 51), temos tudo para acreditar que se trata de um tipo de cruzamento dravidiano que opera entre os Ticuna. Mas existiria um impedimento formal do dravidianato operar com metades e uma terminologia de afins? De acordo com Viveiros de Castro, não. A questão está, acredito, em inserir o sistema de parentesco ticuna nesta "estrutura de aliança mais geral" da qual fala este autor (ibdem).

Tendo examinado as possibilidades do sistema iroquês, minha segunda hipótese aproximaria a terminologia dos Ticuna, nas palavras de Viveiros de Castro, de uma "estrutura aranda-dravidiana" (1996: 54). Ou seja, um cálculo de cruzamento dravidiano compatível com classes matrimoniais. Neste caso teríamos o exemplo etnográfico de um perfeito tipo intermediário entre o ‘dravidiano clássico’ e o iroquês, mas com o elemento das metades dos sistemas australianos ${ }^{92}$. Uma variante sociocêntrica do dravidianato caracterizada pelo cruzamento dravidiano (ao menos em G+1 e G0) e as metades exogâmicas -, com uma inflexão iroquesa - caracterizada pela presença dos termos separados de afinidade ${ }^{93}$.

O caso australiano pode nos iluminar a questão da junção de um sistema de metades com uma terminologia dravidiana. O fato é que existe a possibilidade das metades ticuna serem apenas "uma linguagem cômoda para descrever o sistema matrimonial" (1996: 75-6), mantendo-se uma grade terminológica egocentrada dravidiana. Entretanto, talvez não seja uma questão de comodidade, mas de confusão

\footnotetext{
92 “... presença de termos separados de afinidade (que criam o ternarismo 'paralelos / cruzados / afins') (...) creio que se pode concluir estarmos diante de uma variante sociológica (e ocasionalmente terminológica) do dravidianato, que se localizaria a meio caminho entre o dravidianato clássico - o qual 'tenderia' para a variante sociocêntrica dos sistemas australianos - e os sistemas de tipo iroquês" (1996: 74).

93 "Em ambos os casos [dravidianato e iroquês], o casamento é regulado pela terminologia e por instituições sociais diversas" (1996: 66).
} 
entre duas ordens. A meus ver, e concordando com Viveiros de Castro, a terminologia regularia o sistema matrimonial. O sistema clânico seria mais afim com a regulação das trocas de prerrogativas rituais, de cantos, festas, uso de máscaras, instrumentos musicais. As metades não são terminologicamente reconhecidas pelos Ticuna, apesar de poderem ser distinguidas em "com pena" e "sem pena".

Reforçando este argumento temos uma característica da onomastica ticuna. Ela remete diretamente à filiação clânica e, portanto, a uma das metades. Pelo fato de os nomes serem apenas termos de referência, e não vocativos, faz todo sentido a "convivência" de um sistema de metades com uma terminologia dravidiana. Pude notar isso em campo e meus dados estão de acordo com os de Goulard (2009), ou seja, os termos de parentesco são usados como vocativos com mais frequência que o nome clânico. Este, apesar de também usado como vocativo, é mais usualmente um termo de referência ${ }^{94}$. Retomemos a hipótese da inflexão australiana no sistema ticuna, com um exemplo sul americano.

Pode ser que tenhamos algo semelhante ao que acontece no sistema de parentesco dos Matis, grupo de língua pano habitante da Terra Indígena do Vale do Javari, muito próxima do território ticuna. No sistema de parentesco destes índios, temos uma terminologia vocativa derivada das regras de transmissão de nomes. Contudo, a terminologia referencial seria uma "coexistência de equivalências australianas e de um núcleo dravidiano" (1996: 77). Poderíamos pensar o caso ticuna como uma onomástica que opera com uma regra "australianóide" - filiando um indivíduo a um clã/metade - e uma terminologia referencial também com um núcleo dravidiano. Muitas terminologias pano, assim como a ticuna, "exibem conjuntos mais ou menos completos de termos separados de afinidade" (1996: 78). Temos, com isso, exemplos amazônicos de coexistência de esquemas australianos e dravidianos.

Além disso, devo acrescentar que o sistema terminológico ticuna apresenta uma espécie de efeito semi-complexo (1996: 80), já que equaciona terminologicamente (-taa) as seguintes posições: FZS, FZD, MBS, MBD, ZS, ZD, SS, SD, DS, DD, etc. Ou seja, os primos cruzados são designados pelo mesmo termo que os ChCh e os ZD, ZS, na

\footnotetext{
${ }^{94}$ El nombre se pronuncia con modo vocativo en forma elíptica (...) También, y con más frecuencia, la primera sílaba de los términos que definen los términos de parentesco se utiliza según este modo (...) En todo caso, el nombre clánico es utilizado con más frecuencia como término de referencia" (Goulard, 2009: 91, grifo meu).
} 
terminologia dos consanguíneos. Com isso, são três gerações (G0, G-1 e G-2) que comportam alguma posição com o mesmo termo (-ta-a). Três gerações de parentes terminologicamente desposáveis, de acordo com a "preferência" matrimonial entre primos cruzados (Goulard \& Barry, 1998). Este dado da terminologia aparentemente nos autoriza a transpor o raciocínio de Viveiros de Castro sobre os povos tupi-guarani para o caso ticuna. Parece-me que os primos cruzados ticuna, devido à variabilidade de posições que nomeia, também são bastante "instáveis", marcando "uma espécie de 'valor zero', ou 'casa vazia' que é preenchida diferencialmente" (1996: 81) ${ }^{95}$. A terminologia parece indicar isto, esta "instabilidade". Contudo, isto seria uma característica, diz Viveiros de Castro, do padrão "dravidiano concêntrico", que ele define por oposição ao "arandadravidiano" (ou "dravidiano quase-diametral”, Viveiros de Castro, 1996: 83). Seria, então, o parentesco ticuna uma sobreposição de uma estrutura "aranda-dravidiana" refletida na onomástica e na organização clânica/metades - com uma estrutura terminológica "dravidiana concêntrica", apresentando um termo para primos cruzados que se replica em três gerações?

Como havia dito, os dados de Goulard \& Barry não nos permitem inferir de que tipo de cruzamento se trata a terminologia ticuna. Meus dados de campo tornam possível este cálculo e reforçam os dados apresentados por Cardoso de Oliveira, a classificação dos parentes em G-1, em um artigo publicado pela primeira vez em 1961. Afirma este autor que a terminologia ticuna é do tipo "Dakota-Iroquês" (Cardoso de Oliveira, 1983: 63), mais especificamente tipo "Dakota", por possuírem clãs patrilineares. Existiria, portanto, um perfeito encaixe entre a "terminologia de primos Iroquês" e a divisão em metades. Em suas palavras, "[p]or força do matrimônio de seus genitores, e devido à filiação patrilinear, os primos cruzados pertencem à metade oposta de Ego, ao contrário dos paralelos que, pelos mesmos motivos, pertencem a sua própria metade" (Cardoso de Oliveira, 1983 [1964]: 95). Podemos observar isto no digrama que destaca os indivíduos da mesma metade de Ego (Anexo - 008).

Nota-se, na terminologia fornecida por este antropólogo, uma mistura da terminologia dos consanguíneos com a terminologia separada para os afins. Por exemplo,

\footnotetext{
95 "Tudo isso sugere que uma instabilidade geral na posição dos primos cruzados para os sistemas tupiguarani, uma espécie de 'valor zero', ou 'casa vazia' que é preenchida diferencialmente em cada um dos três padrões básicos" (1996: 81).
} 
à posição $\mathrm{MZ}$, o artigo de Goulard \& Barry atribui o mesmo termo utilizado para $\mathrm{M}^{96}$, Cardoso de Oliveira atribui o termo -népümâ, indicado pelos autores franceses, e confirmado por mim em campo (cf. diagrama de afins, Anexo - 009), com a posição afim FBW. Penso que podemos desconsiderar a classificação do sistema ticuna como "DakotaIroquês". A definição dada pelo autor é insuficiente, esse tipo de sistema é definido apenas desta maneira: ““"Dakota-Iroquês, em que o Irmão da mãe é chamado “Tio” e seus filhos "Primos", e em que a irmã do Pai é chamada "tia" e seus filhos "Primos"” (Cardoso de Oliveira, 1983 [1961]: 63), o que obviamente não dá conta da complexidade do sistema terminológico ticuna ${ }^{97}$.

Entretanto, se compararmos a terminologia coletada por mim em campo com os cruzamentos dravidiano e iroquês, principalmente em G-1, geração em que é possível distinguir os dois tipos de cruzamento, notaremos que nenhum dos dois se adéqua. $\mathrm{O}$ problema se encontra nos descendentes dos primos cruzados, principal distinção entre os dois tipos de cruzamento, todos indistintamente classificados com o termo $-t a-a$. De acordo com a classificação que encontrei entre os ticuna, corroborando os dados de Cardoso de Oliveira, e levando em conta os tipos de cruzamento organizados por Viveiros de Castro (1996: 62) é possível deduzir que o cruzamento ticuna é do tipo kuma, ao menos em relação a G-1. Este tipo de cruzamento é caracterizado por uma maior multiplicação dos afins de Ego em G-1.

Por fim, estabelecido este cruzamento, gostaria ainda de registrar uma última hipótese. Considerando que o casamento entre primos cruzados tem pouquíssima influência sobre o sistema ticuna, levando em conta duas características marcantes deste sistema - metades exogâmicas e terminologia separada de afins - e estabelecendo o tipo de cruzamento da terminologia, uma definição sucinta do sistema terminológico ticuna poderia ser um tipo "kuma-iroquês".

Este primeiro capítulo apresenta um panorama, digamos, bastante denso do parentesco ticuna. Para seguirmos adiante no texto, no entanto, alguns pontos devem ser destacados, pois reaparecerão em momentos importantes, outros nem tanto. A forma

\footnotetext{
96 Mais condizente com a "fusão bifurcada" em G0. Contudo, a terminologia ticuna, como vimos, não funde as posições $\mathrm{F}$ (-natü) e FB (-népü).

97 Devemos levar em conta que nesta época em que escrevia seu artigo, não se tinha nitidamente definidos os tipos de cruzamento terminológico como temos hoje. A distinção, por exemplo, entre "os tipos iroquês e dravidiano em função de seus respectivos cálculos de cruzamento" seria feita pela primeira vez somente em 1964, por Lounsbury (apud Viveiros de Castro, 1996: 14)
} 
como se originaram os Ticuna nos acompanhará por toda a tese. A relação entre o corpo, nome e clã é a base para compreendermos a elaboração do corpo que se pretende com a Festa da Moça Nova. Principalmente, devemos ter em mente que este ritual está estreitamente relacionado com a regulação do casamento e o incesto. Passemos agora a uma consideração mais detalhada da mitologia dos Ticuna. 


\section{Capítulo 2 - Mitologia}

"Eles [os mitos] não se parecem em nada, ou melhor, se parecem na medida em que diferem de vários modos, e são esses modos de diferir que se parecem” Lévi-Strauss, O Homem Nu, p.199

Neste capítulo tratarei principalmente dos mitos que mantêm uma relação mais estreita com a Festa: a história de Ngutapa e Mapana, o casal primordial, registrada no mito de origem dos Ticuna; o mito de To'oena, a primeira moça nova; o mito das cobras Tautchipé e Yewae; e a relação entre as histórias dos heróis Monmaneki e Metare. Antes de começar a análise destes mitos, no entanto, cumpre ainda situar o sistema mítico ticuna numa paisagem mais ampla. Pensando as duas Américas como um grande grupo de transformações que encadeia todas as narrativas míticas de seus povos originários (ver Descola \& Matarezio Filho, 2013), abordarei algumas questões relativas a inserção dos mitos ticuna no grande sistema transformacional mítico da América, delineado por LéviStrauss nas Mitológicas.

\section{1 - A passagem para a América do Norte}

Não é um mero acaso que Lévi-Strauss tenha iniciado o livro A Origem dos Modos à Mesa com um mito Ticuna. Por este povo ocupar uma posição "mais setentrional" na América do Sul, ele imporia uma "passagem de um continente ao outro" (2005 [1988]: 191). A análise dos mitos ticuna deve levar em conta que a mitologia deste povo opera a transição entre as mitologias da América do Sul e do Norte. Se em O Cru e o Cozido o eixo privilegiado é o espacial, em A Origem dos Modos à Mesa - livro que inicia a incursão da análise para as terras mais setentrionais do continente - o eixo temporal está em primeiro plano. Isso demonstra que os mitos ticuna fazem uma passagem para a América do Norte, sendo, portanto, a comparação entre os continentes passando por estes 
mitos bastante frutífera. Uma das evidências desta passagem são os comentários de LéviStrauss sobre o mito "Os erros de Tchimüdyuë"” (Nimuendaju, 1952: 148-150), narrativa que está à beira de se assimilar ao gênero romanesco, devido à exploração do eixo temporal aos moldes deste gênero ${ }^{98}$, algo que aparece mais nas narrativas dos índios norte-americanos. Tal ponto de vista do antropólogo francês, portanto, nos autoriza a explorar ainda mais as comparações com os mitos dos norte-ameríndios ${ }^{99}$.

O mito nez-percé (Lévi-Strauss, 2011 [1971], M602B e M602C), por exemplo analisado no capítulo Peixes Solúveis d'O Homem $\mathrm{Nu}$-, conta a história de um desaninhador que "atravessou as nuvens e pôs o pé num mundo "igualzinho à nossa terra". Como vimos no capítulo anterior, Ipi não chega a tanto, mas assim como o herói CoioteFilho, do mito nez-percé, ele é "retardado pelos obstáculos" que seu irmão faz crescerem no jenipapeiro, justamente para ele não subir mais e chegar à "outra terra". "Coiote fica cansado, sofre com o calor, tem sede e se deixa seduzir pela água refrescante de um rio que o leva até as donas dos salmões. Elas o recolhem e adotam, depois de ele ter assumido a aparência de um bebê. Mas Coiote fura a barragem e libera os peixes" (idem: 348). No mito ticuna, depois que a massa de jenipapo é jogada na água, nada sabemos do destino de Ipi até sua volta, quando sua esposa sente sua falta e (quase) o pesca. A passagem de Coiote bem poderia ter acontecido a Ipi. No fim das contas, a massa de Ipi origina os matrinxãs ${ }^{100}$ ou piabinha (tonõniacü), dependendo da versão, e o próprio Ipi aparecerá como um peixe. Ambos os mitos, portanto, tratam da origem dos peixes. No caso de Ipi, até algo mais, pois ele traz ouro na ponta de seu nariz, em outras narrativas ele traz roupas

\footnotetext{
98 Sobre o encadeamento sintagmático preciso, característico das narrativas míticas, Lévi-Strauss faz o seguinte comentário para o caso do mito de Tchimüdyuë’: “Não poderíamos obter nada de comparável no caso das aventuras de Cimidyuë, pois com exceção de alguns marcos esparsos e difíceis de articular, o número dos episódios, a ordem na qual estão dispostos e os tipos a que pertencem parecem resultar de uma invenção mais livre, pronta para se liberar das imposições do pensamento mítico, se é que já não o fez. Em outras palavras, podemos nos perguntar se a história de Cimidyuë não ilustraria uma passagem significativa do pensamento mítico para o gênero romanesco, cuja curva é mais flexível e não obedece às mesmas determinações." (2006 [1968]: 106).

99 Lévi-Strauss é bem explicito sobre esta necessidade de se comparar certas narrativas ticuna com os mitos norte-americanos ao mencionar o mito ticuna que conta a história do caçador Monmaneki. "[U]m episódio se destaca no mito tukuna escolhido como referência, no qual uma esposa humana, cortada em dois pedaços, sobrevive parcialmente se agarrando às costas do marido. Este episódio, impossível de interpretar a partir da cadeia sintagmática, e que o conjunto da mitologia sul-americana não esclarece, só pode ser elucidado se for remetido a um sistema paradigmático tirado dos mitos da América do Norte. A transferência geográfica impõe-se, assim, empiricamente." (2006 [1968]: 11).

100 Designação regional comum dos peixes do gênero Brycon.
} 
e panelas (Goulard, 2009). Portanto, trata-se de originar algo materialmente valioso, sejam peixes ou ouro. Outra narrativa, o mito do caçador Monmaneki ${ }^{101}$, é indicada por Lévi-Strauss como a origem dos peixes dos Ticuna. Neste mesmo sentido, o autor mostra a conexão que o tema da origem dos peixes faz com os mitos da América do Norte: "Monmaneki cria os peixes a partir de aparas de madeira, tema bastante conhecido alhures, mas cuja área de distribuição, assim como a do tema do homem de pênis longo, engloba as tribos mais setentrionais da América do Norte: Esquimós, índios da costa noroeste e da bacia do rio Colúmbia." (Lévi-Strauss, 2006 [1968]: 73).

Ao que tudo indica, assim como os mitos "dos Klamath-Modoc até os Salish, os quais todos, e de modo homólogo a M1" (Lévi-Strauss, 2011 [1971]: 350), os mitos ticuna "calam ou subentendem a origem do fogo, mas fazem da chuva, da inundação ou de seu equivalente funcional o meio empregado pelo herói para se proteger ou se vingar" (ibdem). A referência que temos é que, após a saga de Yoi e Ipi, o mundo sofre uma série de inundações, que só cessam depois da proibição do incesto com a instauração dos clãs. $\mathrm{Na}$ verdade, existe um mito ticuna que narra a origem do fogo ${ }^{102}$ (Lévi-Strauss, 2004 [1964], M54), mas penso que este acontecimento deve ser localizado antes do nascimento de Yoi e Ipi. Já o mito do Genro do Jaguar (idem: $\mathbf{M}_{53}$ ) - em que um jaguar convida seu genro para comer carne de caititu extremamente apimentada, contribuindo para que ele se torne jaguar (Lévi-Strauss, 2004 [1964]: 153) - se situa depois da origem da caça, que é pescada por Yoi como peixes e se transformam em animais de caça.

Com relação ao fogo, durante as aventuras de Yoi e Ipi, o fogo não é qualificado como culinário. Trata-se, assim como os mitos nez-percé, "não de um fogo doméstico, mas de fogueiras ocasionais" (Lévi-Strauss, 2011 [1971]: 349). Chegamos, então a uma explicação do porquê as narrativas sobre Yoi e Ipi não tratam da origem do fogo. Sendo um desaninhador de frutas, Ipi e seu irmão protagonizam as histórias que originam os adornos, a carne de caça e humana ${ }^{103}$. Ou seja, como muitos mitos norte-americanos, "dos

\footnotetext{
${ }^{101}$ Uma grafia mais atual do nome deste herói seria Mõmanecü. Na versão que coletei deste mito, bem menor que a de Nimuendaju, o caçador é chamado Moe. Este mito também está registrado em Oliveira Filho (1985: 85) e foi retraduzido em Vasques (2010: 42). Analisaremos esta narrativa adiante, neste mesmo capítulo, comparando-a com a história do caçador Õtchi.

102 Não encontrei referências a este mito em campo.

103 Há uma versão ticuna do "desaninhador de pássaros", mas difere bastante do motivo sul-americano. Nesta versão, ao invés de um dos personagens subir e o outro ficar embaixo, os dois irmãos sobem para matar um gavião-real. Ver Nimuendaju, 1952: 124; e Goulard, 2009: 396.
} 
Klamath aos Salish meridionais" (ibdem), as narrativas dos gêmeos ticuna marcam a "passagem", dentro do conjunto de narrativas ticuna, "da categoria de cru para a de $n u$, e associa a cultura menos à origem da culinária do que à do vestuário" (Lévi-Strauss, 2011 [1971]: 350). No mito que Severino me contou sobre a origem do dia (Anexo - 004), com a derrubada da samaumeira que tapava o sol, Ipi sobe o rio que foi criado pelo tronco da grande samaumeira e traz consigo as roupas ${ }^{104}$. Afinal, naquele tempo "ninguém tinha roupa, só tanga”. Neste mito temos mais uma vez a associação de Ipi com o ouro. Na versão de Goulard (2009) ele é um peixe com o nariz dourado. Nesta mesma versão, este herói quando sai da água traz muitas coisas também, panelas, etc. O relato da origem do dia se encontra, não por acaso, no meio do mito de origem dos Ticuna. Desta maneira, os adornos, as roupas e, principalmente, a pintura de jenipapo e a regra de exogamia clânica virão em seguida.

Retomando as semelhanças com os mitos dos Nez-percé, o grupo ${ }^{105}$ a que pertence o mito $\mathrm{M}_{661}$ é considerado como possuidor de uma armação "rigorosamente simétrica à da história do desaninhador de pássaros". Em alguns dos mitos deste conjunto a história do desaninhador é seguida da liberação dos peixes, sequência que podemos notar no mito ticuna. Além disso, a caça também é criada neste mito, pois são pescados antes dos humanos (Lévi-Strauss, 2011 [1971]: 329-330). A questão das vestimentas também é uma importante chave para se compreender o mito do desaninhador. Lévi-Strauss chega a comentar que nas versões norte-americanas deste mito, "a retirada do vestuário pelo herói representa um traço invariante". Algo que nos faz pensar no fato de Ipi ter, na versão de Goulard (2009), se "vestido" com a fruta do jenipapo. O herói entra e se fecha dentro do jenipapo, em seguida, ainda dentro da fruta, ele se joga para baixo da árvore. Ele se "veste", portanto, com a própria substância na qual irá se transformar. Algo mais próximo da ideia de ingerir as próprias roupas (motivo norte-americano), do que a atitude típica do desaninhador, despir-se ${ }^{106}$. Ipi, diferente do desaninhador clássico, não se despe nem

\footnotetext{
${ }^{104}$ Existem registros de diversas versões deste mito, coletei algumas em campo também. Ele se insere na grande narrativa de origem dos Ticuna. Ver Nimuendaju (1952: 124), Goulard (2009), Oliveira Filho (1988), Gruber (1998).

105 Que inclui as narrativas dos Salish da costa, dos Chinook e dos Sahaptin limítrofes (Lévi-Strauss, 2011 [1971]: 329-330).

106 “... pelo fato de ingerir suas próprias roupas, pode-se dizer que ele se veste por dentro, ao passo que o desaninhador, que tira as suas, se despe por fora. E pela mesma razão o herói de M661 se alimenta do de fora - pois que as roupas envolvem o corpo - enquanto o desaninhador, que definha e não tem nada para comer a não ser a própria substância, se alimenta do de dentro" (Lévi-Strauss, 2011 [1971]: 331).
} 
definha. O herói se transforma em água (Goulard, 2009), no que malogra, ou formiga (Oliveira Filho, 1988) para descer da árvore.

Parece-me que os Ticuna possuem uma espécie de "natureza" vegetal, pois são uma transformação da massa de jenipapo. O que é atestado pela etnografia de Goulard (2009) também, sobre os Ticuna do Perú. Este autor menciona a "metáfora vegetal" usada para se referir à "moça nova" quando ela está em reclusão. Em muitos momentos ela é referida como uma flor desabrochando. Além disso, os heróis, ao subirem na samaumeira que Yoi encolhe para desaninharem os filhotes de gavião-real e matá-los, eles se transformam um em uma bola de látex negra, o outro num chumaço de algodão branco ${ }^{107}$. Dois gaviões são mortos e jogados para baixo, para suas irmãs depená-los, dando origem assim aos adornos de pena. Ao subir no jenipapeiro, Ipi também origina um tipo de adorno, a pintura corporal de jenipapo. Na canção do tamborim tutu a moça nova também é referida com esta "metáfora vegetal”. Ao interpelar o "dono da festa” (yü'ünatü, yü'ü= festa, natü = dono /pai), que é o pai da moça nova, o cantor afirma, "tua flor, tua flor" (curitchacu, curitchacu), "tua filha, tua filha" (curiacü, curiacü) ${ }^{108}$.

Notemos que a ralação do próprio corpo de Ipi e sua transformação em jenipapo tem relação com o mito bororo $\mathrm{M}_{20}$, em que "os heróis se incineram voluntariamente" (Lévi-Strauss, 2004[1967]: 24). Neste, os heróis pegam fogo e se transformam em pássaros, das cinzas nascem algumas plantas (Lévi-Strauss, 2004 [1964]: 119-20). Tratase, nas palavras de Lévi-Strauss, de um "procedimento duplamente "ultra-culinário", que mantém, assim, uma relação suplementar com seu resultado: o surgimento dos adereços e adornos, igualmente "ultra-culinários", pois estão do lado da cultura, enquanto a cozinha é uma atividade técnica que faz a ponte entre a natureza e a cultura" (Lévi-Strauss, 2004[1967]: 25).

Poderíamos dizer que o procedimento de $I p i$ - assim como as atitudes dos heróis bororo que se incineram e dão origem aos adornos dos clãs - é duplamente "ultraculinário"? Acredito que sim. Ipi chega a pegar fogo, ao cutucar um tatu defumado. Ele

\footnotetext{
107 Nas narrativas de Nimuendaju (1952: 124) e Goulard (2009: 396) aparece esta cena de desaninhador "clássico", mas não excluem o desaninhamento do jenipapo mais adiante. Na versão de Nimuendaju, Yoi se transforma em macaco da noite e Ipi em gambá.

${ }^{108}$ Canção do tutu, o tamborim tocado na Festa da Moça Nova.
} 
tocou o tatu "com um pau, lambeu os dedos e se queimou como um tronco seco. Não restou mais que cinzas" (Goulard, 2009: 397). Ao ralar o jenipapo e além, ralando a si mesmo, o herói do mito ticuna dá origem ao liquido que será utilizado para pintar (adornar) seu filho. Ou seja, um procedimento culinário - utilizado, p.ex., na ralação da mandioca - que, em seu excesso (pois que rala o corpo inteiro de Ipi) origina a tintura do jenipapo. E a mesma borra de jenipapo que originará o povo Magüta, que são pescados com isca de macaxeira; e também dá origem à carne de algumas caças (queixada e porcodo-mato - objetos duplamente "infra-culinários"), pescados com isca de tucumã. Principalmente, todas estas transformações, ao contrário do que acontece em $\mathrm{M}_{15}, \mathrm{M}_{16} \mathrm{e}$ M20 (Lévi-Strauss, 2004 [1964]), são mediadas pela água, não pelo fogo. A origem dos porcos-do-mato, diz Lévi-Strauss, "recorre, como meio, a diversas substâncias, que mostramos serem variantes combinatórias da fumaça de tabaco" (2004[1967]: 27). Contudo, como vimos, o meio de origem para os porcos-do-mato, no mito ticuna, é a água.

Deste modo, ao analisar variantes do mito do desaninhador presentes em todo o continente americano, Lévi-Strauss conclui que "a armação pan-americana de A [o mito do desaninhador de pássaros] lhe permite evocar alternadamente a origem da água (M1) ou do fogo (M7-M12)" (2011 [1971]: 250). No entanto, o desaninhador ticuna não evoca nem a origem da água, nem a do fogo. Certamente por não se tratar de um desaninhador, mas de um apanhador de frutos, precisamente, um único fruto de jenipapo. Uma inversão interessante que acontece neste mito ticuna é a dificuldade que Yoi impõe à subida de Ipi no jenipapeiro. Diferente dos desaninhadores clássicos, que, em geral, são impedidos de descer, Ipi é atrapalhado em sua subida, de todas as formas, mas desce até que com certa facilidade e esperteza. A certa altura de $\mathrm{O}$ Homem $\mathrm{Nu}$, Lévi-Strauss mostra a relação de homologia que existe entre "o ciclo sul-americano do desaninhador de pássaros e o que se refere à introdução da vida breve" (idem: 257). Podemos considerar o mito de origem dos ticuna menos como um mito de origem de uma etnia do que como um mito que narra como os mortais surgiram, ou seja, a "introdução da vida breve". Assim, os mortais são derivados de peixes que, por sua vez, derivam do bagaço do jenipapo. Contudo, o caldo do jenipapo ralado por Ipi ficou com os imortais e foi utilizado para pintar seu filho. Então, esta separação coloca de um lado os mortais (bagaço de jenipapo + peixes) - que terão que pegar mais jenipapo para se pintarem, como que complementando algo que foi perdido no mito - e os imortais que já se beneficiaram dos efeitos do jenipapo. 
Veremos adiante, no Capítulo 7, tópico 7.3 - Convite e troca ritual, que esta inversão presente na mitologia ticuna - mitos que originam a carne tornam-se mitos que originam os adornos - encontra uma transformação correspondente no padrão de trocas rituais entre os sul-ameríndios. Ao invés de os convidados trazerem carne moqueada para ser trocada por bebida oferecida pelos anfitriões, os convidados ticuna trazem os materiais usados na confecção dos adornos, que são oferecidos em troca de bebida e carne moqueada.

Até aqui podemos notar que Ipi, o enganador ticuna, é um personagem central na mitologia deste povo. A partir deste personagem podemos estabelecer uma estrutura mítica inspirada no Grupo de Klein $\left(\mathrm{X},-\mathrm{X}, \mathrm{X}^{-1},-\mathrm{X}^{-1}\right)$, tantas vezes demostrada por LéviStrauss como correspondendo a uma possibilidade de transformação dos mitos ameríndios. Ipi é o mediador, ele faz a transição entre o mundo dos imortais e dos mortais, passando pelo mundo subaquático. Não se torna ele mesmo um mortal, mas é de sua substância, a massa de jenipapo que se originam os peixes que serão pescados já como humanos. $\mathrm{O}$ anti-mediador pode ser pensado como sendo o demônio (ngo-o) mítico Machi'i, já que ele morre ao atingir a fruta de abiu, não tem sucesso em sua colheita, é ferrado por diversos bichos peçonhentos ${ }^{109}$, exatamente o contrário do que acontece com Ipi. Representa o próprio curto-circuito entre natureza e cultura em si, lugar ocupado pelo veneno na mitologia ameríndia, diz Lévi-Strauss (2004 [1964]: 317). Este demônio cai do alto da árvore como uma presa fulminada pelas flechas envenenadas da zarabatana. Podemos dizer que ele é uma espécie de anti-desaninhador $\left(-\mathrm{X}^{-1}\right)$, levando-se em conta que o desaninhador Ipi $\left(\mathrm{X}^{-1}\right)$ está também invertido, pois desaninha uma fruta. O inverso do desaninhador $(\mathrm{X})$ se encontraria nos mitos de Dona Mergulhão e do menino escondido (-X), analisados por Lévi-Strauss ao longo d'O Homem $\mathrm{Nu}$. No caso ticuna seria uma mulher escondida, a esposa de Yoi, que está dentro da flauta. Note-se que é uma mulher muito desejada quem está escondida, não um menino. A esposa escondida de Yoi será descoberta por Ipi, que a engravidará. O poder de sedução desta mulher está no fato de ser um fruto de umari, uma fruta muito cheirosa, permitindo, então, que o desaninhador (clássico, X) se oponha à mulher escondida e esta implique num desaninhador de frutas

109 "No caminho ele parou, olhou para trás, e viu uma fruta madura no tronco de uma árvore de abiu quase um palmo acima do chão. Ele tentou pegá-la, apressando-se para trás, mas quando ele se aproximou, a fruta subiu mais alto e logo estava fora de alcance" (Nimuendaju, 1952: 125) 
$\left(\mathrm{X}^{-1}\right)$. Esquematicamente, o mesmo Grupo de Klein poderia ser grafado da seguinte forma ${ }^{110}$ :

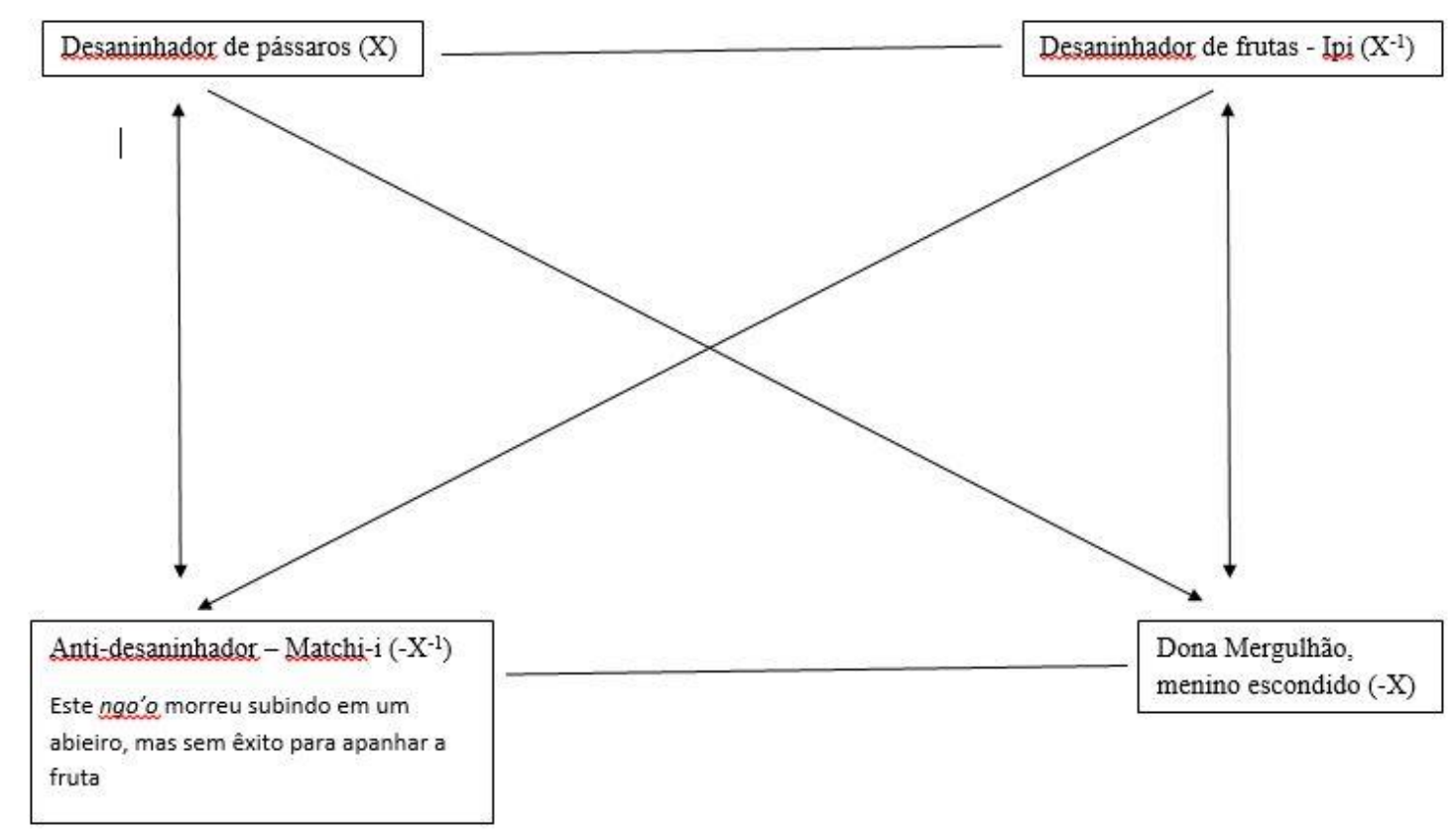

Figura 11 - Relação de contrariedade $(-)$, relação de contradição $(\rightarrow)$ e relação de implicação $(\leftrightarrow)$

\section{2 - Como nascem os mitos}

A noção ticuna do que é um mito pode ser sintetizada na seguinte fórmula "Assim que os velhos contam [nhatagü'ün ga yaguãta ga nüti ugü]”. Esta fórmula aparece durante as narrações, com mais frequência ao final da narração de um mito. Portanto, um mito para os Ticuna não é uma verdade que fundamenta as ações do presente - ou uma mentira, como supõe nosso censo comum - é uma história contada pelos velhos, pelos antigos. Contudo, estas histórias têm uma grande influência sobre o mundo atual.

Os Ticuna usam a palavra ore para se referirem a seus mitos ou histórias. Contudo, este termo possui um campo semântico um pouco diferente de nossa concepção de mito.

\footnotetext{
${ }^{110}$ Este esquema é baseado no quadrado semiótico de Greimas (1973), um equivalente ao Grupo de Klein, ver Almeida, 2008.
} 
Goulard define ore em oposição aos termos ga e dea. O primeiro termo, ga, trataremos mais detidamente dele quando abordarmos as canções, cujos nomes, em geral, recebem a terminação _tchiga. Por hora, basta informa que faz "referencia al tiempo presente, incluido el pasado inmediato" (Goulard, 2012: 26-27). O segundo termo, dea, "vale para los intercambios verbales de la vida cotidiana" (ibdem). De acordo com Goulard, podemos traduzir ore como "uma Palabra (...) Sin embargo, le prestaremos más atención al término ore por ser la palabra de la oralidad, la de los relatos mitológicos, y al mismo tiempo la del papel popera, de lo escrito en relación a lo contenido en la Biblia y en su traducción a la lengua tikuna.”. Como bem destaca esta passagem, ore pode ser a história registrada em papel também. A série de três livros que reúnem diversos mitos ticuna é intitulada Ore $i$ nисӥтаӥgü̈̈ (Firmino, \& Gruber, 2010, 3 vols.), traduzido como "Histórias antigas". Desta maneira, podemos notar que a palavra bíblica e a narrativa mítica são definidas pelo mesmo termo, ore. Por isso, não é de se espantar que os dois tipos de histórias se misturem, à maneira da bricolagem mítica. Quando Ondino, por exemplo, se questiona em que momento se situa a história de Yoi, antes ou depois do Gênesis.

Os mitos (ore) servem também para reforçar aos mais jovens a necessidade de se realizar a Festa e seguir determinadas tradições, como a regra matrimonial. Uma catástrofe, como as narradas no tempo mítico, pode ser iminente, portanto, só se salvarão os que seguirem as regras enunciadas na mitologia, assim como os adeptos dos movimentos messiânicos e religiões evangélicas asseguram sua salvação seguindo as escrituras sagradas ${ }^{111}$.

Os mitos para os Ticuna têm local e momento adequado para serem narrados. Tais condições são delineadas brevemente por Goulard: "El ore mitológico es dicho en ciertas condiciones: solamente se pronuncia dentro de la maloka y al final del día. A pedido de unos, mujeres principalmente, y en presencia de niños, empieza un relato en interacción, siempre en contrapunto con las preguntas de los oyentes. El narrador tradicional, "el que

\footnotetext{
111 "Se entiende mejor que los de la generación actual, cualquiera que sea la adhesión que privilegien, viven en una tierra considerada como vieja, y que, por eso, se acerca cada día al próximo cataclismo. Luego de tal catástrofe la generación actual será reemplazada por una nueva, constituida por los que se hayan protegido, es decir, aquellos que hayan seguido las reglas enunciadas por el ore. Es lo que los últimos narradores no dejan de recordar en sus relatos, para incentivar la recuperación de ciertas prácticas, como el ritual de la pubertad femenina." (Goulard, 2012: 36, eu grifo). E sobre a relação entre a palavra do Evangelho e a narração dos mitos tradicionais ticuna: "El pastor es el que "transmite la Palabra", ore arüauru-ũ, y es el "guardián de la Palabra", ore daru-ũ." (idem: 27).
} 


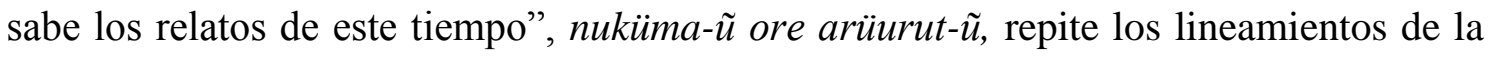
creación del na-ane [mundo] y la explicación de los lugares que les fueron asignados a los seres que hoy se conocen" (2012: 27).

Em uma ocasião pude apreciar uma narração de um mito espontaneamente, sem que eu tenha pedido para que a pessoa contasse. Certa noite, fui para a casa de Dona Benedita, na esperança de gravar algumas canções. Ondino havia me dito que ela tem um bom repertório de acalantos, canções de Festa e histórias. Contudo, a casa estava cheia de crianças, umas 15 e, claro, fazendo uma barulheira. Além disso, Benedita não estava muito bem de saúde, só consegui gravar alguns cantos com ela numa outra ocasião.

Neste dia não havia gasolina para colocar no motor de luz, então a TV e o som estavam desligados. Severino, irmão de Benedita - além de conhecedor de cantos e histórias tem uma performance para narrações bastante admirada - estava deitado com as costas no chão, no meio da sala. Ele começou a entoar trechos de cantos para introduzir uma história. Havia pouco mais de 20 pessoas acomodadas em volta dele. Crianças, adultos e velhos, de bruços, deitados de costas, sentados, nas redes, todos ouvindo a história, alguns perguntando. Contara-me que ele estava contando a história dos espíritos $\left(\tilde{a}^{\prime} \mathfrak{e}\right)$.

Depois, sentou-se de frente para os ouvintes e contou a história do Beru e, em seguida, do Curupira. Enquanto ele contava, algumas pessoas da audiência esclareciam dúvidas de trechos mal compreendidos. A atenção variava de pessoa para pessoa, indo de uma escuta atenta, olhos vidrados, até pessoas que acompanhavam um trecho, mas logo perdiam o foco. Alguns distraídos voltavam a prestar atenção quando começavam a gargalhar com algum trecho engraçado do mito ou quando Severino se empolgava na teatralização na passagem do mito.

Apesar de não ter entendido muito do que foi dito - apenas algumas palavras soltas - pensei, naquele momento, que o aprendizado de uma narrativa mítica para os Ticuna se dá de uma maneira parecida com a própria transformação do mito. Como Lévi-Strauss mostrou em O Pensamento Selvagem (1989[1962]), os mitos são formados por partes tomadas de outros mitos e, nestas trocas, vão se transformando. Como um bricoleur, que, com pedaços de algo que não serve mais, monta algo de útil, que será um “catado", uma junção de partes de outros objetos que são compostas para se tornar um outro objeto inesperado. Mas como se dá isto na transmissão do mito, na narração de Severino? Apenas algumas pessoas acompanham a narrativa do começo ao fim e tenho minhas 
dúvidas se tinham a intenção de memorizá-la fidedignamente. O ponto onde quero chegar é que a cena que presenciei mostra que os mitos são ouvidos como um bricoleur trabalhando. Uma pessoa acompanha um trecho de seu interesse e, sabe-se lá com qual outro pedaço de qual outra história ela - ou, para radicalizarmos nos termos levistraussianos, o funcionamento do seu próprio espírito -, poderá associá-lo, compondo assim um novo objeto, um novo mito.

Ao menos entre os Ticuna, os mitos possuem uma dinâmica transformacional bastante quente. Muitas narrativas coletadas por Nimuendaju eu não encontrei mais, mas ouvi muitas outras que não foram registradas pelo etnógrafo alemão. Os mitos coletados entre os Ticuna do Perú apresentam trechos que não estão nas narrativas destes índios no Brasil. Basta comparar o mito de origem ticuna coletado por Goulard (2009) e o registrado por Nimuendaju (1952), Oliveira Filho (1988) e por mim.

\section{3 - O homem grávido - a questão de gênero como primeiro evento mítico}

O primeiro evento da mitologia de origem ticuna narra o que resumirei em seguida. As versões variam um pouco. Em linhas gerais, Ngutapa, o primeiro homem, e sua esposa, Mapana, estão na floresta e Ngutapa amarra sua mulher de pernas abertas. Mapana, amarrada, recebe a ajuda de um gavião cão-cão (cõw - gralhão - Ibycter americanos $)^{112}$ que lhe dá vespas. Noutras versões ela mesma se transforma em vespa. Mapana, transformada em vespa ou arremessando uma casa de cabas, pica os joelhos de Ngutapa, que engravida neste local. Em cada joelho foi gestado um casal de irmãos. No joelho direito, Ngutapa gestou Yoi e Mowatcha e, no joelho esquerdo, Ipi e Aicüna. Esta é a primeira cena do mito de origem ticuna. O relato segue, mas nos deteremos neste trecho, por hora.

De acordo com Lévi-Strauss, o motivo do homem grávido encontra grade difusão nas Américas. No quarto volume das mitológicas, $\mathrm{O}$ Homem $\mathrm{Nu}$, encontramos muitas referências norte-americanas a este motivo. Narrativas dos Klamath, por exemplo, - com as quais comparamos alguns mitos ticuna acima - descrevem um herói mítico que nasce

112 Esta espécie de gavião tem como hábito se alimentar de marimbondos. 
dos joelhos de seu pai (2011 [1971]: 28). Contudo, a difusão do motivo do homem grávido seria ainda mais vasta na América do Sul (idem: 38). A hipótese de Lévi-Strauss é a de que o motivo do homem grávido é um caso particular "do motivo mais geral em que uma família não deixa que ninguém veja um de seus filhos, tranca-o num esconderijo, lava-o e alimenta-o em segredo (...) esse motivo ocupa um lugar considerável nos mitos da América do Norte" (idem: 38-39). Esta referência a uma criança escondida não seria tão interessante não fosse a possibilidade, indicada também por Lévi-Strauss, de se passar deste motivo para o motivo da esposa escondida. E o que dá a possibilidade de transição, afirma o autor, é o ritual de reclusão das jovens entre os Sanpoil, povo do noroeste da América do Norte (2011 [1971]: 39). Entre os Ticuna, podemos afirmar que os três motivos estão presentes: 1) as crianças escondidas ("vampiros”), 2) a esposa escondida (que Yoi coloca dentro da flauta), 3) e a moça reclusa na Festa ${ }^{113}$. O que nos interessa aqui é ressaltar essa relação que existe nos mitos e ritos das Américas entre o homem grávido e a mulher escondida ou reclusa. Voltemos nossa atenção para a gravidez de Ngutapa.

Na maior parte das versões deste mito, o motivo para Ngutapa amarrar sua esposa na floresta não aparece (Nimuendaju 1952, Oliveira Filho 1988, Goulard 2009). Camacho, em sua versão, apresenta a justificativa de Ngutapa para castigar sua esposa. Vejamos o trecho de Pardo, em que consta a referência: "Gútapa pelea con su mujer y la castiga cruelmente por que ella no tiene vulva, su vagina es como "culo de perro". Luego, gracias a la ayuda de un gavilán que se convierte en persona ella puede vengarse y él es castigado.

\section{Gútapa estaba furioso con su esposa porque ella no le podía dar hijos; por eso la amarró a un palo y le cantó en forma ofensiva. "No tengo hijos a mi lado porque no tienes vulva, por eso no tengo hijos". Luego la dejó abandonada en el monte. La Cacatúa la desamarró y le dijo "Ahora que te he desatado, debes golpear en la rodilla a Gútapa con este cascarón de avispas”. (Camacho y otros 2002: 1-5)”. (Pardo, 2008: 85, meus grifos em negrito).}

\footnotetext{
${ }^{113}$ O primeiro motivo - a família que esconde seus filhos, é algo que apareceu em diversas conversas que tive com Ondino - será tratado quando abordarmos os "bichos" (ngo'o) ticuna, no Capítulo 3, tópico 3.2.1 - Vampiros (nũtchi'i). Os Ticuna chamavam essas pessoas escondidas de "vampiros", que se alimentam de sangue, não tomam sol e ficavam muito brancos por isso. O segundo motivo, a mulher escondida, trataremos neste capítulo mesmo, mais adiante, quando discutirmos o mito de To'oena.
} 
Temos aqui, portanto, uma dupla vingança. Primeiro, Ngutapa, revoltado com a impossibilidade de sua mulher lhe dar filhos, amarra-a na floresta de pernas abertas ${ }^{114}$. Na versão de Oliveira Filho (1988), Mapana é picada na vagina por formigas e vespas. Ou seja, nesta versão ela não é desprovida de vagina ${ }^{115}$. Em seguida, depois de liberta, Mapana joga uma casa de cabas nos joelhos de Ngutapa, o que provoca um inchaço, a própria gravidez de seus joelhos. Na versão coletada por Goulard (2009), Mapana se transforma em vespa e pica os dois joelhos de Ngutapa. Desta maneira, a vingança de Mapana é engravidar Ngutapa, ou melhor, tornar seus joelhos grávidos.

Reforçando a proximidade da mitologia sul e norte-americanas descortinada por Lévi-Strauss, notemos que alguns trechos do mito Klamath A gesta de Aishísh ( M $_{538}, 2011$ [1971]: 46-49) parecem ser variações do mito de origem dos ticuna. Querendo saber por que não tinham pai nem mãe, a menina de um casal de gêmeos flechou o sol para que lhe desse informações. O sol respondeu "que quem os tinha tornado órfãos vivia na água, e mostrou o lugar exato" (idem: 47). No mito ticuna, a onça que comeu Ngutapa só entrega o pai dos gêmeos depois de puxada para o fundo das águas por Ipi ou sua irmã transformados em jacaré. No mito klamath os gêmeos ficam pescando no local indicado pelo sol, trazendo para sua avó "grandes quantidades de peixes e de aves aquáticas. Até que, finalmente, ouviram o grito da assassina: “Gochgochgochgodjip!". Trouxeram, então, a cabeça da assassina de sua mãe no cesto com os peixes. De modo semelhante, os heróis ticuna ouvem o grito que vem do bucho da onça, "nada, nada, nada, meu neto", som que, ao menos em português, tem um ritmo semelhante ao som ouvido pelos heróis klamath. Desse modo, os heróis ticuna conseguem também matar a onça que comeu seu pai, Ngutapa, e salvá-lo.

Invertendo o mito ticuna, cujos gêmeos nascem do joelho de Ngutapa no começo da narrativa, no mito klamath $\left(\mathrm{M}_{538}\right.$ e $\left.\mathrm{M}_{529}\right)$ é o filho da heroína (que guarda alguma semelhança com Ipi, é perguntadora, curiosa, impulsiva), que é pego por Kmúkamch e enfiado em seu joelho, no momento em que ela ia se jogar com o bebê numa pira de fogo. Este, no entanto, seria o começo da versão de Gatschet $\left(\mathrm{M}_{529}\right)$ do mesmo mito. Além

\footnotetext{
${ }^{114}$ Na versão registrada por Bueno, Mapana fala ao gavião o motivo de estar amarrada: "Estou amarrada aqui pelo meu marido, pois ele tem raiva de mim porque eu não consigo engravidar dele" (2014: 60).

${ }^{115}$ Existem versões do mito de origem que relatam que as irmãs de Yoi e Ipi, que nasceram dos joelhos de Ngutapa junto com os heróis, também não tinham vagina (Pardo, 2008: 85-86).
} 
disso, apenas uma criança nasce do joelho de Kmúkamch, Aishísh (2011 [1971]: 48). Kmúkamch engana este último para roubar suas esposas. Convence o filho a se despir e subir num junco para pegar um ninho de águias. "O junco se pôs a crescer. Quando Aishish chegou ao ninho, onde encontrou filhotes que jogou no chão, já não podia descer. Preso no alto, sem comida, foi definhando. Kmúkamch tomou a pequena Esquilo como esposa" (ibdem). As irmãs Borboletas "pegaram um fio de cabelo no ar, e quiseram saber de onde vinha". Ajudam Aishísh a descer e cuidam dele. Yoi, no mito ticuna, também faz com que o jenipapeiro cresça, dificultando a subida de seu irmão, Ipi, até a fruta. Mas este último pega a fruta e consegue voltar ao chão rapidamente.

Tanto no mito Klamath quanto no mito Snohomish (salish) (idem: 366), ocorre um antagonismo entre o pai (grávido) e o filho (fruto da gravidez paterna), o que pode indicar, nas palavras de Viveiros de Castro, um "fechamento edipiano da família diante do socius" (2007: 114) ${ }^{116}$. Este não é o caso no mito ticuna, a armação sociológica do mito dos gêmeos Yoi e Ipi é outra. Ngutapa e seus filhos não se tornam inimigos. Se há algum antagonismo é entre Ngutapa e Mapana, ou entre Ngutapa e a onça que o devora. No mito Klamath há uma disputa entre pai e filho. O primeiro tenta roubar a esposa do segundo e o último é um desaninhador de pássaros. No mito ticuna, Ipi rouba a esposa de seu irmão e torna-se um desaninhador de frutas. Contudo, a oposição e a vingança entre homem e mulher na mitologia ticuna (Mapana X Ngutapa) são a oposição e a vingança primordiais. Ngutapa se vinga de Mapana porque ela não the dava filhos, ela se vinga dele causando lhe uma gravidez nos joelhos. Yo'i, portanto, o fundador da sociedade ticuna, é fruto de uma oposição entre os sexos que implica na derrota e imobilização de Ngutapa, o primeiro homem.

O que temos no início dos tempos entre os Ticuna, portanto, é um antagonismo entre os dois primeiros homem e mulher muito marcado. Em todas as versões do mito, Ngutapa agride sua mulher de alguma forma, seja amarrando-a numa árvore de pernas abertas - o que já indica uma violência sexual -, seja abusando dela sexualmente, num relato mais explícito ${ }^{117}$. Ao ser abusada, Mapana ou Máena (mãe das vespas) sangra e

\footnotetext{
116 "Os mitos ameríndios, naturalmente, também contêm motivos "edipianos", figuras paternas, conflitos entre pais e filhos." (Viveiros de Castro, 2007: 123, nota 178).

117 O relato do ticuna Abel Santos para Valenzuela deixa isso bem claro: "Desde el mito de creación dice Abel Santos que al maltratar Ngutapa a la mujer (Máema, madre de las avispas) ella sangra, además de abusar de ella sexualmente y amarrarla, en este acto de fecundación, ella queda envuelta en sangre y semen." (2010: 90, eu grifo).
} 
permanece "envolta em sangue e sêmen" (Valenzuela, 2010: 90). Esta mistura que originará a imortalidade dos insetos ao se aderirem à Mapana ${ }^{118}$. Portanto, há uma agressão sexual entre o casal primordial ticuna; seja figurada, a mulher amarrada de pernas abertas; seja de fato, o estupro de Mapana. Ou seja, numa versão temos uma ênfase na imobilidade da mulher maltratada por Ngutapa, noutra versão o sangramento fica em primeiro plano. Como vingança, Mapana imobiliza Ngutapa engravidando seus joelhos com picadas de vespas.

Começamos a esboçar, portanto, a relação que os mitos ticuna estabelecem entre o sangramento feminino e um "personagem hermafrodita", o homem grávido. Isso já havia sido notado por Lévi-Strauss, incluindo neste grupo de mitos a origem do escalpo. Chegaremos a este último termo também, não percamos de vista que o ponto alto da Festa é o momento em que a moça tem seus cabelos arrancados. Nos detenhamos, por enquanto, na relação entre o sangramento feminino e o personagem hermafrodita ${ }^{119}$.

Podemos nos perguntar se o mito de origem dos Ticuna apresenta esta relação entre uma personagem hermafrodita e a origem da menstruação. A esposa de Ngutapa não podia lhe dar filhos e ele engravida em seus joelhos dos gêmeos heróis da mitologia ticuna. $\mathrm{O}$ mito indica que ainda não havia menstruação/fertilidade feminina neste tempo. Mapana sangra por ser violentada, numa espécie de menstruação simbólica. A primeira mulher a engravidar na mitologia, com veremos adiante, é a esposa de Ipi - que pode ser equacionada em uma versão do mito à To'oena, que também é a primeira moça nova quando a referência à menstruação aparece também na mitologia. Em todos os casos, trata-se de um sangramento ocasionado por uma violência masculina. Contudo, o escalpo não aparece na mitologia ticuna. Tudo indica que este motivo mítico, recorrente na América do Norte, tenha migrado para a ordem do ritual quando passamos para a América do Sul, ao menos no caso ticuna. Mas para um ritual que envolve a primeira menstruação

\footnotetext{
118 O que Lévi-Strauss chama de "imortalidade relativa" em oposição à "imortalidade absoluta”, buscada pelos humanos (2004 [1964]: 190).

119 "Ao mesmo tempo, compreendemos porque, em todos os nossos mitos, a origem do escalpo e a da menstruação envolvem personagens hermafroditas. " (Lévi-Strauss, 2006 [1968]: 362, ênfases em negrito minhas)
} 
de uma moça e, muitas vezes, a agência de homens com habilidades femininas ${ }^{120}$, algo que está presente deste o primeiro homem ticuna: Ngutapa e sua gravidez.

O tema do escalpo e da menstruação caminham juntos na América do Norte. Sabemos que a mitologia ticuna opera uma transição entre os mitos norte-americamos e sul-americanos. Deste modo, não seria sem fundamento a proposta de que a conexão entre o escalpo ou a cabeça careca das mulheres ${ }^{121}$ e a menstruação migrou - ao passar de um hemisfério ao outro, como as torções que encontramos nos mitos de um hemisfério ao outro - da mitologia, no Norte, para o âmbito do ritual, no Sul. Desta maneira, o "escalpo" da moça nova ticuna está intimamente relacionado com a menstruação.

Na mitologia ticuna, os gêmeos que originaram os Ticuna atuais nasceram de uma aliança interespecífica. Para que ela acontecesse, foi preciso que a esposa de Ngutapa, Mapana, ou se transformasse em vespa ou arremessasse vespas para picarem os joelhos de Ngutapa. Deste modo, para que os joelhos do chamado "primeiro homem", Ngutapa, fossem inseminados, realizou-se uma aliança entre homem e animal. Mas isso não é tudo, a inseminação também inverte o papel de quem insemina e quem é inseminado. Ngutapa é um homem que tem seus joelhos inseminados por uma vespa ${ }^{122}$. Ou seja, a aliança interespecífica é anterior ou o pressuposto da filiação natural, intraespecífica ${ }^{123}$. Isto está presente na vida ticuna, tanto no mito, quanto no ritual, como veremos.

Este tipo de aliança está presente no cotidiano também, mas em forma de desastre. Alguém que é interpelado por um espírito maligno ou um "bicho" (ngo'o) na floresta pode estabelecer uma aliança com este ser. Trata-se da mesma aliança interespecífica, mas que acorre sem benefício para a vítima e seus parentes. Em geral a pessoa nunca mais

\footnotetext{
120 Os "hermafroditas", além dos mitos, aparem nos rituais também. Lévi-Strauss destaca, assim como veremos que acontece entre os Ticuna, a voz destes homens, que "soava intermediária entre os dois sexos": "Tais personagens [hermafroditas] não existiam apenas nos mitos; exerciam, por vezes, funções rituais. Assim, os Cheyenne encarregavam da direção das danças do escalpo um pequeno grupo de indivíduos chamados "meio-homem meio-mulher" e vestidos como velhos. A voz desses homens, que tinham escolhido um modo de vida feminino, soava intermediária entre os dois sexos. Cada um deles possuía dois nomes, um de homem e o outro de mulher." (2006 [1968]: 362, eu grifo).

121 “[Para as mulheres] a cabeça calva corresponde à cabeça escalpelada” (Lév-Strauss, 2006 [1968]: 378)

${ }^{122}$ Viveiros de Castro cita Deleuze \& Guattari: "a sexualidade passa pelo devir-mulher do homem e o deviranimal do humano: emissão de partículas" [Mil Platôs] (2007: 118).

123 “... a filiação natural dentro de cada espécie depende dessa aliança contra natureza entre as espécies." (Viveiros de Castro, 2007: 118).
} 
retorna para os seus. Parte definitivamente para a perspectiva animal, vira "bicho" (ngo'o). Esta aliança reaparece de forma controlada no ritual. Os "bichos" e imortais (ü'üne) são recebidos na Festa para brincarem e dançarem com os Ticuna, ““"contiguidade absoluta" de tipo tangencial-diferencial estabelecida pela aliança contra-natureza" (Viveiros de Castro, 2007: 119). Aliança esta fundamental, pressuposto, como ressalta Viveiros de Castro, da filiação natural. Devemos ter em mente que boa parte do ritual está voltado para um controle da fertilidade das moças novas, produtora da filiação natural. Para tanto, o ritual coloca a "aliança contra a natureza" em andamento.

A história de Mapana e Ngutapa, entretanto, não é a única passagem na mitologia ticuna em que o sangue de uma mulher é lavado na água do rio. Para compreendermos melhor as consequências disto, passemos a outro personagem central desta mitologia relacionada ao ritual da moça entre os Ticuna.

\section{4 - To’oena, a primeira moça nova}

Antes de introduzirmos a versão mais conhecida do mito de To'oena, gostaria de demonstrar como esta moça nova é também uma variação da "fillha do umari”. Vimos no capítulo anterior que Ipi descobre que Yoi escondeu a "filha do umari" em sua flauta, teve relações sexuais com ela e assim segue a história. Contudo, quando pedi a Lorenzo - um

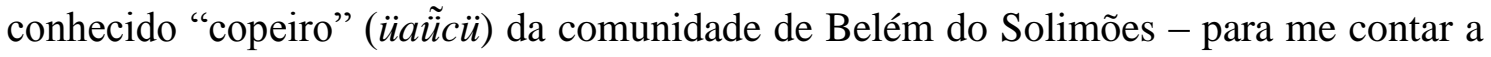
história de To'oena, o que ouvi foi uma fusão do mito da "filha do umari" com a versão do mito de To'oena que veremos mais adiante. Foi importante conhecer esta versão do mito, pois ela demonstra que a "filha do umari", que foi guardada dentro de uma flauta é uma transformação da primeira moça nova. Ou seja, a flauta é também uma espécie de reclusão, como a de To'oena, de onde a "filha do umari" sai inadvertidamente.

É possível encontrar conexões entre a "filha do umari” e as moças reclusas apenas por suas características. O trecho da análise de Goulard da história de Techi, a "fillha do umari”, deixa bem claro a equivalência feita na mitologia ticuna entre a madures da fruta umari e o amadurecimento da moça nova. "Como a futura esposa do mais velho dos gêmeos [Yoi], Techi, fruta da árvore Umari (Poraqueiba sericea), estava "madura" assim que caiu do galho da árvore, a mesma ideia aplica-se à reclusa ao sair de sua reclusão. A história diz que "Techi caiu para nascer": segue-se o nascimento de um ser pleno, de 
uma pessoa que entra na fase adulta. "Quando ele [o fruto] estava maduro, ele caiu e pulou porque estava na puberdade. De lá, ela caiu. Em seguida, apareceu uma bela mulher. Ela se levantou e foi bem decorada. Ela era [de cor] amarela ...”. (2010, 124-25, eu grifo). Certamente a cor amarela remete a cor da menina depois de meses de reclusão. A mudança da cor da pele da moça-fruta será examinada mais de perto oportunamente. Veremos também que esta equivalência entre a moça e um fruto também remete a uma espécie de natureza vegetal dos Ticuna. Detenhamo-nos na equivalência estrutural referida e demonstrada na versão do mito do narrador Lorenzo.

O que a versão de Lorenzo nos dá é um detalhamento melhor do paradeiro de Aicüna - que nasceu do joelho direito de Ngutapa junto com Yoi - quando os gêmeos plantaram o coração da samaumeira mítica (wone), que irá germinar uma árvore de umari. Após a morte de sua irmã, Mowatcha - nascida do joelho esquerdo de Ngutapa junto com Ipi e morta "por causa da caba que ferrou ela"" 124 -, Aicüna fica muito triste e vai embora para a montanha Moruapü com sua filha, To'oena. Lorenzo conta o que acontece da seguinte maneira:

"Mas a filha dela não agüentou e ela mandou voltar. Naquele tempo o coração do wone [samaumeira mítica] que ele plantou já tinha crescido, tinha virado pé de umari. Aí ela [Aicüna] mandou assim, "filha volta, que eu não agüento mais". Parece que ela já era quase moça. Ela disse para To’oena, "você sobe no pé de umari, amarre sua rede e fique lá". Aicüna falou assim com a filha dela, "vai lá com seu tio, fique com seu tio. Mas fique com Yoi, não vai ficar com Ipi, porque Ipi não é bom não, ele é danado, muito ruim". E To’oena foi, amarrou sua rede lá em cima do pé de umari. O umari já estava começando a florar e dar frutos. Yoi foi caçar. Ipi ouviu a música dela, como ela cantava. To'oena estava cantando lá em cima. E o pé de umari já estava começando a dar frutos. E ela cantava lá. [Lorenzo começa a cantar e depois explica o que cantou]. "Não vai ficar com Ipi, porque Ipi é ruim. Você fique com Yoi, o seu tio. Nós gostamos mais dele, porque ele é caçador"."

To'oena canta exatamente o conselho que sua mãe lhe deu. Situação muito semelhante a uma Festa de Moça Nova, em que as mulheres mais velhas cantam conselhos para as moças novas. Até este momento é como se o conselho, por si só, funcionasse, To 'oena está convicta de que não ficará com Ipi. Mas quem a ouve cantar é

\footnotetext{
${ }^{124}$ Esta caba (vespa) é o demônio Matchi'i, responsável pela desonra de Mowatcha, que os gêmeos irão matar e fazer uma flauta com os tornozelos dele.
} 
justamente o gêmeo enganador. Contudo, nesta versão a história muda de rumo, ao invés da "filha do umari" ter relações com Ipi, como trata-se de To'oena, ela vai direto para a reclusão.

\footnotetext{
"Até que começou a madurar o umari e as frutas começaram a cair. Foi caindo, caindo, caindo e o Ipi começou a juntar o umari. Não perdeu nenhum, juntou, juntou, juntou, até que terminou o umari. Aí [To’oena] ficou sozinha lá em cima, virou umari, só amarelando lá em cima. ”
}

Mais uma vez a referência ao amarelado do umari que amadurece. A meu ver, trata-se de uma referência explicita à cor da pele da moça em reclusão. Por isso, ao fundir as duas narrativas, Lorenzo deixa claro a natureza de moça nova da "fillha do umari", o que não fica explicito em outras narrativas apenas pelo fato de Yoi guardá-la dentro de sua flauta. Neste caso, a moça do umari, que terá um filho com Ipi, é também a primeira moça nova, To'oena.

"Yoi foi caçar de novo, nunca ele estava em casa. Yoi já estava sabendo, ele era encantado. Ipi estava cuidando. Um dia Ipi foi até o porto e ficou debaixo do pé de umari esperando cair a fruta. Quando a fruta caiu no chão ela se transformou em gente, numa mulher bem bonita. Yoi falou com ela, "você fica comigo". Aí que Yoi começo a fazer a Festa com ela. [A mulher que caiu do pé de umari era a To'oena?]. Era a To'oena. Aí que começou a Festa. Yoi caçou, caçou, caçou, até ele conseguir algum moqueado para ele. Então convidaram todo aquele pessoal, aí que começou [a Festa]."

A partir deste ponto, a narrativa continua de modo mais convencional. Nesta versão fica claro que To 'oena estava mesmo reclusa, o que é posto em questão por alguns narradores. Yoi guardou ela no quarto de reclusão e de lá ela saiu para ver os instrumentos proibidos. Ipi espera pela moça, mas não tem êxito em sua tocaia. Contudo, nas outras narrativas, Yoi esconde a moça de seu irmão em sua flauta. Nesta narrativa, To'oena vai direto para a reclusão em sua Festa, Ipi não a descobre. Outra inversão com relação às versões mais correntes, como veremos, é o fato dos instrumentos saírem de noite, assim como acontece no ritual. Na maior parte das versões desta história os instrumentos saem de dia, algo impensado durante uma Festa, o que contribui para a moça vê-los inadvertidamente.

Vejamos uma narrativa condensada da versão mais conhecida deste mito, para termos uma ideia geral da história. 
“To'oena era sobrinha de Yo'i, filha de sua irmã Aicüna e do quatipuruzinho. Durante sua festa de iniciação, a jovem desobedeceu às ordens de permanecer no recinto de reclusão e não se aproximar do to 'cü. Atraída pela curiosidade de ver quem produzia aqueles sons e como era a sua pintura, ela fugiu para a mata e subiu numa ingazeira na beira do caminho por onde seu tio Yo'i e os Nge'cutu passariam com o to'cü. Quando o grupo se aproximou, ela impressionou-se com a imagem do to 'cü vendo-o como um jacaré enorme, e com o susto se urinou. Foi então localizada pelos Nge'cutu, que bateram na jovem até matá-la. Lavaram seu corpo no igarapé Eware, cortaram-no em pedaços e fizeram um assado. Depois distribuíram o assado para todo o pessoal da festa. Os Nge'cutu colocaram no to 'cü o espirito de To'oena e o espirito cantou: "É minha carne, mamãe! E minha carne que a senhora está provando. Não é carne de anta. É a minha carne, mamãe!” A mãe entendeu o que tinha acontecido e quis chorar. Yo'i, então, puniu-a por não ter cuidado suficientemente de sua filha, passando carvão nos seus olhos para que a mulher não pudesse derramar uma só lagrima. Outra versão conta que todos os familiares de To 'oena tiveram seus rostos pintados com carvão. Caso chorassem pela morte da jovem, seriam identificados pelas marcas das lagrimas que escorreriam por suas faces desfazendo a pintura, e fatalmente seriam mortos pelos Nge'cutu. O sangue de To'oena espalhou-se pelas águas do igarapé Eware, e até hoje podem ser vistas manchas avermelhadas no local onde lavaram o corpo da jovem. " (Gruber, 1999: 31-32).

Ao longo desta análise adicionarei outros elementos de outras versões deste mesmo mito. Neste ponto basta uma visão panorâmica da narrativa. Esta é a primeira moça nova a sofrer as consequências do tabu das "flautas sagradas" dos Ticuna. O mito, portanto, relata a origem de duas coisas simultaneamente: a interdição sobre alguns instrumentos musicais ticuna e a origem da reclusão das moças que acabam de menstruar. To'oena é considerada a primeira moça nova e sua história conta como ela morreu por ter olhado os instrumentos proibidos para mulheres e crianças.

A versão mais extensa registrada do mito de To'oena está no livro Ore $i$ nucümaügü̈̈: Histórias Antigas (Firmino \& Gruber, 2010, vol. 1) ${ }^{125}$. O relato inicia

\footnotetext{
${ }^{125}$ Estes livros estão escritos em língua ticuna. A tradução da história de To'oena foi feita por mim e pelo professor Ondino. Ver a tradução no Anexo - 005.
} 
afirmando que ela estava "guardada" (aure), contudo, isto é muito incerto, "ninguém sabia se ela estava mesmo guardada". E, principalmente, além de não saberem, isso ainda não era um costume: "naquela época ainda não recolhiam a moça". To'oena, em sua reclusão, ouviu um som e a curiosidade de saber de onde vinha este som a fez sair da reclusão. "Então ela falou, "vamos ver onde os tios (oe - MB) estão cantando". Mas a amiga (mисӥ) dela, a pata Poponari ${ }^{126}$, falou para ela não ir porque eles podem matar. "É

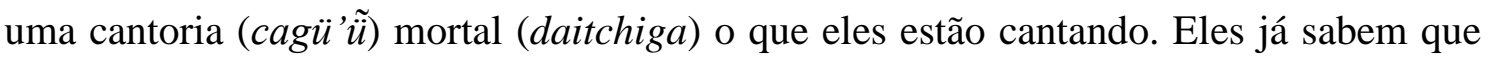

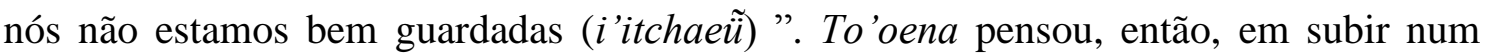
ingazeiro e olhar para lá. Ela falou para sua amiga, a patinha Poponari: "ainda não nos viram. Eu já vi, mas eles nunca vão nos ver”. Já a patinha respondeu o que era mais certo a fazer: "eu não vou subir em nenhuma árvore, agora mesmo eu vou me guardar/cuidar/esconder (ngu' $\tilde{u})$. Depois de dizer isso, a patinha Poponari se escondeu num lugar fechado e não se mexeu" (idem).

Em geral, a aparição desta patinha, Poponari, nos mitos de To'oena é bem rápida, às vezes ela nem sequer aparece na história. Contudo, vale a pena compreendermos melhor o papel que figura esta ave em relação à To'oena, com referência, inclusive, a outros mitos dos Ticuna. Veremos que esta pata se relaciona com duas qualidades valorizadas nas moças pelos Ticuna: 1) a obediência em manter-se reclusa e; 2) a boa audição para o aconselhamento.

O mito lança mão de um hábito do pato paturi, uma ave que frequentemente se esconde no meio das folhagens. A patinha Poponari mostra à To'oena a atitude certa a tomar, esconder-se. Ela alerta a moça nova dos perigos de se olhar o to'cü e fala da necessidade de se "guardar" para não ver os instrumentos sagrados. "Eles estavam na beira do igarapé Eware, o lugar de Ngutapa. Nesta época, o Eware ainda não estava cheio de sangue de To'oena".

Em contraponto à desobediência de To'oena, o mito apresenta a pata Poponari. Além de ser a "moça" obediente da história, que se esconde e não se aproxima dos instrumentos, o ovo desta pata é usado como recurso para retardar a vinda da menstruação da menina. "Para demorar a vir a menstruação a menina deve comer ovo de Poponari.

\footnotetext{
${ }^{126}$ Os Ticuna chamam este pato de paturi, que me foi identificado por Ondino com os patos Amazonetta brasiliensis e Dendrocygna autumnalis
} 
Assim, a menstruação vem lá pelos quatorze anos”, me disse Hilda ${ }^{127}$. Algumas exegeses deste mito apontam para a possibilidade de se equacionar esta patinha à irmã de To'oena, Omatüna. A canção de To'oena, entoada por Margarida ${ }^{128}$, menciona que a irmã da primeira moça nova ficou chorando quando ela foi morta pelos Nge'cütü:

Rü ngigumata na'Aumare'ün/Yayimatürü ga Omatüna/

"Omatüna [irmã de To’oena] ficou lá chorando"

$(\ldots)$

Rü tamaüncü, tamaüncü, tamaüncü rü tamaena

Ya ӥ'üneyaĩ, ̈̈’üneyã̃

Ya Omatüna ga Omatünal

“Omatüna é uma pessoa encantada [ü'üne] para nós”

Por outro lado, a pata aparece também referida como avó (no'e), "vovó verdadeira", na canção da Poponari ${ }^{129}$, que é entoada na Festa. Contudo, isso pode ser apenas um uso metafórico do termo no'e (vovó), como alguns personagens míticos são referidos, vovô (oi), vovó (no'e). De acordo com a canção, a patinha passeia com sua canoa feita de balseira, levinha, na beira do rio celeste Tchowatï ${ }^{130}$.

Em um mito registrado por Nimuendaju (1952: 125), esta mesma patinha é quem tira as penas do ouvido de Yoi. Ela sabia que o demônio Matchi'i estava cantando o nome de Yoi e também sabia que o ouvido de Yoi estava entupido de plumas porque ela era

\footnotetext{
${ }^{127}$ Ver Capítulo 4, tópico 4.2.3.3 - Controle.

128 Margarida Severino Manuel (Mematüna) cantora da comunidade de Campo Alegre que estava presente em uma das Festas que eu etnografei na comunidade de Vendaval. A canção foi transcrita e traduzida por mim e pela professora ticuna Luscita Bibiano Ezequiel

${ }^{129}$ Noeti, noeti'î (rü) / "Vovó, vovó verdadeira".

${ }^{130}$ Veremos mais sobre este rio no Capítulo 6, tópico 6.2.1 - Batizado e Nomes dos trompetes. 0 trecho referido da canção é o seguinte: "Ya poponari poponari / "Patinha poponari"/ Yeani, yeani' / "Aquele, aquele lá" / Deretchiü, deretchiü, Tchowatü, Tchowatü / "Liquido amarelado, liquido amarelado, [rio] Tchowatü, [rio] Tchowatü" / Yepetchina, yepetchinagu\} 3x / "Na beirinha, na beirinha" / Wẽ'ẽguã, wẽ'ẽguãtchi\} 2 x / "Nadando, nadando" / Ngiweün, ngiweünma\}3x / "Com a canoa dela, com a canoa dela" / Ngütchicune, ngütchicu'ün / "Levinha, levinha" / Ngütchicune, ngütchicune / "Levinha, levinha" / Ponenaca, ponecanani' I "Feita de balseira" [A canoa da patinha é feita de balseira, uma árvore de madeira bem molinha]"
} 
encantada (ü'üne). Por isso o herói não ouvia as maledicências do demônio. A pata diz que o herói está com a audição muito ruim e, com uma pena de sua asa, retira uma quantidade de penas de gavião-real das orelhas dos dois irmãos, Yoi e Ipi. Neste momento eles ouvem o demônio jaguar, Matchi' $i$, cantando e zombando da desonra da irmã deles. Só então os gêmeos se vingam e matam o Matchi'i.

No relato coletado por Goulard, muito próximo do resumido acima, Mowacha ("a bem aconselhada", nascida do mesmo joelho que Yoi) é flechada no clitóris pelo ngo'o Machi'i. Ao dizer a seus irmãos que a flecha estava em seu clitóris (cha-ochanü), um deles "pronunciou uma palavra desgraçada e as orelhas de todos se taparam com plumas". Neste momento Mowacha morre e a narrativa se dirige ao tratamento para trazê-la de volta a vida. Mais adiante na história, a pata, vovó Poponari diz aos heróis: - "Quando sua irmã lhes fez ouvir um "palavrão" (malaguerra) (...), suas orelhas ficaram tapadas e vocês não sabiam que seu inimigo lhes insultava. Tinham as orelhas tapadas. Por esta razão até hoje não escutamos de muito longe! O que ouvimos! É porque tinham as orelhas tapadas com plumas de ngokura". Ela [a pata] soprou suas orelhas e eles ouviram um canto zombador (burlón)" (Goulard, 2009: 400). Neste trecho temos a explicação da origem da audição defasada dos atuais humanos em relação aos imortais, ao tempo mítico. Se hoje os humanos possuem os ouvidos "tapados" isso se deve ao desastre de Ipi, que pronunciou "uma palavra desgraçada". Os heróis só retomam a potente audição dos imortais (ü'üne) depois do auxílio da vovó Poponari que, como vimos, é considerada uma moça que acatou a reclusão. Vejamos o que acontece com To'oena na sequência do mito.

Contrariando os avisos da pata, To’oena sobe num pé de ingá ${ }^{131}$ para ver os instrumentos que estavam vindo da beira do rio. O ingazeiro é uma árvore que costuma ser encontrada na beira dos rios. O fato de To 'oena subir numa planta destas indica que ela estava bem próxima da margem do rio, onde $Y o i^{132}$ e os bichos em forma de preguiça (wõerraürü $)^{133}$ estavam fazendo os instrumentos. "Eles vinham tocando as trompas e batendo com os paus em quem estivesse na frente" (Firmino \& Gruber, 2010, vol. 1). O

\footnotetext{
${ }^{131}$ Existem cerca de 300 espécies do gênero Inga, subfamília Mimosoideae, da família Fabaceae.

${ }^{132}$ To'oena é nata'a (sobrinha/neta) de Yoi, filha da irmã deste.

${ }^{133}$ Wõ̃ = preguiça;_raü = forma, foi-me dado o seguinte exemplo, "Edsonraü tem forma de Edson, mas não é Edson".
} 
narrador comenta que já viu este acontecimento, algo que acontece, de fato, na Festa. As pessoas mais antigas faziam isso, traziam os instrumentos e cacetavam qualquer um que estivesse na frente. Quem estivesse dentro da casa não podia sair. Ele conta que na infância dele a Festa era mais rígida (ye'era) que agora.

O momento em que eles sobem da margem do rio com os instrumentos - afinal, o trompete to 'cü fica guardado dentro do rio - era de dia, muito cedo. Podemos dizer que pouco depois do nascer do sol ${ }^{134}$. Nesta passagem há uma importante inversão de uma regra do ritual de passagem feminino dos ticuna. No ritual, os instrumentos só sobem do igarapé para a casa de Festas depois do pôr do sol, quando já está escuro, e permanecem na festa até pouco antes do amanhecer, cerca de 5hs da manhã. Ao que parece, o ritual repara uma falta cometida no mito e que contribuiu para o desfecho fatal da história de To'oena. Na Festa, estes instrumentos não podem circular em plena luz do dia, o que aumentaria as chances de quebrarem a proibição de vê-los, principalmente as crianças.

Na versão mais extensa, do livro (Firmino \& Gruber, 2010, vol. 1), é a combinação da visão do trompete to 'cü, o som da flauta tchuüec $\ddot{u ̈}^{135}$ e o calor (naĩün) vindo dos instrumentos que a derruba da árvore. Quando ela olha para o to 'cü que vem subindo com sua "turma", To'oena vê os olhos dele brilhando intensamente, isso é uma das causas de sua morte:

“E To’oena estava no ingazeiro olhando para lá. De cima da árvore ela estava olhando para baixo para ver o to'cü. Os antigos (yaguãta) contam que quando se olha para aquele trompete a vista se apaga. Quando To'oena olhou para o instrumento, viu os olhos dele brilhando (naiẽ'tü' $\tilde{u})$. Por isso, as pessoas

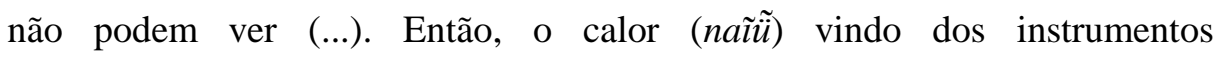
chegou/pousou/tocou (tü' üwwagumema - p. ex. quando um pássaro pousa) nela. Neste momento, ela se urinou (wiyaũ̈maũ) de medo (mu'ũ). Então, eles viram o vermelho da urina dela e perceberam que lá tinha gente. Mas já não era mais

\footnotetext{
134 "Neste momento era de dia, muito cedo. Em cima do ingazeiro ela se espantou (baia'tchiü)".

${ }^{135}$ Esta flauta de embolo é referida mais frequentemente como nge'cütü. "Eles sopravam a nge'cutü, uma flauta embolo feita de um cipó grosso (yowaru). Com o som do sopro, To'oena assustou, caiu e cacetaram ela" (Anexo - 005). Veremos que os Nge'cütü são atualizados na Festa como as flautas embolo. Os tocadores destes instrumentos são os "guardas" que ficam em torno do cercado do to'cü impedindo que o pessoal se aproxime. O mais importante a frisar para entendemos o papel deles na história de To'oena é que eles são referidos como os "guardas" ou "soldados" de Yoi.
} 
gente que estava lá naquele momento. Pode ser que era um bicho que estava lá, em forma de pessoa. Como a urina já era sangue, ninguém sabia se era gente." (Anexo-005).

A intensidade do brilho dos olhos do to 'cü faz To'oena urinar sangue, como um macaco alvejado por um dardo envenenado. $\mathrm{O}$ fato de ter sangue na urina indica que ela provavelmente já não era mais gente. Neste momento, o to'cü parece se identificar com a serpente arco-íris, ao menos com seu brilho letal, venenoso. O sangue de To'oena, esta potência transformadora, indica que não se pode afirmar com certeza sua humanidade. To'oena, naquele momento, estava entre a humanidade e a não-humanidade. Isso vai ao encontro do que diz Belaunde quando afirma que:

"Em muitas partes da Amazônia, considera-se que o sangue derramado, e particularmente o seu cheiro, tem um poder transformador sobre a experiência vivida semelhante ao das substâncias psicoativas, abrindo as cortinas da percepção e comunicação que geralmente separam a experiência cotidiana da experiência de "outros" espaços-tempos cosmológicos. (...) Ele apenas introduz espaços-tempos de multiplicidade transformadora incontroláveis, quando/onde os espíritos de plantas/animais tomam a forma humana - como ocorre durante os espaços-tempos míticos primordiais - e se vingam dos humanos, seduzindo ou raptando os que se tornam perceptíveis pelo cheiro de sangue, tornando-os diferentes de si mesmos, alienados, doentes ou mortos, ou seja, perdidos para seus parentes." (2006: 229)

Ou seja, efeito semelhante ao do veneno, operador de um curto-circuito entre natureza e cultura ou, nas palavras de Belaunde, "espaços-tempos de multiplicidade transformadora incontroláveis". Voltaremos a este curto-circuito operado pelo sangue-veneno de To 'oena. Foquemos, por hora, no brilho dos olhos do to' cü, letal para esta primeira moça nova.

De acordo com Faulhaber - que identifica o motivo pictórico da serpente arco-íris na máscara To' $\ddot{u}$ - a serpente que os Ticuna identificam como serpente arco-íris possui um brilho tão intenso, capaz de matar quem a olha: "uma figura nas cores amarelo, marrom claro e escuro, representando a na'tchamü (casca/pele) da serpente tututchii, 
$Y o i^{136}$ de terra firme ou serpente arco-íris (Epicrates cenchria). Esta serpente tem a propriedade de matar as pessoas que a veem, pois sua pintura brilha tanto que faz os olhos perderem a noção de perigo, até causar o desespero e a loucura. Vive no fundo da água e é amarelada e brilhante" (2003a: 38). Começamos a notar, portanto, uma assimilação dos grandes trompetes à cobra arco-íris (Epicrates cenchria). Estes trompetes são semelhantes às grandes cobras, tanto no formato ${ }^{137}$, quando na textura da "pele". Veremos que eles são feitos de casca de árvore, o que os aproxima ainda mais das cobras, já que estas últimas trocam de "pele" para manterem-se sempre jovens ${ }^{138}$.

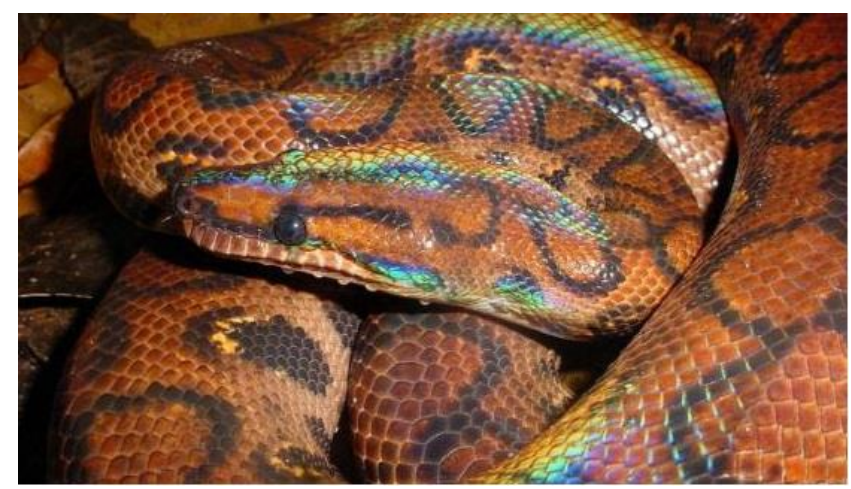

Figura 12 - Foto da serpente arco-íris (Epicrates cenchria).

As mulheres são identificadas com as cobras na medida em que seu sangramento é considerado uma mudança de pele/corpo, como acontece com as cobras. Como menciona Belaunde, muitas vezes a cobra também é identificada ao arco-íris, algo que se evidencia na própria pele da espécie mencionada (ver figura acima). Para além disso, existe uma relação apontada por Belaunde entre o sangramento, a cobra e o arco-íris. "Por toda a Amazônia, o sangramento está ligado à relação íntima das mulheres com as anacondas. A anaconda (...) se identifica com o arco-íris cósmico e a serpente

\footnotetext{
${ }^{136}$ Yoi, neste caso, é um tipo de cobra (atape), não tem nada a ver com o herói mitológico Yo'i. O nome deste tem uma oclusão glotal entre o " $\mathrm{o}$ " e o " $\mathrm{i}$ ". Utilizo, no entanto, a grafia mais convencional dos materiais didáticos ticuna, Yoi.

${ }^{137}$ Veja as fotos da fabricação destes trompetes no Capítulo 6, tópico 6.2 - Aerofones.

138 “É interessante notar que as cobras, entre os índios das Guianas, são reputadas imortais, por sua capacidade de trocar de pele; assim sendo, a partilha da pele, que confere diferenciação, poderia ser vista como uma garantia de reprodução social, um dos muitos significados da imortalidade" (Farage, 1986: 198). Este pensamento pode ser generalizado para muitos outros povos indígenas, inclusive os Ticuna. Junto com as cobras, alguns insetos que trocam de casca/pele também são considerados imortais.
} 
subaquática, considerada "mãe" ou "dona" de todas as cobras. Como as cobras, as mulheres mudam de pele/corpo e produzem substâncias venenosas. (...) sangramento das mulheres causa as transformações mais dramáticas e exige os processamentos mais cautelosos" (2006: 218). É disto que estamos tratando neste mito, uma relação de transformação que relaciona todos estes termos: a cobra, o sangue, o arco-íris, o veneno, as mulheres, a pele, o cabelo e, veremos, a lua.

O sangue e o arco-íris também são evocados na pintura do to'cü feita por Yoi e descrita por Nimuendaju, vejamos o mito que conta como Yoi fez a pintura do to 'cü:

"Yoi tinha inventado o uaricána [trompete] de madeira de paxiubinha para o festival de arrancamento de cabelo do menino Teku-küra', pintou o instrumento de vermelho com carajurú [Arrabidea chica]. Um dos companheiros imortais, eu não sei qual, criticou a pintura. "Como devo pintálo, então?", perguntou Yoi. O outro explicou: "Nas cabeceiras do Igarapé de São Jerônimo, há um barranco alto com argilas de todas as cores. Ela é mole, mas você não deve tocá-la com as mãos. Remova-a enfiando a sua zarabatana nela para que o barro grude no furo!".

"Naquela mesma noite os dois transportaram-se para o local mencionado, onde Yoi meteu a zarabatana em todas as argilas de cores diferentes, cada vez com a profundidade de um palmo. Ao voltar para casa, ele raspou o barro com uma vareta de limpeza, e depois pintou os uaricána de novo".

[Comentário de Nimuendaju]: "O tabu em torno deste instrumento está concentrado na aparência desta pintura" (Nimuendaju, 1952: 134, grifo meu)

Lévi-Strauss, baseado na versão de Nimuendaju, enfatiza que é o aspecto da pintura dos instrumentos a principal causa do tabu relativo aos instrumentos rituais ${ }^{139}$. A pintura tem um efeito alucinógeno na menina, ela começa a falar absurdos, pensando que estava vendo um jacaré no lugar do instrumento. A análise de Lévi-Strauss se baseia na estreita relação entre cromatismo e veneno. Este último, assim como a doença, seria um "ser cromático", mas cujos efeitos são "diatônicos" (2004 [1964]: 363). Ainda sobre o veneno e a doença, Lévi-Strauss menciona que "a observação empírica de seus estragos

139 "Explicam que é o aspecto dessa pintura a causa principal do tabu relativo aos instrumentos, que as mulheres não podem ver" (2004 [1964]). 
acarreta a inferência (ou verifica a hipótese) de que o contínuo traz em si o descontínuo, e até o engendra" (idem: 364). Interessante este exercício que alguns mitos fazem de uma dialética entre contínuo e descontínuo pensada por meio do efeito do veneno. Levando adiante este raciocínio, podemos pensar em To oena como o avatar da continuidade e as gerações de moças que a sucederam como toda uma cadeia descontínua.

Para começar, Yoi está organizando a festa para arrancar o cabelo de um menino, até onde sei, algo que não acontece atualmente. Para isso ele pinta o instrumento de vermelho, com uma planta que muitos povos indígenas associam à menstruação. Podemos pensar que, se o tabu está concentrado na pintura, como afirma Nimuendaju, quando sua pintura era o vermelho do carajurú (Arrabidaea chica) isso não gerava qualquer problema de proibição ${ }^{140}$. O instrumento possuía a cor do sangue, da menstruação. Yoi acatou então a ordem de pintar com a argila multicolor das "cabeceiras do Igarapé de São Jerônimo". O procedimento de coleta da argila também é bastante importante. Yoi enfia sua zarabatana na medida de um palmo em cada argila de cor diferente. Ou seja, podemos imaginar que a argila que se acumulou dentro da zarabatana formou uma combinação de cores, como uma secção num arco-íris, uma fatia de um arcoíris que combina todas as cores ${ }^{141}$. Esta argila multicolor foi usada para pintar o instrumento e é o fundamento da proibição. Mas, neste caso, a pintura inverte a relação que estabelecemos acima entre menstruação e arco-íris. Ao menos na pintura, os dois seriam excludentes. To'oena morre ao ver a pintura de arco-íris do instrumento, mas se tivesse visto a pintura de vermelho, o que teria acontecido? Yoi pintou o instrumento de vermelho, teria feito isso porque trava-se da iniciação de um menino? Neste sentido, o multicolorido da segunda pintura é letal para as mulheres, assim como o vermelho do sangue menstrual é perigoso para os homens. Se este raciocínio estiver correto, teríamos a seguinte equivalência, sangue menstrual : arco-íris/trompetes :: mulher : homem. Retomarei esta relação entre o arco-íris, o veneno, as cobras e a pele/cabelo no tópico seguinte, sobre os mitos das duas cobras Tautchipé e Yewae.

\footnotetext{
${ }^{140}$ Cf. Matarezio Filho, 2014: 138-142, sobre a relação entre esta planta, o sangue e o seu uso no ritual de iniciação masculina dos Waimiri-Atroari.

${ }^{141}$ Ao analisar o mito de To'oena, Lévi-Strauss menciona o efeito venenoso do cromatismo da pintura do instrumento, que remete ao arco-íris: "...encontramos novamente a tripla associação entre o arco-íris, o cromatismo e o veneno; a diferença entre os Bororo e os Tukuna é que estes parecem restringir ao sexo feminino os efeitos deletérios da ornamentação cromática" (2004 [1964]: 366).
} 
Depois que To'oena foi morta a cacetadas pelos sopradores (fe'güru'ü) de Nge 'cütü, levaram seu corpo para ser esquartejado e limpo como uma caça. A partir do momento em que a moça é afetada pelos instrumentos fica a dúvida se ela é ou não gente. No momento em que To'oena vê os instrumentos, de cima do ingazeiro, ela é atingida

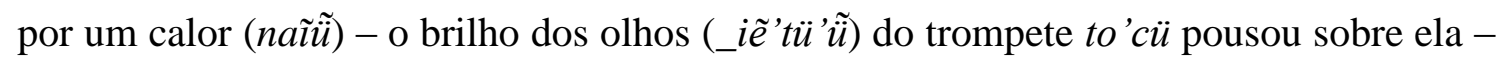
e se urina de medo. Segundo o narrador do mito, os antigos (yaguãta) contam que quando se olha para aquele trompete a vista se apaga. A urina da heroína era vermelha de sangue, o que pôs em dúvida sua humanidade. "Como a urina já era sangue, ninguém sabia se era gente". Vejo neste trecho um exemplo explicito da definição de Lévi-Strauss para o veneno como sendo um operador de um curto-circuito entre natureza e cultura ${ }^{142}$. Naquele momento ninguém sabia ao certo se ela ainda era gente ou não. Comparo esta sequência, fulminante para a heroína do mito, como um macaco sendo atingido por um dardo envenenado de zarabatana, algo que desenvolverei ao longo da pesquisa. Lévi-Strauss, analisando a versão do mito de Nimuendaju, comenta sobre os efeitos do dardo venenoso atingindo o macaco, em como ele se urina ao ser alvejado, exatamente como é narrada a morte de To'oena (2004 [1964]: 366). Os dados utilizados por este autor são retirados das considerações de Nimuendaju sobre o veneno ticuna ${ }^{143}$.

A carne de To'oena já não era mais humana, em algumas narrativas ela se transforma num jacaré (coya), na canção entoada dentro do to 'cü ela vira um veado vermelho. Na versão mais extensa do mito, os dois animais aparecem como transformação do corpo da moça morta. Antes de tratarem a carne dela no igarapé ele era preto. O sangue da moça foi o responsável por tingir a água do igarapé Tünetü ${ }^{144}$ afluente do Eware, rio em que os Ticuna foram pescados - de vermelho. A morte da moça faz com que todos que estavam subindo do rio para a Festa retornem. "Naquele momento, os instrumentos voltaram, não seguiram para a Festa, voltaram para a beira do Eware. Em virtude da morte dela, eles não podiam mais subir para a festa. Todos ficaram interditados

\footnotetext{
142 “Entre a natureza e a cultura, o veneno opera uma espécie de curto-circuito. (...) uma intrusão da natureza na cultura. A primeira invadiria momentaneamente a segunda: por alguns instantes, ocorreria uma operação conjunta, onde suas partes respectivas seriam indiscerníveis." (Lévi-Strauss, 2004 [1964]: 317).

143 "A ação [do veneno] sobre o animal atingido se manifesta imediatamente por uma incontinência de fezes e urina; a queda sobrevém após três minutos aproximadamente" (Nimuendaju, 1952: 30).

144 Também chamado Igarapé São Jerônimo, que desemboca ao lado da comunidade de Vendaval, no Rio Solimões.
} 
(utü' $\tilde{u})$ de subir para a festa, inclusive os tios da moça. Com isso, Yoi e Ipi ficaram desanimados $\left(\right.$ tama $=$ não, nata' $\left.\tilde{a}{ }^{\prime} \tilde{e}=\operatorname{animado}^{145}\right)$ " $($ Anexo -005$)$.

Depois de morta violentamente por ter infringido o tabu das "flautas sagradas", a última ressalva da primeira moça nova é para que sua mãe não se engane, a carne que está no cesto não é carne de caça, e sim sua carne. Neste trecho do mito e da canção ${ }^{146}$, To'oena alerta sua mãe para que não coma a carne, apesar dela parecer carne de veado ou de jacaré. Depois de tratar a carne no igarapé, Yoi colocou-a num cesto, na porta de sua casa de Festas. Trata-se de uma passagem dramática do mito, pois a mãe de To'oena tem que ouvir a alma de sua filha cantando e não pode chorar de modo algum. Para se certificar de que ela não choraria, Yoi passou a fuligem de uma panela de barro embaixo dos olhos de sua irmã. Deste modo, caso ela chorasse, suas lágrimas marcariam sua face de negro. Yoi fez então um discurso para sua irmã.

"Se você respeitar seus festeiros, você vai chamar todo mundo para entrar na

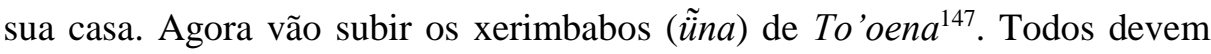
ficar dentro da casa porque ela foi morta. Os xerimbabos já caíram na proibição. Eles não subiram antes, então, tome cuidado. Você já está sabendo. Aquela sua filha, que era moça nova, está morta. Não quero que você chore. Agora vamos subir os xerimbabos dela. Eles vão cantar a música dela. Não chore de jeito nenhum. Se você chorar vai sobrar para você, vai acontecer com você o mesmo que com To'oena. É tudo culpa sua, porque você não aconselhou (ucuẽ) sua filha. Era festa dela, aconteceu isso porque você não juntou tudo que precisava antes e To'oena ficou procurando alguma coisa. Por isso, eu nunca mais vou estar com vocês" (Anexo - 005).

Yoi enfatiza a culpa de sua irmã não ter aconselhado direito To'oena, por isso a moça endoidou. A palavra nhẽaẽ (tchanhẽaẽ = "eu sou doida/desobediente"), que aparece logo no primeiro verso da canção de $T o^{\prime}$ oena ${ }^{148}$ cantada no trompete, me foi traduzida tanto

\footnotetext{
${ }^{145}$ Esta palavra tem como raiz a palavra que designa uma das alma/espírito/duplo dos Ticuna, áe ẽ. Este termo será melhor detalhado no Capítulo 4, tópico 4.1.3 - Ma'ũ e a ãẽ - componentes da pessoa.

${ }^{146}$ Ver História de To'oena, Anexo - 005.

147 Os trompetes na Festa são considerado xerimbabos da moça nova.

${ }^{148}$ Tchaugagü tchanhẽaẽ türü ya nori / "Primeiro, é por minha culpa porque eu sou doida/desobediente" / Ya aüncümacü ya tchuûecü / "É proibido ver a flauta embolo tchuûecü" / Nĩtchacaguün pa iri iri pa worecü ya / "Ela gritou, moça nova" / Guagaya derenecü ya. Ya bunecuya ngaüwa / "Aquela cor amarelada no meio do descampado" / Nünna itchacaguün / "Gritei aqui" / Ya tchuünecü ya / "Flauta
} 
como "doida", quanto como "desobediente". Refere-se às moças que não obedecem a suas mães, respondem a elas com má educação. Esta canção começa com To'oena explicando que ela é a causa da proibição atual. Por uma loucura dela, pelo fato de ela ter desobedecido é que ninguém pode mais ver os instrumentos sagrados.

O mito continua da seguinte maneira: "Yoi mandou que ela [To'oena] cantasse assim dentro do instrumento: "Mamãe, quando eu estava lá com você, na sua frente, $\underline{\text { meu }}$ cabelo esvoaçava (tchingeayaetchigü) (...) Mamãe, não recebe a coxa do veado vermelho. Mamãe, se ele der a coxa do veado vermelho, não receba, pois essa é a minha coxa". Neste momento, Yoi olhou para a cara de sua irmã e viu que ainda não tinha escorrido o pó preto" (idem). O pó não escorreu no rosto da mãe de To'oena. Isso fez com que ela escapasse de ser morta pelo irmão. Yoi, vendo que sua irmã não tinha chorado, disse a ela: "se vocês fizerem Festa, o to 'cü não vai subir mais de dia". A partir de então o to'cü só sobe da beira do igarapé onde está guardado para a festa depois que escurece. E antes dos primeiros raios de sol ele deve ser levado de volta para dentro d'água.

Ao contrário da maior parte dos mitos sobre "flautas sagradas" na América do Sul - os dos povos do Noroeste amazônico, como os Desana (Lana, 2009), os Barasana (Hugh-Jones, 2011), os Yuhupdeh (Lolli, 2010: 123), ou os Hupd'äh (Ramos, 2013: 347), p.ex., ou dos povos xinguanos, como os Kamayurá (Menezes Bastos, 1999[1978]), - o mito ticuna de To 'oena ${ }^{149}$ não mostra uma inversão dos gêneros responsáveis pelos instrumentos. Sintetizando brutalmente estas narrativas, de maneira geral, estes mitos apresentam um estado inicial em que as "flautas sagradas" eram um "domínio exclusivo das mulheres", não satisfeitos com isso, "os homens fizeram uma revolução, tomando as flautas das mulheres e constituindo o mundo como hoje ele é” (Menezes Bastos, 2006: 569). Contudo, a inversão presente no mito de To'oena - que conta a origem da interdição

embolo tchuünecü" / Oi yoyawetcha arü tchuünecü / "Flauta embolo do vovô Yoi" / Pa iri iri pa worecü ga / "Moça nova" / Yeataiya tuegatünetü rü naãnewai / "Lá na terra do igarapé preto" / Tchôün ita tchunaü / "Tiraram minhas tripas" / Pa iri iri pa worecü / "Moça nova" / Naũẽẽta pa mamãe ga / "Mamãe, tome cuidado" / Ya daruta ya cowü matchiaün / "Você pensa [que mina carne] é carne de veado" / Pa õ inhemarü / "Mãe, aquela carne" / Tchamatchii niũpa napüarü yererearü ĩãäungona cawetãün / "Minha carne está na porta da casa/montanha dele [Yoi], dentro de um cesto" / Pa iri iri pa worecü / "Moça nova" IFu fu fu fu fu fu fu fu. (Cantada por Severino Alexandre Gomes - Tõetükü, traduzida por Ondino e por mim).

149 Esta narrativa foi traduzida por mim e pela ticuna Hilda do Carmo (Mutchique'ena) de Firmino \& Gruber, 2010. 
sobre os trompetes e a origem da reclusão das moças que acabam de menstruar - é outra. Como vimos, Yoi, tio (MB) de To'oena, institui que os trompetes agora não subirão para a Festa de dia, apenas a noite. Retomaremos esta consideração sobre os trompetes ticuna e as interdições ligadas a eles no Capítulo 6 - Instrumentos musicais da Festa.

\section{5 - Tautchipé e Yewae}

“Edson: - Essa cobra Norato [Tautchipé] é o mesmo que Yewae?

Ondino: - É o mesmo que Yewae, só que diferente. "

Vimos acima a relação que os trompetes ticuna tem com a cobra-grande. Contudo, o pensamento sobre estes trompetes vai ainda mais longe. Segundo a etnografia de Gruber, ao ser pintado, o to 'cü se transforma em cobra-grande. "No tempo em que Yo'i ainda vivia junto com seu povo, o to'cü era pintado de várias cores. (...) A pintura dava-lhe poderes, tornando-o um instrumento sagrado. (...) A pintura do to 'cü era feita em faixas paralelas que contornavam todo o corpo do instrumento, usando as quatro cores [verde/azul, branco, amarelo e preto]. Essa pintura transformava-o em cobra-grande.” (Gruber, s/d: 30-31, eu grifo). A cobra-grande, figura mítica praticamente onipresente na Amazônia, chama-se Yewae entre os Ticuna. Nimuendaju afirma que ela é a dona da argila, a mesma argila colorida, como o arco-íris, usada para pintar o instrumento ${ }^{150}$. Yewae é quem cuida desta argila. Se uma mulher grávida tocar a argila, esta última se torna imprestável. Nimuendaju transcreve a história de uma mulher grávida que foi levada por Yewae porque retirava argila de um banco na beira do rio (1952: 46).

Este mesmo etnógrafo relata que o xamã Domingos Tchu'necü fez uma visita ao mundo de Yewae para acalmá-lo, pois ele estava causando violentas correntes na boca do Igarapé São Jerônimo. Domingos quase não conseguiu retornar de sua visita. Por duas vezes Yewae tentou levar a canoa do xamã nas costas. "Em uma dessas ocasiões, as folhas

150 “Em todos os igarapés habitados pelo Tukuna, uma argila cerâmica plástica de boa qualidade é encontrada mais ou menos frequentemente; quase sempre ocorre nos lamaçais ao pé das escarpas altas ao longo do rio. A esta matéria-prima é concedido um certo respeito, uma vez que seu dono é um monstro aquático, Yewae, que às vezes se apresenta sob a forma de arco-íris ocidental." (Nimuendaju, 1952: 46). 
das árvores lhe apareceram como um caleidoscópio de cores a partir da reflexão de cores do Yewae" (1952: 120). O mesmo informante que contou a história do pajé Domingos a Nimuendaju, relatou também que certa vez viu Yewae colocar sua cabeça para fora d'água. "Quando a cabeça tocou a superfície da água, houve um clarão de relâmpago, produzido pelo demônio abrir os olhos debaixo da água. Este Yewae é o dono dos peixes do Solimões e aparece como o arco-íris Oriental; o Yewae do arco-íris ocidental é o proprietário do barro de oleiro [ver p. 46]. O inimigo mortal lendário de todo o clã Yewae é o Tautchipé, que, embora de origem humana, por sua educação no mundo subaquático adquiriu qualidades demoníacas que, finalmente, o transformaram em um inimigo da humanidade." (idem: 120). Temos aqui, portanto, um par de cobras presentes na mitologia ticuna, Yewae e Tautchipé. O primeiro, dono dos peixes, da argila colorida, do arco-íris ocidental, possui uma presença mais marcante no cotidiano dos Ticuna ${ }^{151}$. O segundo possui uma história mais complexa, que examinaremos mais de perto, com um foco especial em sua relação com o mito de To'oena.

Quando To'oena se espanta com o to'cü, ela o enxerga como um jacaré. Esta é a mesma forma que possuem alguns demônios subaquáticos mencionados por Nimuendaju, os tënënë'naa, "que têm a forma de jacarés” (1952: 121). No mito registrado por Nimuendaju intitulado "O Fim da Maloca Kuyaru”, eles são os responsáveis pela destruição desta maloca. O mesmo mito me foi contado por Ondino, contudo, os tënënë'naa foram substituídos pelo Tautchipé, numa história que funde os dois mitos registrados por Nimuendaju, "Tautchipê" e "O fim da Maloca Kuyaru” (1952: 120-121). Esta intercambialidade entre o demônio em forma de jacaré o a cobra arco-íris Tautchipé aparece, portanto, no mito de To'oena. Afinal, a heroína delira ao olhar para a pintura multicolorida do instrumento, como um arco-íris, enxergando-o como um jacaré. Na versão do mito narrada por Ondino, ele diz que "a filha do Tautchipé era o jacaré". Este jacaré é caracterizado por ter dois rabos - "filho de Tau'tchipe, o jacaré que tem dois rabos (Türütürü)" ${ }^{152}$-, o que o conecta mais ainda à cobra-grande ${ }^{153}$.

\footnotetext{
151 Ver Capítulo 4, sobre o xamanismo ticuna.

152 Depoimento de Damião Carvalho Neto em Lima, 2006: 134

153 "A anaconda é mestre de desdobramento, já que tem a língua e o pênis bifurcados, pode viver na água, além de viver na terra e em árvores (Lagrou, 1998, p. 241)" (Belaunde, 2006: 218).
} 
A história de Tautchipé $e^{154}$ é um encadeamento de inadaptações do personagem. Quando vivia na água não se sentia pertencente àquele lugar. Quando estava na terra também já não conseguia esconder sua natureza anfíbia. Tautchipé estava na barriga de sua mãe quando toda sua família foi soterrada por um deslizamento de barranco em cima do barco deles. "As outras pessoas morreram, porque a cobra grande comeu, engoliu. Uma arraia grande, Ngumaenã, maior que um forno de torrar farinha, se fechou com uma mulher. A arraia se fechou e a mulher ficou lá dentro". Contudo, a arraia gigante, Ngumaenã, mata a mãe de Tautchipé e gesta o menino, "criou a criança até ela ficar pronta, como pronta para nascer". Depois que cresceu, quando tinha seus quinze anos, Tautchipé começa a ficar cada vez mais com raiva do que aconteceu com sua família. "Ele pensava assim, "agora eu vou fazer terra cair, o mundo inteiro", assim ele falava. E a vovó Ngumaenã dizia que não pode, "não pode ser assim", ela dizia. "Porque minha mãe morreu assim, todo mundo tem que morrer assim”, dizia o Tautchipé. E porque a vó Ngumaenã não deixava ele fazer assim, ele ficou com raiva dela. Ele queria matar a Ngumaenã". Ele acaba então envenenando sua avó e dando um golpe de misericórdia nela com uma lança.

Tautchipé reúne qualidades próprias das moças novas, pois transforma-se durante sua reclusão, na narrativa de Ondino. Ele era um assíduo frequentador de Festas de Moça Nova. "Depois que a avó dele tinha morrido, foi que ele veio para a terra. Ele nunca mais foi para a água. Ele subiu de uma vez, foi andando para todo canto, andando no mundo inteiro. Onde faziam Festa da Moça Nova ele ia para lá. Quando ele estava de porre ele se transformava em cobra-grande, a cobra Norato. As pessoas que faziam Festa já conheciam quem era. Quando viam que ele já estava começando a ficar de porre, procuravam um lugar para ele. Colocavam ele num quarto, e lá ele se transforma em cobra-grande". A transformação dele em cobra-grande é narrada como muito semelhante a reclusão da moça. Quando ele vai se transformar, ele é levado para um quarto e dentro do quarto ocorre a transformação em cobra. Se levarmos adiante a relação, que Belaunde (2006) encontra em diversos povos ameríndios, entre a menstruação e a mudança de pele/corpo, começamos a antever, por indícios da mitologia, que a moça está trocando

${ }^{154}$ Os trechos que seguem são a história de Tautchipé como me foi narrada por Ondino. 
sua pele/corpo na reclusão, assim como Tautchipé. Mas, ao mesmo tempo, também chega para aconselhar Ngutcha e toca aru, como um "copeiro" (üa ̃ücü) ${ }^{155}$.

No local onde Tautchipé estava com sua filha jacaré havia o igarapé Cujarú, ainda não existia como hoje o lago Cujarú, próximo do igarapé Jacurapá. Neste lugar o “pessoal matou esse jacarezinho. Eles nem estavam sabendo que era a filha do Tautchipé. Nesse momento eles estavam num ajuri ${ }^{156}$, para o ajuri que eles mataram aquele jacarezinho. $\mathrm{E}$ todo o pessoal comeu". Ngutcha, se salva por não ter comido a carne da filha de Tautchipé. Como ela estava com um bebê recém-nascido e, portanto, de resguardo, não participava do ajuri em que o jacaré foi comido. Notemos que a filha de Tautchipé é um jacarezinho que "não tinha um braço de um lado" e que foi consumido totalmente ${ }^{157}$. Este dado também aproxima a filha dele de To'oena. Esta última, nas versões em que se transforma em jacaré após ser morta, tem somente "uma banda" de sua carne comida. Pela proximidade estrutural entre To'oena e Tautchipé provavelmente estamos tratando das duas metades de um mesmo jacaré. Ao que parece, o Tautchipé é uma espécie de versão masculina ofídica de To'oena, principalmente por se transformar quando está em reclusão. A semelhança da transformação do Tautchipé e das moças novas é tão notável que Ondino ressalta que o local onde ele se transformava em cobra(s) era justamente ao lado das igaçabas de pajauaru ${ }^{158}$, ou seja, onde é construído o quarto de reclusão da moça nova na casa de Festas. Assim narra Ondino, "ele se transformava em cobra-grande lá, dentro do quarto. Quando amanhecia o dia, quando ele estava ficando bom do porre, ele se transformava em gente de novo. Mas onde não conheciam ele, as pessoas se assustavam quando ele estava de porre. Junto da igaçaba, onde estava o pajauaru, aí mesmo que ele se transformava em cobra-grande. Olha um monte de cobras. Aí o pessoal se assustava. Ele ficava com raiva e destruía a terra. Ficou com raiva e destruiu tudo.

\footnotetext{
${ }^{155}$ Aru é um bastão de ritmo tocado na Festa da Moça Nova, em geral pelo chamado "copeiro" (üa ̃ücü), responsável por conduzir as sequencias do ritual. Recebe esta designação em português ("copeiro") porque uma de suas incumbências na Festa é servir bebida para os convidados.

${ }^{156}$ Palavra derivada do tupi, ayu'ri (dic. Houaiss), usada no português regional para se referir ao mutirão que se faz no roçado.

157 Veremos que este tema da vingança que é gerada porque mataram e comeram alguém pensando que se tratava simplesmente de um animal de caça reaparece no mito do Tchürüne. Abordaremos este mito quando formos analisar a origem de alguns instrumentos tocados na Festa, no Capítulo 6.

158 Igaçaba é um grande jarro de cerâmica onde antigamente se armazenava o pajauaru, a bebida fermentada mais consumida nas Festas.
} 
Destruía a casa e no lugar ficou só o lago". A relação de transformação guardada pelos dois personagens aproxima ainda mais a primeira moça nova - e por extensão todas as moças novas - da capacidade das cobras de rejuvenescerem trocando de pele, fato recorrente no pensamento indígena.

Por outro lado, Tautchipé também possui qualidades de Yoi, o herói cultural ticuna, já que aconselha as pessoas que quer bem no intuito de salvá-las. Para avisar Ngutcha que ela tem que sair da casa para se salvar - pois ele irá destruir tudo para vingar a morte da filha - Tautchipé usa o mesmo recurso usado para aconselhar as moças novas. Vejamos outro trecho do mito contado por Ondino:

“Aí o Tautchipé subiu com o aru (bastão de ritmo) dele. [Ele toca aru?] Toca.

Ele subiu [com cocar], tocando o aru e cantando, igual em Festa de Moça Nova, até chegar no casarão. [Como ele cantava?] [Ondino começa a cantar]. [O que a canção está dizendo, Ondino?]. Está dizendo para aquela mulher Ngutcha, se ela não comeu a carne da filha dele, ela tem que sair [da casa], fugir, nesta mesma hora. Ele está indicando uma montanha. Lá ele vai amarrar a rede dela e vai para lá. Porque o lugar onde está o casarão vai ser destruído, hoje de noite. Assim ele cantava para ela."

O canto do Tautchipé é um aconselhamento para a mulher que não comeu a carne de sua filha. Esta é uma típica forma de uso do canto pelos Ticuna. O canto na Festa serve também para aconselhar a moça nova. Desta mesma maneira, Yoi aconselhou sua irmã para que não chorasse a morte da filha, To'oena, caso o fizesse morreria. No mito, portanto, Ngutcha é aconselhada da mesma forma que uma moça nova recebe conselhos. Quando começa a escurecer, mesmo horário em que as "flautas sagradas" sobem para a Festa, Ngutcha começa a fugir. "Até que deu umas doze horas da madrugada. Aí a casa foi destruída, só era água", esta é a origem do atual lago Cujarú. Quando se transformava em cobra, Tautchipé ficava furioso e começava a destruição, "naquele tempo era muito difícil acontecer a Festa sem que ocorresse algum problema. Onde acontece a Festa sempre há alguém brigando, é porque ele está no meio. Esse é o sinal que ele deixa de sua presença"159. O Cujarú foi o primeiro deslizamento de terra que virou um lago. Segundo Ondino, "ele foi subindo de comunidade em comunidade e destruindo, fazendo lago. Ele que fez ali no Maité, no Alto Camatiã. No Jandiatuba, Amaturá, em Nova Itália

159 Depoimento de Jordão Arapasso, Enepü, em Faulhaber, 2003b: 66. 
também tem um lago bem grande. Tudo que é lago que fica assim na terra firme é ele que faz".

Na versão de Nimuendaju ficam ainda mais evidentes as qualidades de "moça nova" de Tautchipé. No trecho, p. ex., a arraia, mãe adotiva de Tautchipé, "fez uma cestaria mágica, colocou-a sobre a cabeça do menino, e entrelaçou seu cabelo com a cestaria para que o cabelo, e com isso a força do menino, aumentassem.” (1952: 120). Esta cestaria entrelaçada com cabelo, que veremos ser a própria pele de Tautchipé, nos revela a proximidade que o cabelo e a pele possuem no pensamento ticuna. Veremos como a troca de cabelo e a troca de pele correspondem a uma mesma função. Além disso, o que está implícito, mas que me foi contado por Ondino, é que esta cestaria é feita de jacitara $^{160}$ (bu'u), uma fibra mais firme que o arumã ${ }^{161}$, de que é feita a capa de Yewae. Neste sentido, a arraia já prepara seu filho adotivo desde o nascimento para ser mais forte que Yewae, a cobra que matou a mãe de Tautchipé. Assim detalha Ondino:

"[À medida em que ele crescia, Ngumaenã, a arraia que o criou,] fazia um chapéu maior para ele, emendando, emendando... Com esse chapéu é que ele se transforma em cobra-grande. O Yewae fazia também esse chapéu, mas era feito de arumã. Mas esse arumã não é muito duro. Quando ele [Tautchipé] está com a vó dele, Ngumaenã, ele se transforma em gente igual a gente. Chamava ele para jogar bola. Está dizendo que é para jogar bola, mas não é bola. Yewae convidando o Tautchipé. [Eles jogam bola juntos?]. Jogam bola juntos, em cima de uma montanha, Yonüapü. Em cima dessa montanha que ele dizia que jogava bola, mas eles jogavam o chapéu dele. Para eles era bola, mas para quem olhava era o chapéu deles que eles jogavam lá. Mas era tipo um cabo, uma corda, esse chapéu deles. Nessa corda do Tautchipé que o Yewae subia e, quando chegava lá em cima, puxava para arrebentar a corda. Mas a do Yewae que arrebentava, porque a do Yewae era feita de arumã, que é mole, não é muito duro. A corda do Tautchipé era feita de jacitara, que é forte, não arrebenta. Aí morria lá o Yewae, morria porque arrebentava a capa dele." (Ondino).

Antes de abordarmos este jogo de "bola" cósmico das cobras, voltemos um instante nossa atenção para o cabelo de Tautchipé. Uma referência importante também é

\footnotetext{
160 Do tupi yasi'tara, "design. comum às plantas, ger. escandentes, do gên. Desmoncus, da fam. das palmas" (dic. Houaiss).

161 Do tupi tupi ïwaru'ma, "design. comum à diversas ervas do gên. Ischnosiphon, da fam. das marantáceas" (dic. Houaiss).
} 
o fato de ela entrelaçar os cabelos do menino com a cestaria. Ou seja, os cabelos de Tautchipé estão entrelaçados com o arco-íris, sua pele/capa/cestaria (tchamũ ou tchaicüré). Esta última fortalece os cabelos do menino que, por sua vez, fortalecem o próprio menino. Fortalecer os cabelos é, portanto, fortalecer a pessoa. A narrativa registrada por Nimuendaju segue da seguinte forma: "Tautchipé queria matar o Yewae imediatamente, mas a arraia o aconselhou a não tentar ainda, porque ele ainda estava muito fraco. Quando tinha seis anos, seu cabelo já tinha crescido até o seu cinto, e ele voltou a insistir na tentativa de combater o Yewae, mas sua mãe adotiva ainda não permitiria isso. Mais dois anos se passaram e, em seguida, seu cabelo tinha crescido até os calcanhares; então ele não desejava demorar mais." (1952: 121, eu grifo). O trecho em negrito da citação é a demonstração da equivalência funcional que mencionamos acima no pensamento mítico ticuna entre a capa/pele (tchamũ) os cabelos (yae). Quando os cabelos de Tautchipé crescem até os calcanhares - ou seja, cobre todo seu corpo, como uma pele -, ele está pronto para enfrentar o Yewae.

O cabelo que cobre todo seu corpo "até os calcanhares” está entrelaçado com sua capa de cobra arco-íris. Esta capa, que do ponto de vista de Tautchipé e Yewae são seus chapéus, quando eles estão jogando em cima da montanha, é visto por eles como uma bola, mas que também é um tipo de corda ou o próprio arco-íris. $\mathrm{O}$ arco-íris que vemos no céu é a cobra Norato ou Tautchipé. Esta cobra arco-íris é sinônimo de desavença e destruição. "O mundo inteiro terá sido destruído no dia que não aparecer mais arco-íris no céu. Se passar dois, três, cinco ou dez anos sem aparecer um arco-íris, pode contar que o mundo vai terminar", assim profetiza Jordão Arapasso (Faulhaber, 2003b: 66) ${ }^{162}$. Destruição esta que guarda também uma relação com o veneno. Na versão de Ondino, Tautchipé, ao invés de matar o Yewae, como acontece no texto de Nimuendaju, mata sua avó, a arraia Ngumaenã. Para isso ele começa a envenená-la com timbó, antes de matá-la com uma lança. Este fato mostra a relação entre o arco-íris, a capa de Tautchipé, com o veneno.

Tudo indica que esta potência de destruição cósmica e toxicidade do veneno estão agenciados no corpo da moça nova durante a Festa. "Como as cobras, as mulheres mudam de pele/corpo e produzem substâncias venenosas" (Belaunde, 2006: 218). A morte de

\footnotetext{
162 "A existência do arco-íris, que indica uma ruptura e uma passagem entre os dois mundos, no relato de Pedro Inácio é um sinal de que o "fim do mundo ainda não chegou"” (Faulhaber, 2000: 113).
} 
To 'oena, como vimos, mostra uma vítima alvejada por um dardo envenenado. É como se o veneno presente em seu próprio corpo se descontrolasse no momento em que ela olha para o brilho do olho do to' $c \ddot{u}$.

De acordo com Belaunde, existe uma constante relação entre o arco-íris e a menstruação no mundo ameríndio, por intermédio da cobra-grande ${ }^{163}$. De modo geral, todos os astros que possuem alguma relação no pensamento ticuna com a menstruação, Lua ${ }^{164}$ e o arco-íris, estão sempre trocando de pele/corpo. "Por toda a Amazônia, sangrar é a "troca de pele/corpo" par excellence, e são as mulheres quem mais evidentemente fazem com que isso aconteça, em suas regras e no nascimento da criança." (Belaunde, 2006: 207-208). Os Ticuna não fogem a esta regra amazônica, o mesmo acontece com a moça nova ao ter sua primeira menstruação.

Podemos ir ainda um pouco além, afinal trocar de pele é tornar-se mais jovem, seguir na direção de se imortalizar. Segundo relato do ticuna Pedro Inácio, uma das possibilidades de se chegar ao Eware, o local de origem dos Ticuna e morada dos imortais, seria a troca de peles ${ }^{165}$. É justamente isto que está acontecendo na Festa com as moças novas, uma troca de pele rejuvenescedora.

\section{6 - Monmaneki - O Don Juan hiperbólico}

Retomarei adiante estas relações entre menstruação, troca de pele, cabelos, rejuvenescimento, etc. Neste tópico, pretendo introduzir um pouco do pensamento mítico ticuna sobre o que é casar bem. Este tema está intimamente relacionado à Festa da Moça Nova, afinal uma das finalidades do ritual é preparar a moça para seu casamento que virá em breve. Aqui serão abordados dois mitos: 1) a história de Monmaneki, mito de referência e fio condutor do terceiro volume das Mitológicas, A Origem dos Modos à Mesa (Lévi-Strauss, 2006 [1968]), livro que começa a abordar mais profundamente a

\footnotetext{
163 "Por toda a Amazônia, o sangramento está ligado à relação íntima das mulheres com as anacondas. A anaconda (...) se identifica com o arco-íris cósmico e a serpente subaquática, considerada "mãe" ou "dona" de todas as cobras." (2006: 218).

164 Detalharei melhor a relação de Lua com a menstruação entre os Ticuna no Capítulo 4, tópico 4.2.3 Menstruação.

165 “Em depoimento de Pedro, a possibilidade de tal reaproximação [do Eware] é representada como a imagem de troca de pele, que implicaria uma renovação, um rejuvenescimento" (Faulhaber, 2000: 115).
} 
conexão dos mitos da América do Sul e do Norte; 2) a história do também caçador, Õtchi, espécie de negativo do mito de Monmaneki. Estes dois mitos estão em uma relação de oposição pelo seguinte motivo, se no primeiro é uma mulher a "metade grudenta"166, que literalmente gruda no corpo de Monmaneki; no segundo, a "metade grudenta" é o herói do mito, Õtchi.

Para situar o leitor na história, comecemos por uma versão reduzida do mito do caçador $\tilde{O} t c h i^{167}$, assim como fizemos com a história de To'oena:

"Õtchi era um caçador que costumava ir para a mata e brincar de separar seu corpo das pernas, e assim se divertia com o pássaro Auma e o sapo Batü. Como não trazia caça para casa, a mulher desconfiou e foi atrás. Escondida, presenciou a brincadeira, e num dos momentos em que o corpo subiu ela puxou as pernas do marido com um gancho de pau e jogou-as no igarapé. $\mathrm{O}$ corpo perseguiu-a de volta para casa e colocou-se sobre o telhado, de onde cantava: "Õ õ õ õ õ õ o (redução da palavra mamãe), eu quero deitar contigo na rede!" Por várias vezes ele cantou, mas a mulher respondia-lhe outras coisas fingindo não entender. Um dia ele se transformou em onça grande, matou vários maiyu e com os ossos fez uma espécie de carapaça para proteger seu corpo. Assim voltou para casa e continuou chamando em vão pela mulher, que nunca o atendeu. Cantou, cantou, até se transformar num pequeno animal. As pessoas que viviam por ali ouviram esse canto triste, quase um choro. (...) Até hoje os ticunas ouvem a voz do Õtchi, um inseto muito pequeno e raro que vive no alto das árvores e canta dia e noite com uma voz triste, repetindo seu próprio nome: "Õ õ õ tchiiiiiiiil!".” (Gruber, 1999: 35 -36).

Possuo uma versão mais extensa e detalhada deste mito, que traduzi com a professora ticuna Hilda Tomás do Carmo e usaremos para elucidar alguns pontos da narrativa $^{168}$. Da versão acima já podemos perceber alguns paralelos com a Festa e outros mitos dos Ticuna. Õtchi é um bom caçador. No entanto, chega um momento em que ele se torna completamente incompetente em sua função. Ao invés de caçar, ele fica

\footnotetext{
166 Para conferir um desenvolvimento deste tema mítico, ver o capítulo "Uma metade grudenta" do livro A Origem dos Modos à Mesa (Lévi-Strauss, 2006 [1968]).

${ }^{167}$ Este mito foi narrado à Gruber por Manuel Rita para explicar a origem do "canto" do trompete to'cü. Retirei as informações sobre esta origem no mito para não nos adiantarmos neste tema. Abordaremos estas passagens na seção sobre organologia ticuna, no Capítulo 6.

168 Tradução da história Ngatü rü Auma, registrada em língua ticuna em Firmino \& Gruber, 2010, vol. 1.
} 
brincando de separar o corpo das pernas junto dos pássaros Auma e do sapo Batü. Ou seja, sua negligência com a responsabilidade que deveria ter com a caça está demonstrada na falta de medida de seu próprio corpo que, como um elástico, aumenta e diminui de tamanho a partir da cintura. Por isso a separação entre o tronco e as pernas. Depois que sua mulher separa definitivamente o tronco das pernas do caçador, a parte superior de Õtchi toma a mesma atitude da esposa de Monmaneki, persegue seu cônjuge até não poder mais. Se por um lado, portanto, temos na mitologia ticuna uma reflexão sobre uma mulher "grudenta", a esposa de Monmaneki, por outro lado, Õtchi é um homem também "grudento". Neste sentido, as duas histórias refletem sobre a boa distância entre cônjuges, mas de pontos de vista diferentes, do homem e da mulher.

As semelhanças entre Õtchi e Monmaneki não param por aí. Os dois saem todos os dias para caçar e são bem-sucedidos em suas caçadas. Na versão que traduzi com Hilda, o caçador ia para a floresta caçar todos os dias sozinho. Certo dia ele voltou para casa e não trouxe caça, como sempre fazia. Vejamos mais de perto a cena do caçador Õtchi quando encontra com os pássaros Auma na floresta:

\footnotetext{
"Quando o caçador ouviu esse pássaro que estava gritando, ele foi ver e foi caçar o passarinho. Aquele pássaro Auma, não era verdade que ele era pássaro. Ele não era pássaro de verdade (notürü = não é verdade). Então o pássaro sentou no ombro do caçador. O pássaro rasgou a cintura (ayel aratii) do homem e separou as metades. Ele ficava brincando com as metades do caçador [mas não encostava nele, "ele tem poder [pora]"]. A metade de cima subia e descia se chocando com a de baixo e fazendo barulho, “dó, dó, dó, dó...”. Só ficou a medula unindo as duas partes do caçador. A parte de cima dele ia até lá em cima no galho da árvore e voltava, ia e voltava, ia e voltava... (...). Os pássaros eram igual gente e igual bicho (ngo'o). Ele se transformava em gente, mas era bicho (ngo’o), não era pássaro não. Por isso, os velhos contam que quando a gente vai para a terra firme não é bom para a gente perguntar, "o que é esse que está cantando aí?”. Não pode remedar ele, não pode olhar para ele também, nem pensar no pássaro pode, é perigoso.”.
}

Hilda me explicou como acontece esta mudança de perspectivas quando se está na floresta e remeda ou pensa no pássaro. Segundo ela, "se pensarmos no canto dele, o pássaro vai pensar em nós também e vai vir atrás da gente. Mas é perigoso só se estiver sozinho, acompanhado não tem perigo. O perigo é estar sozinho e entrar no pensamento 
dele." Ou seja, o maior perigo é ser pensado pelo pássaro (“entrar no pensamento dele”), uma possível consequência disso é tonar-se um joguete no pensamento do pássaro Auma, como acontece com o caçador na história.

Notemos que o pássaro faz uma algazarra e induz o caçador a fazê-la também, chocando as duas partes do corpo que estavam unidas apenas pela medula. Estas duas referências à algazarra são, seguindo as indicações de Lévi-Strauss, equivalentes à sujeira, inclusive à poluição menstrual, quando passamos para o código sexual ${ }^{169}$. Ao fazer esta algazarra no mato junto com os pássaros, o caçador se equaciona a uma mulher em suas regras. A continuação do mito reforça a "zoada" que fazem os pássaros Auma. Desconfiada, sua mulher resolveu acompanha-lo no dia seguinte. "Então eles chegaram lá onde tinha acontecido aquilo com o caçador. Chegaram onde o passarinho fica gritando (cucutama $=$ fazendo barulho, zoada dos passarinhos), onde os pássaros ficam gritando muito (waigu' $\tilde{u}$ ). O caçador falou para sua esposa, "fique aqui mesmo que eu vou matar ( $\left.f e^{\prime}\right)$ os pássaros Auma que estão fazendo zoada aqui”. Ela respondeu, “está bem, eu vou ficar aqui e esperar você". (...) Ele foi aonde os pássaros Auma estavam gritando. Quando os pássaros viram ele chegando, começaram a gritar muito forte (cucumare $\tilde{u}$ ). E sua esposa lá, esperando, mas ele nunca voltava." Com toda a demora, a mulher resolve ir atrás do caçador, "andando bem devagar", ou seja, evitando qualquer barulho (como o silêncio que se espera de uma moça reclusa). "Foi então que ela viu o corpo do caçador subindo e descendo, como da primeira vez. Ele viu a esposa também. Ela ouvia as partes do corpo dele se entrechocando (cudo'o). Os pedaços dele quando se entrechocavam faziam " $d o$ 'o, do'o, do'o..."."

Eis que finalmente um bando de macacos, inimigos do caçador, cortam a medula dele, separando definitivamente suas duas partes. A parte de baixo transformou-se em veado (cowü) e correu para o mato. Quando viu toda essa cena, a esposa do caçador voltou correndo para casa. "Quando chegou, cercou envolta da casa rapidamente, para o marido não se aproximar. O lugar em que ela estava ficou bem "amarrado", bem fechado". Mas

\footnotetext{
${ }^{169}$ A equivalência entre a algazarra e a sujeira/menstruação encontrada por Lévi-Strauss também em outros mitos ticuna. "Os dois mitos tukuna, $\mathrm{M}_{304}$ e $\mathrm{M}_{310}$, possuem em comum o tema do canibalismo e o da sujeira; em $\mathrm{M}_{304}$, a avó-onça tenta fazer passar o fígado de seu filho morto - víscera congruente ao sangue e mais especificamente ao sangue menstrual - por um cogumelo, que também seria um antialimento (cc: 200, 209-10); em $\mathrm{M}_{310}$, um jaguar que usurpou o lugar de uma mãe obriga a criança a inalar os gases que saem de seu traseiro emporcalhado.". (...) "Através deste viés reencontramos a equivalência, já verificada de outro modo (p. 290) entre os gritos - isto é, a algazarra - e a sujeira: termos mutuamente conversíveis conforme o mito escolha um código acústico, alimentar ou sexual para se exprimir" (2004[1967]: 360).
} 
ele permanece em seu encalço, se movendo com as mãos, pulando e se jogando. Ele a persegue gritando também. Numa nítida oposição ao marido, a esposa permanece "quietinha" dentro da casa. A situação da mulher do caçador se assemelha à moça nova, que deve permanecer fechada na reclusão e em silêncio. Ao mesmo tempo, fora da reclusão o som da música é constante e há o assédio dos seres sobrenaturais - os mascarados, p. ex. - que simulam ataques ao quarto de reclusão, como as investidas do caçador ao bunker de sua mulher.

"Lá pela meia-noite ela escutou a voz do caçador gritando no meio do caminho. Ao longe ela escutava ele chegando. Ele gritava, "nga, a, a, a, a, a, a, a, a,". Ele chamava ela

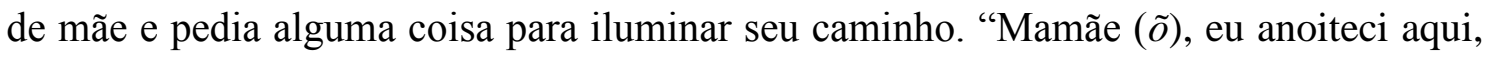
estou perdido, não enxergo mais nada", dizia ele. A mulher pensou assim, "lá vem o bicho (ngo’o) que está gritando". E ela ficou quietinha lá dentro, esperando ele gritar de novo". A equivalência entre sujeira/poluição e algazarra de Õtchi é reforçada ainda pelo narrador ao destacar os barulhos que as tripas do caçador faziam caindo no chão: "Quando ele chegou perto mesmo, ela escutava as tripas dele caindo, “ngüa, ngüa, ngüa, ngüa”. Caíram todas as tripas dele de tanto que sua metade ficava pulando. (...) As tripas dele que ainda não caíram faziam barulho arrastando no chão e ela ouvia lá dentro.”.

Ainda de noite, a mulher jogou carvão em brasa para que o herói pudesse cauterizar sua abertura no abdômen. Quando já estava amanhecendo, "ele começou a flutuar como um imortal (ü’üne). Já sabia para onde ir e já estava flutuando na direção deste lugar para se transformar. Então ficou um silêncio, tudo quieto, porque já tinha amanhecido.” Quando tornou a anoitecer, “o caçador voltou já transformado [no pássaro] Auma e gritou de novo, "mamãe, eu quero deitar na rede com você, como antes". Ele já estava se transformando, como um $\tilde{O} t c h{ }^{170}$. Ele dizia que, como o inseto Õtchi, ele estava fazendo o ninho dele para se transformar. Ele ia sair do ninho dele transformado em pássaro." Hilda me contou que se trata de um tipo de inseto que passa por metamorfoses. "Primeiro é uma lagarta, faz um ninho e depois vira inseto", disse minha colaboradora.

Õtchi pediu a sua mulher que lhe entregasse seu arco, flechas, armas e linha. Ao amanhecer começaram a aparecer as primeiras plumas brancas no ninho dele. "As plumas eram só no ninho, ele não tinha plumas, não virou pássaro. Depois que a mulher dele

\footnotetext{
${ }^{170}$ A versão do mito registrada por Gruber diz que o nome do caçador é Õtchi. Na versão traduzida por mim e por Hilda o nome dele não aparece, mas fica especificado que Õtchi também é um tipo de inseto.
} 
entregou tudo para ele, ele emplumou todo o ninho, entrou nele, saiu voando dentro do ninho e sumiu. O ninho branco saiu voando e sumiu. " Esta transformação do caçador, portanto, possui uma certa semelhança com a moça em reclusão, pois passa por uma metamorfose em seu "ninho". O inseto Õtchi, de lagarta, transforma-se em inseto. O caçador, arrasta-se como uma lagarta até completar sua mutação em um ninho de Õtchi emplumado. Se, como afirma Manoel Rita para Gruber, ainda se ouve a voz de Õtchi entoada no trompete to 'cü, a moça ouve os lamentos deste caçador durante a Festa, da mesa forma que a esposa do caçador ouviu os insistentes chamados dele quando ela estava em sua "reclusão". Não conheci qualquer canto entoado no to'cü que remetesse ao som de Õtchi. No mito ele ficava repetindo que queria que sua esposa o recebesse de volta em casa, mas era insistentemente recusado. No auge de sua transformação, o caçador já chamava sua esposa de mamãe. Ele gritava, "mamãe, eu quero deitar na rede com você, como antes". Contudo, ao contrário da mulher-grampo do mito de Monmaneki, que gruda em seu marido, Õtchi não consegue encostar em sua mulher. Enquanto Monmaneki afasta sua mulher mergulhando na água, Õtchi começa a se transformar e se afastar de sua mulher depois de queimar-se com fogo.

Podemos afirmar que Monmaneki é o exemplo do homem com quem não se deve casar. Lévi-Strauss o apresenta como "um diletante da aliança, uma espécie de Don Juan hiperbólico que, não contente, como dizemos (mas já utilizando diferenças subespecíficas) em passar das morenas às loiras, estende sua curiosidade amorosa até as espécies animais mais variadas, batráquios, aves e invertebrados" (2006 [1968]: 65). O mito de Monmaneki se insere num grupo que reflete sobre a distância ideal entre os cônjuges, que Lévi-Strauss chama de "tema do casamento sensato, nem muito afastado nem muito próximo" (idem: 129). Monmaneki ora se casa com esposas afastadas demais, já que são animais, ou, por último, uma esposa próxima demais, já que passa um tempo grudada nele. Õtchi não é uma má pessoa ou um "Don Juan hiperbólico”, pelo contrário, sua esposa ao falar com a coruja murucututu de estimação diz, "aquele teu dono era bom antigamente". Ou seja, ele ainda não tinha enlouquecido. Sob a influência de um pássaro considerado "bicho" (ngo'o), o Auma ${ }^{171}$, o bom caçador perde a noção de quem é, chama sua esposa de mamãe ${ }^{172}$. A perseguição causada pela loucura do caçador faz sua esposa

\footnotetext{
171 "Quando estamos sozinhos no mato, ele anda atrás da gente. Velho diz que ele vira onça”.

172 Hilda comentou que o fato de ele chamar ela de mamãe indica que ele já estava doido, virando bicho (ngo'o).
} 
retroceder a um estado pré-nupcial, como uma moça nova, reclusa e em silêncio. "Depois que a mulher dele entregou tudo para ele, ele emplumou todo o ninho, entrou nele, saiu voando dentro do ninho e sumiu. O ninho branco saiu voando e sumiu. Os parentes viram só uma coisa branca saindo voando e desaparecendo. $\mathrm{O}$ caçador virou encantado. Ninguém nunca mais viu ele e não viram no que ele se transformou."

\section{7 - Metare - o bom partido}

Se, por um lado, temos a figura de Monmaneki, o mulherengo, com quem nenhuma mãe gostaria de ver a filha casada, por outro lado, Metare, junto com Yoi, aparenta ser o "bom partido" da mitologia ticuna. Existem diversas histórias que contam as aventuras de Metare e Nimuendaju registrou um bocado delas: Metare e Auecuná (1952: 144-45), Metare e Wîtchicü (idem: 145), Metare e o percevejo Tũtchuru (idem: 145-46) ${ }^{173}$. Ondino me contou uma gesta de Metare que é uma mistura de todas estas histórias. A primeira conta o nascimento do herói, as duas últimas versam sobre a relação dele com seus sogros canibais, um exemplo do "arqui-mito" ameríndio ${ }^{174}$. Nestas duas centrarei o foco da análise, mas inicio com a origem de Metare e sua relação com sua mãe de criação, Auecuná.

Ondino começa a história apresentando Dévane. "Esse Dévane era igual a gente, um ser humano mesmo. Igual a nós mesmo, ele tem a roça, tem a capoeira, tem a casa. Na capoeira dele, ele plantava muito abieiro. Quando chegava o tempo do abiu [ta'ü Pouteria caimito], dava muito abiu". Como o pomar de abiu do Dévane beirava o roçado de outras pessoas, elas "passavam na beira da capoeira dele tiravam as frutas do abiu,

\footnotetext{
${ }^{173}$ Adaptei aqui, como farei em toda a tese, com exceção de Monmaneki, os nomes dos personagens escritos por Nimuendaju para uma grafia mais atual, Auecuná Õuecuna = J'vįkinna, Wĩtchicü = vain či'kị, Tũtchuru = tu'čuru.

174 "As figuras centrais dos mitos ameríndios estão canonicamente relacionadas como afins; um personagem conspícuo dessas narrativas, para tomarmos um exemplo, é o sogro canibal, o Mestre nãohumano de todos os bens culturais, que submete seu genro a uma série de provas com intenção de matá-lo; o rapaz as supera todas (frequentemente graças às habilidades de outros animais que se apiedam dele) e retorna ao seio da comunidade humana trazendo o precioso butim da cultura. $O$ conteúdo deste arqui-mito não é muito diferente do enredo prometéico: há o céu e a terra, há um herói preso entre os dois; há o fogo civilizador, e o "dom" das mulheres, e a origem da mortalidade humana." (Viveiros de Castro, 2007: 123, meu grifo)
} 
roubavam dele". Para se vingar, Dévane arrancava os olhos dos ladrões de abiu e comia. "Dévane já tinha tirado os olhos de muitas pessoas, muitos ficaram cegos, sem ver nada. Outras pessoas tinham avisado para não mexerem no abiu que estava na capoeira dele, senão ele arrancava os olhos. Mas tinha o pessoal que era desobediente, como hoje mesmo. Alguns diziam, "é mentira, a gente nem está morto, como que ele vai tirar os olhos”, assim falavam. Mas na hora que ele quer tirar, a gente está como se estivesse morto (yuũrümareti 'ĩ), não sentimos nada. Certo dia, a mãe de Metare - estava grávida já, buchuda - e certo dia ela foi lá também. Passou na capoeira dele para tirar abiu. De noite, Dévane foi lá e arrancou os olhos dela. Quando ela acordou, já estava sem olhos.”

Depois disso, a mãe de Metare estava grávida e sozinha (Nimuendaju, 1952: 144). Quando chegou o momento de dar à luz, Auecuná correu para perto da parturiente. Auecuná tivera muitas filhas, mas nenhum menino.

\begin{abstract}
"Assim que a criança nasceu, a mãe cega sentiu o corpo do bebê e verificou que ele era um menino. Quando ela deitou o bebê ao seu lado, Auecuná lhe roubou a criança, substituindo por sua filha caçula. Quando a mulher cega novamente pegou a criança recém-nascida, ela percebeu que era uma menina e ficou muito surpresa. Auecuná levou o menino embora. Ela derramou medicamento da planta degüne nos olhos dele e esfregou-o com ele. Assim, ele tornou-se imortal e cresceu para ser muito sábio" (ibdem). Metare cresce então com suas irmãs de criação, sem saber que não são suas irmãs de verdade. Quando Auecuná ia trabalhar em sua roça, as irmãs cantavam para ele: "você não é meu irmão. Esta minha mãe não é a tua própria mãe. A tua mãe é aquela que está lá, cega"175 (...). Aí ele escutou esta música, "então essa daqui não é minha mãe. Agora eu já sei quem é minha mãe", assim ele pensa".
\end{abstract}

Metare vai atrás de Auecuná na roça. Ele queria roubar o degüne dela, o líquido da imortalidade $^{176}$. Ele acaba conseguindo pegar o líquido dela, se transforma em japuaçu (Psarocolius bifasciatus) e sai voando para encontrar sua mãe de verdade, Ngerüetu [sem olhos]. Quando encontrou sua mãe cega, Metare, em forma de japuaçu, pingou o líquido

\footnotetext{
${ }^{175}$ Reencontramos aqui o uso da canção como um alerta, um aconselhamento, que detalharemos melhor nos Capítulos 5 e 7.

${ }^{176}$ Durante a narrativa do mito, perguntei para Ondino, "[para que serve esse degüne?]. Quando cai algum cisco no olho da filha dela, aí ela pinga uma gota para limpar o cisco no olho. E serve para a gente ver longe também, para ver como gente encantada [imortal]. Para isso que serve esse degüne. [Você sabe do que é feito? ]. Ninguém não sabe isso daí."
} 
degüne nos olhos dela e a mulher voltou a enxergar. "Ele já tinha se transformado em gente de novo. Mas ele guardou aquela capa de japó. Quando ele quiser passear, ele veste...".

Será com esta capa (tchamũ) de japuaçu que Metare irá derrotar um de seus sogros canibais, o Tũtchuru. Este ser é descrito como "tipo um inseto, tipo um besouro, mas esse daí se transformava em gente", me disse Ondino. Nimuendaju o descreve como um percevejo de um metro "que sugava as pessoas" (1952: 146). "Esse daí também se alimenta de sangue, o Tütchuru. Depois que ele teve uma filha, ele chupou a mulher dele", complementa Ondino. Por isso, ele criou sua filha sozinho. A narrativa de Ondino continua da seguinte forma:

"Até que a filha dele se formou moça. E muitos ticuna casavam com a filha dele. Porque a filha dele era muito bonita. Passada uma semana, ele se transformava em inseto para chupar o genro dele. (...). Então morreu, aquele genro dele, passada uma semana, duas semanas, outro se casava com a filha dele. E aconteceu a mesma coisa. Não se sabe quantos ele matou. Depois que o Metare já tinha crescido, ele falou, "agora eu vou lá matar esse porcaria e vou casar com a filha dele". "Cuidado, meu filho", falava a mãe do Metare, "senão ele vai te comer". "Eu não, eu não sou qualquer pessoa", respondeu Metare. (...) E Metare foi lá pedir para casar com a filha do Tütchuru. E este falou, "está aí minha filha, pode casar com ela". Metare ficou e casou com a filha do Tũtchuru. Quando completou uma semana, o Tütchuru foi dentro do mosquiteiro da filha dele chupar o sangue. Mas todas as noites Metare tirava todo o corpo de sua esposa, porque ele é ü'üne [encantado/imortal]. Ele tirava a vagina dela e colocava seu pênis no lugar. A vagina dela ele colocava nele. Ele colocou seio também, cabeça, tudo ele tirava e colocava nele. Então o Tũtchuru foi lá tocar [no corpo dentro do mosquiteiro], "esse aqui é tcheate, meu genro", disse o Tũtchuru, "e essa aqui é tcheacü, minha filha". Aí ele chupou a filha dele pensando que era o genro dele. Quando amanheceu, o Metare saiu transformado em japó [japuaçu, Psarocolius bifasciatus ] e ficou lá na cumeeira da casa, lá em cima. E ele ficou lá cantando, "tururu, bururu, tücürü". Aí o Tũtchuru amanheceu com a barriga cheia de sangue da filha dele, que ele chupou. Metare estava na cumeeira da casa, ele furou a casa lá em cima. Apareceu um pezinho, igual a um pezinho de criança, de neném. $\mathrm{O}$ Tũtchuru escutou que ele estava cantando lá. Ele estava chorando, o Tũtchuru. [Era um pezinho de japó?]. Era de gente, um pezinho de nenenzinho. Ele era 
japó, mas só o pezinho que era de gente, de neném. (...) E o Metare continuou cantando lá, "buruburu, tururu, tücürï̈". Mas olha o buchão dele [do Tũtchuru], com o sangue da filha dele. Aí ele [o Tũtchuru] foi, se transformou em gente mesmo, subiu assim. Parece que ele subiu no esteio e foi lá na cumeeira do casarão, para chupar aquele pezinho do neném. Mas o Metare já estava pronto lá, com o bico dele, para furar o Tütchuru. Quando o Tütchuru chegou bem pertinho, aquele pezinho suspendia um pouco. Quando ele chegava mais perto, o pezinho suspendia mais, até ele chegar lá na cumeeira da casa. Quando o Tũtchuru chegou lá, Metare bicou ele. Ele caiu mortinho e espalhou todo o sangue."

Notemos que, assim como Monmaneki, a filha do Tütchuru se casa com diversos pretendentes, mas não consegue ficar com nenhum. Contudo, enquanto para Monmaneki quem dificulta seus casamentos é sua mãe, que impõem tarefas inexequíveis a suas noras, Metare se depara com um sogro devorador de genros. A estratégia dele foi uma explicita inversão de sexos feita para enganar o canibal. Metare se transforma em mulher a fim de não ser devorado pelo Tũtchuru. O sangue da barriga do Tũtchuru, depois dele ser furado por Metare, origina a ponta avermelhada do bico do japuaçu. De certa maneira, é como se o sangue do sogro canibal impregnasse ainda o seu matador após sua morte, algo muito presente no mundo ameríndio e também entre os Ticuna.

A história do outro sogro canibal de Metare é muito parecida com essa. Witchicü tinha uma filha e tinha matado a esposa. Diversos pretendentes casaram com ela, mas Witchicü matou todos também. Para matar seus genros, Witchicü pedia para eles amarrarem um cipó no pescoço e subir num pé de patauá (Oenocarpus bataua) para apanharem um cacho da fruta. Quando a vítima estava lá em cima, ele puxava o cipó, o genro caia e morria. "Certo dia, Metare casou-se também com a filha do Witchicü. "Agora eu vou matar um outro bicho, mãe", disse o Metare, "vou matar o Witchicü”. "Cuidado, meu filho", a mãe dele falava. "Eu vou lá, porque eu não sou qualquer pessoa, eu sei como é que eu vou me proteger", disse Metare. E ele foi lá e pediu a filha do Wĩtchicü. E este nem sovinou a filha dele, porque ele estava com fome, "aí está minha filha, pode casar com ela"." (Ondino). Contudo, quando Witchicü tenta matar Metare, este engana o "bicho" (ngo'o) e faz com que ele coma de sua própria carne. Wîtchicü acaba se consumindo e Metare extermina de vez o "bicho" com um tição em brasa (õ̃ne). 
Podemos notar que as histórias de Metare aproximam este personagem da Festa da Moça Nova pelo tema do casamento. Metare é o herói que liberta suas esposas do jugo do pai canibal. Mas existem narrativas em que sua relação com a moça nova é mais explicita. Como a que resumo em seguida, relatada a mim também por Ondino, que conta sobre quando o herói de apaixonou por uma moça nova em reclusão. Esta também uma variação mais extensa e detalhada de um mito registrado por Nimuendaju (1952: 135-36 - A origem da auréola lunar).

"Antigamente, tinha uma moça nova, era bem mais nova, o Metare queria casar com ela, mas ela não gostou dele. Então, ele se transformou em um jabotizinho deste tamanho assim. [Como se chama esse jaboti?]. Ngobuacü. Aí ele apareceu para ela, a moça nova estava sozinha em casa. O jabotizinho vinha e subia assim na coxa dela. [Ela estava guardada?]. Estava guardada... ela pegou e jogou ele ali, "jaboti caga demais", disse ela. Mas o jaboti voltou e subiu de novo. Ela tinha ainda uma irmã mais velha. Aí essa mais velha pegou o jaboti e disse: "eu vou criar esse jabotizinho para mim". De noite ela dormia com ele. Ela colocou o jaboti onde ela dormia, mas de noite esse jaboti se transformava em gente, num rapaz, bonito rapaz, branco. Aí ele se embalava [na rede] com ela, conversavam, brincavam, namoravam."

"Certo dia, a mãe dela perguntou, "com quem que minha filha está conversando, estão rindo?". Mas a filha não quis dizer não, "sozinha", ela disse, "estou rindo sozinha". Quando amanheceu, Metare se transformou em jabotizinho de novo. Ele foi embora para caçar. Mas aquela moça nova que estava guardada, ela tem um xerimbabo dela também, um gavião pequeno, îtawetchinẽ (Gavião-miudinho (Accipiter superciliosus)). Esse daí também se transformava em gente para ela. A moça dizia que o gaviãozinho era mais bonito, por isso que ela namorava com ele. Mas esse ĩtawetchinẽ, ele é panema, pega só calango, aí ele alimentava ela só de calango. (...)"

"Um irmão das duas irmãs se perguntava, "porque a nossa irmã, de noite, ela brinca, fica rindo, namorando, com quem será que ela está?”. Ele ficou escondido para ver quem era, foi andando atrás do jabotizinho. Quando chegou longe da casa, Metare tirou a casca e se transformou em gente, foi embora para caçar. Aí já sabiam que não era um jabotizinho, era gente. Aí não brigou mais com a irmã dele, ficaram sabendo que era gente encantada (ü'üne)". 
“[Ondino narra a morte do monstro Nacütchi'i por Metare, uma anta gigante, "maior que elefante" (nacü = anta, $t$ chi $i=$ grande)]. Quando o Metare já tinha matado esse tal de Nacütchi'i (...). Quando ele voltou da caçada, os cunhados dele tentaram entrar no casco dele, mas não conseguiram. (...). Eles estavam querendo ver quem é que estava com a irmã deles, mas viram que não era jaboti, era gente. Aí deixou a casca dele e os cunhados dele voltaram para casa. De volta da caçada, quando Metare queria entrar de novo na casca dele, já não conseguia mais, porque já pecaram (yunatü), porque já viram. Aí não consegue mais entrar. Virou mortal, a casca não era mais ü'üne (imortal).”

"O cunhado dele chegou e foi ver se ele tinha matado alguma caça. Foi olhar nas costas dele, para ver se tinha algum sinal de sangue. Foram ver nas costas dele e tinha um sinal de sangue nas costas dele. Então, foram embora para o caminho, para pegar a caça. Estava pendurada numa corda de envira. Queriam tirar, mas não conseguiam, porque era muito grande.”

"Então, Metare tirou um pedaço de pau, amarrou aquela casca dele. Aí ele batia na casca dele, assim como o pessoal faz na Festa da Moça Nova. (...) Ele batia na casca de jaboti, dançava, cantava. Meus cunhados já me viram, já pecaram, agora eu não consigo mais entrar na minha casca, assim ele cantava e dançava. [E como era a música?]. [Ondino canta]. [O que ele está cantando?]. Porque os cunhados dele já viram e ele não consegue mais entrar na casca dele, porque já pecaram."

"Foram ver o que ele tinha caçado, o Metare marupiara, para a Festa dele. (...). Foram lá, mas não conseguiram tirar a anta que estava pendurada lá. E foram chamar de novo o Metare. Ele já tinha outra casca dele. Metare se meteu na casca dele, entrou debaixo da anta e assim conseguiu tirar. "Aí está, agora levem para casa", disse ele. Então, levaram para casa. Neste momento, a Festa já tinha começado, a Festa dele. Tiraram a carne, tiraram o couro, para esticar, e ninguém sabia o tamanho daquele couro. (...) O cunhado dele, as cunhadas, sogro, todo mundo estava esticando o couro. Subiram em cima. Aquela moça nova que não queria ser mulher dele estava lá, mas ela não entrou nesse couro aí, dentro do couro. Só o cunhado dele, sogro dele e as outras pessoas estavam sentados no couro. Estava acontecendo a Festa. Nesse momento, ninguém sabia que hora que já tinha subido com ele esse couro. E tem também uma música que sopravam, "que, que, que, que”, quando sopravam essa música aí começavam a subir. [Sopravam no to 'cü?]. Não, não sei o que é, 
era um instrumento. Aí o couro subia junto com a casa. Metare mandou a moça nova, "agora você vai arrancar um aturá de macaxeira para fazer caiçuma". A moça pegou o buré [cesto cargueiro] e foi embora para a roça. Quando ela não estava mais lá, aí que subiu. (...) Ele está dando castigo para ela, porque ele não gostou dela. (...) Ele queria casar com ela, mas ele casou com a irmã mais velha. Por isso que ele ficou com raiva e mandou a moça nova arrancar macaxeira na roça."

"A batata da macaxeira estava bem fininha e ela arrancava muita para encher o buré dela. Nesse momento sopraram de novo, "que, que, que, que", já estava bem na altura da casa, subia já aquele couro. (...) O couro junto com toda a casa que subia, no terreiro da casa que estavam esticando aquele couro. Depois, quando já estavam bem lá no alto, aí ela [a moça nova] voltou, já tinha arrancado umas batatas grandes de macaxeira. Quando ela voltou, cadê a casa que estava lá? Já estava lá no alto. Ela gritou, chorou, "maninha, maninha, venha me buscar", chorava rodando. Metare ficou com pena dela, jogou uma cordinha bem molinha, que chamavam nanenütá. Igual cipó, mas bem molinho. Mas ele deu um castigo para ela, aquele cipó se transformava em cobra. Quando ela tentou pegar no cipó, a cobra avançava nela. Ela falou, "será que não quebra comigo?". E ela pegou na cobra assim mesmo. Ela queria subir, para puxarem ela para cima. Ela pegou, mas arrebentou, porque ela falava assim. Ficou lá chorando, chorando, até que o pessoal que estava subindo junto com o couro sumiu lá no céu, junto com o sol (...). Foi para o sol e foi para o Morügüne e se transformaram em $\ddot{u}$ 'üne [imortais]. E a moça ficou sozinha, chorando. No outro dia, Metare foi ver ela, que ainda estava chorando, “maĩyu, maĩyu, maĩyu, maĩyu". Tem a figura dela, o inhambu que canta assim na mata. Ela está chamando, "maninha, maninha, maninha". Aí Metare se transformava em jaboti de novo, levou aquele líquido, degüne, ü'üne, e entregou para ela. Ela ficou com raiva, pegou, jogou no chão e quebrou, espalhou tudo. Aí ele não conseguiu fazer mais nada com ela. [Ele tinha levado aquele líquido para que?]. Para levar ela, para encantar ela. Depois ele mandou a onça pular em cima dela e matar ela."

Esta narrativa mostra a faceta de grande caçador de Metare, requisito indispensável para um bom marido. Por outro lado, o belo e sedutor gavião, namorado da moça mais nova, é um caçador panema, alimenta sua companheira só com calango. Podemos dizer que o gavião é um sedutor, no sentido atribuído por Lévi-Strauss, ou seja, 
mais um exemplo de alguém com quem uma boa moça não deve se casar. Ao mesmo tempo em que Metare é o símbolo de um "parceiro ideal" para a manutenção da regra de casamento, o gavião atenta contra esta regra. O sedutor, diz Lévi-Strauss, "ele também representa a intrusão violenta da natureza no seio da cultura" (Lévi-Strauss, 2004 [1964]: 317), o que o autor diz ser também uma característica do veneno. A descrição do sedutor por este autor vai completamente ao encontro do que representa o gavião rival de Metare: "o sedutor é desprovido de status social relacionado ao seu comportamento - senão, ele não seria exclusivamente um sedutor -, agindo unicamente em virtude de suas determinações naturais, beleza física e potência sexual, para subverter a ordem do casamento" (ibdem). O excesso de potência sexual também é atacado por Metare, que mata a anta gigante Nacütchi'i depois deste enfiar seu pênis na boca do herói. "Metare mordeu com força e cortou a cabeça do pênis do Nacütchi'i, no mesmo instante este último caiu morto".

Por que este personagem mítico é tão presente também na Festa da Moça Nova? Metare é a própria carapaça de tartaruga que é tocada durante o ritual, o tori. Ou seja, ao longo de toda a Festa ele dança com os participantes, é, por assim dizer, celebrado. O próprio Metare, na última narrativa que vimos, pega sua antiga casca e começa a tocar um lamento por ela não ser mais encantada/imortal (ü'üne). O uso do tori, o instrumento de casco de tracajá na Festa, remete a uma imortalidade perdida também. Tartarugas não podem trocar sua casca para a manutenção de sua juventude, como fazem as cobras e alguns insetos.

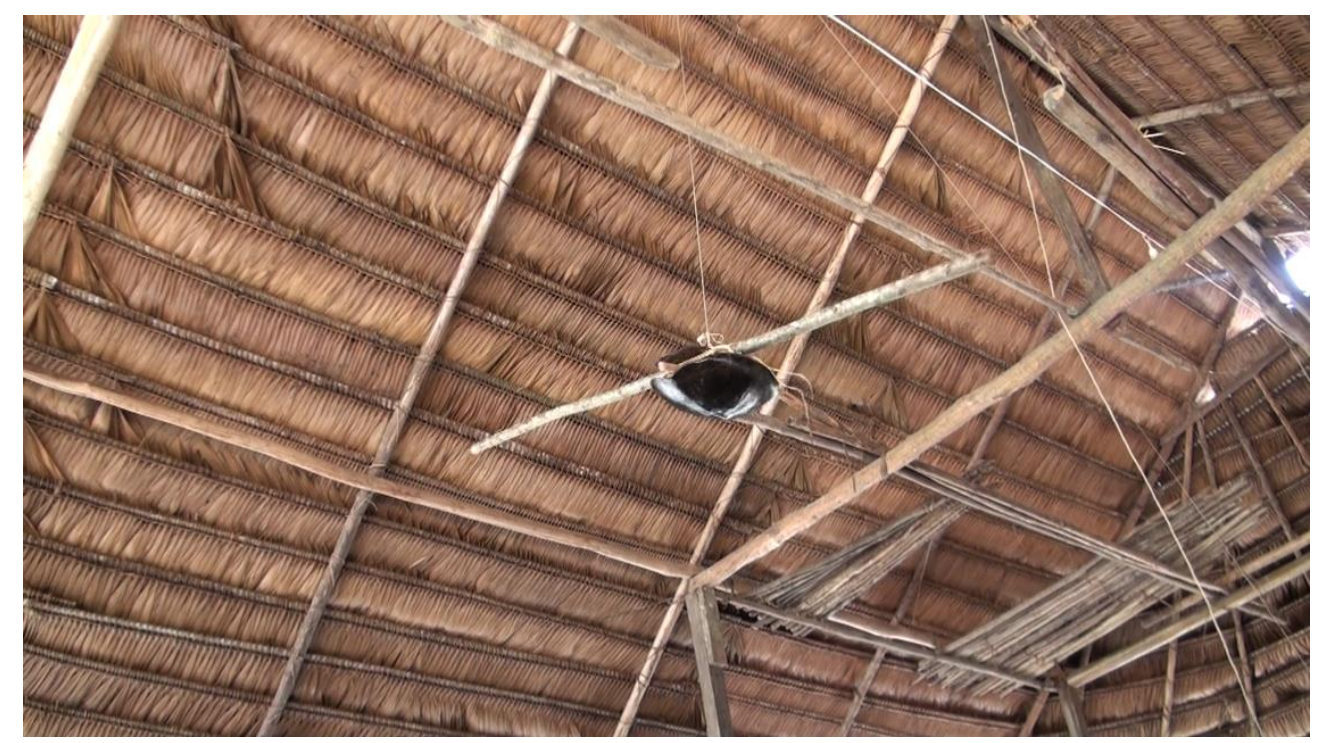

Figura 13 - Tori próximo ao telhado da casa, onde é deixado no intervalo das danças. Esta proximidade com o teto remete à morte do sogro canibal Tũtchuru. 
Uma das metas do ritual é propiciar um bom esposo para as moças que estão sendo iniciadas, mas não tão $\operatorname{logo}$, como frisam as canções. Este virá no momento certo. As filhas dos sogros que são alvo da vingança de Metare todas se casam inúmeras vezes. Todos os pretendentes que se tornam maridos são mortos pelo sogro até que Metare põe fim à matança exterminando o sogro perverso. O herói, que alterna sua aparência em tartaruga e japuaçu, é o símbolo, neste sentido, do parceiro ideal. Não por ser um assassino do pai de sua esposa, mas por possibilitar que haja o casamento e a filha não fique eternamente atrelada ao pai. As mulheres que se casaram com Metare, portanto, são bemaventuradas. Contudo, a recusa em estar com parceiro tão corajoso e, principalmente, excelente caçador - ainda que com o aspecto repugnante de uma tartaruga, "este bicho só caga", diz a moça do mito que escolhe o gavião como parceiro - acarreta na vingança de Metare sobre a garota. Ela é mandada para a roça para colher macaxeira enquanto os participantes da Festa são levados para o Morügüne, a morada dos imortais.

Metare, nas narrativas que colhi em campo e nos relatos registrados por Nimuendaju (1952), aparece se vingando de um sogro canibal. O excesso de sovinice dos sogros de Metare é refletido, por exemplo, no excesso de retenção de sangue do Tütchuru, o que gera seu inchamento e sua morte, explodindo. Metare estourou o bicho que estava cheio de sangue. Por isso a ponta do bico do japuaçu é vermelha até hoje. Este percevejo hematófago, o Tũtchuru, está presente na Festa, de alguma forma, na ornamentação de algumas máscaras. Goulard (2011: 144-146) menciona o motivo do losango, desenhado em algumas máscaras, que remete ao percevejo, paiwekü (Limnogonus aduncus). O motivo, portanto, remete também ao sogro de Metare. No caso do Witchicü, por encanto mágico de Metare, de tão mesquinho, começa a consumir a carne do próprio corpo até se acabar. O herói representa, portanto, a abertura do mundo familiar excessivamente fechado por um sogro canibal, que, ao matar todos os seus genros, não libera suas filhas.

Quando estão reclusas, as moças novas estão sujeitas ao contato benéfico com os imortais (ü'üne), como Metare, ou perigoso com os “bichos” (ngo’o). Na história de Õmi, "um monstro em forma de um lagarto gigantesco" (Nimuendaju, 1952: 74), temos mais uma vez o motivo do ngo'o que chupa a pessoa, ou seja, suga seu sangue e suas carnes, deixando somente pele e ossos. Neste mito, a moça foi retirada da reclusão antes da hora e, aproveitando-se disso, Õmi disfarçado de "belo jovem" - mais uma vez o sedutor rondando a reclusão das moças - pegou ela para dançar, levou para sua casa e matou. "Ele colocou a garota ao lado dele na calha [do quiricá], sugou para fora sua carne e 
sangue, e matou-a (...) Quando a levantaram, seus ossos secos sacudiram dentro de sua pele vazia" (ibdem). Outro ser que chupa o sangue, carne e ossos de suas vítimas é a sombra dos mortos, o natchi' $i$. Este duplo humano, a sombra do cadáver que fica na terra ou segunda alma (Nimuendaju, 1952: 116), possui um hábito semelhante ao do Tũtchuru, chupar o sangue, carne e ossos dos viventes, deixando somente a pele vazia. Este ato é denominado pelos ticuna "colocar jenipapo em alguém" (ibdem), em virtude das marcas negras deixadas pela chupada.

Como acontece no mito do lagarto Õmi, o pior que pode acontecer com uma moça nova é a negligência dos responsáveis por sua Festa. Os mitos contam histórias de moças que foram levadas ou mortas porque os responsáveis por elas as abandonaram. Antes de Õmi pegar a moça nova, "tiraram a worecü [moça nova] do quarto de reclusão, mas, em vez de dançar com ela até o dia amanhecer, eles deixaram ela de pé sozinha no centro da casa e, não prestando-lhe mais nenhuma atenção, começaram a ficar completamente bêbados." (Nimuendaju, 1952: 74). Como ela foi deixada nesta situação, Õmi "dançou com a worecü de cima a baixo na casa de festa, em seguida, do lado de fora, no quintal, e, finalmente, levou-a para a floresta, onde havia uma antiga casa em ruínas, a sua morada" (ibdem).

Algo que pode ser fatal também é a moça dormir durante a reclusão. Nimuendaju conta a história de uma moça "em vez de passar a noite a pé, como a tradição prescreve, a worecü deitou-se em sua rede e dormiu. Eis que um bando de monstros em forma de enormes gafanhotos negros veio e pulou sobre ela, sugando sua carne e sangue. Por fim, a mãe, lembrando-se da menina, enfiou a mão através de uma rachadura na parede do quarto de reclusão, balançando na borda da rede, e chamou: "Desperte, minha filha!" Com isso, ela ouviu o som de ossos secos chacoalhando. Ao entrar no quarto, ela descobriu que na rede estava apenas a pele de sua filha com os ossos dentro. Os convidados reunidos na festa procuraram a trilha e descobriram a fenda por meio do qual os monstros tinham entrado. Eles ainda estavam agarrados à parede do lado de fora da casa, inchados com a sua refeição, e lá eles foram todos mortos.” (ibdem).

O inchaço que a refeição de sangue e carne de gente causa aos ngo'o é sua sentença. Eles acabam ficando cheios de tanto chupar que ficam imóveis, assim são pegos facilmente. Este motivo do chupador de sangue é muito recorrente não só na mitologia ticuna, mas também na vida cotidiana. Em muitos relatos sobre a ação dos vampiros. Ondino relatou diversas histórias de vampiros entre os ticuna, mostrando que o mito está 
bem vivo, mas transformado. É uma forma bem comum de um ngo 'o (bicho) matar suas vítimas. Podemos pensar estes ngo'o como extremos da contensão do sangue, no polo oposto estariam as mulheres, que sangram mensalmente. Os imortais (ü'üne) estariam para além deste continuum sanguíneo - contensão/menstruação - seriam seres despoluídos de sangue, puros, sem males.

\section{8 - Atualização do mito - notas sobre o messianismo ticuna}

O mito de origem ticuna continua vivo na cosmologia destes índios. Vovô (oi) Yoi ainda é uma grande referência no comportamento das pessoas. Quando aparecem rumores de uma possível volta deste herói mítico, muitos acorrem para buscar sua proteção e sabedoria. Goulard, que estudou o profetismo ticuna, comenta esta recorrência em associarem o profeta aos heróis mitológicos, como Yoi. "Como veremos, en lo que se refiere tal profeta o a Dios, se añade la filiación de manera explicita con los héroes mitológicos, esta sustitución se encuentra en otros campos sociales" (2009: 334-335). Por volta de 1945, por exemplo, Manuel Pereira Lima, o Manuelão, nomeado Inspetor do recém-criado Posto Indígena de Umariaçu, "representava pois, na concepção Tikuna, uma espécie de enviado de Dyo'i [Yoi]” (Oro, 1989: 42; ver também Oliveira Filho 1999) ${ }^{177}$.

A hipótese de Goulard é que os distintos movimentos messiânicos protagonizados pelos Ticunas estão fundamentados em "um esquema cultural, feito de invariáveis, isto é, de traços emprestados da mitologia que perduram de um movimento a outro" (2012: 16). Neste sentido, Goulard baseia-se "em algumas das relações que estão em jogo na sociedade Tikuna para mostrar como a permanência do sujeito [leia-se imortalidade] é o horizonte cultural da busca de sentido no qual se projetam infinitamente seus membros, para além da consideração de sua adesão no momento.” (idem: 16-17). Desta maneira, os profetas, uma vez reconhecidos como tais, seriam, nas palavras de Goulard, facilitadores, por catalisarem as esperanças das pessoas (idem: 23).

177 “Cada uno [movimiento profético] ha sido iniciado por un personaje que lleva un discurso escatológico y propone la salvación, o sea la recuperación del estado ü-üne [imortal]. Cuando su propuesta es aceptada, puede ser percibido como un mesías, un profeta, un fundador, uno mandado por dios, o como el descendiente directo de un héroe mítico, su encarnación o incluso el héroe mismo." (Goulard, 2012: 21). 
A mensagem do profeta e do narrador de mitos, portanto, são iguais. A diferença estaria na capacidade transformacional do mito em relação à palavra profética. Diferente do ore do mito, o ore profético é estático e dogmático ${ }^{178}$. Para Goulard, a salvação pregada pelo profeta seria equivalente ou uma alternativa à pergunta que os Ticuna se põem em alguns mitos: porque somos mortais? Deste modo, os ticuna já estariam, pelo próprio teor do questionamento de seus mitos e rituais, predispostos a seguirem profetas salvadores, principalmente em momentos de crises (idem: 28).

As missões, sejam evangélicas ou católicas, foram as responsáveis por algumas levas migratórias dos Ticuna. Muitas das grandes comunidades são fruto destas migrações religiosas. Belém do Solimões, por exemplo, cuja missão dos capuchinhos foi fundada em 1910 e possui cerca de 4.616 habitantes ${ }^{179}$. Outros exemplos são as comunidades de Betânia, com 5.341 habitantes; Campo Alegre, com 4.765; Feijoal, com 4.510 habitantes; apenas para mencionar alguns exemplos de comunidade cujas missões reuniram milhares de ticunas ${ }^{180}$. Estas missões possuem, para os Ticuna, um caráter messiânico. Acredito que a maior parte dos adeptos esperam delas algo que antigamente era realizado nas Festas de Moça Nova, atingir a imortalidade. Oro contabilizava, em 1989, um total de sete movimentos messiânicos registrados entre os Ticuna (1989: 38-43). Goulard, em texto mais recente (2012: 17), contabiliza ao menos dez destes movimentos religiosos.

A migração para o Igarapé Santa Rita ${ }^{181}$ aconteceu, segundo Ondino, por volta de 1958. Esta foi a migração que Ondino detalhou melhor para mim, pois sua mãe participou e contou a ele como aconteceu. O nono movimento mencionado por Goulard parece ser este referido por Ondino. Segundo este autor, “[el] movimiento IX (desde 1953 hasta hoy) empezó con la llegada de una pareja misionera norteamericana a Brasil, de donde se mudó a Perú y formó una comunidad con discípulos.” (2012: 18). Nesta época a comunidade de Santa Rita, localizada no rio Solimões, ainda não estava no igarapé homônimo.

\footnotetext{
178 "El ore profético es un discurso más dogmático que el anterior, en la medida en que es fijo, estático, dado que se encuentra contenido en el papel popera. No conoce variaciones..." (Goulard, 2012: 27).

179 “A Prelazia do Alto Solimões está sob a responsabilidade dos Missionários Capuchinhos Italianos que atuam na região desde 1910" (Oro, 1989: 30).

${ }^{180}$ Dados fornecidos pela FUNAI, Coordenadoria do Alto Solimões, usados no Censo Indígena de 2010, IBGE.

${ }^{181}$ Localizado em Santa Rita do Weil, um pequeno distrito de São Paulo de Olivença, próximo ao Igarapé São Jerônimo.
} 
Segundo Ondino, "disseram que quem não fosse atrás do pastor Paulo americano iria morrer, por isso as pessoas foram atrás dele em Santa Rita”. Era um missionário americano, que os índios chamavam de Paulo Americano. "Diziam que ele era Yoi". Ao saberem que Yoi estava em Santa Rita do Weil, todos os habitantes das comunidades do Igarapé Camatiã mudaram-se para lá. Deixaram tudo para tras, as aldeias ficaram vazias e as roças abandonadas.

Conta Ondino que Paulo Americano passeava de noite por Santa Rita, vestido de padre. Desconfiando do americano e com as crianças já famintas, pois os migrantes ainda não tinham roças para se alimentarem, decidiram espiar por uma fresta na casa do messias. Segundo Ondino, Paulo não permitia que ninguém entrasse em sua casa. Ouviram um barulho de goteira e foram ver. Olharam por uma brechinha na madeira e viram a cocha da criança pela metade pendurada. Vários cadáveres pendurados, pingando sangue numa bacia, provavelmente para ele beber. A mãe de Ondino contou a ele que o pastor Paulo pendurou uma banda (metade) de uma criança dentro do quarto dele. Paulo foi o primeiro pastor batista da região do Alto Rio Solimões. Depois do acontecido, as pessoas voltaram para o Camatiã. Todos já estavam com fome, não havia farinha nem peixe. Ondino diz que, com a volta ao Camatiã, as pessoas voltaram para sua própria cultura, voltaram a fazer Festa de Moça Nova.

De acordo com Goulard, o pastor americano foi expulso do Brasil ainda nos anos 50. Para permanecer no Perú, o pastor e sua esposa tiveram que fazer concessões ao modo de vida ticuna. Principalmente com relação a regra de casamento ticuna. O pastor e sua esposa, inclusive, tiveram que adotar clãs opostos para que pudessem permanecer convivendo com os índios. Contudo, os índios peruanos não permaneceram por muito tempo na religião do pastor americano, "en el transcurso de una de las ausencias del pastor norteamericano sus discípulos adoptaron el rito pentecostal en vez del rito adventista que él había promovido" (Goulard, 2012: 26).

Uma descrição da cidade anunciada pelo xamã profeta Ciríaco, por volta de 1956, revela justamente esta visão que os Ticuna possuem da cidade dos encantados. "Ciríaco anunciava também a aparição mágica de uma cidade que ainda não se podia ver mas que em breve iria se revelar com todo o seu esplendor”. "Animados pela crença, escreve V. de Queiroz, os índios abriram uma larga avenida em plena floresta, - justamente onde seria o centro daquela "cidade" - e, em pleno deserto, plantaram postes nos quais Ciríaco 
afirmava que dentro em pouco, magicamente, brilharia luz elétrica" (Vinhas de Queiroz, 1963: 51)"(Oro, 1989: 42-43).

Uma história que me foi contada por Ondino deixa claro como os imortais estão próximos e muitas vezes os movimentos messiânicos prometem o encontro com as benesses da cidade dos imortais. Notemos que a morada dos imortais é descrita como uma cidade. Ondino disse que, faz algum tempo, Pedro Inácio, considerado pelos índios o chefe de todos os Ticuna, foi com alguns americanos procurar o local de origem do povo Ticuna. Eles foram até o igarapé Eware, que fica próximo da comunidade de Vendaval, onde morava Pedro. Lá encontraram o caniço (powopaeru) que Yoi fincou no chão depois de pescar os Ticuna. Os americanos levaram este caniço para os EUA. Quando estavam no igarapé, os americanos tinham um aparelho que servia para ouvir tudo e eles ouviram o mesmo barulho que se ouve quando se está numa cidade grande. Era uma cidade de encantados. Ondino me disse que o "Eware é um grande descampado (bunecü) e é onde moram os encantados. Lá tem avião, carro, música. Lá se ouve tudo isso, mas não se vê nada. Só com a máquina dá para ouvir. Quando eles estão fazendo Festa [de Moça Nova], escutamos o mesmo barulho das Festas daqui, com tracajá [instrumento de casco de tracajá], [trompete de bambu] coĩri, mas não dá para ver”.

Contudo, o movimento messiânico mais impressionante entre os Ticuna foi sem dúvida o da Irmandade da Santa Cruz, a chamada "Cruzada", capitaneado por José Francisco da Cruz. Nos últimos meses de 1971, Irmão Francisco chega ao Alto Solimões depois de uma imensa peregrinação pela América do Sul. Sua jornada começou em 1964, em sua cidade natal, Cristina, em Minas Gerais. Após passar por vários estados brasileiros, em 1969 ele entra no Peru onde permaneceu até ser expulso pela Igreja Católica e as autoridades locais. Quando entrou novamente no Brasil, sua fama já o precedia entre os indígenas e brancos da região.

“É por isso que nos últimos meses de 1971, quando chegou ao Alto Solimões a nova dando conta de que um Padre Santo, fazedor de milagres, estava descendo o Solimões vindo do Peru, a população Tikuna se pôs repentinamente de alerta: os índios mais próximos das cidades da fronteira se encarregaram de espalhar a novidade nos povoados Tikuna mais distanciados e mesmo naqueles situados no meio da floresta (...). Mesmo se neste momento os sentimentos eram mal definidos e incertos, estavam persuadidos de que acontecia mais uma 
manifestação dos imortais em suas vidas. Em certas áreas Tikuna chegou-se mesmo a comentar que o esperado era o próprio Dyo ’i [Yoi]" (Oro, 1989: 49).

Segundo me disseram, circulava o boato de que "quem não acreditasse nele a roça secaria, não daria nada".

Ondino conta que foi na época da efervescência da religião "Cruzada", mais ou menos 1974, "que as pessoas se juntaram em Vendaval, antes disto elas estavam espalhadas". Muitas comunidades foram formadas por gente que veio de Vendaval. Os primeiros a saírem foram os fundadores da comunidade de Novo Paraíso, depois Ribeiro, Nova Jerusalém, Otaware, Bananal e, por último, Europa. Vendaval ainda é um polo de atração de muitos jovens ticuna por causa do programa "Luz para Todos", do governo federal, que fornece energia elétrica aos lugares mais distantes. Segundo Oro (1989: 85), a igreja de Irmão Francisco chegou a contar com "a adesão de cerca de $60 \%$ dos Tikuna e de $15 \%$ dos não-índios da região do Alto Solimões". Em 1982, com a morte do profeta, a religião messiânica Irmandade da Santa Cruz começa a declinar em número de adeptos. Atualmente apenas algumas comunidades possuem igrejas que são pouco frequentadas. Pude constatar isso em minha passagem pela comunidade de Belém do Solimões, em 2013, onde se encontra uma congregação da igreja fundada pelo Irmão Francisco.

Por fim, os diversos movimentos proféticos acontecidos entre os Ticuna nos fazem pensar nos movimentos migratórios que aconteceram também entre os Guarani. De acordo com Viveiros de Castro, o "modo de ser Tupi-Guarani" comportaria dois polos como "vias de acesso ao Além" (1986: 23-24). Um exemplo destes polos seriam os Araweté, que também se alinhariam com “os gestos excessivos dos longínquos Tupinambá”. O outro polo poderia ser exemplificado pelos referidos Guarani, historicamente seguidores de profetas (H. Clastres, 1978), "cultores do Logos" e do "recolhimento ascético" (Viveiros de Castro, 1986: 23-24). Ascese ou excesso, duas vias opostas por onde desembocam o profetismo e o ritual (ibdem). Arriscaria dizer que o modo de ser dos Ticuna comporta os dois polos. De um lado, o xamanismo e o profetismo ticuna são os forjadores dos acetas do grupo, como acontece em muitos solos ameríndios onde estes fenômenos se desenvolvem. A etnografia e análise da Festa da Moça Nova, que veremos no Capítulo 7, mostrará que este ritual também é equiparável, em alguns 
pontos, ao excessivo ritual de encorporação ${ }^{182}$ do inimigo tupinambá. E ambos estão voltados para a mesma finalidade. O “Além” ticuna está no Eware, a morada dos imortais. A guisa de conclusão deste Capítulo, gostaria apenas de salientar alguns pontos que estarão mais presentes no percurso desta tese. Vimos como o mito que conta a história de Ngutapa e Mapana relaciona, de alguma maneira, sangramento feminino, imortalidade, cabelos e pele. Esta relação retornará oportunamente. Além disso, o ritual ticuna da moça nova atesta a anterioridade que tem a aliança interespecífica com relação à filiação natural, intraespecífica. Tentei mostrar isto na análise da gravidez de Ngutapa. Para que a moça esteja apta para casar e ter filhos, os Ticuna devem atualizar suas alianças com uma variedade de seres que povoam o cosmos. O capítulo seguinte apresenta mais detalhadamente dois seres, ou estados do ser, centrais no ritual: os "bichos" (ngo'o) e imortais (ü'üne). A história de To’oena também é um ponto chave para a compreensão da Festa, retomaremos suas narrativas também.

${ }^{182}$ Ver Viveiros de Castro, 2002: 374, nota 32. 


\section{Capítulo 3 - Cosmologia e o Corpo sem mal}

"Ser imortal é insignificante; com exceção do homem, todas as criaturas o são, pois ignoram a morte; o divino, o terrível, o incompreensivel é saber-se imortal"

Jorge Luis Borges, Os Imortais, p.27

Neste capítulo pretendo apresentar alguns "personagens" que comporão a cena do ritual da moça nova. Começaremos pelos seres que já apareceram quando tratamos da mitologia, mas que também povoam as Festas e o cotidiano dos Ticuna, os imortais (ü'üne). Estes podem ser definidos em oposição aos mortais (yunatü) e será esta oposição que privilegiaremos à princípio. Mas também podem ser contrapostos, em certo sentido, aos "bichos" (ngo'o), contraste que passaremos a explorar quando focalizarmos estes últimos seres ${ }^{183}$. Uma definição destes dois tipos de seres é a base necessária para que possamos responder à pergunta: por que os Ticuna fazem a Festa da Moça Nova?

\section{1 - Imortais ou encantados (ü’üne)}

Muitos dos heróis mitológicos ticuna são considerados imortais, Yoi e Ipi o são, sem dúvida ${ }^{184}$. Neste sentido, a tradução da palavra ticuna ü'üne como “imortal” ou “encantado" é algo imperfeita, apenas aproximativa. A noção de ü'üne é mais ampla do que a simples imperecibilidade que a imortalidade evoca e uma parte deste capítulo será dedicada a enriquecer esta noção.

\footnotetext{
${ }^{183}$ Esta oposição é relativa, refere-se principalmente a atitude que os Ticuna têm com relação aos imortais e aos "bichos". Contudo, existem casos de "bichos" considerados imortais, o que torna o quadro mais complexo.

184 "Todos os personagens centrais dos mitos de origem dos Ticuna são chamados genericamente como ü'üne, são imortais..." (Oliveira Filho, 1988: 141).
} 


\subsection{1 - Corpo e imortalidade}

"Ele, o corpo, afirmado ou negado, pintado e perfurado, resguardado ou devorado, tende sempre a ocupar uma posição central na visão que as sociedades indigenas tem da natureza do ser humano. Perguntar-se, assim, sobre o lugar do corpo é iniciar uma indagação sabre as formas de construção da pessoa. "

Seeger, Da Matta \& Viveiros de Castro, 1979, p. 4

E é pelo corpo ticuna que se deve começar para compreender quem são os imortais. Arriscaria dizer que estes seres são uma espécie de negativo do corpo mortal. Possuo três interpretações do sentido da palavra $\ddot{u}$ 'üne e todas as três o relacionam com o tema do corpo. Para Goulard, uma possível etimologia de $\ddot{u}$ 'üne indica que este termo seria melhor interpretado como "corpo-fogo" (2009: 120). "[O termo utilizado para se referir ao gosto amargo] é o mesmo $\ddot{u}$ raiz que é encontrado em $\ddot{u}$ 'üne ou "corpo-fogo" para descrever os imortais ou o estado imortal ou ainda em $\ddot{u}$ - $\ddot{u}$ para o fogo. Este é um estado único que não pode ter um corolário, até sua determinação clânica” (2004: 85). Reencontramos aqui a sensação dos sabores/odores como o determinador clânico. A raiz $\ddot{u}$, amargo, que também compõe a palavra "fogo" ( $\ddot{u}$ 'ü), coloca o "sabor" dos imortais fora das polaridades próprias dos clãs ticuna - doce/não-fermentado (maikürá): ácido/fermentado (ngü), saboroso (tchî): podre (jî), fresco (nài): passado (ngàré) (ibdem) - daí sua corporalidade sui generis ou, talvez, ausência de corpo.

Em outro texto, mais recente, Goulard adiciona outros sentidos ao termo ü'üne. Segundo o etnólogo, ü'üne é um “'[t]érmino cuya raíz, ü- ü, refiere al fuego y/o al hacer, y -ne, al cuerpo. Se traduce entonces por cuerpo-fuego y/o hacer-cuerpo. Se puede entender el primer significado como que estos seres viven en un medio frío, de ambiente selvático, del que salen pocas veces, y el segundo significado se refiere a un estado completo.” (2012: 20, nota 4). A temperatura do corpo é alvo de extrema preocupação em momentos liminares da vida, em especial para a mulher no pós-parto e para a moça nova. O corpo delas deve ser mantido quente, em oposição aos seres que habitam a floresta, espaço frio. Os mascarados que se apresentam na Festa são alguns destes seres que habitam a floresta. "Eles residem no meio da floresta, espaço de "cheiro frio" onde não vive nenhum mortal, enquanto a casa é um lugar de "cheiro quente" que é característica 
do ser humano" (Goulard, 2011: 134) ${ }^{185}$. Apesar de viverem num meio frio, os imortais são seres de corpo-fogo, ou seja, são puro calor em um "corpo em formação". É esta última definição que examinaremos em seguida.

Outra interpretação do termo ü'üne é dada pelo ticuna Abel Santos Angarita a Valenzuela e também relaciona esta palavra com o "corpo". "El término ü̈̈ne se refiere específicamente según Abel Santos a “cuerpos en formación” es decir, aquellos seres cuya corporalidad está incompleta, se asocia entonces la capacidad de morir al hecho de tener cuerpo" (2010: 86) ${ }^{186}$. Esta explicação relaciona, portanto, a noção de ü'üne à incompletude e a um estágio de formação da corporalidade. Os imortais não morreriam justamente porque não teriam um corpo formado. Quando abordarmos a noção de "sangue" dos Ticuna, neste mesmo capítulo, veremos que esta falta constitutiva dos imortais os projetam para preenche-la através dos corpos dos mortais.

Ondino me disse que depois que a pessoa morre vira ü'üne. Mas, pelo que vimos até aqui, podemos perceber que a noção de ü'üne, o termo que é traduzido como imortais ou encantados, é mais ampla que uma simples distinção entre vivos e mortos. A palavra üne é utilizada para se referir ao corpo. Segundo meu informante, ü'üne pode ser interpretado como "aquele que não tem mais males no corpo". Um dos sentidos do ritual da moça nova é a retirada dos "males do corpo" da menina. Mais adiante detalharei sobre esses "males" (риya), por hora vejamos sua relação com a imortalidade. Quando perguntei a Ondino o que são estes "males do corpo" ele me respondeu que eram yunatü̈̈ne, palavra que se refere aos "mortais" (yunatui) ${ }^{187}$ e ao "corpo" (üne). Isto é, os

\footnotetext{
${ }^{185}$ Ver também Goulard, 2009: 325.

${ }^{186}$ Em sua dissertação de mestrado em linguística, Angarita dá uma definição mais ampla da palavra ü'üne. “El término Üüne está compuesto por tres morfemas: ù-ü-ne. Ü- significa acción (accionar) y hacer. Igualmente es ejecutar, transformar, convertir. $\dot{U}$ - es el origen e inicio del proceso de transformación de -ne "carne, tronco, sustancia, idea"; sea trabajo, idea, pensamiento, saber, conocimiento, estudio, labor, faena, obra, tarea, misión, gestión, objeto, ser animado e inanimado. Ü- es el proceso de toda existencia, de lo que se ve, conoce, scucha, huele, siente, imagina, sueña, canta, habla etc., y de todo lo demás, la naturaleza, el cosmos, universo y el mundo, incluyendo el humano. El morfema -ne se refiere a la imagen, figura, gráfica o diseño del ser (na). Ne significa cuerpo, tronco, carne, sustancia, forma, representación o signo. Ne es o son las formas de existencia animal, humana y vegetal, líquido, gas, vapor, fluido, energía, el bien, el mal, ambiente, tierra, naturaleza, cosmos, universo, mundo, idea, pensamiento, conocimiento, el humano y los Ü̈ünetagü (plural de Üüne). Igualmente, es lo intangible, lo abstracto, lo invisible, lo insensible y lo no perceptivo; no es únicamente lo que se percibe a través de los sentidos, sino que además es el juego de los sentidos para explicar, ver y vivir los mundos invisibles o paralelos, Üüne en tikuna." (2013: 10).

187 Ondino, cristão que é, diz que podemos traduzir yunatü como "pecadores" também.
} 
seres que não possuem mais os "males do corpo" são, mais acertadamente, os que não possuem um "corpo mortal".

\subsection{2 - O lugar dos imortais - as idas e vindas da imortalidade}

Quando decidiram deixar a convivência com os mortais, Yoi e Ipi foram para lados opostos do mundo, Yoi foi para o Oeste e Ipi para o Leste. Contudo, Yoi não gostou da escolha e, à noite, "inverteu a terra para que Ipi permanecesse no Oeste, enquanto ele permaneceu no Leste da terra" (Nimuendaju, 1952: 134). Deste modo, Ipi desceu o rio Solimões e Yoi subiu o rio, nestes locais eles permanecem até hoje. Rio acima, portanto, é a terra onde mora Yoi e muitos outros imortais ${ }^{188}$. Sua casa, Moruapü, muitas vezes é usada metonimicamente como o nome da terra dos imortais. Por isso, quando se diz que, numa Festa bem realizada, a casa sobe para o lugar dos imortais, deve-se ter em mente que esta subida é a montante do Rio Solimões. A terminação desta palavra, _pü, significa "montanha"189. Muitas casas míticas têm esta terminação no nome. Muitas montanhas míticas também possuem uma intensa vida em seu interior, como uma casa. Daí o fato de se ouvir com frequência os Ticuna afirmarem que "os encantados moram no meio da montanha e saem para passear de vez em quando. Eles são gente $\left(d u^{\prime} \tilde{u}\right)$, se transformam em pássaro tüwitüwi ${ }^{190}$, em maguari [cowa - Ciconia maguari] também”.

O tema do retorno do mundo encantado ou mundo dos imortais também é bastante recorrente nos mitos ticuna. Ele aparece, por exemplo, na história de Pai'nü ${ }^{191}$, por exemplo. Trata-se de uma longa narrativa em que o menino (bocü) Pai'nü é abandonado por seus parentes no mato. Em suas perambulações ele encontra com os tamanduás

\footnotetext{
188 "Mortales e inmortales se inscriben entonces, en términos de espacio, en territorios contiguos cuya separación tendrá que desaparecer una vez que los mortales se reapropien de la inmortalidad" (Goulard, 2012: 28).

189 Nimuendaju refere-se ao na'pü simplesmente como “subterrâneo" (underworld) (1952: 118 e passim).

190 Tüwitüwi é espécie de tesourinha grande, maior que a gaivota. Muito provavelmente trata-se do gavião-tesoura (Elanoides forficatus).

191 “Painü rü witchicügü”, traduzida por mim e por Hilda de Firmino \& Gruber, 2010, vol. 1.
} 
(tchaaütügü, pl.) e com os pássaros witchicü̈192. Ao acompanhar estes últimos, "o passarinho mandou Pai'nü ficar com um pé em cada margem do rio. Mas o rio foi se alargando, alargando, então Pai'nü se transformou na árvore Pai'nü, que tem muitas raízes para todos os lados. (...) A alma (ma' $\tilde{u})$ dele ${ }^{193}$, a vida dele foi embora flutuando”.

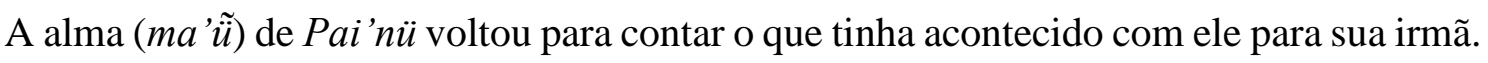
“Quando ele terminou de contar a história, a alma ( $m a$ ' $\tilde{u})$ dele foi embora para onde moram os encantados. Ele só voltou para contar a história dele para a irmã que gostava dele. Ele virou encantado”. De acordo com Hilda, que traduziu este mito comigo, Pai'nü se transformou em árvore na cabeceira do Rio Solimões, ou seja, rio acima, uma referência ao lugar dos imortais.

Ao finalizarmos a tradução do mito de Pai'nü, Hilda fez um comentário bastante ilustrativo da relação entre os erros do herói e e a perda da imortalidade pelo seu corpo. "Por ele ter puxado o nariz do tamanduá e ter arrancado o couro da cabeça do witchicü, o corpo de Pai'nü ficou condenado a ser mortal. Quando se faz o mal para alguma pessoa fica-se na condição de nüpa'a, não atinge mais a imortalidade, não consegue mais ser ü'üne". Deste modo, temos uma situação bastante complexa na imortalização de Pai'nü. Os componentes da sua pessoa, após ele virar uma árvore, se separam, uns se imortalizando, outros condenados à mortalidade. Vejamos um a um e seus respectivos destinos. Como vimos, a história deixa claro que o elemento que se imortalizou foi o ma 'ü de Pai'nü. "Só o corpo/imagem/sombra/foto (tchicüna'ã) dele que virou árvore Pai'nü, a alma (ma' $\tilde{u})$ dele foi embora". Ou seja, o que ficou na terra em forma da árvore que hoje é homônima do herói, Pai'nü, é sua imagem (tchicüna'ã) ou sua sombra (tchipeta). Por ele ter arrancado o couro da cabeça dos pássaros witchicü e ter esticado o nariz dos

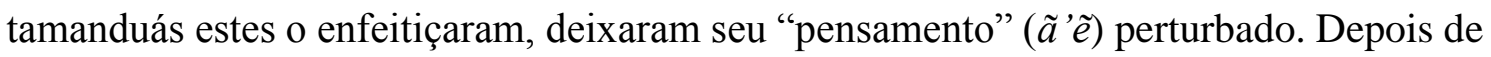
enfeitiçado, Pai'nü começou a chamar de vovó pessoas que não eram seus parentes e começou a ouvir suas fezes chamando-o, e ele respondia, andava em círculos na floresta por causa disso.

\footnotetext{
192 Provavelmente refere-se a subfamília piprinae. Dentre eles podemos mencionar, segundo Sick (1997: 639), Pipra aureola, P fasciicauda, P filicauda, P. mentalis (extrabrásileira), P. erythrocephala, P. rubrocapilla e os Chiroxiphia.

${ }^{193}$ Hilda, professora ticuna, traduziu a palavra $m a^{\prime} \tilde{u}$, que Goulard traduz como “princípio corporal” (2009), simplesmente como "vida".
} 
O mito de Ngowarutcha e Ngunetuma ${ }^{194}$ mostra mais um exemplo do que vimos rapidamente no capítulo anterior ${ }^{195}$, quando descrevemos brevemente a procura por uma cidade dos imortais. Vimos que estes seres possuem uma relação especial com o som. Na cidade dos imortais tudo se ouve, mas nada se vê. Algo que quero destacar agora, e que retomaremos ainda, é a superaudição destes seres. Ngunetuma, uma imortal, mesmo não estando no mesmo lugar que Ngowarutcha, um mortal, "escutou tudo o que ele falou para os parentes dele, escutou tudo, tudo mesmo. Quando falavam sobre ela, ela escutava como se estivessem falando bem pertinho dela". Quando Ngunetuma se refere à alma que vai morar com os encantados, ela fala do "princípio corporal" ( $m a$ ’ũ), não do "princípio vital" (ã'ê). Assim falou Ngunetuma explicando que futuramente a irmã de Ngowarutcha iria morar na terra dos imortais com ele: "Você, Ngowarutcha, agora já é encantado. Você não é mais mortal, já é imortal. Qualquer dia o teu cunhado (ãmacü) vai aparecer aqui. Só ele e a sua irmã que te amam. A alma dela (ngĩrüma'ü) vai viver aqui com você.". O mesmo tempo, e ouvi explicações que me confirmaram isso, o "princípio vital" (ã 'ẽ) é um espírito que fica vagando pela floresta, muitas vezes aparece para as pessoas causando doenças

Além desta relação supersensível que os imortais têm com o som, o mito de Ngowarutcha e Ngunetuma nos mostra uma temporalidade diferente operando na terra dos imortais. Após passar dias na floresta, Ngowarutcha chega na beira de um campo e vê uma casa. "Onde ele chegou era um lugar bom para ele. Era a casa de Ngonetuma". Eis a mulher que o recebe com boas-vindas na terra dos encantados. O nome Ngonetuma pode ser traduzido, segundo Ondino, como "dia que não anoitece" (ngone = dia). Ngonetuma levou então Ngowarutcha para um lugar cheio de "bichos” (ngo'ogü). "Ele olhou dentro do lugar e viu muitos bichos (ngo'ogü) andando com os machados deles. Em meio minuto escureceu e ele viu os bichos". Perguntei a Ondino, que traduzia a história comigo, como aconteceu aquele escurecer tão rápido. Ele me explicou que "não é muito escuro, é como quando a nuvem cobre o sol, só um momentinho. Então clareou de novo". As noites neste lugar passariam assim, rapidamente, e logo clarearia de novo. "Para este pessoal, Ngonetuma, quando passava uma nuvem no sol, escurecia um pouquinho, era como se tivesse anoitecido e passado outro dia. Em um minuto, meio

\footnotetext{
194 "Ngowarutcha rü Ngunetuma”, traduzido por mim e por Ondino de Firmino \& Gruber, 2010, vol. 3.

195 Tópico 2.8 - Atualização do mito - notas sobre o messianismo ticuna.
} 
minuto, já era outro dia para eles. De repente, escureceu, clareou e já era outro dia”. Ondino comentou que neste local o tempo passava muito rápido.

Um conto de Borges, intitulado Os Imortais, nos mostra uma temporalidade parecida quando do encontro de um mortal com os imortais ${ }^{196}$. Ao chegar a terra dos imortais um mortal encontra um homem que, por não falar mais, ele batiza de Argos e que se torna seu companheiro ${ }^{197}$. "Pensei que Argos e eu participávamos de universos diferentes; pensei que nossas percepções eram iguais, mas que Argos as combinava de outra maneira e construía com elas outros objetos; pensei que talvez não houvesse objetos para ele, mas um vertiginoso e contínuo jogo de impressões brevíssimas.” (Borges, 1999: 23-24). As percepções são as mesmas o que muda são os objetos, o que muda é o mundo. Algo aqui nos soa familiar. Apesar de as percepções serem iguais, mortais e imortais constroem objetos diversos com elas. A indiferença pela passagem do tempo proporcionada pela condição de imortal, inserem os habitantes da terra dos imortais, onde se encontram Ngowarutcha e Ngunetuma, em "um vertiginoso e contínuo jogo de impressões brevíssimas”. Uma espécie de excesso de descontinuidade na periodicidade dia/noite. E, ao mesmo tempo, o nome de Ngunetuma nos remete ao extremo oposto, o “dia que não anoitece”, a pura continuidade do dia, sem qualquer alternância com a noite.

Existe também a história do homem que foi morar com os encantados, mas acabou retornando para casa. Trata-se do Maũcütchametü, o homem que foi vivo para o céu, mito que me foi contado por Ondino e que resumo em seguida. Maũcütchametü havia perdido seu filho e sua nora, por isso ele chorava muito, chorou por mais de um ano. "O filho escutou o som do pai chorando e voltou para buscá-lo". A partir daí, quando o filho começa a levar o pai para a cidade dos imortais uma série de inversões de perspectiva acontecem. O tapiri que eles constroem para passar a noite no meio do caminho aguenta um temporal sem que eles se molhem. O que é visto pelo pai como uma mera poça de

\footnotetext{
196 O recurso a este conto me foi inspirado pela palestra intitulada "A morte como quase acontecimento" (2009), proferida por Eduardo Viveiros de Castro no programa de TV Café Filosófico, promovido pela CPFLCultura. Disponível na íntegra no site: http://www.cpflcultura.com.br/wp/2009/10/16/integra-amorte-como-quase-acontecimento-eduardo-viveiros-de-castro/

197 “A humildade e a miséria do troglodita trouxeram-me à memória a imagem de Argos, o velho cão moribundo da Odisséia, e assim lhe pus o nome de Argos e tentei ensiná-lo. Fracassei e tornei a fracassar. Os arbítrios, o rigor e a obstinação foram de todo inúteis. Imóvel, com os olhos inertes, não parecia perceber os sons que eu procurava inculcar-lhe." (Borges, 1999: 23). Mais adiante no conto, o homem que chega a terra dos imortais descobre que Argos era ninguém menos que Homero.
} 
lama o filho enxerga como um imenso riozão. Ao chegarem na cidade dos imortais, onde estava a nora de Maũcütchametü, o filho deste sai para caçar,

\begin{abstract}
"trouxe um montão de gafanhotos. Os Ticuna chamam este tipo de gafanhoto de macaco-barrigudo, munũ ya omẽ. Para nós é gafanhoto, para ele era um monte de macacos-barrigudos. A nora de Maũcütchametü pegou os gafanhotosmacacos-barrigudos e passou no fogo, como se faz para cozinhar os macacos, queimando os pelos e raspando. O pai olhava e via gafanhotos, mas para o filho e a nora eram macacos-barrigudos (...) [e a nora dele insistia] "não meu sogro, esse aí é macaco-barrigudo. Você está vendo gafanhoto porque você é gente mortal. Como nós somos imortais, estamos vendo que é macaco-barrigudo". Assim ela falava para o sogro dela. Todos comiam, menos Maũcütchametü”.
\end{abstract}

As plantas também eram afetadas pela inversão de perspectivas entre os mortais e imortais. Quando foram para a roça foi a mesma coisa. O que os imortais viam como uma bela roça cheia de macaxeiras prontas para serem arrancadas, Maũcütchametü, em sua condição de mortal via apenas ngõnẽ, algo intermediário entre a floresta e a capoeira pronta para a roça. Ao levar seu sogro para apanhar pupunha, o que a nora de Maũcütchametü via como pupunha, ele via como jacitara ${ }^{198}$. Explica Ondino que isso "que ela estava chamando de pupunha, a jacitara, é a pupunha dos espíritos ã ’ẽ, visagem. Para estes espíritos, a jacitara é pupunha, ele come".

Examinando as inversões de perspectiva que acontecem entre mortais e imortais neste mito do Maũcütchametü, podemos notar uma recorrência no ponto de vista imortal. Para esta perspectiva o menos é mais. O que seria insignificante para um mortal gafanhotos, frutinhas de jacitara, um matagal improdutivo - é visto como alimento valorizado pelos imortais. Algo que evoca uma vida em que o trabalho é bastante reduzido. Se os imortais se alimentam de algo que não demanda uma produção árdua, como o alimento dos mortais, isso indica que são seres que apenas vão à floresta pegar seu sustento, sem muito esforço. Tudo isso, é claro, do ponto de vista de um mortal vivendo com os imortais, como é o caso de Maũcütchametü. Produzir este alimento mesmo que intragável para os mortais -, do ponto de vista de um imortal, pode demandar tanto trabalho quanto a um mortal. Fica a questão, o que os imortais veem quando confrontados com os alimentos dos mortais? Esta parece ser uma questão menor na

198 De acordo com o dic. Houaiss, jacitara é a "design. comum às plantas, ger. escandentes, do gên. Desmoncus, da fam. das palmas". 
mitologia ticuna. Se os imortais são seres de corpo em formação, ou mesmo de corpofogo, a alimentação mortal seria um excesso para eles. Isso ficará mais claro quando abordarmos a alimentação acética do candidato a imortal. Guardemos esta questão para seguirmos com a aventura de Maũcütchametü.

Ele não estava contente morando com os imortais, pois ainda era mortal. Ele não se adaptava especialmente com a alimentação dos imortais, então seu filho o levou de volta para a casa dele. O retorno dele para os seus é uma variação do motivo que estou chamando de "apanhador de frutas" ou “'desaninhador' de frutas", em referência ao recorrente motivo sul-americano do "desaninhador de pássaros"199. O trecho do mito é o seguinte: "Os filhos dele que estavam aqui na terra dos mortais saíram para apanhar tütü, uma fruta que só tem lá perto de $\mathrm{Vendaval}^{200}$. O filho de Maũcütchametü que morava no céu, deixou o pai na árvore transformado nesta frutinha. Ele estava lá no último galho. Tentavam apanhar a frutinha com uma vara, mas ela suspendia e eles não conseguiam. Tentaram até conseguir derrubar a fruta. Quando caiu no chão, se transformou em gente. Os filhos dele se assustaram ao ver o pai”. Esta passagem da fruta que sobe quando se tenta apanhá-la é uma imagem recorrente na mitologia ticuna. Aparece, como vimos, no episódio de Ipi que sobe no jenipapeiro para apanhar uma fruta de jenipapo. Na morte do ngo'o Matchi 'i, que sobe num abieiro para apanhar um abiu, mas Yoi faz a árvore crescer. A moça do umari também é uma fruta de umari que cai no chão e se transforma em gente.

O retorno de Maũcütchametü para sua casa, contudo, não se dá sem problemas. Sua esposa já não o queria mais. Ele pede ajuda a seu filho que propõe o seguinte a ele:

“O filho dele já tinha avisado o que ele tinha que fazer. "Quando tu for lá, se a mamãe não gostar mais de você, procure meu cinto que eu deixei lá. Procure também minha flecha e o breu (owü) que eu coloquei na palha do telhado da casa". "Então está bem", disse o pai dele. Passou um dia, no outro dia ele fez o que o filho dele mandou fazer. Primeiro procurou o breu, mas o breu já tinha se transformado em aranha (pawii) e picou a mão dele. Então ele foi procurar o cinturão do filho, mas o cinto era uma cobra jararaca e mordeu a mão dele. Maũcütchametü deitou-se na rede gritando de dor, passou meia hora ele

\footnotetext{
${ }^{199}$ Ver capítulo 2, Mitologia, tópico 2.1 - A passagem para a América do Norte.

200 Comunidade ticuna em que também fiz trabalho de campo e que fica no Rio Solimões, ao lado do igarapé São Jerônimo (Tunetü), um dos afluentes do igarapé de onde os Ticuna foram pescados, o Eware.
} 
morreu. Depois disso o filho dele que morava no céu levou ele embora de vez."

A morte, ou melhor, a causa da morte de Maũcütchametü é a mesma que a do demônio Machi'i no mito de origem dos Ticuna coletado por Goulard. "O abieiro alcançou o céu. Quando Machi'i tocou o fruto, um ninho de abelhas caiu em seus olhos" (20009: 401). Em seguida, uma série de cobras o mordem e ele cai. Tenta se esconder mas outros tantos bichos peçonhentos o mordem. Estava quase morto. Os dois, portanto, são envenenados por uma série de animais peçonhentos. Contudo há uma pequena inversão que indica o caráter distinto dos personagens. Enquanto o demônio Machi’i e Ipi tentam alcançar uma fruta - abiu e jenipapo respectivamente - que está num galho que sobe não os deixando alcançar, Maũcütchametü é a própria fruta (tü̈tü) a ser alcançada por seus filhos.

No mito de Ngowarutcha e Ngunetuma que vimos há pouco também temos uma exploração das diferentes perspectivas de mortais e imortais a partir dos alimentos, especificamente a caça. A primeira vez que Ngowarutcha sai para caçar ele mata uma porção de "pássaros":

"Quando amanheceu, ela perguntou de novo, "Ngowarutcha, você sabe mesmo caçar? ". Ele respondeu, "sim, eu sei”. Então ele olhava no meio do campo e via vários pássaros. Ele pensava que fossem vários mutuns, eram grandes como mutuns. Neste momento, ela deu a Ngowarutcha a zarabatana (ĩe) e o cestinho (yoruta) com as flechinhas. Então ele foi caçar. "Pode ir", disse ela. Ele acreditou na palavra dela e foi caçar. Ele jogou uma flechinha da zarabatana num taracuá ${ }^{201}$. Ele viu que era uma caça, mas era a formiga. Era taracuá de bunda cinza (tautchinücü), mas ele viu um jacamim (äün). Tinha outra formiga, iwi, ele jogava flecha nesta também. Ele pensava que era mutum, mas eram formigas iwi. Ngowarutcha matou muitas destas formigas com a zarabatana, ficou com um montão amarrado. Não demorou muito, ele voltou. Quando ele vinha chegando, ela viu de longe e foi lá com ele. Ngonetuma falou, "isso que você matou não é caça, são formigas maiores", e jogou tudo fora. "Amanhã você vai caçar de novo", disse ela."

\footnotetext{
201 Um tipo de formiga. A palavra é um regionalismo amazônico, vem do tupi (taraku'a). Não saberia identificar esta formiga. Segundo o dic. Houaiss, trata-se de uma "formiga (Camponotus femoratus) da Amazônia, que vive em cupinzeiros arborícolas abandonados e forma colônias numerosas [É agressiva e solta cheiro forte quando esmagada.]"
} 
Podemos reduzir a diferença de perspectivas entre Ngowarutcha e Ngonetuma na seguinte proporção, Ngowarutcha : pássaros :: Ngonetuma : formigas. Ou seja, a caça que Ngowarutcha vê como pássaros, é vista por Ngonetuma como formigas. Percebendo que Ngowarutcha tinha falhado em seu intento, Ngonetuma propôs uma nova caçada ao menino. Passou-se uma breve noite.

"Esta aqui que é a caça", dizia ela. "Com esse dardo (banu) da zarabatana que você vai soprar". Onde ele encontrava uma anta, via uma mulher gorda peneirando o pajauaru dela. Então a Ngonetuma que era caça. Foram mais adiante e encontraram outras pessoas ameaçando eles com um abano, mas era um jacu batendo as asas. Mais para frente, ele encontrou pessoas fazendo ajuri, derrubando os paus, mas eram macacos-prego fazendo bagunça, comendo coquita (tipo de fruta)."

Comparando os dois trechos citados do mito temos o seguinte. Ngowarutcha viu pássaros em sua primeira caçada e os mesmos pássaros eram vistos como formigas por Ngonetuma. Na segunda caçada, eles encontram não só pássaros, mas dois mamíferos: macacos-prego e uma anta. Ngonetuma assume o ponto de vista da caça ao se deparar com a mulher-anta. Com relação aos demais animais, ela é a caçadora. Contudo, os demais animais que Ngonetuma enxergou como caça, foram vistos por Ngowarutcha também como pessoas. A proporção seria então, Ngowarutcha : pessoas :: Ngonetuma : caça. No entanto, há uma exceção que produz a seguinte proporção, Ngowarutcha: pessoas :: mulher-anta : Ngonetuma. A exceção é quando eles encontram uma anta que é uma "mulher gorda peneirando o pajauaru".

Para entendermos como se dá esta exceção, a transformação de uma imortal em caça na presença de uma mulher-anta, devemos sair do "dualismo estrutural estático" (Kelly, 2011: 148) que nos fornece estas proporções ${ }^{202}$. Em outros termos, devemos sair do terreno simétrico das correlações de diferenças totêmicas para compreendermos como se dá a "torção assimétrica do animismo perspectivista" (Viveiros de Castro, 2002: 377) dos Ticuna. A forma como expus as relações até aqui mostra apenas parcialmente as relações em jogo, dispensando o caráter ternário de muitos destes dualismos. O que temos na comparação estrutural dupla acima - do tipo [homem: presa do homem] :: [predador

\footnotetext{
202 Para realizar este exercício inspiro-me aqui largamente no texto de Kelly (2011) que demonstra como a troca de perspectivas procede a mesma transformação operada pela "dupla torção" encontrada nos mitos e sintetizada na Fórmula Canônica do Mito (FCM) (Lévi-Strauss, 2008[1955]).
} 
do homem: homem] (Stépanoff apud Kelly, 2011: 148) - são três termos ou posições: humano, predador e presa. Contudo, apesar de termos a relação de predação (predador e presa) exposta na proporção, o que falta é a explicitação de que a posição de humano é reflexiva (idem: 149), o que, como demonstrarei, só é possível quando entendemos esta situação clássica nos termos da fórmula canônica:

Fpresa (caça) : Freflexividade(humano) $::$ Fpresa(humano) $:$ Fcaça $^{-1}$ (reflexividade)

Pássaros/macacos : Ngowarutcha :: Ngonetuma-caça : anta-mulher

Examinemos mais de perto esta proposição. O lado esquerdo da fórmula mostra um dado verificável etnograficamente: que os pássaros e macacos são as presas canônica para os Ticuna, no mito e na vida, e que a humanidade, como demonstra o perspectivismo multinaturalista, é a “forma da posição reflexiva, o “eu’ enunciado” (ibdem). Contudo, do lado direito da fórmula encontramos a "dupla torção" que nos ajuda a compreender por que Ngonetuma, uma imortal, torna-se caça quando eles encontram uma mulher-anta peneirando seu pajauaru. Sabemos que na terra dos imortais o que Ngowarutcha vê como pessoas é visto por Ngonetuma como caça, pássaros e macacos (Ngowarutcha : pessoas :: Ngonetuma : caça). Contudo, há uma segunda torção quando eles encontram com uma anta, aos olhos de Ngowarutcha. Mas por que uma anta? Por que a anta pode ser considerada uma inversão da caça $\left(\right.$ caça $\left.^{-1}\right)$ ? Vejamos o que a etnografia diz sobre a particularidade deste animal para os Ticuna. Um informante de Goulard faz o seguinte comentário sobre a caça da anta: "Cuando se mata uma danta, no se le debe decir cualquier cosa, porque si se le habla mal, la danta se levanta o se transforma em humano" (2009: 308). Podemos notar, com este relato, que a anta é uma caça para os Ticuna muito suscetível de assumir a "posição reflexiva", transformar-se em humano ${ }^{203}$. Portanto, ao ser confrontada com o ponto de vista de Ngonetuma a anta que é caça ${ }^{-1}$ assume o ponto de vista humano - está “peneirando o pajauaru dela" -, reflexivo, automaticamente Ngonetuma torna-se a presa da relação. Notamos, com isso, que as inversões de perspectiva na terra dos imortais não são tão simples o que torna as idas e vindas dos mortais a esta terra bastante complexa.

\footnotetext{
${ }^{203}$ Fausto comenta esta especificidade da anta dentre as caças ticuna, baseando se no registro de Goulard, da seguinte forma: “Occasionally this activity [of reduces the animal's agentive-transformative capacity] is confined to certain species: the Tikuna ritually treat only the tapir, the sole animal reputed to avenge itself directly on humans (Goulard 1998, 430)" (2007: 504).
} 
O narrador da história de Pai'nü comenta a importância que o retorno de alguns mortais que foram para a terra dos imortais têm para os próprios mortais. Segundo afirma, "por isso que naquele tempo o pessoal tinha sabedoria (küagü), porque ele mesmo, o espírito dele, voltou e contou tudo para o pessoal”. Ou seja, depois de se imortalizar o espírito da pessoa retornava para contar para seus parentes mais queridos sobre as aventuras que viveu. Invariavelmente a pessoa voltava para conversar com os parentes que sentiram sua falta e que o amavam antes dele partir. As falas do parente que se imortalizou - as histórias que ele conta, em geral, as aventuras que ele viveu do momento em que ele se separou dos parentes até se encantar - alimentam a "sabedoria" (küagü) das pessoas que sentem a falta dele.

Outra coisa que os mitos deixam claro e que ouvi de muitos ticuna é que a terra dos imortais não é um lugar inalcançável no espaço e no tempo. Com a devida paciência e os cuidados necessários pode-se chegar lá. Principalmente, ela não pertence ao passado, não é um lugar onde alguns eventos míticos se passaram e hoje não existe mais. Todos sabem a direção do Eware e têm algum parente que já esteve lá. Estes são os casos de buscas individuais do local dos imortais. Alguns voltaram e contaram como é este lugar, outros por lá ficaram e nunca mais foram vistos.

Em geral, as pessoas contam que chegaram perto e escutaram os imortais. Alguns viram o local e muitos objetos dos imortais, mas muito raramente alguém relata que encontrou um imortal pessoalmente. Nas palavras de Goulard, "hay tentativas individuales para acercarse al espacio de los inmortales. Incluso se dice que algunos han podido ubicar esta tierra y hasta han logrado escuchar a los que viven en ella, pero ninguno ha podido entrar en contacto con tales entidades inmortales a causa del estado de impureza de su principio vital." (Goulard, 2012: 28). Uma história destas que ouvi diz o seguinte:

"O tio da minha prima chegou lá. Ele foi caçar lá e chegou lá, ouvia pássaro, galinha, boi, [imortais] tocando tamborim. Uma vez ele se perdeu lá, aí um cavalo apareceu bem na frente dele. Aí o cavalo falou com ele, "vou te deixar lá na sua casa". Aí ele voltou, deixou ele bem aqui. Aqui ainda não tinha nada, era tudo mato. Ele contava a história, tem muita galinha, ele falou, muito boi. [Que mais tinha lá?]. Muitas coisas, peru... [Ele via ou só ouvia?]. Não, ele viu, acho que o ü'üne mostrou para ele. Só que é longe, ele falou, é longe para lá. [Boi, galinha...]. Boi, galinha viva, tinha muitos ovos lá. [Tinha muita fartura?] Muita fartura lá. Só que ninguém pega. [Ninguém pega, não?]. 
Ninguém pega, porque é longe. Ninguém chega, daqui de Belém [do Solimões]. Tem buritizal, depois tem água também. Depois que sai do buritizal, mais para lá tem o Eware. Para lá tem cobra-grande, não podia passar não. Não sei como ele passou para lá. Ele matava anta e trazia para cá. Ele caçava para lá. [Ele andava bastante, então?]. Andava mesmo, porque já conhecia para lá, não tinha medo, né? Ia conversando com o pessoal de lá. Depois que ele morreu, acho que ele foi para lá mesmo."

Existem moças que são levadas pelos imortais e depois retornam:

"Lá na [comunidade de] Vendaval tem uma moça que os ü’üne levaram para o Eware. Estavam fazendo a Festa para ela e ü'üne buscaram ela. [Porque levaram ela?]. Porque, se acontecer alguma coisa é para ela falar e levar o povo para lá. Se alguma coisa acontecer no mundo. [Acontecer o que?]. Não sei não, ninguém sabe. É para isso que estão preparando essa moça. Mas ela já voltou para Vendaval, os ü’üne deixaram ela lá, toda pintada de jenipapo, essa moça. Ela já voltou já.”

O principal empecilho para se chegar ao Eware é ter um corpo “impuro". Veremos mais adiante detalhadamente a principal impureza que nos interessa para compreendermos a Festa da Moça Nova, o puya. Neste ponto da análise, basta-nos ressaltar que a impureza do corpo afasta as pessoas da terra dos imortais. Um dos indícios, por exemplo, de que a pessoa está no Eware é ela encontrar o caniço que Yoi usou para pescar os Ticuna fincado na terra. Hilda me explicou que "os mortais não conseguem ver o caniço de Yoi. Os mortais que olham para o caniço veem uma cobra (atape). Os mortais que tentam chegar no Eware são afastados por uma tempestade com cobras, cabas, que os afastam. O Eware é um lugar difícil de chegar, se a pessoa estiver vivendo com a mesma nação [casado no mesmo clã] é o principal motivo para não chegar no Eware. Por isso que aparece cobra, caba... Se a pessoa pensar que a cobra ou a caba mordeu, já acontece... O que você pensar acontece". Esta referência ao "pensamento que acontece" é importante para a caracterização dos imortais e examinaremos isto em breve. Retenhamos principalmente esta explicação para os que não chegam ao Eware, sua impureza, pois é do processo para se livrar das impurezas que trataremos agora. $\mathrm{O}$ processo ascético para imortalizar-se. 


\subsection{3 - Processos para tornar-se imortal}

De acordo com meus informantes, antigamente as pessoas tomavam um banho de uma mistura para se encantar. O banho era preparado com folha de taperebá (Spondias mombin), casca de ura, olho verde de buriti (Mauritia flexuosa) e devia ser tomado à meia-noite. A moça nova toma banho todos os dias à meia-noite com esta mistura. Estas pessoas que queriam se encantar deveriam se alimentar apenas de bo 'o do buriti (um tipo de verme) e pequenos grãos de milho. Goulard comenta sobre a figura que ele chama de "renunciante" entre os Ticuna, que é justamente esta pessoa que decide tornar-se imortal:

\footnotetext{
"Primero, se trata de una práctica que, aunque haya desaparecido hoy en día, los indígenas todavía reivindican su oportunidad y su función. Así, ha existido una clase de personaje que llamaremos el 'renunciante'. Él utilizaba una técnica que le permitía realizar un proceso mediante el cual se accedía al estado ü-üne. Después de un período más o menos largo, llegaba al mundo de los 'inmortales', en todas las dimensiones de su Ser, es decir con su $m a$ $\tilde{u}$, su $a-e$ con su cuerpo" (2009: 333)
}

Este autor pretende, principalmente, estabelecer uma relação entre esta figura individual do "renunciante" e os movimentos proféticos coletivos. Para Goulard, tanto o "renunciante", quanto os movimentos proféticos buscariam responder a uma mesma

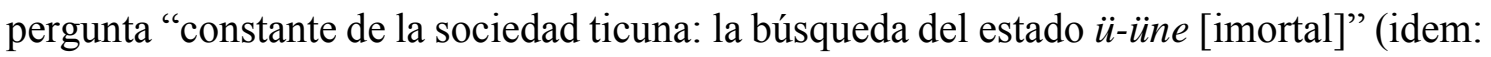
334). A seguinte passagem também ressalta isso, "el horizonte de los ticuna es único: alcanzar a detener el estado ü-üne" (idem: 335). O autor também menciona a relação entre a imortalidade e os rituais pubertários femininos, algo que Nimuendaju já havia ressaltado e que é mencionado em diversos mitos ticuna. Nimuendaju registrou como se fazia antigamente para uma Festa tornar seus participantes imortais:

"Nos velhos tempos, quem quisesse se tornar imortal submetia-se a uma dieta de milho e larvas de coleóptera [ordem de insetos] e, quando se banhasse, esfregaria o corpo inteiro com frutos de buriti. Então, um dia na selva, se encontraria com um menino desconhecido que proporia à pessoa preparar uma festa em tal e tal dia. No dia marcado, de tarde, as aves aquáticas de todas as espécies apareceriam e se empoleirariam nas árvores próximas da casa. Ao anoitecer a dança iria começar dentro da casa fechada. Algum tempo depois, um imortal em forma humana bateria à porta. Devem deixá-lo entrar e conduzi- 
lo até os jarros, onde ele daria ao anfitrião uma cabaça pequena contendo bebida dos imortais, yita'kü tchüü, que deve ser misturada a cerveja festiva (chicha), porque para se tornar um dos imortais é necessário partilhar da sua bebida."

"Na madrugada todos os imortais entrariam, dançariam, beberiam e escolheriam cônjuges, os mortais solteiros fazendo o mesmo, às vezes até mesmo os casais se separariam, a fim de se juntar aos imortais. Ao romper do dia, os espíritos, ao dançar, conduziriam todos os celebrantes para fora da casa, e depois de uns quinze passos mandariam que fechassem os olhos. Quando abrissem de novo, eles já estariam longe, na morada dos imortais.” (1952: 136).

Este é um ideal de Festa bem-sucedida, com todos seguindo com os imortais para a imortalidade. $\mathrm{O}$ começo do relato de Nimuendaju deixa bem claro o que quero mostrar aqui. Há um tratamento a que são submetidas as pessoas que desejam se imortalizar. Este tratamento envolve um tipo de alimentação específico: poucos grãos de milho e "larvas de coleóptera". Estas larvas (bo'o), encontradas nos troncos dos buritizeiros, são um alimento que os Ticuna apreciam. Assim explica um ticuna sobre a "santificação" proporcionada pela ingestão destas larvas: "Quando derrubamos o buritizeiro, encontramos dentro do caule lagartas que podem ser comidas. Antigamente, os Ticunas comiam para santificar. Quem não comia, não chegava no "Éware", lugar sagrado. Essa lagarta é chamada em ticuna TEMATCHI'I ou BO'O" (Lima, 2006: 161). Isso nos remete à concepção que existe de que alguns insetos são imortais, como vimos, por trocarem de pele e, por isso, não envelhecerem.

O banho com as folhas do taperebá também ajuda na purificação do corpo de quem quer chegar no Eware. Numa conversa com Manuel Rita e seu neto, eles me disseram o seguinte: "[Tem um banho que é tomado para se encantar, não tem?] É com folha de taperebá. Tem que tomar banho com isso durante cinco dias. Se banhar com taperebá, você chega lá no Eware (...). Se você não chega lá, você chega na metade... Para lá é mais perto, em Vendaval. De canoa a gente chega lá. É só um igarapézinho (...). Mas depois que tomou o banho, com folhas de taperebá... o Eware não fica perto, não. [Tem que andar muito então?]. Não, se você sai de manhã, chega às 10 hs, porque você já tomou o banho com taperebá". Veremos que o taperebá é largamente usado no ritual para purificar a moça nova. Esta explicação nos mostra que o candidato a imortalidade deve se lavar com esta planta para se aproximar do Eware. 
Oliveira Filho nomeia estas pessoas que tem acesso aos imortais de taü̈̈netchaü, termo que é explicado como "os nossos que desejam virar encantados" (1988: 156). Estas pessoas, "por terem o corpo aberto, podem entrar em contato com os imortais" (idem: 157). O ticuna Pedro Inácio relata como se dá o encontro de um taüünetchaü com um imortal. "Então essas pessoas encantado aparece para essas pessoas que desejam ver essas pessoas üüne [imortal]. Aí conversa com essas pessoas e conta a história de como encantou, de como deve ser, de como deve viver e como deve fazer no futuro para não morrer mais. Aí nesse momento é que o pessoal pode contar para o outro" (inf. Pedro Inácio, Vendaval, 1983)" (ibdem). O contato com os imortais, portanto, traz a sabedoria necessária para se estender a vida, "não morrer mais".

Os imortais são atraídos pelas moças púberes, principalmente pelo sangue menstrual delas. $\mathrm{O}$ ticuna Abel Angarita comenta que os ü'üne estão em busca de sangue, por isso são atraídos para a Festa pela moça. A justificativa que o colaborador ticuna de Valenzuela dá para a busca de sangue feita pelos imortais é o fato deles não plantarem. Segundo afirma, os ü'üne são seres que não plantam, não sentem, não sangram, não falam. Por outro lado, os mortais ticuna, por serem capazes de tudo isso, são a "gente verdadeira" (Valenzuela, 2010: 89, nota 9). O sangue, portanto, atrai os imortais (ü'üne). Ao perceberem um corpo sangrando, como o da moça nova, os imortais são atraídos pela possibilidade de entrar nele 204 .

Ao mesmo tempo - e ao contrário dos “bichos” (ngo’o), que também são atraídos pelo cheiro da menstruação das moças -, o contato com um imortal é algo muitas vezes desejado pelos mortais. Se não desejado, ao menos muitas vezes inevitável. Ondino me contou que "quando um imortal pede a filha para os pais, eles têm que entregar. Se não entregarem aparece "bicho" (ngo'o) para a pessoa". Ondino me contou que uma das acusações sobre o pajé Augusto, que foi executado no igarapé Camatiãã ${ }^{205}$, foi enganar as mulheres se passando por encantado (ü'üne). Augusto teve relações sexuais escondido com várias mulheres. Por ser pajé, ele via encantados (ü'üne), conversava com eles e dizia que pediam as filhas para os pais. Fizeram, então, uma casinha bem cercada para Augusto

\footnotetext{
204 "Lo que perciben los üüne de Worekü es la sangre. Un cuerpo que derrama sangre, está en peligro, es vulnerable a la acción de los üüne, es un cuerpo transparente al que pueden entrar fácilmente" (Valenzuela, 2010: 90, meu grifo).

205 Relatarei a execução do pajé Augusto Basílio da Silva e seus motivos mais adiante no Capítulo 4, tópico 4.1.6 - História do pajé Augusto - a execução do feiticeiro.
} 
receber os encantados ${ }^{206}$. Dois casos me foram narrados sobre este disfarce de Augusto. Cristina, irmã de Severino, casou-se com um encantado e teve duas filhas com ele. Diz Ondino que este encantado, na verdade, era o pajé Augusto. “Amália, mulher do Maduca, foi pedida pelos encantados também. Seus pais, Alexandre e Catarina, entregaram-na para os imortais. Onze horas da noite o encantado chegou para buscar Amália que estava no jirau da casa. Quando ele chegou, Severino estava escondido e viu que era Augusto", me contou Ondino. O fim do pajé, como veremos, foi dramático. Mas há histórias também em que os pais não entregam a filha e sofrem as consequências. Outro relato que ouvi em campo afirma que "Pedro da Silva, pai de Rendina, não entregou sua filha que foi pedida pelos imortais. Numa de suas caçadas, Pedro foi acuado por bichos (ngo'o), teve que cortar um pedaço de cipó e bater nos bichos para se defender".

O fato de Ondino dizer que um pai nunca deve negar sua filha quando um imortal a solicita, pode indicar que talvez os $\ddot{u}$ 'üne, assim como os deuses Araweté, sejam uma espécie de "afins por excelência"207, seres com quem se faria uma aliança privilegiada. Assim como os Guarani, os Ticuna são um povo que historicamente passaram por diversos movimentos proféticos. Acredito que muitas das causas destes profetismos se devem a esta cosmologia voltada para o "divino", para a imortalidade no caso Ticuna. Viveiros de Castro, ao comentar o livro Terra Sem Mal de H. Clastres, refere-se a esta meta de atingir a imortalidade sem passar pela morte, "ideia que faz a originalidade dos Tupi Guarani”:

"É a ela [H. Clastres] que devemos o esboço da visão Guarani do Homem, que o põe como lugar de um compromisso instável e perigoso entre a animalidade e a divindade, bem como a exploração da ideia que faz a originalidade dos TG, de que é possível superar a condição humana de modo radical e se tornar divino sem passar pela prova da morte - um tipo de filosofia que parece recusar os grandes recortes e oposições logico-filosóficos

\footnotetext{
${ }^{206}$ Nimuendaju menciona uma construção semelhante para um profeta ticuna receber as mensagens dos imortais. Cerca de dez anos antes do trabalho de campo etnólogo, um índio chamado Aureliano, morador do lago "Cuyarú, no Rio Jacurapá, começou a ter visões. Fizeram-lhe uma casa ao lado das outras, onde ele permaneceu sozinho para receber as revelações dos imortais" (1952: 138). Há uma curiosidade interessante no caso deste profeta, veremos a relação dele com o gosto ticuna por instrumentos musicais no início do Capítulo 6.

207 Nas palavras de Viveiros de Castro: "os deuses Araweté, mortais imortais, são as afins por excelência" (1986: 693).
} 
subjacentes à maioria das outras cosmologias indígenas sul-americanas" (1986:

105, eu grifo)

Além da proximidade com a divindade - afinal os imortais passeiam pelo mundo chamando os mortais -, a animalidade está presente de forma marcante nas Festas. Afora os mascarados, muitos deles pais e mães da mata e dos animais, há uma encenação dos queixadas sendo caçados. Durante o benzimento dos coĩri, trompete feito de bambu, o pajé cria o caminho para diversas caças se aproximarem. As pessoas se "animalizam" para performar os animais que bebem seu "pajauaru" nas suas Festas. Trata-se, portanto, de uma Festa que marca este lugar ticuna no cosmos, assim como o lugar dos Guarani, "lugar de um compromisso instável e perigoso entre a animalidade e a divindade".

\subsection{4 - Festa e imortalidade}

Quando abordarmos a descrição dos “bichos" (ngo'o) veremos que a principal razão que me foi dada para a execução das Festas é o medo do ataque destes seres. Contudo, existe uma razão tão forte quanto esta e que me foi indicada como um motivo para a realização da Festa: o fato de ela estar estreitamente relacionada com a imortalidade e o mito ticuna de origem da vida breve. Goulard também encontrou uma justificativa semelhante a minha para a finalidade da Festa. Diz este autor que "el objetivo de los rituales entre los tikuna es la recuperación de este estado perdido [de imortalidade]" (Goulard, 2012: 28). Os mitos narram histórias de casas de Festa que, com todos cantando e de porre (ngaün), subiram para o céu dos encantados/imortais (ü’üne). De certa forma, creio que os especialistas no ritual têm a esperança em alcançar a imortalidade através de uma Festa bem realizada. Durante uma explicação sobre a letra da canção dos imortais, Francisco (Üpetücürüngütchiãcü) me disse o seguinte: "todo mundo tem que ficar dentro da casa para serem levados. Quando todo mundo está de porre a casa sobe. Antigamente, durante a Festa da Moça Nova, aparecia um encantado para muitas moças e levava elas. Os encantados levavam todo mundo que estava na Festa com ela".

O que os mais velhos reclamam é do fato de os jovens namorarem antes da hora certa, o que faz com que os encantados não levem mais os festeiros. Um mito coletado por Nimuendaju mostra como este tipo de atitude pode frustrar a intenção do ritual. A narrativa conta que uma moça nova estava sendo iniciada e ouve os imortais entrando na 
casa de Festa. Imediatamente ela responde ao chamado deles e diz que quer se imortalizar. “A worecü [menina que está sendo iniciada] e os outros celebrantes estavam sentados em cima do couro de anta no centro da casa. O tambor de carapaça de tartaruga estava soando, e os convidados estavam dançando. De repente, o couro de anta começou a se mover, subindo no ar" (1952: 136). Uma convidada que estava namorando fora da casa não percebe o que está acontecendo e perde sua carona para a imortalidade. Ao final do mito, o couro de anta com os convidados se torna a aureola lunar.

Deste modo, além de um ritual executado com maestria, a imortalidade é estreitamente relacionada com o cumprimento das regras de casamento. Segundo afirma Goulard, "[la] multiplicación de las relaciones incestuosas ha sido a causa de las catástrofes: "en aquel tiempo [los ticuna] eran incestuosos (womachi). No se reconocían entre familias". Solo han podido conservar su estado primordial los que han respetado las reglas prescritas, son llamados los 'inmortales' (ü-üne), por oposición a los 'mortales' (yunatii) que son los ticuna" (2009: 95). Além disso, a Festa tem o papel de aconselhar os jovens a não começarem sua vida sexual tão cedo. Explicaram-me que a reza que o pajé fez nas meninas iniciadas nas Festas que presenciei, depois das moças saírem do quarto de reclusão (turi), serve para elas não terem filhos. Um pajé pode impedir uma mulher de ter filhos, pode fazê-la menstruar menos, a cada dois meses, por exemplo. A reza do pajé pode ter sido uma escolha delas ou de seus pais. Logo depois que a menina passa pelo ritual, é desejável que ela ainda não tenha relações sexuais e filhos tão logo. Dentro do quarto de reclusão ela é aconselhada para que não comece sua vida sexual muito jovem. Caso as moças queiram ter filhos, têm que chamar o rezador de novo para "desenrolar", retirar o contraceptivo mágico.

As referências míticas a esta intenção de se imortalizar são inúmeras. Nimuendaju coletou uma série de mitos que relatam a conquista ou a perda da imortalidade ${ }^{208}$. Ou seja, existem tanto mitos que relatam o êxito em conseguir a imortalidade pelos participantes da Festa, quanto mitos que contam como a imortalidade foi perdida.

Uma outra narrativa, por exemplo, fala de uma moça em reclusão por ocasião de sua Festa de puberdade. Yoi, um dos gêmeos míticos ticuna, na companhia de outros imortais, chama a todos para segui-lo. A menina não responde, mas atende ao chamado

\footnotetext{
${ }^{208}$ Estes mitos foram analisados por Lévi-Strauss em O Cru e o cozido (2004 [1964]), quando ele trata dos mitos sul-ameríndios que relatam a origem da vida breve.
} 
do espírito da Velhice (dya), que arranca sua pele puxando pelos cabelos. O espírito da Velhice faz o mesmo com a moça e troca de pele com ela. Imediatamente ela se torna uma velha decrépita, "desde então os homens envelhecem e morrem. " Nimuendaju (1952: 135). Numa outra narrativa, ao final de sua festa de iniciação, uma moça é levada por um "jovem que apareceu em forma de anta” (idem: 137). Quando ela volta para visitar a família, seu marido distribui "bebida dos imortais" para as pessoas que estão na Festa do irmão mais novo da moça. "Todos ficaram bêbados e nessa condição foram embora com o casal para a morada dos imortais no Igarapé Eware." (ibdem). Na história do incêndio e do dilúvio mundiais, apenas duas moças que estavam reclusas se salvam do incêndio que consumiu o mundo. "[U]nicamente sua cela de reclusão permaneceu firme, e, enquanto todos os outros estavam morrendo, as duas irmãs permaneceram vivas" (idem: 141). Ao final da história, uma das moças vai para a morada dos imortais também. Os mitos que tratam do tema da imortalidade, portanto, narram situações em que ela foi conquistada ou perdida, uma possibilidade que está aberta também na Festa da Moça Nova.

O que quero destacar aqui, principalmente, é esta intensão de imortalizar-se por meio de um ritual feito com maestria e o encontro de mortais e imortais proporcionado pela Festa ${ }^{209}$. Segundo Goulard, apesar da existencia da figura do renunciante, como vimos, masculina e individual, o acesso a imortalidade é, antes de tudo, uma possibilidade coletiva $^{210}$. A Festa é um momento em que mortais e imortais se encontram, "um período atemporal de conjunção" (Goulard, 2012: 20-21), existindo a possibilidade de os mortais serem levados pelos imortais.

\footnotetext{
${ }^{209}$ Valenzuela comenta que os imortais aparecem para aconselhar quando encontram com os mortais. "Se presenta ante nosotros para decir o aconsejarnos para que nosotros tengamos sentido de vivir, nos dicen cómo hay que vivir, qué hay que hacer y cómo hay que hacer la pelazón [Festa de Moça Nova] con nuestras hijas. Con eso es que vive Yoi" (2010: 97).

210 "La inmortalidad, entre los tikuna, se diferencia de la cristiana en la medida en que sí comprende al ser completo, con todos sus componentes, y se piensa ante todo de manera colectiva" (Goulard, 2012: 21, nota 5).
} 


\subsection{5 - O corpo em formação e o mundo verde}

Não somente os imortais são seres em formação. O lugar onde eles moram é considerado bunecü, ou seja, uma espécie de descampado, onde a vegetação é bem baixa e novinha. Esta referência a um "mundo ainda verde" aparece muito nos mitos e nas canções da Festa. No mito de Pai'nü o narrador comenta que "nesta época o mundo ainda era novinho (nadoü), o pensamento era encantado". Quando Ngowarutcha chega no lugar dos imortais ele encontra "uma clareira (ngo'oneün) muito grande", ou seja, um lugar de mato baixo, um campo grande. A terra dos imortais é descrita deste modo. Na história dos americanos que procuravam a terra dos encantados ${ }^{211}$ e nas canções temos referências de que o Eware é um bunecü, um grande descampado. Um trecho de uma das worecütchiga 1, canção de moça nova, que registrei em campo faz a seguinte menção ${ }^{212}$ :

Yunatü̈̈n gama naãne doonegurü oi, oi gama yoyowetcha

"Quando o mundo ainda estava verde, com o mato baixo, vovô, vovô Yoi"

Tacatürüyena tuune yayima wonetchimegurü tacatürüyena

"Por nós que Yoi derrubou o tronco da samaumeira"

A canção retoma o motivo da derrubada da samaumeira por Yoi, na época em que o mundo ainda era "verde", com o mato bem baixinho, não estava formado completamente. É o tempo das aventuras dos gêmeos Yoi e Ipi. Como dizem os Ticuna, “época em que Ngutapa [o primeiro homem, que gestou os gêmeos em seus joelhos] se criou". Na mesma canção, o tema do "mundo verde", ou seja, não maduro, é evocado pela palavra polissêmica na'ãne. O trecho da canção diz:

\section{Tchaecawai guünarü naãnewa}

"Só eu estou cantando no mundo/terra/roça"

Além destes sentidos que me foram dados para esta palavra (mundo/terra/roça), todos evocadores de espaço ${ }^{213}$, Goulard afirma ainda existir um sentido de tempo também

\footnotetext{
${ }^{211}$ Capítulo 2, tópico 2.8 - Atualização do mito - notas sobre o messianismo ticuna.

212 Gravação de Ondino.

213 “Remarquons qu'il existe un seul terme dans la langue tikuna pour désigner le cosmos et le jardin, ce dernier étant perçu comme un microcosme du premier " (Goulard, 2010 : 122). Angarita ressalta o fato deste espaço ser construído: "El concepto de Naane puede ser traducido como "cosmos, universo,
} 
neste termo. Traduzido também como "cosmos", este termo "expressa, às vezes, o tempo, o espaço..." (2012: 19). O mundo (ane) também é referido por Valenzuela como o “corpo de Ngutapa". Ao semear a terra os Ticuna estariam alimentando o "corpo de Ngutapa": "al sembrar se abre un espacio para uma esencia que alimenta la tierra y Ngutapa la retribuye; el acto de comer no es simplemente eso, nos apoderamos de la escencia de Ngutapa (los cuatro principio s, porá: fuerza o poder, conocimiento y sabiduría: kua, vida: mau y nae: pensamiento).” (Valenzuela, 2010: 93).

A natureza vegetal das coisas é tão presente na vida ticuna que explica mesmo a origem dos peixes e animais. Ngewane é conhecida como a árvore dos peixes, "é uma árvore encantada que existe desde o princípio do mundo" (Gruber, 1998: 36). A história registrada n'O Livro das Árvores conta como esta árvore - cuja dona é a cobra-grande, Yewae - dá origem a muitos animais ${ }^{214}$. Algumas árvores que encontramos atualmente na floresta também possuem o mesmo poder de gerar animais, como a Ngewane mítica, por isso a caça e os peixes não acabam. Tudo indica que a natureza última dos seres, portanto, é vegetal. Mas não só dos seres, há um mito ticuna que conta a origem do terçado ${ }^{215} \mathrm{e}$ outras ferramentas de metal, que também brotaram da árvore Tchaparane:

"A árvore começou a florescer e começaram a sair os terçados. Na época tinha aquele terçado que chamava tchapara, um terçado bem grosso, dava para derrubar pau bem grosso. Nasceram todos os tipos de ferramenta lá. Nasceu trincha [ferramenta para cavar a canoa], enxó, machado, enxada, todo tipo de

territorio". La palabra Naane está compuesta por tres morfemas: na, ser; - $a$, poseer, y-ne tronco o carne, que se refiere a un ser que posee tronco, carne o cuerpo; en otras palabras, Naane significa territorio construido o hecho." (2013: 11).

214 "Quando chega o tempo, depois das chuvas e ventos, as folhas desta árvore caem e no seu tronco começam a aparecer pequenos ovos, parecidos com ovas de rã. Os ovos se transformam em lagartas, muitas lagartas, que sobem pelo tronco e andam até os galhos para comer as folhas novas. Aí elas vão crescendo, crescendo, durante uns dois ou três meses. De repente, as nuvens se juntam para chover, e começa a tempestade. Os raios e os trovões fazem as lagartas descerem e entrarem nas raízes da árvore. Suas cascas, como algodão, ficam soltas sobre as sapopemas. A chuva vai aumentando. Quando a água sobe, as lagartas saem transformadas em peixes, em vários tipos de peixes, grandes e pequenos (...). Os peixes, já ovados, se espalham pelas águas e ganham a caminhada para os igarapés, lagos e igapós. Depois, uma parte alcança o rio, subindo em piracema. Esses peixes servem para alimentar as pessoas" (Gruber, 1998: 37). "Além dos peixes, no ngewane se criam outros animais, como jabuti, jacaré, tracajá, veado, queixada, macaco, tamanduá, tatu, anta, capivara, cobra, calango, cutia e ainda todas as aves. Outras árvores também podem ter o mesmo poder do ngewane, como o tururi, mapatirana, samaumeira, louro, tüütü. O tüütü gera a queixada e o macaco-barrigudo. A samaumeira gera o peixe-boi." (idem: 40).

${ }^{215}$ Facão no português regional amazônico. 
ferramenta nascia naquela árvore. Até que chegou a época que cai aquela fruta, mas era terçado." 216

Os dois mitos, na verdade, se conectam pelo fato destas árvores possuírem um mesmo dono, a cobra-grande, Yewae. A versão do mito de origem dos peixes de Gruber esclarece, "[a árvore] Ngewane é o pai dos peixes, e o dono desta árvore é a cobra-grande, o Yewae." (1998: 40). A narrativa de Ondino que conta como um homem se transformou na árvore de terçados, relata a certa altura, que a "capa do homem era a cobra-grande, o corpo dele virou árvore. A capa dele cuidava daquela árvore. Igual cobra mesmo, andando embaixo e cuidando". A responsável pelas duas árvores, deste modo, é a cobra-grande.

Vimos no Capítulo 1, tópico 1.2 - A Origem dos Clãs, que há uma relação entre a imaturidade do mundo e a imaturidade dos corpos das pessoas. Enquanto os clãs não foram instituídos e as pessoas começaram a casar certo a terra foi destruída várias vezes por diversas catástrofes. Com a instituição dos clãs pelos paladares distintos dos corpos, a terra se estabiliza, "amadurece". A terra do mito e a terra dos imortais é imatura, assim como os corpos destes seres está "em formação" e o corpo da moça nova, também se formando ${ }^{217}$. É importante ressaltar que não só no tempo mítico a terra era "verde", o Eware, a morada dos imortais, também possui essas características. Gruber descreve a vegetação neste lugar desta forma: "Os velhos contam que as árvores do Eware são diferentes. A mata é baixa, nunca cresce e nunca morre. Tem muita sorva, buriti, açaí, ingá, cupuí, araça, bacaba, bacuri, mapati, sapota, pamá. Também tem muitas flores. Essa vegetação do Eware se chama bunecü, porque é sempre pequena e nova, como uma criança, bue" (Gruber, 1998: 22, meu grifo). Ou seja, estamos tratando aqui de uma vegetação imortal, "nunca cresce e nunca morre", por isso ela se mantém sempre jovem.

Cada parte do corpo é associada com uma parte do cosmos e os seres que lá habitam:

"El cuerpo se asocia a su vez a las divisiones o paisajes del mundo tikuna, en los pies están las gentes sin ano ngerü̈̈tagüane que nunca se reproducen y aunque puedan sembrar y hasta cocinar, nunca comen, se alimentan con el aroma de la comidas que cocinan; en la pantorrilla está la gente sin ojos

\footnotetext{
${ }^{216}$ Uma versão menor deste mito, "Tchaparane, A Árvore Dos Terçados", está em Gruber, 1998: 43. O trecho acima é de uma versão narrada por Ondino, mais detalhada.

217 É bastante comum os Ticunas dizerem em português que uma moça que teve sua primeira menstruação "se formou".
} 
Ngeétütágüane, que al igual que los demás inmortales, buscan la perfección; a continuación en la rodilla están los enanos méchita, en la cadera los mortales tikunas yùnatü, que se pueden reproducir, en el pecho el mundo de arriba de los cóndores ẽchatagüane y en la cabeza el mundo de Ngutapa ẽtagüane donde está el pensamiento, el nae, todo está conectado por la médula espinal, de la cadera para arriba hay luz, hacia abajo hay oscuridad y agua es donde habita la boa noratü." (Valenzuela, 2010: 94)

Esta relação entre a terra e o corpo - ou os rios e o sangue - é estabelecida pelo ticuna Abel Santos no seguinte comentário: "La sangre es la esencia, es el agua de la inmortalidad, que circula en un cuerpo cerrado que es el territorio. (Abel Santos, com. per.) "(Valenzuela, 2010: 91). Vimos que existe uma "metáfora vegetal", bem destacada por Goulard, que estabelece o corpo como ainda verde na infância e o mundo dos imortais também ainda verde. A citação acima estabelece uma relação entre o sangue que circula no corpo e os rios que correm no mundo. O corpo seria um território fechado, onde circula o sangue, a "água da imortalidade". Neste sentido, tudo leva a crer que uma abertura deste sistema fechado, o próprio corpo que menstrua, provocaria uma reviravolta cosmológica. O contato com as águas do Eware, ou de um igarapé qualquer após a moça passar por todo o ritual, seria a única forma controlada de lidar com a abertura deste sistema de "rios" de sangue que é o corpo e seu sistema circulatório. Notemos bem que a ligação entre estes dois sistemas deve ser controlada, para isso que serve o ritual, já que quando estão menstruadas as mulheres não podem se aproximar muito do rio, sob o risco de serem raptadas pela cobra-grande (Yewae).

\subsection{6 - Pensamento-ação}

Uma última consideração ainda nesta caracterização dos imortais é necessária. Em diversas passagens de mitos e em relatos colhidos em campo, tenho referências sobre o pensamento dos encantados. Tudo indica que se trata, digamos assim, de um pensamentoação. Ou seja, imediatamente, ao pensarem em algo, este já aparece, ou ao pensarem em alguma ação, esta já está em curso. A palavra ticuna para designar este pensamento-ação é ngümawa, que me foi explicada enquanto traduzíamos, Hilda e eu, a "História do 
caçador que só escuta vozes"218. Hilda me disse que ngümawa é "quando o encantado/imortal pensa e o que ele pensa já está acontecendo". A palavra foi usada para explicar a interação da heroína do mito com as formigas. A passagem da história é a seguinte: "Ela pediu ajuda para as formigas e no pensamento dela já foi acontecendo o que ela pediu. Ela ficou imaginando a formiga chamando ela, "vamos, vamos", como se fosse de verdade. Aí começou a formar-se uma fileira de formigas, com muitas formigas, até o final do caminho. Então ela foi andando no caminho, seguindo a fileira das formigas."

As referências deste pensamento-ação no mito não param por aí. Hilda comenta, por exemplo, porque os tamanduás já sabiam o nome de Pai nü quando o encontram na floresta. Segundo me disse, "quando entravamos no mato nesta época, nosso pensamento já ia se encantando, tornando-se encantado". Os tamanduás perguntaram para ele: "Pai'nü, de onde você veio?", sem nunca tê-lo visto antes. De acordo com minha interlocutora, isto se dá pelo fato de que "naquele tempo nosso pensamento era ü'üne, eles já sabiam o nome dele".

Durante a Festa, evita-se o uso de certas palavras que evocam o estado de mortalidade (yunatiu) nas letras das canções. Assim, por exemplo, o instrumento de casco de tracajá, tori, pode ser referido numa canção como dotchinawe, espécide de tori "sem males". O termo na língua ticuna coloquial usado para se referir ao urucum é üta, mas na Festa da Moça Nova não se usa este nome, usa-se ngugüte, com este nome o mesmo urucum fica "sem males", não fica yunatü. Cuaratchi é o mesmo que üacü (sol), mas a primeira palavra é usada na Festa, cuaratchi é uma palavra sem males, sem azar. Usa-se estas palavras para não fazer mal para ninguém.

Este pensamento que age também pode ser uma palavra que se realiza imediatamente, o que torna bastante perigosa qualquer fala disparatada. Este perigo é marcado pelo uso da recriminação cuguta, usada por Yoi para advertir seu irmão e a encontramos em diversas narrativas de aventuras dos gêmeos Ticuna. Ele sempre diz isso para seu irmão, “cuguta!”. Era um aviso de que aconteceria alguma coisa, o irmão faria alguma besteira. Uma espécie de censura ao mal-uso das palavras, para o irmão não falar qualquer coisa, porque naquela época, todo mundo era encantado, o que se falava

218 “Feneẽcü ga wü’i ga nagaüninücü”, em Firmino \& Gruber, 2010, vol 3. 
acontecia. Quando alguém fala alguma besteira, as pessoas falam "cuguta" = "não diga isso", "não fala assim". Precisamente, cuguta é uma recriminação por criar coisas ou ações indevidamente com as palavras.

Ipi, o gêmeo trapalhão da mitologia ticuna, é o personagem que mais comete este tipo de "mau uso das palavras". No mito de To'oena ele torna a água avermelhada de sangue do Eware ainda mais vermelha, pelo simples fato de comentar a vermelhidão da água. "Depois que estriparam e lavaram as carnes dela no igarapé Tunetü, afluente do Eware, a água do igarapé ficou avermelhada (dutchiü) com o sangue dela. Ipi comentou com Yoi, "irmão, com o sangue da nossa sobrinha que o rio ficou avermelhado". Yoi respondeu, “cuguta” ("você está doido? Quer saber mais do que eu?”). Neste momento, a água ficou mais avermelhada ainda" (Anexo - 005). Ipi é o responsável, por exemplo, por criar os maiores inimigos dos Ticuna, os Awane (Cambewa/Omágua). Em algumas narrativas do mito de origem, quando vai descer do jenipapeiro, Ipi vê os Awane (Cambewa/Omágua) e, lá de cima, fala para seu irmão, que o esperava embaixo da árvore, o que está vendo. "Por causa disso é que os Cambewa (Omágua) ficaram os inimigos mortais dos Ticuna" (Oliveira Filho, 1988: 101, nota 50). Se ele tivesse ficado quieto, os Ticunas não teriam estes "inimigos mortais".

Apesar de localizarem esta potência das palavras no tempo do mito ou no lugar dos imortais, este cuidado com as palavras, evocado pelo termo cuguta, permanece um ideal de conduta dos Ticuna. Como atesta o relato da atitude correta durante a colheita do açaí: "Antigamente, tinha que ter bastante cuidado para tirar o açaí, não falar e nem pensar assim: "O açaí está muito comprido", se você falar assim, o açaí realmente vai ficar comprido. A mesma coisa com as frutas, a gente não deve falar assim: “O açaí está sem carne", porque se você falar assim, o açaí vai ficar sem carne mesmo. Antigamente, para tirar as frutas da natureza tinha que ter firmeza, não falar besteira" (D. Lima, 2006: $160)$.

Os erros de Ipi são uma constante nos mitos. Por sua culpa várias coisas boas foram deterioradas e continuam assim até hoje. O que acontece é uma "fala má" de Ipi que age sobre o mundo e o modifica. Na história do Wone, a samaumeira mítica, que me foi contada por Nailson Pissango, acontece o seguinte: "Antigamente, a polpa do umari era grossa. Mas Ipi falou mau e a carne do umari diminuiu e ficou assim até hoje”. Por outro lado, as trapalhadas de Ipi na mitologia, muitas vezes, não são alvo de reprovação pelos exegetas ticunas que comentam seus mitos. Cabe aqui um pequeno parêntese para 
introduzirmos uma ideia que retomaremos: a moral que os mitos trazem sobre os rigores da educação dos jovens e sua relação com o corpo. Após contar o mito de origem dos carapanãs - como veremos, oriundos de mais uma confusão em que Ipi se meteu - o narrador faz o seguinte comentário no meio da história:

\begin{abstract}
"O irmão dele sempre ajudou muito ele para ele ressuscitar. Porque será que Yoi sempre fazia o bem para ele? Yoi sempre fazia isso. Se Yoi não fizesse o bem para seu irmão, nossa vida agora não seria boa, nós brigaríamos muito. Yoi tinha muita paciência com o irmão. Se Yoi abandonasse o irmão quando ele fizesse besteira, hoje nós seriamos pior ainda. Yoi sempre tinha paciência e ajudava o irmão. Se ele não fizesse isso, hoje em dia nós não cuidaríamos das pessoas. Devemos seguir o exemplo de Yoi e cuidar dos parentes. Yoi sempre cuidava, curava seu irmão. Por isso, quando acontece alguma coisa com alguém, nós não deixamos jogado, nós cuidamos, temos pena (yierü' $\tilde{u}=$ pena, preocupação com a pessoa)"219
\end{abstract}

Neste comentário o narrador conta uma espécie de moral dos mitos de Yoi e Ipi. Isso nos remete ao trecho final d'A Origem dos Modos à Mesa, de Lévi-Strauss, "A moral dos mitos". Se podemos dizer que existem regras de bons modos nos mitos ameríndios, devemos localizá-las “ao mesmo tempo no plano físico e no moral” (2006 [1968]: 453). Isso ficará mais claro quando passarmos ao ritual da moça nova e examinarmos as imbricações entre estes dois planos no corpo da moça. O fato de Yoi ajudar seu irmão inconsequente tem como efeito direto tornar a vida dos atuais ticuna melhor. Ipi representa um ser em "ebulição interna", dotado de "forças incontroláveis que devem ser subjugadas de múltiplos modos que, mesmo em nossa sociedade, foram ou são invocadas para justificar os rigores da educação" (ibdem). Este é justamente o modo como LéviStrauss define a mulher ameríndia menstruada, o "protótipo das "meninas modelo"”, a moça nova que encontraremos passando pelo ritual dos Ticuna. Yoi é o responsável por ajudar seu irmão a se controlar, sob pena de colocar em risco a todas as pessoas. $\mathrm{Na}$ história de origem dos carapanãs, Ipi tem o corpo chupado por insetos gigantes. Mas no final, Yoi consegue traze-lo de volta a vida e diminuir o tamanho dos mosquitos. Eles ficam do tamanho que se encontram hoje.

219 “Nhuãcü nango'ün go agu”, traduzido por mim e por Hilda de Firmino \& Gruber, 2010, vol. 1. 
Pelo que vimos até aqui, há um jogo muito sutil entre mortais e imortais. Uns tentam atrair os outros. Os mortais tentam trazer os imortais para suas Festas e tentam também ir com eles para suas moradas encantadas. Contudo, os imortais também lamentam que, apesar de chamarem os mortais constantemente, estes últimos nunca os ouvem não prestam atenção aos seus chamados ${ }^{220}$. Tratam-se de duas posições irredutíveis, um jogo de soma zero. Mas, em alguns momentos, dá-se o encontro, porque alguém procura este encontro, de uma parte ou de outra. Um mortal que busca o Eware ou que jejua para imortalizar-se, ou um imortal que vem ter relações sexuais com algum mortal. Principalmente, as Festas são os momentos destes encontros. Encontramos uma sugestão da relação dos imortais com as Festas retomando o conto Os Imortais de Borges. Vejamos um trecho que me fez entender melhor esta relação.

“A morte (ou sua alusão) torna preciosos e patéticos os homens. Estes comovem por sua condição de fantasmas; cada ato que executam pode ser o último; não há rosto que não esteja por dissolver-se como o rosto de um sonho. Tudo, entre os mortais, tem o valor do irrecuperável e do inditoso. Entre os Imortais, ao contrário, cada ato (e cada pensamento) é o eco de outros que no passado o antecederam, sem princípio visível, ou o fiel presságio de outros que no futuro o repetirão até a vertigem. Não há coisa que não esteja como que perdida entre infatigáveis espelhos. Nada pode ocorrer uma só vez, nada é preciosamente precário. O elegíaco, o grave, o cerimonioso não vigoram para os Imortais. Homero e eu nos separamos nas portas de Tânger; creio que não nos dissemos adeus.” (Borges, 1999: 30, grifos meus)

Guardadas as devidas proporções, temos duas possibilidades borgeanas de relação dos imortais ticuna com, usando seus termos, "o cerimonioso". Por um lado, estamos diante de seres que fazem Festa continuamente, sem parar, numa "repetição até a vertigem". Como na história do Tchürüne, um imortal que de tanto fazer Festas e tocar casco de tracajá tem seus pés achatados, as peles alongadas. Neste caso, o que o imortal faz é doar alguns itens festivos para os mortais. O casco de tracajá é um dom que os Ticuna possuem até hoje, uma lembrança do vovô Tchürüne, um festeiro hiperbólico. O som da cidade dos imortais muitas vezes é mencionado como um som contínuo de

\footnotetext{
${ }^{220}$ Veremos um exemplo deste chamado na análise da canção dos imortais, Capítulo 5, tópico 5.3.2.1 - A canção dos imortais.
} 
instrumentos de Festa de Moça Nova. Por outro lado, o "elegíaco, o grave, o cerimonioso não vigoram para os Imortais". Interpreto este fato da seguinte forma, se os imortais, ao menos alguns deles, vivem numa Festa sem fim, repetida "até a vertigem", esta perde todo o seu sabor, já não é mais um evento extraordinário. Parece-me que só há uma saída para tal estado de repetição infinita, juntar-se aos mortais quando estes fazem suas Festas. Ao participar da Festa dos Outros - "Outros" já que se trata de uma alteridade radical aqui, cosmológica, entre mortais e imortais - rompe-se por alguns instantes a roda-viva do contínuo ritual dos imortais.

\section{2 - Os "bichos" (ngo'o)}

Após sair de uma missa na comunidade de Nossa Senhora de Nazaré, vi umas pessoas aglomeradas em torno de Dona Benedita. Todos estavam assombrados com o que ela descrevia. Na noite do dia anterior ela tinha visto um bicho (ngo'o) passando atrás de sua cozinha. Ele tinha a forma de um porco, um queixada, mas era bem mais gordo, com as pernas curtas e o queixo branco. Segundo sua descrição, eles fedem tanto que é impossível ficar perto por muito tempo, de tão insuportável que é o cheiro. Este tipo de ngo'o anda em bandos de dois ou três. Se uma pessoa se aproxima, eles correm atrás para comê-la. Ao mesmo tempo, os humanos têm cheiro de macambo (ngu, Theobroma bicolor) para os ngo'o, são fedorentos (nãdiemã) para estes demônios. De acordo com o que me disse Francisco, "é uma fruta fedida, o cheiro parece com fruta verde, muito ruim". O cheiro do macambo atrai os ngo'o. A moça nova tem cheiro de macambeiro, as Festas também servem para atenuar este cheiro e diminuir o perigo.

Os ngo’o são traduzidos como "bichos" para a maior parte dos ticuna a quem perguntei $^{221}$. São considerados muito perigosos, podem matar e comer uma pessoa. “Ngo'o é bicho que come gente", me disse um ticuna certa vez. Nimuendaju (1952) traduz

\footnotetext{
${ }^{221} \mathrm{~A}$ aproximação que farei necessita de uma melhor investigação linguística, mas é curioso notar a semelhança entre esta palavra, ngo'o, e um dos verbos para se referir ao ato de "comer". Em geral, uma pessoa quando diz que vai comer utiliza o verbo tchibu. Contudo, pode-se chamar uma pessoa para comer usando tchibu - por exemplo, ngiã ta tchibue = "vamos comer" -, mas para dizer, por exemplo, "Edson, come esta laranja", é usado o verbo ngo. Esta palavra é usada quando a intenção é "dar de comer", "alimentar", como o verbo feed em inglês.
} 
a mesma palavra como "demônio", o que me foi indicado também algumas vezes como uma possível tradução para o termo. Este etnógrafo descreve um pouco destes seres e o ambiente onde vivem na seção "O Mundo Inferior" de sua monografia sobre os Ticuna:

“Os seres mais antigos do mundo são os demônios, ngo'o. Este é também o mais insultante nome usado entre os Tukuna. Alguns demônios pertencem a um dos numerosos clãs, outros são apenas indivíduos isolados. Eles não são imortais, embora muitos tenham poderes, tornando-os superiores, ou pelo menos perigosos, para os homens. Sua aparência, como representada em certas máscaras, é quase sempre estranha e terrível. Às vezes, eles são representados em forma humana, a sua natureza, no entanto, revelada involuntariamente, é completamente diferente da dos seres humanos" (118).

"Alguns desses demônios habitam aqui na terra, outros, como o Dyure'u [Yureu], no céu. Mas a grande maioria vive em terras subterrâneas (na’pü), a que se tem acesso por cavernas. As regiões subaquáticas são parte deste mundo inferior, que compreende várias terras com condições diferentes e entradas separadas. Os demônios não são seus únicos habitantes; outros residentes são humanos, embora com defeitos estranhos: cegos, anões, pessoas sem ânus. Informação sobre o assunto é dada na lenda seguinte, de tchõë'. " (1952: 118).

A riqueza dos dados de Nimuendaju, como sempre, nos dá muito o que pensar. Exploremos este trecho aos poucos para melhor detalhar o que são e onde moram estes "demônios". Como nos relata o autor, os "bichos" vivem principalmente no mundo inferior. Meus colaboradores ticuna costumam falar que muitos deles moram dentro das montanhas (pü). As constantes referências míticas dos Ticuna às montanhas é algo que intriga, numa primeira mirada, quando nos deparamos com suas narrativas. As montanhas são muitas e a atividade em seu interior bastante agitada. Contudo, da calha de todo o vale do Amazonas, esta região onde habitam os Ticuna talvez seja a de maior elevação com relação ao nível do rio. Assim nos relata o entomólogo e naturalista inglês Henry Walter Bates logo que chegou às cercanias do então vilarejo de S. Paulo de Olivença, no dia 10 de setembro de 1857: "S. Paulo fica situado no alto de um morro, na margem meridional do rio. $\mathrm{O}$ morro era composto de tabatinga, uma argila encontrada regularmente em todo o vale do Amazonas, mas que em nenhum outro lugar forma elevações tão grandes como a que víamos ali, cuja altura devia ser, aproximadamente, de trinta metros acima do nível médio do rio" (1979: 289). A esperança deste naturalista explorador era alcançar o sopé 
dos Andes, que não estavam tão distantes, não fosse seu acometimento por malária e o consequente retorno ${ }^{222}$. As referências a estas elevações podem indicar também alguma migração da região do sopé dos Andes. Não necessariamente uma migração humana, mas as histórias podem ter viajado, descido os montes. As conexões dos mitos ticuna com os dos Machiguenga ${ }^{223}$, povo subandino do Perú, pode indicar uma conexão com estes povos subandinos de uma maneira geral e uma proximidade com as montanhas andinas.

Oportunamente veremos histórias de "bichos" (ngo'ogü, pl.) que saem de montanhas. O que quero ressaltar agora é que a variedade de "bicho" é enorme. Apenas para mencionar alguns deles, há uma variedade de ngo'o que são os matiti. São bichos ( $n g o$ 'o) que andam de noite e cantam para fazer o mal. Eles se alimentam de carne humana e entram no corpo do rezador (xamã) para fazer o mal. O Tchatchacuna também é um tipo de ngo'o, me foi descrito da seguinte forma: “Como criança, um anão, anda com corda, terçado, cacete. Quando a pessoa está no mato, ele sobe nas costas da pessoa. Chegando em casa ele fala para a pessoa pegar corda e se enforcar. Só pajé vê esse bicho. Depois que esse pajé morreu, o Tchatchacuna também morreu, [o pajé] era dono dele". Os ngo 'o, portanto, podem induzir a pessoa ao suicídio. Bueno relata histórias de suicídio influenciadas pelos "bichos". Uma menina que se matou na comunidade de Campo Alegre, por exemplo, porque ouvia a voz de sua mãe chamando e dizendo para ela se enforcar. "Era um ngo’o que estava tentando enganá-la. Já tinham chamado o pajé para tentar resolver o problema, mas não adiantou" (2012: 13). Muitos dos suicídios acontecidos em Campo Alegre (ver Bueno, 2012) são atribuídos à influência dos ngo'o, principalmente por vingarem-se de pessoas que cometiam incesto.

A mitologia também está repleta destes seres. Já vimos nos capítulos anteriores referências ao Matchi'i, o "pai das cabas" (Oliveira Filho, 1988: 143). Este ngo'o mítico é apresentado por Oliveira Filho (ibdem) e Nimuendaju (1952) com atributos que lembram bastante a figura do feiticeiro: o ataque com "espinhos" e a transformação em onça. O Wüwürü, por exemplo, é o dono do buriti, vive no meio do buritizal. "Os velhos contam que o Wüwürü mata as pessoas fazendo cócegas e depois as devora. Ele tem

\footnotetext{
222 “A saúde abalada arrefeceu o meu entusiasmo, levando-me a abandonar o meu plano de continuar a viagem para o oeste, até as cidades peruanas de Pebas e Moyobamba, distantes dali 400 e 900 quilômetros, respectivamente. Com isso eu completaria as minhas pesquisas de História Natural em toda a planície amazônica, até o sopé dos Andes." (295).

${ }^{223}$ A Oleira Ciumenta, Lévi-Strauss, 1986.
} 
dentes fortes, cabeça meio pelada, unhas grandes e esporões nos pés" ${ }^{224}$. Um celebre exterminador de "bichos" da mitologia é o caçador Baia. As histórias "Caçada de Baia" (Baia'arü feneẽtchiga) e “Baia queimou o Ucae” (Baia' rü Uacae' tü'ü') narram o embate entre o herói e diversos "bichos" que tentam pegá-1o ${ }^{225}$. Não é por acaso que Baia seja um matador de "bichos". Ele era parente de Yoi e este herói o deixou aqui quando foi embora. No primeiro mito, o Ucae passava todos os dias no mesmo horário pelo quintal de Baia levando suas frutas $t c h a^{226}$. A esposa de Baia "viu o bicho passando e pensou, “como será que faz para esse vovô aí dar essa fruta para a gente?". Mas ele já sabia o que ela estava pensando. O bicho se transformou no Baia, ficou igualzinho a ele. Ele foi lá transar com ela". O Ucae então estoura a mulher com seu pênis e chupa todo seu sangue. Os filhos de Baia fogem para a floresta e contam para o pai o acontecido. "Quando ele chegou em casa o bicho tinha se transformado igualzinho à mulher dele”. Baia fingia que não percebia que o Ucae tinha se transformado em sua mulher. Quando tinham relações sexuais, Baia revestia seu corpo de pedra, impedindo que o "bicho" fizesse mal a ele. No final da história, o Ucae fica provocando Baia, secando seu pênis sobre a árvore. O herói resolve então acabar com ele de vez, envenenou as flechas de sua zarabatana e foi flechando as partes do "bicho". Cada pedaço do Ucae que era flechado caia no chão. No final, Baia queima o todo o Ucae.

O segundo mito mencionado, "Baia queimou o Ucae", já começa com o fato de Baia ser casado com uma mulher-bicho. "Os parentes da mulher dele eram bichos (ngo'o) e ela também era bicho". Baia fez uma Festa para aniquilar uma porção de "bichos" Ucae e convidou todos os parentes de sua esposa. Temos diversas inversões nesta Festa feita para receber os Ucae. A bebida principal da Festa não é o pajauaru ou outro fermentado de macaxeira, como de costume nas Festas ticuna, mas é feita de cupuí (Theobroma subincanum), uma variedade menor do cupuaçu (Theobroma grandiflorum). A arrancação de cabelos é feita no menino pela mãe dele. Na Festa ticuna os cabelos do menino não são arrancados, são as moças que tem seus cabelos arrancados pelas mulheres mais velhas, preferencialmente as tias paternas ou mulheres mais velhas do clã do pai. Para proteger o filho do perigo que a mãe-bicho representava, Baia o revestiu de pedra

\footnotetext{
224 Trecho da História do Wüwürü, transcrita de um trabalho escolar de estudantes da Escola Estadual Indígena Pogüta, localizada na comunidade de Vendaval.

${ }^{225}$ Ambas as histórias constam em Firmino \& Gruber, 2010, vol. 2.

${ }^{226}$ Provavelmente uma destas duas espécies de Parkia, Parkia oppositifolia ou Parkia pendula.
} 
quando eles foram para o porto para ela arrancar seus cabelos. No final da Festa, o herói soltou um raio pelo seu cocar e queimou todos os Ucae que estavam na casa. O único que escapou foi o Ngẽtacatchi, que teve apenas os pelos da perna chamuscados. "Por isso que os morcegos $(n u)$ [morcego hematófago, "é grande e chupa a gente"] tem a perna fina. Ngẽtacatchi raspou a perna e virou morcego. Se Baia não matasse esses Ucae, eles continuariam a matar as pessoas, acabariam com as pessoas".

A mitologia ticuna tem muitas histórias como as de Baia, de "bichos" que foram mortos pelos heróis míticos. O mundo estaria muito mais infestado destes "bichos" se Yoi não tivesse reduzido bastante o número deles antigamente. Muitos destes "bichos" que escaparam de serem dizimados pelos heróis, transformaram-se em animais hematófagos. Esta é uma das principais características dos “bichos”, se alimentarem de sangue. Vimos o caso do Ngẽtacatchi acima, que se transformou em morcego chupador de sangue. A esposa-bicho de Baia teve sua cabeça queimada por Yoi. "Só sobraram as cinzas, que se transformaram em maruim ${ }^{227}$ (...) Assim que os velhos contam [nhatagü'ün ga yaguãta ga nüti ugü] (...) Por isso que hoje tem maruim por aí. Eles são a transformação das cinzas da cabeça da mulher Ucae. Os carapanãs também são das cinzas do Ucae, por isso que chupam a gente".

Na história "Como foi o aparecimento do carapanã" (Nhuãcü nango'ün go agu, Firmino \& Gruber, 2010, vol. 1), um mutum comeu os pedacinhos queimados de um Ucae. Esses pedaços se transformaram em carapanã e ficaram fazendo zoada na moela e no papo do mutum. Yoi matou o mutum e guardou as partes que faziam zoada para seu irmão não pegar. Mas Ipi continuou procurando pelo som. "Quando ele achou, pegou a buchada do mutum e rasgou na mesma hora. Os carapanãs avançaram nele e não eram pequenos. Eram carapanãs grandes que chuparam Ipi todinho, só sobrou o couro dele”. Quando Yoi foi procurar seu irmão, encontrou só sua pele jogada no chão e viu os carapanãs gigantes empoleirados na árvore. "Os galhos estavam até meio vergados com o peso dos insetos, assim como o galho verga com o peso de uma fruta. Yoi pegou um pau e foi batendo nos carapanãs. Conforme ele bateu, os carapanãs foram diminuindo de tamanho até ficarem do tamanho que a gente vê eles hoje".

\footnotetext{
227 "Design. comum a diversos mosquitos da fam. dos ceratopogonídeos, de até $2 \mathrm{~mm}$ de comprimento, cuja ocorrência no Brasil está associada aos manguezais; as fêmeas são hematófagas e transmissoras da filariose ao homem e aos animais domésticos por meio de picadas dolorosas" (dic. Houaiss).
} 
Esta diminuição dos carapanãs proporcionada por Yoi é análoga à diminuição da potencia de veneno que ele efetuou nos seres peçonhentos que habitam o mundo. Segundo me disseram, o herói do mito de origem dos Ticuna foi o responsável por tirar o excesso de veneno da tucandeira e das demais formigas. Antes de ele fazer isso, o veneno era mais forte. Das cobras ele não tirou nada, por isso o veneno dela é tão forte. Ngutapa também ajudou a tirar o veneno de alguns animais que, antigamente, poderiam ser letais. Segundo Severino, "ele fez isso para não morrer todo mundo". Afinal, um mundo em que todas as formigas tivessem uma picada fulminante seria impossível de se viver. O sapo Munü também está em sua condição atual porque Yoi o fez ficar assim. É um sapo venenoso, ele ferra, tem esporão na mão. Ele costumava atacar as pessoas, era pior que jararaca. Yoi perguntou a ele qual era a cura de seu veneno. O sapo respondeu que a cura era cérebro de gente. Yoi não gostou e pisou nele, até hoje ele é achatado como uma folha. O sapo vivia na terra, depois que foi pisado foi para a água. Antigamente ele tinha dente também, mas, pelo fato do sapo ser muito nervoso, Yoi extraiu os dentes dele. Yoi, portanto, quando não extinguiu completamente aquilo que causava mal aos Ticuna, reduziu significativamente os males que ameaçavam os índios. Deste modo, algumas espécies só não são ainda mais peçonhentas ou os carapanãs só não são grandes como frutas porque vovô Yoi reduziu estes males do mundo.

No final deste mito de origem dos carapanãs temos uma importante referência à estratégia de ação dos "bichos". O narrador faz o seguinte comentário:

"Por isso que agora não aparece mais [Ucae] para ninguém, porque Yoi naquele tempo queimou um monte. Os velhos contam que ainda tem, mas a gente não vê muito como antigamente, porque vovô Yoi já matou muitos naquele tempo. Se Ipi não fizesse o que ele fez, Yoi também não teria matado todos aqueles bichos (ngo'o). Se Yoi não fizesse assim, as pessoas iriam para o mato e não voltavam mais. Eu iria para o mato e não voltaria mais, disse o narrador. O bicho me pega no mato e se transforma em minha imagem e vem igual a mim para cá. O bicho (ngo'o) vem para cá igualzinho a mim, mas eu já estaria morto. [Não é só a imagem não, é igualzinho a pessoa]. Ele, bicho (ngo'o), come a gente e se transforma igualzinho a gente para comer outra pessoa."

Como vimos nas histórias de Baia, os "bichos" possuem uma grande capacidade de tomarem a forma humana. Em geral, eles se transformam em algum parente da vítima 
para poderem se aproximar e devorá-las ${ }^{228}$. Este fato torna sempre suspeita a pessoa que retorna da floresta e começa a agir de maneira estranha. Nunca se sabe com certeza se é o parente mesmo que está ali ou algum "bicho" que tomou a sua forma e quer fazer mal para a comunidade. Contaram-me muitas histórias de "bichos" que aparecem "igualzinho" ao parente da pessoa. Numas destas histórias, um Tchurarune ${ }^{229}$ usou deste artifício para bater em uma mulher do igarapé Tacana. Ela foi com sua mãe para a roça arrancar mandioca. Fizeram fogo para assar umas bananas e cará. De repente, apareceu Tchurarune, igualzinho o marido da mulher. Eles assaram os peixes que ele trouxe e comeram. Então o homem pediu para que ficassem mais um pouco na roça. Quando estavam indo embora, ele pediu para a mãe da esposa ir na frente com o aturá de mandioca. Quando a mulher foi, ele começou a bater na filha dizendo que ela não deveria usar calças, que aquilo era traje de homem. "A mulher chegou em casa nua, Tchurarune deixou ela nua".

\subsection{1 - Vampiros (nũtchi'i)}

A PIASOL, Policia Indígena do Alto Solimões, foi criada pelos Ticuna para a resolução conflitos internos às comunidades. Uma de suas incumbências é também resolver casos de feitiçaria e vampirismo ${ }^{230}$. Esta variedade de "bicho" (ngo'o) chamada nũtchi' $i$ me foi traduzida como vampiro, pois eles podem se transformar em morcegos e chupar o sangue das pessoas. Eles são muito brancos, ficam o dia inteiro dentro do quarto, só saem de noite. Quando perguntei onde viviam, me indicaram algumas das grandes comunidades: Campo Alegre, Vendaval, Belém do Solimões, etc. O comentário em Nazaré é que as comunidades de Campo Alegre e Belém do Solimões são as terras dos vampiros (nũtchi'i). Obadia é o segundo chefe dos vampiros, o primeiro foi queimado.

\footnotetext{
228 “De manera más corriente que los 'padres', estos 'demonios' pueden tomar forma humana; se hacen presentes en ocasiones en que uno no ha respetado una prohibición, por lo que su 'principio vital' está frágil, o cuando una persona en estado de ebriedad se esconde en el monte. Este estado facilita su acercamiento (supra). La entidad interviene, de alguna manera, como si tuviera una relación de causaefecto, cuyas consecuencias no son visibles de inmediato. Así, el ngo-o, busca apropiarse del 'principio vital', introduce la 'enfermedad' que a veces ocasiona la muerte de su víctima” (Goulard, 2009: 286).

${ }^{229}$ Uma forma de se referir a um tipo "bicho" sem chamá-lo pelo nome, Yureu, o que pode evocar sua ira. Veremos sobre este "bicho" logo adiante.

${ }^{230}$ Ouvi relatos sobre a repressão a homossexuais em Campo Alegre também.
} 
"Ele é bem branquinho. Quando estamos deitados no chão [da casa] ele aplica injeção na gente e puxa nosso sangue. Eles só saem a noite, voam igual morcego, têm a cor da macaxeira, bem branquinhos".

Um comentário de Nimuendaju sobre a formação do pajé - sempre suspeito, como afirma este etnógrafo - pode nos ajudar a esclarecer esta figura do vampiro ticuna. Um candidato a xamã deve, além de manter uma dieta rigorosa, se abster de muito sol. "Toda a sua alimentação deve conter muito pouco de sal, ele deve abster-se completamente de pimenta, gorduras, doces e bebidas alcoólicas e também deve evitar a exposição ao sol" (1952: 101). Lembrando que, se o primeiro chefe dos vampiros foi queimado, isto o aproxima do tipo de execução aplicada aos feiticeiros, como veremos ${ }^{231}$, e aos demônios $(\text { ngo'o })^{232}$, já que um dos principais demônios da mitologia ticuna, o Ucae, também foi incinerado.

O aconselhamento público é uma prática muito frequente entre os Ticuna. As Festas de Moça Nova podem ser pensadas como grandes eventos de aconselhamento das moças, principalmente através dos cantos. Atualmente, o aconselhamento é algo que acontece na igreja também. Após a missa da qual participavam alguns evangélicos de Decuãpü, um pastor começou a aconselhar Neuziane, que demonstrou interesse em se converter. Mariazinha, mãe da menina e esposa de Francisco, apareceu dizendo que ela era uma menina muito desobediente. A mãe de Neuziane dizia, aos prantos, que sua filha nunca ouvia seus conselhos e respondia a ela dizendo, "vai procurar outro homem para você". As acusações sobre a moça é que ela não estaria cuidando de seu marido. "Ela deixa ele sozinho em casa e vai passear, já está pensando em se separar dele”. O pastor e Mariazinha aconselharam Neuziane. Segundo o pastor, a culpa é da mãe e do pai, que entregaram a filha muito jovem para o marido, ela estava com dezesseis anos. Ele dizia que ela estava muito namoradeira, apesar de ser casada.

Quando voltamos para casa, Ondino me contou o que estava acontecendo com Neuziane. De acordo com sua versão, durante o período em que ela morou na cidade de São Paulo de Olivença para estudar, um vampiro a pegou e aplicou sangue de vampiro nela. Desde então, “ela ficou doida, não respeitava mais o marido e respondia à mãe".

\footnotetext{
${ }^{231}$ Ver Capítulo 4, tópico 4.1.6 - História do pajé Augusto - a execução do feiticeiro. 232 "Um vampiro é um tipo de ngo'o também".
} 
Um pajé contou a Ondino que Neuziane ainda está com a capa (tchaicure) do vampiro e tem que ser rezada para tirar a capa. Ondino conta que ela fala para a mãe que quer sangue, quer chupar o sangue de alguém. Quando ela foi com Gabriel para o Perú, a cunhada de Gabriel voltou dizendo que ela tinha relações sexuais com vinte homens ao mesmo tempo. Num caso como este de Neuziane, existe mais um agravante. Depois dos tratamentos do pajé, ela teria que ficar "guardada" por um mês, com uma dieta restrita. Ondino me contou que a cura de várias doenças feita por um pajé implicam em reclusão, que pode variar de um dia a alguns meses. E cumpre salientar que para qualquer tipo de reclusão - seja no ritual pubertário, durante o puerpério ou em caso de doença - o termo é o mesmo, aure ${ }^{233}$.

Neste sentido, acredito que seja possível estabelecer uma relação entre a brancura da moça nova, reclusa por quase um ano ${ }^{234}$, e os vampiros, que também não saem de casa. A primeira reclusão é compulsória para a reclusa e desejada pelos parentes. A segunda é por vontade da pessoa e quem está próximo vê perigo na situação. O contraste é semelhante ao dualismo inerente ao xamanismo. Este é, a um só tempo, curador e enfeitiçador. A reclusão também, pode ser benéfica quando feita após a menarca feminina, no pós-parto e na recuperação de doenças. Neste caso, todos a admitem em suas comunidades, assim como os pajés rezadores são admitidos. Já os vampiros, que se escondem da luz do sol por vontade própria, assim como os pajés feiticeiros, existem apenas nas comunidades dos outros.

\subsection{2 - O ataque dos "bichos"}

Das inúmeras vezes que especulei sobre o principal motivo para fazerem a Festa da Moça Nova, o mais explícito era sempre o perigo representado pelos “bichos” (ngo’o). Se a festa não é feita, qualquer um da comunidade, principalmente a moça, podem ser atacados por bichos (ngo'o) e ser comido. Ondino me contou que logo depois que sua filha "se formou" (menstruou pela primeira vez), ela teve um sangramento que não parou por quatro meses. Ele pensou que ela podia ter uma infecção no útero e certamente isso era fruto de feitiçaria. O caso é que a filha de Ondino, logo depois que menstruou, deveria

\footnotetext{
${ }^{233} \mathrm{Na}$ verdade, este termo é ainda mais amplo e inclui “dieta” em seus significados.

234 "Antigamente, as moças ficavam um ano "guardadas" no curral [quarto de reclusão]. As moças ficavam bem branquinhas", me disse um ticuna.
} 
ter sido imediatamente recolhida para a reclusão (aure). Certo dia, ela foi ao banheiro fora de casa e viu uma onça. Depois disso, Ondino "guardou" ela por três meses, até construírem a casa e prepararem o pajauaru (bebida fermentada). Segundo me contaram, a Festa de Deulene, filha de Laelsio, aconteceu no dia 23 de junho de 2012. Logo que ela menstruou, em abril, recolheram-na para o quarto e ela permaneceu lá até o sábado da Festa. Quando a Festa estava preparada, a menina foi transferida para o quarto de reclusão (turi) enrolada num cobertor, para não ficar exposta.

Um dos mais temidos "bichos" que atemoriza os Ticuna é o Yureu. O nome Tchurara é usado para se evitar pronunciar o verdadeiro nome deste demônio (ngo'o). Ele está sempre ouvindo e vendo a gente, por mais que falemos baixo. Quando não fazemos Festa de Moça Nova ele pega a menina e corta seu cabelo, como um aviso. Se não acatarmos ao aviso, o Tchurara pode se vingar, comer a moça. Ondino conta que isso aconteceu no igarapé Jacurapá. As pessoas não faziam Festa e o Tchurara cortou o cabelo de uma moça. Começaram a aparecer pragas, lagartas na roça que comiam toda a plantação. Por fim, acabaram fazendo a Festa para a menina. Segundo me disse Ondino, renomado cantor ticuna e meu principal informante, a principal razão para fazerem a Festa é o medo do Yureu. Esta relação da Festa com a roça nos mostra que este rito ticuna também é um ritual para favorecer a produção de alimentos. Ondino me contou que "se não faz festa de moça nova, as plantas da roça não crescem. Se não fizer a festa a roça não dá nada, dentro da banana nasce espuma, pesca só osso". O roçado é o local onde os demônios (ngo'o) costumam atacar, quando a menina ou seus familiares negligenciam a Festa.

Dizem que os Tchurara são os "policiais de Yoi" (Yoi arü Tchuraragü). "Eles são igual gente encantada, a gente não vê. São invisíveis, às vezes aparece para a gente. Ele que não deixa a gente não fazer a Festa da Moça Nova”. Há uma canção que enfatiza que, caso seja negligenciada a Festa pelos parentes da moça, o Tchurara iniciará a menina com seu jenipapo ${ }^{235}$. Este jenipapo, do ponto de vista Ticuna, é falso; o próprio Tchurara é um falso chefe, diz a canção que me foi descrita como "a canção da moça nova que foi levada pelo bicho porque ninguém cantou para ela". Vejamos o trecho em que isto é mencionado:

\footnotetext{
${ }^{235}$ No Capítulo 4, tópico 4.3 - Jenipapo e Urucum, examinaremos o pensamento ticuna sobre o jenipapo, cuja tintura é essencial na Festa da Moça Nova.
} 
Ãegacü\} 2X Ucaün 32 X Âegacü\} 2X

"Falso chefe" 236

Tatchawata

"Por nossa culpa" [se ninguém cantar a música dela]

Noruwai yaoegane

"O dele [do Tchurara] não serve bem"

Ya'aitchanari \} 2X

"Falso jenipapo"

Ematangiünaenataï

"Pintar ela com jenipapo"

Tatchawata

"Por nossa culpa"

Noruwai\} 2X Oegane\} 2X

"O dele não serve bem"

Ga'aitchanari yaematani

"Com falso jenipapo"

Ngiüntawai naenetaün

"Pintar ela"

Toruwai

"Nossa"

Iri iri pa wowarecü

\footnotetext{
${ }^{236}$ Ãegacü me foi explicado como sendo uma pessoa importante p.ex., o prefeito, chefe, juiz de futebol, este último é chamado "ãegacü do jogo". Ucaũ é "um negócio que não está bom, falso, não está certo". Portanto, podemos traduzir "ãegacü ucaü" como "falso chefe". No caso, Ondino me explicou que a canção se refere ao chefe do Tchurara, que vai pintar a moça nova com o jenipapo dele, para ela ser dele. Goulard traduz este termo como "o que manda": "los representantes de la autoridad, "lo que manda" aegakü" (2012: 22). "El termino aegakü ("principio vital"-"palabra"- "sujeto") se refiere a la autoridad, algo como una nebulosa de los blancos, el poder político, como el gobierno nacional que los domina, y sirve para aceptar a su representante como su encarnación." (idem: 22, nota 9)
} 
"Moça nova"

A vingança proporcionada por se mexer no falso jenipapo (aitchanari ou derepü'üne) dele, como explicita a canção, é o fato de o Tchurara induzir as pessoas a cometerem incesto ${ }^{237}$. Portanto, a negligência com a Festa corrói um dos principais fundamentos da sociedade, demole o tabu do incesto. Ao terem suas filhas iniciadas na (anti)sociedade dos Tchurara, as pessoas não respeitariam mais as interdições matrimoniais. Isso mostra a visão ticuna da importância do ritual iniciático feminino para a manutenção da ordem social.

Enquanto traduzíamos alguns mitos, Hilda comentou comigo que antigamente as pessoas tinham mais medo desses "bichos" ( histórias eram contadas todas as noites, depois do trabalho, antes de dormir. Hoje, com o assédio da TV e outras novidades dos brancos, as histórias são cada vez menos conhecidas. Participando menos do clima criado pelas histórias e conhecendo menos os personagens que as povoam - muitos dos quais estão por aí no mato, até hoje -, as pessoas têm menos medo. Esta é uma das razões, além da proibição da igreja, para as pessoas não quererem fazer mais a Festa da Moça Nova também. Não temendo os bichos do mato (ngo'o), não tem porque se proteger contra eles com as Festas. Não sabendo o que é um imortal, não tem porque querer se imortalizar.

\subsection{3 - Ulisses, o homem que foi levado pelo demônio}

Histórias de pessoas que foram levadas pelos "bichos" são inúmeras entre os Ticuna. O caso de sequestro pelo "bicho" de maior repercussão e mobilização das pessoas enquanto estive em campo foi o de Ulisses, morador da comunidade Mangueira, vizinha de Nazaré, no igarapé Camatiã. Ulisses saiu um dia para caçar e ngo’o levou ele. Nunca mais voltou para casa. Alguns "bichos" (ngo’ogü) são especialistas em enganar os caçadores no mato. Perguntei uma vez a Gabriel porque ele estava há tanto tempo sem caçar. Ele me disse que tinha medo de algum bicho levá-lo embora. Segundo me disse, um bicho poderia aparecer igualzinho sua mulher, com a mesma voz, e deixá-lo doido.

\footnotetext{
237 O jenipapo do Tchurara é falso: "Se mexer nesse jenipapo, ele faz vingança na gente, faz a gente namorar com primo(a), tio(a), faz a gente cometer incesto".
} 
Quando ele percebesse, já estaria morando com o bicho. De acordo com os comentários de Ondino, Ulisses foi levado pelo Tchurara ou Yureu. Este "bicho" estaria alimentando Ulisses. Passado um ano de desaparecido, ele surge na roça de Mariazinha, em Nazaré, pedindo peixe para comer

A segunda aparição pública de Ulisses foi para a filha de Francisco e o ex-cacique Julio. Eles contaram que viram ele nu junto com uma fileira de queixadas que tinham rostos de capivaras. Ulisses, segundo me informaram, estaria morando com estes "bichos" (ngo'o) e sendo alimentado por eles. Depois deste segundo encontro com o desaparecido, decidiram colocar uma troca de roupas para ele no mato e deixar alguma comida também. Fizeram algumas buscas no mato para encontrá-lo. Todas as vezes que conseguiram chegar perto, ele fugiu. Tentaram agarrá-lo também, mas não conseguiram. O pastor que tentou agarrá-lo foi mordido por Ulisses e teve que soltá-lo, deixando-o escapar de novo.

Percebi que havia uma cisão nos esforços para trazer o homem de volta. Havia o recurso aos poderes do xamã e o empenho dos evangélicos para o resgate de Ulisses. Em Decuãpü - comunidade vizinha de Nazaré, onde a Igreja Batista tem uma forte influência -, fizeram uma corrente de orações para que ele voltasse. A atuação da Igreja Católica, capitaneada por Ondino, foi discreta. Presenciei uma visita dos parentes do desaparecido a missa da capela de Nazaré para fazerem preces chamando por Ulisses. A relação destes parentes com a pajelança também é ambígua, como o próprio xamanismo ticuna. Convocaram Aricildo, renomado pajé da comunidade de São Domingos II, para uma longa sessão madrugada adentro para buscar o homem perdido. Os resultados não foram imediatos, Aricildo disse que teria que fazer mais vezes. Os parentes de Ulisses pensaram que isto resolveria rapidamente a situação e não foi o caso.

Por outro lado, os evangélicos se empenham em suas correntes de orações, cultos, cantorias, repetindo trechos da bíblia, falando línguas, para afastar Satanás que levou Ulisses e evocando Jesus e o Espírito Santo para que tragam ele para casa. Ondino observa aquela situação com incredulidade. Dá para notar que ele não está contente com os evangélicos batistas vindo todo o sábado para fazerem culto na capela católica de Nazaré. Mas nunca recusa quando pedem a ele para usarem o espaço, apesar de ouvir muitas vezes que a religião católica é de Satanás. Ele apenas fica cioso dos jovens de Nazaré que - ao verem o culto efusivo dos evangélicos com seus jovens extremamente apegados à religião, cantando animadamente, bem diferente da missa católica -, pensam em se 
converter e serem batizados pelos pastores de Decuãpü ${ }^{238}$. Contudo, além de promover esta atração dos adolescentes para a religião batista, conseguir resgatar a alma de Ulisses seria uma vitória sobre o xamanismo, repudiado pelos evangélicos.

O culto dos evangélicos de Decuãpü é de uma intensidade impressionante. Durante os cânticos, é possível ouvir o coro a vários metros de distância. A coordenação do que é recitado também é impecável. Os jovens têm diversos trechos da bíblia decorados. No meio de uma pregação em ticuna - feita na casa de Mariazinha, local mais próximo de onde Ulisses havia aparecido pela última vez - o pastor mencionou num tom de voz elevado, “Tiago 4:7"239, se referido ao capítulo e versículo da bíblia, e todos recitaram a plenos pulmões o trecho mencionado. Muitas foram as vezes que ouvi referências ao livro do Apocalipse ${ }^{240}$. A certa altura, Mariazinha - esposa de Francisco, que encontrou com Ulisses pela primeira vez depois de um ano de desaparecido - narrou como o encontrou em sua roça. Estava bastante emocionada, começou a chorar. Um dos pastores colocou a mão em sua cabeça e fez uma oração. Segurava suas costas, sua barriga e todos falavam ao mesmo tempo, recitando alguma prece. Para chamar a alma (áâe de Ulisses, o pastor incitou a que todos fizessem o chamado. O trecho da bíblia Mateus 10:20 - "pois não serão vocês que estarão falando, mas o Espírito do Pai de vocês falará por intermédio de vocês" - foi evocado e cada um começou a gritar bem forte numa "língua" diferente um do outro, como é feito nos cultos pentecostais. O som era uma massa indiscernível. A cada trecho evocado pelo pastor, um grupo de jovens recitava o mais alto

\footnotetext{
238 Um culto mais animado é um motivo apontado por Goulard também para se mudar de uma igreja para outra: “... en el transcurso de una de las ausencias del pastor norteamericano sus discípulos adoptaron el rito pentecostal en vez del rito adventista que él había promovido. Se decía que el rito pentecostal era dinámico, en el sentido de que suscitaba más alegría entre los participantes que el otro." (2012: 26). Para um relato sobre as disputas entre evangélicos, católicos e pajés ticuna, principalmente com relação aos tratamentos de saúde, ver Goulard, 2012: 35. Bueno Silva comenta também sobre a oposição entre a pajelança e os evangélicos na resolução de uma "onda" de suicídios que acometia Campo Alegre: "A reação da comunidade para identificar os culpados e combater as mortes começou por uma reunião geral realizada pelo cacique, cuja pauta principal foi se se recorreria a pajé(s) ou a um grupo de oração "forte" para descobrir quem está provocando esses suicídios. Em votação, decidiu-se pela oração da igreja: chamariam "uma profeta", segundo a designação nativa, da comunidade Vera Cruz e outra profeta da comunidade Belém do Solimões." (2012: 14).

239 “Portanto, submetam-se a Deus. Resistam ao Diabo, e ele fugirá de vocês".

240 P.ex., Apocalipse 15:1, 2:17, outros trecho eram, Mateus 4:10, João 4:14, dentre outros. Não por acaso, este último versículo da bíblia, João 4:14, faz referência à "vida eterna", que pode ser comparada à imortalidade, tão referida nos mitos e rituais ticuna.
} 
possível o versículo de cor. Depois disto, todos ajoelharam no chão e começaram a rezar, cada qual falando uma coisa diferente, o resultado era um som completamente caótico.

Enquanto as pessoas falavam em "línguas", em algumas pessoas a bíblia era passada no peito e barriga, em movimentos circulares. Uma mão segurava as costas e a outra passava o livro na pessoa. No meio do vozerio, os pastores recitavam trechos da bíblia. Uma menina caiu desmaiada no chão, teve as mãos cruzadas sobre o peito e a bíblia colocada sobre a barriga. Outras ficavam paradas, em transe, com os olhos fechados. Uma garota abria caminho com as mãos para uma outra arremessar, de olhos fechados e com muita força, uma bíblia adiante de si. De repente, depois de circular a casa várias vezes atirando o livro para frente, caiu desmaiada no chão. Outra moça estava deitada no chão com a cabeça no colo de uma pessoa que lhe passava a bíblia no corpo enquanto ela falava na "língua" do Espírito Santo.

Os evangélicos estavam fazendo cultos regularmente aos sábados em Nazaré durante meu segundo período de trabalho de campo (outubro, novembro e dezembro de 2012). A meu ver, a insistência deles em trazer Ulisses de volta se misturava com a intenção de arrebanhar novos adeptos para a religião batista. A cada vinda deles mais pessoas, principalmente os jovens, diziam que gostariam de se converter. Ondino se incomoda bastante com estas declarações dos moradores de sua comunidade, mas ficou inconformado mesmo quando um dos pastores de Decuãpü disse para ele que a Igreja Católica é de Satanás. Os evangélicos se aproveitam do desaparecimento de Ulisses para fazerem cultos insistentemente em Nazaré. Além do que, se realmente o desaparecido retornasse, o mérito seria dos batistas e sua persistência. A disputa para trazer o homem de volta se dá então, entre os "crentes" e o xamanismo, já que não vejo qualquer manifestação religiosa dos católicos para este fim. O que fizeram foram algumas preces, junto com alguns familiares de Ulisses, durante a missa em Nazaré.

Se a postura dos evangélicos é de total negação do xamanismo, os católicos não chegam a tanto. Ondino e os demais católicos de Nazaré recorrem com frequência aos pajés para obterem tratamento para suas moléstias, rezar seus filhos, etc. Já a relação dos xamãs com a Igreja Católica é diferente. Logo que o pajé Aricildo chegou na comunidade, foi para a casa de Gabriel examinar a filha deste que estava com diarreia e comendo muito mal. Perguntei a ele quando ele iria começar a sessão. Aricildo me respondeu que só depois do final da missa. Quando é dia de missa - às quintas-feiras e aos sábado às vezes se reza o terço, a missa acontece aos domingos - as sessões de pajelança começam depois 
que a cerimônia católica acaba. As duas coisas não concorrem. Perguntei a ele, então, se ele iria à missa e ele assentiu com a cabeça. Mais tarde procurei ele na capela durante missa mas não o encontrei. Depois voltei para a casa de Gabriel e tornei a encontrá-lo lá. Gabriel comentou que, em cinco anos morando em Nazaré, nunca viu o pajé Roberto, que mora na comunidade, ir à missa. Antes de uma sessão de cura de sua filha, Gabriel perguntou a ele porque não ia à missa, ao que Roberto respondeu em tom de deboche, “como pode um demônio (ngo ’o) como eu ir à missa?”.

Da parte xamânica, chamaram um dos pajé ticuna mais poderosos do Alto Solimões. Gabriel me contou que Aricildo voltaria para mais algumas tentativas. Tanto que deixou com ele alguns cartuchos para que Gabriel matasse uns guaribas para o pajé. Perguntei a Arnaldo, um dos pajés de Nazaré, sua opinião sobre o que havia acontecido com Ulisses. Arnaldo, então, me contou que havia sonhado com o homem desaparecido. Em setembro de 2012, ele sonhara que Ulisses estava no meio dos soldados - os Tchurara são referidos desta forma também, ou como policiais -, quando estes tentaram pegá-lo, ele caiu num buraco.

No domingo, dia 11 de novembro de 2012, no final da missa oficiada por Ondino, este comentou com os presentes sobre um princípio de incêndio que quase consumiu a capela de Nazaré. É um costume frequente deixarem uma ou duas velas acesas no altar da santa padroeira. Daquela vez, a vela havia tombado e queimou metade do pano em que se via escrito "Viva Nossa Senhora de Nazaré" e chamuscou as madeiras por detrás do pano, deixando-as enegrecidas. Depois que ele apontou o ocorrido, todos se levantaram para ver de perto o estrago. Aldinha ergueu a voz em meio ao burburinho e disse sua versão do que tinha ocorrido. Poucos dias antes ela havia escutado palmas e vozes próximas à igreja. As vozes afirmavam que queimariam a capela. Ondino falou que devia ser o Tchurara, o mesmo "bicho" (ngo 'o) que levou Ulisses. Em seu discurso, Aldinha comentou que estas coisas acontecem por causa da desunião das pessoas da comunidade. Está acontecendo muita fofoca, estão falando muito da vida dos outros, o que provoca este tipo de desastre.

Contaram-me sobre outro caso de sumiço deste tipo. Uma menina de cerca de seis anos sumiu numa praia de São Paulo de Olivença. A mãe dela foi levar o feijão que acabara de colher para a canoa, quando voltou, a menina já não estava mais na roça. Chamaram o exercito, poderosos rezadores, evangélicos fizeram corrente de orações, para assegurar que a menina retornasse. Ela apareceu do outro lado do rio, impossível de ser 
atravessado por uma criança de seis anos sem alguém para ajudar ou sem uma canoa. Disseram-me que foram os encantados (ü'üne) que moram no fundo do rio que levaram ela. Segundo os relatos, este tipo de desaparecimento costuma acontecer quando se casam dentro da mesma nação. "Quando isso acontece, o "bicho" pode levar". Esse "bichos", no entanto, não agem sozinhos. Quando ocorre alguma manifestação deles, ela está associada a uma ação xamânica.

Passaremos, no próximo capítulo, a um exame mais detalhado do xamanismo ticuna. Veremos também algumas considerações sobre o "sangue" para este índios. Para fecharmos este capítulo, devemos ter em mente que os dois "personagens" aprensentados aqui - os imortais (ü'üne) e os “bichos” (ngo'o) - estarão presentes na Festa e são fundamentaris para compreendê-la. Como vimos, a Festa é um momento privilegiado para o contato entre mortais e imortais, além de ser um momento em que os primeiros podem conseguir uma carona para a imortalidade. O ritual também é ocasião de encontro com os "bichos", mas de maneira controlada. Estes seres, que são temidos no cotidiano ticuna, ao aparecerem nas Festas da Moça Nova, são submetidos a um processo de domesticação que traz as vantagens deste contato para os humanos festeiros. 


\section{Capítulo 4 - Xamanismo, o corpo e seus "males"}

\section{1 - Os pajés, yu'ükü}

"Pode-se frequentemente observar que entre os Tukuna nenhum xamã é sempre livre de suspeita"

Nimuendaju, The Tukuna, pg.100

Yu'ükü é o termo ticuna usado para se referir ao xamã. De acordo com Goulard, o termo $y u$ - $\ddot{u}$ se refere aos espíritos assistentes do xamã, "se refiere a un conocimiento, a un uso o propiedad de una especie (planta, animal o 'padre') " (2009: 82). A terminação_kü indicaria uma espécie de propriedade ou conhecimento sobre os $y u$ - $\ddot{u}$, ou seja, o pajé é o “dono" ou conhecedor de determinados yu-ü. Em meu trabalho de campo encontrei a mesma palavra. Contudo, yu'ü me foi traduzido muitas vezes como “oração”. Esta é uma forma dos ticuna não evidenciarem o potencial maligno que possui este conhecimento. Mas também me disseram que yu'ü pode ser "pajelança", "trabalho do pajé”, um termo que evidencia mais a ação do xamã, ao mesmo tempo em que pressupõe um conhecimento. A tradução de yu'ü como “oração" logo se mostra uma armadilha, pois não estamos tratando de um texto recitado, como as orações cristãs. Os yu 'ü são passados de pajé mais velho para o aprendiz, misturados na bebida. $\mathrm{O}$ xamã mais velho coloca a "oração" no pajauaru (bebida fermentada de mandioca), no caldo de pajauaru (pajauarunatü) ou na cachaça e o neófito bebe a "pajelança", cultivando-a dentro dele. Nesta medida, percebemos que não é apenas uma espécie de conhecimento, mas algo que é ingerido fisicamente. Entre os Ticuna, aprende-se o xamanismo bebendo a "pajelança" de outro pajé.

Estes у у 'ӥ vão se reproduzindo dentro do pajé, "criando filhos dentro dele". Roberto, p. ex., xamã de Nazaré, já tem muitos. Quando um xamã possui poucos, como 
Arnaldo, também de Nazaré, ele não consegue fazer mal, só quando tem muito yu'ü que o pajé pode fazer o mal. É como se a quantidade gerasse um possível descontrole dos $y u$ 'ü. Disseram-me que Aricildo tem muito yu'ü no peito dele. Os pajés podem guardar estas "orações" no paneirinho invisível (paturuna) deles. Este cesto invisível também é ganho de outro xamã mais velho, mais experiente. Outro nome que me foi dado para o paneiro do xamã é wotüra. É um paneirinho invisível localizado nos flancos do corpo do pajé. Neste local o xamã guarda suas “orações” (yu'ü). Quando o pajé vai fazer uma cura, ele retira a oração de dentro do wotüra. Se a pessoa ainda está aprendendo a ser pajé, outro xamã mais velho coloca "orações" no wotüra do pajé mais novo. Demora cerca de um ano para aprender a rezar. A "oração" parece com espinho. O xamã, para efetuar a cura, deve retirá-la do corpo da pessoa doente. Depois que ele aspirou a “oração" do corpo de enfermo, utilizando tabaco, tem que colocar ela para fora, regurgitando.

\subsection{1 - Tipos de Pajé}

Todos os pajés são referidos como yu 'ücü, não existem diferenças terminológicas para designar distintos tipos de pajé ${ }^{241}$. Contudo, conhecendo alguns xamãs ticuna e conversando com os índios sobre pajelança, descobri que existem graus de conhecimento no xamanismo. Hilda, por exemplo, comentou que seu pai é um grande tocador de to 'c $\ddot{u}^{242}$ e conhecedor da arte de fabricação do instrumento. Segundo me disse, o pai dela mesmo coloca o espírito (ã 'ẽ) no to 'cü, umas das incumbências do xamã durante as Festas de Moça Nova. Perguntei a Hilda, “então ele é pajé?”. Ela respondeu, "não é não, só um pouquinho, ele sabe colocar na'ã'ẽ (espírito) no to 'cü'.

Fumar e gostar de tabaco são um pré-requisito para ser pajé, o que acaba levantando suspeitas sobre os fumantes quando as acusações de feitiçaria estão circulando. Faz algum tempo, Severino foi acusado de feitiçaria na comunidade de Bom Caminho. Ondino comentou que "ele gosta de fumar, quem gosta de fumar sabe curar. Antigamente ele curava. Hoje, quem sabe, a gente não está no corpo dele”. Num ritual de moça nova acontecido em 2014 na casa de Festas nova de Umariaçu I, foi ele quem rezou

\footnotetext{
241 Dois outros termos que me foram dados para designar o "feiticeiro" foram ngouwai ou maguwai. 242 Trompete tocado na Festa, ver Capítulo 6, tópico 6.2-Aerofones.
} 
as meninas que estavam se iniciando. Notamos, com isso, que também há idas e vindas da pajelança. Um pajé pode ficar um tempo "de molho" até as acusações de feitiçaria se dissiparem, depois, por algum motivo, podem retomar as atividades.

Como disse acima, me parece que o conhecimento xamânico ticuna se apresenta em graus maiores ou menores de acordo com o interesse da pessoa. Neste sentido, podemos estabelecer três graus de aprendizado do xamanismo:

1) Existem pessoas, e estas são relativamente muitas, que sabem rezar os enfermos, benzer crianças doentes, bebês que dormem mal, soprar tabaco para tirar alguma dor causada por feitiço ou vingança de algum animal, etc. $\mathrm{O}$ irmão de Ondino, Ulisses, por exemplo, não é reconhecido como pajé, apesar de no passado ter sido, inclusive foi acusado de feitiçaria. Contudo, na ausência de melhor rezador, de vez em quando ele fazia seções para soprar tabaco em seu sobrinho (BS) recém-nascido.

2) Outros que estão em menor número são os pajés que "recebem" espíritos de outros pajés, humanos e não-humanos. Estes fazem seções mais demoradas, podendo ficar uma noite inteira "trabalhando" sobre a pessoa enferma. Acompanhei uma sessão de cura da filha de Gabriel, feita pelo pajé Roberto. Ele "recebeu” espíritos de diversos pajés para auxiliá-lo.

3) Esta última categoria de xamãs é a mais poderosa, são os xamãs cantores. Eles conhecem os cantos indicados para cada doença ou situação que se queira resolver. Conheci um pajé deste de passagem por Nazaré. Aricildo é um renomado xamã entre os Ticuna, para o bem e para o mal. Por isso, não costuma se demorar muito nas comunidades onde é chamado para "trabalhar".

Como vimos, apesar destas variações de saberes xamânicos, todos os xamãs são designados pelo termo yu'ücü. Contudo, nenhum xamã admitiria ser um destes. Perguntei a Aricildo se ele era um yu'ücü e ele negou enfaticamente. Não há, entretanto, outra palavra em ticuna para se referir a um pajé. Em geral, quando um pajé está se referindo a si mesmo ele se diz pajé ou rezador. Admitir ser um yu'ücü implicaria em poder fazer mal a alguma pessoa, fazer tchũta - espinhos vetores de enfermidades - ao invés de "oração". Aricildo me contou que somente cura, não faz tchũta, disse que é um rezador e só faz o bem para as pessoas. Em certos ambientes, mesmo que todos reconheçam que todo xamã é um yu'ücü, mencionar isto é muito mal visto. Seria como se ele se auto declarasse um feiticeiro. Ondino falou sobre os yu'ü de Arnaldo e de Roberto apenas 
porque estávamos na roça. Fora de locais afastados, como este, os pajés são referidos apenas como rezadores.

\subsection{2 - Vetores de feitiço}

As doenças são todas causadas por feitiço, ou seja, pela intenção de alguém. Tão logo uma pessoa sente dores ou começa a adoecer, começa a especular sobre quem poderia estar causando aquilo. E, da mesma forma que um doente se pergunta pelo causador, a presença de um renomado feiticeiro na comunidade pode suscitar "dores" onde antes não havia. Durante a presença de Aricildo em Nazaré, Ondino reclamava de dores nas costas. Um ou dois dias depois da saída do pajé da comunidade, ele parou de reclamar das dores.

Todo pajé que pode efetuar curas tem conhecimento de como adoentar ou matar pessoas. Ele pode, por exemplo, sufocar, furar com faca, atirar em quem deseja fazer o mal. "Muitos ticuna morrem de feitiço", dizem as pessoas. A palavra ticuna para pajé, como vimos, é yu'ücü, mas também pode ser designado como ngo 'ocü, o que ressalta sua relação com os ngo'o (“bichos”). Certa vez, numa noite de bebedeira do xamã de Nazaré, Roberto, pude ouvi-lo cantando bêbado pela comunidade. No outro dia, Ondino me falou que ele dizia: "Eu sou um bicho (ngo’o) mesmo". Não por acaso, construíram a capela da comunidade em frente a sua casa.

O tchüta é o feitiço que o pajé manda soprando com tabaco (pori) para sua vítima. "Ele é jogado com uma zarabatana, é um tipo de dardo de zarabatana que é soprado. O pajé tem uma zarabatana invisível em que ele sopra o tchũta". Pode ser feito de talo de buriti, espinho de tucumã, agulha, arame, qualquer tipo de espinho. Ele reza em cima do espinho, sopra tabaco, fala o nome da pessoa e o tchüta vai para dentro do corpo de quem o xamã quer enfeitiçar. Segundo me disseram, o "bicho" (ngo’o) causador da doença vai dentro do espinho ${ }^{243}$. O tchũta pode ser mandado não só por um pajé, mas também pela cobra-grande (Yewae), boto e espíritos (ã'ẽ). "Este tipo de espírito fica vagando no fim da tarde e pode jogar "flechas”, tchũta. Espíritos ã'ẽ são visagem também”. Ondino me

${ }^{243}$ Outros dizem que o próprio tchũta é um tipo de ngo'o também. 
contou que a filha de Juarêncio, de três anos, estava gritando certa tarde porque foi flechada por um espírito $\tilde{a}^{\prime} e \tilde{e}$. Afinal, é perigoso uma criança desta idade ficar brincando no terreiro durante a tarde. Arnaldo, um dos pajés de Nazaré, foi chamado para retirar o tchũta dela.

O tchũta é invisível, só se torna visível quando retirado pelo pajé. Quando o pajé o retira do corpo do enfermo, o tchũta aparece em forma de espinho, agulha, arame, espinho de tucum, etc. Presenciei Arnaldo retirando um espinho tchũta da mãe de Ondino. Ele estava rezando Dona Verônica e me falou, "tem bichinho, Edson, na barriga dela". Verônica estava com uma forte diarreia que já durava alguns dias. Perguntei que bicho era, ele disse, "tchũta". "E você está vendo o tchũta?", perguntei novamente. Arnaldo, que havia passado as mãos várias vezes no ventre da enferma, contou que sentia o tchũta, nas mãos, ao apalpar a barriga de Verônica. O pajé fazia movimentos circulares na barriga dela como se estivesse juntando grãos esparramados, fechava a mão, puxava e soprava. Depois, como que jogava fora o que tinha juntado. A certa altura, pediu a Ulisses, que estava lhe auxiliando, que lhe trouxesse limão e misturou com álcool para beber. Durante o tratamento, pouco antes de me falar do tchũta, Arnaldo tinha soprado tabaco nos próprios braços. O tabaco é soprado nas mãos para poder achar o "espinho". É o tabaco que localiza o tchũta. Depois que o álcool com limão estava pronto, Arnaldo passou fumaça de tabaco e um pouco de álcool nas mãos. Deu um gole na mistura que havia preparado, passou um pouco de álcool na barriga de Verônica e aspirou com força. Primeiro, engasgou e regurgitou, como os pajés fazem com frequência. De repente, estava com um espinho nas mãos, era o tchũta. Ele o arrancara da paciente. Mostrou para mim com ar vitorioso e continuou as aspirações na barriga de Verônica, puxando com as mãos os males que estavam lá. Logo que Arnaldo extraiu o espinho, assobiou sobre ele, apertou bem, depois saiu da casa e jogou longe assoprando o tchũta. A sessão de cura continuou, ele puxava com as mãos, assobiava, passava fumaça de tabaco, puxava, tomava álcool com limão e passava álcool na barriga de sua paciente.

Em geral, os pajés bebem cachaça para "amolecerem" o espinho que está causando o mal no enfermo. O pajé canta para o tchũta ficar mais mole (do'úca). Ao amolecer o "espinho", ele sai com mais facilidade. Tanto assobiar, quanto cantar dá no mesmo, tem o mesmo efeito sobre o feitiço. A cachaça ou o álcool, na falta da primeira, é passada no corpo do paciente para o tchũta ficar de porre e sair mais facilmente. $\mathrm{Na}$ ausência de cachaça, presenciei Arnaldo algumas vezes dando pequenos goles num copo 
com álcool diluído em água. Com o causador da doença "amolecido", ele fica mais fácil de ser retirado pela aspiração. O pajé aspira para extrair o "mal de vingança" (wa'a) do doente. Pode ser um esporão de peixe, formiga, cobra, onça, etc. Se a pessoa pisa no "caminho" destes bichos, eles podem se vingar, então, a pessoa fica doente. O pajé vai aspirando, regurgitando e jogando fora os males que retira da pessoa. Mas nem tudo ele joga fora. Alguns são guardados em seu paneirinho invisível (paturuna), para usar depois, seja para curar ou para enfeitiçar. Ele vai guardando os males neste paneiro. Se for bom (wa'a me'ün) ele guarda para curar outra pessoa. Se for mau (wa'a tchieün) seu dever é jogar fora. Contudo, se o pajé quiser fazer o mal para alguém, ele pode usar este $w a$ 'a tchieün para enfeitiçar.

Outro vetor de feitiços é o tchatchacunã, que é chamado de "bonequinho de bicho (ngo'o)". Este “bonequinho" é invisível, uma espécie de vodu que o pajé usa para atingir a pessoa. Ele penetra no corpo e pode se transformar em gente. O pássaro ti'titchicü tem esse nome provavelmente em virtude do feitiço mortal, chamado ti'titĩ. A alma do pajé toma a forma do ti'titchicü e vai fazer feitiço. Ondino e eu identificamos o ti'titchicü com o pássaro saci (Tapera naevia) ${ }^{244}$. Em português regional é chamado matintim. Contaramme que o pajé manda o xerimbabo dele neste pássaro para matar. A ave vai até a casa das pessoas e traz o tchũta, assim como ele faz quando sopra o tchũta com tabaco. O pássaro dá uma flechada na vítima do xamã. Para os Ticuna, este pássaro não é verdadeiro (tchicü), daí a terminação de seu nome. O ti’ti, portanto, só passa a existir, como ti’titchicü, quando o pajé o manda para sua vítima. De acordo com o Livro dos Pássaros (Werigü arü ae) ticuna, traduzido por mim e por Ondino, ele "só canta a noite. Joga flechinhas na gente, mas não podemos ver. Se não tem pajé para tirar, a gente morre. Quando ele canta a gente fica assustado. Não podemos remedá-lo quando ouvimos ele cantar, senão ficamos fracos e não conseguimos correr. O pajé manda o xerimbabo dele neste pássaro" (OGPTB, 2002b).

Para entendermos melhor a associação desta ave com um vetor de feitiços ticuna, vejamos mais de perto alguns de seus hábitos. Sick destaca sua invisibilidade: o pássaro é notado mais pelo som que produz. "É bem conhecido pela voz e muito difícil de se ver"

\footnotetext{
${ }^{244}$ Outro pássaro que me foi indicado com o nome de ti'titchicü foi o Tico-tico-do-campo (Ammodramus humeralis).
} 
(1997: 389). Este fato é comentado pelos ticuna. Contudo, existe uma característica em sua reprodução que o aproxima mais da ideia de um vetor de feitiços. O saci possui um tipo de aninhamento parasitário, ou seja, seus ovos são chocados no ninho de outras aves, pelos próprios hospedeiros. Como os filhotes de saci têm um tempo de incubação menor que o dos ovos de seus hospedeiros, diz Sick, “[o] sacizinho toma rapidamente a dianteira. A ponta do seu bico é um alicate afiado (...) que seria instrumento próprio para dar cabo de seus pseudo-irmãos (Sick 1981) (...). Os pseudo-irmãos do saci desaparecem pouco depois do nascimento do saci..." (1997: 389). Pela descrição fornecida por Sick, notamos que o indivíduo adulto da espécie Tapera naevia é inofensivo. Entretanto, para se reproduzir, ele deposita seus ovos no ninho alheio e mata os filhotes do hospedeiro. Os ovos do saci, portanto, assim como o tchũta enviado pelo pajé, são uma espécie cavalo de troia. Eles são levados pelo pássaro e penetram no corpo da vítima imperceptivelmente, causando sua morte.

Por meio de qualquer um destes vetores, seja qual for a forma como o "bicho" ( go 'o) penetra no corpo da pessoa, a vítima fica doida (tauẽ), como se estivesse bêbada. Sob o efeito destes agentes, a própria pessoa se mata, com faca, corda, timbó, etc. Por outro lado, aparentemente, os "espinhos" ou objetos semelhantes também são usados para se defender ou combater os possíveis feitiços que ameaçam as pessoas. Ondino, por exemplo, com a ajuda de seu filho Arlindo, preparou uma mistura de pelo de porcoespinho $^{245}$, chifre de boi e penas de anhuma, popularmente conhecida também como aricó $^{246}$ (türicu, Anhima cornuta). Todos os ingredientes foram colocados em uma lata e queimados. Ondino, então, passou seu bebê nesta fumaça, que tinha um forte mau cheiro. Depois de defumar o neném, ele colocou a lata fumegante em cada uma das quatro paredes da sala, para defumar todo o ambiente.

Perguntei para que servia esta defumação e me responderam apenas que serve para proteger o bebê. Podemos nos perguntar, no entanto, o que há em comum nestes três itens - espinho de porco-espinho, chifre de boi e penas de anhuma - que os tornam poderosos preventivos de ataques ao recém-nascido? A julgar pelos dois primeiros, espinhos e chifre, podemos deduzir que os espinhos e agulhas - que, como sabemos, são vetores de feitiço - ao serem queimados podem atuar como preventivo de doenças. Mas que relação

\footnotetext{
${ }^{245}$ Chamado regionalmente de quandu ( $n h a^{5} \tau^{2}$ - Coendou prehensilis).

${ }^{246}$ Trata-se muito provavelmente de uma corruptela da palavra "Alencó", que também é derivada de Alencorne, um nome comum para designar este pássaro na região do médio Rio Solimões (Sick, 1997: 242).
} 
teriam com as penas da anhuma. Examinemos, então, esta ave. O simples fato de a anhuma possuir esporões nas asas e uma crista que parece um chifre, já nos remeteria a algo em comum no conjunto mencionado. Mas não é só, de acordo com o ornitólogo Sick, os esporões são "armas poderosas em caso de usarem as asas na defesa do ninho" (1997: 241). Ou seja, os registros dizem que os esporões são acionados na defesa da prole, assim como Ondino planejava com a defumação do neném ${ }^{247}$.

Outra forma de um feiticeiro atacar sua vítima é enviar ou transformar-se numa onça. Gabriel me contou que certa vez matou uma onça debaixo da casa do cacique. Perguntei se comeram a onça. Foi uma pergunta provocativa, desconheço qualquer grupo indígena que coma carne de onça. Ele me falou o que eu esperava, "não se come carne de onça". Mas explicou melhor porque ela não é comida. Se alguém comer carne de onça, os pelos $\left(t c h i^{\prime} i\right)$ do espírito ( $\left.\tilde{a}^{\prime} e \tilde{e}\right)$ dela enroscam na garganta e a pessoa fica tossindo. Com o passar do tempo, se um pajé não tirar os pelos enroscados, a pessoa morre. Além disso, não é só quem come que é afetado pelo felino, seus filhos, pais, irmãos, todos adoecem. Depois desta explicação, Gabriel concluiu dizendo que encontrar uma destas no mato não é tão perigoso. "A onça perigosa é a que é mandada pelo pajé. As onças do mato têm medo da gente. É só assustar ela que ela corre"248.

Nimuendaju também descreve um pajé transformando um boneco em onça e enviando-o para matar pessoas:

"Quirino, que morreu em 1932, jurou que, entre os Tukuna de Peruate, Peru, ele tinha sido uma testemunha ocular de um ato de magia, que ele descreveu como segue. Um dia, enquanto ainda era menino, ele seguiu um velho indo para a selva. Lá, Quirino assistiu-o tecer a figura de um jaguar de arumã, no qual ele colocou uma faixa de tururi que se estendia desde a ponta do focinho à ponta da cauda. Ele havia recebido este tururi, bem como o arumã, do submundo, na'pü (a morada dos demônios). Ele estendeu o tururi até cobrir a figura inteiramente, depois pintou-o com manchas pretas, como as de um jaguar. Então ele virou-se para o menino e disse: "Não se assuste!" e

\footnotetext{
247 Sick menciona que há pouca documentação sobre combates entre os espécimes desta ave. Contudo, "encontram-se às vezes as coberturas córneas dos esporões (as quais periodicamente são mudadas à semelhança da plumagem, não sendo, portanto, muito fixas) cravadas na carne do peito dessas aves." (1997: 241)

248 Bueno conta sobre uma expedição de ticunas na floresta, o líder da viajem "via diversos bichos passando, inclusive uma onça ( $a i)$, mas ela não faria mal para as pessoas do grupo, a não ser que um pajé (yu'ücü) colocasse uma alma nela" (2014: 56).
} 
jogou a figura em cima de um cupinzeiro. Imediatamente ele foi transformado em um jaguar vivo, que fugiu uivando para a selva. Este jaguar matou pessoas e trouxe seus corpos para o velho, que os comeu" (1952: 103).

As coisas que um pajé possui ou tocou são muito perigosas. Eles colocam ngo'o ou nawa nelas ${ }^{249}$. Ondino me relatou que um dia pegou um machado do pajé Roberto emprestado. Depois que usou o machado, ficou com o cotovelo doendo. Segundo ele, provavelmente Roberto teria colocado seu ngo 'o ou seu nawa no machado, colocando em risco quem o usasse. Para sarar seu braço, Ondino misturou assacu (watchiwa, Hura crepitans) com outras ervas num emplasto e colocou no cotovelo. Sentiu-o formigar durante a noite, quando acordou não doía mais. Nimuendaju comenta esta contaminação através de objetos, no caso, de pai para filho: "Mesmo após o período de restrição o pai não pode aproximar-se do seu filho se ele tocou algum objeto que possa prejudicá-lo. No Igarapé de São Jerônimo disseram-me que o pai não está sujeito a quaisquer restrições alimentares ou outras, desde que ele não toque na criança.” (1952: 70)

\subsection{3 - Ma' $\tilde{\ddot{u}}$ e $\tilde{a}^{\prime} \tilde{e}-$ componentes da pessoa}

Existe um tipo de intervenção de cura xamânica, praticada por pajés que dominam o canto xamânico, que é a busca do espírito (ãê) da pessoa que foi sequestrado. Contudo, antes de abordarmos como este resgate é feito, cumpre definir melhor dois dos componentes da pessoa: ma' $\tilde{u}$ e $\tilde{a}^{\prime} \tilde{e}$. São dois termos que costumamos traduzir nas etnografias, na falta de palavra melhor, por "espírito" ou "alma". Façamos, no entanto, uma apresentação mais detalhada destes termos e suas relações com a pajelança. Comecemos pelo primeiro termo.

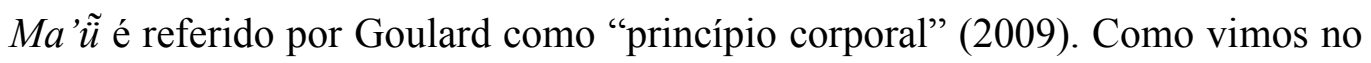
tópico 1.4 - A face expressiva dos clãs do Capítulo 1, a criança recebe seu ma' $\tilde{u}$ ao ser nomeada ${ }^{250}$. O ma 'ü seria uma espécie de "fio" que une, tanto uma pessoa ao seu clã, por meio do nome pessoal, quanto o "fio" que amarra a canoa ao porto. Este "fio" também dá

\footnotetext{
${ }^{249}$ Perguntei a diferença entre ngo'o e nawa para Ondino, mas ele só me disse que são diferentes.

${ }^{250}$ Ver sobre o batismo do recém-nascido no tópico 4.2.2 - Gravidez, nascimento, parto e pós-parto, deste mesmo capítulo.
} 
ao xamã acesso aos “pais dos animais", propiciando abundância de caça e peixes. Goulard o descreve como "uma ligação metafórica":

“[O termo ma' $\tilde{\ddot{u}}$ é] usado para descrever todos os tipos de fios de ligação ou conexão: assim, durante suas curas, o xamã segue seu "fiı" ma' $\tilde{u}$ para conduzir suas viagens aos seus pacientes, ou para visitar os "pais" dos animais que vivem nas salinas. O mesmo termo também se refere à corda usada para amarrar um barco. Finalmente, ele é usado para nomear o caminho, como "caminho de caça”, fenema'ũ. Podemos, assim, legitimamente considerar o ma' $\tilde{u}$ como uma ligação metafórica entre o humano, seu epônimo e as espécies associadas. " (2004: 82).

Esta mesma conexão entre humano, epônimo clânico e espécie existe entre espécies, como vimos, quando estas possuem um mesmo 'desenho-retrato' ou cores semelhantes. A ligação pode se dar por meio do odor também. O ma'ü de um ser pode ser compartilhado com outros seres que possuem o mesmo "cheiro", assim explica um informante de Goulard: “A formiga tem o mesmo ma' $\tilde{u}$ que o fruto de Thevetia e o esquilo, porque ela possui o mesmo cheiro." (idem: 85). Muitas vezes este termo é traduzido simplesmente como "vida". Neste caso, o significado está concentrado no morfema "ma-, que significa "o estado de vivo [du vivant]"” (idem: 91). O mesmo morfema é encontrado na palavra ma'üne, usada para designar o “coração", órgão, portanto, literalmente portador da vida para os Ticuna (ibdem). Pode ser traduzido

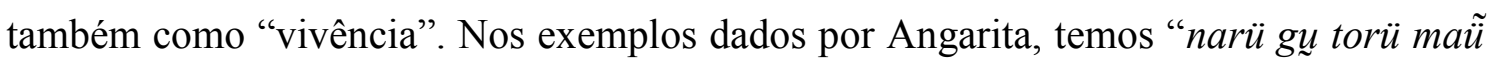

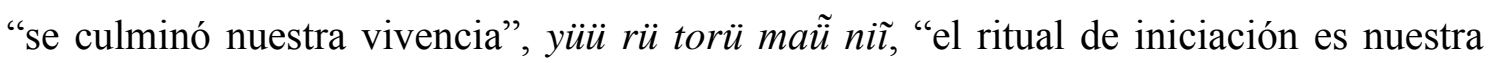
vivencia”, estos son algunos usos del principio maüٌ” (2013: 153).

O ma' $\tilde{u}$ como noção de "caminho" é muito recorrente no trabalho dos pajés. O "caminho do tabaco" (porimã ; pori = tabaco, $m \tilde{a}=$ caminho) possui a mesma designação

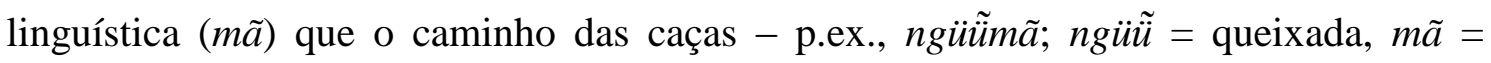
caminho - ou o caminho dos peixes, tchonimã tchoni = peixe, mã = caminho - que o pajé constituirá durante a Festa da Moça Nova, ao benzer alguns instrumentos musicais. Este "caminho" prepara o corpo do pajé para "trabalhar" o corpo do enfermo. No caso do ritual, é no corpo da moça nova que o pajé irá "trabalhar". O "trabalho" com o tabaco se inicia na cabeça das moças, vai para a coluna e se irradia pelas juntas do corpo. Estas juntas e outros orifícios, são "pontos abertos" que devem ser fechados pelo pajé ${ }^{251}$.

251 "Los chamanes se apoderan "roban" las propiedades o capacidades del espíritu del tabaco, para poder curar. El cigarro largo es el "camino" (dice Abel, sobre lo que ha visto de don Paulino) el cigarrillo prepara 
Quando perguntava o que o pajé estava fazendo no corpo da moça, rezando com tabaco, me respondiam que ele estava "fechando" o corpo dela.

Outra qualidade de "espírito" dos Ticuna é o ãẽe. A este duplo da pessoa Goulard chama de "princípio vital" (2009). O ã’ẽ é também o "pensamento" da pessoa ${ }^{252}$. Ouvi referências a este termo em diversos mitos ticuna que traduzi. Valenzuela relaciona o $\tilde{a}^{\prime} \tilde{e}$ com a capacidade de trabalho de um homem recém-casado, algo que não pude averiguar em campo ${ }^{253}$. A sombra que projetamos no chão é o contorno de nosso a a' $\tilde{e}^{254}$. Quando estão vagando pelo mundo este "espíritos" representam um grande perigo para as pessoas. Eles podem ser encontrados na floresta, mas só em lugares distantes, onde ninguém anda. De vez em quando aparecem histórias de gente que encontrou com eles. "É perigoso porque dá medo na gente", me disse um ticuna. Quando uma pessoa é assassinada, seu á'ẽ busca por outro corpo para se apossar dele ${ }^{255}$. Isso pode gerar um estado de "loucura", uma perturbação do pensamento, em quem é tomado pelo $\tilde{a}$ 'ẽ do morto.

Ondino me contou um dado interessante sobre a perspectiva destes "espíritos". "Quando um espírito (ã 'ê) vê gente, ele vê igual pau podre. Contam que uma pessoa se deitou no chão para ver um espírito passar. Mas quando ele passou, não percebeu a pessoa deitada lá, viu apenas pau podre. Estes espíritos ficam vagando pela floresta”. Ou seja, os humanos, do ponto de vista dos $\tilde{a}^{\prime} \tilde{e}$, são vistos como madeira podre. Esta frase de Ondino também evoca o "chamado da madeira podre", de que fala Lévi-Strauss, e que está relacionado à origem da vida breve. Nos mitos jê que tratam do motivo do "chamado da madeira podre" os humanos que aceitaram o chamado da madeira podre têm, por isso, a duração de suas vidas encurtadas ${ }^{256}$. Este tipo de perspectiva dos espíritos (ã 'ê) ticuna,

su cuerpo, ahí es que él empieza a trabajar "towari" para los posesionados, enfermos, tienen en su cuerpo puntos abiertos que son cerrados: corona, nariz, hombros, rodilla, cadera, tobillos, coyunturas de pies y manos." (Valenzuela, 2010: 93).

252 “Naẽ es el principio de conocimiento, pensamiento y razonamiento" (Angarita, 2013: 153)

253 "El naẽ de un muchacho recién casado es su poder, su capacidad de trabajar, hacer chagra, pescar, cazar, mantener a su familia y educar a sus hijos; para que estos sepan con quién deben casarse" (Valenzuela, 2010: 92)

254 “...sombra (tapechita), isto é, um aspecto visual do corpo projetado sobre o chão, contorno que é o reflexo do princípio vital (na-ae) da pessoa." (Goulard, 2011: 143).

255 “El naẽ de la persona (pensamiento) se apodera de uno y se lo lleva. Cuando una persona es asesinada al derramar su sangre, su naẽ queda ahí, latente buscando un cuerpo donde vivir." (Valenzuela, 2010: 90).

${ }^{256}$ No mito apinayé de Origem do Fogo ( $\mathrm{M} 9$ ), por exemplo, "[o herói] tinha a permissão de responder aos chamados sonoros do rochedo e da madeira dura e, se tivesse agido segundo os conselhos recebidos, os 
que vêem os humanos como madeira podre, portanto, remete a este grupo de mitos sobre a vida breve. O mesmo motivo do "chamado" que pode encurtar a vida humana aparece nos mitos e rituais ticuna, mas em sentido inverso. O chamado é feito pelos imortais no sentido de imortalizar os personagens do mito ou os participantes da Festa. A moça não deve se enganar com o chamado do "inimigo", do Tchurara, por exemplo, como no trecho de uma das canções entoadas dentro do trompete to 'cü na Festa ${ }^{257}$ :

\section{Pa wowiyu \\ "Moça [nova] sozinha" \\ Ẽcuwai meãtürü cuaure'ün \\ "Pode [ficar] bem guardada" \\ Taũtama ucaũ nũtchama}

"Não atenda ao chamado da pessoa errada/do inimigo"

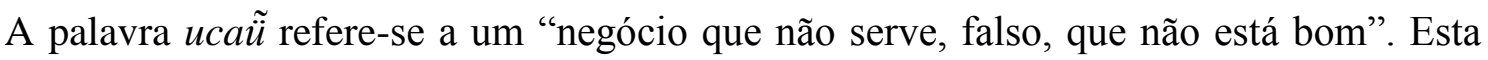
pessoa pode ser o Tchurara, que assedia a moça nova para iniciá-la caso sua Festa seja negligenciada por seus parentes. Atender ao chamado da pessoa errada pode levar à perda da imortalidade.

Viveiros de Castro nos mostra que este tipo de chamado está no cotidiano também, principalmente na caçada, e que pode alterar a perspectiva:

"Quem responde a um tu dito por um não-humano aceita a condição de ser sua 'segunda pessoa', e ao assumir, por sua vez, a posição de eu já o fará como um não-humano (...) A forma canônica desses encontros sobrenaturais consiste, então, na intuição súbita de que o outro é humano, entenda-se, que ele é o humano, o que desumaniza e aliena automaticamente o interlocutor, transformao em presa - em animal" (Viveiros de Castro, 2002a: 397)

Além deste paradigma da caça em que foi estruturado o perspectivismo - ou seja, transformar-se em presa, em animal - a etnografia ticuna nos mostra que isto também acontece em outros planos: vida e morte (torna-se imortal, ü'üne), gente e "bicho" (torna-

\footnotetext{
homens viveriam tanto quanto os seres minerais ou vegetais; mas, como ele também responde "ao doce chamado da madeira podre", a duração da vida humana seria, a partir de então, encurtada" (Lévi-Strauss, 2004 [1964]: 179).

${ }^{257}$ Canção gravada com Francisco.
} 
se $n g o^{\prime} o$ ). Estamos tratando, portanto, do tipo de mudança de perspectiva envolvida na relação entre humanos e espíritos ( $\left.\tilde{a}^{\prime} \tilde{e}\right)$. Os espíritos das árvores, que também são ã 'ẽ, veem os humanos como pau podre, ou seja, o máximo do perecimento para uma árvore ${ }^{258}$. Contudo, como os humanos veem estes espíritos? Esta seria uma pergunta que um pajé teria mais condições de responder, afinal é ele quem se relaciona com estes espíritos. Contudo, a forma como o fazem é bastante controlada. Os pajés acendem ao ponto de vista destes espíritos, assim, ao menos neste momento, os pajés os veem como gente. Estes espíritos falam pela boca dos xamãs em suas seções de cura $^{259}$. O pajé narra seu passeio entre as árvores, procurando seus espíritos auxiliares. Examinaremos uma sessão de cura mais de perto, do pajé Aricildo, no tópico seguinte. O espírito ã ẽ de uma pessoa

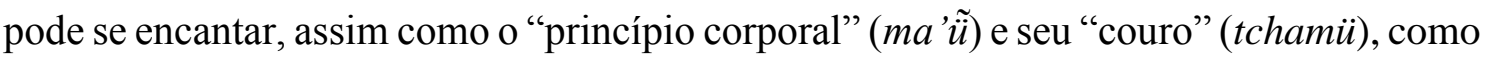
vimos na narrativa sobre Pai’nü. Vimos também que um encantado/imortal (ü'üne) é muitas vezes caracterizado por não possuir uma cisão marcada entre o pensamento e a ação. Imediatamente ao pensar em algo ou em fazer alguma coisa, o encantado já está agindo do modo como está pensando ou a própria coisa que ele pensou aparece. A comunicação entre os pensamentos também é uma característica dos encantados. Eles são capazes de "ler" o pensamento de uma pessoa, saber o que o outro está pensando. Assim, uma das consequências de uma pessoa se encantar é o fato de seu espírito ã’ẽ não se confinar ao pensamento introspectivo. A partir do encantamento, o $\tilde{a}$ 'ẽ torna-se um pensamento-ação que se comunica com os outros pensamentos.

Em alguns mitos, este "pensamento" (ã 'ê) aparece como perturbado, confuso, e o herói do mito confunde os graus de parentesco de seus parentes ou mesmo confunde um desconhecido com um parente dele. Vimos isso na história do caçador Õtchi. Ele começa a chamar sua esposa de mãe (o), pois já estava com o pensamento completamente perturbado. Há outros exemplos também nas histórias de Pai’nü e Torama. Comecemos por um trecho da história do primeiro: "Ele viu uma vovó que estava em pé, tecendo uma hamaqueira (rede de fibra de tucum). Ela estava fazendo uma hamaqueira bem grande. Ele disse, "essa daí é vovó", e foi lá com ela. Mas os parentes dos witchicü, que ele tinha

\footnotetext{
${ }^{258}$ Há algo de intrigante também com relação à madeira e a perspectiva dos imortais. Manuel Rita, exímio tocador e construtor de trompetes, me contou que ao chegar no Eware, o lugar dos imortais, "você não pode usar a lenha morta, tem que usar a lenha viva mesmo. Tem que cortar o pau vivo e fazer o fogo. Se você fizer o fogo com a lenha morta, com pau seco, aí você morre lá mesmo".

259 Semelhante aos xamãs araweté, que são o "rádio" por quem cantam as palavras alheias (Viveiros de Castro, 1986: 543).
} 
arrancado o couro da cabeça tinham feito feitiço para ele e ele estava com o pensamento perturbado/atrapalhado. Qualquer pessoa que ele olhava era a avó dele”. Notemos que por meio do feitiço é possível deixar alguém com o pensamento (ã 'ê) perturbado, doido. Este é um sintoma que aparece na história de Torama também (Firmino \& Gruber, 2010, vol. 1). O homem que se veste de onça acaba ficando com o pensamento tão perturbado que começa a considerar sua esposa como sua avó (noe).

Na canção do tamborim tutu (tututchiga) encontramos outra referência à "loucura" que acomete ao ã 'ẽ da pessoa. Para além da "loucura" patológica, que o xamã deve tratar para recuperar a sanidade da pessoa, esta canção fala da embriaguez que também altera o á'ẽ de quem bebe. A canção menciona:

\section{Tchadai'ã'ẽ, dai'â'ẽ}

"Estou igual doido, doido"

Este tipo de doideira referida na música me foi explicada que é como se o cantor estivesse de porre. "É quando se está dançando meio doido". A doideira é, portanto, o jeito como o cantor costuma dançar quando está tocando o tamborim tutu. É na alma (á'ê) do cantor que está a doideira, "é dentro dele que endoidece". Mas há outra palavra na mesma canção que me foi traduzida também como "doido":

Tchape'e, tchape'egu

"Na minha frente, na minha frente"

\section{Cudaire, tadairetchigu}

"Você doido, outra pessoa (ele ou ela) doido"

Daire também me foi traduzido como "doido". "Anda todo doido, meio porre. Mas a doideira está fora do corpo". Este tipo de doideira é diferente do dai 'â'ẽ, que vimos acima. Este último afeta a alma (ã 'ê) da pessoa. Já a doideira daire, como me disseram, "está fora do corpo". A canção relaciona a embriaguez do tocador de tamborim (tutu), à "loucura" da sua alma causada pela embriaguez e também o seu jeito de dançar:

Daire ta daire, daire

"Doido, doido, doido"

Cudaire, pa dairepara 
"Você doido, trançando as pernas de doido"

$(\ldots)$

Nacae, nacaenã

"Para ela, para ela"

Tchamarü tchanha'ane

"Eu estou andando por todo lado"

Neste trecho acima podemos notar que a canção comenta o jeito como o tocador dança com o tutu. Isto é bastante recorrente na canção. O cantor diz que está como um "doido", cantando, tocando e dançando. De fato, a pessoa que toca o tutu e canta nas Festas o faz dançando para os demais se animarem e o acompanharem.

Examinamos até aqui algumas características destes dois componentes da pessoa ticuna, o ma' $\tilde{u}$ e o $\tilde{a}^{\prime} e \tilde{e}$ Este último, em especial, é bastante suscetível, especialmente com relação a feitiçaria e ao ataque de alguns seres do cosmos. É sobre esta dinâmica própria ao $\tilde{a}^{\prime} \tilde{e}$ que nos debruçaremos agora.

\subsection{4 - O resgate da alma $(\tilde{a} ’ \tilde{e})$}

Os Ticuna costumam dizer que uma criança quando nasce é como um pezinho de milho, muito sensível e os "bichos" (ngo'o) adoram devorá-la. Esta é uma fase muito delicada, em que ela tem o espírito (ãẽ) ainda muito instável e pode diminuir em quantidade, ser roubado por algum ser com más intenções. Uma criança que cai no chão, por exemplo, pode ter o espírito levado pela cobra-grande ou pelo boto. Existe uma palavra usada para se referir a uma criança que está como pouco ã 'ẽé é tautameaitauã'ẽ, que me foi traduzida como, "ainda não chegou bem a alma dela". No caso de sequestro do $\tilde{a}$ ’ẽ, o pajé terá que fazer uma "viagem" para ir buscá-lo.

Quando uma criança perde sua alma (ã ê), ou parte dela, o pajé tem que viajar até a "cidade" do ser que a roubou para resgatá-la. Os seres que costumam fazer este tipo de roubo são a cobra-grande (Yewae), o boto, a onça d'água, dentre outros. Quando o xamã "desmaia”, o que pude presenciar nas diversas seções de pajelança que acompanhei, é

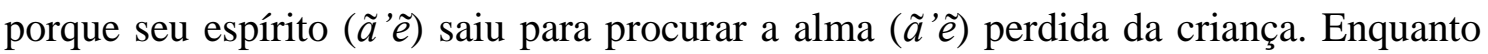
isso o espírito de outro pajé pode penetrar no corpo dele e continuar "trabalhando". 
Terêncio me falou que o corpo do pajé fica aberto, a capa dele fica aberta, então entra o espírito ( $\left.\tilde{a}^{\prime} e \tilde{e}\right)$ na abertura. Este é o momento em que o pajé levanta, quando o espírito sai ele cai. Esta abertura da capa fica na região do peito. Quando um espírito sai, outro entra. Ao chamar o espírito ã 'ẽ de outro pajé pelo assobio, o espírito do rezador sai de seu corpo, assim como acontece durante o sonho do xamã. Por isso, ele consegue realizar curas enquanto sonha, da mesma maneira que quando está acordado.

Durante a viagem que o xamã empreende com seu espírito (ã ê), ele vai procurando a alma perdida na cidade destes seres. Estas cidades me foram descritas como grandes emaranhados de lojas, quartos, gaiolas, dentro dos quais pode estar a alma que se deseja encontrar. Em sua procura, a fumaça do tabaco constitui o caminho que o conduz por onde ele viaja. O "caminho do tabaco" (porimã ; pori = tabaco, $m \tilde{a}=$ caminho) cuja partícula linguística_mã também designa o "caminho da caça" e, como vimos, um dos princípios ou almas constituintes da pessoa ticuna, que Goulard (2009) chama de

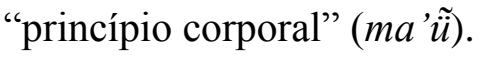

Esta outra qualidade de "espírito" (ã 'ẽ) dos Ticuna, como disse acima, pode variar em quantidade em uma pessoa. Principalmente em recém-nascidos, eles podem ter mais

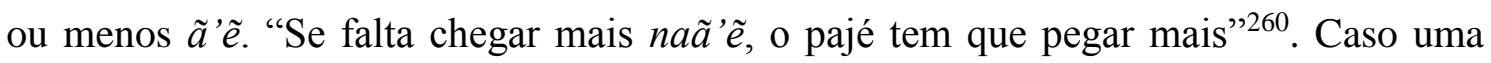
criança fique doente, é um indicador de que seu "espírito" está sendo roubado pela cobragrande (Yewae). Contaram-me que, "a cobra-grande pega o naã'ẽ da criança e transforma em xerimbabo ( $\tilde{u} n a)$ dele. Transforma num passarinho e coloca numa gaiola. Quando a cobra-grande não alimenta o passarinho, a criança fica fraca e adoece. Tem que ser um rezador [xamã] que sabe muito para ir buscar o naã 'ẽ [que está em forma de passarinho] da criança na casa da cobra-grande. Às vezes o pajé não consegue chegar lá, então tem que soprar a criança várias vezes até conseguir [resgatar o naã ’ẽ do doente]”. Ondino me disse que a filha mais nova de Gabriel, minha afilhada, caiu no rio umas duas vezes. E ela só tinha quatro meses. "Foi aí que a cobra-grande (Yewae) aproveitou para levar a alma ( $\left.\tilde{a}^{\prime} e \tilde{)}\right)$ dela, agora ela só tem um pouquinho. Ela era um bebê bem gordinho e forte. Mas as irmãzinhas dela deixaram ela cair no rio umas duas vezes. Ela caiu da rede também, isso favorece Yewae [cobra-grande] levar o naã'ẽ da criança".

\footnotetext{
${ }^{260}$ A palavra para espírito é sempre referida usando-se o possessivo. Então, ã'ẽ é sempre referido como naã'ẽe, "espírito dele, de alguém".
} 
Assisti a diversas sessões de xamanismo do pajé Arnaldo sobre o filho recémnascido de Ondino. Depois de algumas sessões, Arnaldo me revelou porque a criança estava dormindo mal à noite. Segundo me disse, ele estaria sendo vingado pelos espíritos

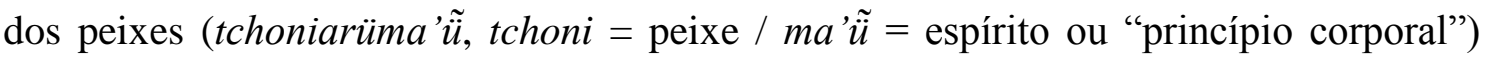
aruanã, tucunaré e curuaçu. Arnaldo me contou que o espírito ( $m a$ 'ã) do peixe gruda nas costas do neném, então, tem que bater com a folha do pião-roxo (piãowaü'ü) no local afetado. Se o peixe que está vingando o bebê tem ferrão, como algumas espécies de tucunaré, ele pode ferroá-lo também.

Os Ticuna consideram que algumas árvores também tem estas duas qualidades de espírito, ma' $\tilde{u}$ e ã 'ẽ (Nimuendaju, 1952: 57 e 100). Segundo Nimuendaju, os espíritos das árvores ( $\left.\tilde{a}^{\prime} \tilde{e}\right)$, assim como a cobra-grande (Yewae), podem roubar a alma das crianças ${ }^{261}$. Mas este não se confunde com o ma' $\tilde{u}$ de algumas árvores, estes espíritos são reputados auxiliares dos pajés ${ }^{262}$. O Livro das Árvores dos Ticuna apresenta o seguinte relato sobre estes espíritos e sua relação com os pajés: "O espírito de certas árvores ajuda o trabalho do pajé. Quando uma pessoa fica doente, chama o pajé. E o pajé chama o espírito das árvores para curar. O espírito chega e entra no corpo do pajé. Aí ele canta. Depois vem outro e mais outro. Se a pessoa está muito mal, é preciso chamar vários espíritos" (Gruber, 1998: 46). Esta é uma síntese de algumas sessões de pajelança que presenciei.

Veremos abaixo alguns trechos da pajelança realizada pelo xamã Aricildo para trazer Ulisses de volta ${ }^{263}$. Antes de analisarmos a interação entre o pajé e sua assistência - que farei também entremeando a narrativa - notemos de saída que o espírito (áễ) de Aricildo está procurando o homem desaparecido entre as árvores e sobre a montanha. Os espíritos de outros pajés que vão se revezando no corpo de Aricildo estão enumerados em sequência. Este é o trecho referente ao início da interação do xamã com os presentes na sessão que se estendeu por toda a madrugada. Nestas sessões em que o rezador “desmaia",

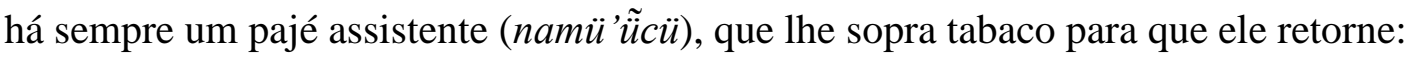

\footnotetext{
261 “Os espíritos das árvores também gostam de roubar almas das crianças...” (1952:70).

262 Não pude verificar isso em campo, mas tenho minhas dúvidas se os auxiliares dos pajés são os espíritos das árvores $m a^{\prime} \tilde{u}$ ou os a $\tilde{a}^{\prime} \tilde{e}$. Goulard se refere aos auxiliares como yu'ü (2009: 82), que está na raiz do termo usado para se referir ao xamã (yu'ücü) e que traduzi acima como "pajelança".

${ }^{263}$ Ver tópico 3.2.3 - Ulisses, o homem que foi levado pelo demônio, neste mesmo capítulo.
} 


\section{$\underline{\text { Pajelança de Aricildo }}^{264}$}

Pajé 1: "Boa noite, meus companheiros ${ }^{265}$. Vocês que estão precisando de mim?"

Esposa de Ulisses: "Eu mesma que estou precisando de você, para encontrar meu marido. Para a gente saber onde ele está."

Pajé 1: "Eu só vim dar uma passada aqui. Muito obrigado"

Pajé 2: "Boa noite meus companheiros. Agora que eu cheguei aqui"

[cumprimenta as pessoas pegando na mão de uma por uma]

[aos que estão deitados]: “Já dormiram já?” (risos).

Logo que o espírito chega no pajé, ele saúda as pessoas que estão presentes numagü (“olá a todos"), no que é respondido da mesma forma. Durante as primeiras chegadas dos espíritos auxiliares, Aricildo chegou a apertar a mão de muitos que estavam assistindo a sessão.

Pajé assistente passando a garrafa de cachaça: "Aqui está o nosso liquido quente"

Pajé 2: "Eu estava ali viajando, batendo nas nuvens, até chegar aqui. Aqui está" [e passa a garrafa de volta]

Pajé 2: "O que aconteceu com vocês?"

Filho de Ulisses: "O meu pai, os "bichos" (ngo’o) levaram ele. Ele já tinha aparecido mas sumiu de novo. Queremos saber como eles está. Já faz muito tempo que ele sumiu, estou com saudade dele. Por isso que a gente mandou o pajé trabalhar, para ele contar onde é que ele está"

Pajé 2: "O pajé que me mandou só para perguntar o que vocês querem. Logo mais vocês vão saber de tudo. Eu vou abrir meu bico ${ }^{266}$ ”,

[Começa a cantar]

Rü danĩyaĩ ya naĩnecü, naĩnecü, naĩnecü

"Ali estão as árvores, árvores, árvores"

Nheatürü nĩ cunhemaün nĩ

"É lá que você está"

\footnotetext{
${ }^{264} \mathrm{~A}$ tradução das falas foi feita com a professora Luscita Bibiano Ezequiel.

$265 \mathrm{Pi}$ é a expressão usada pelo pajé para saudar os presentes, um jeito carinhoso de chamar a pessoa. Usa-se mais com as crianças.

266 Titcho pawe'e = "eu vou abrir" [tcho] "meu bico" [pawe'e]". Assim que pajé diz que vai cantar, Titcho pawe'e, como faz o passarinho.
} 
Pajé 2: "Eu acho que ele [o homem perdido] está passeando no outro mundo [toina'ane]" [Começa a cantar]

Rü danĩyaĩ ya naĩnecü, naĩnecü, naĩnecü

"Ali estão as árvores, árvores, árvores"

Bunecü arü ye'eragu i curütaumare'ün'ücü

"Você sumiu mais longe do lugar descampado [bunecü]"

Temos aqui, com bunecü, uma clara referência à morada dos encantados ( ̈̈'üne). O descampado onde moram os encantados, Eware. Como o Eware é sempre referido como um lugar muito distante, ao afirmar que Ulisses está mais distante que o Eware, o pajé localiza o desaparecido em um lugar quase inalcançável.

Mãe para o filho: "Você tem que ter coragem de falar agora, porque você só vivia chorando com saudade do seu pai" [enquanto o pajé está cantando].

Pajé 2 (cantando): Yemapüne arü ye'eragu ni ĩ icurutau'ün

"Você está para além da montanha [mapüne]"

Mapüne arü witape'ewa ni'ĩ cunhema' $\tilde{u}$

"Ele está lá no topo da montanha"

Yea i cunhemaünwa rü ngo'ogü rü marü cuün naütchirücü nairacü'ünma

"Lá onde ele estão os "bichos" já vestiram ele com uma roupa de ouro [nairacü 'ü̃]"

[Conversa]

Pajé 2: "Vai acabar o sofrimento de vocês. É só o começo do espírito [naã e] que o pajé mandou. Vocês vão descobrir depois. Eu vim só para olhar"

Esposa de Ulisses: "Vocês têm que conseguir trazer meu marido"

A Esposa de Ulisses diz "vocês" para se referir aos vários espíritos que estão ajudando Aricildo em sua busca.

Pajé 2 (cantando): Rü danĩyaĩ ya naĩnecü, naĩnecü, naĩnecü

"Ali estão as árvores, árvores, árvores"

Bunecü arü ye'eragu i curütaumare'ün'ücü

"Você sumiu mais longe do lugar descampado [bunecü]"

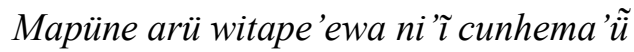

"Ele está lá no topo da montanha"

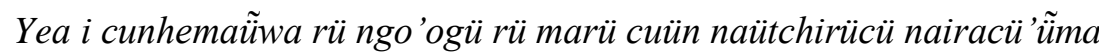

"Lá onde ele estão os "bichos" já vestiram ele com uma roupa de ouro

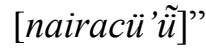


Esposa de Ulisses: "A gente quer que ele chegue de uma vez"

O Pajé fuma e faz o caminho dele [namã ' $\tilde{u}]$ levantando os braços para o homem perdido voltar.

Pajé 2: "Vocês querem que a gente traga ele de volta?"

Esposa de Ulisses: "Nós queremos sim. Queremos que vocês faça o caminho para ele voltar"

Pajé 2: "Nós só viemos para fazer o caminho. Só para isso que ele [o pajé] nos mandou"

Pajé 2: "Já está chegando o outro espírito. Ele vai falar tudo o que vocês querem"

Pajé 3: "Boa noite meus companheiros [pi]. Aqui que vocês estão amontoados. Eu estou um pouco envergonhado. Será que eu mostro minha mão feia para vocês?" [e começa a cumprimentar as pessoas]

Pajé 3: "O que aconteceu?"

Filho: "Faz tempo que meu pai sumiu. Ele saiu para caçar e até hoje não voltou. De tanto sentir saudade eu fui lá chamar o pajé. Tente fazer de tudo para que ele chegue"

Pajé 3: "Tudo bem"

Pajé assistente passando a cachaça: "Aqui está o suco"

Filho: "Enquanto ele estava perdido as crianças ficaram chorando por causa dele em casa. Tente de tudo para que ele volte".

Pajé 3: "Depois ele [Ulisses] vai dizer o lugar onde você poderá encontrá-lo".

Pajé faz caminho novamente para o retorno de Ulisses.

Pajé 3: "A gente está tentando arrastar ele [o pai] para cá. É neste mundo mesmo que ele estaria. Lá está ele".

Esposa de Ulisses: "Tente trazer ele para cá!”

Pajé 3: "Depois ele vai vir para cá [o espírito de Ulisses]"

Começa a cantar.

Pajé 3: "Eu aprendi esta música com vocês"

Pajé assistente: "Não, acho que a gente que está aprendendo com você"

Pajé 3: Nhumarücü \} varias vezes Nünãtcha' $\tilde{u}\}$ varias vezes

"Agora eu vim aqui"

Cucaena $\}$ varias vezes

"Por você"

Nhumarüena üanecü'ünwa curütomare' $\tilde{u}$

"Agora você está sentado naquele lugar cerrado [cheio de mato]"

Pajé 3: "Eu vou até aí com você" [ele vai até o homem perdido]

"É verdade que é você mesmo que vai lá comigo". 


\section{Começa a cantar.}

Numata cu'ünguena

"Se você vier para cá"

Numata cu'üntchigu

"Você vai se aproximando"

Tchauca ena pinhemagü'ün i nhama arü na'anewa

"Vocês estão com saudades de mim"

\section{Cucanhematürü toca nhema quitchi 'itchi}

"Quando gente for lá, você vai sair do meio daquele cerrado"

Pajé 3: "É isso que vocês querem, que ele saia do meio daquele cerrado [nainecü]?"

Ouvintes: "Isso mesmo que a gente quer"

Pajé começa a cantar para o homem voltar

Pajé 3: "Não vão se assustar com ele. É só uma pessoa que vai ver ele"

Finalmente, chega o espírito do homem desaparecido

Pajé 4: "Boa noite, meus irmãos"

"Me chamaram e eu vim para cá. Teve um dia que quis voltar"

Esposa de Ulisses (bastante emocionada): "É você?"

Pajé 4: "Sim, sou eu mesmo. Vocês não estão me vendo?"

A esposa cumprimenta o pajé ao perceber que é seu marido o espírito do pajé.

Esposa de Ulisses: "Boa noite, quando você vai voltar para mim? Toda noite eu fico chorando por sua causa"

Pajé 4: "Eu nunca estive longe, sempre estive aqui perto. Tem muitas barreiras na minha frente, por isso eu não consigo voltar. Você sempre passava por perto, mas sempre tem alguém que não quer que eu volte para minha casa. Mas eu vou chegar"

Esposa de Ulisses: "Eu quero que você volte. Todos os teus filhos ficam chorando por sua causa em casa. Enquanto você está longe, tudo é silêncio, calmo"

Pajé 4: "Agora que eu estou aqui. Eu só vim dar uma volta. Vocês tem que fazer de tudo"

Mãe: "A gente vai fazer"

(...)

Pajé 4: "O meu colega que eu me perdi junto com ele já voltou para a casa dele. Ele já está com a mulher dele. Será que é verdade que a família dele chorou por ele?"

Mãe: "A gente já viu, porque a gente estava lá quando ele chegou"

Pajé 4: "Façam de tudo, paguem para eu poder voltar"

(...) 
Esposa de Ulisses: "Eu já tinha te visto, só que eu me assustei. Eu quero que você me perdoe. Só Deus sabe a dor que eu estou sentindo. Eu nunca consegui dormir por não ver mais você. Queria tanto que você voltasse para casa"

Pajé 4: "Façam de tudo para que eu volte, porque eu quero muito voltar também"

Pajé assistente: "A gente vai deixar na mão de Deus para que você volte para a gente"

Pajé 4: “Agora eu vim aqui só para dar uma volta. Mas porque que vocês não estão me vendo?"

Pajé 4: "Cada um de vocês tem que fazer de tudo"

Ouvintes: "A gente vai fazer de tudo"

Pajé 4: "Eu estou indo embora"

Esposa de Ulisses: "Volta para mim"

Pajé 5: "Boa noite meus companheiros. Já falaram com o pai de vocês?"

Ouvintes: "Já"

Esposa de Ulisses: "A gente está pedindo a você que ele volte para a gente"

(...)

Pajé 5: "Deixa eu cantar um pouquinho"

Pajé 5: "Eu sou uma pessoa que é velha"

Pajé assistente: "Quem é você?"

Pajé 5: “Advinha quem eu sou? Deixa eu cantar um pouquinho e você se lembrará de quem eu sou"

Pajé 5: "Aquela pessoa que vocês querem tanto está se aproximando um pouco"

Esposa de Ulisses: "Queremos que você traga ele mais para perto"

Pajé assistente: "Queremos muito que ele volte. Tente arrastá-lo mais para perto"

A narrativa por si só é impressionante. A sessão de pajelança como um todo foi uma das coisas mais impressionante que presenciei em campo. Podemos notar aqui um paralelismo entre a perda da sanidade do homem desaparecido e sua condição de pessoa perdida numa floresta. Retomamos, assim, a própria noção ticuna de na'ane - noção ao mesmo tempo espacial (cosmos, mundo, terra, roça) e que também faz referência ao espaço - que possui os mesmos atributos da pessoa: força (pora), os duplos (ma' $\tilde{u}$ e $\left.\tilde{a}^{\prime} \tilde{e}\right)$ e sabedoria $(k u a)^{267}$. O cosmos (na'ane) ticuna é, diz Goulard, "corporificado" (2009: $323)^{268}$, podemos dizer que trata-se de uma pessoa magnificada ou numa escala ampliada.

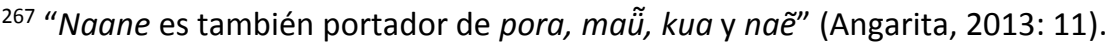

268 “Tal percepción tiene sus fundamentos en una concepción antropomórfica del medioambiente. En otras palabras, en la concepción del espacio del monte, predomina la percepción de un cuerpo que se
} 
No lugar onde ele está, vivendo com os "bichos" (ngo'o), o homem enfrenta barreiras “Tem muitas barreiras na minha frente, por isso eu não consigo voltar" - que não o permitem voltar para casa, por mais que ele o deseje. Isso pode indicar uma projeção da confusão dos pensamentos ( $\left.\tilde{a}^{\prime} \tilde{e}\right)$ de Ulisses - e sua "barreiras" mentais que impedem ele de retomar sua lucidez - num plano espacial, em que "barreiras" físicas e a sedução dos "bichos" o impedem de retornar para casa.

\title{
4.1.5 - Waia, a origem do feitiço, do pajé e sua formação
}

No tempo de Yoi a pajelança não existia. Ondino me contou como surgiu a feitiçaria.

\begin{abstract}
"Depois da época de Yoi, existia uma menina que chorava muito. Eles moravam numa casa redonda, toda fechada só com uma porta. A menina se chamava Awemaná. Foi jogada para fora de casa. Aí apareceu um sapo chamado cunauaru [Phrynohyas venulosa], ele virou uma mulher bem velha e levou Awemaná para a casa dela. Quando ela voltou para casa da mãe dela ela já era adulta e pajé. Ela já sabia matar gente, se transformar em onça, cobra grande, sucuriju. Aí a pajelança (yü̈̈tchiga) se espalhou. Quando as crianças iam tomar banho, Awemaná se transformava em cobra e as comia. Quando descobriram, todos se juntaram e mataram Awemaná. Cortaram o corpo dela todo em pedacinhos e jogaram na água. Mas muita gente aprendeu a fazer feitiço e ainda tem até hoje"269.
\end{abstract}

Este motivo da "criança chorona" nos é familiar. Lévi-Strauss o analisou principalmente nos mitos da América do Norte em sua "correlação e oposição" com o motivo da "criança escondida":

"Apesar de ser uma indicação ínfima, ela sugere que a criança escondida, intimamente conjugada ao corpo do pai, ou então a toda a sua família, quando esta a mantém escondida, apresenta alguma relação de correlação e oposição com a criança chorona que afasta todos de si. Ora, a criança chorona da

\footnotetext{
desprende de lo visto, lo que refuerza el uso de un vocabulario corporal para nombrar sus diferentes partes, a la par con el orden imperante" (Goulard, 2009: 321).

269 O mesmo relato, um pouco mais longo, está em Nimuendaju, 1952: 100.
} 
Califórnia não suporta a visão do sangue menstrual, enquanto a criança escondida dos mitos sul-americanos, ao contrário, se lava com ele ou até se alimenta dele..." (Lévi-Strauss, 2011 [1971]: 38)

A criança escondida ticuna (seja nos joelhos, seja na reclusão da moça) pode ter alguma relação com Awemaná, que dá origem ao feitiço. Awemaná é expulsa da aldeia por ser uma criança muito chorona. Um sapo cunauaru a encontra e a adota. Se, como diz Lévi-Strauss "a criança chorona da Califórnia não suporta a visão do sangue menstrual”, Awemaná é uma criança chorona que se alimenta de sangue, não sangue menstrual, expelido pelo corpo, mas da medula dos ossos, ou seja, "sangue" interno aos ossos ${ }^{270}$. Deste modo, Awemaná, apesar de chorona, possui uma qualidade que não a opões às “crianças escondidas", pelo contrário, ela não evita o sangue e até se alimenta de medula. Além de ser a origem do feitiço este mito explica porque a alma da vítima entra no corpo no assassino $^{271}$. Veremos que o sangue da vítima, que impregna o homicida, é tão venenoso quanto o sangue menstrual.

A história de Awemaná é a origem do feitiço no tempo mítico, algo que aconteceu "antigamente". Contudo, existe um lugar de formação de feiticeiros que é referido como Waia. Apesar de ninguém conhecer este lugar pessoalmente, acredita-se que poderosos xamãs vão ao Waia para aprender suas pajelanças. Muitos referem-se a esse lugar como a "origem do pajé". "Lá ninguém pode pegar nada, por que é tudo dos feiticeiros, seria muito perigoso. É onde os pajés mais poderosos se formam, onde eles vão aprender com grandes feiticeiros". Os pajés que moram neste lugar consomem tabaco e se alimentam apenas de um tipo de minhoca grande (bure) que vive no lamaçal (de'ü / ngowacüwa) e tem escamas. No Waia, quando algum aprendiz chega, ele é recebido com uma grande cuia de pajauaru (bebida fermentada). Entretanto, não se trata da bebida comum que é

\footnotetext{
270 "Awemaná tornara-se muito velha e, quando sua força física a abandonou, ela pediu a algumas meninas para preparar sua comida, mas estas se recusaram porque não gostavam dela. Então durante a noite, enquanto dormiam, Auë'mana extraiu os ossos das pernas de seus corpos. Na manhã seguinte eles viram-na sentada ao lado de seu fogo comendo a medula dos ossos, uma vez que este era seu único alimento. Entretanto, as meninas não podiam mais levantar-se." (Nimuendaju, 1952: 100, eu grifo).

271 "Quando isso se tornou amplamente conhecido, o povo matou Awemaná, cortando seu pescoço com uma faca de pedra. Ela pegou o sangue que escorria, em sua mão em concha, soprou em direção ao sol, e disse: “u: u ta'ta pë gü na nge'i pë ngu a'ëë!" [“A alma entrar em ti, também!"]. Desde então, a alma de uma vítima entra no corpo do assassino." (Nimuendaju, 1952: 100, eu grifo).
} 
tomada nas ocasiões festivas. Neste pajauaru os pajés colocaram muitos ngo'o: cobragrande, escorpião, tucandeira, onça, etc. O neófito aprende a pajelança desta maneira.

Hilda comenta sobre o Waia que "é lá que estão os Ticuna mesmo, de antigamente. Parece que fica na Colômbia. Fica lá para o centro do [igarapé] Jacurapá". Este comentário de Hilda relaciona o Waia não com um lugar de perigo, por ser um lugar de "formação" de pajés, mas como sendo um local onde os Ticuna ainda cultivariam os costumes e valores de antigamente. Os discursos, em geral, tendem a eleger o Waia - às vezes referido como localizado na Colômbia, às vezes localizado no Peru - como um local de conhecimento mais ancestral, seja de uma forma temporal, os "Ticuna mesmo, de antigamente", ou atribuindo a ele uma intensa pajelança. Nesta última acepção - que ouvi, por exemplo, de Ondino -, o excesso de feiticeiros poderosíssimos transformaria o Waia no passado dos atuais Ticuna. Os "Ticuna de antigamente" seriam tão feiticeiros quanto os pajés que engrossam a população do Waia.

Hilda mencionou, enquanto traduzíamos o mito do "Homem que matou as mulheres dele" (Namatü daí'cü) ${ }^{272}$, que “o Waia é um lugar perigoso, lá todo mundo é feiticeiro/pajé". O mito conta a história de um caçador que mata suas esposas depois delas terem quebrado seu pote com curare (veneno). Depois disso o caçador foge para o Waia e, quando ele dá uma festa, seus cunhados aparecem para vingar a morte das irmãs. Pelo desenrolar do mito, o Waia também é um lugar onde feiticeiros e outras pessoas, como o homem que matou as esposas, vão se refugiar, para escaparem de atos vingativos. A fala do cunhado, por exemplo, deixa isso mais ou menos claro. Vejamos o trecho: "Então o filho do cunhado, sobrinho dos irmãos, apareceu. Ele já estava grandinho, 6, 7, 8 anos, já sabia conversar. Este menininho percebeu, ele dizia, "papai, será que não é meu tio (oe) que está cantando? ". O menino reconheceu seus parentes pelo som do canto deles. Ele era filho de uma das irmãs que morreram e estava refugiado com o pai assassino. $\mathrm{O}$ homem que matou as esposas respondeu, "não devem ser eles, porque o lugar de onde eles vêm é muito distante. Eles não chegam aqui, aqui é muito longe".

Esta jornada ao Waia - um tanto obscura, pois nunca encontramos alguém que conheça pessoalmente o local - é uma das formas de se adquirir conhecimento xamânico. A outra via, mais comum, é a formação dos pajés nas próprias comunidades. Algumas

${ }^{272}$ Ver Firmino \& Gruber, 2010, vol. 2. 
informações podem indicar que os conhecimentos xamânicos são passados de pai ou mãe para filho(a). Arnaldo me contou que aprendeu suas rezas de pajé com sua mãe, no igarapé onde nasceu. Segundo Aricildo, ele aprendeu com seu pai. Nimuendaju também comenta sobre isso que "[a]lguns xamãs começam a educar os seus filhos quando os meninos têm seis anos de idade" (1952: 101).

Assim como as sessões de pajelança, as lições que o pajé mais velho dá aos noviços começam depois do pôr do sol (ibdem). A primeira coisa que o pajé que está aprendendo faz é receber o tacaca (tipo de "oração", canto do pajé) do xamã mais experiente, através do canto. Cada "oração" é um tacaca que a pessoa aprende. Estas “orações” cantos (tacaca) são armazenadas no wotüra (paneiro do xamã) também. O pajé mais velho tem que fazer isso ao menos duas vezes, uma só não basta. Gabriel me contou que, para se formar pajé, Roberto teve que receber um bicho (ngo'o) de outro pajé. Este bicho foi retirado de uma pessoa doente e colocado em Roberto. Para mantê-lo no corpo, ele deve alimentar o bicho com tabaco, fumando regularmente. Durante sua formação ele se alimentou só de sardinha sem sal durante três dias ${ }^{273}$. Apesar de sempre existir a suspeita sobre ex-pajés, existem meios de se expurgar os bichos (ngo'ogü) do corpo. Ulisses, irmão de Ondino, segundo me contou Gabriel, foi rezador durante um tempo. Um dia ele foi acusado de feitiçaria pelos moradores da comunidade de São José, vizinha de Nazaré, que queriam matá-lo. Diante da situação, Ondino o fez tomar um preparado de cebola e alho para expurgar os bichos de seu corpo.

Este tacaca é ingerido pelo candidato a pajé numa cuia cheia. Nimunedaju comenta que esta ingestão, de infusão de tabaco, faz o neófito "vomitar todas as impurezas (puya) adquiridas através de contatos sexuais” (ibdem, eu grifo). Esta referência às "impurezas" (puya) é importante para compreendermos a Festa da Moça Nova. Neste caso, sabemos que ela é transmitida pelo contato sexual. Analisaremos suas variações logo abaixo. Nimuendaju relata que esta purificação prepara o neófito para receber o tacaca, que nada mais é do que uma bebida feita da goma da mandioca, contudo, transformada em "substância mágica". Após vomitar as "substâncias" que ele possui, o pajé segura o vômito "na palma da sua mão, ele mostra isso para o discípulo, convidando-

\footnotetext{
273 Nimuendaju comenta o pouco uso de sal na dieta do noviço e menciona ainda a abstenção de pimenta, doces, bebidas alcoólicas, exposição ao sol e abstinência sexual. Alguns peixes ele está autorizado a comer: "cachorra, traira, sardinha, curimatã, caraüacu vermelho, e jiju, mas não peixes sem escamas" (1952: 101)
} 
o para escolher [os poderes que ele deseja]: "Você quer estes dois? Eles são bons. Ou aqueles dois? Eles são ruins. Ou este outros? " O discípulo engole os escolhidos. " (1952: 101-102). O dia seguinte é dedicado ao aprendizado das canções dos espíritos das árvores e um procedimento parecido acontece durante o sonho do novo pajé (ibdem).

Certa noite, Arnaldo tinha acabado de rezar o filho recém-nascido de Ondino. Este último havia comprado uma garrafa de 51 (cachaça) especialmente para o xamã rezar seu filho. Até então eles estavam improvisando com álcool. Depois da sessão de cura, Arnaldo continuou bebendo sentado na rede com Ondino e eu fiquei na rede do lado. Ficamos conversando. Aproveitei a maior abertura de Arnaldo para minhas perguntas que, em geral, ele evitava - para especular mais sobre o xamanismo ticuna. Então, ele me perguntou, "você quer aprender?". Respondi que sim, simulando uma certeza que, no fundo, mascarava minha insegurança. Não sabia o que estava por vir. Ondino me avisou que poderia ser perigoso, mas somente eu poderia decidir se queria ou não. Arnaldo perguntou várias vezes se eu queria mesmo, para ter certeza de que era uma vontade minha e deixar claro que não estava impondo nada a mim. Aparentemente, a especulação sobre os mecanismos do xamanismo é algo um tanto estranha. Se alguém está perguntando muito é porque quer aprender a ser pajé.

Para começar a receber meu paneiro de Arnaldo e preenchê-lo de "orações", tive que tragar um cigarro de tabaco, que eu mesmo enrolei, cinco vezes sem soltar a fumaça. Fiz isso com uma dificuldade imensa, algo que qualquer pajé faz sem nenhum problema, meus olhos encheram de lágrimas, comecei a tossir. Arnaldo e Ondino viam aquilo tudo apiedados, dando risada, com um olhar do tipo, “o que ele está fazendo, quer ser pajé e mal consegue tragar o tabaco". Depois disso, Arnaldo colocou o paneiro nos flancos do meu corpo. Passou fumaça de tabaco na minha cabeça, pernas, nas minhas costas. Disse que depois de um mês eu poderia começar a rezar outras pessoas, mas que eu tinha poucas "orações" ainda. Para acessar a estas orações, devo soprar a fumaça nas mãos e trazê-la para o onde está o paneiro no meu corpo.

Perguntei ao pajé que tipo de "orações" ele colocou no paneiro que eu acabara de receber. Segundo sua explicação, eram do tipo não muito poderosas, de xamã iniciante. Uma delas foi a "oração do pássaro" (weri güarü; weri = pássaros, güarü = ?). Outra "oração" que recebi serve para ficar com o sonho bom. Isso quer dizer que meus sonhos ficarão mais potentes para a comunicação. Poderei, por exemplo, falar com minha esposa, com o pai do jabuti e do buriti, durante o sonho. Se eu encontrar com o pai do jabuti no 
sonho e falar com ele, posso pedir a ele para encontrar jabuti na floresta. Ao acordar, se eu for procurar jabuti, encontrarei com facilidade. Caso meu encontro onírico seja com minha esposa, devo falar com ela, se ela estiver me traindo, ficarei sabendo. Existem, entretanto, "orações" que são passadas para os xamãs que estão avançados em seus aprendizados no xamanismo. Titĩtĩ e nguingui são "orações” consideradas letais, podem matar pessoa. Arnaldo me disse que as conhece, mas estou certo que só comentou isso porque já tinha bebido um bocado e estava desinibido. Este não é o tipo de comentário que um pajé faça para qualquer um.

No dia seguinte aos meus primeiros passos como xamã, amanheci muito doente. Vomitei durante a noite e acordei com febre e forte diarreia. Assim que comuniquei a Ondino que não estava bem, ele me contou que existem pajé que colocam tchũta na bebida para a gente tomar. Indiretamente ele estava acusando Arnaldo, ao menos colocando-o sob suspeita quanto à causa de minha doença.

Neste momento, ao menos para esta viajem de campo, acabou meu trabalho na floresta. Fui levado para o hospital de São Paulo de Olivença e fiquei internado tomando soro na veia. Passei o resto de meu trabalho de campo fazendo traduções na cidade, retornei para Nazaré apenas para passar mais dois dias, peguei minhas coisas e fui embora.

\subsection{6 - História do pajé Augusto - a execução do feiticeiro}

A história do pajé Augusto Basílio é emblemática da força de cura e destruição que tem o xamanismo entre os Ticuna. Qualquer doença para este povo é causada pela intenção de alguém, foi mandada em forma de feitiço. Sempre que eu comentava sobre alguém doente, me falavam sobre alguma coisa que a pessoa fez e que teria desencadeado um processo de vingança.

Segundo me contaram, em Nazaré morreram cerca de oito pessoas enfeitiçadas por Augusto, um pajé antigo morador da comunidade. Ondino exagera dizendo que o pajé Augusto matou mais de 50 pessoas enfeitiçadas. O aparecimento de onça na comunidade é sempre relacionado com feitiçaria. Me contara, que enquanto Augusto ainda morava em 
Nazaré, sempre apareciam onças de noite, eram “bichos” (ngo ’o) dele. As crianças viviam doentes, principalmente com desinteira. Quando começaram as mortes, foi a gota d'água.

Conforme seu poder foi aumentando, a fama de feiticeiro de Augusto cresceu também. À medida que o cerco se fechava contra o feiticeiro, ele começou a acusar seu cunhado (WH) de feitiçaria e ele era acusado de ter feito um filho em sua neta. Disseram que a morte de três de seus filhos foi "feitiço que mandaram de volta para ele". Nesta época, toda doença grave que aparecia na comunidade era atribuída à agência xamânica de Augusto.

Notícias como a da execução de Augusto corriam não somente todo o Alto Solimões, mas também a imprensa nacional, juntamente com as repercussões da criação e das ações da PIASOL - a Policía Indígena do Alto Solimões, criada pelos Ticuna. Notícias de jornal sobre a atuação da PIASOL registram também a carbonização do pajé como a forma de execução dos feiticeiros. Seria esta morte relatada no jornal a mesma que ocorreu com o pajé Augusto? Ao menos a forma como me foi relatada e descreverei abaixo é muito semelhante: "Uma das mortes investigadas aconteceu em São Paulo de Olivença (AM). Em setembro, o corpo de um índio foi achado carbonizado e com as pernas acorrentadas. O motivo seria o envolvimento com feitiçaria" (Brasil, 2009, Folha Online).

Quando estava vivo, Augusto abriu a porta da montanha onde está localizada a comunidade de Tchowariãp $\ddot{u}^{274}$ durante um sonho dele. Ao fazer isto, ele libertou os BuriBuri (Yare $)^{275}$ que lá moravam. Eles saíram fazendo uma grande zoada (aũgatanü). A voz dos Buri-Buri (Yare) é uma zoada forte, parece trovoada, barulho de tempestade. Os moradores da comunidade se assustaram, pegaram os barcos e foram para o meio do rio, fugindo. O irmão de Augusto, Manuel Maduquinha Basílio, que também é pajé, viu no sonho (nanegü) dele que tinham aberto a montanha. Então ele fechou no próprio sonho mesmo. Deste modo ele evitou a destruição da comunidade de Tchowariãpü.

No final das contas, quem resolveu a situação em Nazaré foi a PIASOL. Ao que parece, esta polícia indígena atua nos casos em que a polícia estatal é omissa, como os casos de acusação de feitiçaria. O pajé Augusto foi morto e queimado em 31 de novembro

\footnotetext{
${ }^{274}$ A comunidade é homônima a montanha, como atesta a terminação pü (montanha) do nome. É a primeira comunidade ticuna do igarapé Camatiã.

275 Um tipo de "bicho" (ngo'o).
} 
de 2010, pouco mais de um ano antes de meu primeiro trabalho de campo em Nazaré. Me relataram que, no dia da morte do xamã, foram até a casa de Augusto dizendo que precisavam dele para fazer uma cura em Santa Rita do Weil. A princípio, o feiticeiro ficou meio desconfiado, mas acabou embarcando na canoa. Então cacetaram ele e atearam fogo. Depois que queimaram o corpo de Augusto, jogaram-no no porão da embarcação e o corpo pegou fogo espontaneamente de novo. Uma outra versão diz que cacetaram ele e depois queimaram, mas apenas metade do corpo incendiou, da cintura para cima não queimou.

Até hoje, Juarêncio, morador de Nazaré, pensa em voltar para sua comunidade natal, Vendaval. Ele tem medo de que o filho do pajé Augusto vingue a morte do pai, mandando feitiço para Nazaré. Quando o pajé ainda estava vivo, Edna, esposa de Juarêncio, ficou muito doente. Ela via e sonhava com "bichos" que ninguém mais via, que haviam sido mandados pelo feiticeiro para fazerem mal para ela. O medo de retaliação por parte dos parentes do feiticeiro morto faz com que Ondino, por exemplo, não vá mais às festas na comunidade vizinha de Tchowariãpü. "Lá moram muitos parentes do pajé Augusto".

Este não é o primeiro relato de execução de um feiticeiro entre os Ticuna. Nimuendaju comenta que nada foi mais instrutivo para ele sobre as "crenças mágicas" dos Ticuna do que o relato da execução de um feiticeiro. Durante uma breve incursão em terras ticuna, em 1929, Nimuendaju ouvira falar de dois ticunas de Belém do Solimões que haviam matado um feiticeiro "acusado de instigar a morte de várias crianças. Eles cortaram o corpo em pedaços com facões, jogando-os no igarapé. ” (1952: 106).

O etnógrafo alemão conta também a história de Isidoro, um homem que "gradualmente tornou-se o terror dos Tukuna" (1952: 106). Antes de sua fuga para o Perú, Isidoro fora preso diversas vezes, principalmente acusado de ter matado a cacetadas seu sogro e cunhados. Ao voltar do Perú - vimos que este país é associado ao Waia, a “origem do pajé" -, com uma fama de feiticeiro ainda mais ampliada, o pajé não encontrava lugar para ficar, devido à suspeita que levantava. Quando estava bêbado, Isidoro se gabava dos conhecimentos de feitiçaria que havia adquirido no Perú. "A recusa de um cigarro era suficiente para fazê-lo ameaçar qualquer pessoa com morte por feitiçaria”. Após sofrer ameaças de morte, o feiticeiro fugiu para o Rio Jacurapá. Contudo, sua má fama o acompanhou e não tardou para que as mortes e doenças do local fossem creditadas a ele, principalmente da família de um índio chamado Hipólito. 
No dia 5 de junho de 1942, conta Nimuendaju, Hipólito e mais dois parentes viram Isidoro e sua família descendo o Rio Solimões em direção ao Rio Jacurapá. Decidiram, então, que a hora da vingança havia chegado.

"Eles o pegaram no meio do Solimões, o dominaram, amarraram os pés e as mãos, e jogam no rio. Golpearam a criança mais velha, cerca de três ou quatro anos de idade, com seus remos, também jogaram-na na água. $\mathrm{O}$ filho mais novo foi arrancado dos braços de sua mãe e também se afogou. Eles atacaram a mulher várias vezes e atiraram-na no rio também, mas Cristóvão a puxou para sua canoa e, assim, salvou sua vida. Os parentes de Hipólito tinham deliberadamente realizado o abate do feiticeiro sem derramamento de sangue, para o derramamento de sangue seria muito complicado o rito de purificação subsequente. $"(1952: 107)$

Em seguida, dois dos três assassinos foram pedir a um pajé que os purificassem.

"Então o xamã "ordenou-lhes que se agachassem diante dele, e, passando suas mãos sobre eles a partir dos calcanhares até o alto da cabeça, tirou-lhes a alma do morto, juntou-a na frente deles, e arremessou-a, dizendo: "Vá embora! Fizemos isso para você porque você era o inimigo de todos! ”. Então ele deu a cada homem três pimentas para comer e finalmente pintou com jenipapo, que ele já tinha trazido em cima de algumas folhas. Ele os levou para casa, deu-lhes comida, e se despediu deles" (1952: 108)

Nos relatos que ouvi sobre a morte do pajé Augusto não comentaram sobre estes tratamentos dos assassinos. Atualmente, este tipo de caso é resolvido pela PIASOL, ou seja, pessoas que não são da comunidade. Portanto, não conheci os matadores do feiticeiro de Nazaré. Entretanto, foram diversas as vezes que presenciei estes movimentos, descritos por Nimuendaju, do xamã purificando o corpo dos assassinos, mas em outros contextos. Vi os pajés de Nazaré realizando este juntar das mãos, passando-as sobre o corpo do enfermo, para retirar doenças, feitiços. O jenipapo também me foi referido muitas vezes como um poderoso antídoto contra os "males" (puya) do corpo.

Deixo aqui registrada apenas uma suspeita. Uma única vez presenciei um ticuna totalmente pintado de jenipapo. Perguntei a ele diversas vezes porque estava todo enegrecido daquele jeito. Ele sempre me dizia que era porque fazia bem para a pele dele, algo que não me satisfez de forma alguma. Nimuendaju menciona que os assassinos do 
pajé estavam "pintados de preto da cabeça aos pés", assim como o ticuna suspeito a que eu inqueri ${ }^{276}$.

\subsection{7 - O estranhamento dos nativos ou a descoberta de que eu não era um americano cortador de cabeças}

Este sub-tópico encerra o tópico maior sobre xamanismo ticuna. Escolho colocar este relato aqui por alguns motivos. Por um lado, ele mostra um aspecto de como foi minha entrada no campo e a recepção dos índios, algo que considero importante quando estamos fazendo etnografia. Por outro lado, a narrativa abaixo mostra também que o éthos pacífico dos Ticuna - que possuem um histórico de evitação do confronto guerreiro com seus inimigos - se contrapõe a extrema belicosidade no plano cosmológico. Espero ter apresentado um pouco desta "guerra" xamânica que acontece na vida ticuna. Contudo, não terei condições nesta tese, que tem como foco uma festa de iniciação feminina, de desenvolver melhor a análise do relato que segue, por mais interessante que ele seja. Uma análise, que farei futuramente destes episódios, deve levar em conta uma literatura que começa a se adensar sobre os "corta cabeças" na região da tríplice fronteira Brasil/Colômbia/Peru ${ }^{277}$.

Judith, tia (MZ) de Ondino, questionou a ele se eu comia peixe. O hábito alimentar das pessoas é um assunto de bastante interesse para os Ticuna. Ele disse a ela que eu comia de tudo, o que deve tê-la surpreendido. $\mathrm{O}$ fato de eu ser estrangeiro à cultura ticuna deveria remeter a uma alimentação diferenciada, como a da ticuna peruana mencionada por Ondino. Ela se alimentava só de ovos e sopa. Os moradores de Nazaré são bem curiosos para saber mais sobre minha "aldeia". Perguntam principalmente sobre minha alimentação, como fazemos nossa farinha, se tem igarapé perto da minha casa, qual o tamanho dele. Respondia que onde eu moro existem rios e córregos sim, mas são muito

\footnotetext{
${ }^{276}$ Retomaremos a questão do derramamento de sangue e da pintura corporal do homicida com jenipapo no tópico 4.2.1 - Homicídio, neste mesmo capítulo

277 Alguns dos textos que tratam do assunto: Goulard (1992) trata do motivo da "cabeça cortada" entre os Ticuna; Valdivieso (2005 e 2007) aborda o rumor que circula na fronteira do Brasil, Peru e Colômbia; Gow (2001: 256-60) dedica parte de um capítulo de seu livro aos Pishtaco e Sacacara, nome que os "corta cabeças" assumem no Peru.
} 
sujos, as pessoas jogam muito lixo neles. Mas este não foi, dentre outros, o estranhamento mais impressionante pelo qual passei, como relatarei.

Quando seguimos pelo Camatiã rumo à cidade, logo no início da terra demarcada ticuna há uma grande e chamativa balsa com um, não menos chamativo, hidroavião. É uma família de missionários batistas norte-americanos que possuem visivelmente uma grande estrutura para evangelizar os nativos. Certa vez, voltando de uma ida à cidade, passando em frente à balsa dos "americanos", Severino, tio (MB) de Ondino, começou a esbravejar. Severino os descreveu como verdadeiros inimigos. Disse que plantavam coca e maconha, que cortavam cabeças, guardavam e depois transportavam um monte de cabeças para algum lugar. Muitas cabeças eram levadas para os EUA para serem colocadas em corpos de borracha que formariam um exército a serviço dos americanos. Ele descrevia como eles circulavam pela área com suas capas, de modo assustador. Fiquei impressionado com a descrição, mas, naquele momento, não entendi direito porque ele estava contando tudo aquilo para mim.

A roça era um local onde meus informantes se sentiam mais à vontade para falar de feitiçaria, incesto, e outras coisas que se evita comentar na presença de muita gente. Numa destas idas ao roçado de Ondino ele me disse que no ano de 2000 o Camatiã estava infestado de americanos. Eles chegaram num navio e andavam com suas capas a caça de Ticunas. Nesta mesma época, conta meu informante, um pescador acertou um pirarucu com um arpão. O peixe foi nadando até a margem, tirou a pele de pirarucu e se revelou como um americano. Estava com o arpão fincado no calcanhar. Logo que ele chegou à margem, cortou a corda do arpão e fugiu para a floresta. Retornando para a comunidade, o pescador arregimentou uns 20 homens armados para irem ao encalço do americano. Encontraram-no e mataram. Junto a ele havia duas mochilas como a que eu tinha levado para campo, fez questão de frisar o narrador. Em uma tinham algumas cabeças e crianças que estavam vivas, mas não falavam. Na outra mochila havia alguns milhões de dólares.

Os americanos chupam e comem as pessoas que conseguem capturar. Usam seus olhos como óleo de avião, às vezes levam os corpos também. Eles vão à noite debaixo das casas e levam agulhas ou espinhos para extrair o sangue das pessoas. Esta é também a mesma ação a que um pajé feiticeiro ou um vampiro pode recorrer para prejudicar alguém. 
Notei que Severino tinha uma certa desconfiança de mim. Depois de algum tempo fiquei sabendo que ele pensava que eu era um americano e que, a qualquer momento, poderia me revelar como um cortador de cabeças. Esta ainda é uma desconfiança recorrente. Contaram-me que os visitantes da comunidade costumam perguntar - alguns perguntam diretamente a mim - se eu sou americano ou porque me aceitaram na comunidade, já que um americano é um perigo iminente.

Durante a festa da padroeira de Nazaré, como havia muitos convidados de fora, muitos deles me abordaram para saberem quem eu era. Um senhor peruano, casado com uma ticuna, num certo momento se aproximou para conversar. Perguntou se eu não era americano ou se meu pai não era. Por muito tempo ele fora militar, soldado de infantaria do exército peruano, tendo passado por conflitos em selva. $\mathrm{O}$ homem corpulento, estava vestido de camisa e chapéus que evocavam uma roupa de militar. Mas o mais impressionante era sua tatuagem facial ${ }^{278}$. Perguntei a ele se era o desenho de algum clã. Ele me respondeu que sua pequena tatuagem no queixo era um sinal que todos integrantes de seu pelotão possuíam. Servia para identificar os aliados, em meio aos confrontos na floresta, evitando o "fogo amigo" no calor do combate.

Como era minha segunda ida a campo, desta vez eu sabia que se tratava de um rumor conhecido por toda a gente da tríplice fronteira Brasil-Perú-Colombia. Os narradores das histórias dos pishtacos são, em sua maioria, indígenas, mas é uma história que circula entre a população local também (Valdivieso, 2005 e 2007). Naquele momento eu já estava entendendo melhor sobre os rumores dos americanos. Pedi a ele que me explicasse melhor quem eram esses pishtacos. Ele me disse que estes americanos cortam a cabeça dos indígenas para extraírem o rosto, que é colocado na cabeça de outra pessoa nos EUA. Eles trocam de rosto porque estão sendo perseguidos pela lei e precisam mudar de identidade para não serem reconhecidos. Do corpo da vítima é extraído todo o óleo e as entranhas, que servirão de combustível para os aviões.

Comentei com Ondino sobre toda aquela confusão. Dando risada disse a ele sobre a ingenuidade de Severino em me confundir com um americano. Ondino respondeu: “claro, que bobagem” e após um breve silêncio mandou: “mas você não é americano, é?”.

\footnotetext{
${ }^{278}$ Ele não era o único na festa que possuía tatuagem facial. Um senhor, na faixa de seus 50 e poucos anos, de Nova Jerusalém, comunidade também do igarapé Camatiã, mantinha em suas faces o antigo costume ticuna de tatuar o desenho clânico. Seu clã era mutum. Cf. foto no final do tópico $1.4-A$ face expressiva dos clãs do Capítulo 1.
} 


\section{2 - Sangue e os "males do corpo" (puya)}

"Porque os Ticuna viviam muito tempo, 96, cem anos (...) Porque desde quando a filha ficou menstruada, primeiro, ele [o pai] nunca vai olhar a filha dele, não tem puya, não tem nada de panema, nunca. Por isso que ele viveu muitos anos. Por isso que os Ticuna demoravam para morrer antigamente. "

Professora Adélia Luis Bintencout

A noção de puya já apareceu algumas vezes até este ponto da tese. Quando apresentamos os imortais ( $\ddot{u}$ 'üne), vimos que Ondino se refere a eles como “"aqueles que não tem mais males no corpo". O aprendiz de xamã deve tomar um emético para vomitar todas as impurezas do seu corpo, ou seja, eliminar o puya para poder receber as "substâncias mágicas" com as quais fará sua pajelança. A intenção deste tópico é mostrar a relação estreita que estas "impurezas" (puya) possuem também com o sangue, principalmente a menstruação. Valenzuela inclui ainda os cheiros e os humores femininos dentro do sentido de $p u y a^{279}$.

Como vimos no Capítulo 1, tópico 1.10.1 - Incesto, o sangue identifica a pessoa à metade exogâmica a qual ela pertence. Pessoas da mesma metade, por possuírem o mesmo "sangue", não podem se casar. O sangue seria uma substância tão fundamental para os Ticuna que estaria, segundo uma etimologia arriscada de Goulard, na raiz da palavra dü'ü, que podemos traduzir como "gente", mas que inclui a todos os "seres viventes" 280 : "aunque la etimología no sea cierta (...) el radical $\boldsymbol{d u}$, una referencia a la "sangre", y gü, expresión del plural, lo que autoriza a traducir el término $d u$-ûgü por "los de sangre"." (Goulard, 2009: 61, meu grifo). Os "seres viventes", portanto, são os potenciais contaminados de puya, pelo fato de serem seres "de sangue".

Os dois duplos da pessoa, ma' $\tilde{u}$ e $\tilde{a}^{\prime} \tilde{e}$ - que, na verdade, estão presentes em todos os $\operatorname{seres}^{281}-$, também são vinculados ao sangue: "El $m a-\hat{u}$ muestra a la persona,

\footnotetext{
279 "Este término también se asocia a los olores o humores femeninos" (Valenzuela, 2010: 109).

280 “...el término $d u$-ûgü (...) incluye a los ticuna, pero también a todos los seres vivos, visibles e invisibles, especies animales y vegetales. Permite más bien expresar un estado, el del 'ser viviente'." (Goulard, 2009: 61).

281 "La afirmación de un informante de que "cada uno tiene su a-e y su ma-û" vale para todos los seres, inmortales o mortales." (Goulard, 2009: 188). Ver também Angarita (2013).
} 
identificable por características de orden nominal, física, etc., llevadas por la sangre" (Goulard, 2009:188-9); o sangue também é "la sustancia que conlleva las características

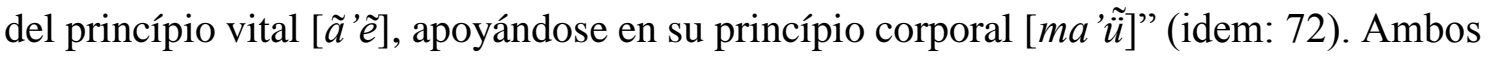
os princípios ou espíritos, de acordo com Goulard, portanto, estão vinculados de alguma forma ao sangue.

Para os Ticuna, o mundo atual é caracterizado como "algo corrompido e que escapa ao desígnio de seus criadores" (Oliveira Filho 1988: 145) ${ }^{282}$. Em um trecho registrado por Oliveira Filho, seu informante estabelece uma relação direta entre a corrupção atual do mundo e os desentendimentos entre as pessoas. Além da relação explicita entre os desentendimentos e a corrupção, podemos entrever uma relação entre a corrupção do mundo e o sangue: "Eles [Yoi e Ipi, gêmeos míticos ticuna] deixaram, abandonaram esse lugar, porque o pessoal já não obedecia a ele. Às vezes, diziam alguma coisa pro povo que viviam ali, mas ninguém obedecia a eles. Então o povo... cada vez, mesmo... entre eles se acabava! Cada vez piorava. Foi (o Yoi) não agüentô mais! Que a terra já estava muito suja, muito cheia de sangue..." (idem:147). Este relato deixa claro que, como uma pessoa impura, poluída por sangue, o mundo (na'ane) em que os Ticuna vivem atualmente está contaminado por o que eles chamam de "males" (puya).

A caça entre os Ticuna - com exceção apenas da anta, que é retalhada no mesmo local onde foi abatida - utiliza técnicas que visam reduzir o derramamento de sangue, para evitar a vingança do animal. Assim relata Goulard para os Ticuna do interflúvio peruano:

"La caza con cerbatana tiene como característica reducir al mínimo el derramamiento de sangre (...) la pesca con barbasco [timbó], principal forma para obtener peces em las comunidades del interflúvio, tampoco conlleva derramamento de sangre. Se puede pensar, por tanto, que estas práticas evitan que se escape la sangre o reducirla al mínimo (...) La sangre es una sustancia que es conveniente manejar con precaución (...) El cazador, para quien el contacto con la sangre es inevitable, se defiende siguiendo un proceso que disminuye la posibilidad de ser contaminado (...) la sangre de los no-humanos es tan fuerte por su pora [força], que su simple contacto pone en peligro al humano" (2009: 308-9)

\footnotetext{
282 "Em função da conduta errada do homens, foram surgindo os diferentes males e vícios, e os imortais se afastaram do convívio dos demais" (Oliveira Filho 1988: 145).
} 
Existem procedimentos, portanto, que fazem com que o caçador não seja contaminado pelo sangue do animal morto. Este perigo que envolve o sangue da caça é um dos motivos para que ela seja moqueada antes de ser entregue aos mascarados na Festa da Moça Nova. "Se ofrece un trozo de carne ahumada a los que se han presentado con máscaras. Después de un largo ahumado realizado por los hombres, esta carne animal ha sido liberada de su sangre: de roja se ha vuelto negra." (idem: 175). De acordo com Goulard, defumar a carne que é oferecida aos mascarados - alguns deles "pais" (natï) dos animais da floresta - poderia ser uma medida de segurança contra possíveis ações vingativas: "para neutralizar una posible devoración, para neutralizar su predación" $(\text { ibdem })^{283}$.

\subsection{1 - Homicídio}

Não somente na caça, o derramamento de sangue, de um modo geral, pode trazer graves consequências. Vimos que o sangue veicula o espírito $\tilde{a}$ ’ẽ da pessoa, Valenzuela detalha melhor o que acontece quando o sangue é derramado violentamente:

"Derramarla [o sangue] significa perder ese naẽ [ã'ê], si pisa sangre puede quedar afectado por el espíritu de esa persona sangrante. La sangre derramada brutalmente, una acción provocada por otro; al golpear, ese naẽ cae, se separa del cuerpo "ñemata nuê" dicen los abuelos: se cayó su pensamiento. La sangre maltratada, asesinada, cae con la muerte y queda ahí, latente y el que la pisa le va mal, así sean varias personas las que pisen, incluso puede pasar muchísimo tiempo pero ahí permanece ese naẽ. La sangre irradia, esa irradiación se debe proteger..." (2010: 91-92)

Ou seja, onde o sangue é derramado fica o espírito $\tilde{a}$ ’ẽ da pessoa que foi assassinada. $\mathrm{O}$ contato com este sangue, mesmo depois de muito tempo, pode causar danos. Principalmente, o sangue derramado torna-se um "sangue invisível" que impregna o corpo da pessoa que entra em contato com ele. Isso pode acontecer em algumas ocasiões:

\footnotetext{
${ }^{283}$ No Capítulo 7, tópico 7.2 - Convite e troca ritual, analiso mais detidamente este intercâmbio "cosmológico" entre os anfitriões da Festa e as entidades que comparecem no ritual.
} 
1) em casos de homicídio, 2) no parto e pós-parto, e 3) enquanto a mulher está menstruada. Examinemos cada um destes casos.

Vimos no tópico 4.1.6 - História do pajé Augusto - a execução do feiticeiro, num registro feito por Nimuendaju, que os executores do feiticeiro Isidoro tiveram o cuidado de não causar derramamento de sangue quando deram fim no pajé. O simples fato de terem executado o xamã os colocava num estado de interdição alimentar, sob o risco de o espírito ã'ẽ do feiticeiro entrar no corpo deles. $\mathrm{E}$ caso tivesse acontecido o derramamento de sangue, os assassinos “também teriam que usar um pedaço de pau para se coçar, em vez de suas unhas, uma vez que, se o sangue é derramado, o corpo do assassino torna-se cheio de sangue invisíveis" (Nimuendaju, 1952: 108). Todos os procedimentos foram tomados para que o espírito ã 'ẽ do feiticeiro não entrasse no corpo dos homicidas.

Com exceção desta descrição de Nimuendaju e da minha leve suspeita sobre o ticuna com o corpo todo pintado de jenipapo, desconheço outras descrições das consequências e do tratamento do corpo do homicida. Passemos à outra circunstância em que o corpo fica envolto em "sangue invisível", o parto e o pós-parto. Neste caso, tive o privilégio de estar hospedado na casa de Ondino quando nasceu seu filho e pude acompanhar parte do resguardo de Raissa, sua esposa, e o bebê.

\subsection{2 - Gravidez, nascimento, parto e pós-parto}

"O Tukuna, como o Apinayé, acreditam que os atos dos pais se refletem na saúde de seus filhos, e vice-versa, não só no período imediatamente posterior ao nascimento, mas também ao longo da vida", Nimuendaju, 1952: 70

Segundo Nimuendaju, a deusa Ta'e, a mesma que recebe as almas dos mortos e as julga ${ }^{284}$, é a responsável pela formação do corpo e da alma da criança que vai nascer. “Após a relação sexual, a concepção depende da vontade da deusa $T a$ 'e, é ela que dá ao feto o seu corpo e alma. Quando, sobrecarregada de tarefas, $T a$ 'e cresce descuidada, a

${ }^{284}$ Ver Capítulo 1, tópico 1.10.1 - Incesto. 
criança nasce com defeitos de mente ou o corpo" (1952: 68). Isso acontece neste plano, digamos, "cosmológico". No plano "sociológico", de acordo com a etnografia de Goulard, o pai seria o responsável pela gravidez, a mãe seria apenas um "continente" onde se desenvolve a criança (Goulard, 2009: 146). Além disso, segundo me confirmou Ondino, um criança pode ter mais de um pai, tantos quantos forem os que tiverem relações com a mãe $e^{285}$.

Depois de minha primeira noite em N.S. de Nazaré, acordei às 7 hs com meu anfitrião dizendo: "bom dia, quer ir cortar um cordão?”. Do exato momento em que abri os olhos até estar com uma tesoura ${ }^{286}$ nas mãos cortando o cordão umbilical de um recémnascido não se passaram 10 minutos. Cortei o cordão e falei seu nome. Estava batizada, tinha um nome ticuna. $\mathrm{O}$ nome em português ainda estava sendo pensado. O compadre é quem deve escolher o nome da criança. Quando ele corta o umbigo ele tem que dizer o nome em ticuna que terá o bebê. No meu caso, me disseram o nome que queriam colocar na menina. Agora eu já tinha relações sociais estabelecidas na comunidade. Com menos de dois dias de campo eu já tinha um compadre, uma comadre e uma afilhada.

Para entendermos como se dá o estado poluído (puya) da mãe e do pai no parto ${ }^{287}$ e no pós-parto devemos inserir esta condição no quadro mais amplo do tabus do puerpério, para os dois pais da criança. Depois do nascimento da criança, ela e seus pais estão sujeitos a uma série de restrições e perigos de ataques. O corpo da pós-parturiente está "verde" (do’ü) como a terra em suas origens ${ }^{288}$ (Goulard, 2009: 145), o corpo da criança ou um fruto que ainda não está maduro. O pai e a mãe devem tomar cuidado com certas plantas. Não podem passar perto do painü (a árvore do mito do Painü), piri (tipo de capim), tiririca (ngüratchicü $)^{289}$, jacitara $\left(b^{\prime} u\right)^{290}$. O risco é de alguma destas plantas se vingar da criança. Ela começaria a chorar e ficaria doente. Quando uma mulher está grávida, ou durante o resguardo pós-parto - aure, mesmo termo usado para a reclusão da

\footnotetext{
${ }^{285}$ Yaumaré = mulher que teve relações sexuais com vários homens e não sabe quem é o pai da criança. ${ }^{286}$ Antigamente o cordão era cortado com uma flecha bem afiada.

287 Há duas palavas em Ticuna para se referir ao parto, tanguacü = parto, quando a mulher ainda está sentindo as dores do parto, mas o neném ainda não nasceu; tairacü = parto, quando o neném já nasceu.

${ }^{288}$ Ver no Capítulo 3, tópico 3.1.5 - O corpo em formação e o mundo verde.

289 Um capim comprido e cortante, usado antigamente para cortar cabelo.

${ }^{290}$ Sobre esta planta, o dic. Houaiss diz o seguinte: designanção comum às plantas, ger. escandentes, do gên. Desmoncus, da fam. das palmas.
} 
moça nova -, os pais não podem passar debaixo da samaumeira (Ceiba pentandra). Segundo me disseram, o Õmi - uma lagarta que pode se transformar em gente - mora na samaumeira, "ele é dono da samaumeira, igual curupira, é muito perigoso. Uma mulher da comunidade de Otaware costumava ter relações com seu marido debaixo da samaumeira. Um dia, Õmi se aproveitou e transou com ela. O filho deles nasceu todo mole".

Outros "bichos" podem se vingar também. Na comunidade de São Francisco, uma mãe mexeu com uma preguiça e seu bebê virou uma preguiça. Mesmo um pão pode se vingar, o filho de Ondino, por exemplo, depois que seu pai comeu pão, sua barriga estufou. Piranha também é perigoso comer durante o puerpério. Os peixes ideais para os pais comerem durante este período são sardinha, curimatã e traíra. Tudo com pouco sal. Pela manhã as mães no puerpério comem mingau de banana verde, chá de capim santo, de folha de abacate. Café também não pode tomar. Devem-se restringir principalmente alimentos que contenham muito sangue e gordura. "El estricto respeto de la dieta no permite más que consumir alimentos desprovidos de fuerza (pora), en realidad los que tienen poca sangre y poca grasa..." (Goulard, 2009: 142). Nimuendaju comenta sobre a alimentação dos pais no puerpério: “...ambos os pais comem apenas peixes pequenos, pequenas aves, banana, mandioca e bolos, evitando todos os alimentos ácidos" (1952: 69).

Durante um tempo do pós-parto, a mãe costuma tomar algum remédio nativo para sua menstruação não voltar logo e ela se recuperar mais rápido. Celina, esposa de Gabriel e minha comadre, depois que deu à luz a minha afilhada, estava tomando uma garrafada de casca de copaíba com esta intenção. Para "desinfetar" o útero da parturiente é administrada uma infusão de folhas da planta "escama de pirarucu” (detchitchico).

Goulard destaca o aprendizado da caça como um importante atributo de um homem adulto que deseja obter uma esposa:

"A caça é realmente a atividade principal dos homens. Ela fornece carne que os Ticuna consideram a única alimentação verdadeira. Mas saber caçar é parte de um longo aprendizado. (...). Daí em diante, ele aprende e se aproxima dos vários aspectos de uma atividade essencial para a sobrevivência do grupo, mas importante para ele na medida em que é uma habilidade que será levada em conta quando ele tomar sua esposa. " (2002: 112). 
Contudo, o pai do bebê fica impedido de sair para a caça, o que é bem difícil para alguns ticuna que tem muitos filhos para alimentar. Gabriel, meu compadre, é o pai da menina que nasceu em meu segundo dia de trabalho de campo em Nazaré, sua quinta criança. Segundo Ondino, é melhor que ele fique em casa para não correr o risco de sofrer a vingança de algum animal. Contudo, Gabriel é bom caçador, isso faz muita diferença na dieta não só de sua família, mas de outras pessoas mais próximas dele na comunidade. Isso influi inclusive em sua posição política em Nazaré291. Em pouco tempo Gabriel se tornou vice-cacique da comunidade.

Um dia antes de a menina nascer, Ondino emprestou a ele uma espingarda. De onde fazia minhas anotações eu podia ver os cartuchos expostos ao sol para secar. Tudo indicava que ele caçaria naquela noite. No dia seguinte, ele ainda não tinha ido à caça. Ficava muito dentro de casa, deitado na rede. Pelo jeito estava respeitando o tabu de não circular muito. Era a segunda noite que ele passava deitado com Ondino na rede conversando. Os Ticunas gostam de sentar em par na rede e ficar conversando, dando risada. Nesta ocasião, deitado numa rede vizinha, perguntei se ele sairia naquela noite para caçar, ele respondeu que não. O tempo não era dos melhores para isso, muita chuva e lama.

Durante a couvade de Ondino, eu o ajudei em várias situações em que ele não poderia se envolver, principalmente na cozinha. No terceiro dia após o parto, ele me pediu que cozinhasse o pirarucu salgado para o almoço. Na condição dele, colocar a mão em um peixe destes seria muito perigoso. $\mathrm{O}$ pirarucu poderia se vingar, engolir a criança. Perguntei se ele poderia ao menos comer o peixe que eu estava preparando. Ele afirmou que poderia, mas de colher, não podia colocar as mãos nele. Durante os primeiros dias depois do nascimento, Ondino sequer jogava bola, algo que os Ticuna adoram e que ele fazia todos os dias. Ele me contou que seria perigoso para o bebê, ele poderia "estufar". No dia da festa da padroeira de Nazaré, Ondino convidou um pajé para rezar Raissa. Perguntei se o neném estava bem e porque ele tinha chamado o rezador. Ele respondeu que era para "bicho" (ngo'o) não "vingar ela”. Fiquei curioso para saber se havia algum motivo para um bicho querer se vingar dela. Ondino falou que não sabia o motivo, mas o "bicho" poderia querer se vingar.

${ }^{291}$ Ver Capítulo 1, tópico 1.9 - Clãs e Chefia - equilíbrio político. 
De noite, em Nazaré, costumamos ficar deitados nas redes da sala de Ondino. Certa noite eu troquei as cordas do violão dele, que já estavam bem gastas. Ele nunca tinha trocado desde que comprara o instrumento, há alguns anos. Era por volta das $19 \mathrm{hs}$, o motor de luz não estava ligado, então, ele me pediu que tocasse uma música no violão. Toquei uma canção e depois perguntei se ele não queria tocar também. Ondino respondeu que não podia tocar, porque seu filho ainda era recém-nascido. O perigo de se tocar violão durante o puerpério, disse ele, é a criança começar a chorar (au) igual ao som do vilão. "O som do violão passa para a criança".

O filho temporão de Ondino nasceu um dia antes da minha chegada para o meu segundo período de trabalho de campo. Como estava hospedado na casa do casal, pude acompanhar boa parte da reclusão de Raissa, a mãe do bebê. Ela já tem mais de quarenta anos, portanto, está com a idade avançada para uma gestação. Durante o parto ocorreram complicações que fizeram com que eles embarcassem para o hospital de São Paulo de Olivença. Mas o bebê não quis esperar mais, Raissa deu à luz no barco, no meio do igarapé Camatiã.

Havia um motivo muito forte para Raissa, esposa de Ondino, fazer sua reclusão pós-parto com tanta dedicação. Sua circulação estava bastante restrita, ela só saia para ir ao banheiro. Ficaria ao menos um mês com poucas saídas do quarto. Passando cerca de 20 dias, ela já podia circular mais pela casa, deitar com seu filho na rede da cozinha. No vigésimo terceiro dia, p. ex., ela almoçou próxima de todos na cozinha, mas não se somou à roda de pessoas que comiam sentadas no chão. Vez ou outra ela começava a sair um pouco do quarto para conversar com alguém, sentada na soleira da casa. O motivo de tanto cuidado foi uma forte infecção no útero que ela teve depois de seu parto anterior. A infecção foi atribuída ao fato de ela não ter seguido corretamente as restrições exigidas. Raissa ficou dezessete anos sem poder engravidar. Quando se curou de seus problemas no útero, ela engravidou de seu neném temporão. Agora ela está cuidando bem para não adoecer de novo e para que não aconteça nada com ninguém da família, já que a quebra de resguardo pode atingir aos parentes mais próximos também.

O mais restrito é o contato com o rio. Antigamente, quando as mulheres menstruavam, elas não tomavam banho no rio. Dizem que hoje em dia muitas coisas ruins acontecem porque este tabu é pouco observado. O banho no rio deveria ser evitado, só depois de cerca de 3 meses a mãe que cumprisse mesmo o resguardo poderia banhar-se no Camatiã. Por enquanto, Raissa só toma banho dentro de casa. Ondino ferve a água 
para ela se banhar. A água tem que estar um pouco quente, mas não muito, também não pode estar in natura, tem que passar pelo fogo. Mesmo as roupinhas do neném não devem ser lavadas no rio, são lavadas com água da chuva. É uma fase muito perigosa para a mãe, o pai, a criança recém-nascida e seus irmãos. A mãe deve evitar circular muito, seria um perigo se, por exemplo, ela pisasse num pé de tajá292, ou no "lugar" de uma paca.

Segundo Ondino, depois que nasce a criança, a mãe e o pai ficam "sujos", com males (риуа) - assim como a mulher que menstrua -, por isto ficam interditados de fazerem muitas coisas, principalmente prepararem as refeições. Até mesmo o osso do peixe que a mulher no puerpério comeu não é dado aos cachorros, senão eles ficam panema. Caso os pais da criança não se pintem de jenipapo, eles podem ficar com dor de estômago (tãgoneca).

Durante o período do puerpério, portanto, uma mulher preparar a comida seria muito perigoso. Ondino comentou comigo sobre o estado de sua mulher, que acabara de dar à luz. "Se a mulher fizer comida quando ela está menstruada ou quando acaba de ganhar neném, ela pode fazer mal ( puya) para quem come a comida dela”. Quando a mulher está menstruada ou durante o puerpério, diz Ondino, o corpo inteiro dela fica com sangue invisível. Se ela faz comida, o sangue pega na comida e as pessoas comem o sangue dela ${ }^{293}$. Por isso, as refeições de Raissa eram preparadas por Ondino. Ela não podia trabalhar como em seus dias antes do parto, então Ondino assumiu as tarefas dela. Adélia me disse que o desempenho desta regra entre os Ticuna é muito importante, só não sei se é bem cumprida. "Quando a mulher está de menstruação, ele não pode comer comida dela. Ele mesmo [o homem] tem que fazer tudo, até terminar [a menstruação]”.

Belaunde comenta que este tipo de acontecimento gera um certo equilíbrio do poder e uma interdependência entre homens e mulheres. "Frequentemente os homens cozinham e cuidam de suas famílias enquanto as suas esposas permanecem no confinamento (Mahecha, 2004, p. 170; Århem et al, 2004, p. 210). O sangramento das mulheres, portanto, cria uma arena onde o equilíbrio das relações de poder e

\footnotetext{
292 De acordo com o Dic. Houaiss: tajá = “tupi ta'ya 'nome genérico de planta da fam. das aráceas', lit. 'que arde, picante', às vezes red. a 'aya 'ácido, azedo'". Os exemplos de tajá fornecidos pela mesma fonte são: taioba (Xanthosoma violaceum), tinhorão (Caladium bicolor), antúrio, copo-de-leite, inhame.

${ }^{293}$ Quando está menstruada ou no pós-parto, a mulher não pode produzir cerveja de mandioca: “... la tarea principal de la mujer (con excepción de las que le corresponden al interior de la casa) es sembrar la yuca. Al madurar, ella mediante su masticación la transforma en masato, salvo si se encuentra en situación de impedimento (regla, período post-partum)." (Goulard, 2009: 189).
} 
interdependência entre homens e mulheres se realiza" (Belaunde, 2006: 220). Ou seja, o sangramento do parto gera a entrada dos homens em domínios femininos. O mesmo podemos notar no ritual, o sangramento da moça nova faz com que os domínios dos gêneros sejam permeados um pelo outro. Veremos isso quando abordarmos o canto em falsete dos cantores ticuna ${ }^{294}$. O sangramento, portanto, potencializa esta permeabilidade das fronteiras que são mais rígidas no cotidiano ${ }^{295}$. E talvez a principal fronteira que é abolida durante a Festa, como pretendo mostrar, seja entre mortais e imortais ${ }^{296}$.

A primeira refeição de Raissa foi galinha caipira, temperada com chicória, alho, sal e um pouquinho de pimenta do reino. Depois em sua dieta entraram os pequenos peixes, curimatã, sardinha. A carne de caça só poderá ser consumida depois de cerca de três meses. A refeição não é feita no prato, ela come somente num recipiente feito de coroatá (eyu), a base da folha de algumas palmeiras (paxiubinha, açaí, etc.), isso ajuda a menstruação demorar para voltar. O neném é banhado num recipiente como este também. Quando a mãe come e dá banho no coroatá, a criança aprende mais rápido, porque o coroatá é molinho.

Em algumas comunidades ainda se faz um ritual para a mãe voltar a tomar banho no rio. Passadas cerca de três semanas, um mês, de parida, a mulher pega um punhado de cinzas e vai espalhando no chão em que vai pisando até a beira do rio. Ela deve pisar exclusivamente em cima das cinzas até chegar à água. Elas servem para a mulher não pegar frio (deyuĩ / dematchi), porque as cinzas ficam sempre quentes. Dematchi ${ }^{297}$ dá na mulher quando ela está menstruada ou quando está no puerpério e vai tomar banho no rio. A dematchi entra no corpo da mulher. "Principalmente quando a moça está na sua primeira menstruação. Por isso que tem que guardar a menina quando ela menstrua".

É o pajé que faz o caminho (mã) de cinzas para a mãe, da mesma forma que ele faz o caminho dos peixes $($ tchonima, tchoni $=$ peixe $/ m \tilde{a}=$ caminho $)$ e o caminho dos

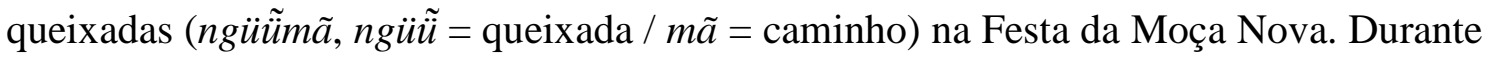
a Festa, o pajé abre os caminhos dos peixes e dos queixadas quando benze os trompetes coĩri. Mas a moça nova pode passar por uma caminhada em cima das cinza também. Isso

\footnotetext{
${ }^{294}$ Ver Capítulo 5, tópico 5.2.2 - Falsete e gênero - o "travestismo vocal".

295 Talvez algo próximo do que se dá entre os Pirahã. Para este povo o "sangue é uma espécie de móvel da transformação, a possibilidade de dar surgimento a outros seres" (Gonçalves, 2001: 233).

${ }^{296}$ Ver Capítulo 7 e Considerações Finais.

${ }^{297}$ Dematchi $=$ mãe da friagem (gaũ' $\left.\tilde{u}\right)$ no corpo, gaũ' $\tilde{u} a e=$ mãe da friagem.
} 
pode ser feito antes ou durante o ritual. Ela vai pisando nas cinzas até o rio e o pajé abre o caminho dos peixes. Ao fazer isto, tanto com a moça nova quanto com a mãe que está no puerpério, ele está assegurando que nunca faltem peixes para a comunidade.

Listo abaixo uma possível classificação das crianças segundo sua faixa etária:

Õtchanã = recém-nascido

Õcthanã manayaurá $=$ neném um pouco maior

Manaua'a = enquanto ainda está engatinhando

Buriyana $=$ bebê de até mais ou menos um ano de idade

Marünataunecü = com aproximadamente um ano, quando já está de pé.

Tarearütaunecü $=$ com cerca de dois anos, $\mathrm{já}$ fala, come.

Bũü = criança

Bũü maya $=2,3$ anos

$\tilde{U} y i n \ddot{u}=$ mais ou menos 10 anos

Crianças de 1, 2 anos até os 11, 12 anos são referidas como bué.

\subsection{3 - Menstruação}

“É, portanto, enquanto seres periódicos que as mulheres podem pôr em risco a ordem no universo. "

Lévi-Strauss, A Origem dos Modos à Mesa, p. 199

Pardo (2008: 85-86) menciona uma das histórias de Yoi e Ipi em que aparece uma versão da origem da menstruação para os Ticuna. Antigamente as irmãs dos heróis não tinham vagina nem menstruavam. Os irmãos sobem numa árvore para pegarem as crias de um gavião em seu ninho. O relato de Pardo é o seguinte: 
"allí matan sus crías y llevan a las hermanas las pechugas para comer. Como Ipi come tan rápido, cuando se le acaba su porción pide a su hermana que le de la suya, y ella, para que "el hermano loco" no le quite, guarda la pechuga entre sus piernas, de modo que la carne se queda pegada a su cuerpo y la vagina de la mujer se conforma. Pero Ipi la registra provocándole una hemorragia y una gran vergüenza que la mata; de ahí que el origen de la menstruación sea producto de lo que parece una relación incestuosa que tiende a ser evitada con el rito de la pelazón." (ibdem $)^{298}$.

Podemos notar aqui o retorno do motivo clássico do desaninhador de pássaros, que analisamos no Capítulo 2. No entanto, ao contrário de muitas narrativas amazonenses, em que a menstruação era originalmente masculina e é apropriada pelas mulheres ${ }^{299}$, na narrativa ticuna, Ipi provoca o sangramento em sua irmã. Na interpretação de Pardo, a menstruação se originaria de uma relação incestuosa e o ritual de pelazón ${ }^{300}$ seria um modo de evitar que o incesto se repita.

No caso ticuna, originalmente o primeiro homem, $N g u t a p a$, ficou grávido ${ }^{301}$. Isto é, a gravidez era um atributo masculino, já que Mapana não dava filhos a Ngutapa. Esta história só se inverte, no mito de origem, quando Ipi copula com sua cunhada, uma transformação de To'oena, a primeira moça nova. O mito de origem ticuna, portanto, admite duas soluções para os primeiros sinais de fertilidade feminina: 1) a saída da reclusão (a moça dentro da flauta) e a relação com um homem (Ipi) que gere filhos, o mito enfatiza também a extrema importância de a criança ser pintada de jenipapo após o nascimento; 2) escapar da reclusão, atraída pelo som dos instrumentos proibidos, olhar para eles e morrer como uma presa de caça. Ao final do mito, além de tornar-se a carne que é consumida da Festa, o sangue de To'oena se esvai no rio Eware (uma clara referência à menstruação), tornando-o vermelho. A mitologia também impõe os limites

\footnotetext{
298 Uma versão deste mito também está em Bueno (2014: 73-74).

299 “As narrativas míticas amazonenses que explicam a origem da menstruação como oriunda de uma mudança de poder, expressa por exemplo em estórias sobre como originalmente os homens, e não as mulheres, sangravam, são apresentadas por diversos antropólogos para apoiar o argumento de que as mulheres têm um status subordinado na sociedade" (Belaunde, 2006: 221). Vimos no Capítulo 2, tópico 2.4 - To'oena, a primeira moça nova, que o mito das "flautas sagradas" dos Ticuna também não opera esta inversão de atribuições dos gêneros.

${ }^{300}$ Como a Festa da Moça Nova é chamada nos países de língua hispânica, Colômbia e Peru.

${ }^{301}$ Capítulo 2, tópico 2.3 - O homem grávido - a questão de gênero como primeiro evento mítico.
} 
da filiação e da aliança. Neste sentido, se, por um lado, o mito de origem (Ngutapa) afirma que a geração das crianças será uma tarefa feminina, por outro lado, o mito de Lua mostra que o sexo não pode ser feito com o irmão, estabelece o que é o incesto, os limites das alianças de parentesco.

No mesmo tópico sobre o motivo do homem grávido no Capítulo 2, em que analisamos a história de Ngutapa, apenas sugeri a relação que existe entre a menstruação e o escalpo. Como mostra Lévi-Strauss, a relação é bem complexa. O escalpo, assim como a menstruação, está relacionado ao afastamento que a sociedade impõe aos casais, "a menstruação tira a esposa do esposo, como se os parentes nessa ocasião reafirmassem seus direitos sobre ela" (2006 [1968]: 360). Num plano, portanto, temos um afastamento definitivo entre duas pessoas pela regra do incesto, também relacionada à menstruação, por intermédio de Lua nos mitos ticuna. Em outro plano, digamos, num grau menor, temos um afastamento temporário entre os cônjuges, ocasionado pela menstruação periódica das mulheres. A Festa da Moça Nova ticuna pode ser pensada também como um ritual para a educação de uma jovem que se casará em breve. Inúmeras vezes durante a Festa ela é aconselhada a não se casar-se tão cedo, escolher bem o marido, etc. Se nos mitos norte-americanos há uma equivalência entre escalpos e as mulheres menstruadas ${ }^{302}$, tudo indica que esta equivalência aparece de alguma forma no ritual ticuna. Não temos dúvida de que a menstruação é um "afastamento periódico que a natureza coloca entre eles" (idem: 361), os cônjuges. Mas, se o escalpo é a maneira em que "a sociedade se encarrega de separá-los por uma intervenção ainda mais sangrenta" (ibdem), os cabelos arrancados da moça nova ao final do ritual indicam, da mesma forma, que ela, apesar de seu corpo estar pronto para o casamento, não deve se aproximar de seus pretendentes tão $\log \mathrm{o}^{303}$.

\subsubsection{1 - Veneno}

As situações descritas acima, homicídio e puerpério, são passíveis de contaminar a pessoa com puya, a "poluição" proporcionada pelo contato com o sangue. Contudo, não

\footnotetext{
302 "[O]s mitos sobre a origem dos escalpos introduzem uma equivalência entre esses troféus e as mulheres menstruadas" (Lévi-Strauss, 2006 [1968]: 359).

${ }^{303}$ A relação entre cabelos e maturidade sexual será abordada também no Capítulo 7, que descreve a Festa, mas será nas Considerações Finais que delinearei uma hipótese que explica esta relação.
} 
há situação mais contaminadora que a menstruação ${ }^{304}$. A menstruação está diretamente ligada à ideia de impureza, poluição, contaminação, algo bastante generalizado para os povos ameríndios. A equiparação da menstruação com o veneno, feita por muitos destes povos, demonstra o perigo que ela pode trazer. Overing mostra esta equiparação para os Piaroa. Vejamos o que diz esta autora sobre a menstruação:

"Ao sangrar, sua vagina expele todos os venenos perigosos que ela havia internalizado durante o mês ao conviver com outras pessoas (...) Uma mulher menstruada não pode cozinhar para pessoas vulneráveis, pois elas poderiam ingerir o odor venenoso do seu sangramento, e isso as impregnaria, deixandoas doentes. Para a mulher, porém, é a eliminação desse mesmo sangue que a torna forte e fértil de maneira sadia. Entra em jogo outra vez a ambiguidade dos princípios geminados de degeneração e regeneração: a excreção é procriadora, a excreção contamina. " (2006: 42-43).

Neste trecho, Overing mostra a relação, para os Piaroa, entre o sangue menstrual e o veneno, ou melhor, o caráter venenoso do sangue menstrual. A mesma relação destacada por Lévi-Strauss para os "índios das Guianas". "Se os índios das Guianas deixam suas filhas e esposas com fome quando elas estão menstruadas, é porque, dizem, para que seus corpos eliminem o veneno..." (2006 [1968]: 455). Esta relação, para os Ticuna, pode ser verificada no mito "Origem do Timbó", narrado a mim por Ondino. O mito mostra a relação entre uma moça virgem que senta em cima do cipó do timbó e engravida dele. Depois de nove meses nasce seu filho, o filho do timbó, e descobriu-se que ele era extremamente venenoso, como seu pai. O final da narrativa de Ondino, ele conta que o filho do timbó correu o mundo espalhando timbó. "Onde ele cuspia (fai), onde ele defecava (woeün), onde ele urinava (wiya), nascia um filhinho dele, um cipó timbó. Ele andou pelo mundo inteiro e espalhou a planta do timbó por todos os lugares onde passou. Ele nunca mais voltou".

A versão abaixo do mito d'O Filho do Timbó, coletada por Nimuendaju, é bastante próxima da versão que coletei com Ondino. Contudo, possui uma informação fundamental que não consta na narrativa deste último, a mãe do filho do timbó é uma moça nova (worecü). Ou seja, trata-se de uma moça em seu período de menarca. Além

${ }^{304}$ Menstruação = tamaninanãgu 
disso, os parentes dela estão na floresta para tirar timbó para banhá-la com o sumo do cipó. Vejamos o mito d'O Filho do Timbó coletado por Nimuendaju:

"Os parentes da worecü levaram ela consigo para a selva, a fim de puxar timbó para seu banho. Estavam tão ocupados que deixaram-na sentada na excrescência nodular de uma raiz de Timbó, onde ela permaneceu esperando o tempo todo, enquanto os parentes estavam ocupados no suporte do timbó. Sem ter tido nenhuma relação sexual, ela ficou grávida pelo espírito do timbó e deu à luz um filho. Quando, depois de seis meses, ela levou o filho pela primeira vez para tomar um banho no igarapé, notou que, tão logo ela mergulhou o menino na água, os peixes morreram em grande número ao seu redor. Quando, no segundo banho, este fenômeno se repetiu, ela percebeu que o menino era a causa e que ele era o filho do Timbó. A partir de então ela já não banhou no igarapé, por medo de que todos os peixes pudessem morrer, mas o banhou em terra. Quando o menino cresceu, seus parentes o usavam para matar os peixes, o que lhe permitiu nadar um pouco no igarapé.” (1952: 92).

Nimuendaju descreve também uma cerimônia que ocorria "nos velhos tempos" em que se banhava a moça nova com timbó, para garantir a abundância de peixes:

"Nos velhos tempos, havia uma cerimônia adicional imediatamente após o encerramento da festa [da moça nova], da qual uma lembrança é preservada nas lendas. A worecü [moça nova] foi levada pelos seus parentes a algum ponto de pesca no igarapé e, de pé, ereta na água, foi lavada com uma solução da droga Timbó. Esperava-se que isso iria garantir uma grande captura de peixes" (91-92).

Deste modo, os mitos associam a dispersão do cipó venenoso ao filho de uma moça nova e um rito mágico propiciatório de peixes levado a cabo pelo banho de uma worecü com o veneno do timbó. O último trecho deixa entrever que a moça é usada como um cipó de timbó para a pesca. Neste trecho a relação entre a moça na água e a pesca são patentes, o que não fica tão claro no banho final que ocorrem em todas as Festas de Moça Nova. Contudo, em todas as Festas que participei o pajé trabalhava para criar o "caminho dos peixes" (tchonimã), ato relacionado ao benzimento dos trompetes coĩri. Estas relações estabelecidas entre a menstruação, o veneno e a pesca podem indicar que o banho final seja também um rito propiciador de peixes. 
A relação entre veneno e menstruação se dá também por vias indiretas. Podemos considerar que a moça inicia uma troca de pele, como fazem as cobras, quando tem sua menarca, mudança esta que é exacerbada durante o ritual. Segundo Luisa Elvira Belaunde, “[p]or toda a Amazônia, sangrar é a "troca de pele/corpo" par excellence, e são as mulheres quem mais evidentemente fazem com que isso aconteça, em suas regras e no nascimento da criança.” (2006: 207-208) ${ }^{305}$. Para os Ticuna isso fica evidente na primeira menstruação da menina. $\mathrm{O}$ processo começa com o primeiro sangramento da moça, veremos também que a pintura de todo o corpo com jenipapo favorece a renovação da pele e, ao final do ritual, os cabelos arrancados finalizam a "troca de pele", o rejuvenescimento da moça.

A primeira menstruação da moça implica em ela passar por uma transformação que deve cumprir as etapas do ritual, para que não haja perigo. Além da transformação do corpo pela qual a moça passa, o cheiro de sua menstruação é um forte atrator de seres sobrenaturais. Um descuido neste momento pode ocasionar o roubo ou devoração da moça ou de seus parentes pelos “bichos” (ngo'o) ou pelos imortais (ü'üne) ${ }^{306}$. Belaunde destaca a generalidade na Amazônia do fato de o cheiro do sangue tornar a pessoa perceptível para determinados seres daninhos.

"Em muitas partes da Amazônia, considera-se que o sangue derramado, e particularmente o seu cheiro, tem um poder transformador sobre a experiência vivida... (...) Ele apenas introduz espaços-tempos de multiplicidade transformadora incontroláveis, quando/onde os espíritos de plantas/animais tomam a forma humana - como ocorre durante os espaços-tempos míticos primordiais - e se vingam dos humanos, seduzindo ou raptando os que se tornam perceptíveis pelo cheiro de sangue, tornando-os diferentes de si mesmos, alienados, doentes ou mortos, ou seja, perdidos para seus parentes." (2006: 229).

\footnotetext{
${ }^{305} \mathrm{Em}$ Iquito, por exemplo, existe uma relação terminológica entre a menstruação e "tirar a pele": "Em Iquito, Qu++raqui, "menstruação", é o radical do qual deriva qu+raani, "pelar, tirar a pele". Qu+racama é uma cabana usada pelas mulheres durante suas menstruações e considerada um lugar perigoso - qu+rana significa perigo (Sullón, 2005, p. 5)." (Belaunde, 2006: 234, nota 9).

${ }^{306}$ Os imortais, como vimos, são atraídos pelo sangue, "“la sangre gusta, seduce a los inmortales que todo el tiempo quieren apoderarse del territorio, y de cuerpos sangrantes para poder vivir sintiendo la mortalidad, por eso hay dietas; para apaciguar ese impulso es que se hace pelazón" (Valenzuela, 2010: 109).
} 
No trecho de Overing citado acima temos uma referência ao odor da menstruação como um "odor venenoso". Esta indicação é muito importante para o que descreveremos agora. Além dos perigos de contaminação por puya através da menstruação, há ainda um agravante nesta condição feminina, o perigo do odor do sangue.

\subsubsection{2 - Periodicidade}

No mito, Ipi gera o sangramento primordial em sua irmã e, desde então, as mulheres menstruam. Nos dias de hoje, o responsável pelo primeiro sangramento das moças é um astro. Lua tem um ciclo de vida de trinta dias, desde quando aparece criança até tornar-se velho.

"A lua é um homem que a cada trinta dias modifica a pessoa dele e a ele próprio. A cada trinta dias, ele envelhece, morre, e se transforma. Deixa o corpo de velho e se torna criança novamente, até se tornar um homem jovem, que por sua vez ficará também velho. E o velho irá "remando" para um outro jovem, "remando" na busca de meninas que estejam prestes a menstruar. Isso ocorre porque ele habita com ela. Depois disso, a moça se forma. A primeira parte é feita pela lua, e por isso a menstruação passa a vir todos os meses" (Faulhaber, 2000: 112).

O parágrafo acima, apesar de um pouco confuso, nos fornece uma informação que coloca em evidência um dado muito estudado por Lévi-Strauss no terceiro volume das Mitológicas (2006 [1968]), a relação que existe na mitologia ameríndia entre a periodicidade da lua e a periodicidade do corpo das mulheres. Desenvolverei melhor este ponto adiante. Quando está para menstruar, a menina recebe a visita de Lua, que "habita" com ela, um eufemismo que os Ticuna usam para dizer que Lua tem relações sexuais com a menina. Depois que isso acontece, "a moça se forma", ou seja, tem sua primeira menstruação e menstruará todos os meses. Vimos no Capítulo 1, tópico 1.11.1 - Incesto, que o mito do incesto primordial ticuna é muito semelhante a suas variantes bem conhecidas para a América indígena ${ }^{307}$. Podemos notar, portanto, que incesto e menstruação estão intimamente relacionados na mitologia ticuna. Ipi provoca a

\footnotetext{
${ }^{307}$ Ver a narrativa de Nimuendaju (1952: 143) que transcrevemos no tópico mencionado.
} 
menstruação primordial em sua irmã através de um incesto simbólico. Lua, autor do incesto primordial, é também quem dá início ao sangramento mensal das mulheres.

Camacho (2000) nos apresenta três variantes muito semelhantes do mito de Lua. Este astro e sua irmã são do clã da garça (idem: 41). O sol é do clã da arara. Lua e Sol, portanto, são de nação "de pena”, são primos, mas têm raiva um do outro (idem: 45). Camacho também faz referência a Lua como o responsável pela menstruação mensal das mulheres: "O jovem Lua gosta das mulheres, cada mês ele baixa à terra, por esta razão vem às mulheres a menstruação" (idem: 44). Baseados nisso, podemos afirmar - como veremos que Belaunde generaliza para todas as Terras Baixas da América do Sul -, o mesmo para os Ticuna: a menstruação não é considerada algo natural do corpo feminino. Pelo contrário, a menstruação "vem às mulheres" por efeito da visita de Lua à terra todos os meses. Para subir ao céu, Lua vai pelo tronco oco de uma árvore, quando chega lá em cima vemos a lua cheia (natamüï) (ibdem).

Em uma das worecütchiga 1 que gravei em campo a referência ao sol aparece ao longo de toda a música, como nos seguintes trechos ${ }^{308}$ :

Natchawatayecu awreün ya oi oi gamacuaratchi

"Por sua causa eu estou de resguardo, vovô, vovô, sol"

Iri iri iri pa worecü

"Moça nova"

Nhumarüwai moünrütawai cunamawai oi oi yama cuaratchi

"Agora mesmo, amanhã mesmo, você mesmo, vovô, vovô, sol"

Cumatürüwai baĩatchigu

"Com seus raios na aurora"

Natanũwata icü tchiitchigu curügunegü

"Saia e fique de pé no meio dos festeiros, teus festeiros"

Iri iri iri pa worecü

"Moça nova"

308 Gravação de Ondino, apresentei um trecho desta mesma gravação no tópico 3.1.5 - O corpo em formação e o mundo verde. 
$(\ldots)$

Tchinagücü ya oi, oi yama cuaratchi cumatürüna natchinagügu

"Vovô, vovô, sol, ficará de pé com você"

Tacatürüyecu tchiitchiün

"Apareça, saia do curral para nós"

Iri iri iri pa worecü

"Moça nova"

Contudo, este pedaço da canção só fará sentido se remetermos a letra ao mito da samaumeira derrubada por Yoi. O mito trata da origem do dia (Anexo - 004). Antigamente não se via a luz do dia porque uma enorme samaumeira (wõne) cobria o céu com seus galhos ${ }^{309}$. O mundo vivia na escuridão. Yoi tentava derrubar a árvore, mas ela não caía, por dois motivos. Um deles era o fato de a árvore sempre se regenerar quando o herói tentava derrubá-la. Yoi então descobre que no tronco da samanumeira morava um sapo (tautütchii), dono da árvore. O caule só parou de se regenerar quando Yoi passou a alimentar o sapo gigante com caça. Então ele conseguiu cortar o tronco, mas mesmo assim a árvore não caía, havia uma preguiça-real na copa segurando no céu. Yoi precisou da ajuda do quatipuruzinho, que levou pimenta (mé'ẽ) socada com batata vermelha

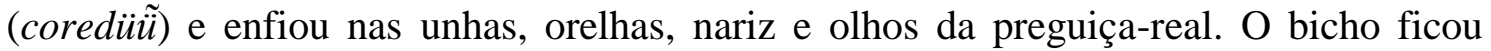
agoniado, largou do céu e a samaumeira caiu. A queda da árvore não só originou a alternância entre o dia e a noite, como seu tronco, galhos e folhas se tornaram o rio Solimões, os igarapés e lagos.

A existência de uma periodicidade astronômica, a alternância entre o dia e a noite, portanto, é colocada em paralelo com o ciclo menstrual feminino: "por sua causa eu estou de resguardo, vovô, vovô, sol", diz a canção acima. A alternância entre o dia e a noite precede a periodicidade do corpo feminino. É como se a origem do dia, num mundo onde só existia a noite, fosse o princípio de toda a alternância. Como a menarca que transforma uma menina estéril num corpo fértil cíclico. Se este raciocínio estiver correto, teríamos a seguinte proporção, dia : noite :: menstruação : não-menstruação. Um mundo com uma

\footnotetext{
${ }^{309}$ A samaumeira wõne é apenas a que está no mito. A árvore que encontramos na floresta é designada por outro termo.
} 
noite eterna, como antes de Yoi e Ipi derrubarem a samaumeira mítica, seria como uma mulher que nunca menstruou.

O controle da periodicidade feminina é feito também no sentido de não “comprometer a ordem do mundo" (Lévi-Strauss, 2006 [1968]: 200) ${ }^{310}$. Devido à equivalência postulada pelo pensamento indígena entre as várias periodicidades, a falta de controle sobre a menstruação pode "pôr em risco a ordem do universo" (idem: 199). Lévi-Strauss usa propositalmente a palavra regras em seu duplo sentido para evocar o duplo perigo da "insubordinação social" e da "insubordinação fisiológica" das mulheres (ibdem). As regras são impostas às moças novas durante iniciação. Principalmente nos inúmeros cantos de aconselhamento que elas ouvem durante os três dias de Festa, mas também numa espécie de educação corporal pela qual a moça passa, submetendo sua postura, pele, dieta, resistência à dor, seu silêncio, etc., também à regras estritas. Todas estas regras inculcadas pelo ritual "constituem o penhor e o símbolo de outras regras, cuja natureza fisiológica atesta a solidariedade que une os ritmos sociais e cósmicos" (ibdem).

Sabiamente, Lévi-Strauss lembra que o controle da menstruação pelos ameríndios refere-se também a um asseguramento da periodicidade temporal de um modo geral. $\mathrm{O}$ perigo de uma ausência de periodicidade, ou uma periodicidade excessivamente acelerada, é retratado nos mitos que falam dos imortais. O mito de Ngowarutcha e Ngunetuma ${ }^{311}$ nos mostra não somente que a terra dos imortais é um lugar onde, num piscar de olhos, literalmente, o dia se transforma em noite e vice-versa, mas onde a caça são formigas, animais cuja imortalidade é atestada em inúmeros mitos ameríndios ${ }^{312}$. Ngowarutcha é uma criança que é abandonada por seus cunhados na floresta, exceto um. Trata-se, no mesmo mito, de uma dupla negação da periodicidade: 1) a viagem de Ngowarutcha para um local onde a periodicidade é rápida demais e 2) a negação da

\footnotetext{
310 "O perigo de qualquer desrespeito das mulheres a uma periodicidade estrita comprometer a ordem do mundo, com gravidade comparável à de uma suspensão da alternância entre dia e noite ou o embaralhamento das estações, evidencia-se também no modo como os mitos e ritos procedem para fundar uma equivalência entre os vários tipos de periodicidade do calendário." (Lévi-Strauss, 2006 [1968]: 200).

${ }^{311}$ Analisei este mito no tópico 3.1.2 - O lugar dos imortais - as idas e vindas da imortalidade.

312 Cf. Nimuendaju, 1952: 135-36, para os Ticuna e Lévi-Strauss, 2004 [1964]: 189-190, para uma generalização da imortalidade dos insetos para os amerídios.
} 
regularidade da troca de cônjuges, já que, expulsando o atual doador de esposas (as irmãs de Ngowarutcha) e futuro tomador, quebra-se a periodicidade da troca de cônjuges.

O pensamento indígena transpõe esta desregulação da periodicidade astronômica para a desregulação da periodicidade do corpo feminino. Vejamos como Lévi-Strauss demonstra esta transposição entre estes dois códigos:

"Se principalmente as mulheres precisam ser educadas, é porque são seres periódicos. Devido a isso, elas se encontram constantemente ameaçadas - e por causa delas, o universo inteiro - pelas duas eventualidades que acabamos de evocar. Seu ritmo periódico pode se desacelerar e imobilizar o curso das coisas. Ou pode se acelerar, e precipitar o mundo no caos. Pois o espírito pode com a mesma facilidade imaginar que as mulheres deixem de gerar e de ficar menstruadas, ou que sangrem sem parar e deem à luz a torto e a direito. Em qualquer uma dessas hipóteses, os astros que regem a alternância dos dias e das estações não poderiam mais desempenhar seu papel. Sempre afastados do céu pela busca, doravante impossível, de uma esposa perfeita, sua demanda jamais terminaria." (2006 [1968]: 459).

Uma desregulação da periodicidade feminina se desdobra num caos cósmico. Seja pelo excesso de sangramento ou pelo estancamento definitivo dele. Numa cosmologia em que Lua é o responsável por iniciar a primeira menstruação das moças, uma desregulação do corpo implica num comprometimento da alternância entre dia e noite, e entre as estações do ano.

O aparecimento da aura lunar na lua-cheia, para os Ticuna, indica que alguma moça da comunidade terá sua menarca: "entre los tikuna se cree que cuando se ve el aura de la luna en un plenilunio es una señal de que alguna niña tikuna comienza su pubertad" (Valenzuela, 2010: 59). No pensamento ticuna, Lua é o responsável por "abrir” a moça pela primeira vez. Dizer que a moça se "abriu" é uma maneira ticuna de afirmar que ela teve sua primeira menstruação. Por isso a metáfora da flor desabrochando, se abrindo, em diversas letras de canções de Festa de Moça Nova, em algumas delas fala-se da "flor da moça nova". Goulard descreve este momento da vida da menina. "Quando os seios "se abrem e começam a desabrochar", sua mãe cuida dela para não ser vista pelos outros habitantes da casa. (...) tudo na moça nova remete a uma atrativa flor, tanto para os habitantes da casa como para os seres da floresta" (2002: 113). Numa explicação sobre 
os sinais dados pelos seios quando a moça está para menstruar, Adélia ${ }^{313}$ me disse que "quando partiu um [bico do peito] é porque a menstruação já está perto". A mesma canção que mencionei acima, por exemplo, worecütchiga 1 (canção de moça nova), começa com a seguinte frase:

\section{Noritamawae botünacuaẽyiẽgü}

"No começo, quando ela se abriu [menstruou], ela sentiu no pensamento dela"

\section{Batünacuãẽyĩ̃güena}

"Ela já estava aberta e sentiu no pensamento dela"

A canção inicia mencionando que a menina se abriu, isto é, menstruou e sentiu no "pensamento" dela. Esta referência ao pensamento pode remeter também ao espírito da moça, já que uma mesma palavra (áễ) pode ser usada para designar espírito ou pensamento. Quando perguntei se a menina não sentia quando Lua copulava com ela, Adélia me disse que "ela não sente... parece que é na alma [ã '̃ $]$ da gente que acontece". Esta ideia de "abertura" ou de "floração" remete, mais uma vez, à maturidade do mundo e dos corpos. Valenzuela vai adiante com a comparação da imaturidade do "mundo" e a imaturidade do corpo. $\mathrm{O}$ autor menciona que a fala de seu informante demonstra uma conexão entre a madures e a menstruação. Ao menstruar a moça estaria amadurecendo, como uma planta: “.... se dice que en tiempos de Ngutapa (dios tutelar) el mundo era verde, biche, en el tiempo de hoy el mundo ya es maduro "naana marü ya". Esta última palabra " $y a$ " contiene la noción de maduro y es usada por el abuelo Jorge Manduca al referirse a la mujer luego de su menstruación "yagú"." (Valenzuela, 2010: 56). Outras palavras também se referem à menstruação e seu amplo espectro de significados para os Ticuna. Valenzuela aponta ainda a palavra daweeine, mas não informa a tradução, e a expressão ngewaka tã nguüchi que significa "novo desenvolvimento" (idem: 108, nota 117). Goulard mostra que a menarca é considerada "o sangue verdadeiro" (tagü-uchi)" (2002: 113). O termo que me foi dado para "menarca" é diferente, yaacügü, que pode conter a partícula " $y a$ " mencionada por Valenzuela.

A questão das "aberturas corporais" nos mitos da América do Sul foi examinada por Lévi-Strauss em $\mathrm{O}$ Cru e o Cozido, incluindo referências a mitos ticuna. $\mathrm{O}$ mito $\mathrm{M}_{53}$ dos Ticuna, intitulado “O Genro do Jaguar", talvez seja uma inversão do pensamento

\footnotetext{
${ }^{313}$ Uma de minhas colaboradoras ticuna, Adélia Luis Bitencourt.
} 
Ticuna sobre a Festa da Moça Nova. Ao sentar-se para jantar com seu futuro sogro jaguar, "a mulher do jaguar avisa ao caçador, em segredo, que a carne será bem apimentada e que, ao comer, ele não deve demonstrar contrariedade. $\mathrm{O}$ jantar realmente lhe queima a boca, mas o homem consegue, a muito custo, esconder seu sofrimento" (2004 [1964]: 153). O caçador tenta retornar para sua casa diversas vezes, mas se perde e sempre acaba voltando para a casa do jaguar. Ele então acaba casando com as filhas do jaguar e tornase um deles. Este mito pertence a um grupo que apresenta variações sobre o tema da “abertura corporal". Neste grupo, diz Lévi-Strauss, "todos os nossos mitos têm em comum uma dialética da abertura e do fechamento que opera em dois níveis: o dos orifícios superiores (boca, orelha) e o dos orifícios inferiores (ânus, uretra, vagina)" (idem: 165). O herói do mito ticuna estaria no polo do "herói continente: ele contém os gemidos quando o fazem ingerir uma comida irritante" (idem: 163), em oposição aos "heróis incontinentes", que não contém o riso, ou abre a boca enquanto come, ou abre as orelhas, ou seus esfíncteres, ou peida demais (idem: 163-164). O que temos neste mito, portanto, é um homem que contêm na boca (orifício superior do corpo) um alimento que não lhe é próprio, mas sim comida de jaguar. "Em consequência disso, o homem se identifica definitivamente ao jaguar" (idem: 154). Entendo que a Festa da Moça Nova celebra uma inversão deste mito. Uma moça que não contêm o sangue que lhe sai do corpo pela vagina (orifício inferior do corpo), o que, parafraseando Lévi-Strauss, a “identifica definitivamente” aos humanos após o ritual.

\subsubsection{3 - Controle}

Primeiramente, devemos ter em mente que a menstruação, para os ameríndios de modo geral, não é um processo orgânico. A menstruação, acontecimento fisiológico por natureza para o mundo ocidental, não é da ordem da natureza para os povos ameríndios. Partindo de sua etnografia sobre os Airo-pai, povo da Amazônia peruana, mas lançando mão de uma vasta etnografia do sangue nas Terras Baixas da América do Sul, Belaunde defende que a "menstruação certamente não é concebida como um processo orgânico que ocorre "naturalmente". Ela é produzida por outros, por meio de intervenção ritual ou manipulação física da genitália feminina, inclusive por meio do ato sexual" (2006: 217). Portanto, a intervenção mágica sobre a menstruação das mulheres é um destes "elos 
suplementares" no "encadeamento das causas naturais" próprias às operações mágicas ou rituais, tais como definidas por Lévi-Strauss ${ }^{314}$.

Para o agente da ação mágica, sua operação lhe parece, nas palavras de LéviStrauss, "uma adição à ordem objetiva do universo". Ou seja, sua ação se insere na cadeia de causas naturais, como "elos suplementares" desta cadeia. A seus olhos, as operações rituais lhe são exteriores, "como se ela não emanasse dele". Ao dizer que a menstruação não ocorre "naturalmente" devemos ter em mente que esta "natureza" é algo da ordem do dado, não do construído, nos termos de Wagner (2010) e desenvolvido no âmbito do parentesco ameríndio por Viveiros de Castro (2002b). Em suma, a menstruação nas mulheres é algo construído intencionalmente nas culturas ameríndias de um modo geral. Da mesma maneira que a consanguinidade deve ser construída, destacada de um fundo geral de afinidade ${ }^{315}$.

Dente de jacarerana, o mesmo que foi usado para fazer o caldo que criou os clãs, é usado como pingente pelas crianças. Usando este pingente a menina não terá problemas menstruais. Sua menstruação não vem tão "forte". Quando a menina usa este pingente a menstruação vem e vai embora no mesmo dia. Se não usar, a menstruação pode durar 3, 4 dias. Temos aqui, portanto, mais um exemplo de controle deste evento perigoso que acontece no corpo feminino. Interessante também o fato de ser o dente da jacarerana, o animal que foi usado para fazer o caldo que criou os clãs ticuna. Ou seja, os sabores/odores distintos proporcionados pelo caldo criaram os diferentes clãs e, em consequência, as duas metades que reúnem os clãs. Recordando que as metades são consideradas de "sangue diferente", há uma relação entre o caldo da jacarerana e o sangue para os Ticuna. Assim como vimos que há uma relação entre o sangue e odor. Podemos

\footnotetext{
${ }^{314}$ Sobre a distinção entre ação prática e ação mágica ou ritual: "Na verdade, a diferença entre a ação prática, dotada de rendimento, e a ação mágica ou ritual, desprovida de eficácia, não é aquela que se acredita perceber quando as definimos respectivamente por sua orientação objetiva ou subjetiva. Isso pode parecer verdadeiro se são consideradas as coisas de fora, mas, do ponto de vista do agente, a relação se inverte: ele concebe a ação prática como subjetiva em seu princípio e centrífuga em sua orientação, pois que resulta de sua intromissão no mundo físico. Enquanto que a operação mágica lhe parece uma adição à ordem objetiva do universo: para aquele que a realiza, ela apresenta a mesma necessidade que $o$ encadeamento das causas naturais, onde, sob a forma de ritos, 0 agente crê inserir apenas elos suplementares. Imagina-se, portanto, que ele observa de fora e como se ela não emanasse dele." (Lévi-Strauss, 1989 [1962]: 246-247, eu grifo).

315 Mostrei isso na análise do ritual de iniciação masculina dos Waimiri-Atroari, as festas Bahinja Maryba, Festa de Criança (Matarezio Filho, 2014 [2010]). Estas Festas são as responsáveis por criar a relação de consanguinidade do menino iniciado com seus parentes.
} 
pensar que se a carne da jacarerana foi um potente proporcionador da regra de casamento (não casar com o mesmo "sangue"), evitando que o mundo se destruísse mais vezes em virtude dos incestos que ocorriam incessantemente, esta potência ainda está na jacarerana e é usada nos dias de hoje como um regulador do sangue. A jacarerana, portanto, funda os "sangues" distintos no tempo do mito e controla o seu funcionamento adequado nas jovens púberes.

Há o controle tanto para que a menstruação não dure muito tempo, quanto o controle para que ela não chegue tão cedo para a menina. Quando a moça é bem cuidada, "remédios" são ministrados para que isso aconteça. Adélia me contou que a primeira menstruação "sempre acontece quando a moça tem 13 [anos]. Uma moça bem cuidada, forma com 13, 14 anos. Quando a mãe dá o remédio, a menina vai se formar com 13, 14 anos. [Tem remédio para não vir logo a menstruação?]. Tem, por isso que a moça se forma com 13, 14 anos. Se ninguém curar a menina, desde pequena, ela se forma com 11, 12, é assim. Agora é assim, nesse tempo, a moça se forma com 11 anos". Um destes "remédios" é preparado com o ovo da pata poponari, a mesma ave que aparece no mito de To 'oena e que vimos na análise do tópico 2.4 - To oena, a primeira moça nova, Capítulo 2 . Hilda me explicou o processo da seguinte maneira, "a gente cozinha ele bem, depois enterra, faz fogo e deixa passar uma semana. Depois de uma semana com o ovo lá dentro que tem que dar para a menina. É só remédio mesmo, é só para curar. Uma parte ela come, outra parte a gente enterra. Depois ela come o resto que está enterrado. [Tem que dar todos os dias?] Não, só uma vez. [A sua mãe deu para a senhora este ovinho?]. Foi, aí demorou mais para vir a menstruação, [veio com] 14 anos". Lembremos que a pata poponari aparece no mito com uma moça obediente, bem aconselhada e que não foge da reclusão, em contraponto à desobediência de To'oena.

A contaminação por puya, sobretudo através da menstruação, afeta principalmente a capacidade de caça do homem. Quando disse que se os tabus forem cumpridos o homem terá sucesso na caça, Hilda fez o seguinte comentário:

"Isso, por isso que quando ele vai caçar, ele pega peixe, ele caça o animal, e qualquer coisa ele vê. [O que ele vê?]. Ele vê a caça, ele fica mais esperto, porque não tem aquele puya. [O que é puya?]. Puya é aquela coisa que... quando você come a comida da mulher quando está menstruada, você fica sem força. A gente fica relaxado, preguiçoso. Porque ela tem alguma coisa nela, isso daí é o puya. Não dá vontade de caçar. Isso dá quando homem come a comida dela [que 
está menstruada]. [Fica panema?]. Isso. [E homem tem puya também?]. (Risos), não. [Não pode ter?]. Não. [Nunca?]. Nunca, só com alguma coisa, assim, que ele faz... [Não passa para ele o puya da mulher?]. Passa, por isso que homem, quando a mulher está assim, homem não pode mexer nela não. [Não pode ter relação sexual com ela?]. Não, não, até ela ficar boa, de dois dias, de três dias, de uma semana. Por isso que nenhum dos Ticuna tinha câncer antigamente. Era bem cuidado."

Pelo que entendi da explicação de Hilda, o homem não "produz" o puya - da mesma maneira que não menstrua - contudo é contaminado por ele, como quando não cumpre as proibições durante a menstruação de sua esposa ou em caso de homicídio.

\subsubsection{4 - Moral}

Um dos eixos principais do terceiro volume das Mitológicas é o exame dos bons modos entre os ameríndios, como remete o próprio nome do livro, A Origem dos Modos à Mesa. Isso aparece principalmente no final do livro, no terceiro capítulo da sétima parte, intitulado A moral dos mitos. No entanto, ao analisar o que poderíamos chamar de "moral dos mitos", Lévi-Strauss também realiza um exercício de simetrização para pensar os usos dos "bons modos" entre nós e para os povos ditos "primitivos". De acordo com o autor, o uso dos "bons modos" é invertido quando passamos da nossa sociedade para os "primitivos". Enquanto estamos preocupados com o que nos contamina de fora, os "primitivos" se preocupam em evitar que o corpo impuro contamine os seres e as coisas:

\footnotetext{
"Poderíamos dar muitos outros exemplos comprovando a completa inversão entre os motivos que os povos ditos primitivos e nós mesmos damos para justificar os bons modos. (...) Em lugar de, como pensamos nós, proteger a pureza interna do sujeito contra a impureza externa dos seres e das coisas, os bons modos servem, entre os selvagens, para proteger a pureza das coisas e dos seres contra a impureza do sujeito" (2006 [1968]: 456).
}

Neste sentido, o contato com a moça nova é passível de contaminação por puya, os "males" transmitidos pelo sangue. Há também consequências para as moças que não tomam as devidas precauções. Muitas referências, assim como entre os Ticuna, apontam para uma vida curta para as moças que não respeitarem as proibições: "morrerá na flor da 
idade", "seus cabelos ficarão grisalhos antes do tempo", "só conseguirão velhos para se casarem" (idem: 457). Assim, a negligência com as proibições "acelera a existência" das moças, em virtude de fatores internos. Para os outros, contaminados por elas, interrompe o curso da existência, em função de fatores externo (ibdem). Estes fatores também encurtam a vida dos outros, Hilda me contou que "se o pai ver ela [a moça], o irmão ver ela, aí morre mais rápido. Não vive tanto, a doença vem logo, rápido. Por isso que antigamente os velhos tinham uma vida longa. Cuidavam mais das coisas que fazem mal, se protegiam muito antigamente". Como vimos, um dos principais afetados pelo puya é o caçador, que fica panema em contato com o "sangue invisível” da menstruação.

O "protótipo das "meninas modelo"” dos Ticuna, portanto, fazendo eco às conclusões de Lévi-Strauss para a América do Norte, é concebido "à imagem das jovens menstruadas" (2006 [1968]: 453). A singularidade aqui está no fato de os planos moral e físico estarem indissociáveis e implicados um no outro. Para os Ticuna, as "virtudes femininas" e o controle das "funções fisiológicas" (ibdem) são obra de um mesmo trabalho de construção ritual do corpo e de aconselhamento. Capacidade para as tarefas domésticas, regularidade da menstruação e pontualidade no parto se misturam numa mesma educação moral e corporal.

\subsubsection{5 - Fertilidade}

Em um comentário sobre mito de origem ticuna ${ }^{316}$, Valenzuela dá uma explicação de porque a borra de jenipapo jogada na água ganhou vida, ou seja, se transformou em peixes. A razão deste acontecimento é bem anterior. O episódio em que uma vespa ou um gavião cão-cão (cõw - gralhão - Ibycter americanos) auxilia Mapana após ela ser amarrada na floresta por seu marido, $\mathrm{Ngutapa}^{317}$, é detalhado por Valenzuela: “Al oír sus quejas otro kou (avispa) la auxilia, la asea y la baña en yutaküchì, y el agua queda fecundada con sangre, sudor y semen. Desde ese momento, aquel que tiene contacto con la quebrada yutaküchí queda impregnado con los cuatro principios del ser tikuna. Ahí el agua se vuelve fertilizante, se "consagra el agua". La quebrada está en ambos mundos, el de arriba y el de abajo" (2010: 90). Ao ser auxiliada por “kou” ( cõw) - vespas na tradução de Valenzuela, mas pode ser o gaivão kou também, que se alimenta de vespas -

\footnotetext{
${ }^{316}$ Ver tópico 1.1 - Magüta - A Origem dos Ticuna, Capítulo 1, para a análise deste mito.

${ }^{317}$ Ver tópico 2.3 - O homem grávido - a questão de gênero como primeiro evento mítico, Capítulo 2.
} 
, este a banha nas águas do yutaküchí, que fica, desta maneira, fertilizado com sangue, suor e sêmen. Este detalhe raramente aparece nas narrativas do mito de origem, que começa com a história de Ngutapa. Contudo, o mesmo acontecimento está presente em todas as versões do mito de To'oena. Após a morte dela, seu corpo é lavado no Eware. A derrubada da sumaumeira mítica, wone - esta árvore tapava o céu, gerando uma noite eterna - por Yoi e Ipi, separa o yutaküchí em dois: Tchowatü, o rio celeste, e Eware, que está embaixo (Valenzuela, 2010: 91), no lugar onde moram os encantados. Estes rios continuam fertilizados. O sangue de To oena também é lavado no Eware, o que pode contribuir ainda mais para a fertilidade deste rio. Em outras versões do mito, o sangue de To’oena é lavado no Tünetü, o "igarapé preto", afluente do Eware. Pela etimologia da palavra "Eware" que Abel Santos Angarita dá a Valenzuela, este rio mítico também é enegrecido de jenipapo: $e=$ jenipapo, $w a=$ negro, "que foi enegrecido de jenipapo (Abel Santos conv. pers.).” (idem: 91, nota 96). Temos uma mistura poderosa atuando aqui, portanto. Os Ticuna são fruto das águas fluviais enegrecidas de jenipapo e tingidas com o sangue de To'oena e Mapana.

Temos, portanto, o encadeamento de três transformações internas ao mito de origem ticuna e que se relacionam estreitamente com a reclusão da moça nova no ritual: 1) Mapana é imobilizada, abusada por Ngutapa, fecunda os joelhos deste e a água do rio com seu sangue; 2) To'oena vê os trompetes proibidos, morre, seu corpo é lavado no rio tingindo-o de sangue; 3) a mulher de Yoi - "a moça do umari", uma transformação de To'oena -, depois de ser abusada por Ipi, se banha no Eware fertilizando-o também ${ }^{318}$. Veremos, na descrição e análise do ritual, que o banho da moça no rio é o último evento da Festa da Moça Nova.

\section{3 - Jenipapo e Urucum}

A relação com o sangue e seu antídoto, a pintura com o jenipapo, é um traço comum partilhado pela moça nova, o homicida e o recém-nascido ${ }^{319}$. Até onde sei, um

\footnotetext{
318 "Luego del abuso de Ipi (...) sobre la mujer de Yoi, esta se baña en Eware dando al agua nuevamente las propiedades generativas de la sangre y el semen” (Valenzuela, 2010: 91).

${ }^{319}$ Viveiros de Castro atesta a equivalência entre os rituais de menarca e os de primeiro homicídio entre os Tupinambá antigos. "Sem ter morto um inimigo um homem não existia; a execução ritual era a cerimônia de iniciação masculina, que assim, além de cancelar uma morte prévia, vingança restauradora,
} 
ticuna pode ser inteiramente pintado de jenipapo em três momentos de sua vida: 1) poucos dias após seu nascimento; 2) durante os rituais que um xamã realiza sobre um homicida, o assassino é inteiramente pintado com sumo de jenipapo caso ele tenha entrado em contato com o sangue do morto; 3 ) quando as moças são iniciadas também são pintadas. Ou seja, estes três momentos possuem uma forte necessidade de "retirada dos males", isto que torna as pessoas vulneráveis para tornarem-se outra coisa que não humanos. Nos três casos também estes "males" se relacionam com o sangue, seja a menstruação, o sangue da vítima ou o sangue do parto. Nestas situações a tintura do jenipapo possui algumas funções: 1) nas palavras de Adélia, "ele tira o puya, panema. Tira aquela coisa que não é boa, que tem no corpo. Para proteger a vida das pessoas"; 2) ele renova a pele da pessoa, retirando a pele velha; 3 ) ele inibe a propagação do cheiro do sangue.

Ondino me contou que seu filho recém-nascido estava com diarreia. Isso seria devido ao fato de uma mulher ter pegado no braço do neném. Ela foi soprada por um pajé na juventude e poderia ter ficado algum "bicho" (ngo'o) do xamã com ela. Ao pegar no braço da criança, ela pode ter transmitido a doença. Alguns dias depois que Ondino comentou isto comigo, a mulher apareceu na comunidade para soprar o filho dele, só assim ele melhoraria. Isso já havia acontecido antes, Ondino falou que já havia transmitido diarreia para um menino só de pegar no braço dele.

Para evitar este tipo de contágio, após uma semana, no máximo dez dias, de nascida a criança, passam jenipapo no corpo todo dela. Pude observar esse tratamento na minha afilhada, filha de Gabriel. Passada uma semana de nascida, vi sua avó (MM) passar jenipapo em seu corpo. O pai deve pintar os braços e as canelas, a mãe pinta os braços e as coxas. Observei, nos dias seguintes, que todos os filhos de Gabriel foram pintados de jenipapo. Se não passam jenipapo na criança, após mais ou menos uma semana de nascida, pode sair feridas pelo corpo dela ou, o que é pior, algum "bicho" (ngo'o) pode levá-la embora.

criava vida, inventava homens. Só um matador podia casar-se e ter filhos, pois os Tupinambá, semelhantes aí a muitos outros povos, equacionavam a função guerreira e mortífera do homem à função reprodutiva e vital da mulher. Os ritos da menarca e os do primeiro homicídio eram idênticos; as jovens "cumpriam o mesmo ritual dos carrascos" (Thevet, 1978:133): escarificação, tatuagem, reclusão, abstinência. Ambos, mulher e matador, derramavam um sangue vital para o grupo" (1986: 648, grifo meu). 
Algo digno de nota é o fato de Ipi, no mito de origem, ao se ralar junto com o jenipapo, não sangrar, mas sim transformar-se em jenipapo ralado, substância completamente antitética ao sangue no pensamento ticuna. A partir de uma única fruta, Ipi gera uma quantidade de sumo para pintar seu filho e o monte de borra que sobra é jogado no rio e se transforma em peixes, que serão pescados e se tornarão pessoas e caça. Poderíamos pensar numa oposição como Ipi : jenipapo/sêmen :: Yoi : sangue/ poluição? Mas onde estaria a conexão de Yoi com o sangue/poluição? Se esta proporção estiver correta, seria ele uma espécie de homicida poluído? Talvez, ninguém sabe ao certo se ele matou sua sobrinha, To'oena ou se foram somente seus "soldados"320. O filho de Ipi, ao que parece, já é um mortal. Diferente de seu pai e seu tio, ele não nasceu dos joelhos de seu pai, nasceu pela vagina de sua mãe, sangrando. Por isso, deve ser pintado de jenipapo, mais que isso, é o primeiro personagem da mitologia que será tratado com o jenipapo despoluidor. Yoi não precisa passar por tratamentos, não é um mortal, não tem males no corpo.

O jenipapo não é só um desentoxicador da pessoa que tem “males" no corpo, ele opera uma mudança de pele em quem é pintado. Esta ideia está presente entre os Barasana também ${ }^{321}$. O jenipapo serve para afastar os "males do corpo" (puyaüne) do neném ${ }^{322}$. Mas, principalmente, para trocar a pele do recém-nascido. Muito provavelmente, algo próximo do que fazem os Cubeo ao pintarem os bebês com jenipapo. "Los Cubeos aplican pintura negra (genipa) sobre el cuerpo de los bebés recién nacidos, para que muden su piel fetal (Goldman, 1963, 169)." (Hugh-Jones, 2011 [1979]: 242-nota 137).

Entre os Ticuna existem uma série de cuidados que são tomados para que a criança nasça com a pele clara, o que indica uma preferência pela cor mais clara da pele: “... [a mulher grávida] come as tripas do jacaré (jacaré-tinga), de modo que a criança deve

\footnotetext{
${ }^{320}$ A dúvida, na verdade, é se Yoi comeu da carne de sua sobrinha ou não. "A sobrinha (_ta'a) de Yoi tinha morrido cacetada pela turma e tinha se transformado em jacaré (coya), mas foi comida só uma banda dele. (...) Ninguém sabe se Yoi comeu a carne dela." (Anexo - 005).

321 “..., la aplicación de pintura negra al comienzo de Casa He está pensada con el propósito de cambiar la piel de los iniciados" (Hugh-Jones, 2011 [1979]: (241-42).

322 "Mesmo antes do nascimento, a parteira tem o cuidado de ralar jenipapo, com o qual a criança é pintada da cabeça aos pés, no primeiro dia, um velho costume instituído pelo herói cultural Yo'i (ver p. 128). Esta é considerada uma proteção eficiente contra qualquer mal que possa acontecer ao recémnascido." (Nimuendaju, 1952: 69)
} 
nascer com uma pele clara, beber a água do cipó barü, durante a gravidez produz o mesmo efeito, assim como olhar para as pessoas de pele branca. (...) Se uma menina é mordida por um tipo de formiga chamado kaë'na, ela posteriormente terá filhos de uma tez escura" (Nimunedaju, 1952: 68). O fato da moça ficar com a pele mais clara depois da reclusão é um indicativo de que trocou de pele também, com uma ajuda do jenipapo e a renovação de seus cabelos. O material para a reflexão sobre a cor da pele de uma moça reclusa por muito tempo me parece que está dado primeiramente no trecho do mito de origem dos Ticuna, chamado de "a filha do umari”. Esta moça, como mencionei acima, foi "guardada" por Yoi dentro de sua flauta, para que seu irmão, Ipi, não a encontrasse. O umari é uma fruta que, quando amadurece, fica amarelo claro. A cor não é exatamente branca, mas o amarelo do umari maduro remete à cor da pele que não toma sol.

O jenipapo é utilizado no pós-parto para não propagar o odor do recém-nascido. "Los ticuna insisten mucho en el poder de atracción por el olor: "se le pinta para que desaparezca el olor que tiene el niño. Tiene un olor que parece a la sangre de un animal descuartizado. Si no se hace, cuando el niño va al monte o al río, es contaminado"” (Goulard, 2009: 140). Do mesmo modo que o recém-nascido rescende a sangue, o odor da menstruação é o que atrai os ngo'o. Assim como os imortais, eles também são sedentos por sangue, mas tem medo de urucum ${ }^{323}$. Este fruto, junto com o jenipapo são excelentes repelentes de "bichos". Na versão do mito de Lua de Nimuendaju (1952), é pelo odor que Lua percebe que sua irmã o pintou de jenipapo - o mesmo jenipapo que ela ralou para pintar seu filho recém-nascido, fruto do incesto com seu irmão. Ou seja, o odor marcante do jenipapo é usado para aplacar o odor perigoso do sangue menstrual ${ }^{324}$. A mesma versão do mito de Nimuendaju diz que Lua enegreceu o Igarapé São Jerônimo lavando seu rosto para se livrar do jenipapo, a marca de sua transgressão. Sabemos que o São Jerônimo é conhecido na língua ticuna como Tünetü ou igarapé preto. Em algumas versões do mito de To'oena, é neste mesmo igarapé que a carne da heroína será lavada, tingindo o igarapé de vermelho. Deste modo, o que era negro e símbolo do incesto torna-se vermelho, símbolo da manutenção da reclusão.

\footnotetext{
323 "Ngòo: que hace daño. Los seres inmortales, acechantes por sangre, tienen miedo al achiote." (Valenzuela, 2010: 97, nota 103).

324 "Sus propiedades espirituales o las creencias alrededor de éste son principalmente su capacidad de ocultar el olor de la sangre y el cuerpo de la muchacha iniciada, al olfato y gusto de los inmortales, se dice que con su sabor amargo se "amarga" el cuerpo" (Valenzuela, 2010: 98).
} 
A tarefa de bater o tururi e ralar o jenipapo de madrugada, durante a Festa da Moça Nova, é iniciada com o toque do aru, as duas atividades começam juntas (Nimuendaju, 1952: 86). Contudo, Nimuendaju nos dá uma informação importante sobre algo que acontece neste momento da Festa: "antes desse trabalho ser iniciado, o tio paterno vai até a reclusão da garota para fechar suas narinas com um gesto mágico que consiste em torcer alguma coisa; se ela sentir o odor do jenipapo prematuramente, ela vai morrer" (ibdem). Não saberia explicar porque o mesmo jenipapo é passado no corpo da moça para protegê-la dos "bichos" e é também uma ameaça. Assim como os "bichos", a moça é vulnerável ao cheiro do jenipapo, mas principalmente vulnerável ao falso jenipapo.

Como vimos no tópico 3.2.2 - O ataque dos "bichos", do Capítulo 3, um dos artifícios dos "bichos", principalmente o Tchurara, é usar um falso jenipapo para iniciar as moças que são negligenciadas por seus parentes. Podemos notar no trecho da "canção do to 'cü' - para ser cantada dentro do to 'cü, gravada com Francisco - que a metáfora da moça nova dentro do curral, além de "vegetal" (Goulard, 2009, 2010), também tem relação com a crisálida da borboleta:

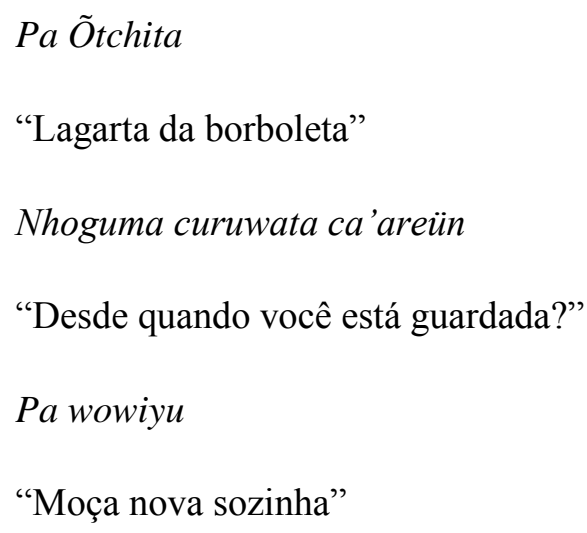

A moça seria a lagarta dentro de seu casulo, que é o quarto de reclusão. Entretanto, ao que tudo indica, o quarto apenas cumpriria o papel de proteger a maturação da "lagarta", o que tornaria a moça nova uma jovem ticuna seria o jenipapo com que ela é pintada e os conselhos do cantor. Isto fica evidente na importância dada ao jenipapo na canção da moça nova que foi iniciada pelo Tchurara. Por mais que tenha passado pela reclusão, ao ser pintada com o falso jenipapo do Tchurara a moça é iniciada como um deles. Por isso que o cantor deve orientar a moça e os festeiros para que ela não fique sem canto e sem jenipapo. 
Vimos acima, no tópico 4.4.3.2 - Periodicidade, uma canção de moça nova em que o sol é evocado como um dos responsáveis pelo resguardo da menina. O sol também está intimamente relacionado ao urucum que é passado no corpo da moça. No livro Histórias de los abuelos de Moruapü, organizado por Camacho (2000), existem mitos de origem do astro. Sol chegou onde sua sogra cozinhava sumo de urucum. Ao pegar a vasilha onde era cozido o urucum ela se quebrou. Uma parte escorreu por seu corpo, outra caiu no chão. O que sobrou no fundo da vasilha ele tomou. Voltando da caça, carregando uma anta, algo impossível para uma só pessoa, Sol recolheu o urucum que estava no chão e tomou tudo. "Neste momento, saiu correndo da casa, ali recebeu um grande Poder, chauaru, e o sol tornou-se muito forte" (idem: 39). O urucum passado no corpo da moça, portanto, evoca essa história de Sol, que era uma pessoa que tomou uma panela de urucum fervendo e tornou-se sol. A eternidade do fogo do sol é passada no corpo da moça. "El sol fue el que tomó el zumo del achiote [urucum] y por eso es resplandeciente, caliente, don Paulino dice que el achiote en el cuerpo de la niña es con ese mismo sentido, que no se queme, que no se acabe, es cuerpo y es territorio". (Abel Santos com. per.)" (Valenzuela, 2010: 99)

Pelo mito que resumi acima, sabemos que o sol é incandescente, quente, porque no tempo mítico ele tomou um líquido de urucum quente. Mas há ainda uma relação entre urucum, tabu do incesto, as frequentes queimadas pelas quais o mundo passou e a moça nova. Devido ao fato das pessoas se casarem da maneira errada, a terra se queimava inteira e rapidamente. O urucum liquefeito é usado para "marcar a terra" em que se vive, desta forma o fogo se apaga no ponto em que foi marcada com urucum. O corpo da moça é marcado de urucum pelo mesmo motivo, para evitar os casamentos errados ${ }^{325}$.

Quando retomarmos o tema do jenipapo e do urucum será para mostrar como eles são manipulados na Festa. O começo deste capítulo deu um panorama do xamanismo para os Ticuna. Os pajés são fundamentais, como veremos, para uma boa realização dos rituais de iniciação das moças. Esta figura reaparecerá em diversos momentos da Festa. Mas,

325 “El achiote [urucum] es para emplumar el cuerpo de la Worekü, eso es porque la tierra no era como ahora, cada rato se quemaba, pues al achiote, Yoí le dijo, tienen que hacer eso, deben hacer, si quieren vivir, con eso es que van a vivir. Deben marcar con achiote la tierra donde van a vivir si quieren vivir, van tirando mojando, arrojando, mojando, para que la quema de la tierra llegue hasta ahí, que se apague la tierra quemada ahí. Antiguamente se quemaba la tierra rápidamente se quemaba y harto y así es que se iban casándose entre ellos mismos, como la tierra se quemaba Yoí dijo que debe coger achiote y hacerlo líquido, macerarlo y marcar con achiote, eso que venía quemando, los que se salvaban se casaban entre ellos y el resto del mundo se moría. Así es por eso es que es importante en el cuerpo de la Worekü. [Domingo Pedro, comunidade de Arara, Colômbia]" (Valenzuela, 2010: 128). 
gostaria de destacar, principalmente, a reflexão que desenvolvi sobre o sangue entre os Ticuna, em especial, sobre a menstruação. Apesar de os preparativos começarem bem antes, a primeira menstruação da moça é um sinal importante para que o ritual tenha início. Além disso, as implicações da menarca estão tanto relacionadas ao corpo da moça, que passa por uma intensa transformação, quanto às relações dos Ticuna com o cosmos e seus habitantes.

O próximo capítulo é o início da abordagem da Festa da Moça Nova propriamente. Começo por uma via privilegiada, pela música. Digo privilegiada pois para os Ticuna música e festa são indissociáveis. No Capítulo 5, portanto, temos uma incursão pelo canto entoado no ritual, mas partindo de um enfoque mais amplo, do som às canções. 


\section{Capítulo 5 - Canções da Festa da Moça Nova}

Este capítulo trata especificamente da música Ticuna executada na Festa da Moça $\mathrm{Nova}^{326}$. Mas porque não a música Ticuna de uma forma geral? Pelo simples fato de que seria necessário escrever uma tese inteira para dar conta da relação que os Ticuna possuem com os diversos gêneros musicais presentes atualmente na cultura deste povo. Entre os Ticuna existem inúmeros grupos musicais dedicados à música gospel, à cumbia, ao technobrega, ao forró, dentre outros gêneros ${ }^{327}$. As músicas da Festa representam apenas uma pequena parcela do som presente na vida destes índios.

Uma primeira etapa, diríamos de uma Antropologia do Som (Oliveira Pinto, 2001), se impõe para delimitarmos, antes de tudo, o que os ticuna consideram música, destacando-a dos sons que não o são. Estamos, portanto, no âmbito do que Menezes Bastos chamou de "metassistema de discurso verbal sobre a música" (1999[1978]: 197). O próprio termo "música”, por exemplo, que consideramos tão básico, segundo Oliveira Pinto, do ponto de vista de outros povos, "talvez até nos idiomas não-ocidentais como um todo", pode ser uma "abstração inútil” (2001: 244). Esta primeira tarefa, então, visa uma definição "êmica" precisa de alguns termos que se disponham no continuum entre os pólos "som humanamente organizado" (Blacking, 2000[1973]) e "corrente sonora qualquer" ou ruído (Meneses Bastos, 1999[1978]).

\section{1 - Som e Silêncio}

Existem muitas palavras na língua ticuna para indicar diversos tipos de som. Começemos pelos termos que mais se aproximam da noção de ruído. Encontrei duas palavras para "barulho" ou "ruído", na’aga e cucu. Com o sufixo pluralizador_gü

\footnotetext{
${ }^{326}$ Abro exceção apenas para as canções de ninar, no tópico 5.2.3.1 - Acalantos.

327 Os Cds de música Ticuna são facilmente encontrados nos camelôs que vendem Cds piratas em Tabatinga. Os próprios grupos e artistas vendem suas gravações também. Além disso, há uma intensa circulação de arquivos de música (MP3 e WMA) entre os pendrives dos ouvintes.
} 
(na'agagü e cucugü), elas indicam um barulho muito forte, um barulhão. Não tenho exemplos de uso de na'aga. Сucu é usado, por exemplo, para indicar o barulho da chuva

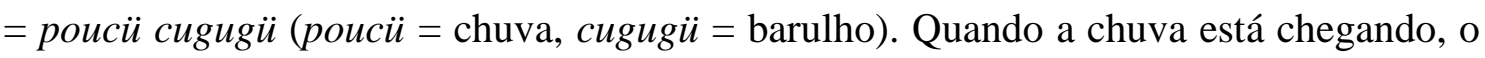
som dela é pocünacucu ou pocünadova. Os sapos quando estão cantando/fazendo barulho, estão cucugü. A zoada de muitos pássaros é designada como cucutama ou

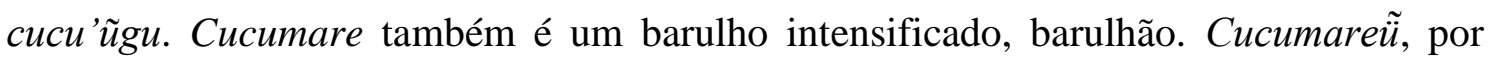
exemplo, seria "gritar muito forte". A palavra cu'tene, por exemplo, pode se referir ao bater de um sino ou o som que faz a semente de milho que cai no fundo da igaçaba. $\mathrm{O}$ silêncio é designado pelo termo tchianẽ $\tilde{u}$.

O som é um recurso importante para a comunicação na floresta densa. A localização das pessoas que vão para a roça se dá por meio sonoro. $\mathrm{O}$ campo visual de quem entra na floresta não passa de 10 metros. A partir daí, localiza-se onde a pessoa está com chamados: "uuuuuuu", "ngia [vamos!]”, "Mariuuuuuuu" (quando estão chamando Maria, p.ex.), etc. A pessoa escuta e responde da mesma maneira. Nas pescarias, o som é formado na região mais posterior da boca e nasalizado: "ũũũhh". Este som é produzido de cima da canoa, no igapó, e o outro pescador responde com o mesmo som. Assim localiza-se sua direção ou marca-se o momento de se encontrar.

Somente a muito custo consegui encontrar uma palavra ticuna que correspondesse à "melodia". Perguntei ao meu principal informante como se diz "melodia" em sua língua. Ondino é um dos ticunas que melhor falam português que eu conheço, um grande cantor e ávido de conhecer palavras novas em português. Ele conhecia a palavra, sabia que se relacionava com música, som, mas não sabia exatamente o que significava. Eu disse a ele: "é como se eu cantasse uma canção, mas não falasse a letra”. Em seguida, assobiei a melodia de uma canção conhecida dele. Imediatamente ele falou, "claro, melodia é fene'ewa". Pensei, "foi mais fácil do que eu imaginava". Para ter certeza que ele tinha entendido, perguntei o que era fene'ewa, ele respondeu: "fene'ewa é assobio". Muitos dias depois eu descobri, como apresentarei em seguida, uma palavra mais próxima de "melodia" em língua ticuna. Naquela tarde achei melhor deixar como estava. Ondino saiu para seus afazeres.

Numa outra ocasião, conversando com Ondino sobre as canções que tínhamos gravado naquele momento, sobre dois mascarados To'ü (macaco caiarara ${ }^{328}$ ) e Mawü

${ }^{328}$ Palavra do tupi, kaya'rara, de ka'i "macaco" + a'rara "arara", Dic. Houaiss. 
(mãe da mata), ele me disse que estas canções eram as mesmas, só mudavam as palavras. Tínhamos chegado ao ponto que eu queria. Segundo me falou, as duas canções tinham o mesmo "ritmo". Perguntei, então, como se diz "mesmo ritmo" na língua ticuna, e ele contou, "nawüigumare". Aos poucos fui descobrindo que o termo wüigu corresponde a tudo o que tem numa canção, exceto as palavras. Ou seja, wüigu, assim como nãga, significam ritmo (durações rítmicas) e melodia (alturas) de uma canção. Estas palavras não servem para designar o som dos instrumentos (ritmo, melodia e timbre), apenas da VOZ.

Ondino possui um raciocínio espantoso para minhas questões musicais. Ao entender o que eu estava buscando, ele me pediu para cantar uma cantiga de roda clássica, O sapo não lava o pé. Depois que eu cantei, ele cantou uma versão da música que eu nunca tinha ouvido antes. A canção dele tinha exatamente as mesmas palavras que a minha, mas a melodia e o ritmo eram totalmente diferentes. Ondino então concluiu que esta diferença entre uma versão e a outra era wüigu ou nãga.

Sabemos, como bem destaca Wisnik, que "as frequências sonoras se apresentam basicamente em duas grandes dimensões: as durações e as alturas (durações rítmicas, alturas melódico-harmônicas)" (1989: 18). Contudo, alerta o autor, estas duas dimensões não são campos totalmente distintos. Pelo contrário, haveria uma passagem entre os dois campos. Podemos, p. ex., transformar uma frequência rítmica em melodia acelerando as "batidas" e tornando-a um contínuo sonoro para os ouvidos ${ }^{329}$. Por outro lado, podemos pensar a dimensão da melodia-harmonia como "uma outra ordem de manifestação de relações rítmicas" (1989:19). Portanto, duração e altura, ritmo e melodia, são opostos que convivem em um mesmo continuum, "uma mesma sequência de progressão vibratória" (ibdem). Além de serem fruto de um mesmo continuum vibratório, devemos considerar que, lembra o autor, ritmo e melodia são interdependentes, "um funcionando como portador do outro. É impossível a um som se apresentar sem durar, minimamente que seja, assim como é impossível que uma duração sonora se apresente concretamente sem se encontrar numa faixa qualquer de altura, por mais indefinida e próxima do ruído que essa altura possa ser" (1989:19).

\footnotetext{
${ }^{329}$ Segundo Wisnik, "se as frequências rítmicas forem tocadas por um instrumento capaz de acelerá-las muito, a partir de cerca de dez ciclos por segundo, elas vão mudando de caráter e passam a um estado de granulação veloz, que salta de repente para um outro patamar, o da altura melódica" (1989: 18).
} 
Não nos espanta, então, que os Ticuna tenham unido em um único termo tudo o que está na canção, exceto as palavras. Ou seja, retirando as palavras de uma canção e não levando em conta qualquer acompanhamento instrumental, sobram apenas melodia e

ritmo. É a união destas duas dimensões musicais que estes índios denominam wüigu ou nãga. Um instrumento de percussão ticuna também parece partilhar desta mesma indistinção entre melodia e ritmo. Ao escutar um músico ticuna percutindo um tamborim tutu, não temos dúvida de que se trata de um instrumento para marcar o ritmo, com suas batidas cadenciadas. Contudo, junto à pele resposta deste membranofone, há uma corda que vibra produzindo um som contínuo. Temos, então, num único instrumento e simultaneamente, nas percutidas do tocador, a produção de um ritmo, como num membranofone comum, e a produção de um som passível de ser registrado numa faixa de altura, dependendo da frequência vibratória do cordão preso atrás do instrumento. Contínuo e descontínuo são condensados no corpo de um único instrumento musical.

\subsection{1 - "Ficar no silêncio"}

Vimos no Capítulo 3, tópico 3.2.2 - O ataque dos "bichos", uma canção com um nome bem peculiar. Quando perguntei o nome da canção da moça que foi iniciada pelo Tchurara, Ondino me disse que se chamava "canção da moça nova que foi levada pelo bicho porque ninguém cantou para ela”. Este título nos revela algumas coisas. Primeiro, para muitas das canções não há uma preocupação entre os Ticuna de se colocar um nome nelas. Este título foi arranjado apressadamente por efeito da minha pergunta, muito provavelmente ele não existia antes. O nome da canção foi tão improvisado quanto as próprias canções o são. As extensas canções - tanto no repertório quanto na duração delas - são em parte memorizadas e em parte improvisadas na hora, dificilmente se registra no gravador exatamente a mesma canção. Em segundo lugar, o título da canção demonstra como o canto sintetiza o ritual. Ter alguém que cante para a moça é quase sinônimo de realização da Festa da Moça Nova.

"Ficar no silêncio", dizem os Ticuna, é o grande perigo que correm as pessoas que não passam pelos rituais durante a vida. Este risco é enfatizado nas canções da Festa, não somente para a moça nova, mas também para as crianças e bebês. Temos um exemplo disso na "Canção de Ralar Jenipapo", que retomaremos adiante. O trecho que nos interessa agora é este: 


\section{Nü'ünmayetcharü tchaipüne \\ "Eu faço barulho com o meu pedacinho de avaí" \\ Ngemacanĩwai nünematatürü taũtürüwai toüncuyangepüne'ün \\ "Por isso que [o bebê] não ficou no silêncio"}

Esta música é cantada para as crianças que são pintadas na Festa. Há sinais disto ao longo da letra, principalmente no final da música, quando a criança é chamada por um vocativo indicado pela partícula pa (pa torü buriyana = "nossa criança"). O cantor está dizendo que ele pegou o aru (instrumento de percussão) e a criança não vai ficar no silêncio. Podemos notar, portanto, esta oposição recorrente, entre cantar para os neófitos ou deixálos em silêncio, a mercê do canto de outros seres.

O som, como nos mostra o desenrolar do ritual da moça nova, forma pessoas entre os Ticuna, mas não necessariamente forma o cosmos. Cabe neste ponto um pequeno parêntese para uma crítica à ideia de uma inextricável relação entre o código auditivo e as cosmogonias. Vejamos, por exemplo, o seguinte trecho de Wisnik:

"Marius Schneider (o estudioso mais informado sobre o lastro mítico do mundo modal, que ele estudou nas mais diferentes tradições), afirma que todas as cosmogonias têm um fundamento musical. "Toda vez que a gênese do mundo é descrita com a precisão desejada, um elemento acústico intervém no momento decisivo da ação". Em outros termos, sempre que a história do mundo fosse bem contada, ela revelaria a natureza essencialmente musical deste" $(1989: 33)^{330}$.

Uma possível crítica a ser feita é se outros códigos não poderiam ser produtores do cosmos. A lição estruturalista nos ensina que não se deve privilegiar um determinado código em detrimento dos outros. Lévi-Strauss deixa isso bem claro em diversas passagens de sua obra, especialmente na "Abertura" de O Cru e o Cozido (2004 [1964]: 19-52). Em A Oleira Ciumenta, o autor é categórico, “[a] originalidade da reflexão mítica está, pois, em operar por meio de vários códigos" (1986: 215). Neste mesmo livro há também uma célebre crítica feita a Freud. Dois erros do pai da psicanálise em suas análises míticas são enumerados por Lévi-Strauss em sua crítica: 1) "querer decifrar os mitos por meio de um código único e exclusivo [o código sexual], quando é da natureza

\footnotetext{
${ }^{330}$ Mais adiante Wisnik menciona uma frase de Schneider que sintetiza esta ideia: "A fonte de onde emana o mundo é sempre uma fonte acústica" (Schneider apud Wisnik, 1989: 34).
} 
do mito empregar sempre diversos códigos, de cuja superposição decorrem as regras de tradutibilidade (...) [2)] o segundo erro consiste em acreditar que, dentre todos os códigos à disposição dos mitos, um ou outro seja obrigatoriamente empregado" (idem: 231). O código "sonoro", portanto, pode ser privilegiado em algumas cosmogonias, como as hindus ou judaico-cristãs, mas está longe de ser o único possível.

Por outro lado, o código "sonoro" está bastante presente nos mitos ticuna que abordamos até aqui. Uma das referências foi a variante ticuna do motivo do "chamado da madeira podre" ${ }^{331}$. A história do carapanã, que abordei brevemente ${ }^{332}$, já nos mostrava uma relação entre o som e a reclusão. Há neste mito uma referência implícita à Festa da Moça Nova. Por meio desta narrativa podemos deduzir que Ipi aparece como uma versão masculina de To'oena. Lembremos que a heroína do mito foi atraída inicialmente pelo som dos trompetes proibidos para ela. Ipi é atraído pelo som no mito de origem, quando encontra sua cunhada e tem uma relação sexual com ela. Na história da origem do carapanã, Ipi também desobedece a ordem de seu irmão depois de escutar o som dos mosquitos. Temos, portanto, um grupo paradigmático com três personagens que se substituem em função de suas relações com o "chamado" do som externo. 1) To'oena, que sai inadvertidamente da reclusão ao ouvir o som;2) Ipi, que procura o som, mas é proibido de ver o que o produz e; 3) A filha do Umari - que já vimos ser uma variante de To’oena - também sai de sua reclusão na flauta de Yoi, numa explosão de risos.

Por meio deste quadro de relações dos personagens com um "chamado" sonoro começamos a antever a importância que o código auditivo possui nos mitos e na vida ticuna. Comparando um mito apinayé (M9) ${ }^{333}$ com o mito bororo de referência de $\mathrm{O}$ Cru e o Cozido (M1) e um mito dos Timbira Orientais (M10), Lévi-Strauss tira conclusões sobre a relação entre ruído e silêncio que nos ajudam a entender esta mesma relação nos mitos e no ritual dos Ticuna:

\footnotetext{
${ }^{331}$ Ver Capítulo 3, tópico 3.1.4 - Festa e imortalidade, e Capítulo 4, tópico 4.1.3 - Ma'ũ e ã'ẽ componentes da pessoa.

332 "Nhuãcü nango'ün go agu" (Firmino \& Gruber, 2010, vol. 1), ver Capítulo 3, tópico 3.2 - Os "bichos" (ngo'o).

333 Vimos este mito, que fala do "doce chamado da madeira podre", no Capítulo 4, tópico 4.1.3 - Ma'ũ e $\tilde{a}^{\prime} \tilde{e}$-componentes da pessoa.
} 
"Em M1 e M10, o herói é sujeito de ruído; faz um pouco de ruído, mas não muito. Em M9, ele é objeto de ruído, e ouve muito, não pouco. Não se poderia supor que, nos três casos, o caráter da vida na terra, de ser - por sua duração finita - uma mediatização da oposição entre a existência e a não-existência, é concebido como uma função da impossibilidade em que o homem se encontra, de se definir sem ambiguidade em relação ao silêncio e ao ruído? " (2004 [1964]:179-180)

Estes mitos apresentam, segundo Lévi-Strauss, uma "proposição metafísica" (2004 [1964]: 180). Esta mesma proposição - que relaciona ruído e silêncio com existência e não-existência, de diferentes maneiras - podemos encontrar na Festa da Moça Nova. A moça deve permanecer em silêncio durante toda a reclusão, sob pena de morrer atacada por um ngo'o. Ao mesmo tempo em que a moça deve permanecer em silêncio, ela não pode ser deixada no silêncio. Ela e as crianças que são iniciadas. Deixá-los no silêncio significa dar a chance para que outro ser maléfico os inicie. O Yureu ou Tchurara, o "bicho" mais perigoso para a moça nesta fase, possui uma super-audição. Qualquer um que evoque seu nome, mesmo que no volume mais baixo possível, corre o risco de atrair este "bicho" e ser devorado. Os imortais (ü'üne) também possuem uma potente audição, contudo, insistem em chamar os mortais e estes não os ouvem.

A Festa dura cerca de três dias, assim tem seus momentos de maior ou menor animação. Contudo, durante toda a Festa, mesmo que esteja bem esvaziada, há ao menos uma pessoa percutindo um tamborim (tutu). Ou seja, o tutu produz um som contínuo que é ouvido durante todo o ritual. A música está presente do começo ao fim da Festa, sob pena de outros seres de audição aguçada perceberem o silêncio e causarem algum mal.

\section{2 - Da voz ao canto}

\subsection{1 - Voz, canto e cantor}

"A serpente do Gênesis era gente. Como ela enganou Adão, virou serpente. " Prof. Ondino, cantor ticuna

A voz, assim como o idioma, são designados pela palavra ga. Muitas palavras são decorrentes desta raiz. Vimos no Capítulo 1, tópico 1.3 - Onomástica e corpo, que este 
morfema pode significar a "língua", a "palavra', a "voz", o "dito" (Goulard, 2009: 91-2). $\mathrm{O}$ ato que o pássaro japiim faz de imitar o canto, a "voz" ( $g a)$, de outros pássaros é chamado ni ĩyauga, ou seja, imitar outra voz. Ga pode significar também “som” de modo geral ou "barulho". Neste caso, quando intensificado, torna-se na'aga ou na'agagü, muito barulho. Uma das palavras que os Ticuna traduzem como "música" parece conter esta partícula, pagane. E não somente a "voz" ou a "fala" é designada por ga, a "língua" também recebe o mesmo termo. Por exemplo, língua portuguesa $=$ corigüga $($ corigü $=$ brancos/ ga = língua), espanhol dos peruanos = peruanagüga .

Para indicar o som de alguma coisa os ticuna colocam o sufixo _gawa, que aparentemente contém a mesma partícula _ga, na palavra que se refere ao objeto que produz o som. Por exemplo, $\underline{\text { som do violão }}=$ violãogawa ou som do tamborim tutu $=$ tutugawa. Neste sentido, os instrumentos musicais também teriam a sua "voz", assim como os humanos. Outros instrumentos musicais têm seu som referido por palavras específicas. Por exemplo, o som do bastão de ritmo (aru) é mencionado na "Canção de Ralar Jenipapo", no mesmo trecho que vimos acima:

\section{Nü'ünmayetcharü tchaipüne}

"Eu faço barulho com o meu pedacinho de avaí"

O instrumento inteiro é referido por sinédoque como "meu pedacinho de avaí". As sementes de avaí são uma das partes que compões o aru. A palavra tchaipüne ou somente tchai remete justamente ao som deste instrumento, resultado do entrechoque destas sementes. Tutucutchi é a palavra usada para indicar que se está batendo no instrumento de casco de tracajá, tori. Dirieũ designa não somente o som do idiofone ba'ma, mas também engloba o som do vento chegando ou do trovão (diriane) e o som do queixada (dirimütanü).

Durante meu trabalho de campo dediquei grande parte de meu tempo gravando, transcrevendo e traduzindo canções, referidas com a terminação _tchiga, termo que possui a mesma raiz, _ga, vista acima (Goulard, 2012: 26-27). Tchiga é um termo da língua ticuna usado para se referir à diversas ideias relacionadas à "palavra". Segundo a linguista Montes Rodríguez, em um sentido amplo, tchiga corresponde à "palabra" de una "entidad mítica o humana, el significado de las cosas, la historia de algo ou alguien, las historias míticas" (2005: 58). Esta mesma autora dá os seguintes exemplos, Yoitchiga seria "la historia, el cuento, el mito y la palabra del héroe mítico Yoi". Cutchiga pode ser traduzido como "tua história", trata-se de um termo que aparece com frequência nos 
"cantos rituales de iniciación femenina posiblemente para referirse a todo el proceso vivido por la joven iniciada". Tchiga é uma palavra inalienável, portanto, sempre é referida com um "dono", no máximo pode-se dizer natchiga, a palavra, história, mito, conto, significado de alguém ou de algo.

Outra palavra para se referir à canção é wiyae e, por extensão, temos a palavra para "cantor", wiyaeruũ. De acordo com Goulard, "[o] vocábulo wiya-e reagrupa todos os tipos de cantos do repertório ticuna" (1995: 140). Uma determinada canção pode ser referida com este termo, wiyae, como, por exemplo, tori arü wiyae = "canção do instrumento musical tori”. Mas a mesma canção pode ser chamada toritchiga, o que é mais recorrente, indicando que se vai cantar uma história sobre o tori. Já o verbo "cantar" seria cagü. Cagü' ǘ seria uma cantoria, mais de uma pessoa cantando junto.

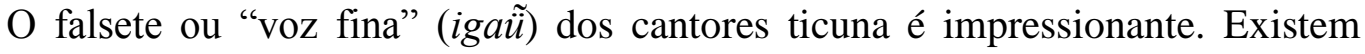
canções entoadas totalmente em falsete, canções que alternam o falsete e a voz "normal" e canções sem falsete. Durante meu primeiro trabalho de campo, Severino cantou duas

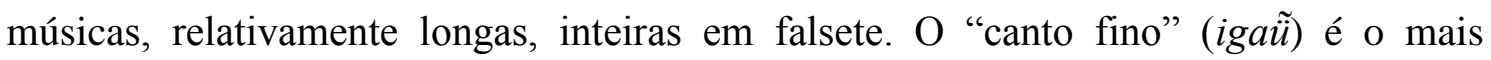
valorizado entre os Ticuna, ao contrário, p. ex., dos Suyá (Seeger, 1987). Ao que tudo indica, é possível usar esta mesma palavra, igaũu, para se referir ao volume baixo da voz, que não se pode ouvir de longe ${ }^{334}$. Já a palavra utilizada para se referir à voz grave (a $\left.\tilde{u} g a \tilde{u}\right)$ é a mesma que se usa para dizer que o som da voz é volumoso. Isto se conecta com o próprio modo de cantar dos ticuna. Os bons cantores, homens e mulheres, cantam com a voz bem aguda e num volume muitas vezes inaudível, algo que foi notado por Nimuendaju (1952) $)^{335}$. Além disso, um homem que cante em falsete dificilmente conseguirá emitir um som num volume muito alto. Para dizer que um som é muito alto, usa-se a palavra para voz grave junto com o sufixo tchiü. Desse modo, temos a $\tilde{u} g a \tilde{u} t c h i \tilde{u}$, um "barulhão", som ensurdecedor. E para um som muito baixo, inaudível, igaũtchiü. Podemos deduzir, portanto, que as duas palavras devem corresponder também, respectivamente, a som gravíssimo e som agudíssimo. Som agudo e grave também podem

\footnotetext{
${ }^{334}$ A palavra iraga também denota "som de volume baixo".

335 A inteligibilidade das palavras proferidas no ritual é muitas vezes considerada secundária: “... uma função primária da língua é ser um meio de comunicação entre as pessoas. Por definição, as pessoas se comunicando devem entender uma a outra. No ritual, a linguagem parece ser usada de maneira que viola a função de comunicação" (Tambiah, 1968: 179).
} 


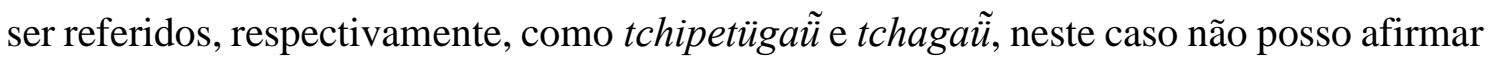
que exista referência ao volume do som.

Severino comentou comigo que é bom cantar quando tem pajauaru e seu caldo

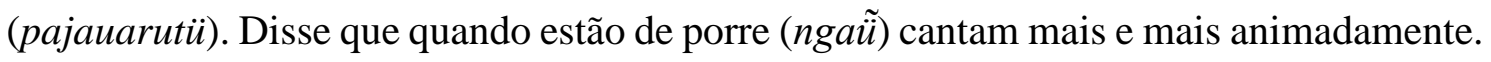
Pude notar isto pessoalmente nas Festas de Moça Nova das quais participei. Ouvi duas pessoas comentando sobre a embriagues dos cantores numa das Festas da comunidade de Vendaval. Segundo Lucita, professora em Vendaval e natural de Campo Alegre, o cantor deve saber cantar quando não está de porre também. Disse que em Campo Alegre existem muitos jovens que cantam sem estarem bêbados. Clarícia, cantora da comunidade de Vendaval, diz que antigamente tinham mais jovens que cantavam durante a Festa. Celso, vice-cacique de Vendaval, também comentou que em Vendaval as velhinhas cantoras já morreram e as pessoas que cantam hoje só cantam quando estão de porre, por isso, não cantam bem.

Os cantos são entoados, de preferência, depois que anoitece. Certa vez, chamei Ondino para fazer umas gravações com o sol ainda quente, ao que ele respondeu prontamente, "não sou guariba para cantar de tarde". A combinação perfeita para se cantar é ter um tamborim em punho e uma cuia de caldo de pajauaru (bebida fermentada) para se tomar. Combinação esta que é propiciada pelo ritual da moça nova. Quando vou fazer as gravações de cantos, invariavelmente as pessoas preferem cantar acompanhadas do tamborim tutu. Acredito que se sintam mais à vontade cantando com o instrumento. Para os Ticuna cantar as músicas da Festa da Moça Nova é praticamente indissociável de acompanhar com o tamborim. Quando perguntei a Ondino quando ele costuma cantar, ele disse que gostava de cantar de noite, quando estava deitado na rede. Neste horário e ambiente lhe dava vontade de cantar, além das Festa da Moça Nova e da missa aos domingos. Ao deitar na rede de noite, ele ia lembrando-se das canções. Este foi, na maior parte das vezes, o ambiente em que fizemos as gravações.

A melhor ocasião para se aprender canções é a Festa da Moça Nova. Na Festa, quem sabe cantar, canta, imita o cantor, mas a maioria fica com vergonha de cantar. Ondino me contou que pode-se aprender remedando o cantor, ou seja, cantando junto com o cantor ao mesmo tempo em que ele canta. Mas também tem gente que aprende só de ficar escutando, prestando atenção. Clarícia, cantora mencionada acima, diz que sua mãe cantava também e ela aprendeu com outras pessoas que ela ouvia e via cantando. Segundo me disse, ela aprendeu durante sua Festa de Moça Nova também. Não é uma 
regra, mas se a moça consegue aprender as canções que lhe são entoadas, tanto melhor. Clarícia se lembra de canções de sua Festa.

Ondino comentou que a canção da To'oena o emociona muito. Quando ele canta tem vontade de chorar. Disse também que as velhas também choram quando cantam esta música nas festas. Hilda também me contou a mesma coisa, "antigamente quando a pessoa cantava, ela chorava. Quem ouvia chorava também". Uma coisa que me impressionou muito foi o caráter sacrificial do canto dos cantores. Os(as) cantores(as) também choram bastante quando estão cantando os cantos de moça nova. O caráter sacrificial está no fato de que se canta à exaustão, dando o máximo da voz, muitas vezes em tons agudíssimos. A bebida e a dança também ajudam. As cantoras realmente dão tudo de si, como que se consumissem no canto, um sacrifício à moça "formada". É como se a cantora ou o cantor agora pudessem chorar o lamento da mãe de To'oena, que foi impedida pelo seu irmão, Yoi, de chorar, sob pena de morte. Na verdade, não só os cantores, todos que ouvem a canção também se compadecem chorando. Durante a Festa, ao contrário dos momentos cotidianos, é permitido o "exagero dramático do sentimento" que também está presente no dia-a-dia, mas que irrompe com outra intensidade no ritual ${ }^{336}$.

Depois de cada gravação, os ticuna sempre me pedem para ouvir o resultado. Em geral, ouvimos tudo do começo ao fim, o que gera muitos comentários, risadas. Fizemos algumas gravações numa tarde quente com Benedita, tia (MZ) de Ondino. No começo da noite, ele me disse que sua esposa, Raissa, queria ouvir a gravação, então, liguei o som para eles ouvirem. Depois de ouvir a gravação, Ondino disse que aquilo os emocionava. Percebi que Raissa estava chorando na rede e seu marido falava com a voz embargada. Ele me contou que Benedita já estava velhinha e doente, deu a entender que em pouco tempo ela não estaria mais entre eles e a gravação seria uma bela recordação. Felizmente, quando retornei para meu segundo período de trabalho de campo, Benedita estava com a saúde bem melhor.

Atualmente tenho um diálogo amistoso com diversos ticunas. Mas meu primeiro e até hoje mais importante colaborador é o Professor Ondino Casimiro

\footnotetext{
${ }^{336}$ Me baseio aqui nas conclusões de Houseman \& Severi sobre a dramatização das emoções no naven: “... a especificidade do naven não reside na exibição de emoções incomuns na vida cotidiana, mas, de fato, no exagero dramático do sentimento assim expresso" (1998: 24).
} 
(Doctürécurügõecü), da comunidade de N.S. de Nazaré. Ouvi sobre sua fama de conhecedor dos cantos e das tradições ticuna desde minhas primeiras sondagens com os ticuna que moram em Manaus. Quando eu dizia que queria estudar a música, os cantos e as festa ticuna, me diziam, "você tem que conhecer o professor Ondino". Considerado um grande cantor entre os ticuna, ele lamenta que sua voz tenha engrossado com o tempo. Disse que, quando jovem, sua voz era bem fina. Ele comenta também que já não tem mais a memória de quando era jovem. Em sua juventude, diz ele, bastava ouvir qualquer canção uma única vez para memorizá-la. Os ticunas valorizam o cantor que tem um repertório extenso, boa memória e que não precise ler para cantar.

Ondino tem uma forte formação católica, desde muito jovem sofreu a influência dos padres italianos que estavam por São Paulo de Olivença ${ }^{337}$. Atualmente é ele o oficiante da missa em Nazaré. Até outubro de 2012, a missa era realizada na escola da comunidade, poucos dias depois que cheguei para meu segundo período de trabalho de campo inauguraram a capela de Nazaré. Esta conquista é motivo de grande orgulho para Ondino, afinal todas as comunidades adeptas de religiões evangélicas possuem um local de culto, Nazaré precisava também de sua igreja.

Na missa, além de seguir a liturgia católica, Ondino também canta e toca violão. Francisco, o construtor de instrumentos e da casa de festas, o acompanha com pandeiro, junto com Ulisses, irmão de Ondino, que toca um tambor mais grave. As canções são entoadas em português e ticuna, assim como os trechos da bíblia. Em cima da mesa do altar da capela, Ondino mantém duas versões da bíblia, nos dois idiomas. Ele faz questão de frisar que as canções dos ticunas católicos são diferentes das canções dos evangélicos. Para a decepção dele, os maiores hits gospel entre os ticuna são as músicas evangélicas, as católicas não são tão conhecidas.

Fico impressionado com a desenvoltura de Ondino ao transitar dos relatos de feitiçaria que envolve seus parentes e o culto católico. Muitas vezes as histórias misturam temas católicos e indígenas. Ele me disse um dia, por exemplo, que satanás mora no Vaticano. "O papa teve que se mudar por uns tempos, porque satanás está morando lá. Ele come gente também”. Contou também que em Tabatinga, cidade próxima de São Paulo de Olivença, há uma cobra com cabeça de gente que mora numa igreja. "A cobra

\footnotetext{
${ }^{337}$ Esta missão é a mais antiga do Alto Rio Solimões. Foi fundada em 1910 por missionários da Ordem dos Frades Menores Capuchinhos, oriundos da Úmbria (Itália). Cf. Argañaraz (2004, 2006) e Mura (2007).
} 
come gente e fala com as pessoas. Somente quando o padre reza ela é que ela para de comer as pessoas". Certa manhã, Ondino me contou que havia sonhado com um rato e uma jiboia passando em seu pescoço. Ele acordou, rezou um pai nosso e um credo e disse que dormiu bem. Perguntei se poderia ser feitiço, ele respondeu que sim.

Ondino costuma dizer que se sua religião não permitisse que ele fizesse a Festa da Moça Nova - como fazem os pastores batistas, por exemplo - ele largaria dela. Em muitas comunidades ticuna os missionários evangélicos não permitem a Festa, como é o caso da comunidade vizinha, Decuãpü. E são muitas as vezes que os "crentes" desta comunidade vêm para evangelizar em Nazaré. Ondino explica que qualquer um da comunidade tem a liberdade de se converter à religião evangélica. Mas enfatiza principalmente que não abre mão de sua "cultura", principalmente da Festa.

Enquanto observávamos Ondino trançar um tipiti, um rapaz comentou comigo que Ondino era o único homem que ele conhecia que sabia trançar fibra de arumã (Ischnosiphon sp.). O trançado é uma atividade considerada feminina pelos Ticuna ${ }^{338}$. A maioria das pessoas que tecem redes são mulheres. Ondino é uma exceção, ele aprendeu com sua mãe a arte da tecelagem para fazer rede de dormir, e do trançado de fibra de arumã, para fazer cestos, espremedores de massa de mandioca (tipiti), peneira, etc. Diz que não importa o sexo da pessoa, o importante é estar interessado. Vê-lo torcendo tucum ou fazendo um cesto sentado ao lado de sua mãe não é uma cena rara em sua comunidade. A maior parte das canções e o jeito certo de cantá-las, Ondino me contou que aprendeu com suas tias, principalmente mulheres. Por outro lado, Ondino não caça, uma atividade eminentemente masculina (Goulard 2002: 112).

Para que o filho se tornasse um grande cantor, a mãe de Ondino passava a língua do japiim (cauré - Cacicus cela $)^{339}$ na língua dele quando ele era pequeno. Isso fez com

\footnotetext{
338 Nimuendaju, o primeiro a fazer uma monografia etnográfica sobre os Ticuna, comenta em alguns trechos de sua obra que o trançado do tucum - fibra usada na confecção de redes para dormir - é uma tarefa feminina: "O fio do tucum, torcido pelas mulheres na coxa nua ou no abdômen..." (1952: 13), ou neste trecho, "[as] índias mulheres sabem como produzir diferentes padrões decorativos através da inserção de fios pretos ou até mesmo vermelho, amarelo, e verde." (ibdem).

339 Japiim xexéu (Cacicus cela) é famoso por imitar outra voz (Ni'r̃yauga). Este nome não é ticuna, mas foi o nome dado a este pássaro por Ondino. Depois, Ondino deu o nome de Mõõtchu ao xexéu e disse que era um tipo de cauré. De acordo com o Guia de Campo - Aves da Amazonia Brasileira (Sigrist, 2008), que usei para identificar as aves, o cauré é um falconídeo (Falco rufigularis).
} 
que ele desenvolvesse a capacidade de aprender cantos rapidamente. Quebrar o ovo do japiim em cima da cabeça do futuro cantor ou passar o miolo do pássaro no ouvido também faz a criança aprender mais rápido. Sabemos que o japiim é uma ave que aprende o canto dos outros pássaros. "Ele pode imitar papagaio, tucano, vários pássaros. Japiim gosta de cantar", disse Ondino. O tratamento com a língua da ave pode se iniciar a partir dos 4 meses de vida da criança. Os olhos, a língua, os miolos e os ninhos são bons para curar as crianças doentes. Se a mãe queimar o ninho do japiim e passar as mãos da criança na fumaça, ela crescerá com boas habilidades manuais, será uma boa trançadora de esteira, tipiti, etc.

Muitos cantores recorrem a um pajé para tornarem sua voz mais fina. Para fazer isto, o xamã tem que colocar uma "oração" chamada Mõwütchinawe no cantor. Segundo me explicou Ondino, quando o cantor quer ter uma voz fina, ela pede ao pajé para rezar a voz dele. O pajé canta junto com o cantor uma "oração" e coloca um Mõwütchinawe, um tipo de "espírito" ( $\left.\tilde{a}^{\prime} \tilde{e}\right)$ invisível, vivo $\left(m a^{\prime} \tilde{u}\right)^{340}$, na garganta do cantor. O cantor ingere um líquido que o xamã lhe ministra e, a partir desta ingestão, tem uma dieta restrita por um ou dois dias. Ele deve comer só uns peixinhos pequenos, sem sal, como, sardinha, curimatã, etc. Com isso, a voz fica mais fina. Para manter vivo o Mõwütchinawe, o cantor deve alimentá-lo com tabaco, fumando constantemente, senão ele morre e o cantor perde a voz fina. Este tipo de iniciação por ingestão de um princípio mágico aparece também, com vimos, na iniciação xamânica e, veremos, pode fazer parte do aprendizado dos tocadores de trompete.

\subsection{2 - Falsete e gênero - o "travestismo vocal"}

Existe um gênero vocal ticuna do qual Ondino é mestre e que é executado preferencialmente nas Festas de Moça Nova, denominado ütü. Ütü é a palavra usada para se referir ao canto executado com a voz mais aguda possível, mas também ao canto dos pássaros. Os homens cantores da festa da moça nova, por exemplo, para realizarem este

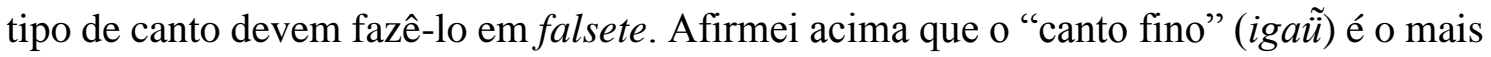

\footnotetext{
${ }^{340}$ Esta palavra usada para se referir a algo que está "vivo", é o próprio "princípio corporal" ( $\left.m a^{\prime} \tilde{u}\right)$ da pessoa. O que não se confunde com o "corpo" (ũne), mas está mais próxima deste do que o "princípio vital” ( $\left.\tilde{a}^{\prime} \tilde{e}\right)$.
} 
valorizado entre os ticuna. Trata-se nitidamente de uma imitação da voz feminina, o que chamei, inspirado nos estudos de rituais melanésios ${ }^{341}$, de "travestismo vocal".

Nimuendaju menciona que alguns índios recordavam vagamente que há muitas gerações os meninos eram colocados em reclusão quando suas vozes começavam a mudar $^{342}$. Isso mostra que a reclusão nem sempre foi exclusivamente feminina. Valenzuela (2010: 15-16) chama a atenção para um registro de Francis de Castelneu em Expédition dans les parties centrales de L'Amerique du Sud (Paris, 1850-1851, vol. 46) mencionado por Sir James Frazer no vol. 10, Balder the Beautiful (1913), de sua célebre série de livros, O Ramo de Ouro. Frazer menciona um ritual de iniciação masculina descrito por Castelneu em que o joven neófito ticuna é submetido à picadas de formigas em suas mãos ${ }^{343}$. O mais curioso é que Frazer alude ao ritual ticuna num capítulo intitulado "A reclusão das garotas na puberdade" (Frazer, 1913: 22-100) e nenhuma menção é feita à reclusão das moças ticuna.

Há ainda referências a um outro tipo de iniciação masculina presente entre os Ticuna: a perfuração dos lábios, das narinas e das orelhas. Goulard menciona a perfuração dos lábios, seguida da inalação de fumaça de tabaco como a iniciação masculina dos Ticuna do Peru:

"Em torno da idade de oito ou nove anos, o menino passa por um ritual de perfuração do lábio inferior para permitir a colocação de um tembetá, antes de se submeter a insuflação do fumo do tabaco nas narinas. Não se pode deixar de estabelecer uma homologia entre o sangue labial e o primeiro sangue feminino: o primeiro fluxo de sangue do menino é o resultado desta perfuração, enquanto a primeira menstruação da menina significa que ela tem "sangue verdadeiro". A inalação da fumaça do tabaco é adicionada à iniciação masculina e marca a mudança de classe de idade, mas especialmente a passagem do mundo feminino ao mundo masculino. Se a criança suporta, em

\footnotetext{
${ }^{341}$ Certamente o pioneiro nestes estudos do travestismo melanésio foi Bateson (2006) em sua monografia sobre o Naven, ritual de travestimento dos latmul da Papua Nova Guiné, diversos outros se seguiram a ele.

342 "Muitos Tukuna ainda vagamente lembram que nos tempos antigos os meninos eram colocados em isolamento quando as suas vozes mudavam, mas eu não pude obter detalhes dessa cerimônia, uma vez que caiu em desuso há muitas gerações." (Nimuendaju, 1952: 73).

343 Este recurso é muito comum em rituais de iniciação masculina na América do Sul. Cf. Matarezio Filho (2014) para o caso Waimiri-Atroari e uma revisão do uso das formigas em rituais de povos de língua Caribe.
} 
seguida, a fumaça, lhe é permitido pela primeira vez ver os instrumentos musicais que são proibidos para as mulheres. Após este ritual, ele está autorizado a dar seus primeiros passos entre os homens com quem ele começa uma longa aprendizagem. ” (2002: 111)

Nimuendaju menciona ainda duas práticas que, já em sua época de trabalho de campo, estavam em desuso: "Os Tukuna abandonaram a prática da perfuração do septo, que acompanhava a perfuração dos lóbulos das orelhas" (1952: 38).

Gostaria de destacar, principalmente, a interessante comparação feita por Goulard, acima, entre o sangue labial masculino e o sangue da primeira menstruação feminina. Esta descrição de Goulard é a única referência que possuo de perfuração labial masculina entre os Ticuna. Contudo, como bem destaca Goulard, e podemos incluir o dado da perfuração nasal e auricular nesta conclusão, o sangramento resultante da perfuração remete ao sangue menstrual das moças que são iniciadas ${ }^{344}$. Neste sentido, o sangramento do menino - seja por perfuração labial, nasal ou auricular - marcaria sua transição para a idade adulta da mesma maneira que o sangramento feminino ${ }^{345}$.

Este tipo de sangramento masculino, não mais praticado, compõe um ritual mais complexo. Segundo Nimuendaju, como vimos, a reclusão masculina era feita quando a voz do menino começava a mudar, ou seja, a engrossar. Este dado é o que mais nos interessa neste ponto da análise. Valenzuela indica o termo buku woremanaãkü para se referir ao menino que muda de voz ${ }^{346}$. Adélia me contou sobre a reclusão de um menino

\footnotetext{
${ }^{344}$ Overing, por exemplo, fala de um tipo de menstruação masculina entre os Piaroa, a menstruação ritual dos xamãs. Em "tal ritual, o xamã oficiante atravessa a própria língua e a língua de seus aprendizes com um ferrão de arraia. Eles menstruam pela língua, não pela vagina. (...) $O$ sangramento da língua masculina é, contudo, muito perigoso para as mulheres. " (2006: 43-44). Notemos que, assim como as cerimônias das "flautas sagradas" são interditas à visão das mulheres, a "menstruação" masculina também não pode ser vista por elas entre os Piaroa. Parece, portanto, que ocorre uma reciprocidade de interdições.

${ }^{345}$ Valenzuela menciona a furação das orelhas das meninas ticuna da comunidade de Arara, na Colômbia: "[Doña Dioselina] Agrega que su hijita será parte de la ceremonia, sus orejitas serán perforadas. Esta práctica ritual es una primera intervención que se acostumbra hacer a las niñas en edades tempranas entre los tres y los seis años de edad aproximadamente, como una preparación para la fiesta de pubertad. En idioma tikuna la pequeñita y las demás niñas a quienes se les perfora las orejas se llaman Wepachinüe bue" (2010: 182). Nimunedaju ainda presenciou a furação de orelha das meninas entre os Ticuna do Brasil: "Hoje, apenas o cabelo é arrancado - se, de fato, não é cortado com tesoura e os lóbulos das orelhas das meninas são perfurados." (1952: 70).

346 "Buku Woremanaãkü es el nombre en tikuna para los niños que cambian de voz. wore es dispuesto, ma es forma que indica hueco, túnel o algo tubular, es la forma del esófago que es tubular. -naã es formema de garganta. (Santos, com .per.)" (Valenzuela, 2010: 16, nota 6).
} 
que aconteceu há muitos anos na comunidade de Barro Vermelho, próxima a Vendaval, mais para dentro do igarapé São Jerônimo:

“Agora não tem, mas lá no Barro Vermelho, onde eu trabalhava, teve um rapaz que a mãe dele fez a festa dele. Ele teve que ficar escondido, (...) quando engrossou a voz dele, aí ele falou, "mamãe, ficou grossa minha fala". Na mesma hora a mãe dele disse, "shshsh, cala a boca!", respondeu para ele logo. A mãe tem que procurar o jenipapo para ralar e pintar ele, assim [Adélia faz movimentos passando a mão na garganta, mostrando onde a mãe pintou o filho com jenipapo]. [Pinta a garganta, só a garganta?]. Isso, para ficar o som bem regular (...). Aí ela tem que dar conselho para ele também. Tem que guardar ele por três anos! (...) E ele ficou três anos guardado, e cresceu, cresceu o cabelo dele, ficou bem aqui o cabelo dele [indica a altura da cintura]. E o rapaz ficou bem limpinho [com a pele branca]. Limpinho porque ele não sai (...). Até que chegou o dia da Festa, aí que a gente viu ele. [E é igual a Festa da Moça Nova?] Huhum, fizeram, convidaram o pessoal e chegaram muitos convidados deles. Aí arrancaram [o cabelo dele] assim como moça nova mesmo. [A senhora lembra quando foi isso?] Fazem treze anos, mas eu vi só essa, nunca mais."

A voz, portanto, é um importante marcador de gênero para os Ticuna. Quando a voz do menino muda, ele começa a sair da indistinção de gênero da infância para tornase homem. Este seria também o equivalente masculino da menstruação feminina. A mudança de voz dos meninos adolescentes ticuna é o indício de que o garoto deve passar pela iniciação à vida adulta, ou seja, está tornando-se adulto. Esta mudança em sua voz é equivalente à menarca da moça, já que esta marca a entrada da moça na reclusão. Contudo, como podemos pensar a relação desta mudança vocal masculina com a voz dos cantores homens na Festa? Seria uma espécie de retorno ao estado indiferenciado entre homens e mulheres? O cantor para cantar para a moça que está sendo iniciada não só adotaria uma voz feminina, mas também adotaria a voz de um pré-iniciado?

As cantoras sempre estão em maior número nas Festas da Moça Nova. Os cantores também participam ativamente do ritual, mas são em número menor. Além disso, sempre que questionei com quem determinado cantor aprendeu a cantar, a resposta sempre indicava alguma mulher, em geral a mãe, as tias (FZ e MZ), e as avós (no’e, $q$ G+2). 
Diferente do uso do "travestismo" que pretendo mostrar aqui, para alguns povos melanésios, como os Iatmul, o travestismo - agora sem aspas - "significa zombar o caráter convencional psicológico do outro" (Houseman \& Severi 1998: 21). Mas seria o que os homens ticuna fazem, ao cantarem em falsete, uma zombaria do sexo feminino? Quando os homens começam a imitar as mulheres no cantar e nas atividades produtivas, estariam se apropriando de seus "poderes"? Seria isto uma forma de controle dos "poderes femininos" (Strathern 2006: 159)? Muito pouco provável. Ao longo da Festa mais de um cantor(a) pode entoar canções diferentes ao mesmo tempo e as vozes femininas sempre sobressaem. Notei que os cantores(as) durante a Festa da Moça Nova, muitas vezes cantam ao mesmo tempo canções diferentes. Na maior parte das Festas que presenciei, havia cantores, principalmente mulheres, cantando cada um para uma única moça. Em uma das Festa da comunidade de Vendaval, por exemplo, havia três moças sendo iniciadas e três cantores(as) de braços dados com elas cantando, cada qual com uma moça. No momento de arrancar os cabelos, como ficavam muitas mulheres ao redor de cada moça, muitas vezes, mais de uma cantora cantava para a menina, mas canções diferentes.

Devemos ter em mente que as relações em jogo num ritual como a Festa da Moça Nova - senão em boa parte dos rituais sul-ameríndios - estão para além da relação entre humanos. Os mascarados, que entram durante a Festa batendo em seu pênis e investindo contra o quarto de reclusão das moças, são claramente uma zombaria do excesso libidinoso do macaco caiarara e do macaco prego. São eles, dentre outros mascarados, quem ameaçam a moça nova com seu pênis. Não só mulheres que cuidam do ritual (üa ücü, “copeiras”), mas também as próprias moças novas e suas mães seguram estes mascarados pelas costas, evitando serem pegas por eles. Os insistentes e cômicos mascarados só desistem de seu intento quando recebem bebida e carne moqueada. Entretanto, se a zombaria está neste nível cosmológico - ou seja, entre humanos e nãohumanos (os mascarados) - não parece ser o caso do canto em falsete dos cantores ticuna $^{347}$.

\footnotetext{
${ }^{347}$ Um caso evidente de zombaria entre homens e mulheres são os rituais Pawana dos Waiwai, povo caribe-guianense. "... muitos dos atores que desempenham o papel dos "visitantes" vestem-se como o sexo oposto: mulheres portam arco e flecha (que tentam grotescamente usar), homens chegam vestidos com roupas femininas e dando de mamar a bonecas..." (Howard, 1993: 243).
} 
Meigs comenta que os Hua, da Nova Guiné, possuem dois mecanismos de redução/neutralização da oposição masculino-feminino (1976: 394). O primeiro seria o comportamento imitativo, que encontramos entre os Ticuna também. Os cantores cantam

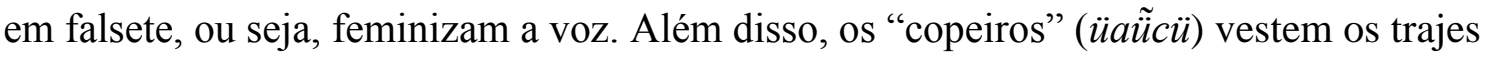
da moça nova para apresenta-los, antes de adornarem as moças. No entanto, o pertencimento às categorias originais (homem e mulher) é disputado entre os hua, o que define novas linhas de oposição. Não saberia se este segundo mecanismo opera entre Ticuna. Talvez o fato de cantar em falsete, considerado o canto mais bonito, seja a maneira de alguns homens disputarem esta posição feminina no ritual. Veremos que há uma possível reclassificação dos gêneros ticuna, três fatos contribuem para isso: o canto em falsete dos homens, o travestimento ${ }^{348}$ dos "copeiros" e a execução dos trompetes pelas mulheres que não menstruam mais. No entanto, como ressaltou Strathern, no caso ticuna, a visibilidade ${ }^{349}$ dada a esta reclassificação dos gêneros talvez seja muito mais sutil que entre os povos da Melanésia.

O mais curioso é que o mesmo falsete adotado pelos cantores no ritual é usado pelos pajés ticuna quando estão cantando. Com este dado podemos pensar o falsete também como simplesmente uma modificação vocal em relação à voz "normal". LéviStrauss analisa as modificações vocais, em especial a nasalização, nos termos "de retenção ou de incontinência orais" (1986: 206-207). Este tipo de modificação costuma aparecer em seres sobrenaturais ${ }^{350}$ ou em fórmulas rituais e encantamentos xamânicos ${ }^{351}$.

\footnotetext{
${ }^{348}$ Neste caso, trata-se de um travestimento de fato.

349 Para Strathern a diferença principal entre Amazônia e Melanésia está na "visibilidade da divisão de gênero" de cada região: "A diferença mais interessante, creio (...), estava nos papéis dos dispositivos de gênero em cada região, na visibilidade da divisão de gênero." (1999: 170).

350 “O demônio amazônico Jurupari arrota e peida, lamenta ruidosamente e canta aos berros. Os monstros canibais dos mitos suyá falam de modo estranho e deformando; Boré, o senhor das bananas yanomami, é cicioso. Na América do Norte, um personagem sobrenatural dos mitos nootka troca todas as consoantes sibilantes por consoantes laterais (s por I, etc.); entre os vizinhos Kwakiutl, um outro personagem sobrenatural faz o inverso. Geai, dos mitos wishram, começa as palavras com ts!. Os Kutenai dizem que Coiote não consegue pronunciar o $s$. Dama-Riqueza dos Haida, a ogra Dzonoqwa dos Kwakiutl gaguejam, Texugo dos Cree fala por entre os dentes... Fora da América, lembramos dos deus Raposa japonês, Kitsune, que não consegue terminar as palavras. Mas uma pesquisa comparativa pelo mundo afora não teria fim." (Lévi-Strauss, 1986: 206-207).

351 “Notou-se na América do Norte, na região de Puget Sound, que certos personagens invocados por fórmulas rituais, cantos religiosos ou mitos costumam transformar as oclusivas sonoras em nasais. A razão poderia ser semelhante à que, entre os Cuiva da Colômbia, faz com que o xamã, escondido por trás de
} 
Neste sentido, tudo indica que esta simples modificação vocal seria análoga a uma modificação de ponto de vista, de perspectiva. Ou seja, os exemplos de Lévi-Straus e o caso ticuna mostram que a mudança de perspectiva acarreta uma mudança vocal análoga. O pajé canta em falsete demonstrando a sua audiência que se encontra em outro mundo, no ponto de vista dos seres com quem se relaciona. Podemos nos perguntar, se o cantor ticuna ao cantar em falsete, com voz feminina, provocaria um deslocamento análogo, mas de gênero, assumindo o ponto de vista da mulher cantora?

Até então as análises sobre o aspecto perspectivista do pensamento ameríndio se debruçaram principalmente em seu sentido visual. Entretanto, as formulações deste pensamento (Viveiros de Castro, 2002; Lima, 1996) deixam patentes a existência de uma "perspectiva" acústica diferenciada para as diferentes "gentes" que habitam o mundo ${ }^{352}$. Os dados apresentados acima também nos mostram uma possível intersecção entre perspectiva e gênero. $\mathrm{O}$ fato de o pajé ticuna acessar outro ponto de vista pelo mesmo mecanismo que um cantor ticuna canta como mulher nos mostra algo próximo ao que Belaunde notou em sua etnografia sobre os Airo-Pai do Peru. "Do ponto de vista dos deuses airo-pai, os homens são japus (Icteribus sp.), pássaros carnívoros, cantores e tecedores de ninhos que ficam pendurados nos galhos das árvores. As mulheres são papagaios-verdes (Amazona sp.), comedoras de sementes e formam seus ninhos em buracos abertos nos troncos das árvores” (2006: 209). Até onde sei, não há um ponto de vista que atribua espécies diferentes aos gêneros entre os Ticuna, como fazem os AiroPai. Contudo, o recurso para indicar uma mudança de perspectiva, o falsete, é utilizado pelos homens para - assim como fazem os pajés em suas viagens para outros mundos, com outros seres do cosmos - predarem uma característica feminina desejável.

\footnotetext{
uma tela, nasalize os seus encantamentos, "pois é extremamente perigoso que a boca ponha a garganta em comunicação direta com o meio externo". (Lévi-Strauss, 1986: 206-207).

352 Lima nos dá um belo exemplo neste trecho: "Assim, para si mesmos, os porcos tocam flautas, que para os humanos são simplesmente os cocos (esvaziados do miolo, comida desse animal) que os porcos fuçam, provocando a emissão de um som que lembra o apito para uma audição humana, mas cuja musicalidade, na audição dos porcos, é tão rica como aquela das flautas" (1996: 31).
} 


\section{3 - Canções}

\subsection{1 - Acalantos}

Durante todo meu trabalho de campo gravei, transcrevi e traduzi mais de vinte canções que são entoadas na Festa da Moça Nova. Mas não somente estas, no início da pesquisa procurei saber quais outras canções "tradicionais" compunham o repertório destes índios. Registrei, por exemplo, as canções que os Ticuna ouvem em seus primeiros dias de vida, as canções de ninar. Acalanto pode ser traduzido em ticuna como wawe ou como bu' $\tilde{u}$ arü petchiga, que ao pé da letra seria “canção para criança dormir”. Os bebês são ninados com estas canções e fazendo-se um barulho com os lábios "brbrbrbrbrbr", como se estivesse soprando um trompete, fazendo os lábios vibrarem suavemente com a coluna de ar.

Os acalantos que gravei foram cantados por Catarina Maria Basílio da Silva (Waigeremunã), esposa de Severino Alexandre Gomes (Tõetükü), um dos meus principais colaboradores. Uma das canções, digamos, é uma versão ticuna do acalanto "Boi da cara preta", que os ticuna costumam chamar de "canção do boi" 353 (Anexo - 002). A figura do boi aqui é evocada como um animal amedrontador, que vai pegar o neném caso ela não durma, não muito diferente do efeito que se busca na nossa tradicional canção "Boi da cara preta" (Machado, 2012: 27-86). Por meio desta canção, podemos notar que o boi também é uma figura monstruosa para os Ticuna. Interessante notar que, para os Wayana $^{354}$, por exemplo, o boi é identificado linguisticamente como uma "anta monstruosa" (maipurimë, Van Velthen, 1995: 144), sendo que o sufixo_imë em wayana pode significar tanto "monstruoso" quanto "sobrenatural".

Os ticuna são muito hábeis em transpor canções do português para sua língua materna. Tive a oportunidade de fazer uma gravação com Hilda de uma versão da "Canção do povo de algum lugar", de Caetano Veloso, feita por um grupo de professores ticuna. A “canção do boi” também é uma destas versões, que nasce num contexto em que

\footnotetext{
${ }^{353}$ Boi = woca, corruptela do português "vaca".

354 Povo de língua Caribe, da região das Guianas.
} 
muitas mulheres indígenas cuidam dos filhos dos brancos na cidade. E, se por um lado, o boi representa uma ameaça, por outro lado, o pai surge num outro acalanto como uma figura de proteção ${ }^{355}$. Mas nesta canção de ninar, a figura ameaçadora são os "bichos" ( $n g o$ ’o), e o cantor(a) avisa ao neném para ele não chorar, pois o papai já vai chegar, como podemos notar no trecho:

\author{
Nhocutainãgu curupa papa mĩ \} 2x \\ “Teu pai está para chegar, neném" \\ Nhocutainãgu rü taũirüauün \\ "Está para chegar, não chore" \\ Nhuma pa mĩ rü napawa nicuma tcha nhẽgara \\ "Agora ele vai cantar com você na rede" \\ (...)
}

Numaün pa mĩ rü ngo’o pa mĩ

"Aqui está, neném, o bicho, neném"

Cuaugu rü cucanĩ nadawenü rü

"Se você chorar ele vai olhar para você"

Peripa mĩ rü taũirüauün

"Durma, neném, não chore"

Como disse, os Ticuna assimilam muito facilmente as canções dos "brancos" em seu repertório. Alguns casos são impressionantes. Numa passagem de Mario de Andrade pelo município de Fonte Boa (AM), em 1927, o autor relata o que segue:

"Uma feita, em Fonte-Boa, no Amazonas, eu passeava sob um solão de matar. Saía um canto feminino duma casa. Parei. Era uma gostosura de linha melódica, monótona, lenta, muito pura, absolutamente linda. Me aproximei com a máxima discrição, para não incomodar a cantora, uma tapuia adormentando o filho. $\mathrm{O}$ texto que ela cantava, língua de branco não era. Tão nasal, tão desconhecido, que imaginei fala de índio. Mas era latim... de tapuio.

\footnotetext{
355 A mesma oposição "boi ameaçador" X "pai protetor" é encontrada na canção "Acalanto", gravada por Dorival e Nana Caymmi (apud Machado, 2012: 78-79).
} 
E o Acalanto não passava do Tantum Ergo em cantochão. Uma sílaba me levou pra outra e, mais intuição que realidade, pude reconhecer também a melodia. A deformação era inconcebível. Porém, jamais não me esquecerei da comoção de beleza que recebi dos lábios da tapuia" (Andrade, 1980: 184) ${ }^{356}$.

Sabemos que Fonte Boa, situada no Alto Solimões, possui uma forte presença ticuna. Não seria descabido pensar que esta índia "tapuia" 357 fosse uma ticuna entoando um "Tantum Ergo em cantochão" para seu filho adormentar. Uma questão interessante proposta por Machado é a seguinte, "por que o tantum ergo? O que teria motivado a escolha deste canto pela mãe tapuia?" (2012: 98). Mario escutou a canção da índia tapuia no dia 14 de junho de 1927, mesmo mês em que é celebrado o Corpus Christi, "em que se canta o tantum ergo" (ibdem). Machado relata que Mario "chegou a uma missão franciscana, em Tonantins ${ }^{358}$ e encontrou, no piano da casa dos padres, "o Tantum Ego e o Kirie manuscritos e visivelmente sem caráter religioso" [Andrade, 2002: 94]. A audição do canto em Fonte Boa e a presença dos manuscritos em Tonantins indicam a proximidade da festa de Corpus Christi” (2012: 99).

Outro acalanto que gravei com Catarina, e que descobri depois ser também um clássico das canções de ninar brasileiras, é o Murucututu. O murucututu é um nome regional amazônico de uma espécie de coruja, Pulsatrix perspicillata. Os Ticuna identificam está espécie como murucututu, mas outras também o são: Corujinha-relógio (Megascops usta), po'u (Megascops choliba e Megascops guatemalae) e woru (Lophostrix cristata). Trata-se de um pássaro de "hábitos crepusculares e noturnos" (Machado, 2012: 104), ou seja, seu canto é ouvido no momento em que as crianças são ninadas de noite. A canção, “das mais antigas e resistentes nas canções de ninar brasileiras" (idem: 106), é referida por Machado como originária “dos grupos indígenas nativos da região do amazônas" (idem:104). Entre os Ticuna é um acalanto bem conhecido entre as mães e as crianças. Na canção ticuna a coruja Murucututu é equacionada a um “bicho" (ngo'o). Neste sentido, é através do acalanto que o bebê ticuna

\footnotetext{
${ }^{356}$ Tomei conhecimento deste registro de Mario de Andrade por meio deum curso que fiz sobre a "Canção de Ninar Brasileira", ministrado por Silvia Machado no IEB-USP. O trecho de Mario que transcrevo também está em Machado, 2012: 88-89. O mesmo acontecido em Fonte Boa é lembrado por Mário n'O Turista Aprendiz (2002: 91-92). Agradeço à Silvia pelo excelente curso e pelas referências.

357 Tapuia é também um termo usado para designar o "índio genérico", não falante de língua tupi, ou o filho de branco e índia (dic. Houaiss).

358 Outra cidade do Alto Solimões povoada de ticunas.
} 
tem seus primeiros contatos com os ngo'o ("bichos"), os bichos-papões que povoam os sonhos das crianças. Vejamos o trecho da canção em que isto aparece:

\author{
Numacüyamurucutu \\ "Aqui está a coruja murucututu" \\ Caünnacaũetü pa mĩ e mĩ e \\ "Ele arranca teus olhos, neném" \\ Cuaugu \\ "Se você chorar" \\ (...)
}

Taũirüauün

"Não chore"

Numaün ya ngo’o pa mĩ

"Aqui está o bicho/demônio, neném"

Cuaugu ya cucainanha

"Se você chorar, ele vem de lá para você"

\title{
5.3.2 - Canções da Festa da Moça Nova
}

Como afirmei de passagem no tópico 5.1.1 - "Ficar no silêncio", as letras das canções da Festa, de modo geral, sofrem um tipo de variação sobre um texto de base que poderíamos chamar de improvisações. Não sei se um cantor(a) ticuna concordaria comigo nestes termos, pois ele(a) diria que está cantando como aprendeu. A questão é que existe uma variação - seja na ordem dos versos, na colocação de novas palavras e novos versos - que faz com que consideremos boa parte da letra como improvisada sobre uma base melódica fixa. As melodias são repetidas e mudam as letras que são cantadas. As canções ticuna fazem o que Lévi-Strauss afirmou como uma característica geral dos rituais, no Finale d'O Homem $\mathrm{Nu}$, elas fragmentam o processo ritual e seus versos são exaustivamente repetidos. Temos, portanto, as duas características definidoras de ritual 
para Lévi-Strauss, fragmentação e repetição ${ }^{359}$. Num esboço de análise das canções, posso dizer que é nítida a diferença melódica entre o que chamarei de "canções de dança" e “canções de aconselhamento". Estes termos são analíticos, até onde sei os ticuna não possuem uma tipologia de suas canções da Festa da Moça Nova.

O primeiro tipo, as "canções de dança", são entoadas durante a maior parte da Festa. Suas letras trazem resumos ou detalhamentos dos mitos (canção do rio tchowatü, da pata poponare, da To'oena), falam sobre características de personagens míticos (canção do Yoi, do Tchürüne, da Etüena), marcam um momento específico do ritual (canção de ralar jenipapo), falam sobre algum elemento da Festa (canção do tamborim, do instrumento ba'ma, do quarto de reclusão (turi), do casco de tracajá (tori), da estrela), sobre os imortais e os "bichos" (canção dos imortais, da moça que foi levada pelo bicho), sobre pássaros (canção do mũtchicütü, canção da poponare, canção do wiwiruya), sobre os mascarados (canção do Mawü, do Õma, do To'ü). E os temas das letras se permeiam, isto é, uma canção pode tratar de mais de um destes temas ${ }^{360}$.

\footnotetext{
359 Houseman \& Severi criticam a definição de ritual nestes termos. "Para nós, ritualização não determina uma tipologia dos atos, mas descreve um modo particular de ação. Este não é definido por suas propriedades funcionais ou por quaisquer características sintáticas (por exemplo, a repetição ou fragmentação), ou qualidades dependendo das considerações pragmáticas (performatividade, os procedimentos de preparo, etc.), mas, principalmente, pela criação de um tipo particular de configuração relacional" (1998: 262). Concordo com os autores que as características sintáticas do ritual não são definidoras do que seja o ritual, num sentido amplo. Contudo, quando repetição e fragmentação estão fortemente presentes, como na quase totalidade dos rituais ameríndios (cf. Menezes Bastos 2007), sua tomada em conta na análise faz-se mais que necessária. Veremos que o ritual ticuna também é fruto de "um tipo particular de configuração relacional", contudo, fragmentação e repetição estão lá e são importantes na caracterização do ritual, principalmente da música da Festa.
}

${ }^{360}$ A consideração de Houseman sobre a "comunicação linguística" que acontece durante o ritual se encaixa perfeitamente na análise das canções que pretendo desenvolver. "[O]s rituais não contam histórias, eles encenam determinadas realidades. Eles não tanto dizem coisas (...) como fazêm-nas. Por este motivo, a comunicação lingüística é um modelo pobre para entender o que está acontecendo no ritual. Alguns rituais podem ser em grande parte composto de fórmulas litúrgicas. No entanto, fórmulas mágicas, cânticos e outros pronunciamentos rituais são caracterizados por uma diminuição acentuada das suas propriedades semânticas, que são muitas vezes obscuras ou altamente ambíguas. Assim, o discurso ritual é usado para transmitir menos informação do que para realizar certos atos, para demonstrar a presença de certos agentes não-humanos, estabelecer autoridades inegáveis, ou para definir a identidade de quem fala." (2006: 414). De fato, o canto ticuna entoado durante a Festa é uma "diminuição acentuada das propriedades semânticas" do que encontramos na mitologia, na cosmologia, na organização social e no ritual deste povo. Muitas letras de canção que são entoadas nas Festas, para serem bem compreendidas, necessitam que a pessoa conheça, por exemplo, o mito a que ela se refere ou a liturgia da Festa. 
O segundo tipo, as "canções de aconselhamento", são cantadas em momentos e locais muito específicos do ritual e diretamente para as moças: dentro da reclusão, quando as moças são pintadas de jenipapo no recinto dos instrumentos e durante o arrancamento dos cabelos das moças. Comecemos por um exemplo do primeiro tipo, o que chamei "canções de dança".

Algumas destas canções já foram mencionadas, como: canção do Wiwirutcha, do rio Tchowatü, da Poponari, do tamborim tutu, da moça nova que foi levada pelo bicho e canção de ralar jenipapo. Outras ainda abordaremos, quando tratarmos do tema central da canção $^{361}$. Para uma análise detalhada das canções da Festa seria necessário a dedicação de mais espaço nesta tese, o que não nos é possível. Gostaria aqui de mostrar apenas alguns apontamentos sobre uma das "canções dos imortais" 362 que registrei em campo (Anexo - 003).

\subsubsection{1 - A canção dos imortais}

Um mito dos Mascouten $^{363}$ relaciona a menstruação à vida breve. Caso as mulheres não se isolarem numa "cabine afastada (...) encurtarão a vida de seus maridos" (Lévi-Strauss, 2011 [1971], 183). O costume dos Mascouten também está relacionado com festas: "Ela [a avó do herói] logo foi contar a uma vizinha, que organizou uma festa e proclamou o novo costume" (ibdem). O que acontece na canção ticuna dos imortais (ü'ünetchiga) é algo semelhante. Para os Ticuna, não ter jejuado, cometerem incesto e perdido a carona da casa voadora fez com que perdessem a imortalidade ${ }^{364}$. Mas não fazerem a Festa pode encurtar ainda mais a vida. Como os mortais não ouviram os

\footnotetext{
361 Por exemplo, veremos algum conteúdo da canção de cada mascarado quanto examinarmos o momento em que eles aparecem no ritual.

${ }^{362}$ Agradeço ao(à) parecerista anônimo(a) da Revista LIAMES pelos comentários à análise abaixo. Em virtude destes comentários reduzi bastante a análise original. Pretendo retomar futuramente os pontos revistos pelo(a) parecerista e reelaborar esta análise.

363 "[P]opulação de lingua algonquina que vivia na frente dos Menomini, na margem oposta do lago Michigan [América do Norte]" (Lévi-Strauss, 2011 [1971]: 138).

364 Vimos alguns exemplos de relatos míticos que contam isso no Capítulo 3, tópico 3.1.4 - Festa e imortalidade. Com relação ao jejum, veremos que os imortais cobram os mortais para jejuarem para eles.
} 
imortais e não foram para a casa de Yoi, não se tornaram imortais. Por isso, fazem a Festa da Moça Nova hoje na casa de Festas, assim evitam a morte violenta nas roças pelos "bichos" (ngo’o).

Entretanto, antes de abordarmos a canção dos imortais propriamente, gostaria de introduzir aqui as considerações de alguns autores sobre as relações que existem entre imortalidade e música, especialmente o canto. O que quero mostrar aqui é que o simples fato de entoar as canções nos rituais indica uma intenção de se imortalizar. Vejamos primeiro a consideração de Wisnik sobre o canto e a presença de um corpo vivo. Tomando como pressuposto o fato da língua ser um "sistema de diferenças", diz o autor:

“... o canto potencia tudo aquilo que há na linguagem, não de diferença, mas de presença. E presença é o corpo vivo: não as distinções abstratas dos fonemas, mas a substância viva do som, força do corpo que respira. Perante a voz da língua, a voz que canta é liberação: o recorte descontínuo das sucessivas articulações cede vez ao continuum das durações, das intensidades, do jogo das pulsações; as ondas menos periódicas da voz corrente dão lugar ao fluxo do sopro ritualizado pela recorrência" (Wisnik, 1978: 12).

Neste sentido, portanto, acredito que podemos considerar esta colocação de Wisnik - linguagem : diferença :: canto : presença - como análoga à proposição de LéviStrauss, de que o mito efetuaria a passagem do continuo ao descontinuo, enquanto o ritual operaria uma reversão disto, transformaria o descontinuo em continuo ${ }^{365}$. O trecho citado de Wisnik, portanto, nos mostra que a "remendagem minuciosa" operada pelo ritual deve muito à presentificação proporcionada pelo canto. Ou seja, ao cantar durante o ritual os Ticuna estariam atualizando o mito, atualizando suas relações com os imortais, no sentido de tentarem reatar uma ligação que os mitos narram como foi perdida. O que o mito e a linguagem estabelecem como descontinuidade e diferença, a palavra entoada em forma de canção no ritual afirma como presença, como continuidade.

A julgar pela opinião destes especialistas em canção, Wisnik e Tatit, a canção e a ideia de (i)mortalidade estão estreitamente relacionadas. Nas palavras de Tatit:

\footnotetext{
365 "Fracionando operações que detalha ao infinito e que repete incansavelmente, o ritual se dedica a uma remendagem minuciosa, tapa os interstícios e nutre assim a ilusão de que é possível remontar a contrassenso do mito, refazer continuidade a partir de descontinuidades. " (Lévi-Strauss, (2011 [1971]): 650).
} 
"A voz que canta prenuncia, para além de um certo corpo vivo, um corpo imortal. Um corpo imortalizado em sua extensão timbrística. Um corpo materializado nas durações melódicas. É quando o cancionista ultrapassa a realidade opressora do dia-a-dia, proporcionando viagens intermitentes aos seus ouvintes. É quando o cancionista tem o poder de aliviar as tensões do cotidiano, substituindo-as por tensões melódicas, em que só se inscrevem conteúdo afetivos ou estímulos somáticos." (2002[1996]: 15).

Podemos transpor este raciocínio para a canção dos imortais da seguinte forma. A tensão que existe entre não serem imortais e a possibilidade de serem, ou terem sido. Qual é a "tensão do cotidiano" no caso ticuna? Eles são mortais porque o incesto ainda está presente, os jovens ainda namoram antes do momento certo, as pessoas não fazem mais jejum para os imortais e, quando estes os chamam, eles não percebem. Alguns destes motivos estão enunciados na letra da canção da qual veremos alguns trechos abaixo. Estas tensões quando passam para o plano melódico revelam vogais alongadas e saltos intervalares que intensificam os conteúdos afetivos presentes no texto ${ }^{366}$.

O trecho de Tatit, acima, vai ao encontro do que Lévi-Strauss propõe na Abertura de $O$ Cru e o cozido, ao estabelecer o "caráter comum do mito e da obra musical", mas com relação ao ouvinte da música. "[T]udo se passa", diz o antropólogo, "como se a música e a mitologia só precisassem do tempo para infligir-lhe um desmentido. Ambas são, na verdade, máquinas de suprimir o tempo". E conclui o autor, que "[a] audição da obra musical, em razão de sua organização interna, imobiliza, portanto, o tempo que passa; como uma toalha fustigada pelo vento, atinge-o e dobra-o. De modo que ao ouvirmos música, e enquanto a escutamos, atingimos uma espécie de imortalidade." (2004 [1964]: 35). Não seria esta a própria "teoria" ticuna de como se atingir a imortalidade cantando no ritual?

Temos aqui, portanto, duas imortalidades: a do cantor - o corpo imortal da voz que canta ${ }^{367}$ - e a do ouvinte de música - inserido num tempo suprimido. A canção demonstra a noção ticuna da relação entre a música e a imortalidade, neste caso,

\footnotetext{
${ }^{366}$ Ver a transcrição da Canção dos Imortais no padrão metodológico de análise criando por Tatit (Anexo - 011). Cada linha da tabela em que é feita a transcrição representa um semitom. Marquei com uma linha vertical o ponto em que as vogais são alongadas, único momento em que a duração é pertinente nesta análise.

367 "Dessa singular convivência entre o corpo vivo e o corpo imortal brotam o efeito de encanto e o sentido de eficácia da canção popular" (Tatit, (2002[1996]: 16).
} 
principalmente do cantor. Quando estávamos gravando a canção, Ondino me contou que “o $\ddot{u}$ 'üne [imortal] que canta essa música. Ele ensinou para os Ticuna que cantam ela na Festa da Moça Nova". Isto é, quem está falando na canção dos imortais são os próprios imortais, o eu lírico da canção. Contudo, a canção é entoada por uma pessoa que está viva, o corpo vivo presentificado na canção. Para além de uma letra que fala das possibilidades passadas e presentes de imortalidade, o fato de entoar uma melodia imortaliza o corpo em sua "extensão timbrística". A canção que se refere à imortalidade e que imortaliza um corpo em suas "durações melódicas" reflete esta concepção na própria extensão da canção, que vai aos extremos da tessitura vocal do cantor, exigindo inclusive o recurso ao falsete.

Ao longo desta análise pretendo desenvolver a hipótese de como a Canção dos Imortais - entoada durante estes rituais - deixa claro o ponto de vista destes seres sobre a perda da imortalidade por parte dos mortais. Um possível estudo desta música, utilizando a metodologia de analises de canções desenvolvida pelo linguista Luiz Tatit pode indicar que (1) a canção expressa a inconformidade dos imortais com as negligências dos humanos, que os mantém na condição em que estão e; (2) a melodia da canção reflete e intensifica o lamento inconsolável dos imortais pela negligência dos mortais em não atenderem seu chamado. $\mathrm{O}$ ponto (1) pode ser verificado na própria letra da canção, como nos trechos abaixo que falam da inconformidade pelos mortais não terem jejuado:

\author{
Tücüena, tücüena \\ "Por que, por que?" \\ Pa yui, yui, pa yunatüta \} 2X \\ "Mortais, mortais, mortais" \\ (...) \\ Pe tocatürü, pe auregutchi $\} 2 \mathrm{X}$ \\ "Se vocês tivessem jejuado para nós" \\ Nawaücü rü pe ütürü tagagücüra'ũ $\} \quad 2 \mathrm{X}$ \\ "A gente teria levado vocês naquela casa"
}

O lamento também fala da negligência dos mortais em não perceber que os imortais sempre estiveram por perto, contudo nunca são percebidos: 
Pefaega'ũ, Pefaega'ũ, (tücüena)Pefaega'ũ

"Vocês não estão sabendo"

Este trecho me foi explicado por Ondino como a afirmação dos imortais de que “estávamos perto mas vocês nunca perceberam. Está perto mas as pessoas não estão vendo". Na canção, os imortais dizem que estão batendo no buritizeiro, que está no bubuetü, um grande descampado, na frente de todo mundo, mas ninguém está vendo. Eles querem que os mortais os percebam e têm pena de quem não está os vendo:

Rü ререwa, ререwa, ререwa

"E na sua frente"

Rü bubuetü, bubuetü

"No descampado, descampado"

Rü temanecüma, rü temanecüma

"E no meio do buritizal"

(...)

Duwaисӥ, duwaucü, peтаисӥ, tauãtchiã $\} 2 \mathrm{X}$

"Eu tenho pena de vocês"

E a importância de se permanecer dentro da casa de Festas para ser levado pelos imortais. Caso algum cataclismo aconteça, é na casa de Festas que os Ticuna se salvarão:

Ngemaũcü $\} 2 \mathrm{X}$

"Lá [naquela casa]"

Düawacü rü naane rü taetünameegü, taetünameegü

"Pode ser que acabe o mundo, naquela casa vocês se salvarão"

(...)

Nawaücü ya Morugünē"

"Lá na casa Morugünẽ”

Rü Taurüpë̈

"Não vai acontecer nada com vocês" [nunca vão morrer] 
Devemos ter em mente que a tensão semiótica de base, aquela entre sujeito e objeto, é o que direciona - aqui está o sentido da semiótica e que a diferencia da semântica - o sujeito para o objeto da falta. A imperfeição é o que constitui o ser greimasiano ${ }^{368}$. Ou seja, este ser é marcado por uma falta, uma imperfeição mesmo, e que será o motor de suas ações. Esta falta é que dará sentido, direção, aos seus atos em busca de preenchêla. Esta ideia é desenvolvida por Tatit $(1994,2002[1996])^{369}$, tendo como objeto de análise as canções, mas também podemos pensar, para nos aproximarmos mais do mundo primitivo, do universo do sacrifício. Afinal, o sacrifício cria uma quase-continuidade entre um sujeito sacrificante e um "objeto", a divindade a quem se faz o sacrifício. Nestes termos, cria-se uma tangente que (quase) une os dois (Viveiros de Castro, 2002, 2008) ${ }^{370}$. Muito bem, então onde estaria esta "assimetria constitutiva" 371 dos Ticuna? Assim como está tematizado numa infinidade de mitos ameríndios - especificamente os que formam o grupo chamado por Lévi-Strauss de mitos da vida breve - a imperfeição foi fundada com a perda da imortalidade pelos mortais. A partir deste momento, resta aos mortais tangenciarem eternamente este estado, sem nunca o alcançar. É isto que fazem os Ticuna em suas Festas de Moça Nova.

O chamado dos próprios imortais cria um "querer", no sentido dado pela chamada "semiótica tensiva", "que arremessava o ser do sujeito adiante de si mesmo"372. Ao

\footnotetext{
${ }^{368}$ Notadamente, o último livro de Greimas chama-se “Da imperfeição” (2002).

369 O autor tem como referência principalmente Greimas \& Fontanille (1993), mas também muitos desenvolvimentos de Zilberberg, cf. p.ex. 2006.

370 "Recorrendo a uma alegoria matemática, diríamos que o modelo das transformações estruturais do totemismo é a análise combinatória, ao passo que o instrumento necessário para explorar o "reino da continuidade" (a expressão é de Lévi-Strauss) estabelecido pelas metamorfoses intensivas do sacrifício remeteria, antes, a algo como o cálculo diferencial: imagine-se a morte da vítima como o traçar de uma tangente, a melhor aproximação à curva da divindade..." (Viveiros de Castro, 2008, eu grifo).
}

${ }^{371}$ Em entrevista, Viveiros e Castro caracteriza "duas linhas" do pensamento lévi-straussiano da seguinte maneira: "[c]uriosamente a interpretação canônica que se faz da obra de Lévi-Strauss sempre pretendeu que ele era o pensador do equilíbrio, da ordem, da estrutura, a combinatória perfeita, quando, na verdade ele sempre enfatizou o contrário. Ainda que se possa dizer que são dois estruturalismos contraditórios, que ora ele fala uma coisa ora outra, eu diria que há uma linha fundamental, e que essa linha é a linha menor, a linha do desequilíbrio, da imperfeição, da assimetria constitutiva do real. " (Lagrou \& Belaunde, 2011: 19, eu grifo). Neste sentido, teorias que privilegiem o desequilíbrio, característico do dualismo ameríndio, ou a imperfeição, nos termos de Greimas, são uma via privilegiada, como pretendo mostrar, para a abordagem da canção em foco.

372 Lopes explica em seu artigo como, na "semiótica tensiva", sujeito e objeto funcionam como "investimentos passionais primordiais", entendendo paixão aqui "como transformação do ser que leva a uma transformação no fazer que leva a uma transformação no ser do ator..." (1990: 157). "Assim, o ato de ser de cada ator narrativo, dado o seu caráter antropomorfo, identifica-se com o ato de querer: se se 
chamarem os mortais está criada a tensividade passional que fará com que estes ajam em função de se imortalizarem. O chamado dos imortais é um evento inesperado no mito. Este chamado gera um desequilíbrio tensivo no espírito de quem é chamado. Aceitar ou não a imortalidade? Algumas histórias mostram personagens que atendem ao chamado. Em outras, algum desastre acontece que impede que o chamado seja atendido. Aos imortais resta questionar, como no refrão da canção: "Por que? por que? ". Por que não atenderam ao chamado constante? Estávamos sempre por perto e vocês não percebiam, fizemos barulho no buritizal e vocês não percebiam, não agiam da maneira correta, não jejuavam para subirem com a gente para a morada dos imortais.

O pensamento mítico ticuna admite uma tensão criada no tempo mítico. Esta tensão é a separação entre mortais e imortais, ou, nos termos consagrados por LéviStrauss, é o próprio tema da origem da vida breve. Ao analisarmos a canção dos imortair notamos que este tema da separação tensa entre mortais e imortais está presente na melodia da canção em foco. Ou seja, quando abordamos os contornos melódicos desta canção, estamos abordando os "acréscimos tensivos" (Tatit, 2011[1997]: 117) depositados sobre os investimentos modais presentes na letra ou mesmo subentendidos nos mitos. Uma canção é bem construída quando há uma ressonância entre o sentido que encontramos na melodia e na letra ${ }^{373}$. Neste sentido, pretende-se aqui contribuir para a exploração de ferramentas metodológicas voltadas para a análise da "sobreposição semântica", fundada numa inerência formal, entre mito e música, enfatizada por Werlang (2008: 36).

retira o querer de um ator humano, ele perde a sua característica humana e se transforma numa coisa (só as "coisas" não têm um querer). Dessa forma, o ser humano é um ator cujo ser é, já em si mesmo, para dizê-lo com a expressão de Santo Tomás de Aquino, "um ato de tender para": esse est tendere. A vida se faz, assim, ela é, primordialmente, um ato de paixão - de perspectivas que se estendem no rumo de um futuro infinitamente aberto, em cujo horizonte cada ser humano antevê a sua plena realização enquanto ser, naquele instante supremo da imersão do sujeito no seio do objeto, para a conjunção final. Aí, então, ficarão ambos a tal ponto identificados que desaparecerá qualquer possibilidade de distinguir um do outro, porque sujeito e objeto estarão fundidos e já não serão nunca mais dois, mas um e o mesmo ente simples (simples, quer dizer, completo, como se diz do ser que possui en propre tudo aquilo que é requerido para que ele surja como uno, acabado e perfeito, segundo a sua natureza). Então, aquela tensão do querer que arremessava o ser do sujeito adiante de si mesmo, no rumo aberto à perspectiva de um infinito poder ser, se resolverá, identificados sujeito e objeto no mesmo ser primordial, na distensão eufórica de todos os nirvanas" (1990: 156-57, grifo meu).

373 “Produzir canções significa produzir compatibilidade entre letra e melodia” (Tatit, 2011[1997]: 117). 
Sztutman, comentando o texto "A estrutura dos mitos", de Lévi-Strauss (2008[1955]), revela numa nota de seu texto que "Lévi-Strauss atenta aí para o fato de que a lógica do pensamento mítico revela uma dialética sem síntese, em que contradições são resolvidas por novas contradições..." (2009: 297, nota 4). Ou seja, uma contradição apontada pela narrativa contada na canção é transposta para a melodia. Neste caso específico da canção dos imortais, a distância irredutível entre mortais e imortais é transposta para a melodia, com seus saltos intervalares exagerados, criando uma distância entre sujeito (mortais) e objeto (imortais). Contudo, o que temos na canção é a relação (a distância) dada entre eles, mas, novamente, o eu lírico da canção é um imortal. Deste modo, estes últimos se colocam, por meio da elocução da canção, como sujeitos da relação. Os mortais são os objetos distanciados. Mas há outro porém. Ao ser encarnada por um cantor, este se imortaliza entoando a canção, suspende o tempo cronológico. Ao menos durante o ritual, ao entoar a canção, o cantor se torna imortal.

Durante a maior parte de sua duração, a canção dos imortais não é moderada na exploração da tessitura. Sobe até tons bem agudos, tanto que o cantor recorre a falsetes, algo comum entre os cantores ticuna. Temos aqui, portanto, uma característica da passionalização atuando dentro dos blocos melódicos recorrentes, característicos da tematização. O "projeto geral de dicção do cancionista" (Tatit, 2002[1996]: 24) consistiria nestes dois processos - passionalização e tematização -, aliados à figurativização, que analisaremos mais adiante.

Quanto ao traço de passionalização que podemos notar nesta canção, afirma Tatit, sua tendência básica é a desaceleração, quando são valorizados os "tons", as "alturas", as “notas" (1994: 97).

"[C]ada nota passa a ser ampliada em sua duração valorizando os contornos melódicos do percurso sintagmático e se compatibilizando, assim, com letras que acusam um distanciamento entre sujeito e objeto cuja tensão é resolvida por algum tipo de busca narrativa. Trata-se, quase sempre, de um sujeito que sente falta de um objeto, associado a uma meta, mas que mantém conjunção com o valor, a duração, a direcionalidade ou o percurso que leva a esse objeto" (idem: 95-6).

Existe uma fratura inicial, entre os mortais e imortais, causada pela negligência dos primeiros. Esta fratura está reforçada pela tensão dos grandes intervalos da melodia, revelando a "disjunção imediata com o objeto" - ou seja, os mortais não atenderam ao chamado dos imortais - mas ainda "em conjunção à distância com o valor do objeto" - a 
própria inconformidade dos imortais com a atual separação e a esperança de uma conjunção ${ }^{374}$.

Contudo, apesar de termos saltos intervalares bastante acentuados, eles compõem temas que são recorrentes durante toda a parte central da música - exceto no começo e final -, uma característica do que Tatit chama de "tematização". Ou seja, a parte central da canção é composta por apenas alguns motivos, aparentemente dois, que se repetem ao longo de seu desenvolvimento. Esta alternância dos dois motivos, impulsiona a evolução da melodia. Mas o que predomina, em termos de desenho motívico, é uma involução da melodia, isto é, um "retorno ao proto-actante indiferenciado, à fusão original, na medida em que seu curso prima por evitar a orientação" (Tatit, 1994: 76).

Com relação à exploração da tessitura, a canção diminui sua extensão no final, com blocos melódicos recorrentes de pouca extensão vocal. A "concentração melódica" que temos no final da canção aponta para a reparação da disjunção entre sujeito (os imortais, sujeitos da canção) e objeto (os mortais a quem os imortais se referem) ${ }^{375}$. Deste modo, os imortais lamentam a ruptura inicial e os saltos intervalares reforçam esta tensão. Entretanto, a voz que canta presentifica sua imortalidade potencial, no que é intensificada pelo recorrente tema melódico, que enfatiza, repito, o "retorno ao proto-actante indiferenciado, à fusão original" entre sujeito e objeto, imortais e mortais.

Tudo indica que a imortalidade alcançada por quem canta, tão comentada por Tatit e Wisnik, também está presente no pensamento ticuna. Este relaciona as Festas com a ascensão para o céu para atingirem a imortalidade. O que a canção dos imortais faz é comentar esta possibilidade, mostrar para os ouvintes durante o ritual que se cantarem e dançarem todos juntos e ficarem de porre a casa se elevará do chão e eles irão para Morugüne, se imortalizarão. No caso da canção em foco, os "compositores" são os imortais. Trata-se, portanto, de um mito cantado com autor, mas cujo autor - como ocorre com as canções compostas por Yoi ou pelo Tchürüne - é um ser mítico. O que temos aqui

\footnotetext{
374 "A passionalização melódica é esse tempo de espera ou de lembrança (cuja definição depende da letra), essa duração que permite ao sujeito refletir sobre os seus sentimentos de falta e viver a tensão da circunstância que o coloca em disjunção imediata com o objeto e em conjunção à distância com o valor do objeto. Por isso, a extensão passional é também a exploração de outros espaços de tessitura" (Tatit, 1994: 99).

375 "A noção de concentração melódica pressupõe que, nas instâncias fundamentais do percurso gerativo da significação (...), a junção sub-objetal esteja fraturada em virtude de uma apreensão descontínua da foria pelo sujeito da enunciação. O próprio sentido da concentração - definido por forças de convergência a um centro - já acusa um movimento de reparação de um conteúdo (ou de um tema) que se dispersou, suspendendo os elos sub-objetais" (Tatit, 1994: 73, eu grifo).
} 
é uma concepção de Tempo ticuna, embutida nesta canção. Retomando uma passagem d'O cru e o cozido, a obra musical e o mito são os "regentes de orquestra" e seus ouvintes, seus "silenciosos executores" (Lévi-Strauss, 2004 [1964]: 37). Desta maneira, o ouvinte se "imortaliza" anulando a inexorabilidade do Tempo. Mas qual as consequências de uma canção "composta" pelos imortais e dirigida para os mortais? Seria, então, uma reflexão sobre a imortalidade - ou as possibilidades de alcançá-la - enviada da forma mais adequada, cantada, ou seja, operando a suspensão temporal típica das obras musicais e do mito, tornando também o ouvinte imortal?

Seria difícil pensarmos numa canção, do nosso cancioneiro em português, com tão grandes saltos intervalares e um alongamento das vogais finais nas frases que fosse cantada numa ocasião festiva, para dançar. Entretanto, porque uma canção tão lamentosa como esta dos imortais é cantada num ritual no qual se dança quase ininterruptamente? A resposta pode estar na sintaxe melódico-temática da canção. As unidades menores, os motivos da canção são claramente passionais, indicam uma distancia radical entre sujeito e objeto, mortais e imortais, vida e morte. E do ponto de vista de um imortal. Contudo, tomando a canção como um todo, podemos observar a reiteração destes grandes motivos, quase sem alteração, apenas um estreitamento cada vez maior entre a nota mais alta e a mais baixa do fraseado. Sendo que no final da canção ocorre uma estabilização, uma periodização do motivo final, terminando a canção numa "direcionalidade temática" (Tatit, 2011[1997]b: 140).

Este esboço de análise me leva a elaborar uma hipótese arriscada. Acredito que dois aspectos da estética do canto ticuna tornam algumas de suas canções praticamente desprovidas de figurativização ${ }^{376}$ : o uso do falsete e os saltos intervalares enormes, em algumas canções. Ambos os aspectos caminham juntos, já que os grandes saltos que encontramos na canção dos imortais são possibilitados pela alternância entre o falsete e a voz “normal”. Contudo, esta canção não está totalmente desprovida de melodia figurativa, existem passagens em que é nítido o excesso de sílabas numa frase melódica, em contraste com a mesma frase dita anteriormente com uma sílaba para cada nota. Nestes pequenos momentos, a melodia é quase apagada em proveito de uma letra mais longa, por exemplo,

\footnotetext{
${ }^{376}$ Nas palavras de Tatit, a figurativização é "a neutralização dos investimentos melódicos. A melodia figurativa é dessemantizada tal como a entoação linguística que se dissolve no instante em que o texto é compreendido pelo falante (...) A melodia radicalmente figurativa não pretende dizer além do que já está no texto linguístico. Passaria muito bem sem ser notada: figurativiza a fala cotidiana" (Tatit, 2011[1997]b: 142).
} 
no lugar onde caberiam apenas algumas sílabas. Estes pequenos efeitos figurativos presentes na canção dos imortais revelam uma voz humana executando a canção.

\subsubsection{2 - Canções de aconselhamento}

A canção dos imortais, de que vimos um exemplo acima, é do tipo que se canta durante as danças, são endereçadas a uma audiência mais ampla no ritual. As canções que abordo agora são mais direcionadas às moças que estão sendo iniciadas. Qualquer um que se aproxime do(a) cantor(a) poderá ouvir o que é cantado, contudo, as letras das canções servem de conselho para as moças que estão se "formando". Muitas letras possuem o refrão "Pa iri iri pa worecü", dois vocativos que apelam à moça nova, iri iri" ${ }^{377}$ e worecü. Os conselhos vão desde a postura que a moça deve adotar na Festa até sobre seu futuro casamento, enfatizando bastante a relação dela com a mãe. Estas canções são entoadas principalmente quando a moça está dentro da reclusão, quando está sendo pintada de jenipapo e quando tem os cabelos arrancados, ao final do ritual.

Algumas canções são feitas para serem cantadas dentro da reclusão, no quarto (turi) feito de talos de buriti, onde as moças ficam "guardadas" (aure). Vimos alguns trechos, em capítulos anteriores ${ }^{378}$, de um registro que fiz de uma Worecütchiga cantada por Ondino. Quando fizemos a tradução, Ondino comentou que esta canção é entoada por uma avó da menina ${ }^{379}$. Ela aconselha a moça nova dentro da reclusão com esta música. Um dos conselhos enfatizados nas canções entoadas dentro da reclusão é a postura que a moça deve ter ao sair da reclusão. Na referida canção, um trecho que já foi mencionado $\operatorname{diz}(\text { Worecütchiga } 1)^{380}$ :

\footnotetext{
377 Sobre o termo iri, que aparece com frequência junto com worecü nas canções, Goulard diz o seguinte. "El término iri es equivalente al de worekü. Se utiliza en las celebraciones, a diferencia de worekü que es un término vocativo en la vida cotidiana" (Goulard, 2009: 338: nota 4)

378 Capítulo 3, tópico 3.1.5 - O corpo em formação e o mundo verde, e Capítulo 4, tópico 4.2.3.2 Periodicidade.

379 Quando Ondino diz que é uma "avó" quem aconselha a moça, devemos ter em mente que se trata simplesmente de uma mulher mais velha. Os Ticuna chamam de no'e (avó) a as mulheres de G+2 ou geração superior.

${ }^{380}$ Como possuo três versões de canções que são entoadas dentro da reclusão para as moças, intitulei-as Worecütchiga e enumerei-as de 1 a 3 para distingui-las.
} 


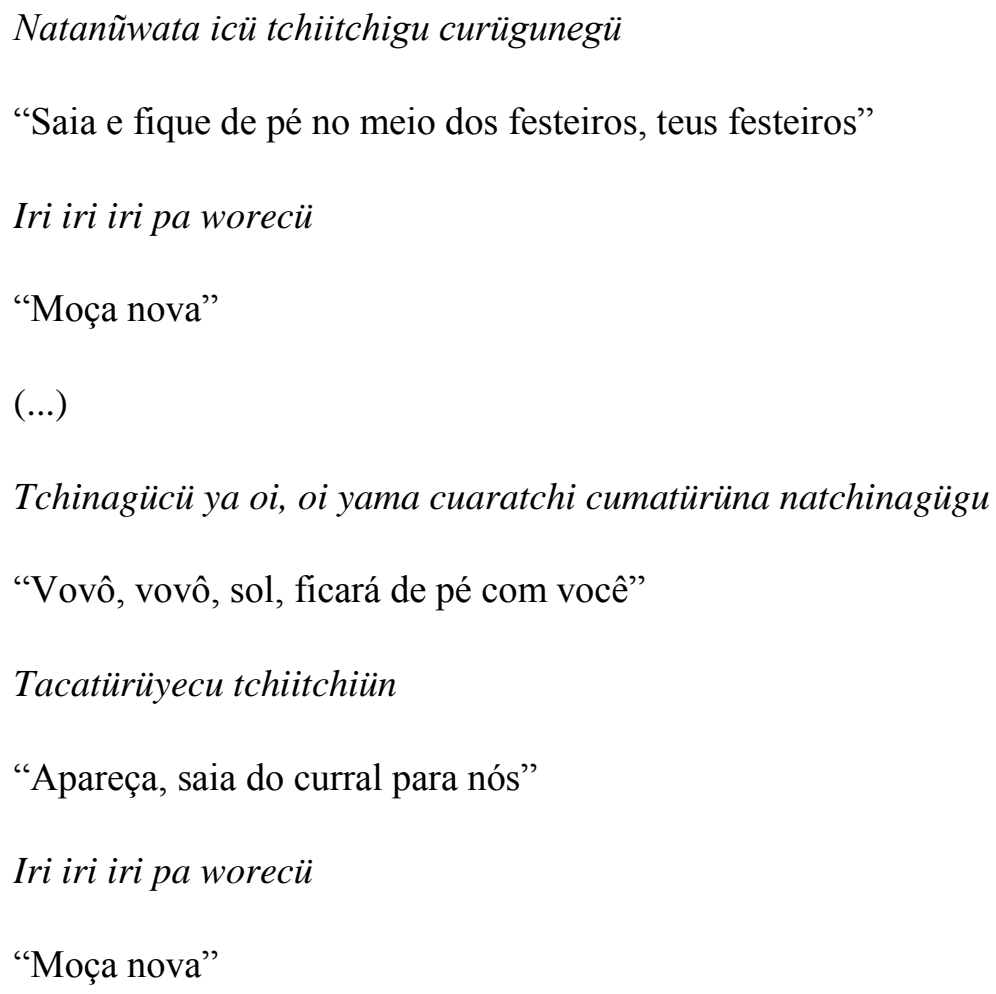

No trecho em que lemos, "Vovô, vovô, sol, ficará de pé com você", parece-me que a referência é ao sol que estaria "de pé" no firmamento depois que Yoi derrubou a samaumeira. O tradutor, Ondino, comentou comigo que "o sol está de pé no toco da samaumeira". Seria uma referência a algo firme e forte que está de pé. Ela deveria fazer o mesmo ao sair da reclusão, sair de pé, confiante. Existem muitas referências à vergonha

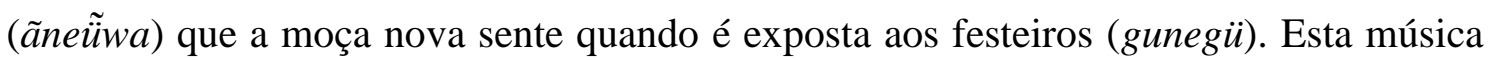
serve para encorajá-la a ficar de pé fora do quarto de buriti e não se intimidar. A imagem do sol nascendo é evocada antes do cantor pedir à moça que saia e fique de pé.

O trecho abaixo deixa claro que o "vovô Sol” apareceu no tronco da samaumeira mítica que cobria o céu (wone). O Sol subiu no tronco da árvore e "cantou a história". Não ter vergonha de cantar em público também é uma atitude que se espera de uma moça (Worecütchiga 2):

Nhumarüwai nüncuma' '̈̈tchi

"Agora, antigamente"

Nünma ga yunatü' ü̃ gama na'ãne

"Na terra dos mortais"

Do'onegu rü oi, oi gama yoyowetcha 
"Na terra virgem do vovô, vovô Yoi"

Tacatürüyena tu'uneyayi yema wonetchimegurü

"No tronco da Wone [samaumeira da história]"

Tacatürüyena tchinagücü

"Ele subiu"

Ya oi oi yama cuaratchi

"Vovô, vovô sol"

Cumatürüna tchinagugü tacatürüyena tchinagugü $\} 2 \mathrm{X}$

"Ele subiu e se apresentou lá cantando a história"

Iri iri pa worecü

"Moça Nova"

Em alguns trechos, os raios vermelhos do sol aludem ao cocar que a moça usa durante sua iniciação (Worecütchiga 3):

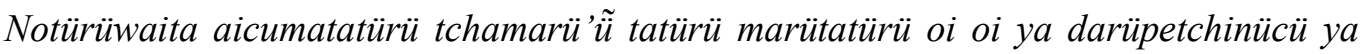
üacü rü'üta nama'ã yequi tchinagü ga curü conümata cutchonagü pa iri, iri, pa woworecü.

"Será que é verdade que você, como eu, já vai ficar como o sol, com o entorno avermelhado $^{381}$, em pé cantando ${ }^{382}$ com sua língua [conü], moça nova?"

No trecho abaixo, o cantor faz pouco da festa. Diz que os festeiros estão amarrando suas redes à toa, que está cantando sozinho no mundo ( $n a$ 'ane). Esta situação envergonha a ele e a moça nova. Ao dizer que está como uma arara com o rabo para baixo, afirma que está desanimado. Afinal, as araras, me disseram, “cantam sem parar”. Cadê tuas avós, tias e tios paternos, pergunta o cantor. São as pessoas encarregadas de cantar para a moça nova dentro do curral. Em geral, é desejável que a cantora seja uma tia (tükü - MZ) ou uma avó (noẽ, $+\mathrm{G}+2)$ (Worecütchiga 2):

Ẽcuwai curuwai no'ẽ tanücu tchamarü' ünwai

\footnotetext{
${ }^{381}$ darüpetchinü $=$ ao redor do sol avermelhado.

${ }^{382}$ tchinagü = posição do sol, em pé em cima das árvores.
} 
Ãneünwa rü cutchigamaye wawae

"Eu estou envergonhado, só por sua causa que estou cantando 383 "

Pa iri iri pa worecü

"Moça Nova"

Tchai'cawai guünarü naãnewa cutchigamayetchana tchonaguün

"Só eu, em todo o lugar do mundo, estou cantando a sua história [cutchiga]"

Pa iri iri pa worecü

"Moça Nova"

Ngecüenacü cunepü rü cutucü

"Cadê o titio [cunepü] e a titia [cutucü] ",

Tchamarü̈nwai aneünwa tutchacuracü

"Que não cantam como eu, envergonhado?"

Ngo'ürünwai cutchigamãyena wawai

"Vou cantar sua história como a voz da arara"

Iri iri pa worecü

"Moça Nova"

(Worecütchiga 1 ):

Ngecuenatürü cunepürü cutucü

"Cadê teu tio (FB) e tua tia (FZ)?"

Tchamarü̈̈nwai aneünwa tutchacüracü ngourü̈̈nwai

"Eu tenho vergonha, como a arara que está com o rabo para baixo"

Cutchigamayena wawai

"Estou cantando a sua música"

Iri iri pa worecü

${ }^{383}$ Wawae = cantar. 
"Moça nova"

Ngumarüwai yeaiyema no'ẽ, no'ẽ wopaenarü̈̈n curuwai curügünegü noturüwai

"Agora mesmo, como aquela vovó, vovó aranha que faz sua teia, os festeiros estão à toa armando as redes deles"

$\mathrm{O}$ (a) cantor(a) deixa claro que não é de sua vontade estar ali cantando, ele(a) está fazendo somente por consideração à mãe da moça. De acordo com a letra, a moça não merecia toda aquela atenção, seja do cantor(a) ou seja dos festeiros, que "à toa" amarram suas redes. A suspeitas dos(as) cantores(as) é sempre de que a moça está zombando dos conselhos deles. Assim Hilda me explicou enquanto estávamos traduzindo um canto de aconselhamento gravado por Malvina, "quando as velhas cantam para a moça, elas pensam que as moças estão mangando delas" (Worecütchiga 3):

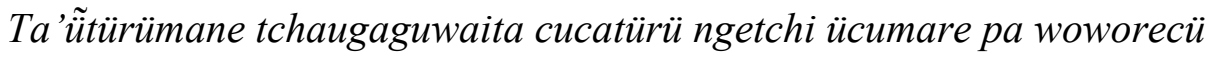

"Não foi minha vontade entrar aqui [na reclusão] com você, entrei aqui só por causa da sua mãe, moça nova"

Nhuacürütürü tchoümatürü i cucugü'ü̃ na cutchigama yetcha rü tchicutchi pa iri, iri, pa woworecü

"Parece que você está zombando de mim agora, porque eu estou cantando a tua canção [cutchiga], moça nova"

\section{(Worecütchiga 1 )}

Nhẽẽtchiwai curüwai noẽtanüncü tchamarü̈̈nwai

“Cadê tuas vovós como eu?"

Ãneünwa cutchigamayena wawai

"Você tem vergonha da tua música quando eu estou cantando"

As canções de conselho apontam a postura muitas vezes debochada das moças, ou mesmo o fato de ficarem sorrindo como fazem alguns macacos. Tudo isso é alvo de reprovação pelos(as) cantores(as) (Worecütchiga 3):

Nhumarütawai nhuacürümatürü ye'erawatürü tchoü icucugü pa iri, iri.

"Será que você está mangando de mim agora, moça nova?" 


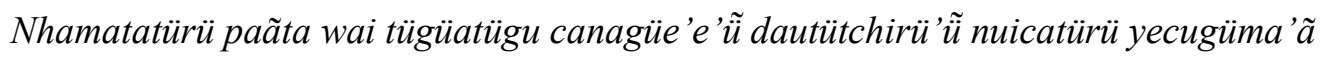
yeiqui ngigü'a tchiü pa iri, iri, pa woworecü.

“Assim como o mico leão que as moças colocam no ombro delas que você olhava sorrindo para todo canto, moça nova?"

Muitas vezes o riso debochado da moça é referido ironicamente, o(a) cantor(a) diz para ela rir como faz o macaco da boca branca:

\author{
Oegaün gama tchotchotcho tchowiri yarirününta, yiitchamata nacatürüwai \\ curücugüma'ã
}

"Quando você sair do seu curral, saia com um sorriso, igual ao do macaco de boca branca [yari, Saguinus sp]"

Nuĩcatawaicu ngiãtchi

"Olhando para todos os lados e dando risada como o macaco de boca branca"

Iri iri pa worecü

"Moça nova"

O aconselhamento faz duas referências ao mito da To'oena, a primeira moça nova. A primeira é o rio Panatü, que, segundo o tradutor me informou, "é um rio que fica no igarapé Tunetï’. Ou seja, foi neste último que a carne de To'oena foi tratada, e com seu sangue a água está tingida de vermelho até hoje. Na cabeceira deste rio está um ingazeiro crescido, no qual a primeira moça nova subiu para ver os instrumentos proibidos (Worecütchiga 1 ):

\title{
Tatügayema Panatü aru wiewarü
}

"No final da cabeceira do rio Panatï"

Ü̈̈ne yayima pama aru ngemanerü̈̈n natanüguyecu ngemagüün curügunegü

“A fruta verde daquele ingazeiro lá que já está crescido. A Festa está como um ingá magrinho, ninguém canta com você"

Iri iri pa worecü

"Moça nova"

A Festa é comparada a um ingá magrinho e o corpo da moça também. Temos novamente aqui um exemplo da "metáfora vegetal" usada para se referir à pessoa ticuna. A 
maturidade do corpo da moça é pensada nestes termos, como o amadurecimento de uma planta. Hilda, que traduziu esta canção comigo, me disse que o trecho abaixo faz referência "às crianças que apanham o ingá verde, antes da hora" (Worecütchiga 3):

Tautatürü aicümatatürü damaücütürü bacatchacane ya tuerü'üta ngipe'eguwai curü bacaparane curümama damatatürü buãtatürü i bugune yayima nhemane yapama rü' $\tilde{u}$ doüemata cuи̃iyacawe aitchatarü ngetücü pa iri, iri, pa woworecü.

"Será que você vai ficar bonita como olho da macaxeira na frente da sua mãe, com a batata da perna bem grossa e bonita? Será que você vai ficar igual o ingá ainda verde (doü), magrinho, que a criança apanha? O aitcha rapaz solteiro vai apanhar você, moça nova?

Em contraposição ao "ingá magrinho" temos a macaxeira vistosa, como se pretende que a moça fique. Isto está indicado pela palavra baca, que me foi explicada como "quando a maniva está bem bonita, bem madurinha, com os brotos das folhas bonitos". Na música a cantora compara a planta da macaxeira bem viçosa com a moça nova que vai sair da reclusão.

Na Worecütchiga 1 aparece o pássaro aitcha. Não consegui identificar esta ave, mas ele aparece no livro dos pássaros ticuna. Sobre ela, Ondino me disse apenas que este passarinho é todo amarelo e com as costas cinza. Um pássaro pequeno como um beijaflor, mas com o bico curto. Aqui temos a referência de que o aitcha pegará a moça ainda "verde", como o ingá verde. Trata-se uma comparação com um casamento ou relação sexual feitos antes do tempo. A moça depois de sair da reclusão ainda deve esperar um tempo para se relacionar com seus futuros parceiros. Vejamos outro trecho em que este pássaro aparece:

Tauüntamawai oegacü aitchata'arü ngeyungeyu

"Dá raiva a rapaziada do aitcha"

Yiitchamata nü̈̈ntawai cutüãtchi

"Não abrace/agradeça ele, o outro é melhor"

Pa iri iri pa worecü

"Moça nova" 
Noturüwai goaniyayima oegacü gama aitchata aru

"Naquele aitcha irresistível você vai"

Ngetü̈̈cü yiitchamãta nhamãücuturï̈ ${ }^{384}$

"Hoje em dia ela escolhe o rapaz"

A palavra yiitchamata, usada para falar do aitcha, é de difícil tradução. Explicaram-me ela da seguinte forma: "tem duas pessoas, uma delas vem em sua direção, mas você queria a outra, não queria a pessoa que está vindo". Isto é, o conselho aqui é para que a moça não fique com o primeiro rapaz que aparecer, os mais afoitos (Worecütchiga 2):

Aitchata arü nge'tü' ’ücü yitchamata nhamaücütürü oegaün gama tchotchotcho

"Se você rir [tchotchotcho] para aqueles homens vai ser um desgosto"

Tchowiri ya 'rirü'ünta ya yitchamata nacatürüwai

“Como ri o macaco caiarara [ya'ri]" [macaco com a boca branca]

Curucuguma nünicatawai cungiatchi'ün

"Mas sozinha você pode sorrir"

Iri iri pa worecü

"Moça Nova"

A moça é lembrada em muitas passagens das canções de sua relação com sua mãe, especialmente de todas as vezes em que a desobedeceu ou faltou com o respeito. A imagem evocada é a da cotia, como um animal raivoso (Worecütchiga 2):

Õerutawai cu'üntürüwai na mũcüraüngu

"Quando a mamãe mandar"

Taũtama taũgacuya ya ocutiara

"Você não responderá com preguiça"

Tchigurünwai cutchamata ngĩetügu i cuya puragü'ün

"Como a cotia, com arrogância"

\footnotetext{
${ }^{384}$ Ngetüücü = quando ainda não é pai
} 


\section{Iri iri pa worecü}

"Moça Nova"

Notürüwai guni ya yema oegacü gama (...)

"Porque seria um desgosto"

Em nosso imaginário o caniço não remete a algo que tenha força (pora). Contudo, na cultura ticuna, em que o mito relata que eles surgiram da pescaria com caniço de $Y o i$, este caniço remete a algo muito forte, indestrutível. Muitos foram os relatos que ouvi de que o caniço de Yoi ainda pode ser visto no Eware. Na passagem abaixo vemos a alma da mãe da moça sendo comparada à força do caniço. Em contraposição está a moça que ainda não controla sua raiva quando vai falar com a mãe (Worecütchiga 1):

Tauütchima poraneyayima nainecü ngiaeyiũgurü otchametü

"A festa só está acontecendo porque a alma da tua mãe é forte como um caniço"

Õẽrutawai taü̈ntchimawai

"Se tua mãe não tivesse força [pora], não teria festa"

Yeaiyema curüwai

"Aquela lá é sua [mãe]"

Otchametü õẽrütawai cuũtürüwaina mucüraüngu tauüntamã oegacüya

"Quando sua mãe manda em você, não pode ficar com raiva"

Ocutiara yatchigurü̈̈wai cutchamatatürü ngietügü cuyapuragü

"Não responda para a sua mãe, como faz a cotia, [com raiva]. Não fale com raiva ao mesmo tempo que ela"

Pa iri iri pa worecü

"Moça nova"

Como podemos ver, o aconselhamento da moça é bastante duro. Além da provação física pela qual a moça está passando, e que culminará com o arrancamento de seus cabelos, ela deve passar por esta exposição moral. O tema do desrespeito à mãe aparece nestas canções, que são entoadas dentro da reclusão, mas são mais presentes 
quando a moça tem os cabelos arrancados. Neste momento, me disseram alguns ticuna, “a moça tem que sofrer". Ela, então, é lembrada de todas as vezes que tratou mal sua mãe, por isso estaria passando por aquela provação. Abordaremos as canções que são entoadas quanto a moça tem os cabelos arrancados quanto for descrever este momento do ritual ${ }^{385}$.

Antes de passarmos aos instrumentos musicais dos Ticuna, no entanto, vejamos uma das origens míticas das canções. Algumas canções vimos que foram "compostas" pelos imortais, outras foram ensinadas por Yoi. Veremos ainda que o personagem mítico Tchürüne também foi o responsável por mostrar alguns instrumentos e ensinar canções aos Ticuna. O relato que segue abaixo foi registado por Gruber, de seu colaborador ticuna Manuel Pereira Ângelo, conhecido por Manuel Rita, que reencontraremos quando abordamos os trompetes ticuna. A origem das canções seria a seguinte:

"Uma moça já estava no recinto de reclusão, turi, esperando o início de sua festa. Sua família tinha saído para buscar mais caça e deixou-a sozinha em casa. De repente, um dos moqueados que estava no jirau pulou lá de cima e começou a dançar. A moça espiou por uma pequena abertura do turi [quarto de reclusão] e viu que se tratava de um macaco, um daqueles macacos que seu pai tinha caçado e moqueado para a festa. O macaco usava um chocalho de vara e dançava sem parar ao redor do turi. Depois de um tempo, pediu a moça que prestasse atenção nos seus cantos e aprendesse as letras e as melodias para ensiná-los aos parentes. A moça ouviu cada um deles atentamente. Após algumas horas, percebendo que alguém se aproximava, o macaco subiu rápido para o jirau e lá se transformou de novo em moqueado. Quando a família da jovem entrou na casa, a mãe logo perguntou à moça quem tinha estado por ali batendo com alguma coisa no chão e sujando com cinzas a casa. Ela então contou da visita do macaco, dizendo que de agora em diante não deveriam mais ser cantadas músicas feias durante a festa, mas sim aquelas que havia aprendido com ele."

"Segundo o narrador, a moça adquiriu com o macaco-caiarara o conhecimento dos cantos, a capacidade de improvisar canções bonitas e reproduzir o repertorio que ele lhe ensinara. Assim, o macaco despertou-a para a música, dotando-a de poderes especiais de interpretação e criação, e por isso

\footnotetext{
${ }^{385}$ Ver Capítulo 7, tópico 7.9-Cabelos arrancados.
} 
ela deveria continuar cantando, sem nenhuma vergonha, para que todas as pessoas pudessem ouvir e aprender" (1999: 13-14, meu grifo).

Vimos no Capítulo 2, tópico 2.7 - Metare - o bom partido, o perigo de se deixar uma moça sozinha. No mito do lagarto Õmi a moça é deixada "de pé sozinha no centro da casa" (Nimuendaju, 1952: 74) e acaba sendo vítima do gigantesco lagarto. No relato acima, para que o macaco apareça para a moça cantando, dançando e tocando aru, a moça deve estar sozinha. De acordo com Goulard, a narrativa que conta a origem das máscaras narra também o início da interdição de se caçar durante a Festa da moça: "agora a caça não será mais praticada durante a celebração de rituais, o que viola a presença de seres sobrenaturais" (2011: 133). Contudo, mesmo antes da celebração, não é seguro deixar a moça sozinha sem ninguém, principalmente a mãe ou alguma tia, próximo dela. Existe sempre o perigo da moça ser iniciada ou mesmo morta por alguma outra entidade. Entretanto, a moça do mito acima, apesar de violar o interdito de sair da reclusão, acaba aprendendo as canções da Festa e recebe a incumbência de ensinar aos seus parentes. Esta tarefa ainda está presente na iniciação das moças. Elas devem ouvir atentamente o que dizem os(as) cantores(as) e decorar para que possam, futuramente, cantar sem timidez nas Festas de outras moças.

Passaremos no capítulo seguinte a uma consideração sobre a música instrumental e os instrumentos musicais da Festa da Moça Nova. Apesar de termos nos dedicado a explorar diversas noções ticuna sobre o som e o canto, cumpre destacar alguns pontos que serão mais relevantes para o que segue da tese. 1) vimos que há uma indissociação entre cantar para a moça e fazer uma Festa para ela. As moças não podem "ficar no silêncio". 2) o cantor ticuna pussui uma característica que ainda será mais explorada adiante, o fato de cantar em falsete, com voz feminina. 3) A variedade de temas das canções do ritual é bastante ampla, contudo, existe um tipo de canção que será fundamental para a compreensão da Festa, que são as canções de aconselhamento. 


\section{Capítulo 6 - Instrumentos musicais da Festa}

Mencionei em nota ${ }^{386}$, brevemente, a relação do profeta Aureliano com os imortais. O fato curioso que guardei para mostrar agora é o que segue. O pendor por construir e aprender a tocar instrumentos musicais entre os Ticuna é referido por Nimunedaju (1952: 138). Este autor menciona a introdução do violino em aldeias ticuna. Não bastasse aprenderem a tocar o instrumento, em princípios da década de 1930, um jovem índio chamado Aureliano, do lago Cujaru no Rio Jacurapá, passou a fabricá-los. E tão bem que, em pouco tempo, muitos civilizados acorriam a ele para fazerem encomendas. Resultado, não demorou muito para que as autoridades de São Paulo de Olivença mandassem prendê-lo por sonegação de impostos dos violões e violinos que ele fazia.

Contudo, Aureliano não foi preso, obviamente, simplesmente porque não pagou impostos referentes à venda de seus violões e violinos. Ele começara a ter visões dos encantados/imortais (ü'üne). Quando um fato como este acontecia, os civilizados de São Paulo de Olivença começavam a suspeitar de um início de movimento messiânico, o que, como vimos ${ }^{387}$, é bastante comum na história dos Ticuna. Temendo uma revolta dos índios que se juntavam ao movimento, os civilizados locais intervinham com maior ou menor brutalidade (Nimuendaju, 1952: 138). No caso de Aureliano não foi diferente. Usando, então, o pretexto do não pagamento de imposto, ele foi preso para que não oferecesse perigo de sublevação.

Segundo Lévi-Strauss, a organologia ticuna é uma das mais ricas da América tropical (2004[1967]: 347). De fato, estes indígenas apresentam, além dos enormes trompetes de que tratarei mais detidamente, bastão de ritmo (aru), membranofone (tutu), idiofones (ngobu, tori e ba'ma), flauta pan (tchecü), flauta de embolo (nge'cütü) e um trompete menor, de bambu (coĩri). Todos estes instrumentos são executados durante a Festa da Moça Nova (Worecütchiga). Ao longo do meu trabalho de campo, pude participar de algumas Festas de Moça Nova e acompanhar a fabricação destes instrumentos ticuna.

\footnotetext{
${ }^{386}$ Ver Capítulo 3, tópico 3.1.3 - Processos para tornar-se imortal.

${ }^{387}$ Ver Capítulo 2, tópico 2.8 - Atualização do mito - notas sobre o messianismo ticuna.
} 


\section{1 - Sopro}

A razão da predominância dos aerofones entre os sul-ameríndios tem uma estreita relação com a importância do sopro para estes povos. Vejamos o trecho de Hill \& Chaumeil sobre isso:

"[P]ara explicar a predominância de aerofones ao invés de outras famílias de instrumentos, devemos nos voltar para os entendimentos indígenas sobre o sopro [breath] e a respiração [breathing] como expressão de força de vida e os aerofones como formas de canalizar o sopro em atividades coletivas concebidas para assegurar a fertilidade continuada da natureza animal, assim como a regeneração dos mundos sociais humanos" (2011: 19).

Deste modo, antes de começarmos a explorar a organologia ticuna, em especial os enormes aerofones, devemos passar em revista toda uma noção que concerne ao sopro. Vimos nas descrições que fiz da pajelança ticuna que o assobio é um importante instrumento do xamã ${ }^{388}$. O aguardente, ingerido pelo curador e passado no paciente, assim como o canto e o assobio servem para "amolecer" (do 'ũca) o "espinho" (tchũta) mandado para enfeitiçar e adoecer a vítima. Roberto, o pajé que tratou da filha de Gabriel, assobiou muitas vezes durante sua performance. $\mathrm{O}$ mesmo pude perceber nas sessões xamânicas de Arnaldo e Aricildo. Ao que parece, este assobio se conecta intimamente ao sopro do tabaco e a reza. Goulard ressalta ainda a relação entre o sopro xamânico e a caça com zarabatana:

\footnotetext{
"Se puede comparar la práctica de la caza con el acto chamánico en la medida que el término $k w e^{389}$ significa tanto el trabajo del chamán como el del cazador. La acción de 'soplar' (el cuerpo) - que consiste en regresar el principio vital de la persona enferma - estaría en el mismo orden que la de 'soplar' (en la cerbatana) para alcanzar al animal y quitarle la vida. Añadimos que los 'padres' o las 'entidades' se apoderan del principio vital de uno por el kwe. El valor de este término se verifica cuando el animal herido vuelve junto a su 'padre' que se ha encolerizado" (2009: 321).
}

\footnotetext{
${ }^{388}$ Cf. Capítulo 4, tópico 4.1.2 - Vetores de feitiço.

${ }^{389}$ Kwe é uma outra grafia, variação livre da mesma palavra, $f e$, "sopro".
} 
A reza do pajé é referida como tafecune, sendo que a partícula " $f e$ " do meio da palavra significa "soprar". Assim como a palavra "assobiar" (fenee), que também possui esta partícula. Contudo, além de soprar o tabaco, o xamã suga os males que estão no corpo do enfermo. O ritual de cura, portanto, é um jogo entre aspiração e sopro. O tabaco é aspirado e soprado. $\mathrm{O}$ mesmo acontece com os males que são retirados do paciente. $\mathrm{O}$ pajé os aspira e depois regurgita, como se estivesse vomitando algo indigesto. Além dessa função de "amolecedor" do vetor de feitiços, pelo que me disseram, o pajé assobia para chamar o espírito ( $\left.\tilde{a}^{\prime} \mathfrak{e}\right)$ de outro xamã. Ele pode chamar, inclusive, o pajé de algum bicho também. O assobio é referido por Nimuendaju como um chamativo da alma (ã 'ê) perdida de uma criança ${ }^{390}$, algo próximo do que afirma Goulard, acima, quando diz que o sopro faz regressar o "princípio vital” (ã ’ê) da pessoa ${ }^{391}$.

Veremos que a "voz" ( $g a$ ) dos trompetes é muitas vezes considerada a voz de um demônio ou "bicho" (ngo ’o). Esta voz demoníaca remete também às potências perigosas relacionadas ao sopro e ao vento entre os Ticuna. O trompete to 'cü e a zarabatana (ĩe) possuem relações muito próximas no pensamento ticuna. Ambos podem ser feitos do mesmo material, a paxiúba, e funcionam da mesma maneira, são soprados. Como vimos, o verbo ticuna utilizado para se referir a "soprar" é $f e$, mas esta palavra possui outros significados. Ela pode significar também "caçar" e até mesmo "matar"392. Os termos usados para designar "assobiar", $f e^{2} n e^{4} \hat{e}^{3}$, e "caçar", $f e^{4} n e^{33} e^{3}$, diferem apenas nos tons de cada sílaba e possuem a mesma raiz, $f e$. Esta associação terminológica entre caça e sopro - mortal ou musical - não causa espanto, já que a zarabatana foi por muito tempo a arma de caça por excelência dos Ticuna.

A explicação para o to 'cü ter cerca de 3, 4 metros de comprimento, não ser maior, explica Francisco, é que, se ele fosse maior, não combinaria com o "vento" (buanecü) da gente. Para se falar do fôlego e do sopro de uma pessoa usa-se, além da palavra sopro

\footnotetext{
390 "Se alguém vai à noite para a floresta escura com um lactente, a criança corre o risco de perder a alma de seu corpo. Para evitar isso, é preciso assobiar e chamar a criança pelo nome." (1952: 70)

${ }^{391}$ Goulard encontrou também a relação entre "sopro" e "dom" entre os ticuna. Ter uma visão atesta que a pessoa tem um "dom" de Deus, fe: "En el transcurso de un ritual religioso, un hombre o una mujer pueden tener una visión, lo que atestigua que poseen un don, literalmente, un soplo, fue." (2012: 34).

392 No mito Ngatü rü Auma (Firmino \& Gruber, 2010, vol. 1), traduzido por mim é pela ticuna Hilda do Carmo (Mutchique'ena), temos um exemplo do uso de fe' com o sentido de "matar": "O caçador falou para sua esposa, "fique aqui mesmo que eu vou matar ( $\left.f e^{\prime}\right)$ os pássaros Auma que estão fazendo zoada aqui".
} 
(fe), a palavra utilizada para se referir ao vento propriamente. Esta suposta confusão na tradução das palavras "sopro" e "vento" que notei conversando com alguns ticuna, não é fortuita. Severino, por exemplo, dizia que já não conseguia soprar com força o iburi que havíamos construído, porque seu "vento" estava fraco. Francisco também se referiu ao seu fôlego e sopro como "vento". Ter um "vento" forte é um atributo desejado pelos Ticuna.

A força do vento é personificada nas Festas de Moça Nova pelo mascarado Õma, mais especificamente por seu enorme pênis. Daí o fato de perguntarem a este mascarado qual o segredo de ele ser forte como o vento. "A dona da festa fala assim para ele, "Õma, cuna pora...", "Õma, tenha mais força, seja mais forte, com o vento. Como é que você faz para ser igual ao vento (buanecü)? ". "393. Ou seja, deseja-se ser forte como o vento e ter um sopro, "vento", igualmente forte, ao mesmo tempo em que o mascarado também é temido, assim como o forte vendaval destruidor. Por um lado, se o poder de Õma é conhecido por derrubar árvores, por outro lado, é açoitando o vento com uma vara que $N_{\text {gonetuma }}{ }^{394}$, na terra dos imortais, obtém lenha. Portanto, na terra dos mortais, o vento é gente $\left(d u^{\prime} \tilde{u}\right)$ e derruba árvores (madeira), entre os imortais, este mesmo vento fornece a lenha em feixes pequenos e prontos.

Em uma conversa com Manuel Rita, ele me contou que o vento é a canoa dos imortais, seu meio de transporte para chegarem à Festa que eles querem visitar:

"Na Festa de Moça Nova, o ü'üne [imortais] quando vem para cá, ele vem com o vento, quando o vento está chegando. Esse vento são eles que estão chegando, quando é Festa de Moça Nova. O vento é a canoa deles, o avião deles. Eles vão chegando, vai chovendo um pouco e eles vão chegando. Se eles voltarem para cá, assim [aponta para a direção contrária ao rio, para a terra firme], a gente não tem mais vento não, porque eles estão no caminho [de terra] andando, eles vão a pé. Se eles vêm pelo rio, eles vêm com o vento, se eles vêm pela terra, a pé mesmo, não tem mais vento."

\footnotetext{
${ }^{393}$ Trecho da história de "Como se cuida da moça nova" (Nhuũũãcü worecüma icufaũ, Firmino \& Gruber, 2010, vol. 3), traduzida com Ondino.

394 "Neste lugar o vento (buanecü) era igual gente também. Ele devia bater no vento com a vara para obter um feixe menor de lenha". Ver o mito de Ngowarutcha rü Ngunetuma (Firmino \& Gruber, 2010, vol. 3), que conta a passagem do menino Ngowarutcha pela terra dos imortais.
} 
Devemos ter em mente, então, que se os imortais se locomovem com o vento. Isso nos leva a pensar que este vento é evocado e enaltecido na Festa para que ele conduza os participantes para a imortalidade. A casa que sobe pelos ares levando os participantes da Festa para a imortalidade seria movida por um grande vendaval.

Os ventos nas Terras Baixas da América do Sul são, em geral, bastante calmos. Os viajantes e moradores da região conhecem bem a sensação de abafamento causada pelo calor e a praticamente ausência de circulação de ar. A média anual da velocidade do vento na região do Alto Solimões não passa de $1 \mathrm{~m} / \mathrm{s}$, um tipo de vento designado “aragem”, vento brando e intermitente ${ }^{395}$. Contudo, isso não quer dizer que inexistam temporais e borrascas relativas na região e possam, com isso, povoar o imaginário ticuna. Em relação à média anual, um vento de $11 \mathrm{~m} / \mathrm{s}$ ou $39,6 \mathrm{Km} / \mathrm{h}$, por exemplo, pode ser um vendaval, como o ocorrido no dia 28 de fevereiro de 2011 (ver gráfico abaixo).

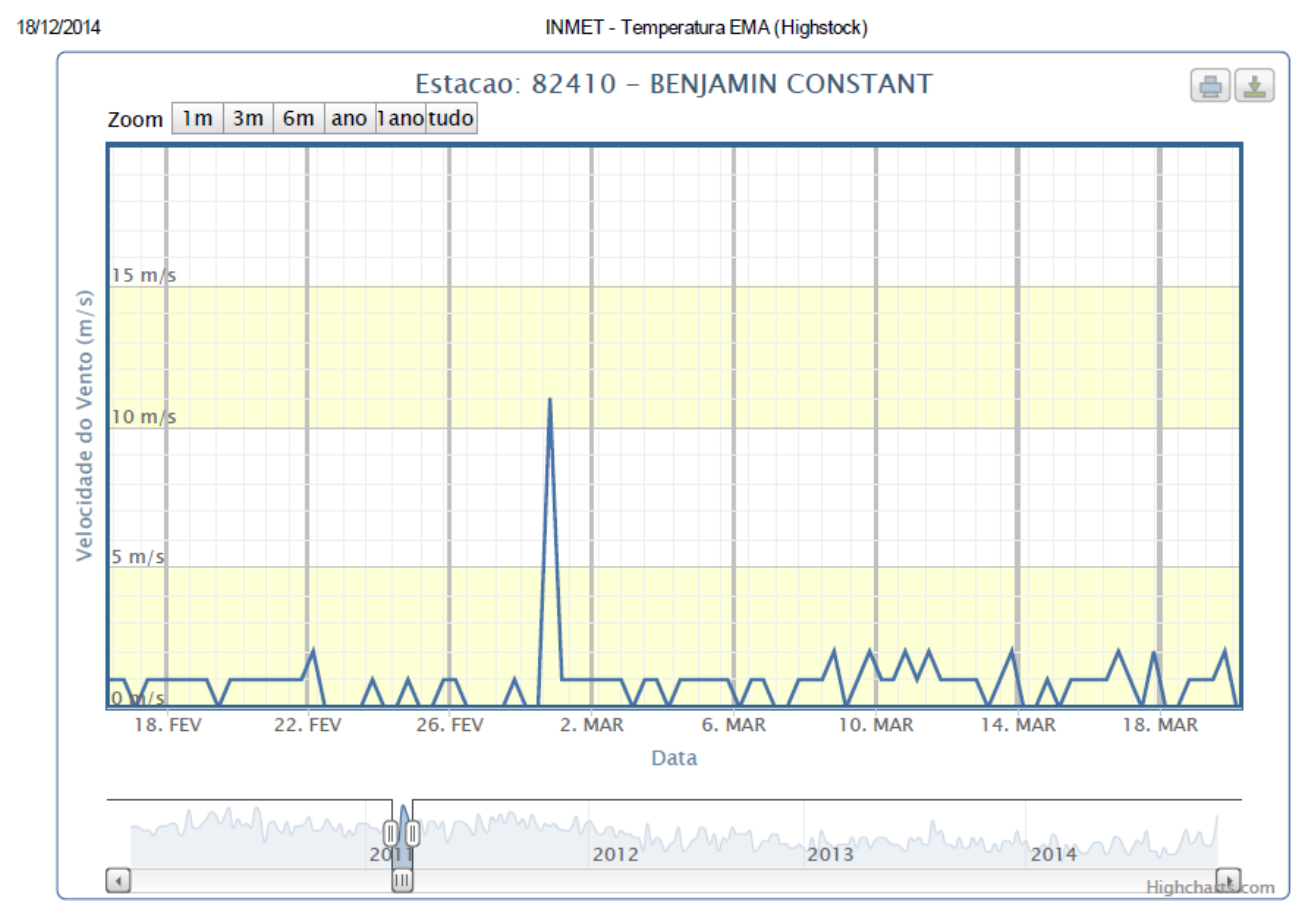

Figura 14 - Gráfico de velocidade do vento gerado a partir da estação meteorológica de Benjamin Constant (AM). Site http://www.inmet.gov.br/portal/index.php?r=home2/index

\footnotetext{
395 Ver classificação das intensidades de vento no site http://pt.windfinder.com/wind/windspeed.htm, consultado em 18 de dezembro de 2014.
} 
Vez por outra, as tempestades com ventos fortes acontecem no Alto Rio Solimões. Presenciei um vendaval com chuva durante uma noite em Nazaré que pensei que a casa ia sair voando. Quando amanheceu e eu pulei da rede, pude ver os estragos. Uma parte do telhado da casa de Gabriel, em frente à casa de Ondino onde eu estava, foi arrancada pela chuva. No momento da chuva, mesmo a casa de Ondino, que possui um telhado de folhas de zinco bem fixado, pensei que não resistiria. Este tipo de vendaval é inesperado e raro de acontecer, talvez por isso gere uma impressão marcante entre os índios.

\section{2 - Aerofones}

"Se tudo pode ser humano, então nada é humano inequivocamente" Eduardo Viveiros de Castro, 2002a: 377

São quatro tipos de aerofone que possuem os Ticuna e que são executados na Festa da Moça Nova: uma flauta pan, tchecü, e três trompetes, coĩri, iburi ou buburi e to 'cü. Os

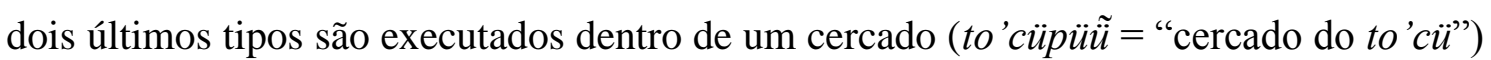
anexo à casa de Festas, bem atrás do quarto de reclusão (turi) das moças, e é por estes dois instrumentos que começo este tópico sobre os aerofones ticuna ${ }^{396}$.

Estes trompetes, designados em conjunto sob o nome de aricano ou uaricána ${ }^{397}$ (Nimuendaju, 1952: 42; Pereira et al, 2009), são considerados tabu para mulheres e não iniciados, o que nos coloca o problema da especificidade de sua inserção no conhecido complexo das "flautas sagradas", um fato etnográfico bastante recorrente na literatura, especialmente da América do Sul e Nova Guiné ${ }^{398}$. Podemos notar, portanto, que as

\footnotetext{
396 Uma versão resumida da exposição que segue sobre os trompetes ticuna encontra-se em Matarezio Filho, 2013: 131-141, em português; 2015 (no prelo), em espanhol.

397 Nimuendaju afirma que uaricana é um termo emprestado da "língua geral" (1952: 42) para designar os grandes trompetes. De acordo com o dic. Houaiss, o nome aricano é o mesmo que aparia. Segundo Porro (2007: 18 e 145), esta palavra se refere tanto ao nome de aldeias Omagua (Kambeba) do século 17 - localizadas próximas às cidades de S. Paulo de Olivença, Loreto e Tabatinga, territórios onde estão localizados os atuais Ticuna -, quanto ao nome ou título do cacique ou senhor principal destes índios, o que suscita uma possível origem exógena deste instrumento.

398 Um panorama das "flautas sagradas" na América do Sul foi traçado numa coletânea de artigos organizada por Hill \& Chaumeil (2011). Uma comparação entre os contextos etnográficos dos ameríndios
} 
chamadas "flautas sagradas" podem não ser exatamente flautas. No caso ticuna, tratamse, a rigor, de trompetes, ou seja, um tipo de aerofone em que uma "corrente de ar entra em vibração através dos lábios do tocador” (Hornbostel \& Sachs, 1961[1914]). Mas também se canta dentro deles, isto é, os trompetes são usados para amplificar a voz do tocador, são "megafones” (Nimuendaju, 1952: 42) 399 .

Trompetes como o iburi, feitos de casca de árvore enrolada, são encontrados em diversos povos da América do Sul. Dentre eles, por exemplo, podemos mencionar os Wakuénai, Curripaco, Baniwa, do Alto Rio Negro (Hill \& Chaumeil, 2011b: 12); os Apurinã; e os Yagua, vizinhos dos Ticuna e também de língua isolada (Chaumeil, 2011: 49). A seguir apresento as imagens ${ }^{400}$ mostrando o passo-a-passo da fabricação do iburi, o trompete feito da casca da árvore $d u r u^{401}$ (Croton palanostigma; Glenboski, 1977: 122).

Nas imagens abaixo temos Francisco Alexandre Filho (Üpetücürüngütchiãcü) e Cirineu Gomes Geraldo ${ }^{402}$ construindo o trompete na antiga escola da comunidade de Nossa Senhora de Nazaré, igarapé Camatião. O senhor de camisa branca é Severino Alexandre Gomes (Tõetükü), um dos que executou o instrumento, junto com Francisco. Este último foi muito paciente com todas as minhas perguntas sobre o instrumento e o processo de sua construção. Suas habilidades manuais não se restringem a construção dos instrumentos da Festa da Moça Nova. Ele também é o responsável por consertar o motor de luz da comunidade, sabe construir a casa de Festas e casas de moradia.

\footnotetext{
e dos povos da Nova Guiné, incluindo os dois complexos de "flautas sagradas", pode ser encontrado em Gregor \& Tuzin (2001).

399 Menezes Bastos destaca, esta variabilidade das chamadas "flautas sagradas" na América do Sul indígena. "Não tratamos somente de flautas, pois as "flautas sagradas", dependendo de cada caso etnográfico, podem compreender aerofones de vários tipos ou mesmo, como no caso xinguano (kamayurá) aqui abordado, além de várias espécies de aerofones ("flautas", "trompetes", "clarinetes", "zunidores"), várias categorias de idiofones (chocalhos globulares, em fieira etc.)" (2006: 558).

400 Estas imagens são frames retirados do filme IBURI Trompete dos Ticuna, Matarezio Filho, 2014, 14'.

401 Nesta mesma árvore que um casal sobe para fugir da vingança dos "bichos" (ngo'ogü) numa das narrativas do mito do Tchürüne (Bueno, 2014: 88-92).

${ }^{402}$ Francisco está de camiseta amarela e Cirineu de camisa azul.
} 

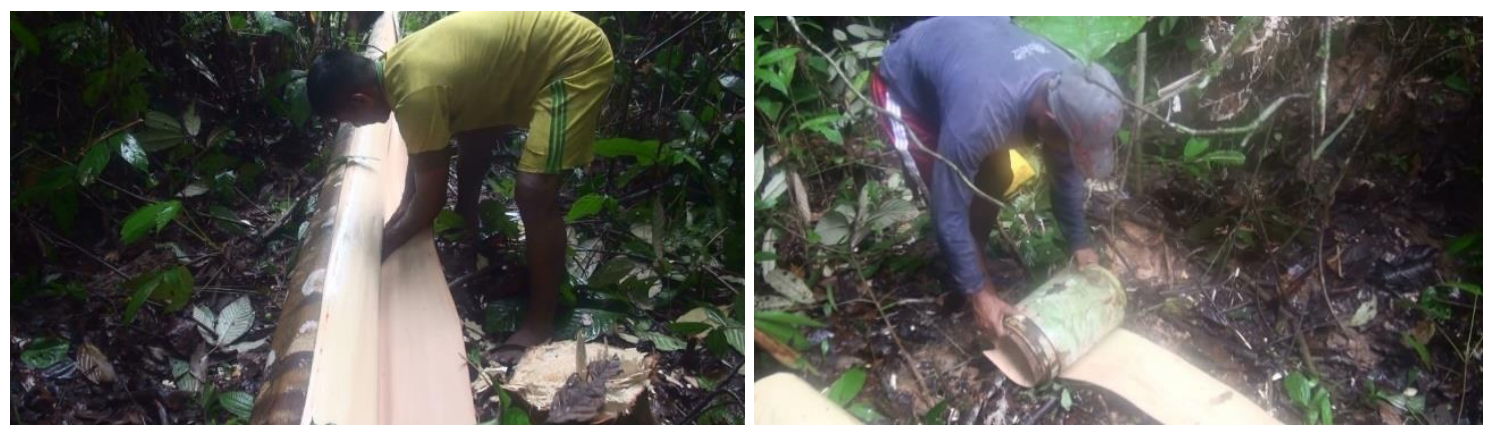

Figura 15 - Primeiro, a casca da arvore é cuidadosamente retirada, dividida ao meio num corte que acompanha a altura do tronco e (Figura 16) enrolada para o transporte.
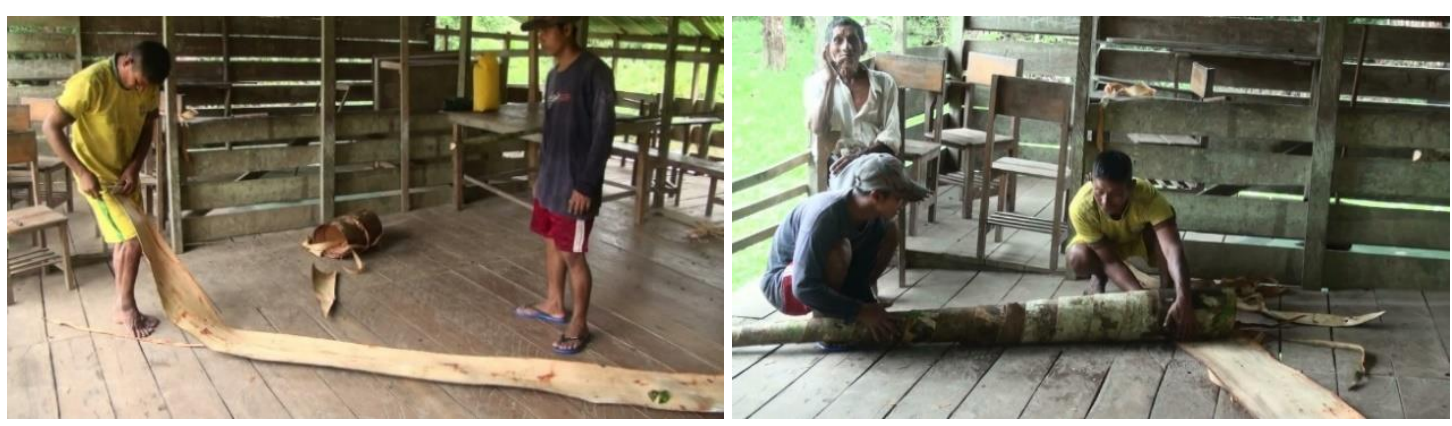

Figura 17 - Num segundo momento, uma metade da casca é enrolada, iniciando com a medida de um dedo para a largura do bocal do trompete. Figura 18 - Ao terminar de enrolar a primeira parte da casca, emenda-se a outra metade para estender o tamanho do instrumento.

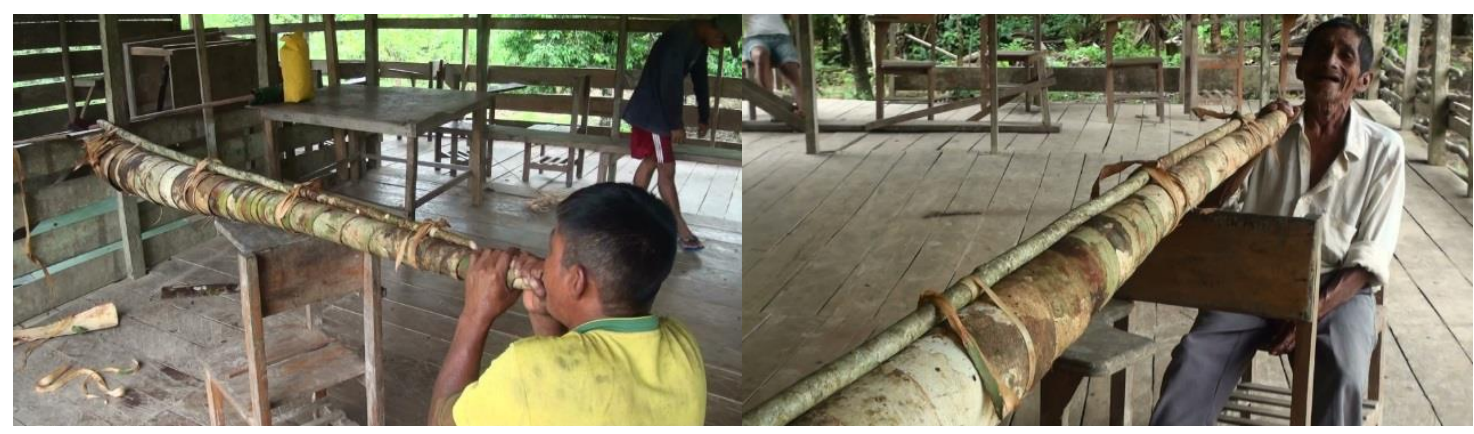

Figura 19 e figura 20 - Para dar sustentabilidade ao trompete, a casca enrolada é amarrada a uma vara. Durante os rituais os trompetes são apoiados em forquilhas fixadas no chão. Como estávamos na escola da comunidade, improvisamos com as carteiras para experimentarmos o som.

O iburi que construímos ficou maior que o de costume, com um registro mais grave. Por isso transcrevi suas notas em clave de fá. Estes instrumentos, em geral, são feitos um pouco menor, ficando seu som mais agudo, com uma extensão que se registra em clave de sol, como no exemplo da extensão do iburi tocado no CD MAGÜTA AR $\ddot{U}$ WIYAEGÜ. 


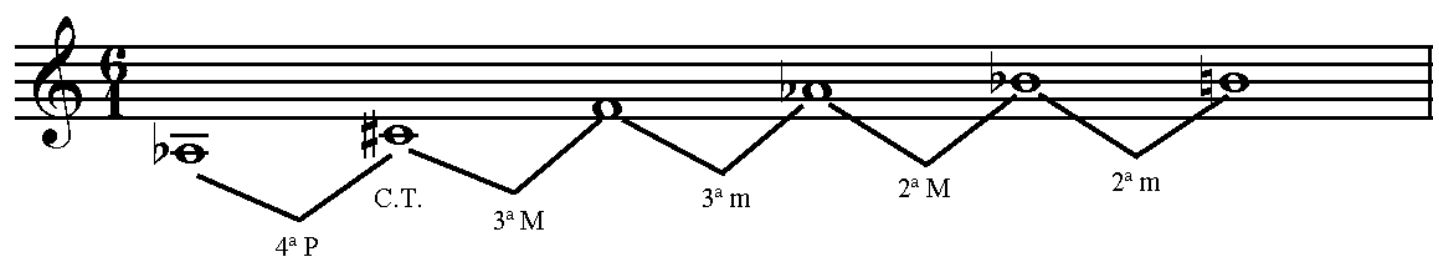

Figura 21 - Extensão de notas do iburi tocado no CD Magüta arü wiyaegü - Cantos Tikuna, faixa 11 (Pereira et al, 2009). C.T indica o centro tonal (dó sustenido) das melodias tocadas no instrumento.

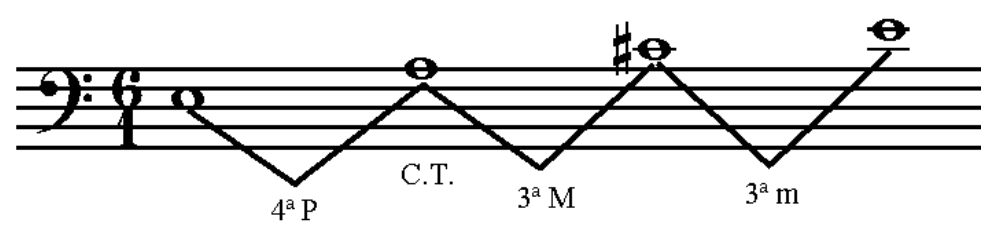

Figura 22 - Extensão de notas do iburi construído durante meu trabalho de campo. C.T. indica o centro tonal (nota ré) das melodias deste instrumento.

Durante as Festas de Moça Nova, são necessários ao menos três tocadores, pois os trompetes são tocados geralmente em trios, um to 'cü e dois iburi. Nimuendaju (1952: 77) comenta que "há sempre dois ou mais deste último", referindo-se ao iburi. Enquanto estão preparando a Festa da Moça Nova, o iburi é tocado todos os dias, às $17 \mathrm{hs}$ da tarde, até chegar o dia da festa. Severino conta que é "para o pessoal ficar animado", Ondino complementa que é também "para saberem que estão fazendo festa".

Antigamente, outra função deste instrumento era a de anunciar o convite da Festa. Para se convidar uma determinada comunidade não se pode mandar recado. $\mathrm{O}$ "dono da Festa" (yü̈̈natü $(\mathrm{m} / \mathrm{f})$, y ӥ̈̈ = festa, natü = dono/pai) deve ir pessoalmente fazer o convite, mais ou menos uma semana antes dos festejos. O dono da Festa não pode ver o tururi $^{403}$ - nem sequer falar ou ouvir esta palavra - antes da Festa. Caso ele olhe para o tururi, estará correndo risco de vida. Por isso que o trompete iburi era levado no barco do dono da Festa até as outras comunidades. Quando chegavam próximo à comunidade da pessoa a ser convidada, começavam a tocar o trompete, justamente para que os convidados

${ }^{403}$ Tururi são os diversos tipos de cascas de árvore usados na confecção das máscaras das festas. 
escondessem o tururi. Atualmente o dono da Festa, pai da menina, continua interditado de ver o material das máscaras, contudo, o trompete não é mais tocado na canoa.

O outro trompete, to 'cü, de que tratarei em seguida, quando é comparado ao iburi é chamado de to 'cü "verdadeiro", o iburi seria apenas um acompanhante do primeiro, companheiro do to'cü (to 'cümãcügü). Outros acompanhantes do trompete "verdadeiro" ficam dentro do cercado (to 'cüpü̈ü) com ele. Antigamente, estátuas antropomorfas em

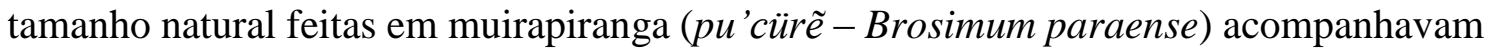
o to 'cü. Um comentário recorrente entre os especialistas rituais ticuna de hoje em dia é que "antigamente a Festa era sagrada. Hoje muita coisa se perdeu, muita gente não respeita mais a festa". A escultura feita em muirapiranga é uma delas. Nimuendaju comenta que nelas "entravam as sombras de demônios, que cantavam através do to'cü, sem que ninguém tivesse que se aproximar do instrumento, não havia homens para tocar" (1952: 77). Segundo os mais velhos me informaram, o pajé soprava com tabaco e colocava espírito (ã'ẽ) nela. A escultura era guardada dentro d'água, junto com o to 'cü, para protegê-lo e apenas os membros do clã do japó é que podem esculpi-la.

Junto com a estátua de muirapiranga, no tempo dos antigos, faziam um caniço que também ficava dentro do recinto dos trompetes. É o mesmo caniço (powopaeru) que foi usado por Yoi para pescar o povo magüta, de quem descendem os atuais Ticuna. Este caniço - que aparece no mito da primeira moça nova, To ’oena - também é usado como uma arma. As pessoas que estão subindo do rio para a Festa com os instrumentos usam o caniço para bater em quem está na frente e quer olhar os trompetes. Os "guardas" da Festa são os tocadores das flautas de embolo (nge'cütü), eles subiam na frente do to 'cü, protegendo este último instrumento da visão dos curiosos ${ }^{404}$. "Eles ficam rondando a casa com o rapé (cawï) para soprar no nariz de quem quiser fugir ou ver os instrumentos". Examinaremos adiante a importância do rapé cawü, principalmente sua relação com os "males" (рuya). Todo o conjunto de instrumentos, as estátuas e o caniço gravitam em torno da importância do “to’cü verdadeiro”, são seus acompanhantes (mãcügü).

O to 'cü é o mais importante instrumento musical dos Ticuna. Nimuendaju, etnógrafo de vasta experiência entre diversos povos ameríndios, chega a afirmar que um

\footnotetext{
404 Nimuendaju comenta esta função dos tocadores de flauta embolo. "Na frente dos instrumentos cerimoniais marcham dois ou três tocadores de flauta de embolo (nge'cütü) (...), e alguns batedores (kwaidũ' $\tilde{u}$ ) armados com porretes, com os quais eles correm em volta da casa de festa batendo sobre a cobertura de palha, para amedrontar as mulheres e crianças" (Nimuendaju, 1952: 77).
} 
instrumento como este "nunca foi encontrado, exceto entre os Ticuna, para quem é o de maior importância" (1952: 77). Este trompete é feito do tronco da paxiúba (Socratea exorrhiza ou I.exorrhisa) ${ }^{405}$, uma palmeira de raízes aéreas bem características. Antigamente a madeira desta palmeira era usada para fazer o assoalho e a parede das casas, além da fabricação da zarabatana ${ }^{406}$. Em algumas comunidades pode-se ver partes de casas feitas do tronco desta palmeira. Os ticuna identificam dois tipos de paxiúba: a paxiúba barriguda (ngapé) e a paxiubinha (eta). A primeira é grande e tem a casca muito dura, não serve para fazer o to 'cü. O instrumento é feito com a segunda, que é mais baixa, fina e maleável. Para se fazer um to 'cü, a paxiúba tem que estar bem madura (yacü), assim ela terá a casca mais firme. Um indício de que a árvore está madura é seu tamanho, mas também a cor de sua casca quando é desbastada. Quando está verde, ao desbastá-la, percebemos uma coloração clara, cor da parte mais interna da paxiubinha madura. A casca desbastada da paxiubinha madura é mais escura do que a verde. É importante que a raiz central esteja bem alinhada com o tronco, para que o instrumento não fique torto e tenha um bom bocal, pois é na base desta raiz que será soprado o instrumento. No momento em que se cortam as raízes da palmeira para derrubá-la, deve-se tomar cuidado para que a raiz central permaneça intacta. Se ela rachar, poderá comprometer o bocal do instrumento.

Se o trompete de paxiubinha não for guardado dentro d'água sua madeira apodrece. Daí o fato de no mito de To'oena (Anexo - 005), os tocadores do to 'cü virem subindo da beira do rio. Isso indica que eles pegaram o instrumento que estava guardado dentro d'água. Muitas vezes alguns Ticuna exageram, dizendo que um to'cü que fica guardado na água dura para sempre. Perguntei a Francisco, quem construiu o trompete comigo, quantos anos dura um instrumento deste, ele disse que uns 8, 10 anos. A madeira da paxiubinha é colocada dentro d'água para absorvê-la e não apodrecer. Depois que ela é retirada da água, por estar encharcada, fica mais pesada, o que deve influir também no som do trompete.

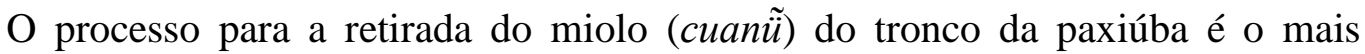
demorado. Em geral, o tronco é deixado durante meses dentro d'água para que o miolo apodreça e saia com mais facilidade. Contudo, se precisam do instrumento para uma Festa

\footnotetext{
${ }^{405}$ Etamenaa; eta $=$ paxiuba, menaa $=$ tronco.

${ }^{406}$ A zarabatana pode ser feita também de muirapiranga (Brosimum paraense). O esteio da casa também é feito com esta madeira.
} 
que vai acontecer em breve, é possível fazer o to 'cü em menos tempo. Atualmente, com as ferramentas certas e cerca de 2 ou 3 pessoas ajudando, dá para se fabricar um trompete destes em uma semana. As pessoas vão se revezando na retirada do miolo, usando grandes formões de metal ${ }^{407}$. Depois que a paxiúba ficou dentro d'água tempo suficiente para amolecer o miolo e retirá-lo, o grande caule é lixado por dentro com cipó ambé (Philodendron sp.), que é cheio de espinhos. Após este procedimento, o tronco não pode ser deixado fora d'água, senão apodrece, e deixá-lo no igarapé garante que ninguém irá olhá-lo.
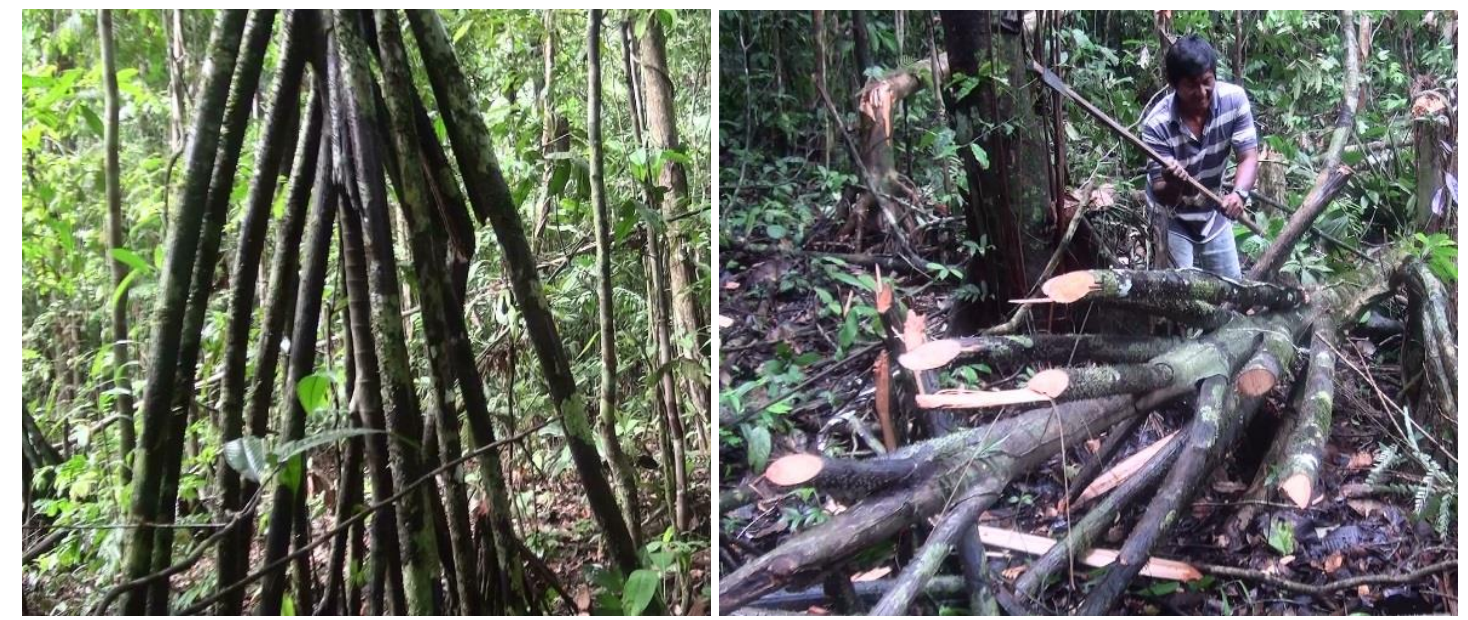

Figura 23 - Raízes aéreas da paxiúba, palmeira utilizada na fabricação da trompa to'cü. Figura 24 Francisco desbastando as raízes da paxiúba em torno da raiz central.
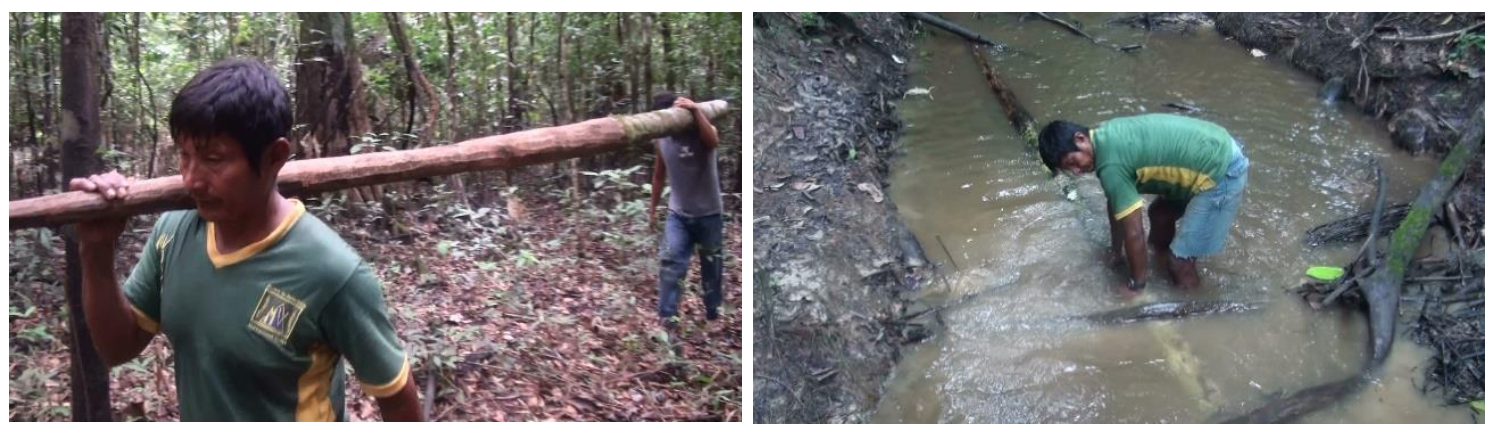

Figura 25 - Tronco da paxiúba já desbastado sendo levado para o igarapé. Figura 26 - Ele ficará dentro d'água até seu miolo (cuanũu) amolecer para ser retirado.

${ }^{407}$ Acompanhei o processo de fabricação de um to'cü até este ponto. Por motivos de saúde tive que abandonar o campo. 

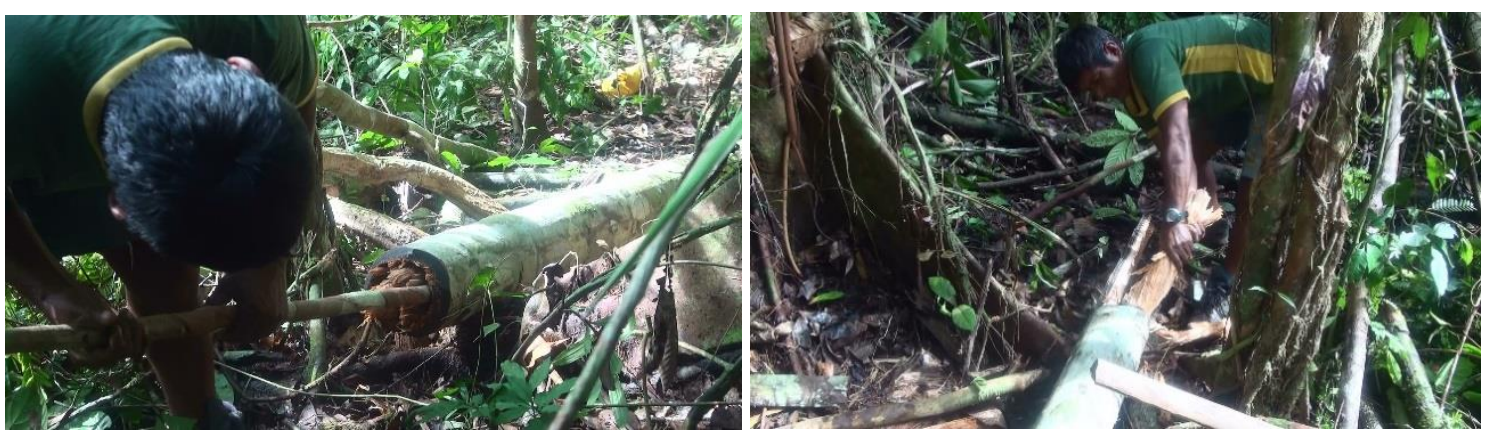

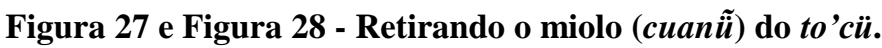

Francisco comenta que seu avô fez um to 'cü certa vez que ficou muito bonito e guardou-o na água. "Mas o instrumento se encantou, foi embora. Diz minha mãe que quando ela vai ao lugar onde ele estava guardado ela escuta. Quando iam procurar não encontravam. Ele já tinha dono, ü'üne [imortais/encantados] tinha levado ele. Eles são muito inteligentes, mais do que a gente e eles que tocavam o to 'cü. Mas a gente não via, só ouvia a voz do to 'cü’. Segundo me disseram, quando jogam o trompete fora ou deixam por aí, vamos procurá-lo e ele não está mais no lugar onde deixamos. Se isto acontece é porque os encantados/imortais (ü'üne) levaram. Isto costuma acontecer quando as pessoas já não querem mais o to 'cü, desistem dele. Então os imortais pegam para eles e levam para fazer Festa também. Em consequência, o to 'cü se encanta e vira gente ( $d u$ 'ü). Hilda (Mutchique'ena) me contou que onde o pai dela deixava o to'cü dele o instrumento tocava sozinho. As pessoas o ouviam tocando sozinho, lá no quintal de sua irmã. Podemos notar, portanto, que esta invisibilidade dos imortais - ninguém nunca os vê, só os ouve ao mesmo tempo exacerba, digamos, a sonoridade destes seres ${ }^{408}$.

Pelo que ouvi, os encantados (ü'üne) são bem apegados ao som, especialmente aos instrumentos. Ouvi histórias de to 'cü que são ouvidos soando sem que ninguém esteja tocando. A explicação que me deram é que os imortais estão tocando o trompete, mas nunca são vistos fazendo isto. Uma ticuna me contou certa vez que qualquer um pode ouvir os imortais ( $\ddot{u}$ 'üne). Existem relatos de pessoas que ouviram um assobio, um canto, conversa, barulho. Depois, quando iam verificar do que se tratava, não encontravam nada.

408 Sobre a invisibilidade e a sonoridade exacerbada dos imortais ver no Capítulo 2, tópico 2.8 Atualização do mito - notas sobre o messianismo ticuna, a história dos americanos que procuravam o Eware. 
"Se acontecer de vermos um imortal é porque já nos tornamos um deles. Apenas os pajés conseguem vê-los sem morrer antes. Eles visitam os imortais em sonhos. "

O abandono ou a longevidade de um to 'cü podem transformá-lo em cobra-grande (Yewae) também. Pelo fato de ser guardado dentro d'água o instrumento mantém uma ligação com este meio, especialmente com o "dono" deste ambiente, Yewae.

"[O] instrumento é colocado dentro do igarapé onde permanece até o dia da festa. Aí ele passa a pertencer ao mundo das águas, cujo "dono" é o Yewae, o sobrenatural cobra-grande (...). "Ai sua "nação" [clã] já é de Yewae. Com o tempo, ele vai virando cobra-grande, se transforma em cobra, mas se ele quiser pode se transformar em veado. Aí sai pela terra. Esse to 'cü é vivo, tem alma, vira 'bicho' e anda por aí”, conforme me explicou Eliseo anos atrás. O to 'cü adquire poderes próprios dos sobrenaturais, podendo transitar pela água, como cobra, e pela terra, como veado, assim como os demais seres da mitologia ticuna. A medida que "envelhece", que participa de muitas festas, o to'cü vai ganhando força, neste caso a força do Yewae, e pode cantar sozinho no igarapé sendo ouvido por seu proprietário. Depois de um tempo, ele pode até sumir transformado em cobra e ninguém mais vê. Por tal motivo, as vezes é preciso amarrá-lo no fundo do igarapé." (Gruber, 1999: 29)

O contexto ideal para o uso destes instrumentos é a Festa da Moça Nova. Neste momento, os instrumentos que ficam dentro do cercado anexo à reclusão da moça são considerados xerimbabos (üna) da moça. Os trompetes servem também para o aconselhamento dela, assim como os cantores que estão no centro da casa. Os instrumentos são colocados com "a campana voltada para a parede atrás da qual a menina permanece em reclusão" (Nimuendaju, 1952: 77). O “copeiro" (baecü ou $\tilde{u} a \tilde{u} c \ddot{u})$ encarregado de cuidar para que se cumpra o processo ritual e de servir bebida fermentada (pajauaru) para os convidados -, fala para o soprador de to 'cü (to 'cü fe'e ou fe'güru' $\tilde{u}$ ) o nome do clã da moça. Então o to 'cü canta falando sobre o clã dela, pedindo caldo e moqueado. 


\subsection{1 - Batizado e Nomes dos trompetes}

O pajé (yu'ücü) batiza os instrumentos quando está colocando o espírito (ã 'ẽ) neles, no começo da Festa. Durante a sessão de batismo, ele pergunta às pessoas que nome querem colocar no trompete. Ambos os trompetes (iburi e to 'cü) devem ser batizados, receber um nome e um espírito ( $\left.\tilde{a}^{\prime} \tilde{e}\right)$. De acordo com o nome que o trompete recebe, ele deverá executar um determinado repertório, será cantada a história (tchiga) dele dentro do instrumento. Francisco diz que o to 'cü também tem relação com o caminho ( $m a \tilde{)})$ dos peixes e da caça. Veremos que o coĩri (trompete de bambu) recebe um tratamento do pajé para que os peixes subam para a superfície e a caça também seja abundante. "Quando não tem peixe, é esse aí [o to 'cü] que sabe fazer eles virem para a superfície da água”.

Alguns nomes que recebem os trompetes são, digamos, inofensivos. Gruber menciona o nome do to'cü de Manuel Rita, “chama-se baitacu igacu. Segundo Manoel, o primeiro nome significa "alguma coisa lisa, bonita, brilhante, como o tronco do tchiwa, mulateiro", e o pelo da onça. O outro nome, igacu, diz respeito a "voz bonita" deste animal" (1999: 28). Observa a autora que este nome vincula o instrumento à metade exogâmica "sem penas", mesma metade do construtor do trompete, que é do clã do jenipapo (ibdem). Esta é a única referência que possuo sobre a vinculação dos trompetes com os clãs. "Depois de dado o nome, seguem-se as rezas do pajé com cigarro de tabaco, cuja fumaça vai "alimentando" o instrumento, dando-lhe vida." (ibdem).

O costume de se batizar o to 'cü foi instituído por Yoi. Já no final da história de Tóoena (Anexo - 005) ${ }^{409}$, depois da morte da heroína e do teste a que Yoi submete sua irmã, diz o narrador do mito, "Yoi avisou para os que estavam lá: 'depois de mim, vocês vão dizer como será o nome dele. Vocês vão colocar o seguinte nome: $\underline{\text { o dente vermelho }}$ de sangue do Tchoreruma (durutchte'e ya Tchoreruma)'. Depois que ele pediu para batizar o to'cü, Yoi se afastou, não ficou mais com o pessoal. " Até hoje o nome Tchoreruma é usado para batizar instrumentos. Se ele recebe o nome de Tchoreruma, canta-se a música do boto dentro do to 'cü. Este boto, no entanto, não é o boto que encontramos nos rios e igarapés. É o boto gigante que mora no rio celeste, chamado Tchowat $\ddot{u}^{410}$. Antigamente era possível escutar o banzeiro dele lá no céu. Segundo

\footnotetext{
${ }^{409}$ Ver Capítulo 2, tópico 2.4 - To’oena, a primeira moça nova.

${ }^{410}$ Vimos alguns trechos da canção deste rio no Capítulo 1, tópico 1.3 -Onomástica e corpo.
} 
Ondino, "acima de nós é igual casa de cabas [marimbondo], [os patamares ficam] um em cima do outro".

Faulhaber nos fornece uma imagem que ilustra bem esta explicação de Ondino do cosmos ticuna ${ }^{411}$ :

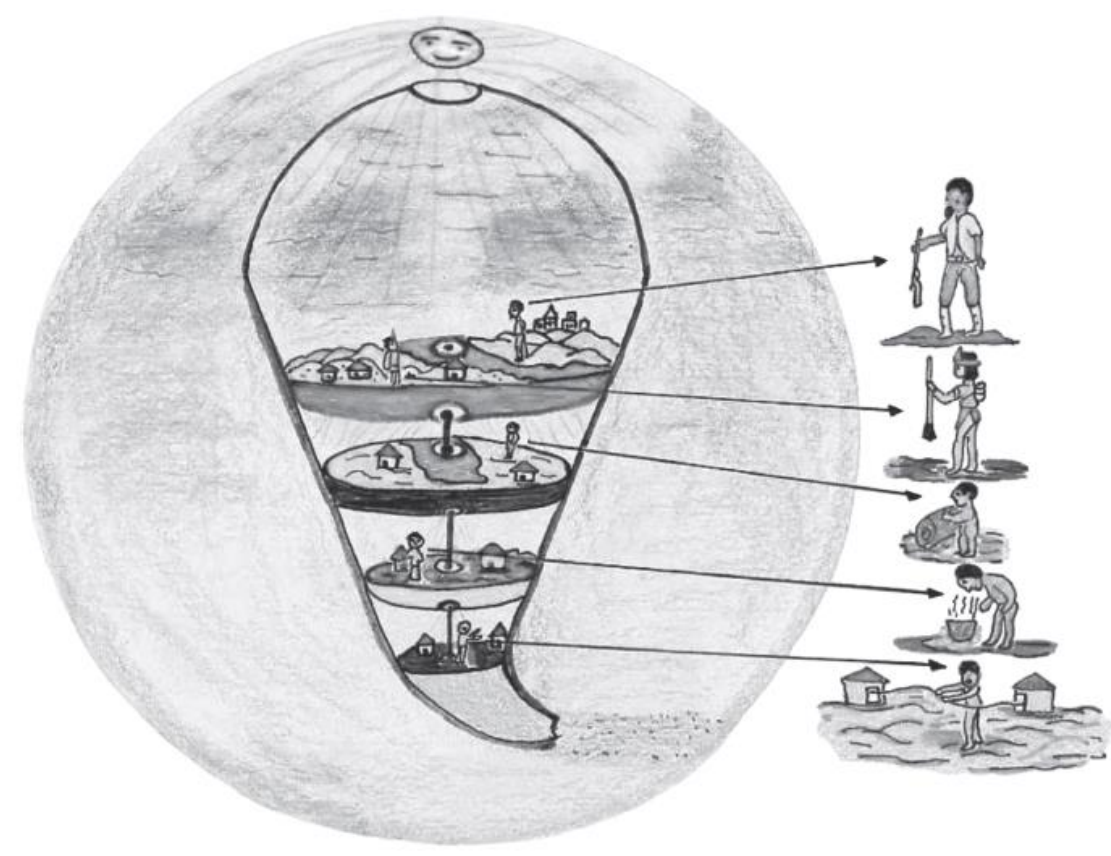

Fig. 7. Lugares cósmicos Ticuna. Desenho do Ticuna Dui.

Figura 29 - Desenho retirado de Faulhaber, 2007: 355

Com a crescente escolarização e cristianização dos Ticuna, relatos "dos antigos" de como é a cosmologia "tradicional” são cada vez mais escassos. Vimos no Capítulo 3, típico 3.2 - Os “bichos" (ngo’o), um trecho de uma breve descrição de Nimuendaju (1952: 118) sobre o "mundo inferior". Oliveira Filho nos oferece uma sintética descrição dos patamares celestes ${ }^{412}$, num dos quais se encontra o Tchoreruma de que estamos tratando, e do mundo inferior. A descrição que segue serve como uma explicação do desenho acima:

"Em descrições obtidas recentemente foram mencionados oito mundos: o mais profundo dos mundos subterrâneos, na direção do centro da Terra, é onde mora um deus chamado Ngonütuma. Nos outros mundos inferiores habitam seres

\footnotetext{
${ }^{411}$ Cf. também Faulhaber, 2004, para uma análise das constelações ticuna.

412 Para uma descrição mais pormenorizada do cosmos ticuna, ver Angarita 2010.
} 
humanos incompletos; $2^{\circ}$ ) é onde mora um povo de cegos, que se movimentam por aqueles lugares através de cordas que lhes indicam o caminho; $3^{\circ}$ ) é onde habitam pessoas que têm uma vida muito semelhante à dos homens (plantam, caçam, fazem festa), mas não têm ânus e por isso não ingerem os alimentos, mas apenas se nutrem com os cheiros e vapores; $4^{\circ}$ ) aí reside um povo de anões (méetita), que compensa sua pequena estatura com uma força extraordinária. $\mathrm{O}$ mundo em que os seres humanos vivem, onde permanece uma parte da alma e onde surgem inclusive os demônios (ngo 'o), constitui o $5^{\circ}$ mundo. A partir daí existem três céus: o primeiro é habitado por Taé e pelas almas dos mortos, aí vivendo também o Urubu-Rei; o mundo seguinte é ocupado por pessoas que vivem transformadas em pássaros e que não mais executam serviços nem vivem como os humanos; o último mundo é o céu que se avista, onde moram o sol e as constelações de estrelas (inf. João Laurentino, Vendaval, 1981).”(1988: 142143).

O rio onde mora o boto Tchoreruma, que pode nomear os trompetes, fica no primeiro patamar celeste. O boto vive dentro deste rio e é de um tamanho descomunal, muito maior que o tamanho médio de um boto que encontramos nos rios amazônicos. Neste mesmo patamar onde está o boto, também reside o ẽtchatatchiũ, o urubu-rei. Este urubu é o epônimo do clã que muitas vezes acompanha a subida do trompete do rio para a casa de Festas ${ }^{413}$ e, como afirma Nimuendaju, um dos possíveis nomes de batismo para os trompetes também.

Nimuendaju relaciona o boto Tchoreruma com a punição para os pecadores que chegam ao céu. Para compreendermos o porquê da presença deste ser monstruoso no ritual, como nome dos trompetes, devemos lembrar que um dos principais empecilhos para a entrada na morada de Ta'é após a morte é o incesto. A punição praticada pelos Tchoreruma é descrita por Nimuendaju no mito em que um viúvo é levado para o céu por sua esposa que morreu:

"Quando o homem entrou na casa de Ta'é, viu fora dois animais, os Tchoreruma, amarrados em um curral. Ta'é fez um deles vir lamber o homem de seus calcanhares ao topo da sua cabeça, a fim de purificá-lo dos seus pecados. Esses animais têm o corpo de uma anta e a cabeça de boto. Ta'é solta-os para

\footnotetext{
413 "Neste momento também subiam junto com o to'cü pessoas do clã do urubu-rei (ẽtcha)", trecho da História de "como se cuida da moça nova" (Firmino \& Gruber, 2010, vol. 3).
} 
rasgar a alma de um pecador que consegue passar pelo portão. Tão logo eles vejam uma alma eles se lançam nas águas do Rio Tchõwatü, que corre através do mundo superior, nadam até a margem oposta, mergulham de novo com um grande estrondo e retornam. Ouve-se este estrondo na terra, se ao mesmo tempo um trovão forte é ouvido, em seguida, o Tchoreruma estão rasgando alguma alma em pedaços" (1952: 110).

A “voz” do iburi é referida como iburiga e do to'cü é to'cüga. Esta partícula, ga, já nos é conhecida ${ }^{414}$, usada para se referir ao idioma ou a voz de uma pessoa. Com relação a esta voz que sai dos trompetes, as opiniões se dividem. Francisco disse que a voz que sai do to’cü não é a voz de um demônio (ngo'o), “é a voz da pessoa mesmo que está cantando". Alguns relatos que obtive em campo sobre a voz dos trompetes vão de encontro aos registros etnográficos de Nimuendaju (1952) ${ }^{415}$ e Goulard (2009). Apenas Severino, meu informante de mais idade, me confirmou, assim como os referidos etnógrafos, que “é ngo'o [demônio] que fala no to'cü, curupira também” 416 . Ao receber o nome de Tchoreruma, portanto, o que a moça ouve dos trompetes é a voz do ser que pune violentamente as pessoas que cometem incesto. Ao mesmo tempo, como vimos, esta voz demoníaca dos trompetes remete às potências perigosas relacionadas ao sopro e ao vento entre os Ticuna.

Tchenawa é um dos outros nomes usados para batizar o iburi e o to 'cü. É o nome do pajé ou pai da anta. "Ele é igual pajé, mas é anta. Ele bota feitiço no caminho do caçador para ele ficar com o joelho dobrado. O canto do pássaro Nguga i Tchenawa [Crypturellus variegatus] é igual o assobio do pajé da anta". O Tchenawa vive na montanha, "é um animal grande, que a gente quase não vê". Disseram-me que ele é uma anta enorme, com cerca de cinco metros. "No tempo que defumaram a montanha Decuãpü deram esse nome para ele". Essa defumação da montanha é um mito que conta a origem de muitos cantos e do idiofone de casco de tracajá (tori). Veremos este mito mais

\footnotetext{
${ }^{414}$ Ver Capítulo 5, tópico 5.2.1 - Voz, canto e cantor.

415 “O to'cü, na minha opinião, nunca foi encontrado exceto entre o Tukuna, para quem é da maior importância, sendo a voz de um demônio [ngo'o]” (Nimuendaju, 1952: 77).

416 Nimuendaju afirma que o termo usado para se referir aos "responsáveis pelos instrumentos cerimoniais" (1952: 76) é ngo'o-taniĩ ou to'cü-taniĩ. O segundo nome faz referência ao instrumento, to'cü, mas o primeiro faz referência direta aos bichos, ngo'o.
} 
detalhadamente quando abordarmos este instrumento. Se o trompete é batizado como Tchenawa, xamã/chefe das antas, como acontece com os outros nomes, só poderão ser cantadas músicas referentes a este nome dentro do to 'cü. Vejamos um exemplo de canção do Tchenawa que se canta dentro do to'cü que gravei com Ondino:

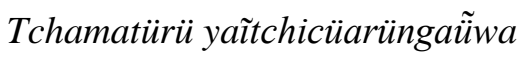

"Eu no meio da capoeira"

Cucayetcha nguatatchigucü nacütchaya'̃

"Eu sou anta andando ondulando as costas para você"

Pa iri iri pa wowarecü

"Moça nova"

Nheünena yacürü yacutchacu

"Cadê tuas flores?"

Coretchacuma'ã

"Com flores da batata"

Tchoü' '̃̈ma'ã icutchipe'e

"Você está esperando por mim"

Pa iri iri pa wowarecü

"Moça nova"

Notacümã deri deyu'ün tcha'õ'e'ü

"Estou aqui à toa sofrendo e com frio"

Pa iri iri pa wowarecü

"Moça nova"

Tanheünena curüwai deretchiüne yadeütchiüma'ã

"Cadê o teu líquido de cor amarelada, o liquido do canamã [chavascal, lamaçal]?"

Tchoüma cutchipe'e

"Você está esperando por mim"

Pa iri iri pa wowarecü $\} 2 \mathrm{X}$ 


\author{
"Moça nova" \\ Notacüma oegaũ deri deyu’u \\ "Não gosto de ficar com frio e à toa"

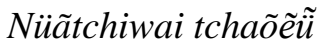 \\ "Aqui estou sofrendo" \\ Pa iri iri pa wowiyu \\ "Moça nova"
}

A canção começa situando o Tchenawa em seu ambiente, ele está no meio da capoeira. Quando ele diz que está com frio atesta que está em ambiente de floresta, espaço frio, em oposição ao espaço habitado pelos humanos, quente ${ }^{417}$. A grande anta está indo na direção da moça e ela está esperando por ele. A moça nova está esperando com o caldo

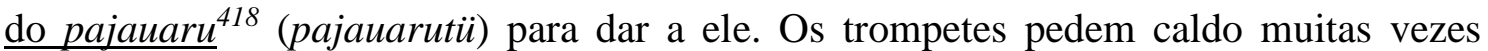
durante a Festa, veremos canções que são entoadas no instrumento só para isso, e a moça deve estar atenta a estes pedidos. Na canção em foco, o Tchenawa pede o que do seu ponto de vista é a bebida pajauaru, o "líquido de cor amarelada, o liquido do canamã". Esta bebida é um indicador de perspectiva, me disseram que "o chavascal (de'ü) é o pajauaru da anta" ${ }^{419}$. Ondino me disse que para o Tchenawa a "flor da batata", de que fala a canção, é o caldo do pajauaru da anta. Contudo, e ao mesmo tempo, a canção pode também estar se referindo à moça nova quando fala de flor, recorrendo, assim, à "metáfora vegetal" mencionada anteriormente ${ }^{420}$.

\footnotetext{
${ }^{417}$ Ver Capítulo 3, tópico 3.1.1 - Corpo e imortalidade.

${ }^{418} \mathrm{O}$ caldo é retirado da massa que será coada para fazer o pajauaru (fermentado de mandioca), é mais líquido e mais alcóolico que o pajauaru.

${ }^{419}$ Ondino me explicou isso da seguinte forma: "Quando o pai [Tchenawa] chama a anta, ela chupa a lama do chavascal. O chavascal é o pajauaru da anta. Antigamente, a anta era Tchenawa. Agora, Tchenawa mora no canamã e chama a anta. Ele vai na frente e a anta vai atrás, mas ele é igualzinho a anta. Eles tomam pajauaru [a lama do chavascal] juntos".

${ }^{420}$ Vimos algumas considerações sobre esta "metáfora vegetal" de passagem no Capítulo 2, tópico 2.1 A passagem para a América do Norte e desenvolvemos melhor a ideia no Capítulo 3, tópico 3.1.5 - O corpo em formação e o mundo verde.
} 
Registrei outros dois nomes de batismo de trompete ${ }^{421}$. Um deles é Beru, que é um ogro mítico ticuna e nome de uma espécie de borboleta azul grande (Morpho sp.) em que ele se transforma. Esta borboleta pode se transformar em gente e Beru pode virar vários bichos. O Beru é uma espécie de antítese do que se espera da moça nova, seu aspecto remete a um envelhecimento precoce para os Ticuna. Ele tem o corpo coberto de pelos e os seios caídos. Oportunamente veremos a relação entre estes indicadores de velhice do Beru e os cabelos da moça nova que serão arrancados na Festa. Segundo Ondino, quando o tocador faz " $f u, f u, f u$ " no meio da canção que é entoada dentro dos trompetes, é a voz do Beru que está saindo do instrumento.

Beru em sua forma de borboleta é também um motivo que aparece desenhado em algumas máscaras. Este motivo pictórico Beru seria uma contrapartida feminina do motivo do jaguar"422. "Ambos são temidos, evitados e nunca nomeados, exceto por metáforas" (Goulard, 2011: 142). O fato deste ogro ou ogra ${ }^{423}$, ser tão perigoso quanto o jaguar, sua contrapartida feminina, nos leva a alguns desdobramentos. Tudo indica que o ato de cantar dentro dos grandes trompetes seria um ato predatório similar ao ato de soprar uma zarabatana. Mostrei acima que o sopro da zarabatana e o sopro do to'cü estão estreitamente relacionados. A anta, presente na figura do Tchenawa, e o veado (cowü), que também nomeia os trompetes, são caças dos Ticuna. Já o Beru e o Tchoreruma são predadores sobrenaturais, mas que também são alvo da potência predatória dos trompetes. Severi explica que para o xamanismo ameríndio, cantar pode ser caçar. O pajé canta para caçar o espírito que está predando o doente a fim de curá-lo. Nas palavras do autor, no xamanismo ameríndio, de maneira geral, “cantar a fim de curar uma pessoa é, (...) caçar o mais perigoso caçador de seres humanos, muitas vezes encarnado (...) por um animal sobrenatural (por exemplo, um jaguar ou uma sucuri)" (2002: 33). Quem estaria na mira do trompete predador aqui, os perigosos sobrenaturais, Beru e Tchoreruma; o veado; a anta Tchenawa; ou a moça que está na reclusão?

\footnotetext{
${ }^{421}$ Nimuendaju apresenta ainda outros nomes de trompete. "Cada to'cü tem um nome dado por seu dono: o de Yoi é chamado Ẽtave ("da Estrela"). Outros nomes de to'cü são, Ẽ'tchá ("Urubu-rei" [Sarcoramphus papa]), I'rawá (Urubu Gereba [Urubu-de-cabeça-vermelha (Cathartes aura)]), Maĩa' ("Ariranha/Lontra"), e assim por diante." (1952: 77-78). Notemos que ou são animais predadores, Ariranha e Lontra, ou a estrela e urubus, que estão próximos do primeiro patamar celeste.

422 “...o jaguar é o "pai” ou "avô" da floresta e sua contraparte feminina, a borboleta Beru (Morpho sp.), considerada a "mãe" ou "avó" (Goulard, 2011: 142).

${ }^{423} \mathrm{O}$ gênero de Beru muitas vezes não fica claro.
} 
“Este to'cü é proibido, ele pode vingar (tünanaütanü), porque aquele to'cü era gente (du'ün). Aquele iburi/buburi também era gente, mas igual veado, alguns deles". Este é um trecho da história de "como se cuida da moça nova" ${ }^{424}$, ela nos revela um outro nome com o qual são batizados os trompetes, o veado. "Quando a gente coloca o nome de veado no to'cü é ele quem fala. E só canta música do veado dentro dele”, explica Ondino. A canção do veado (cowütchiga; cowü = veado, tchiga = canção) que é cantada no trompete, gravada por Ondino, é bastante semelhante à canção da anta Tchenawa. Ele também pede pajauaru à moça se referindo à bebida como se fosse o lamaçal do chavascal.

O uso do nome de animais para batizar os aerofones nos mostra que alguns animais não são bons somente para comer ou para pensar, mas também para tocar, cantar e dançar nos rituais ${ }^{425}$. O papel que o veado (cowü) cumpre na mitologia ticuna pode esclarecer por que se nomeia o trompete com o nome deste animal. Provavelmente, tratase de uma referência ao veado do mito de origem das plantas cultivadas. No final do mito "El venado y la historia de los alimentos", registrado em Camacho (2000: 47), existe uma menção ao ritual da moça nova. O veado diz para quem roubou a bolsa para plantar os cultivares e, quando estivessem maduros, para fazer uma Festa e chamá-lo que ele levaria vários animais: “ - Nieto ... nieto, ya ganó los alimentos que hay dentro de la mochila, ahora tiene que hacer un gran chagra para cultivarlos, una vez esté buena la comida, invite a una Fiesta de Pelazón, yo iré con todos los animales, grandes y pequeños-, gritaba el abuelo" (idem: 49). A voz do veado dentro do trompete remete, portanto, tanto à visita que os não-humanos fazem ao ritual quanto ao caráter propiciatório de caça que possue a Festa $^{426}$.

Mencionei acima que o “to'cü era gente $\left(d u\right.$ 'ü) ${ }^{\prime 427}$. Os trompetes possuem uma espécie de "humanidade de fundo" (Viveiros de Castro, 2002: 377), mas se apresentam sob a forma animal ou de monstro sobrenatural. Isto revela que a noção de $d u$ ' $\ddot{u}$, que

\footnotetext{
${ }^{424}$ Nhuũũãcü worecüma icufaũ (Firmino \& Gruber, 2010, vol. 3), traduzida com Ondino.

425 “O instrumentarium Amazônia é, em certa medida, também um instrumentarium zoológica Amazônia que une povos específicos e espécies animais locais em configurações músico-coreográfico. Animais não são apenas bons para comer e pensar, mas tocar, cantar e dançar quando estão em rituais" (Hill \& Chaumeil, 2011b: 18-19).

${ }^{426}$ Há outra versão deste mito de origem das plantas cultivadas em D. Lima, 2006: 159.

427 Goulard (2009: 168-9) confirma tal informação.
} 
traduzimos simplificadamente como "gente", expressa a noção de "humanidade de fundo" dos Ticuna. Esta "humanidade" se revela em diversos animais quando estes se encontram em seus domínios, como a anta ou o veado quando estão bebendo seu "pajauaru".

Um de meus colaboradores, Lorenzo, conhecedor de Festas de Moça Nova e frequentemente chamado para ser "copeiro" (üa ücü) nos rituais de Belém do Solimões, confirma a natureza "bicho" (ngo'o) do to’cü, ao menos para "aquela época”, no tempo do mito. Enquanto estava contando para mim a história de To'oena ele fez o seguinte comentário:

“Não é como agora, o to'cü era outra coisa. [Como era?]. Taudautü, assim. Era encantado, não sei, algum animal que tinha aricano. Não é como agora, já passou o tempo já. [Era animal é?]. Era animal, por isso que ele matou ela. Ele começou fazendo curral [cercado dos trompetes], fazendo cocar dele, pintou tudo as coisas dele, começou a Festa dele. Convidaram tudinho o [pessoal] que tem lá no Eware. Começaram a festa (...) Aí morreu a To oena, e eles se encantaram, foram para a [montanha] Moruãpü. Só o corpo dela que parece que eles comeram, não sei. [Quem comeu, Yoi?]. Não, a tal de to 'cüzada ${ }^{428}$. Era bicho, naquele tempo to 'cü era bicho, não é como agora. [Era ngo'o?]. Era ngo'o."

Os trompetes chegam na Festa sedentos ${ }^{429}$. Eles frequentemente pedem cantando bebida à reclusa. Quando ele pede o caldo para a moça nova, ela suspende as palhas do cercado dos instrumentos e entrega a vasilha com a bebida para os tocadores. Nimuendaju (1952) e Goulard (2009) comentam que a bebida é vertida na "boca" dos trompetes também. Francisco diz que se o caldo estiver forte - com alto teor alcoólico - o tocador fica por lá mesmo, nunca sai, e lá mesmo “capota”. Os tocadores (fe'güru' $\ddot{u})$ dos aricanos costumam ficar dentro do cercado dos trompetes durante a noite da Festa da Moça Nova. Passam a noite tocando, comendo e bebendo dentro do curral. Alguns exageram dizendo que os tocadores não podem sair do curral do to 'cü.

\footnotetext{
${ }^{428} T o^{\prime}$ cüzada é uma mistura de palavra ticuna com português usada para designar o conjunto dos trompetes.

${ }^{429}$ Assim explica um informante de Goulard: “Cuando el tokü llega "tiene sed, viene para tomar"” (2009: 168).
} 
O canto que transcrevo a seguir é a maneira como o tocador avisa a moça nova que ele e o trompete querem beber. A canção foi entoada por Severino, no mesmo dia em que fabricamos o iburi. Para a gravação pedi que Severino cantasse a canção fora do trompete, o que não se faz no ritual, para que eu pudesse gravar e traduzir. Fiz isso para todas as canções que vimos e que são cantadas dentro dos trompetes. Ondino e eu as traduzimos posteriormente.

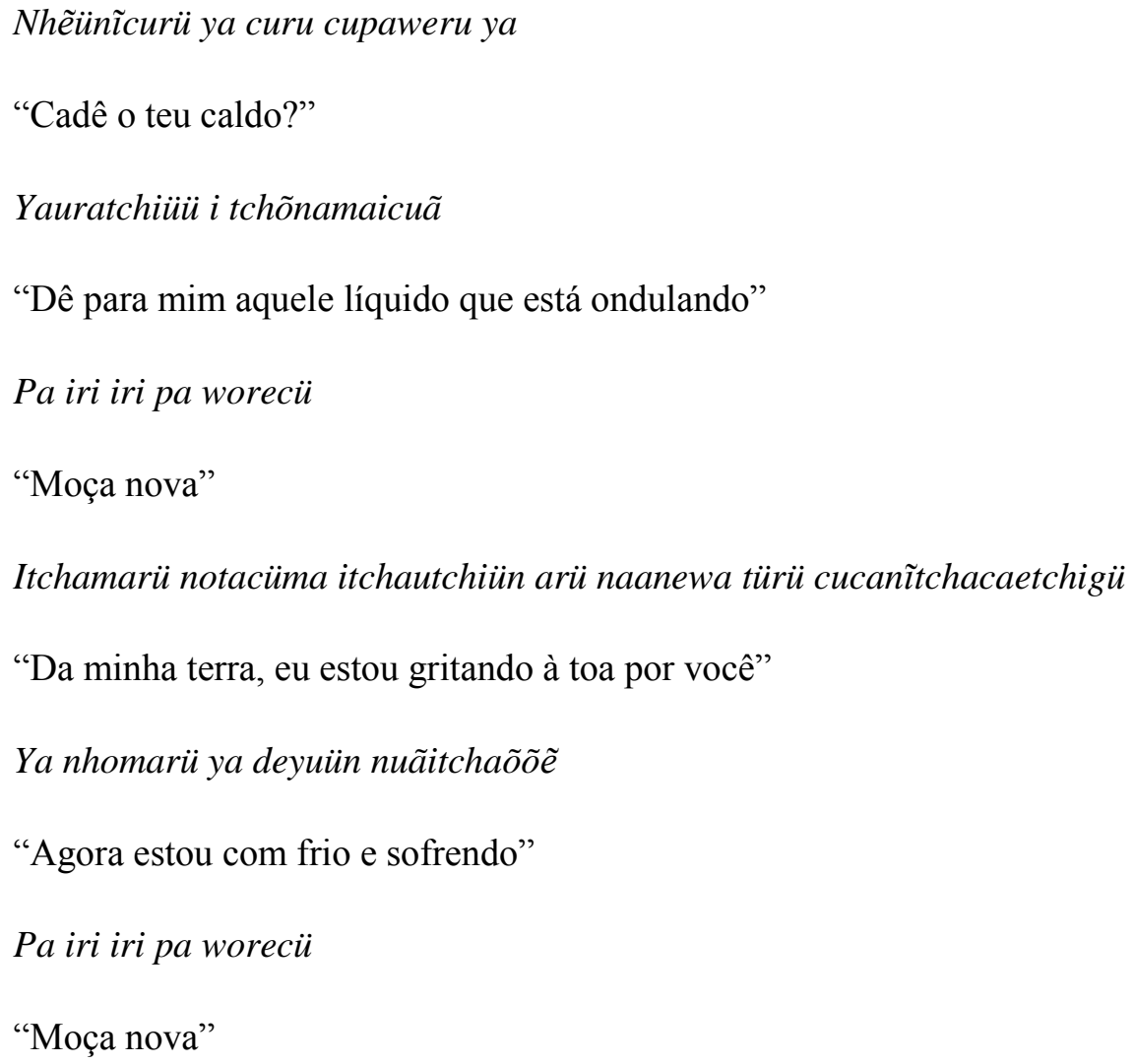

A moça nova não pode dormir enquanto estiver dentro do "curral". Deve estar sempre atenta aos pedidos de caldo dos tocadores de to'cü. Um informante me contou também que "às vezes, ü'üne [imortais/encantados] pede caldo e ela tem que ouvir. Ü'üne vem tocar o to'cü [trompete] e pedir caldo. Ela tem que ouvir e dar caldo para ele. Isso acontece quando todo mundo já está de porre, então, ü'üne pega o corpo da gente para tocar o to' cü'.

O que mais gostaria de destacar da fala mencionada acima é a referência a este momento crítico da Festa. Não por acaso, é quando estão todos bêbados que os imortais "pegam" o corpo das pessoas para tocar os trompetes. Afinal, neste momento existe a possibilidade de a casa subir para o céu e todos os que estiverem lá dentro se tornarem imortais. Antigamente, a Festa da Moça Nova era feita para ela ver os encantados (ü'üne). 
Fazendo a Festa da forma correta, a casa inteira era levada para o Morügüne, casa de Festa que fica no lugar dos encantados. O problema é que hoje em dia, as pessoas não respeitam mais a sacralidade do ritual. As crianças olham os instrumentos, as pessoas saem para namorar no meio da Festa e as moças namoram com os primos antes de fazerem sua Festa.

Existe uma pista linguística que pode associar a bebida com que os trompetes são alimentados, e que é tomada por todas as pessoas da Festa, e o esperma. A "massa de mandioca", que será peneirada com água para se fazer a bebida, é designada pelo termo yomû. "La raíz mû tiene varias aplicaciones: sirve para designar cualquier "masa liquida de cualquier cosa" (Montès $\mathrm{s} / \mathrm{f}$ ) y entra en la composición del término para el 'esperma' (namû)" (Goulard, 2009: 174-5). Se como afirma Goulard, o que não pude presenciar nas Festas, os trompetes são alimentados com bebida fermentada e esta mesma bebida é associada ao sêmen, isso nos indica que pode haver uma associação entre os instrumentos e o pênis. Vejamos o trecho em que Goulard afirma a relação entre a bebida e o sêmen: "el instrumento se coloca sobre el recipiente de masato [bebida fermentada] (...) Lo que confirma otra interpretación entre la bebida fermentada y el esperma. Solamente los hombres tienen la capacidad de engendrar, las mujeres no producen más que prehumanos." (Goulard, 2009: 169-70). Para este autor, portanto, a relação que existe entre a bebida e o esperma se conectaria com a exclusividade masculina sobre as capacidades procriativas.

Temos exemplos de instrumentos que são "falos" na América do Sul. Para os Araweté, o chocalho corresponderia ao filho ou à vagina. Viveiros de Castro o designa como "filho-falo" (1986: 537). De acordo com o mesmo autor, o maracá dos Tupinambá também é considerado um "filho", este fato sugere, diz ele, "que aray [chocalho araweté] estaria para o homem como a filho para a mulher: figuras do falo." (idem: 538). Seria possível pensarmos o mesmo para os grandes trompetes ticuna ${ }^{430}$ De fato, a vida ritual feminina ticuna recebe uma atenção de toda a cosmologia ticuna que faz inveja, ou gera uma falta, ao mundo masculino. Não seria difícil vermos estes instrumentos executados

\footnotetext{
${ }^{430} \mathrm{~A}$ aproximação que proponho aqui, entre o chocalho araweté e as "flautas sagradas", é sugerida por Viveiros de Castro: "o aray é um objeto ambíguo - e se poderia assim aproximá-lo das flautas Tukano e Alto-Xinguanas e de suas análogas melanésias" (1986: 538).
} 
durante a Festa como "um símbolo da criatividade mística masculina" em oposição "ao papel "mágico" da mulher na criatividade biológica"431.

\subsection{2 - Rapé, iniciação aos trompetes}

“Antigamente, curumim não chegava perto [do cercado dos instrumentos]. A gente torrava o tabaco, bem torrado, e misturava com o pó branco raspado da casca do açaí [Euterpe edulis] e do javari [Astrocaryum jauary] também”. Esta mistura chama-se cawü $\ddot{u}^{432}$. Severino (Tõetücü) conta que é um pó bem fino, como café. Ele é soprado com o osso da perna do gavião-real no nariz das pessoas que se aproximam da reclusão da moça para ver os instrumentos. Não precisar ser necessariamente criança, mas elas são as maiores vítimas do rapé. Somente os velhos podem tocar os instrumentos, homens e mulheres na pós-menopausa. Eles podem entrar no curral do to 'cü, não precisam tomar o cawü para ver o to'cü. A pessoa que recebe uma dose desta mistura nas narinas começa a defecar, urinar e vomitar descontroladamente. "De repente a gente fica embriagado, se quiser se mijar, pode se mijar, se quiser se cagar, pode se cagar", diz Ondino. O emético causa uma embriagues instantânea e uma forte incontinência dos excrementos. Depois deste tratamento, a pessoa fica liberada para entrar no cercado dos instrumentos, olhar, não sofrerá mais nenhum mal.

O cawü serve também para deixar a pessoa marupiara, bom caçador, mas hoje em dia ele não é mais usado. Dizem que é por isso que as crianças olham os instrumentos. Severino, aparentando pouco mais de 60 anos, diz que quando era criança, lá pelos seus 10 anos, nenhuma criança chegava perto do cercado do to'cü. Os "policiais" dos instrumentos, que tocam as flautas embolo (nge'cütü), ficavam vigiando em volta da reclusão. Mas as crianças ouviam e achavam o som bonito, queriam ver de onde vinha a música. Quando chegavam perto, os "policiais” as agarravam, seguravam pernas, braços,

\footnotetext{
431 “...corpo-receptáculo, e ao mesmo tempo falo, não seria difícil ver no aray [chocalho araweté] um símbolo da criatividade mística masculina, que corresponderia ao papel "mágico" da mulher na criatividade biológica, minimizado na teoria da concepção e revelado por inversão na produção do chocalho" (Viveiros de Castro,1986: 538).

432 Nimuendaju (1952: 79) inclui ainda dentre os ingredientes da mistura as cinzas de casca de cupuhy (Theobroma subincanum), de pau mulato (Capirona sp), de banana verde e de fruto de envira matamatá.
} 
cabeça, sopravam o cawü nas narinas delas e depois soltavam. Depois de descrever esta aplicação do rapé nas crianças, muito semelhante às descrições que ouvi, Nimuendaju conclui que "[t]alvez nos velhos tempos esta iniciação dos meninos nos mistérios dos instrumentos cerimoniais fosse mais solene do que agora, quando já estão em vias de desaparecer por causa da profanação crescente destes mistérios” (1952: 79).

Segundo Hilda, “quem toca o nge cütü [flauta embolo] é o guarda da festa. Ele fica rondando a casa com o cawü para soprar no nariz de quem quiser fugir ou ver os instrumentos". Esta informação é muito importante para compreendermos o papel do tocador de nge 'cütü no mito da To'oena. Em geral, eles eram os mais agressivos e subiam na frente do to'cü, aparentemente protegendo este último instrumento da visão dos curiosos. No mito de To'oena eles aparecem como seres "com forma de preguiça" que tocam as flautas nge'cütü e batem nela até a morte. Eles não só protegem os instrumentos da vista das pessoas não autorizadas, eles também impedem que as pessoas saiam de dentro da casa. Em algumas Festas os nge'cütü ficam batendo em cima da casa com um caniço para que as pessoas não saiam da casa. $\mathrm{Na}$ fala acima está relacionada a ascensão à imortalidade ao fato de haver segurança na Festa. Ou seja, na medida em que as pessoas eram impedidas de sair da casa, quando a turma de Yoi e Ipi apareciam (os próprios imortais), levavam todo mundo com eles.

Assim como me confirmaram meus colaboradores, segundo Gruber, a flauta nge 'cütü pode ser feita do cipó apuí (yowaru) ou mucunã (tchutchi) (1999: 32-33). A

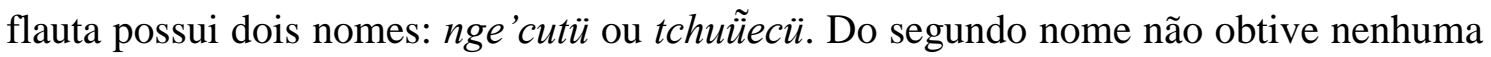
explicação. Já o primeiro, pode ser decomposto em - comecemos pelo final da palavra cutü = pé; e nge, palavra que corresponde a um corte que se abre por si mesmo. Explicaram-me esta palavra próximo a um jogo de futebol. Disseram que nge pode se referir a uma rachadura do pé que vai se abrindo conforme se vai jogando bola, p. ex. Gruber traduz o nome da flauta como "pé partido" (idem: 32).

O uso do rapé cawü é um tratamento compulsório de todas as crianças que se atrevem a tentar espiar o que se passa no cercado dos trompetes. Se o menino quer aprender a tocar os trompetes o caminho é mais longo. Tive uma longa conversa com Manuel Rita, um dos últimos conhecedores da arte de construção e aprendizagem dos segredos dos trompetes. Segundo Manuel Rita, o cawü estabelece uma espécie de conexão onírica entre a pessoa e o to 'cü. Transcrevo alguns trechos da conversa que tivemos: 
"[Com quantos anos a pessoa começa a aprender a tocar?]. Com 11 anos, parece. Eu tinha 9 anos quando comecei a aprender a tocar. Depois que você toma o cawü, nunca perde mais o to 'cü. Quando tem Festa de Moça Nova, você tem que só tocar. Sempre que faz Festa de Moça Nova vai lá tocar, não perde não. Porque ele que chama, o to 'cü que chama."

[Mas sempre que for tocar tem que tomar o cawüi ou só quando é pequeno?]

Primeiro ele canta contigo. Assim, conversando, assim, te explicando como é que você vai tocar. Depois que você passar pelo cawü aí que você toca. Mas o cawü toma só uma vez. Se você soprar, depois você nunca esquece da voz do to' $c \ddot{u}$. Ele mesmo chama para onde tem Festa. Ele chama e o corpo da gente vai. [Ele chama no sonho?]. Isso, sonha aí vai. Antes de chegar o convite já está sabendo, o to'cü que chama.

[Às vezes o Sr. sonha com o to 'cü?]

Depois de soprar [pela primeiras vezes], o to 'cü vai de noite no sonho. Primeiro a gente sopra o cawü, depois não vai tocar muito, não. Depois a gente dorme e no sonho da gente o to 'cü vai conversando, falando como a gente toca o to 'cü. [E o que ele fala?]. Ele vai conversando... [Ele aparece igual gente, $d u^{\prime} \tilde{u}$ ?]. É, assim como gente mesmo, ele fala ensinando como é que a gente toca. Aí você dorme e outro dia ele vai também no sonho, ensinando outra coisa. Depois que você aprende o que ele ensinou, depois de muitos anos, ele vai de novo. Se você aprender tudinho o que ele canta, desaparece o dono do to 'cü, porque o conhecimento já deu para a gente. Por exemplo, a gente está sonhando e todo dia ele está ensinando. Depois que eu aprendi tudinho, o to 'cü desaparece, não aparece mais no sonho, porque já deu o conhecimento para mim, para nunca esquecer. Dois anos, três anos, você pode não querer tocar, mas está na sua memória. Fica tudo no corpo da gente, está no corpo da gente o conhecimento do to 'cü. Aí ele desaparece, vai embora, não sei para onde. Mas o conhecimento do to 'cü fica no corpo da gente, até morrer."

Esta seria, digamos, a dimensão onírica do aprendizado do "soprador" de trompete. Existe também uma outra dimensão, em que o aprendizado é feito de modo similar a transmissão de conhecimento xamânico ${ }^{433}$. Para tanto, o aprendiz de "soprador"

${ }^{433}$ Cf. Capítulo 4, tópico 4.1.5 - Waia, a origem do feitiço, do pajé e sua formação. 
ingere o espírito $\mathrm{movi}^{434}$, o mesmo que é colocado pelo pajé no trompete. Gruber registrou o relato de como Manuel Rita, com quem conversei muitos anos depois, aprendeu a tocar com um experiente trompetista ticuna:

\begin{abstract}
“Durante essas orações, o pajé coloca no to 'cü o movi, o espirito que lhe dá a capacidade de cantar, de cantar bonito, de transformar a voz do tocador em canto. O tocador também deve ser iniciado com o movi através do pajé ou de outra pessoa que por sua vez já tenha sido preparada com esse espirito. Manoel Rita contou como recebeu o movi do velho Eliseo Manoel, reconhecido tocador da aldeia. A iniciação se deu no primeiro dia da festa da filha de Manoel Rita, para a qual ele tinha fabricado uma aricana [trompete]. $\mathrm{O}$ velho pediu uma cuia cheia de pajauaru, sentou-se ao lado do instrumento e falou: "Vem cá, senta aqui comigo que eu vou te ensinar como se toca". Manoel Rita ficou um pouco temeroso, mas Eliseo lhe disse que estava muito velho, achava que ia morrer e precisava passar esse conhecimento para ele, para que um dia também pudesse transmiti-lo a outras pessoas. Eliseo fez um cigarro grande de tabaco, acendeuo e rezou por um longo tempo, soprando a fumaça em direção a Manoel Rita e fazendo movimentos com os braços. Depois juntou sua boca a do iniciado e passou o movi. Em seguida, fez Manoel Rita sentar-se junto ao instrumento e foi contando, parte por parte, toda a história do to 'cü. Para aprender, Manoel Rita repetia no to'cü cada uma dessas partes, e assim seguiram até o final da noite. A sessão continuou no dia seguinte, com novas histórias e lições. Pouco tempo depois da festa, Eliseo morreu.” (1999: 28-29).
\end{abstract}

Se as mulheres ou crianças que não passaram pelo tratamento com o cawü olharem o to'cü, correm o risco de ficar amarelo, doente. "A gente amarela se vê o to 'cü", diz Severino. Se uma criança ver um aricano, explica Francisco, ela não obedecerá mais aos pais, "pega doença, fica amarela e morre". O iburi e to'cü, enquanto não foram rezados pelo pajé, são considerados como não sendo de verdade. Depois que o pajé coloca alma ( $\left.\tilde{a}^{\prime} \tilde{e}\right)$ neles, então, crianças e mulheres não podem mais chegar perto, não podem vê-los. Somente os velhos que vão tocar, os fabricantes do instrumento e o pajé podem ver os

\footnotetext{
${ }^{434}$ Em meu trabalho de campo não ouvi menções a este espírito, movi. Me foi relatado que o espírito que é colocado no trompete é o $\tilde{a}^{\prime} \tilde{e}$, um dos duplos da pessoa.
} 


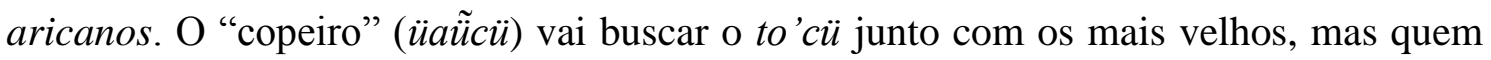
toca o trompete são apenas os mais velhos.

A amarelidão que acomete a quem olha para o to'cü é algo que nos deixa intrigados. No tempo de Yoi, quando o to 'cü era pintado com argila de várias cores, a visão desta pintura era letal para as mulheres, como acontece com To'oena no mito. Alguns informantes de Gruber disseram que o instrumento deve ser pintado de argila ou resina amarela. "É a visão desta cor que faz adoecer as pessoas. Elas vão ficando amareladas e podem até morrer se não receberem em tempo um tratamento adequado do pajé.” (Gruber, 1999: 31). Esta mesma referência da pessoa que fica amarela e morre ao ver o instrumento, como vimos acima, aparece na fala de meus colaboradores. Ao que parece, se no mito, To'oena viu a pintura colorida e foi morta, tingindo com seu sangue o igarapé Eware, atualmente, ao olhar o instrumento amarelado, a pessoa também se amarela, como se estivesse esvaído todo seu sangue, uma espécie de menstruação levada ao extremo. Olhar o instrumento tabu - marca de uma ausência de "bons modos" -, portanto, faz com que falte uma mediação entre os períodos de menstruação. A ausência de intervalos entre os períodos de menstruação criam, então, uma menstruação sem fim, um excesso que torna a pessoa amarela por falta de sangue ${ }^{435}$.

Poderíamos pensar este tratamento como uma atualização masculina do que aconteceu com To'oena. Lembremos que ao ser alvejada pelo dardo envenenado da zarabatana, ela se urina como um macaco atingido por um dardo envenenado. Contudo, o fim de To'oena é a morte. A criança, ao passar pela experiência do cawü, sofreria uma espécie de "morte de To'oena". A partir de então, a visão dos instrumentos estaria liberada. O rapé tem uma função purificadora. Ao vomitar e colocar todos os excrementos para fora, quem inalou o rapé elimina os "males" (puya) que tem no corpo. Vimos que o vômito limpa as impurezas adquiridas no ato sexual do candidato a xamã ${ }^{436}$. Este é mais um exemplo de inversão entre coito e vômito que verificamos na vida dos Ticuna ${ }^{437}$.

\footnotetext{
${ }^{435}$ Encontramos ressonâncias desta "amarelidão" e a perda de sangue em outros povos ameríndios. "Para os Mamaindê [Nambiquara], "ficar amarelado" indica perda de sangue que é associado ao espírito (yauptidu)." (Miller, 2007: 269, nota 218).

${ }^{436}$ Cf. Capítulo 4, tópico 4.1.5 - Waia, a origem do feitiço, do pajé e sua formação.

437 "[S] egundo Lévi-Strauss (1966: 210), "no plano do imaginário (ou seja, no plano do mito), o vômito é o termo correlativo e inverso do coito" equivalência que é verificada entre os Tikuna, no plano do real." (Goulard, 2011: 151).
} 
O recorrente discurso ticuna, pessimista sentimental, de que atualmente as pessoas não respeitam mais o tabu dos instrumentos pode ser uma falsa indicação de uma degeneração dos costumes. Um comentário do narrador de uma das versões do mito de To'oena nos mostra que o início deste "pessimismo sentimental" é contemporâneo à partida de Yoi. Depois que o herói foi embora, após a morte de sua sobrinha, a Festa nunca mais foi a mesma:

"O narrador comenta que se ele não tivesse matado sua sobrinha, a música da moça nova seria diferente. Agora já é diferente, não é mais como a música que ele cantou. Até então, ninguém conhecia a música que ele tinha cantado. Depois que passou o tempo de $Y o i$, a Festa ficou meio bagunçada. As pessoas ficam fora da casa, namorando, não fazem mais os instrumentos, etc. Se conhecem bem a história de $Y o i$, fazem bem a Festa, como ele fez com a gente. O que se faz agora já não é mais como antigamente, é uma Festa mais empobrecida. Antigamente, no tempo de Yoi, a Festa era sagrada. Ninguém saía da casa, a casa saía voando, se encantava, ia para Morügüne, um lugar no Eware e o nome da casa de Yoi." (Anexo - 005).

Talvez as crianças olhem os instrumentos hoje como sempre o fizeram em todos os tempos. Afinal, se a curiosidade das crianças não fosse esperada, não haveria a preocupação de montarem "guarda" em torno do instrumento ou de aplicarem o rapé cawü nos curiosos. Muito provavelmente este pessimismo sentimental se liga ao fato de que o tabu dos instrumentos para os Ticuna tem uma relação direta com os "bons modos" que se espera de todas as crianças, especialmente das moças que estão passando pela reclusão. To'oena é um exemplo extremo de uma moça sem modos, que sai da reclusão para olhar os instrumentos. Esta falta de medida de To'oena a transforma em puro fluxo de sangue. Tanto sangue que até hoje é possível ver o rio vermelho de sangue. Faltar com os "bons modos" é o mesmo que anular a periodicidade do corpo.

\section{3 - Demais instrumentos musicais}

Os Ticuna possuem ainda um terceiro tipo de trompete, o coirri, que é feito de bambu e em maior número para as danças da Festa. O tamanho das tabocas usadas para fazer estes instrumentos varia de cerca de 30 à $50 \mathrm{~cm}$. Os coĩri são feitos aos pares, para cada macho fazem uma fêmea para ele. O trompete fêmea não tem "boca". O trompete 
macho possui corte serrilhado do lado oposto ao bocal, este corte é a "boca" e os "dentes" do boto celeste Tchoreruma. Mais uma vez temos o boto vingador do incesto presente no ritual, agora mostrando seus dentes talhados no bambu. Outro colaborador ticuna me disse

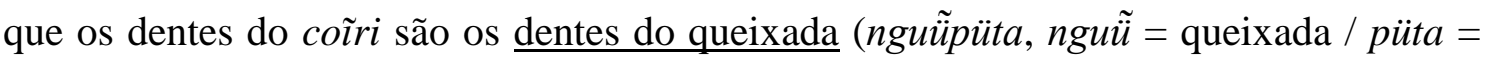
dente). A relação entre o coĩri e os queixadas é mais explicita, já que os trompetes são benzidos para atrair estes animais para perto da comunidade. Uma presença, no entanto, não exclui a outra. Os botos celestes estão presentes nos trompetes de bambu tanto quanto o pessoal que dança tocando os instrumentos é uma vara de queixadas. A canção dos coĩri gravada por Ondino é toda construída com referências aos queixadas, como no trecho:

Ira' ǘtchinë yacurü aiyanewa

"Aquele lugar pequeno onde vocês tomam banho"

Peyugü̈̈ta

"Caem juntos no banho"

Pa Nguи̃̈ta tchirucütü

"Queixada"

Quando são executados durante o ritual da moça nova, os homens tocam os machos e as mulheres tocam os trompetes fêmea (Gruber, 1999: 17). Além disso, antigamente só as pessoas dos clãs "sem pena" podiam tocar o coĩri. Comentei com Ondino que nas Festas que presenciei este critério não foi seguido, ele me disse, "isso era antigamente, hoje eles não sabem mais. Tem que entregar para os sem pena". Este comentário de Ondino é um ensejo para uma reflexão sobre o script da Festa como um todo. Estas "regras de funcionamento", pelo que pude observar nos rituais que presenciei e nos relatos que ouvi, tem suas idas e vindas. Muitas vezes, um "copeiro" (üa $\tilde{\ddot{u} c u ̈})$ - o mestre de cerimônias do ritual, que pode conhecer mais ou menos as "regras" antigas coloca ênfase nestas "regras" que podem ser seguidas ou não. Em geral, quanto mais "regras" são lembradas e se consegue colocar elas em prática no ritual, mais a Festa é valorizada como "tradicional", como faziam os antigos. Retomarei esta questão teórica do script ritual mais adiante. 

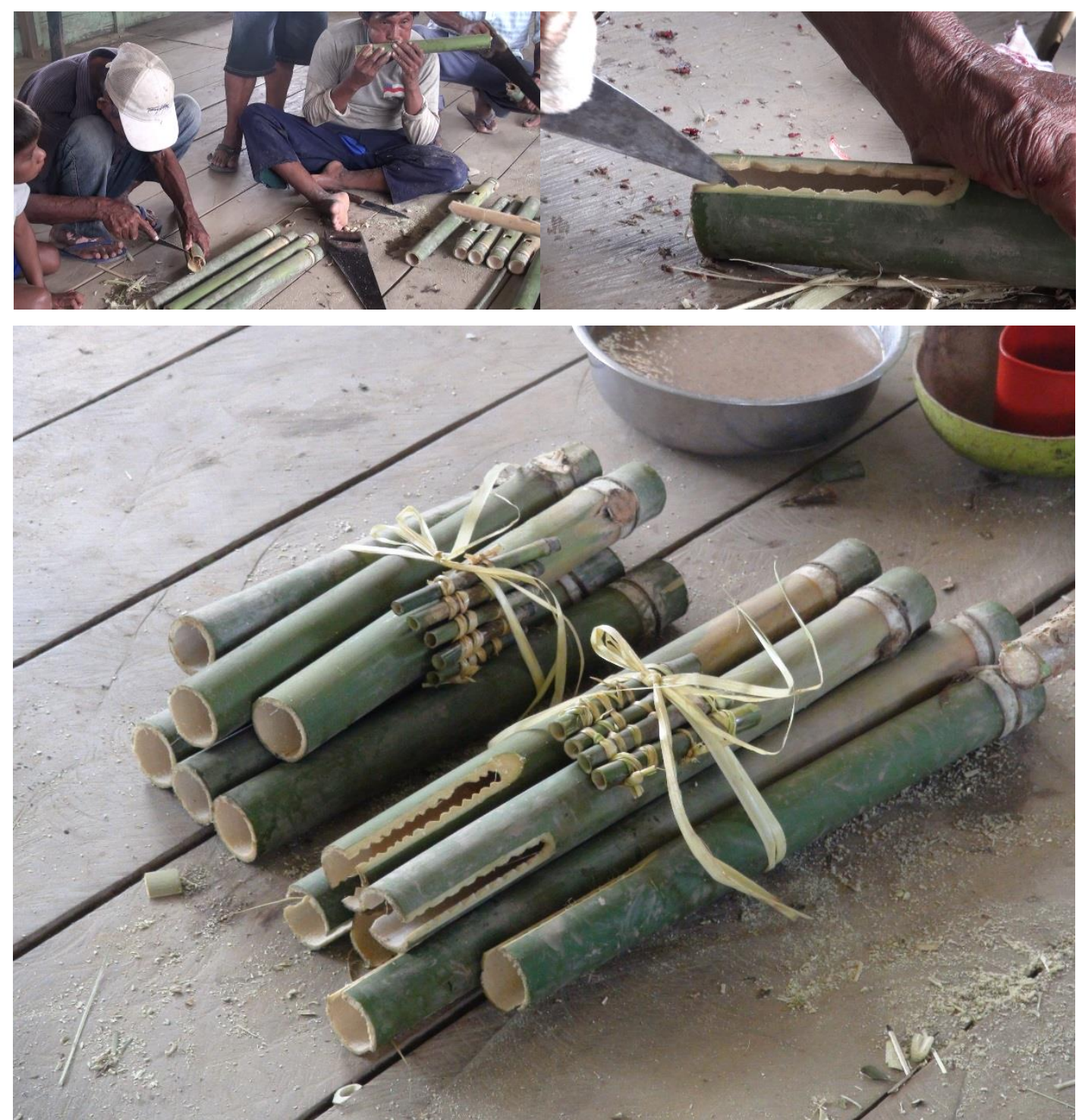

Figuras 30, 31 e 32 - Trompetes de bambu (coĩri) e flautas pan (tchecii)

Os coĩri são - junto com o casco de tracajá (tori) e o chocalho de vara (aru) - um dos instrumentos que saíram da montanha Decüãpü trazidos pela turma do Tchürüne (Nimuendaju, 1952: 80-81). Em regra, estes dois instrumentos estão em oposição correlativa à oposição que existe entre as metades exogâmicas. Se, como vimos, os trompetes de bambu são usados pelos clãs "sem pena", o instrumento de casco de tracajá é uma prerrogativa dos clãs "com pena” (Gruber, 1999: 14). As flautas pãn, tchecü, eram também, antigamente, exclusivas dos clãs "sem pena" e "representam os filhotes das queixadas." (idem: 18). Retomaremos as explicações sobre os coĩri quando abordarmos sua confecção e benzimento, que são feitos em um momento determinado da Festa. 
Existem dois idiofones ticuna que são muito parecidos, chamados ngobu e tori. A diferença é que o primeiro é feito de casco de cágado, um quelônio terrestre, e recebe o mesmo nome do cágado. Já o tori é feito de casco de tracajá, um quelônio que passa muito tempo na água e desova nas praias dos rios. Os membros dos clãs responsáveis por fabricar e tocar estes instrumentos também são diferentes. O casco de cágado (ngobu) é feito e tocado apenas pelos clãs "sem pena". O casco de tracajá (tori), como vimos, pode ser feito e tocado por qualquer clã "com pena".

O mais frequente nas Festas, destes dois instrumentos, é o tori. Mencionei acima que foi tocando este instrumento que o Tchürüne saiu da montanha Decüãpü. Esta narrativa é importante para compreendermos a origem de muitos elementos da Festa da Moça Nova, principalmente as máscaras e alguns instrumentos musicais. Existem muitas versões deste mito, Nimuendaju apresenta duas versões (1952: 80-81). A narrativa registrada por Bueno (2014: 88) mostra um começo de história igual a história do Tautchipé (cobra Norato). Um grupo ou alguém caça um animal que na verdade não é apenas um animal, o que desencadeia um ciclo de vinganças. Há também uma versão mais sucinta em Gruber (1999: 23).

Tchürüne vive dentro da montanha junto com diversos ngo'o. As narrativas não deixam claro o estatuto ontológico deste ser. Manuel Rita me confirmou que o Tchürüne é "gente" $(d u$ 'ũ). Ao menos, o fato de ele não comer carne humana o exclui de ser um "bicho" (ngo'o). É possível resumir as versões deste mito a partir das vinganças que desembocam na fuga do Tchürüne e da sua turma de dentro da montanha. 1) Um ngo'o é morto ao sair da montanha, confundido com um animal de caça. 2) Os ngo'o se vingam atacando aos Ticuna. 3) A forma como se dá a segunda e última vingança é recorrente nas narrativas: os habitantes da montanha são expulsos com fumaça de pimenta. Um trecho do mito registrado por Gruber resume bem o final da história:

"Sufocados pela fumaça, os "bichos" começaram a morrer. Para constatar se todos estavam mortos, os homens amarraram um Yawa $^{438}$ numa corda e o mandaram para dentro da montanha. Lá, o Yawa encontrou um velhinho, escondido bem no fundo, que gritou: "Não me matem, eu sou igual a vocês!", era Tchürüne. Em seguida ele saiu da montanha, todo enfeitado, batendo o casco

\footnotetext{
438 Provavelmente se refere a etnia Yagua, do Peru, que os Ticuna consideram em seus mitos como seus "escravos".
} 
de tracajá e cantando acompanhado de sua turma que levava outros instrumentos: os coîri e o chocalho de vara. Eles tocaram e dançaram por muito tempo, até que todas as pessoas pudessem aprender. Depois foi procurar um outro local para morar com sua gente. Por fim encontrou a montanha Etagüne ("lugar da estrela"), onde está até hoje batendo o tori, sem nunca mais se sentar. "(1999: 23).

A figura do Tchürüne evoca a relação com a periodicidade que vimos estar estreitamente relacionada com a Festa ${ }^{439}$. Este personagem é um festeiro eterno. Dentro da montanha ele não para nunca de tocar e dançar com o casco de tracajá ${ }^{440}$. Isso se reflete em seu aspecto físico, a pele das suas juntas é alongada, seus pés são grandes e chatos. O momento em que o instrumento de casco de tracajá é tocado na Festa é chamado de "dança do tracajá", em referência ao instrumento. Esta dança repete a performance que o Tchürüne ensinou aos Ticuna e que executa até hoje na montanha para qual se mudou depois de sair de Decü̃apü ${ }^{441}$. De acordo com Gruber, esta dança é feita para expandir o mundo, evitar que ele diminua e promover a fartura:

"Segundo os ticunas, a dança do tracajá serve para ampliar o mundo. Os movimentos dos dançarinos, para trás e para frente, vão abrindo e espalhando cada vez mais a superfície da terra. Quando não se realizam festas, o mundo diminui porque não há danças. E diminui a fartura de alimentos na aldeia porque não são oferecidas as bebidas feitas com os produtos da roça. (...) os ticunas precisam corresponder ao esforço do sobrenatural Tchürüne, que ainda permanece dentro da montanha batendo seu tambor de casco de tracajá para o mundo continuar vivo" (1999: 22-23).

É, portanto, com um sacrifício do próprio corpo - que se desgasta e se alonga - que o Tchürüne dá o exemplo aos Ticuna de como manter o mundo amplo e propício para uma roça produtiva.

\footnotetext{
${ }^{439}$ Ver Capítulo 4, tópico 4.2.3.2 - Periodicidade.

440 "De tanto bater, a pele de seu cotovelo cresceu, cresceu, caindo quase até o chão. Ele nunca para, pois se assim fizer a terra diminuirá e com o tempo se acabará" (Gruber, 1999: 22-23).

${ }^{441}$ A montanha de destino do Tchürüne e sua turma variam segundo a narrativa. No trecho de Gruber citado acima a montanha chama-se Etagüne ("lugar da estrela"). Na narrativa contada a mim por Manuel Rita a montanha se chama Deragüne. Noutra versão contada por Severino trata-se da "montanha do papagaio".
} 
Lévi-Strauss (2004 [1964]: 149-151) analisa algumas narrativas que podem ser identificadas como variações míticas do mito do Tchürüne. No mito M40 dos KayapóGorotire, Origem do Riso, uma "expedição punitiva" faz uma fogueira para asfixiar os seres (morcegos) que moram dentro de uma gruta. Os animais escapam por uma abertura no teto da gruta, mas os índios não recebem nenhum objeto, apenas um novo morador morcego para a aldeia. Na "expedição punitiva" dos Apinayé, os humanos conseguem "machados rituais e adereços" dos animais defumados que fogem. No mito dos Tacana, etnia boliviana, talvez os bens culturais doados pelo morcego tenham sido instrumentos musicais, diz Lévi-Strauss.

Entretanto, ao contrário do que acontece nestas narrativas analisadas por LéviStrauss, segundo um comentário de Hilda, "eles [o Tchürüne e sua turma] não deram o tracajá para os Ticuna. Os Ticuna viram o tori e aprenderam a fazer. Ele ainda existe, mas

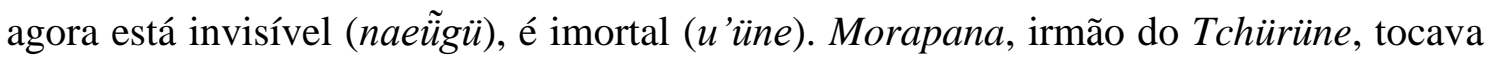
junto com ele o tori. As pessoas seguravam nele e o seguiam”. Interessante esta preocupação em dizer que havia alguém tocando junto com o Tchürüne o tori, pois tratase de um instrumento que só é possível tocar em duas pessoas. As duas seguram o tori no ombro, apoiando a vara amarrada ao casco, e uma percute a baqueta no casco do tracajá.
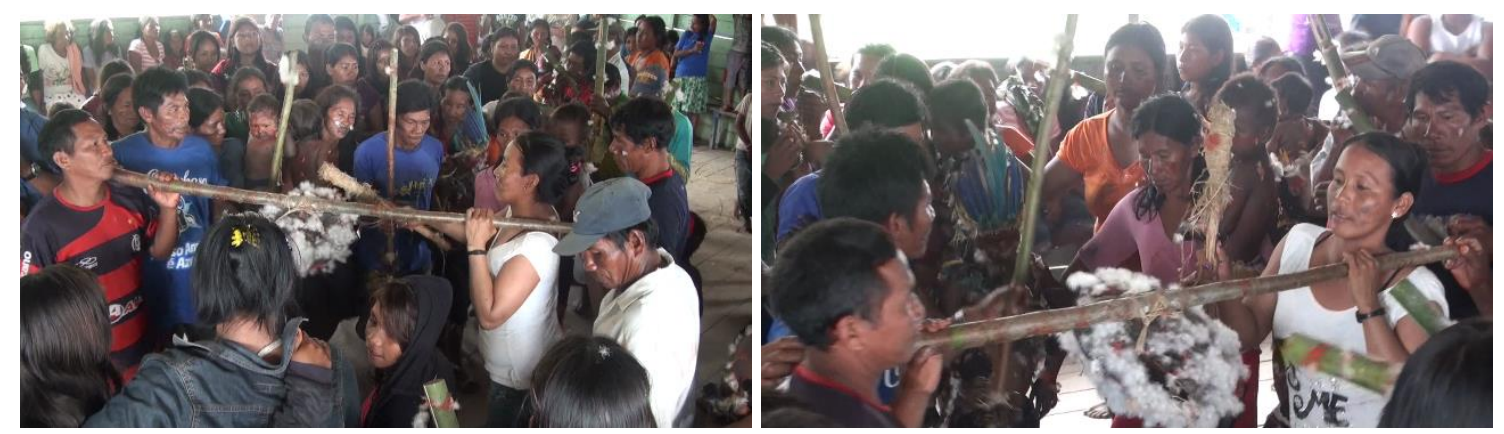

Figuras 33 e 34 - Dança do tracajá com o tori em Santa Clara.

Muitas toritchiga, canções que falam sobre o instrumento de casco de tracajá, mencionam o Tchürüne. Os trechos da canção que menciono abaixo deixam bem claro uma das razões para se fazer a Festa da Moça Nova: garantir a produção abundante de alimento. Ondino, enquanto estávamos traduzindo a canção, comentou, "quando não queremos fazer roça, pescar, trabalhar, Tchürüne canta esta música para a gente. Tem que acompanhar ele para ter fartura".

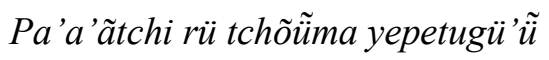


"Rápido, me acompanhem, segurando minhas costas, pelo braço, pelo corpo todo" [disse

o Tchürüne]

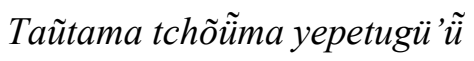

"Se vocês não me acompanharem segurando / muita gente segurando ele"

Penawaena ta pengematchiane

"Vocês querem ficar sem alimentação".

Patchauta'a pa yunatüta

"Meus netos/sobrinhos, mortais"

Ngianagürü ya oi oi ga Tchürüne

"Assim fala o vovô, vovô Tchürüne"

(...)

Yaicawü yangita'a

"O lago do tori Icawï"

Ya nata'agu

"Lá naquele lago"

Ngiünmayeta matchicu

"Flecharam com flecha de arco"

Gama torü tori yana tori

"Nosso tori"

O trecho da canção do Tchürüne gravada por Hilda e traduzida por nós dois, também traz menções ao herói chamando seus "netos" para dançarem garantirem a produção das roças:

Nhumawai pa tchauta'a pa yunatüta

"Ele disse, "meus netos, mortais"”

Tchoüntürü petugü̈̈nta na taüntama

Pengematchineünca pa tchauta'a

"Meus netos, vocês têm que me acompanhar [dançando], senão as plantas da roça não vão dar raízes e frutos" 
Hilda me explicou este trecho da canção do seguinte modo, "todos tinham que acompanhá-lo, senão quando plantarem macaxeira não nascerá batata, raiz, da mandioca, as plantas não vão nascer. As plantas vão nascer, mas não terão batata e não terá banana”.

Um dos trechos acima faz menção à caça do tracajá, uma carne muito apreciada pelos Ticuna. Os instrumentos feitos de casco de quelônios estão presentes não somente nas histórias do Tchürüne. O personagem Metare aparece como uma tartaruga em diversas narrativas. Sobre o papel da tartaruga na mitologia dos Ticuna da Colômbia, Camacho comenta o seguinte:

"Para los tikuna esta tortuga [Motelo (gobii)- Testudo spp.] permitió, en tiempos míticos de los inmortales, que la gente descendiente de animales de plumas pudiera volar al espacio para encantarse en el cerro Moruapü; por esto, cuenta el mito, el caparazón de motelo se usa ritualmente como instrumento musical de percusión en ocasión de los cantos de los clanes aves durante la ceremonia de Pelazón [Festa da Moça Nova]" (2000: 108, nota 9).

O autor faz referência aqui ao herói Metare, sobre o qual nos debruçamos no Capítulo 2, tópico 2.7 - Metare - O bom partido. A tartaruga, no pensamento ticuna, é associada à longevidade. O tori, a presença de Metare na Festa, evoca, portanto, esta longevidade. Goulard comenta sobre o motivo da tartaruga nas máscaras para enfatizar a vida longa associada a este motivo. "A presença sobre a máscara do motivo da tartaruga é devido às qualidades do animal, que tem uma longa vida, dificilmente morre e sua grande capacidade de resistência é conhecida de todos. Sua carne é muito apreciada pelas mulheres." (2011: 141-142).

$B a$ 'ma é um idiofone usado na Festa da Moça Nova. É um instrumento percutido no chão que raramente se vê hoje em dia. Feito de bambu bem grosso, ele é tocado aos pares, macho e fêmea, três ou quatro pares. O bambu do qual é feito o instrumento deve ser cultivado, o que o torna ainda mais difícil de fazer, pois depende de alguém que o tenha plantado bem antes da Festa. Gruber fornece um relato de como eles eram executados nas Festas: "Os homens carregavam o ba'ma "macho", as mulheres a "fêmea", e assim dançavam cruzando-os em X e percutindo-os ao solo com a extremidade inferior. Esses instrumentos eram fabricados no mesmo momento da preparação dos coĩri e dos tchecu." (1999: 25-26). 
Sobre o pertencimento clânico deste instrumento, ouvi informações discrepantes, provavelmente por ser um instrumento musical raramente feito e executado atualmente ${ }^{442}$. Segundo me disseram, o ba'ma é usado apenas por quem é de nação de onça. O vínculo entre este clã e o instrumento é evidenciado no aspecto que se quer dar ao instrumento. Ondino comenta que "no ba'ma é feita a figura da onça. Com dente, pedaço de espelho para os olhos, fazem a cara da onça". Em alguns trechos da letra de uma canção do ba'ma que Ondino cantou para mim a onça também está presente:

Ngo'o, ngo'o

Bicho, bicho

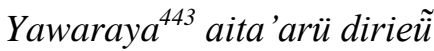

"Onça, onçazada, som do ba'ma"

(...)

Nhaüma'ã tchawatchayanawatcha

"Assim que eu vou cantar"

Tiriãpünapü arü tuãtchiwa

"Pé da montanha Tiriãpü"

Ãtchiün yananatü

"Lá que ele mora, o pai [do $b a ’ m a] "$

Yowaru nanatü yatocuara ba'ma itcharüyü'ü

"Pai da onça d'água, vou dançar lá com o ba'ma"

${ }^{442}$ Gruber também aponta algumas discrepâncias no pertencimento clânico do ba'ma (1999: 26-27).

${ }^{443}$ A primeira palavra desta frase yawara é "onça" nos idiomas tupi. Uso na tradução a palavra "onçazada", como os Ticuna costumam traduzir aita, com o sentido de "um monte de onças". 


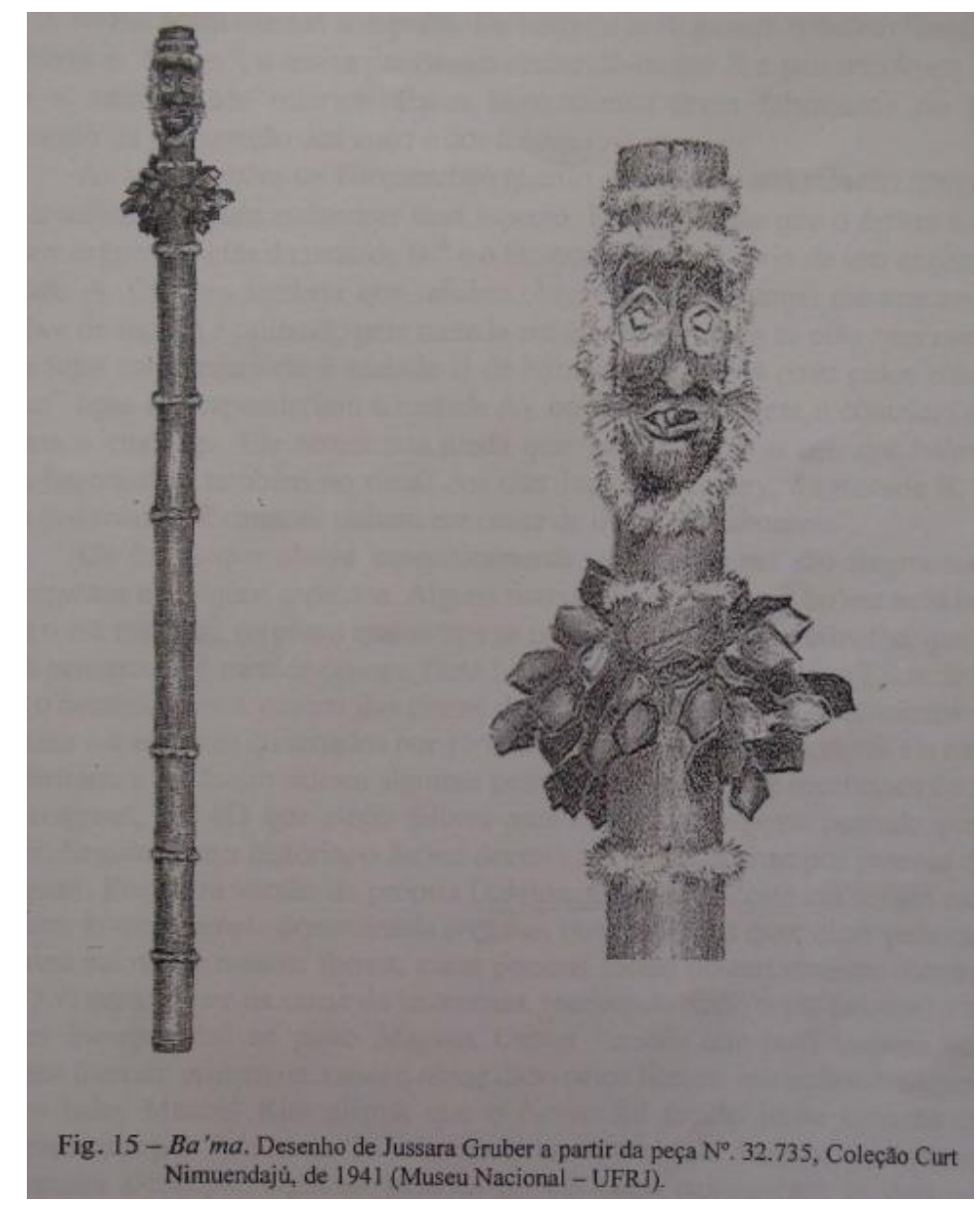

Figura 35 - Desenho do ba'ma retirado de Gruber, 1999: 25

Ondino, por outro lado, me contou que já viu gente da nação de maguari tocando o ba'ma. Alguns me asseguraram que este idiofone pertence ao clã do maguari. Se a menina que está sendo iniciada for deste clã, tem que ter $b a$ 'ma na festa. Ele é adornado com um rosto e seus dentes são feitos de espelho ou dentes de onça. Somente os membros do clã do maguari podem fabricá-lo e tocá-lo. Com relação aos Ticuna residentes no Perú, Goulard afirma que o ba'ma pertence aos clãs "sem penas", mas é executado pelos clãs “com penas", ao modo bororo de pertencimento da parafernália ritual ${ }^{444}$.

\footnotetext{
444 "Al igual que los bororo, los miembros de un clan ticuna nunca son los representantes de su propio emblema; "ellos invitan a miembros de los clanes de la mitad opuesta para que sean los actores" (Crocker 1977: 168). Como ya se ha visto, unos son los depositarios de la gestión del ritual de los otros. El bamachiga es propio de los clanes con plumas (apachi) y es celebrado por los miembros de los clanes sin pluma. Por el contrario, el ngobüchiga es el de los clanes sin pluma (ngechi-i), entonces, él está a cargo de los clanes con plumas" (Goulard, 2009:148). Goulard, no entanto, menciona um trecho de Nimuendaju (1952) em que o ba'ma é associado ao clã da onça, o que pode indicar uma diferença entre os Ticuna do Perú e do Brasil. "Nimuendaju hace notar que el bama y el ko-îri [trompete de bambu] se utilizan juntos. Actualmente son distinguidos por los ticuna y el primero no se refiere más que a los clanes de la misma mitad. La especificidad del bama está asociada al clan del jaguar porque "en el clan del jaguar no se hace ngobü [idiofone de casco de cágado]", asegura un informante" (2009: 149).
} 
De acordo com uma narrativa sobre o herói Metare que registrei ${ }^{445}$, após queimar o ogro Wîtchicü com um tição em braza, no mesmo local nasceu bambu ( $b a$ 'ma) e deste bambu sairam muitos inimigos dos Ticuna. Ondino me contou esta passagem da seguinte forma:
"No lugar onde foi queimado o Wĩtchicü, acontece que nasceu um bambu aí.
[Com eu digo bambu?]. É ba'ma. Aí que vai ser o surgimento do povo Awane, os
Cambeba. [Ali que surgiu Awane?]. Ali que surgiu Awane. Quando passou umas três semanas, duas semanas e meia, ele foi lá de novo ver e já tinha nascido um bambu deste tamanho. [É o ba'ma mesmo que o instrumento?]. É esse daí mesmo. O Metare cortou aquele bambu que tinha nascido. Passou duas, três semanas, estava lá o bambu de novo, tinha crescido de novo, já estava deste tamanho o bambu. Metare cortou de novo, muitas vezes ele cortou, mas sempre nascia de novo. Quando completou dois meses ele não foi ver mais o bambu. O bambu ficou grande, espocou e saíram milhares de Awane, Cambeba. E eles já saíram com tudo, eles já tinham machado, terçado, facão, todo tipo de objeto, já saíram com tudo. Assim foi o surgimento do povo Cambeba, Awane, não é pescado de Yoi não.”

Aqui o bambu ba'ma revela sua faceta de potente regenerador - o que aparece no mito "O caçador que se transformou em gavião woe", narrado a mim por Ondino, como atributo de outra planta, gotüne $e^{446}$, que regenera a perna do herói do mito - além de recipiente de gestação dos inimigos. A primeira destas duas qualidades encontra eco em outro elemento do ritual, a planta taperebá. A segunda, na mitologia, numa outra origem destes mesmo inimigos. Veremos que o taperebá é largamente utilizado no ritual em virtude de seu poder de brotamento. Dizem meus informantes que é uma arvore que "pega

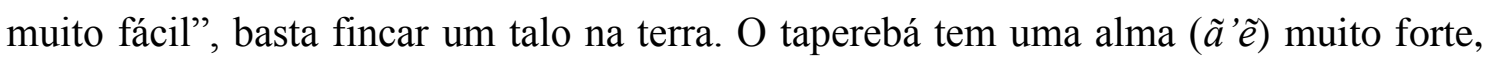
por isso aparece em diversos momentos do ritual. Quanto à origem dos inimigos, a história dos gêmeos, Yoi e Ipi, narra de forma diferente. Os Cambebas são originados porque Ipi os avista de cima do jenipapeiro. Quando ele grita a seu irmão, que estava embaixo da árvore, que os inimigos estavam no rio, automaticamente eles se criaram, no que é recriminado por seu irmão. Caso Ipi não tivesse gritado que tinha visto os inimigos, hoje eles não seriam inimigos.

\footnotetext{
${ }^{445}$ Cf. Capítulo 2, tópico 2.7-Metare - O bom partido.

${ }^{446}$ Go $=$ nasce/cresce, como um broto de planta, tüne = ?
} 
Se a origem do ba'ma é relatada no final de uma das histórias de Metare, sua introdução na Festa da Moça Nova aparece em um mito registrado no trabalho de Gómez (2009). Ao que tudo indica, esta narrativa explicita a origem da dança com este instrumento. Diz o narrador, “a realização da festa, a princípio, não era assim”. A história começa com um grupo de velhos (yaguãgü), do clã da garça-real (yawüru), saindo para uma Festa na montanha dos pássaros. Os mais velhos chamavam um jovem que estava demorando, mas este respondeu para seguirem sem ele, pois seu tambor e suas folhas de palmeira ainda não estavam prontos. Enquanto todos já haviam chegado na Festa, o rapaz ainda estava no meio do caminho. Neste momento, ele ouviu o ruído de um demônio invisível (ngo'o) e convidou o bicho para ir para a Festa na montanha dos pássaros. "Vamos, espírito invisível, dançar na festa do instrumento de pelação ${ }^{447}$ na montanha dos pássaros", disse o jovem. Quando se deu conta de que era um demônio que ele estava convidando, o rapaz quis correr, mas o bicho o seguiu. $\mathrm{O}$ fato de o rapaz ter atraído um demônio (ngo’o) para a Festa, causou uma modificação na estrutura da celebração. Durante todo o ritual, o jovem é perseguido pelo demônio, que também não o deixa beber, tomando toda a bebida que é oferecida ao rapaz (idem: 61). Já embriagado, o diabo começou a dançar e disse: "assim que é a verdadeira festa do instrumento de pelação (ba'ma)" (idem: 62).

O maracá, instrumento bastante difundido entre os ameríndios, é aparentemente desconhecido pelos Ticuna. No entanto, o bastão de ritmo (aru) está presente em todos os momentos da Festa da Moça Nova. Sua batida está em contraponto, segundo Nimunedaju (1952: 45), à marcação do membranofone tutu, num tempo mais lento. Assim como os tamborins tutu, o aru está sempre marcando, mesmo que em andamento lentíssimo, porque não pode ficar silêncio (tchianẽ̃u) na Festa. Em geral, uma Festa tem

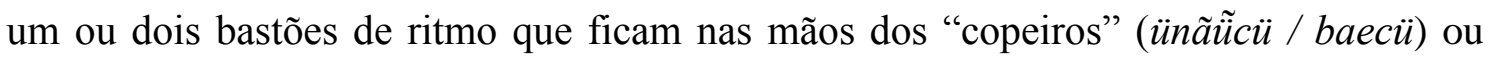
quem conheça suas canções, pois é um instrumento perigoso.

O instrumento é uma vara de taperebá de pouco mais de um metro no qual é atado um conjunto de sementes que estão amarradas num cordão trançado. Existem dois tipos de sementes que podem ser atadas ao galho grosso de taperebá (Spondias mombin). Uma é considerada o "aru verdadeiro" (cõtaru) a outra é simplesmente aru (mõtchicua). Segundo Francisco, o “aru verdadeiro” só é encontrado no Perú. Em Nazaré as pessoas

\footnotetext{
${ }^{447}$ Pelação é uma das formas de se referir à Festa da Moça Nova, especialmente no Peru e Colômbia.
} 
encomendam a semente para o pessoal de Umariaçu, em Tabatinga, que fica mais próxima do país. A semente mais comentada nas etnografias Ticuna é chamada avaí (aru), da planta auaí (Thevetia nerifolia ou Thevetia peruviana) - que estão presentes na paramentação do mascarado Mawü também.

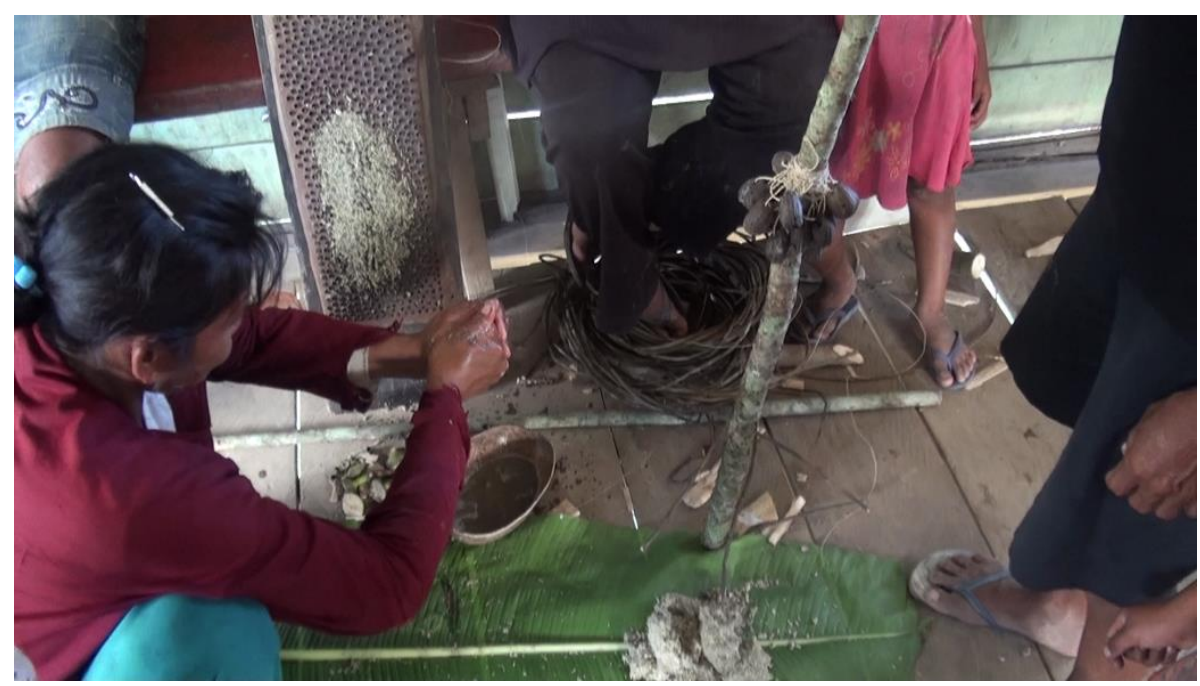

Figura 36 - Bastão de ritmo (aru) tocado ao lado de mulher espremendo massa de jenipapo

Esta planta é extremamente tóxica, devido à presença de glicosídeos cardíacos em todas as suas partes (Schvartsman, 1979). Numa outra referência, este bastão de ritmo, aru, é também denominado em espanhol "palo de cascabel” (Sparing, 2008[1976]: 113), um nome popular da planta auaí mencionada. De fato, o som dele lembra o guizo de uma cascavel. Não por acaso, o chocalho feito de sementes de auaí é muitas vezes atado no bastão na altura dos joelhos, digamos, numa área sujeita à picada de cobras. Isto coloca, portanto, juntamente com o curare (veneno de caça) este instrumente musical no sistema ticuna do veneno. De acordo com Lévi-Strauss, o veneno, no pensamento ameríndio, como já mencionei, operaria um curto-circuito entre natureza e cultura, ou seja, reduziria ao mínimo o intervalo entre estes dois termos, causando uma invasão momentânea da segunda pela primeira (Lévi-Strauss, 2004 [1964]: 317). Sabemos que os chocalhos possuem um caráter mediador na América do Sul indígena (Lévi-Strauss, 2004[1967]: 397). No entanto, teríamos entre os Ticuna um instrumento mediador venenoso, o que põe em relação o sistema do veneno com a mediação (instrumental) com os espíritos. Apesar de ser considerado um instrumento perigoso e apenas ser manejado por pessoas 


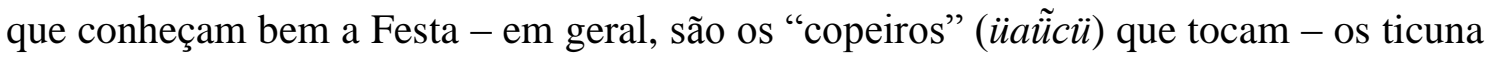
a quem perguntei não reconhecem a toxicidade da planta avaí.

Nas Festas que presenciei, o bastão de ritmo (aru) marca o momento exato do início e do fim de todas as atividades coletivas que compõem a Festa. Em 1882 o Dr. Melo Moraes publicava na Revista da Exposição Anthropológica Brazileira a mesma impressão que tive ao notar um pouco desta sincronia proporcionada pelo $a r u$, que ele chama "cascavel":

“... ao som de um cascavel feito de cipó, com pedras ou contas dentro, ou de uma espécie de busina, e de um modo e ordem, que ás vezes cem homens bailando e cantando em carreira enfiada, uns atraz dos outros, acabam todos juntamente ao mesmo tempo, a um signal ou pancada no chão, como se estivessem todos no mesmo lugar." (1882: 55)

Por fim, gostaria de apresentar o tutu, membranofone que deve permanecer soando do começo ao fim da Festa, ininterruptamente. Desenvolvi no Capítulo 2 algumas conexões da mitologia ticuna com as de outros grupos indígenas da América do Norte. Devido a grande presença de tambores entre os índios do norte-americanos, o tamborim ticuna aparece como mais uma possível conexão entre os continentes. O acervo de instrumentos sul ameríndios é maior que o da América do Norte indígena. Mas, além disso, os instrumentos preponderantes variam também. Enquanto no Sul a variedade de instrumentos de sopro é mais numerosa, no Norte os tambores predominam ${ }^{448}$. No entanto, não diria tratar-se de uma difusão do tambor para o sul - o tamborim ticuna aparenta ser um empréstimo europeu, devido ao tipo de amarração -, mas, assim como os mitos, o gosto pelos instrumentos de percução pode ter migrado no mesmo sentido ${ }^{449}$.

A presença de tambores na mesma região onde habitam os Ticuna, o tambor de fenda dos Omágua, é atestada por Metraux. O mesmo membranofone usado pelos Ticuna (double-headed skin drum) é referido pelo autor como de origem espanhola:

"O instrumento musical mais conspícuo Omágua e Cocama antigamente era o grande tambor de fenda. Entre os Cocama, quatro ou cinco tambores de diferentes tamanhos de até 15 pés $(4,5 \mathrm{~m}$.) de comprimento eram percutidos

\footnotetext{
448 "South America is even at first glance much richer in musical instruments than North America. There is a great variety of wind instruments, while in North America drums preponderate" (Herzog, 1940: 340).

${ }^{449}$ Para um panorama já bem antigo sobre os membranofones sul-americanos, ver Izikowitz, 1931 e 1935.
} 
simultaneamente, produzindo "sons diversos e harmoniosos que eram ouvidos de longe" (Figueroa, 1904, p. 101). O moderno tambor de duplo encouramento [double-headed skin drum] é, obviamente, copiado do tipo espanhol" (Metraux, 1948: 701).

Ao longo dos rituais que presenciei, todo o tempo ouve-se o som do tamborim tutu, sem cessar ${ }^{450}$. Não é raro os mais velhos se lembrarem de Festas com cinquenta tamborins tocando ao mesmo tempo. As festas que presenciei tinham, no máximo, 10 e o som era bastante alto, sendo possível escutar a dezenas de metros de distância. Mesmo quando não estão dançando - quando estão, por exemplo, preparando o pajauaru (bebida fermentada), fazendo os instrumentos, as máscaras e os adornos -, o tamborim não para de soar.

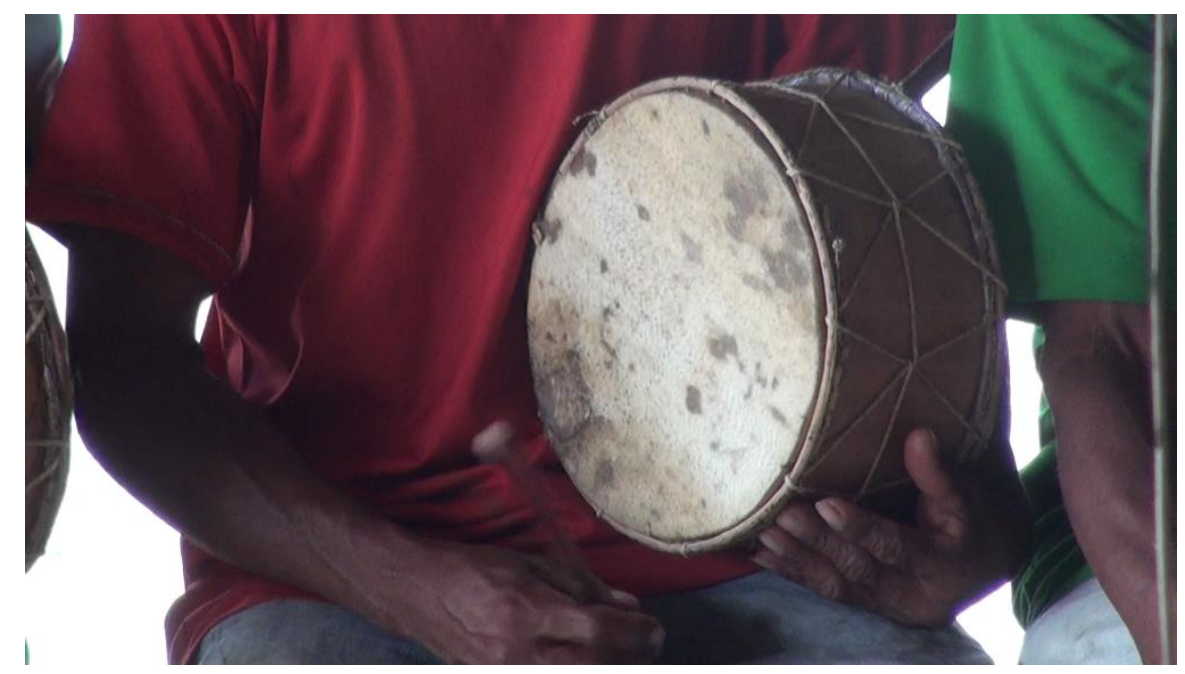

Figura 37 - Percutindo o tambor tutu

O corpo destes instrumentos é feito de madeira cilíndrica escavada, inteiriça e são encourados dos dois lados. Para a confecção do corpo do tambor, podem ser usados vários tipos de tronco de árvore: urucurunzeiro (detanẽ), embaúba ${ }^{451}$, mas esta não é muito boa porque tem uma madeira pesada, são preferíveis madeiras leves, como descreve o trecho da canção do tutu (tututchiga), gravada por Francisco:

Nama, namata

"Com ele, com ele"

\footnotetext{
${ }^{450}$ Sobre a importância de se manter o som constante na Festa, ver Capítulo 5, tópico 5.1.1 - "Ficar no silêncio".

${ }^{451}$ Designação comum às árvores do gên. Cecropia, da fam. das cecropiáceas. Dic. Houaiss.
} 


\section{Ngutchicu, ngutchicune}

"Levinho, levinho"

\section{Tchori tamborinhoma'a}

"Com meu tamborim tutu".

A madeira do tutu de Francisco, quem construiu os trompetes comigo, é da urucurana de terra firme (de 'tane). Segundo me disse, é a melhor para fazer o tamborim. Não é uma árvore oca, portanto, o corpo de madeira do instrumento deve ser cavado no tronco. As beiradas da madeira são lixadas com a língua do pirarucu, para não rasgar o couro, o plástico ou o tecido que é colocado no tamborim. Outras madeiras de que são feitas o corpo do tutu são, a seringarana (ina), súcuba (mayiũ), bauene, sorva (ngetchi), cedro (ocadiva). Francisco conta que todas estas madeiras são boas e a dificuldade na confecção é a mesma. O instrumento pode ser encourado com a pele de diversos animais, entretanto, o melhor couro para o tutu é o da cotia, pois é mais duro, sendo menor o risco dele furar. Mas também podem usar o couro do guariba. O problema desta pele é o trabalho que dá para tirá-la do animal morto. A pele da cotia, além de mais rija, é mais fácil de tirar.

A sistemática de Hornbostel e Sachs (1961[1914]), quase centenária, é ainda uma das mais importantes referências na classificação dos instrumentos. Se formos estabelecer uma classificação rigorosa para este tamborim, seguindo esta sistemática, teríamos a seguinte especificação para o tutu: membranofone tubular ou de corpo menor que o raio da membrana, com alça, percutido diretamente e com apenas uma membrana utilizável. Tal rótulo não diz muita coisa para alguém não familiarizado com classificação de instrumentos musicais. Para ficar mais claro, podemos decompor este nome, o que nos mostra tanto uma possível descrição do instrumento quanto uma visão geral de como funciona este tipo de classificação e do tamborim, em especial. 1) membranofone, pois o que produz o som do instrumento - lembremos que este é o principal critério da classificação de Hornbostel \& Sachs - é a vibração do couro esticado no corpo do instrumento. 2) tubular, este critério não está muito exato em minha classificação, pois muitos (talvez a maioria) dos tamborins ticuna têm a altura do corpo menor que o raio da membrana, digamos, são mais largos na parte da membrana do que um tambor tubular. Neste caso, ele não é considerado tubular e entra o critério de possui alça ou não. 3) Todos os tamborins ticuna são percutidos diretamente com uma baqueta numa mão enquanto a 
outra suspende o instrumento por uma alça. 4) Apesar de ser encourado dos dois lados, apenas um lado do instrumento é percutido.

Algo que ficou fora destas especificações é que os tamboris tutu possuem uma fina corda esticada, junto da pele resposta (a pele oposta a que é percutida), como a esteira de uma caixa clara. Esta corda influi bastante no som do instrumento, ela acaba prolongando o tempo da nota do tamborim. A sensação que temos é de ouvir dois sons, um da membrana que é diretamente percutida pela baqueta e outro - mais contínuo, mas que é acentuado a cada batida - da pele resposta vibrado em contato com a corda ${ }^{452}$.

As pessoas que tocam este tambor não fazem questão de entrar no tempo em que as outras estão percutindo. Não raro, há uma defasagem entre os instrumentos, em outros momentos há sincronia, principalmente nas danças. O tutu, ao que tudo indica, serve para dar um andamento à canção e à dança. Para se cantar mais lento, bate-se mais lento no instrumento, e o contrário para as canções mais ligeiras.

A intensão deste capítulo foi mostrar a rica organologia dos Ticuna e sua importância para a realização da Festa da Moça Nova. Todos os instrumentos musicais aqui apresentados aparecerão em algum momento do ritual que descrevo no capítulo seguinte. Alguns destes instrumentos, como veremos, serão construídos durante a Festa, outros levam tempo para serem feitos e já estão prontos para o ritual. Passemos, enfim, à descrição do mais importante ritual dos índios Ticuna.

\footnotetext{
${ }^{452}$ Discuti no Capítulo 5, tópico 5.1 - Som, algumas possíveis relação entre o uso desta corda no tamborim e a noção ticuna de melodia e ritmo.
} 


\section{Capítulo 7 - A Festa da Moça Nova}

"Pero, en ninguna parte de Sudamérica, las fiestas de pubertad de una joven eran tan primorosas o tan espectaculares como entre los indios Tucunas del alto Amazonas"

Alfred Metraux, 1945: 124.

O modo como a Festa é feita e o que se pensa sobre ela varia um pouco de acordo com o local e a época em que foi feita. Muitas vezes a Festa é bastante simplificada, feita apenas com seus elementos mínimos, que também podem variar. O que apresentarei neste Capítulo é uma liturgia do ritual misturando minhas observações das Festas que etnografei, os comentários dos Ticuna sobre como deve ser e como eram as Festas, e os dados etnográficos de outros pesquisadores que se debruçaram sobre o tema, incluindo etnografias dos Ticuna do Peru e da Colômbia. Como comentei anteriormente, os elementos que existiam apenas "antigamente" têm suas idas e vindas ${ }^{453}$. Daí a importância de se ressaltar os elementos que, apesar de estarem em desuso, permanecem na memória das pessoas como característicos da Festa. Podemos dizer que os Ticuna possuem uma espécie de ethos messiânico. Existem ocasiões em que uma volta à "tradição" é aquecida pelos acontecimentos, especialmente em momentos de crise. Nestas ocasiões o saber ritual que estava hibernando na memória dos velhos vem à tona como uma diretriz para as ações.

Optei por fazer uma descrição que mostra cronologicamente os eventos da Festa, mas muitas vezes persigo alguns objetos do ritual. Podemos resumir a Festa da Moça Nova, grosso modo, em uma mistura de danças, confecção de objetos - o que pode envolver a ação do pajé -, e intervenções no corpo da moça. Como alguns objetos são importantes no ritual e aparecem em diversos momentos, elaborei tópicos que focam

${ }^{453}$ Ver tópico 6.3 - Demais instrumentos musicais, a consideração sobre a variação do uso ritual dos trompetes de bambu (coîri). 
nestes objetos - por exemplo, máscaras, jenipapo, quarto de reclusão, etc. - e mostram o quanto eles costumam aparecer na Festa. Abordemos abaixo, finalmente, o ritual, suas etapas, o processo ritual da Festa da Moça Nova.

\section{1 - Preparativos, menarca e início da reclusão}

Quando estive em meu primeiro trabalho de campo em N. S. de Nazaré - janeiro e fevereiro de 2012 -, um dos compadres de Ondino já estava juntando uma grande quantidade de mandioca para fazer o pajauaru (bebida fermentada) da Festa da filha dele. Ondino disse que a Festa seria provavelmente em julho, ou seja, cerca de 5 meses de antecedência para os preparativos. Além de providenciar uma boa quantidade de bebida fermentada para as pessoas tomarem, o dono da Festa, pai da menina, tem que caçar e pescar bastante, moquear e guardar toda a comida. Antigamente, me contaram, a roça de macaxeira para o pajauaru começava a ser feita depois da primeira menstruação da moça. Isso contribuía para prolongar sua reclusão, que poderia durar anos.

Algo que demora a se fazer para uma Festa é a construção ou reforma de uma

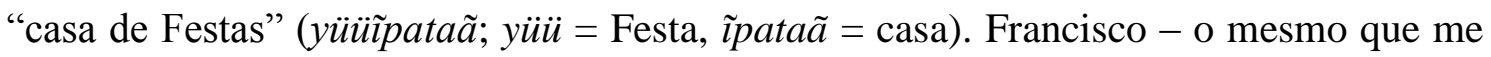
ensinou a construir os trompetes ticuna - foi o responsável por construir a casa de Festas de Nazaré. No entanto, ele não construiu sozinho. Os pais das meninas que estão para menstruar são convidados a ajudar na obra. As comunidades ticuna que fazem o ritual da moça nova possuem, em geral, uma casa especialmente construída para estas festividades. É uma casa feita aos moldes das moradias antigas, mas sem o fechamento nas laterais. A casa de Festas de Porto Lima, p. ex., onde pude acompanhar um ritual, havia sido construída especialmente para aquela Festa. Com duas águas feitas de palha de palmeira caranã (tchuãnecüwã), em formato retangular e toda aberta nas laterais. A casa era toda ladeada de bancos de madeira. O quarto feito de talos de buriti (turi), onde estavam reclusas (aure) as duas moças que estavam sendo iniciadas, ficava numa das laterais mais compridas. Na lateral oposta, estavam penduradas cerca de dez redes onde descansavam alguns convidados. Toda esta parte anexada à casa de Festas, onde estão as redes, o local de reclusão e o cercado dos instrumentos é referida como wipacu. 
"A Lua tem relação [sexual] com a menina, aí ela vai se formar [menstruar pela primeira vez] mesmo", assim me foi explicado como a menina tem sua primeira menstruação. Depois que a moça tem a primeira menstruação (yaacügü), ela tem que ficar "guardada" (aure $e^{454}$ ), escondida. Apesar de Nimuendaju afirmar que nenhuma alimentação específica é prescrita às moças reclusas ${ }^{455}$, o mesmo termo "aure" usado para indicar "reclusão" - seja da moça, de uma pessoa enferma ou da mulher no puerpério pode ser traduzido também como "dietar". "El término dietar, ta aurè, describe el estado de la muchacha púber en reclusión antes de la iniciación. En los textos de los cantos relativos a la pelazón, se dice que ella dieta como el mojojoy o como las larvas, y las crisálidas que están en su cubierta antes de estallar". (Maria Emilia Montes Rodrígues citada em Valenzuela, 2010: 141$)^{456}$.

Nesta fase, a moça não pode ser vista e ninguém pode falar com ela. "A moça não conversa nem com pai, nem com a mãe, nem com ninguém, por que é perigoso", me disse Hilda. A mãe da moça já ensinou a ela como deve se portar depois de sua menarca. "Se a menina menstruou hoje de manhã, ela entrega seu colar [usava-se antigamente] para o irmão mais novo", disse Adélia. O irmão leva o colar para casa e pendura num lugar visível. Ao ver o colar pendurado, a mãe já sabe que a moça está escondida esperando para ser buscada.

\begin{abstract}
"Ela vai embora para o mato e a mãe tem que procurar ela. Nem o pai, nem irmão, nem irmã, ninguém vai saber. Quando a mãe vai atrás, tem que levar tururi $^{457}$ para forrar a moça. Todo mundo tem que correr, correr para ninguém ver. Aí tem que guardar ela escondida. Senão, irmão, irmã, primo, qualquer um vai ver ela. O primo, a onça vai aparecer para ele, é perigoso. Então, quem vai olhar é só a mãe." (Adélia)
\end{abstract}

\footnotetext{
454 Goulard usa uma palavra diferente de aure para se referir à reclusão, mukuchi: "Ela é "fechada" (mukuchi) em um "abrigo fechado", isolada dos outros moradores da casa, com exceção de algumas mulheres, sua mãe e a irmã de seu pai, que cuidam dela durante todo seu período de reclusão" (2002: 113).

${ }^{455}$ A moça nova não recebe nenhuma alimentação especial durante a reclusão: "Nenhuma dieta é prescrita" (Nimuendaju, 1952: 74).

${ }^{456}$ Segundo Valenzuela, a moça deve comer somente sardinha. "Me contó que la muchacha para hacer una "dieta de verdad, debe comer sólo sardina, para que así ni el diablo ni el tigre le digan nada, es como una protección cuando uno va al monte, en Brasil si sucede, eso que comen gente"." (2010: 148).

${ }^{457}$ Casca de árvore de que são feitas as máscaras da Festa.
} 
A mãe que vem tocando aru e tutu e levam ela para o quarto. Lorenzo, experiente "copeiro" de Belém do Solimões, me contou que a mãe deve procurar uma cantora para buscar a moça. "O pai ou a mãe devem procurar a velha que mais sabe cantar para cantar para a menina. A velha, ou um cantor, chega até a menina tocando aru (avaí), dançando e cantando. Cantando e tocando, o(a) velho(a) leva a menina para a casa dela”. Ela passa a noite no quarto sem falar com ninguém.

Na manhã seguinte, cedo, ela vai jogando uma praga no taperebazeiro (yomeru), dizendo, "tchoruuwanãamãnado'ãẽ ("meus inimigos que tem a alma fraca, que morram antes de mim"). Se não tem árvore de taperebá, ela pode jogar a praga na pupunheira (ĩtu). Pelo que especulei com meus colaboradores a moça nova tem um forte poder de rogar pragas, mas também pode ser praguejada. Francisco cantou para mim uma canção que parece inverter isso, chamada "música que jogaram praga na moça nova" (worecü ngimatagu tchigacü).

De acordo com o relato da narradora da história "Como se cuida da moça nova" (Firmino \& Gruber, 2010, vol.3), Romualda Joaquim Costódio Ücürana, traduzida por Ondino e por mim,

\footnotetext{
"a moça está em proibição [natchuuma] porque ela sente que tem um imortal / encantado [ü'üne] dentro dela. A partir do momento em que ela está "guardada", ela fica com ü'üne dentro dela. Só o irmão, o pai e o tio [nepü-FB] que podem ver ela, porque não tem vingança para eles. As pessoas que não são do clã dela e que são boas para ela casar, não podem ver ela. Se aparecer algum, ela tem que se esconder. Caso algum deles insista em ver, aparece vingança para ele. Se eles vão para algum lugar e viram a moça nova, a onça aparece para eles. Por isso que não é bom ter vontade [ngutchaũ] de ver a moça nova. Deixa ela lá, a vontade de ver a moça nova não serve para nada.".
}

A fala da narradora nos mostra um pouco da condição da moça que está na reclusão. Ela tem um imortal dentro dela. Explorarei melhor esta condição mais adiante. Por hora, basta ressaltar este estado ambíguo da moça, ela é mortal e imortal ao mesmo tempo enquanto está em reclusão. Este estado dúbio é uma das fontes de seu perigo. Algumas posições de parentesco mencionadas acima, imunes à vingança pelo simples fato de terem este parentesco com a moça nova, diferem também de outros relatos que ouvi. Na fala de Adélia e de outras pessoas, apenas a mãe ou uma tia mais velha tem acesso à moça. Por um lado, dentre as pessoas que podem ver a moça, Romualda, na fala 
acima, destaca "o irmão, o pai e o tio (nepü - FB)". Por outro lado, as pessoas que a narradora destaca como sendo proibidas de ver a moça são "boas para ela casar", ou seja, pertencentes à metade oposta à dela. O risco de estas pessoas verem a moça é eles serem vingados. Ondino me contou que a vingança que acontece é a pessoa ficar panema ou a onça ir atrás quando a pessoa for para a roça. Dentro do curral só entra quem é da mesma nação da moça nova, isso até hoje é assim.

Uma pessoa de central importância na Festa são os copeiros (ünãücü / baecü), que também tem acesso permitido à moça e não fogem à regra de serem do mesmo clã dela. Os tios paternos (FB e FZ), que pertencem ao mesmo clã da moça, são frequentemente incumbidos de serem os copeiros da Festa ${ }^{458}$. Gruber descreve esta figura desta maneira:
"Os tios paternos desempenham importante papel na festa, üa ̃̈̈сü, devendo realizar e coordenar os trabalhos que não podem ser cumpridos pelos pais das crianças e das moças. Como a festa costuma ser feita para mais de uma moça, em conjunto com as crianças, cabem aos tios paternos atribuições especificas, mas um deles, geralmente o tio de uma das jovens, assume uma posição de destaque, fazendo uma espécie de coordenação geral do evento.” (1999: 4-5).

Neste trecho a autora ressalta a posição de parentesco dos "copeiros", tio paterno. Com esta posição de parentesco, o "copeiro" necessariamente será do clã da moça, já que a descendência clânica é patrilinear. Contudo, a especificação que coletei em campo diz apenas que o "copeiro" deve ser do mesmo clã da menina iniciada. De qualquer maneira, dá-se preferência ao tio paterno como "copeiro".

458 “O principal üaũ̃ü é, preferencialmente, o irmão do dono da festa.” (Gruber, 1999: 11, nota 10). 

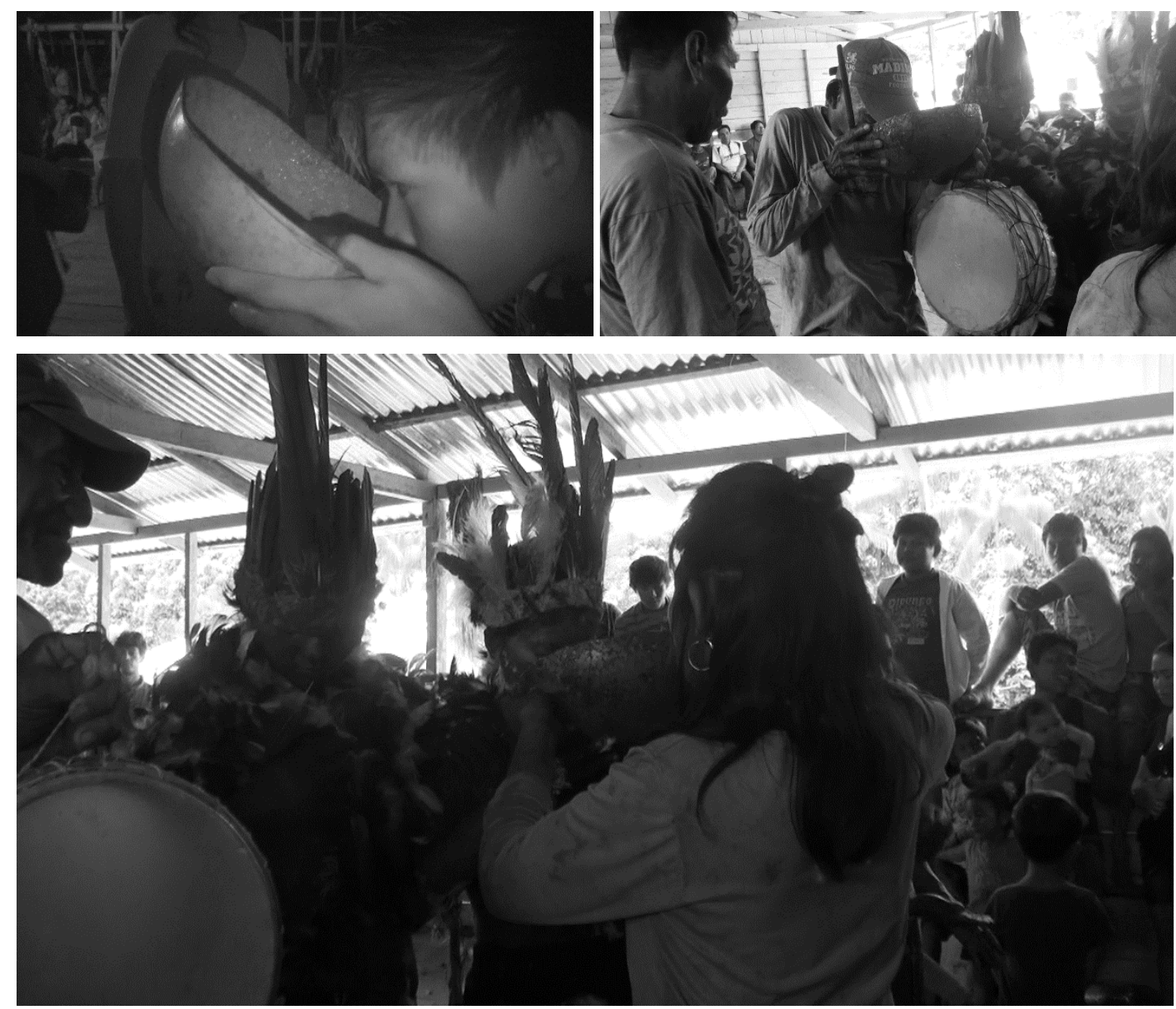

Figuras 38, 39, 40 - Bebendo pajauaru

Este mestre de cerimônias deverá ficar acordado durante todo o ritual, cuidando para que todos bebam pajauaru. Daí o fato de os Ticuna traduzirem esta posição dentro da Festa como "copeiro", ele serve as pessoas de bebida fermentada, especialmente as que acabam de chegar à Festa. A grande cuia é entregue a uma pessoa, que pode tomar todo o conteúdo de uma vez ou entregar o restante para alguém que está do lado tomar. A cuia é passada de mão em mão pelas pessoas que estão sentadas nos bancos laterais da casa. O "copeiro" vai acompanhando o trajeto da cuia e as pessoas vão bebendo à vontade. Quando a cuia se esvazia ele pega de volta e leva para encher de novo. No calor da Festa, principalmente nos intervalos das danças, as rodadas de bebida são constantes, todos bebem à vontade. A "copeira" de Deulene - moça que acabara de ser iniciada quando cheguei para meu $2^{\circ}$ trabalho de campo em Nazaré - foi a irmã do pai de Laelsio (FFZ). Ou seja, a "copeira” é do clã de avaí, mesmo clã da menina, se a copeira tivesse marido, ele seria "copeiro" também junto com ela. 
Durante sua reclusão, a menina deve fabricar um rolo de corda de tucum $($ nãpatchicu - nãpa $=$ rede de dormir / tchicu $=$ rolo) para presentear o "copeiro", é o seu "pagamento" 459 . Na segunda Festa de que participei em Vendaval, o "copeiro" ostentava um rolo de tucum torcido pendurado no pescoço. Muito provavelmente foi um presente que ele ganhou do dono da Festa e da moça. O "copeiro" fazia questão de mostrar o presente que recebeu por coordenar toda aquela Festa. Adélia me contou que a única tarefa da moça reclusa é tecer o tucum:

"A [Festa] da minha mãe demorou um ano e seis meses, quase dois anos [para ficar pronta]. Ela ficou guardada, ninguém via, só tecendo tucum. A moça tem que tecer. Só isso daí que é o trabalho dela"

O tucum é uma palmeira espinhenta que dá um coquinho pequeno cheio de água. Sua carne endurece com o tempo, mas é comestível enquanto não amadureceu completamente. Para preparar a corda feita da fibra do tucum, retira-se um talo de folha de tucum ainda no olho (nãitchaca natchacu). Ele é desfiado e tira-se apenas a parte de dentro das tiras (ñ̃̃). Esta parte é posta na água de um dia para o outro. No dia seguinte é posto para secar ao sol. Depois de um ou dois dias secando, está pronto para ser torcido esfregando as tiras secas na coxa da perna.

Uma das funções da reclusão é fazer com que a neófita aprenda os atributos de uma "moça prendada". O trançado é um atributo feminino fundamental. Ao menos era antigamente e, em algumas comunidades, isto ainda se mantém. Notemos que, quando o informante de Valenzuela fala sobre este aprendizado, isso contribuirá para que ela seja uma boa esposa, "quando ela conseguir um marido, já saberá tudo":

"porque antiguamente la niña que está recién de menstruación tiene que aprender, tejer canasto, la mochila durante toda esa época la mamá tiene que enseñar canasto, tipití, cuando ya hacen pelazón ella tiene que saber ya todo, cuando ella

\footnotetext{
${ }^{459}$ Não notei isto em nenhuma das Festa que observei, mas, de acordo com Ondino, depois da pintura de jenipapo, no meio da Festa, a neófita senta-se no rolo de tucum. Nimuendaju também confirma esta informação: "em duas ocasiões, quando estava presente a worecü estava sobre uma grande e achatada bola de fibras de tucum, que seu tio removeu no final da cerimônia. Ela tinha feito esses fios durante o período de sua reclusão, para provar que ela seria uma menina trabalhadora e em gratidão a seu tio por todo o seu cuidado com ela." (1952: 86).
} 
va conseguir su marido ya sabe de todo, en antiguo si un muchacho le canta bien, bien con ella dizque le entrega, ya se casa" (2010: 70).

Antigamente, a reclusão durava cerca de um ano. $\mathrm{O}$ quarto de reclusão era construído bem antes da Festa para a moça ficar "guardada" lá dentro. "Quando faltavam três, quatro meses já faziam o curral [quarto de reclusão] e a moça ficava morando lá. Não é como agora que fazem o curral junto com a festa, não era assim" ${ }^{460}$. Atualmente, uma moça que fique reclusa alguns meses pode-se dizer que ficou bastante tempo. Em geral, ela fica dentro da casa dos pais. O quarto é construído no dia da Festa e ela é trazida para dentro da reclusão toda coberta, para se esconder dos olhares das pessoas ${ }^{461}$.

\section{2 - Convite e troca ritual}

Vimos no Capítulo 6, tópico 6.2 - Aerofones, que, antigamente, usava-se o iburi (trompete de casca enrolada) para convidar as pessoas para a Festa. O instrumento era levado no barco do dono da festa até as outras comunidades. Quando chegavam próximo à comunidade da pessoa a ser convidada, começavam a tocar o aricano. As pessoas ouviam de longe o pessoal chegando no barco. Isso era feito para que os convidados escondessem o tururi, usado na confecção das máscaras, pois o dono da Festa não pode vê-lo. Ele tem que levar um jenipapo para cada casa de convidado que ele visita. Nimuendaju nos oferece uma boa descrição de como era feito o "convite definitivo" com o iburi:

"Em geral, os convites definitivos são dados na véspera das festividades, geralmente simultaneamente por mensageiros em duas canoas, uma indo rio

\footnotetext{
460 Trecho da história de "Como se cuida da moça nova" (Nhuũũãcü worecüma icufaũu, Firmino \& Gruber, 2010, vol. 3), traduzida com Ondino.

461 Van Gennep nos mostra um exemplo ameríndio de construção de cabana de isolamento entre os Ogibwa. "Da mesma maneira os Ogibwa (como muitos outros semicivilizados) construíam cabanas especiais de formas diferentes para cada atividade especializada e em cada nova ocasião, cabana que só servia uma vez, sendo em seguida abandonada. A cabana servia para conselho de guerra, conselho de paz, banquete de festa, cura de um doente, isolamento de um xamã, um adivinho, uma mulher grávida, uma criança que ia ser iniciada, etc. Cf. KOHL, Kitschi Gami. Brema, 1859, t.I, p.60" (2011[1909]: 67, nota 24).
} 
acima, outra rio abaixo. Cada homem carrega um grande trompete de casca, iburi (ver p. 42), coberto com folhas de bananeira para escondê-lo dos olhares de mulheres e crianças quando a canoa chega à margem. Soprando esse instrumento, cujo som pode ser ouvido de longe, os mensageiros viajam de uma casa para outra, contando ao proprietário o dia e a hora exatos (por posição do sol) quando a cerimônia começará, e verificando a potencial presença ou ausência do convidado." (1952: 76).

Segundo Lorenzo, ticuna de Belém do Solimões, o iburi também acompanha a caçada que é feita para juntar o moqueado para a Festa:

\begin{abstract}
"Depois que o pajauaru está pronto, o dono da Festa diz assim, "vamos caçar", procurando as pessoas que vão com ele. Passam duas semanas caçando e pescando. Na caçada levam também o iburi. Tem que levar também, antigamente era assim. Na canoa já iam soprando. As pessoas já estavam sabendo. Para onde for caçar, vai soprando o iburi na canoa. Passados três dias, três semanas, às vezes um mês, a gente volta de lá. O responsável ("copeiro") pela Festa já sabe o dia em que o dono da Festa vai voltar. Quando voltam da caçada vêm soprando o iburi também. As pessoas que estão esperando ouvem o iburi e comentam, "lá vem o dono da Festa". Nisso, o responsável já está esperando lá no porto, para receber as pessoas que chegam da caçada. $\mathrm{O}$ responsável e a turma dele esperam as pessoas tocando tamborim. O responsável leva o moqueado para a casa da moça nova. Tem que procurar lenha para esquentar o moqueado quase todo o tempo, todo dia. Nunca pode faltar lenha debaixo do moqueado, para secar bem"
\end{abstract}

Apesar de Nimuendaju relatar que "[u]m Tukuna raramente se atreverá a vir sem ser convidado" (1952: 75-76), Ondino me mostrou um outro ponto de vista. Em tom de brincadeira, ele disse que Ticuna é igual formiga, "nem precisa convidar que eles aparecem. Se chamamos 20, aparecem 40". Ao ser convidada a pessoa recebe uma sugestão do que levar e confirma que levará tal presente para a Festa. Com relação a vir sem ser convidado, Ondino me contou que isso acontece, existe inclusive termos distintos para designar a pessoa que foi convidada e a que não foi, mas veio para a Festa. Gunegü, ao contrário do aetanü, é o festeiro desconhecido, que não foi convidado. No trecho da canção que fala sobre o quarto de reclusão da moça nova (turitchiga), o cantor interpela os dois tipos de festeiro, o não convidado ou não conhecido (gunegü) e o convidado ou conhecido (aetanü): 


\section{Aetanü, aetanücü}

"Festeiro conhecido"

Pa gunegü, gunegü\} 2X

"Festeiro desconhecido"

De acordo com Ondino, atualmente, para se convidar uma determinada comunidade não se pode mandar recado. $\mathrm{O}$ dono da Festa deve ir pessoalmente fazer o convite, mais ou menos uma semana antes dos festejos. Os itens que serão pedidos pelo anfitrião aos seus convidados não podem ser pronunciados pelo dono da Festa. Deste modo, existem recursos linguísticos usados para não falar diretamente o que se está pedindo. Ao chegar na comunidade o dono diz para os convidados, por exemplo, "costura sua roupa velha". Deste modo, o convidado já sabe que tem que levar tururi para a Festa. O anfitrião usa este recurso, porque falar a palavra "tururi" pode deixar o dono da Festa doente. Ele pode ficar enfeitiçado e não haveria modo de curá-lo. Se ele olhar para o tururi estará correndo risco de vida e caso o dono da Festa pronuncie os nomes das dádivas que os convidados trarão para o ritual, a máscara grudará em seu portador e ele se tornará o personagem da máscara ${ }^{462}$.

O mesmo acontece com o antigo bastão de dança $(d u$ 'pa) e com as fibras de tucum. No momento do convite o dono da Festa não pode pronunciar o nome destes itens. "Quando faz o primeiro convite, o dono da Festa costuma recomendar aos homens que levem os bastões. No entanto, não lhe é permitido pronunciar a palavra $d u$ 'pa, pedindo apenas para confeccionarem o naitchipane (“pau fino")." (Gruber, 1999: 11). Pronunciar a palavra "tucum" (naĩ) no momento do convite também pode ser perigoso. "Quando faz a encomenda, o dono não pode usar a palavra tucum, naĩ, mas outras, como towae ["uma dança para as crianças"] ou tarumaa (fibras).” (idem: 12).

Outra forma de chamar os convidados é dizer "você tem que tirar taperebá para mim”. A referência ao taperebá (Spondias mombin) é devido a sua força. Quando esta árvore cai, logo nasce de novo. A incumbência de procurar o taperebá que será usado na festa é do "copeiro". O taperebá é usado para fazer o bastão de ritmo ( $a r u)$ e para a moça nova segurar enquanto estiver dentro do quarto de reclusão. Na última noite da Festa ela

\footnotetext{
462 "Se o dono desrespeitar essas normas, a entrecasca ficara grudada na pele do usuário da vestimenta, transformando-o para sempre no sobrenatural que ela representa." (Gruber, 1999: 39).
} 
não pode dormir na reclusão, um dos recursos para isso é o galho de taperebá que fica atravessado no quarto de reclusão, para a moça ficar com os braços para cima, segurando no galho.

O "copeiro" é a pessoa responsável por receber os convidados ainda no porto da comunidade. Especialmente se a casa de Festas, como acontece muito, está localizada próxima à margem do rio. Não presenciei este tipo de acolhida dos convidados pelo "copeiro" nas Festas das quais tomei parte. Em geral, estes mestres de cerimônia estão bastante atarefados com os preparativos da Festa e as sequências de atividades que compõem o ritual e acabam não buscando quem está chegando. Lourenço, contudo, descreveu para mim a recepção dos convidados, que trazem suas dádivas para a Festa:

"Então o copeiro da Festa vai receber os convidados no porto, com o tamborim [tutu]. Quem tiver hamaqueira [rede] pode ir colocando na casa, enfileirando. Logo que chegam, o copeiro leva o pessoal para tomar pajauaru, primeiro caldo [de pajauaru], depois pajauaru. Pessoa que trouxer tambor pode dançar, pode bater tambor. Quando chegam os convidados, eles podem ser recebidos com o tracajá. Depois da 18 hs já pode tocar o tracajá."

Os rituais atualmente duram cerca de três dias. Começam no início da noite da sexta-feira e terminam no domingo no início da tarde, podendo se estender um pouco mais pela tarde. Na noite de sexta-feira, pude ver isso acontecendo em duas Festas, há uma dança feita para as crianças. Gruber também notou que no início das Festas os Ticuna fazem uma "dança para as crianças" (towae). A autora descreve a dança enfatizando os adornos de tucum usados na dança, o que presenciei em outros momentos do ritual:

"Há uma outra dança que também pode ser realizada no início da festa, a qual nunca tive oportunidade de assistir, pois em Belém [do Solimões] raramente ocorre. Trata-se do towae, uma dança para as crianças, em que os participantes carregam fibras de tucum, ainda verdes, que trazem para a festa por sugestão do dono (...). Os homens costumam transportar as fibras com as pontas amarradas em uma das extremidades do bastão ou numa simples varinha, ao passo que as mulheres as trazem ao redor do pescoço. Para dançar, o tucum é colocado sobre os ombros, com as pontas jogadas para trás, formando uma espécie de manto. A dança é sempre acompanhada dos tamborins. O tambor de carapaça de tracajá só participará se houver crianças da metade "de penas". Ao final da dança, os participantes entregam o tucum para o dono da festa, 
que fica com uma parte e distribui a outra para os üa $\tilde{u} c \ddot{u}$ [“copeiro”].” (1999:

12).

A "dança para as crianças" abre a festividade. Neste momento, em geral, estão presente as pessoas da comunidade. Os convidados de fora chegarão ao longo do dia seguinte, no sábado, quando acontece a noite principal da Festa. $\mathrm{O}$ final do trecho de Gruber, acima, aponta o que quero destacar agora, as dádivas entregues pelos convidados para o anfitrião. O convite formal é feito principalmente para as pessoas que serão encarregadas de trazer alguma coisa para a Festa. Identifiquei ao menos três dádivas que são trazidas pelos convidados: talos de buriti, fibras de tucum e tururi. As dádivas são especificadas pelo dono(a) da Festa no momento em que ele faz o convite. Assim, o convidado já sabe o que levará para a Festa e não há excesso ou escassez dos materiais necessários.
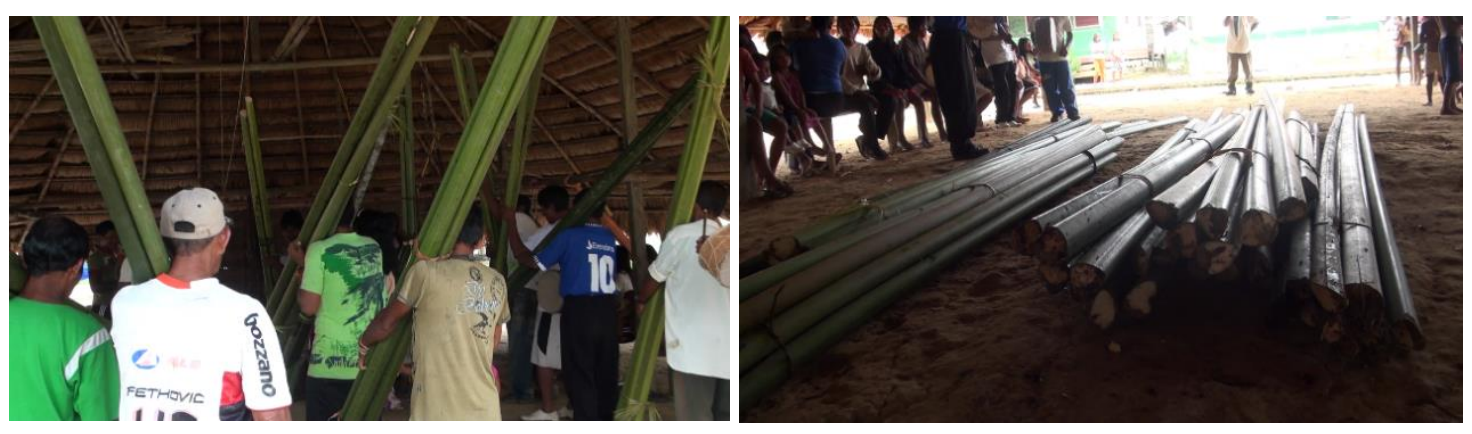

Figuras 41 e 42 Talos de buriti trazidos pelos convidados

Nas duas Festas de Vendaval, me deram um talo de buriti para eu entrar na casa. Talvez porque seja muito estranho oferecerem tanta bebida para alguém que não trouxe nada para a Festa ou não sabe ajudar em nada dos preparativos. A troca ritual ticuna é feita entre, da parte dos anfitriões, as bebidas e a carne moqueada e, da parte dos convidados e mascarados, os materiais para a fabricação de adornos: tucum, talo de buriti e tururi. Além disso, ao que tudo indica, esta troca acontece em dois planos durante a Festa. Chamemos, apenas para fins de análise, um deles de "plano sociológico", a troca entre convidados e anfitriões; e o outros seria o "plano cosmológico", a troca entre o dono da Festa e os mascarados.

Este tipo de troca que acontece entre a bebida e alguma coisa (carne, p. ex., para os Caribe) é bastante recorrente entre os ameríndios. Para os ameríndios, de um modo geral, a carne moqueada cumpre um importante papel como dádiva doada pelo grupo que 
vem para a Festa em troca das bebidas que o grupo anfitrião proverá. De acordo com Viveiros de Castro (1986), a oposição complementar entre a carne, trazida pelos convidados, e a bebida, oferecida pelos donos da festa, é difundida por todo continente. Tal troca conformaria a "armadura simbólica das relações" ou o próprio "arcabouço dos ritos" (Teixera-Pinto, 1997:350). No caso das trocas rituais Arara, Teixera-Pinto conclui que a "caça é a condição da bebida, como a predação é a da troca" (idem: 365, nota 27).

Em meu livro sobre o ritual de iniciação masculina dos Waimiri-Atroari, desenvolvi a hipótese de que este tipo de troca pode ser "mais um "tema geral Caribe", como o sublinhado por Rivière, do qual tratamos no cap. II: doadores de cônjuges são superiores aos tomadores, a carne doada pelos convidados é a "condição real" do ritual Arara (Teixeira-Pinto, 1997:383), "dá-se bebida e faz-se o rito em nome da oferta de carne, jamais o inverso" (Teixeira- Pinto, 1997: 365).” (Matarezio Filho, 2014[2010]: 136). Este tipo de troca ritual é bastante comum entre os povos de língua Caribe. Para os Waimiri-Atroari, também não é diferente. Um informante assim relata a importância desta troca: "Nós levamos a carne e o pessoal tem que dar o mingau..." (Do Vale, 2002: 70). Neste caso, existem inclusive evidências linguísticas de que carne e bebida são dons recíprocos por excelência: “... sabemos, por exemplo, que um mesmo verbo é utilizado para designar o ato de colher plantas e o ato de flechar (pykwase), o que estabelece a matéria-prima da carne moqueada e das bebidas como fruto de uma mesma ação, como que dons recíprocos por excelência.” (Matarezio Filho, 2014: 136).

Retomando o exemplo dos índios Arara, em seus rituais de Ieipari, os visitantesmutuns, doadores de carne moqueada, esperam ser "atraídos" pelo canto dos anfitriõesguariba, doadores de bebida fermentada. "A eles é servido o piktu, a bebida fermentada, para que não retornem e comam toda caça moqueada no acampamento, como os porcos do mito ([Teixeira-Pinto, 1997] idem: 370-1). Ou seja, o oferecimento ritual de bebida na chegada evoca a humanidade dos Arara em contraste com a animalidade dos porcos." (Matarezio Filho, 2014[2010]: 136-137). Neste sentido, a consequência de não oferecer bebida aos convidados é eles comerem toda a caça, não trazerem ela em troca da bebida. A intensão é que os convidados fiquem, que se tornem parceiros rituais ${ }^{463}$.

\footnotetext{
463 “Henley (2001: 198- 199) também fala de uma conciliação gradual com os convidados "invasores" na iniciação masculina dos Panare, povo caribe-guianense. A entrada se dá, resumidamente, da seguinte maneira. Um toque em um chifre de vaca informa os convidados de outro grupo local (panakon), acampados ao lado, que a dança recomeçará. Afirma um panare, com ironia, que os convidados estão realmente zangados, agressivos. Inicia-se uma dança exclusivamente masculina, chamada panakon tchan, literalmente "os visitantes estão chegando". O canto evoca o nome de uma mosca atraída pelo cheiro da
} 
Com relação à Festa da Moça Nova dos Ticuna, podemos interpretar o fato de os mascarados receberem carne moqueada e bebida do mesmo modo que Teixeira-Pinto interpreta as trocas entre convidados e anfitriões para os Arara. Ou seja, o oferecimento de bebida aplaca o investimento violento dos convidados. Contudo, se isso se dá entre os convidados humanos para, por exemplo, os Arara, Waimiri-Atroari e Panare - apenas para mencionar alguns grupos Caribe ${ }^{464}$-, a relação violenta para os Ticuna vem da parte de outros seres nocivos do cosmos, personificados nas figuras dos mascarados. Em se tratando destes últimos, a intensão é inversa ao que acontece no ritual dos Arara, os anfitriões querem que eles vão embora e não causem problemas na Festa. Provavelmente, se não recebesse bebida e carne, o mascarado seria bem-sucedido em sua intenção de invadir a reclusão da moça e molestá-la, mas, logo que recebe a carne e bebe pajauaru, ele vai embora satisfeito. Em outro momento o dono da Festa receberá como "pagamento" o tururi da máscara.

cerveja. Os visitantes arrombam a entrada da casa ruidosamente, portando galhos e com o rosto pintado de modo bizarro. Fazem uma gritaria e se comportam como se fossem atacar os dançarinos, que continuam cantando como se nada estivesse acontecendo. Tendo falhado em sua intervenção, os panakon deixam a casa. Terminada a dança, os convidados tomam uma bronca. Aos poucos o dialogo se torna mais conciliatório: "Instead of encouraging them to leave, the hosts are now trying to persuade the panakon to dress the initiands in their new loincloths (...) After an extended show of reluctance, the panakon eventually agree"(idem:199)." (Matarezio Filho, 2014[2010]: 133).

464 Para outros exemplos de oferecimento de bebida para convidados que chegam como "inimigos" no ritual, ver Matarezio Filho 2014[2010]: 129-138, especialmente a nota 7 da pg. 132. Além de mais um exemplo caribe, os Caribe do Suriname (Roth, 1925: 474), apresento dois exemplos Tupi, os Cinta Larga (Dal Poz, 1991) e os Nhambkwara (Lévi-Strauss, 1976 [1949]: 107). 


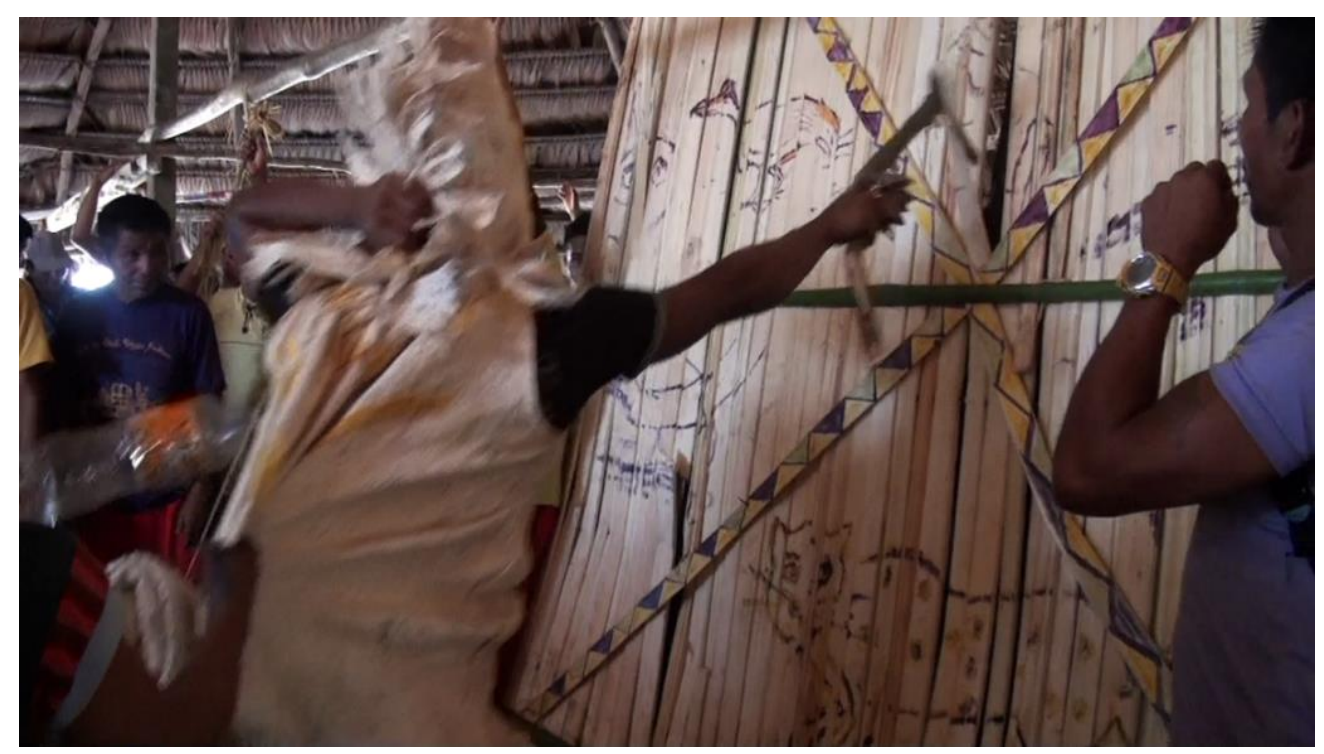

Figura 43 - Mascarado atacando a reclusão das moças

A interpretação de Goulard sobre esta troca com os mascarados vai no mesmo sentido, aplacar o perigo predatório das máscaras:

"El producto de la caza se inscribe en este intercambio. Se ofrece un trozo de carne ahumada a los que se han presentado con máscaras. Después de un largo ahumado realizado por los hombres, esta carne animal ha sido liberada de su sangre: de roja se ha vuelto negra. Notemos que los animales que la proporcionan a los humanos son representaciones de sus 'padres' que son honrados a través de las máscaras y regados con masato. Entonces, la mediación asegurada por el intercambio de carne ahumada con masato podría ser una respuesta equilibrada para neutralizar una posible devoración, para neutralizar su predación. La carne, puede ser ofrecida ya que las entidades, por intermedio de las máscaras, han tomado suficiente masato; de esta manera son compensados, en vez de la carne humana. La ofrenda regular de esta bebida al mundo 'invisible' se hace explícita en el ritual, como objeto de un intercambio exacerbado para el porvenir de la sociedad" (2009: 175).

O trecho acima ainda nos apresenta o importante dado de que algumas máscaras são os "pais" dos animais. Não diria que todas elas, algumas são, como veremos, "pai" do vento (Õma) ou "mãe" da mata (Mawü). Nos rituais que presenciei, o oferecimento de bebida para os "pais" dos animais fica evidente no benzimento dos trompetes de bambu (coĩri), em que o "pai” dos queixadas é atraído para beber seu "pajauaru” na Festa. 

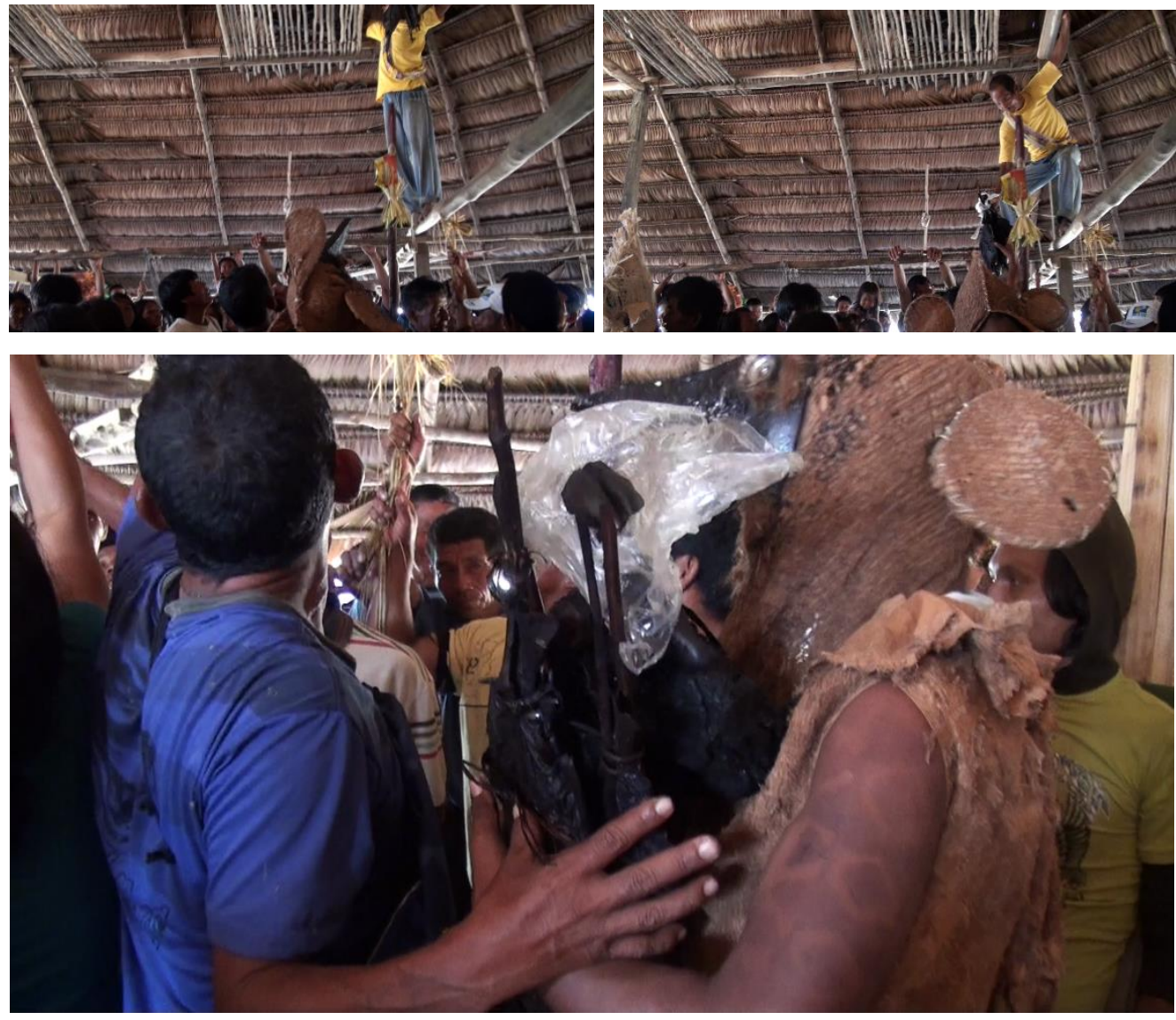

Figura 44, 45, 46 - Retirando a carne moqueada do jirau para entregar aos mascarados

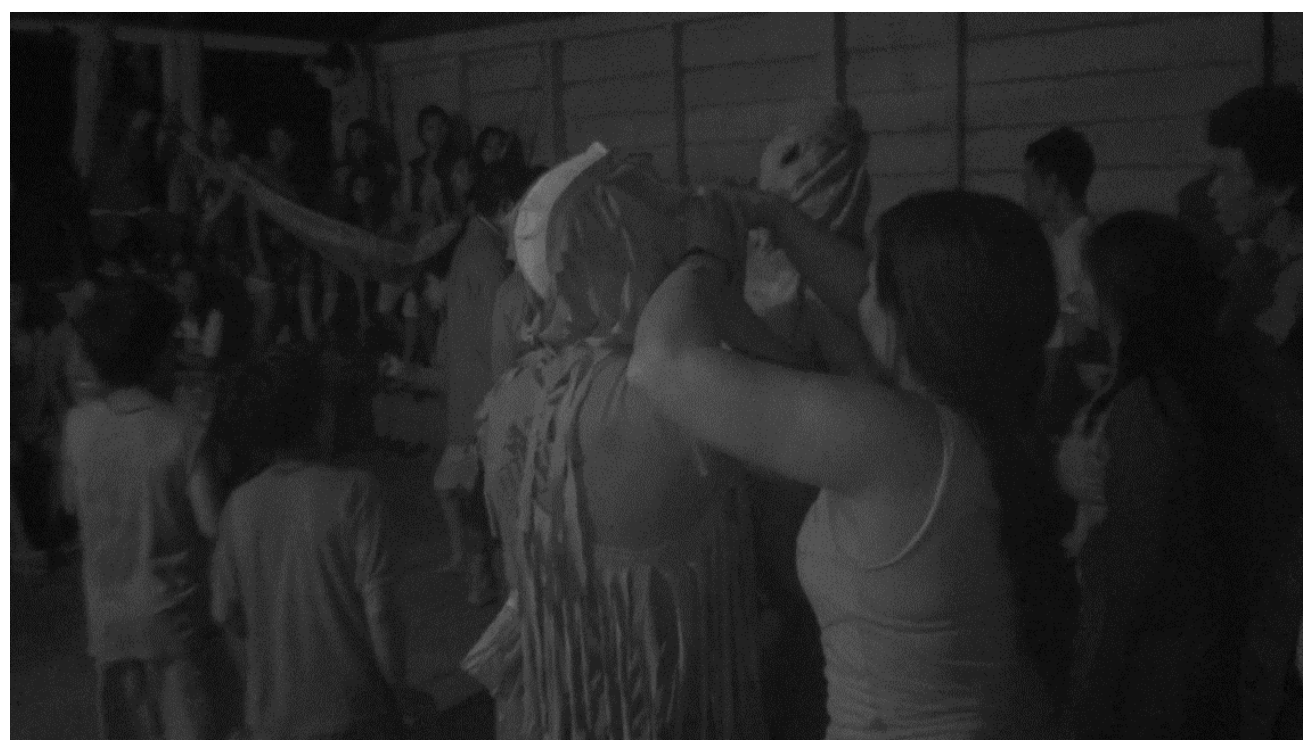

Figura 47 - Mascarado recebendo bebida de madrugada

Apesar de haver uma troca comum, entre convidados e anfitriões nos rituais ameríndios, há uma diferença fundamental na troca ritual ticuna. Diferente dos índios de língua tupi ou caribe, que trocam bebidas por carne, os ticuna trocam bebidas e carne 
moqueada por máscaras, fibra de tucum e talos de buriti. Ou seja, a oposição encontrada aqui é entre bebida/carne $\mathrm{X}$ adornos, algo já notado por Lévi-Strauss ao mostrar que os mitos do desaninhador de pássaros, ao passar para a América do Norte, ao invés de narrar a origem da carne, descreve a origem dos adornos. Mostrei, no Capítulo 2, tópico $2.1-A$ passagem para a América do Norte, alguns dos percursos operados pela mitologia ticuna ao passarmos para os mitos da América do Norte.

Devemos levar em conta, além do fato de Ipi "desaninhar" uma fruta, o fato de esta fruta, apesar de comestível, ser importante na pintura dos corpos. A principal referência ao jenipapo é à informação de que ele é a base de uma tintura para se pintar o corpo de negro, principalmente a moça nova em sua Festa. Isto é, estamos no plano de algo mais próximo dos adornos do que dos alimentos. A passagem do mito de origem registrado por Goulard (2009: 396) também atesta isso ao mostrar os gêmeos depenando águias no ninho e jogado para suas irmãs. Isso dá origem aos adornos de pena. Isso se conecta com o tipo de troca que acontece na festa da moça nova, bebidas/carnes trocadas por adornos.

Com relação ao "plano sociológico" da troca, Nimuendaju descreve a chegada dos convidados para a Festa. Assim como me contou Lorenzo, de Belém do Solimões, de acordo com Nimuendaju, alguns convidados são recebidos no porto com o dono da Festa tocando tambor e outros parentes percutindo o aru no chão. "Os convidados vão até a casa, com longas fibras de tucum arrastando para baixo atrás das suas costas." (1952: 85). Presenciei este tipo de chegada dos convidados na casa. Ao chegarem na Festa, eles recebem imediatamente uma boa porção de bebida e iniciam uma dança com as fibras de tucum que trouxeram. Em seguida, o "copeiro" se encarrega de guardar os presentes. Após uma Festa de Moça Nova, é comum ver os donos(as) da Festa colocando suas fibras de tucum para secar ao sol. Fazem isso durante dias. A fibra (nã̃) do tucum (nã̃ne) é utilizada para tecer a hamaqueira, bolsa (ngeri), braçadeira da moça nova (petchina tchacüï), tornozeleira da moça nova (pena), pulseira, colar, as cordas do tamborim tutu, etc. Antigamente era usada também como corda do anzol, do arpão. 


\section{3 - Bebida, o pajauaru}

O naturalista inglês Henry Walter Bates, que permaneceu um período no médio Rio Solimões, destacou o gosto dos Ticuna por suas bebidas. "Os Tucuna se entregam às danças semi-religiosas e às bebedeiras rituais - comuns às tribos sedentárias do Amazonas - com muito mais desregramento que a maioria das outras tribos" (1975: 293). Após chegar de Liverpool no Pará em 1848, Bates passa uma temporada de quatro anos e meio em Tefé, no médio Rio Solimões, área com marcante presença ticuna. O desenho que consta no seu livro Um Naturalista no Rio Amazonas, publicado pela primeira vez em 1863, mostra claramente o que se considera atualmente uma Festa da Moça Nova:

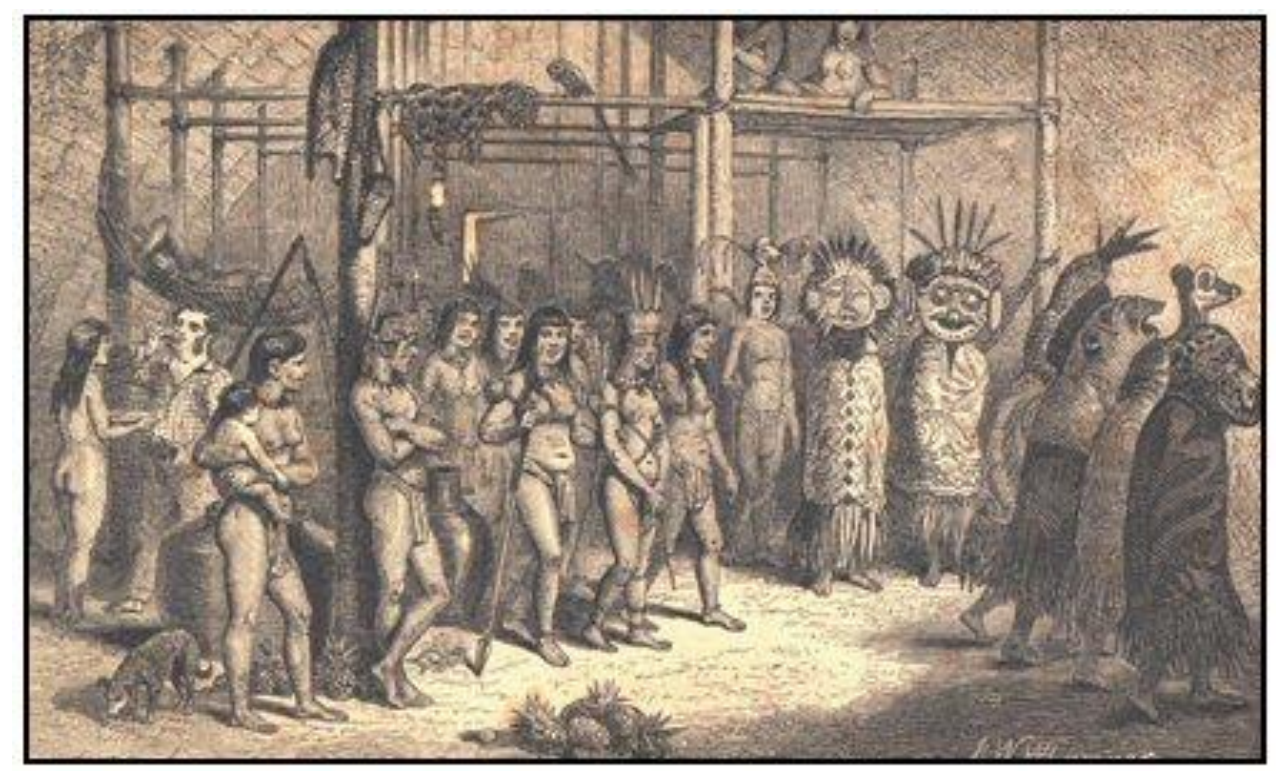

Figura 48 - Gravura retirada do livro Um Naturalista no Rio Amazonas de Henry Bates

Nimuendaju comenta a confusão do naturalista inglês, pensando tratar-se de um casamento. "Bates (1857-1858), dá uma descrição, com uma ilustração de uma cerimônia com máscaras que ele testemunhou perto de São Paulo de Olivença. Obviamente que diz respeito ao fim de uma cerimônia de puberdade, que o autor considerava ser um casamento" (1952: 10).

Ao longo das Festas que participei, o pajauaru foi fartamente distribuído para todos, velhos, adultos e jovens. Mesmo as crianças tomam um pouco da bebida. Logo que a menina menstrua, até mesmo antes, começa-se a preparar o pajauaru. Durante este tempo ela fica reclusa (aure) no quarto, até que os preparativos para a Festa estejam 
encaminhados. A farinha para preparar o pajauaru tem que ficar bem sequinha, mais que a farinha de comer. Para fazer o pajauaru não pode colocar a macaxeira de molho, como é costume para fazer farinha. Se colocar a macaxeira de molho, a farinha apodrece e não fermenta. A massa da bebida é feita apenas ralando a macaxeira, torrando no forno e guardando num paneiro coberto por folhas. A massa é embrulhada em folhas de bananeira junto com folhas de maniva, "para adoçar". Depois deste processo, a massa é colocada dentro da igaçaba ${ }^{465}$ - um grande pote de boca estreita - para fermentar. Fica fermentando por cerca de um mês, dois meses. Quando chega o dia da Festa, ela é coada na peneira dissolvendo-se na água. Este processo é feito pelas mulheres na manhã de sábado ${ }^{466}$. Deste modo, os que forem chegando e quiserem beber já terão a bebida à disposição.
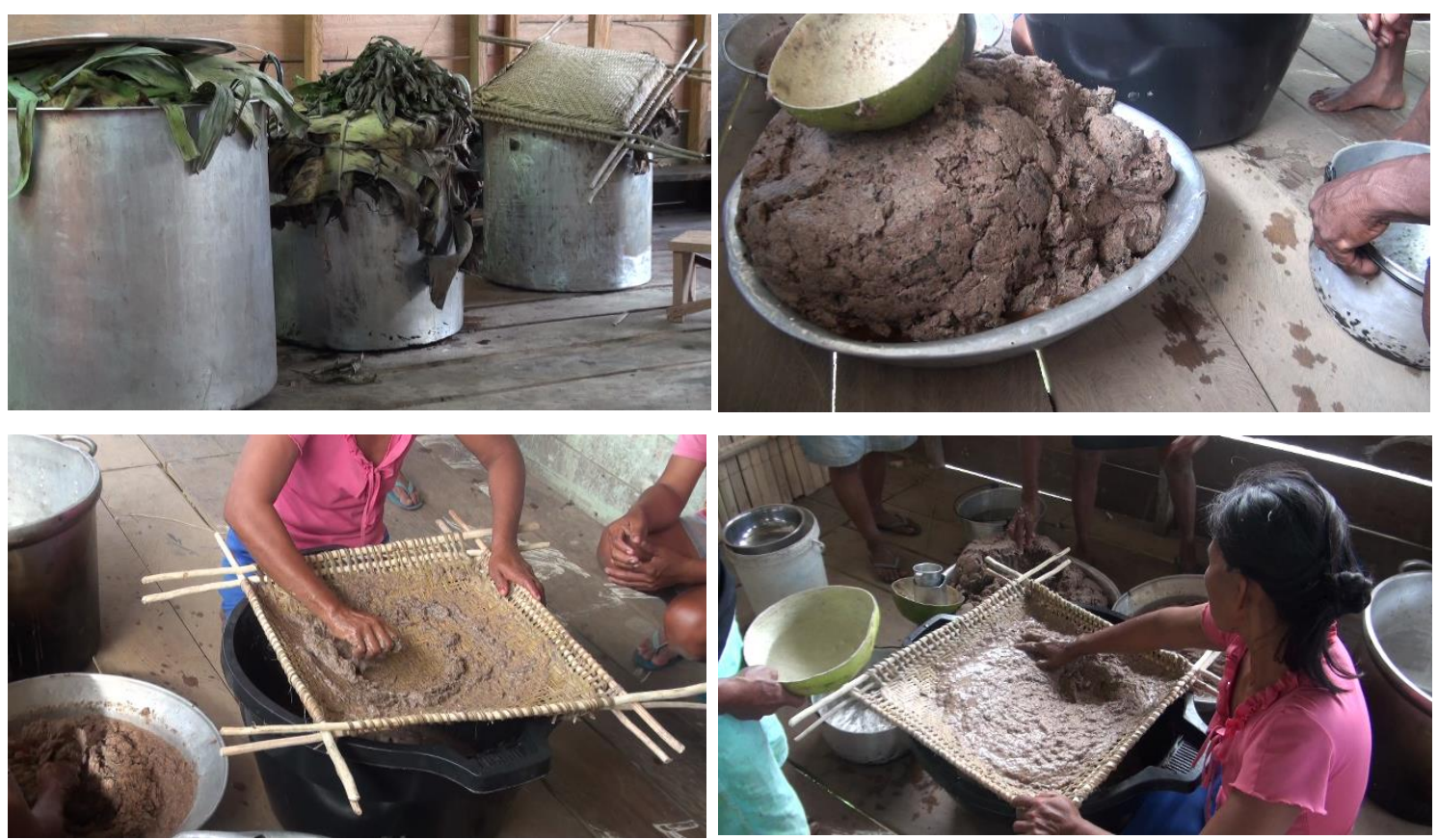

465 Atualmente usam-se panelas de alumínio ou grandes tambores de plástico. Bates comenta sobre os potes de barro utilizados para se colocar a caiçuma, considerada pelos Ticuna de hoje a bebida dos rituais de antigamente: "Os Tucuna se sobressaem entre todas as tribos na manufatura de objetos de barro. Fabricam potes de boca larga, para o tucupi e a caiçuma - ou molho de mandioca - com capacidade para vinte ou mais galões [cerca de 90 litros], ornamentando-os na parte externa com listras diagonais cruzadas de várias cores" (1975: 293).

${ }^{466}$ Valenzuela comenta sobre a dieta de quem prepara o pajauaru, o que não pude verificar em campo. “Durante el camino, don Rufino me contó que hacer payawarú (vino de yuca) es una actividad individual. La persona que lo prepara debe dietar, sin comer nada ácido ni muy salado, todo debe ser dulce incluso si toma agua esta debe tener azúcar" (2010: 152). 

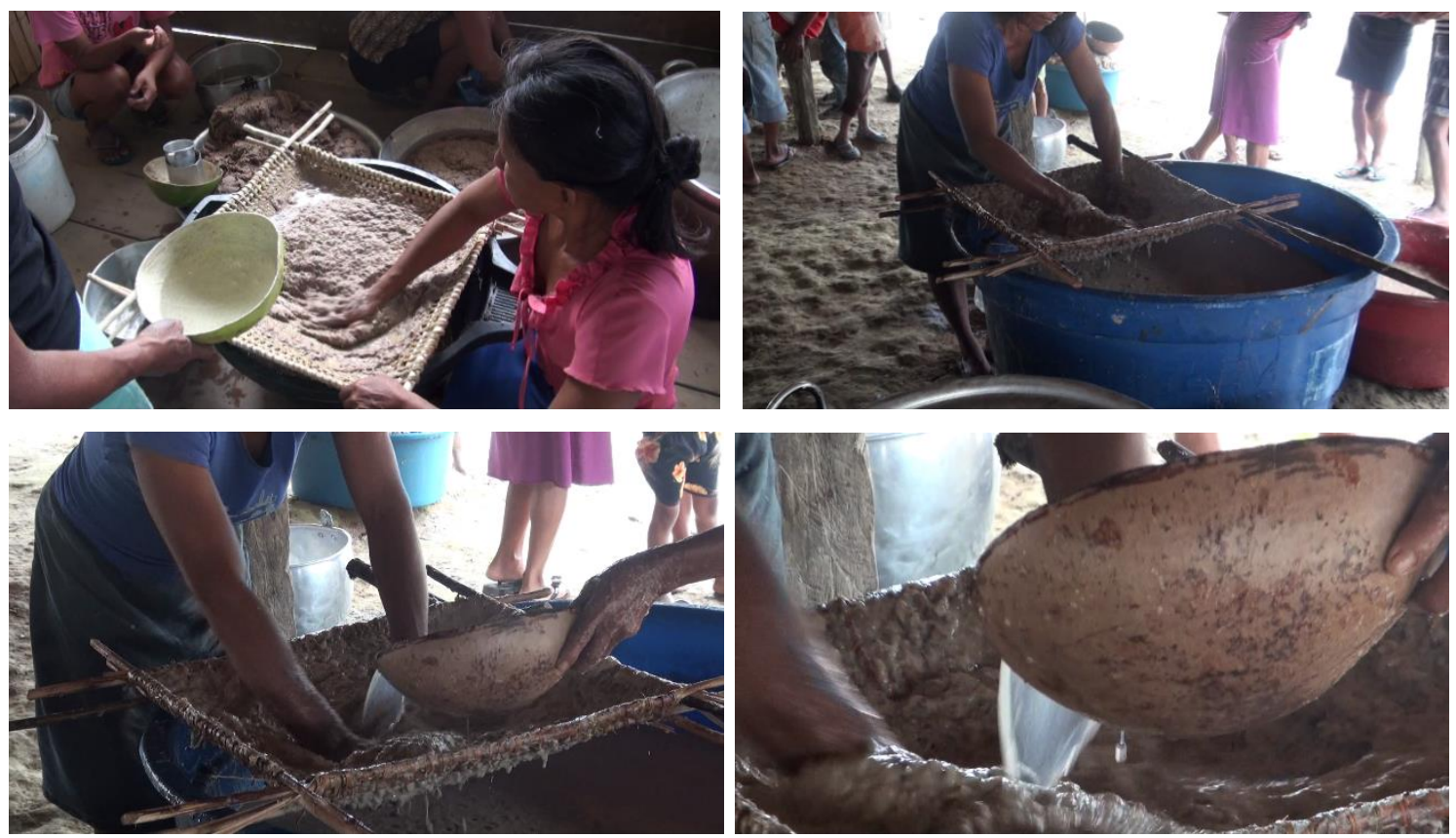

Figuras 49, 50, 51, 52, 53, 54, 55, 56 - Processo de preparo do pajauaru.

O dic. Houaiss menciona a palavra "pajuari" como uma variante do caribe "paiuá"467, da qual pajauaru ou paiauaru também derivam ${ }^{468}$. Outras variantes são paiwari, dos Macuxi ${ }^{469}$, e parikara, atribuida aos povos de língua aruaque (Lima, 1975: 306). Não se trata, portanto, de uma palavra de origem ticuna, mas é a mais utilizada pelos índios para se referir a esta bebida. Baseando-se em Farabee (1924), O. Lima faz uma descrição do preparo do paiwari muito próxima do que pude acompanhar entre os Ticuna:

"A técnica de preparo do paiwari (ou parikara) é descrita com cuidadosa minúcia. Os beijus destinados à bebida são feitos um pouco mais espessos do que os usuais e, ainda quentes, são mergulhados rapidamente em água fria, e logo colocados no solo em um canto escuro da casa, em um leito de folhas de bananeira, coberto com folhas de mandioca. Os beijus úmidos e quentes são espalhados em camadas, até que tenham a espessura de duas polegadas, sendo cobertos com folhas de bananeira. "Após quatro dias, quando as folhas são removidas, a massa de beijus está fermentada e tem o duplo da espessura

467 “[E]spécie de bebida estimulante us. pelos indígenas” (dic. Houaiss).

468 Os Caribe do Rio Maroni, p. ex., também bebem pajauaru em seus rituais de iniciação feminina. "Por volta do oitavo dia a mãe da menina faz a bebida nativa de mandioca, normalmente pa:yawa:Iu." (Kloos, 1969: 901).

${ }^{469}$ Povo de língua Caribe, localizado no estado de Roraima. 
original". "Sua superfície está inteiramente coberta com um mofo branco espesso". "Estão, assim, prontos para ser fragmentados e acumulados em grandes potes onde permanecem mais dois dias, para completa fermentação". "Uma canoa pequena ou uma grande gamela feita para tal fim, é colocada no centro da área de dança, usualmente em frente a uma casa grande, sendo os beijus fermentados para ela transferidos onde se lhe adiciona água segundo o sabor de um experimentado especialista na elaboração da bebida" (O. Lima, 1975: 306-307).

A narradora da história "Como se cuida da moça nova" (Nhuũãcü worecüma

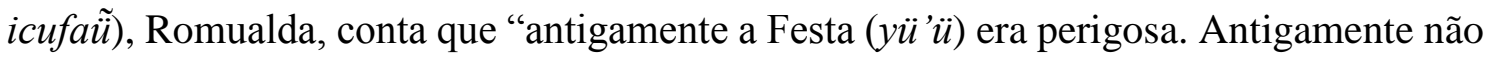
tinha pajauaru, só caiçuma [fermentado de macaxeira]. Cantavam bastante com ela [a moça nova] até chegar as 12hs" (Firmino \& Gruber, 2010, vol. 3). Goulard nos apresenta ainda uma terceira bebida, considerada a bebida da imortalidade, a cerveja de milho. Além de registrar qual bebida é considerada a bebida da imortalidade, algo que remete aos mitos que mostram como se atingia a imortalidade, Goulard aponta um interessante paralelo feito por Lévi-Strauss entre a fermentação da bebida e a "fermentação" da moça reclusa:

\footnotetext{
"A bebida fermentada que é abundantemente servida assegura uma mediação e provoca um processo de transformação que favorece a metamorfose que virá. Os mortais oferecem às máscaras cerveja de mandioca (ver Figura 3), substituto da bebida da imortalidade que é a cerveja de milho. Para Lévi-Strauss, analisando o material etnográfico ticuna, "a preparação [desta bebida] está a meio caminho entre a fermentação e putrefação" (Levi-Strauss, 1964: 167). Por esse motivo, a jovem é "comparável à virgem reclusa, forçada a jejuar, e que "fermenta", por assim dizer, acedendo à puberdade" (ibid. 168)." (2011: 139).

Vimos no Capítulo 6, tópico 6.2.1 - Batizado e Nomes dos trompetes, que o pajauaru é um importante indicador de perspectiva. O que os humanos veem como um lamaçal (de' $\ddot{u})$ onde a anta chafurda e bebe água, a anta vê como sua bebida, o "pajauaru da anta". Outros animais também têm o seu pajauaru. "Para eles é pajauaru", dizem as pessoas. Como o sapo a'wü, cuja carne pode ser consumida. Ele canta quando o rio começa a encher. Quando chove muito, ele canta no lamaçal (de'ü/ngowacüwa). Quando eles se juntam e cantam muito é porque estão fazendo festa (petae). Eles cantam em cima d'água, nadando e segurando um ao outro, macho e fêmea. Os velhos contam que a água em que eles cantam é a bebida deles, como o pajauaru é a bebida dos humanos. Quando
} 
não chove eles não cantam nem bebem. Mas quando chove, eles coam a bebida deles na peneira e festejam, como os Ticuna fazem com o pajauaru.

De acordo com Goulard (2009), haveria uma homonímia entre as palavras ticuna que designam um tipo de canto, alma e bebida, todas sendo referidas como áe é. $\mathrm{O}$ antropólogo indica que isto mereceria ser investigado com mais atenção. Em minhas inquirições encontrei algumas pistas sobre esta homonímia. Quanto ao uso da palavra para designar algo próximo do que chamaríamos de alma, não tenho dúvidas. Contudo, com relação à bebida, pelo que entendi, á 'ẽ não é tanto um substantivo para designar a bebida, mas o ato de dar uma bebida a alguém, por exemplo, cuãtcha'ã'̃̃ = "dar bebida para você”. Existem outras palavras para expressar o ato de cantar ou a ideia de canto, como, wiyae, mas ã 'ẽ pode ser usado também, por exemplo, na frase werigü arü á'̃e = “canto dos pássaros" (werigü = pássaros / a ' $\tilde{e}=$ canto) ou weri nã a a $\tilde{e}=$ "o passarinho canta" ou "o canto do passarinho".

Algo que devemos ter em mente quando estudamos a música de outros povos é o fato deste termo, "música", ser uma abstração quase exclusivamente européia. Segundo o musicólogo alemão Carl Dahlhaus:

"Se, pois, a categoria "música" (...) é uma abstração que em muitas culturas se levou a cabo, e noutras não, encontramo-nos então perante a infeliz alternativa ou de reinterpretar e alargar o conceito europeu de música até a alienação quanto à sua origem, ou de excluir do conceito de música as produções sonoras de muitas culturas extra-europeias". (Dahlhaus, 2009[2001]: 15)

O que se apresenta como uma "infeliz alternativa" para o grande musicólogo europeu, contudo, é o material por excelência do etnomusicólogo. Talvez uma das questões mais interessantes da etnomusicologia seja: o que é música para determinado povo? Nesta tese, apresento alguns aspectos do o que é música para os Ticuna, algo de que ainda possuo um conhecimento bastante limitado. Contudo, o ato de cantar é algo que debati bastante com os cantores ticuna e gostaria de comentar um pouco sobre o canto destes índios antes de abordar sua relação com a bebida.

Muitas palavras são usadas na língua ticuna para se referir ao canto, mais especificamente ao ato de cantar. Cantar, para um ticuna, pode indicar muitos tipos de artes verbais. Mostrei no Capítulo 5, tópico 5.2.1 - Voz, canto e cantor, que a palavra 
wiyae pode ser traduzida como "canção" ou "canto". Tudo indica que wiyae seria a noção mais geral de canto, a idéia mais próxima de nossa palavra "canto". Dentro desta idéia de wiyae, existem outras categorias mais específicas. Wawe, por exemplo, é uma palavra que designa o que chamamos de acalanto. Serve para se referir a um canto mais suave, como quando se canta para uma criança dormir. No mesmo referido tópico vimos também que existe ainda uma noção mais próxima do canto que é entoado no ritual. Utü é a palavra usada para se referir ao canto executado na Festa da Moça Nova, com a voz aguda, mas também ao canto dos pássaros. Os homens cantores da Festa da Moça Nova, por exemplo, cantam em falsete e este tipo de canto é denominado utü. Não serve para se referir ao cantor de forró, por exemplo.

Por fim, temos o canto que nos interessa neste tópico sobre a bebida do ritual, e que é designado por uma palavra já evocada: $\tilde{a}$ 'ẽ. Este gênero vocal ou forma de cantar é aprendido pelo aprendiz de xamã ao entrar em contato com os espíritos das árvores. $\mathrm{O}$ aprendiz de pajé se põe em contato com os espíritos das árvores e aprende seu canto gradualmente (Nimuendaju, 1952:100-102; Goulard, 2009: 83). Curiosamente, a bebida fermentada também pode ser designada pelo mesmo termo. A mesma bebida que irá alimentar os instrumentos que tocarão aconselhando a moça nova durante o ritual. Outro significado deste mesmo termo, podemos traduzir como "princípio vital" ou espírito, duplo da pessoa. O ã'ẽ, junto com o ma'ũ, são os dois "princípios" que conformam a pessoa ticuna. Ou seja, temos, portanto, uma notável confluência de significados neste termo, ã'é: canto, bebida fermentada e 'princípio vital' (Goulard, 2009: 169).

A carne moqueada será distribuída ao final da Festa. Ao longo do ritual apenas o pajauaru é largamente consumido. Nota-se aqui a mesma oposição entre, de um lado, cantar e beber e, de outro lado, silêncio e comer destacada por Viveiros de Castro (1986: 339-340) entre os Tupi-Guarani:

"Durante o cauim, ninguém come nada - a clássica - disjunção cauim/comida que já era notada para os Tupinambá (...) [nota 38] Léry 1972: 91; Cardim 1978: 104; Abbeville 1975: 239, todos contrastam a moderação e o silêncio Tupinambá durante o comer com os excessos e a cantoria no beber (cauim), e se surpreendem com a mútua exclusão entre o cauim e a comida (para os europeus da civilização do vinho à mesa, de fato isso devia saltar aos olhos). Beber, fumar, cantar entram em um contexto; comer, em outro. O que vale destacar aqui é a oposição latente: bebida + palavra (canto) X comida + 
silêncio, que reenvia ao que considero uma polaridade oral básica Tupi-

Guarani: cantar X comer (cf. supra, pps. 260-1)" (1986: 339)

Esta oposição que Viveiros de Castro notou para os rituais Tupi-Guarani, "bebida + palavra (canto) X comida + silêncio", de modo geral, também pode ser encontrada na Festa da Moça Nova dos Ticuna. Nestas ocasiões, apesar de serem distribuídas as carnes moqueadas, elas não são consumidas durante a Festa. Além disso, uma provável evidência linguística pode reforçar esta oposição para os Ticuna. Sabemos que um único termo pode ser usado entre os Ticuna para se referir à bebida, ao canto e a uma qualidade de espírito ou duplo da pessoa, ã ẽ. Este termo também está na raiz da palavra "animada" (dai 'â'ẽ ou nata'â'ê) ou "animação", o que remete ao momento festivo em que se bebe e canta.

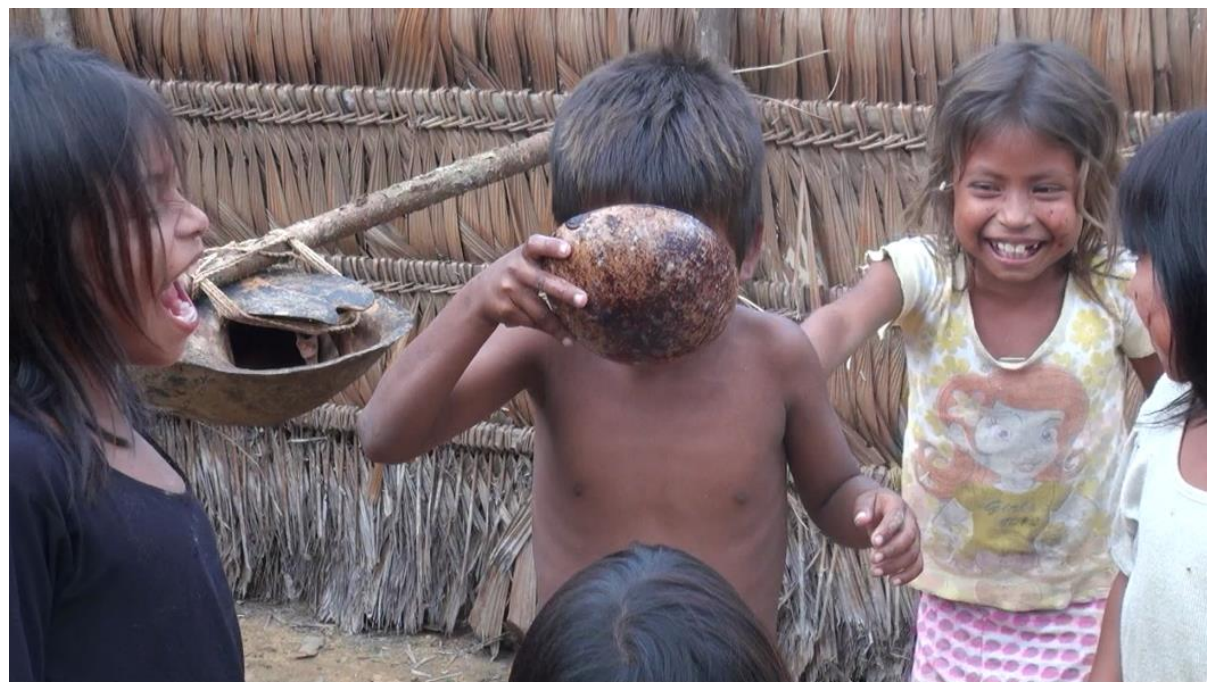

Figura 57 - Crianças tomando pajauaru

\section{4 - Danças, quarto de reclusão e adornos}

"Dança” na língua ticuna é referida como yü'ü. A palavra para "dança” é a mesma usada para se referir à "festa" e, como vimos, pode significar tanto "festa" de modo geral, quanto "domingo", "feriado". Interessante notar que todos os festejos ticuna que presenciei tinham música e dança. Mesmo as festas que não são "tradicionais" como a Festa da Moça Nova, são dançadas. Durante a comemoração da padroeira de Nazaré, fizeram uma festa de noite em que tocava forró. Os índios dançavam animadamente. 
Fiquei meio avexado de dançar, o que gerou uma certa preocupação dos anfitriões. Era como se eu me recusasse a festejar com eles.

As danças durante a Festa da Moça Nova são constantes. Começam na noite de sexta-feira, com uma dança para as crianças. No sábado, enquanto a área central da casa de Festas não é usada na confecção dos materiais do ritual, a dança com o tamborim tutu é a mais frequente e pode durar bastante tempo, dependendo do ânimo dos dançarinos e tocadores. Esta dança é uma fileira de tocadores que vão serpenteando no espaço central da casa de Festa. Alguns dos movimentos desta dança, realizados pela fileira de tocadores, são: circulares, o desenho do infinito $(\infty)$, etc. O primeiro da fileira é quem dá a direção e o andamento para os demais da fila. Me parece que o que se pretende é não repetir os movimentos, tornando imprevista a direção e o desenho que se formará com a fila de dançarinos. Todos podem participar desta dança, homens, mulheres, crianças.
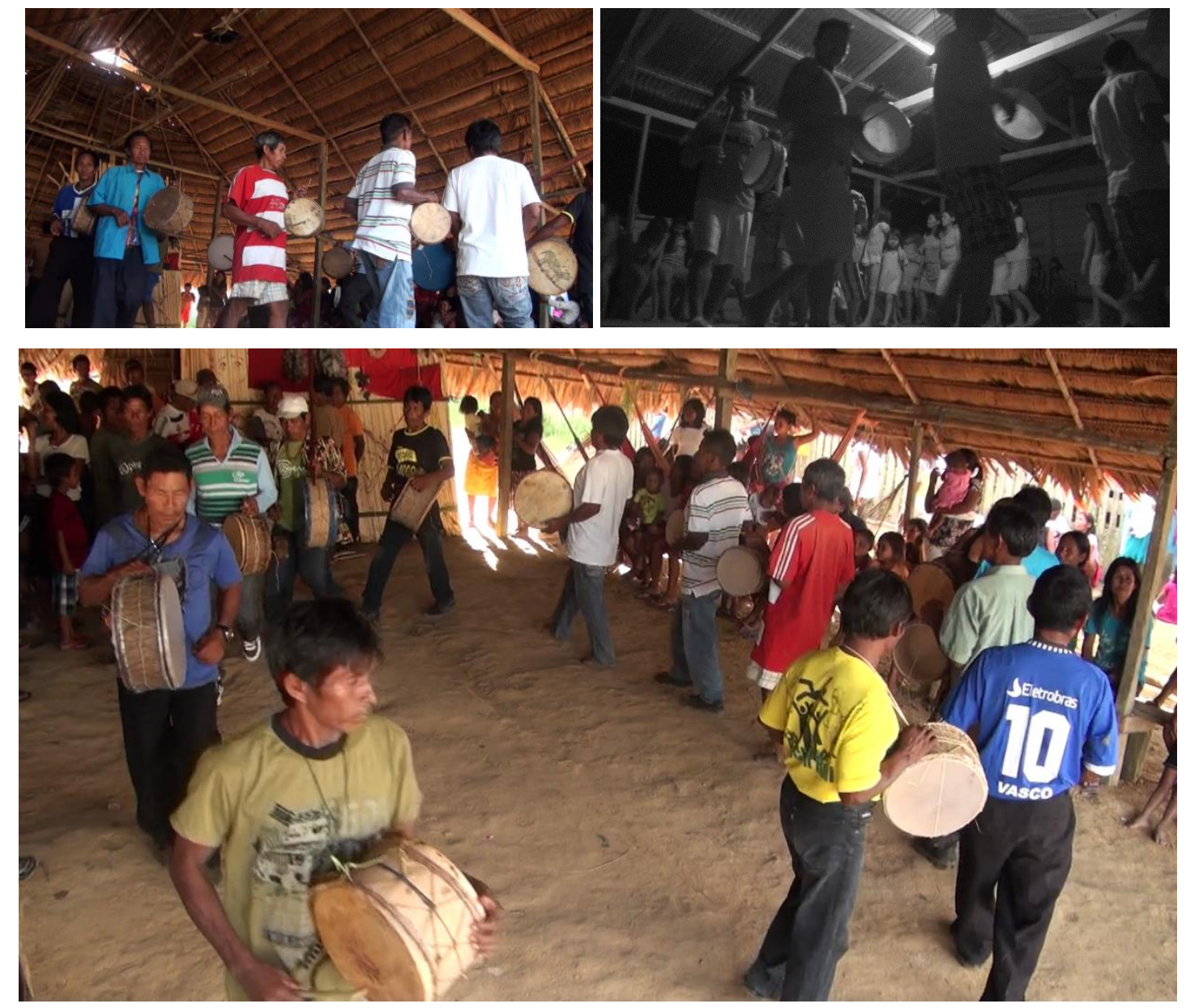

Figuras 58, 59, 60 - Dança do tamborim tutu 
A presença de seres sobrenaturais e personagens míticos ticuna se dá principalmente por intermédio dos mascarados na Festa, mas também acontece de forma figurada nas danças. Um informante de Gruber compara a dança em fila que acontece na Festa e os movimentos da cobra:

"Em fila indiana, 10 a 15 homens iniciam uma dança que consiste numa caminhada rápida, ao ritmo dos tambores que tocam juntos, fazendo círculos e meias-voltas, como o serpentear da cobra, conforme comparou um de meus informantes." (1999: 10).

Este comentário nos leva a pensar que a fila de dançarinos seria uma cobra-grande, como Yewae, a cobra-grande que mora nos rios e lagos e aparece nos mitos. Existe uma máscara que é feita para esta cobra. Assim, ela pode estar presente na Festa não só por meio da máscara, mas também serpenteado na frente do quarto de reclusão na forma de uma fila de tocadores de tamborim, do mesmo modo como os outros mascarados irão se exibir no ritual.

Com a chegada dos primeiros convidados no sábado, e logo que o pajauaru começa a ser servido, se o tori (casco de tracajá) está pronto, iniciam-se as primeiras danças do tracajá. Para preparar o instrumento, ele é levado até o porto para ser lavado. O “copeiro" vai acompanhando o casco de tracajá e tocando o bastão de ritmo (aru). Depois de ser cuidadosamente lavado, fica secando por um tempo para ser adornado com uma mistura de urucum com o leite do tururi vermelho (peiyu) o que o torna grudento, assim as plumas se fixam melhor na pintura. Este mesmo tipo de mistura e de plumas ${ }^{470}$ serão usadas na pintura da moça nova.

470 Antigamente se usavam as plumas brancas do peito do gravião-real. Atualmente, com a escassez desta ave, usam-se plumas brancas de pato ou de garça. 

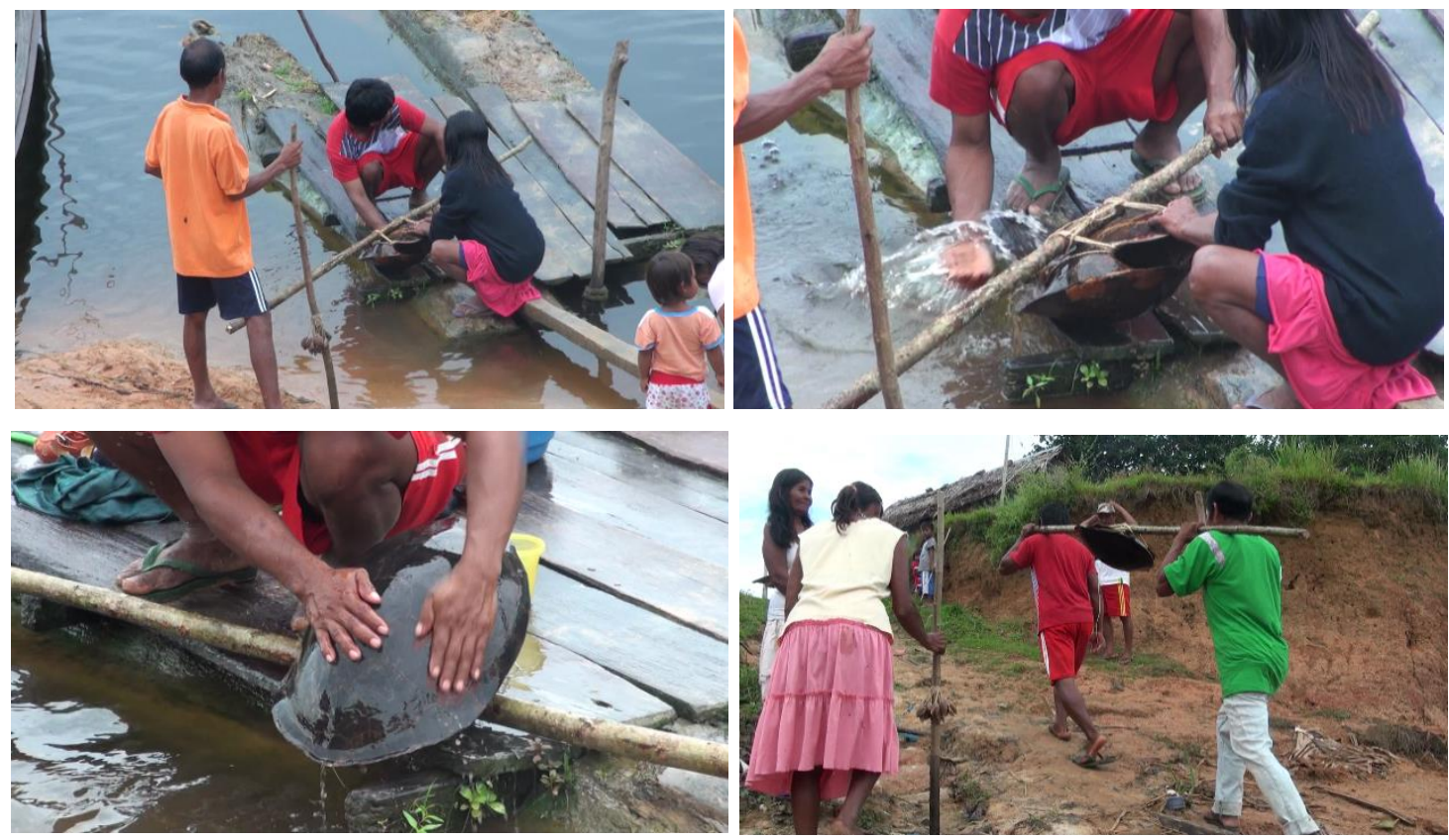

Figuras 61, 62, 63, 64 - Lavando o casco de tracajá (tori).

Nesta dança as pessoas ficam de braços dados, aos pares, trios, quartetos, segurando os instrumentos: tamborim (tutu), trompete de bambu (coĩri), flauta pan (tcheciu) e bastão de ritmo (aru). São necessárias duas pessoas para tocar o tracajá. Cada um segura numa ponta do galho em que está amarrado o casco e toca com uma baqueta feita especialmente para o instrumento. Metade das pessoas fica atrás de um dos tocadores a outra metade se posiciona atrás do outro, as metades ficam de frente uma para a outra e a dança começa. O movimento é bastante simples: cinco, seis passos para frente, e o mesmo para trás, com o tracajá no centro. 

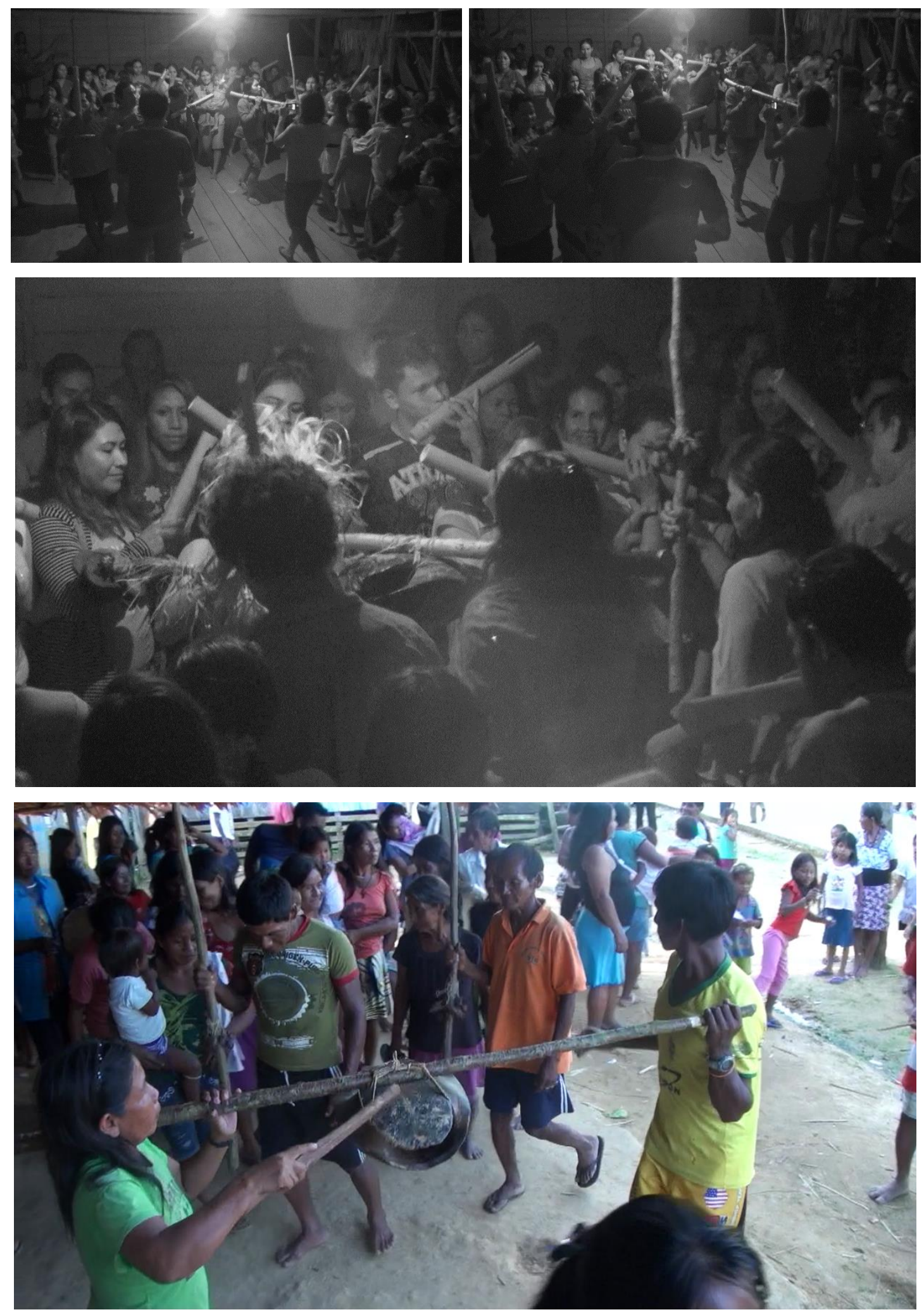

Figuras 65, 66, 67, 68 - Dança do Tracajá

Em todas as Festas que fui, a dança do tracajá foi repetida inúmeras vezes, do começo ao fim da Festa, podendo participar todos os que se animarem para a dança. Nela, 
o idiofone de casco de tracajá (tori) desce do teto - onde fica guardado nos intervalos das danças do tracajá - e o bastão de ritmo ( $a r u)$ é percutido também. Uma corda suspende o instrumento para junto do telhado da casa quando a dança termina. De acordo com Gruber, esta dança teria uma relação estreita com as crianças:

"Está relacionada diretamente às crianças e realiza-se em diferentes momentos do ritual, trazendo grande animação. Os ticunas sempre comentam que uma festa de moça-nova só estará completa com a participação das crianças, pois assim pode acontecer a dança do tracajá, a dança que dá vida à festa" (1999: 14).

De fato, é nesta dança que as mulheres levam crianças em tipoias para dançar ${ }^{471}$. Paralelamente à iniciação das moças, muitas crianças passam pelo ritual também, são adornadas e têm o cabelo cortado.

O momento de construção do quarto de reclusão pode variar. Na Festa de Porto Lima e Santa Clara, o chamado “curral” da moça nova (turi) já estava pronto no sábado, provavelmente foi construído na sexta-feira. Nas duas Festas das quais participei em Vendaval, o quarto de reclusão foi construído na tarde de sábado. O material para a construção do turi é basicamente os talos ou "braços" das folhas de buriti.
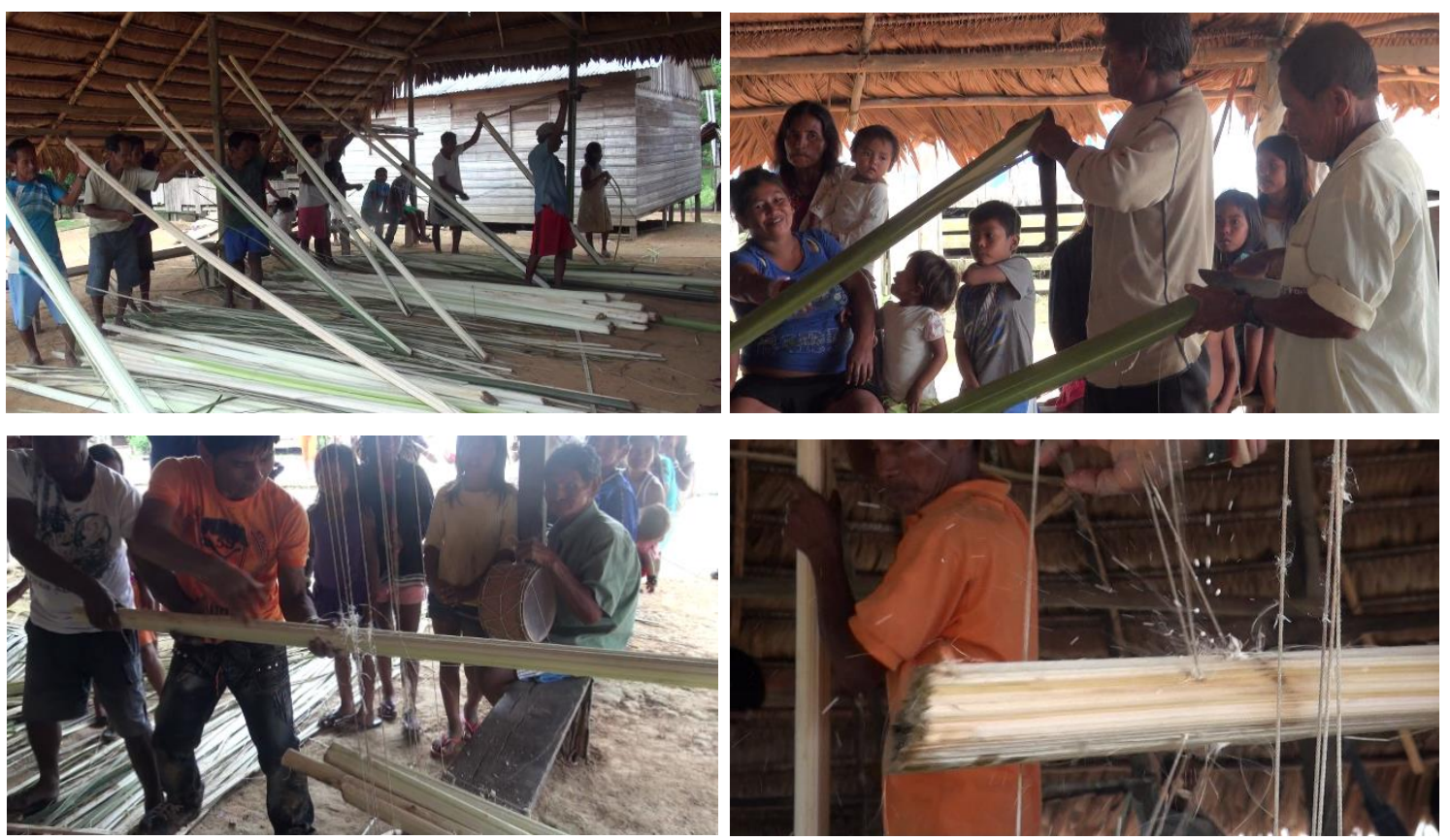

471 "Nessa dança as crianças são carregadas pelas tias paternas, em geral numa tipoia feita de folhas verdes de buriti." (Gruber, 1999: 16-17). 

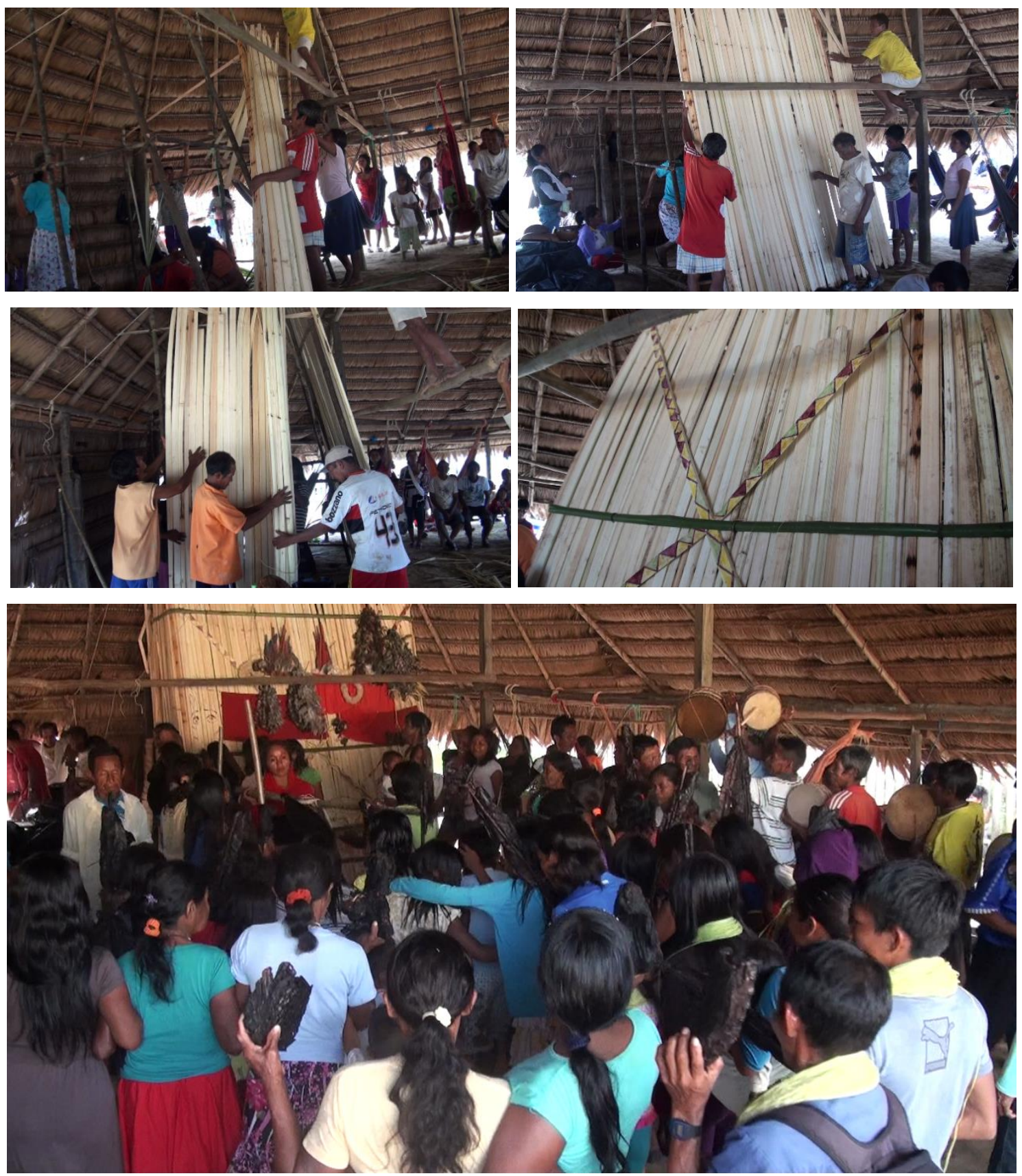

Figuras 69, 70, 71, 72, 73, 74, 75, 76, 77 - Construção do quarto de reclusão (turi). Os adornos das moças estão na parte da frente do quarto.

A primeira etapa é descascar os talos de buriti. Para dar início, o "copeiro" dá um toque com o bastão de ritmo (aru) e um grito “yüü̈ü̈”. Os responsáveis pela construção da reclusão começam o trabalho ao mesmo tempo, o "copeiro" acompanha todo o processo tocando o aru. A retirada da casca dos talos de buriti, material do curral da moça é feito coordenadamente. Ao sinal do copeiro as pessoas começam a descascar os talos, dos quais se aproveita tudo. O miolo será usado na confecção das paredes do quarto de reclusão e com a casca farão a esteira onde ficará a moça nova dentro do quarto. Depois 
de tirada a primeira parte da casca do buriti com a faca, o restante é puxado com a mão. Isso é feito coordenadamente. À ordem do copeiro as pessoas começam a puxar as cascas dos talos. O final da retirada das cascas do buriti também é coordenado. As pessoas que estão descascando seguram o finalzinho da última fibra e esperam para puxarem juntas, ao comando do aru todos puxam a última casca. Desta maneira, o início e o fim do processo são marcados pela coordenação do aru e pelo grito de “yüü̈̈̈̈̈!”.
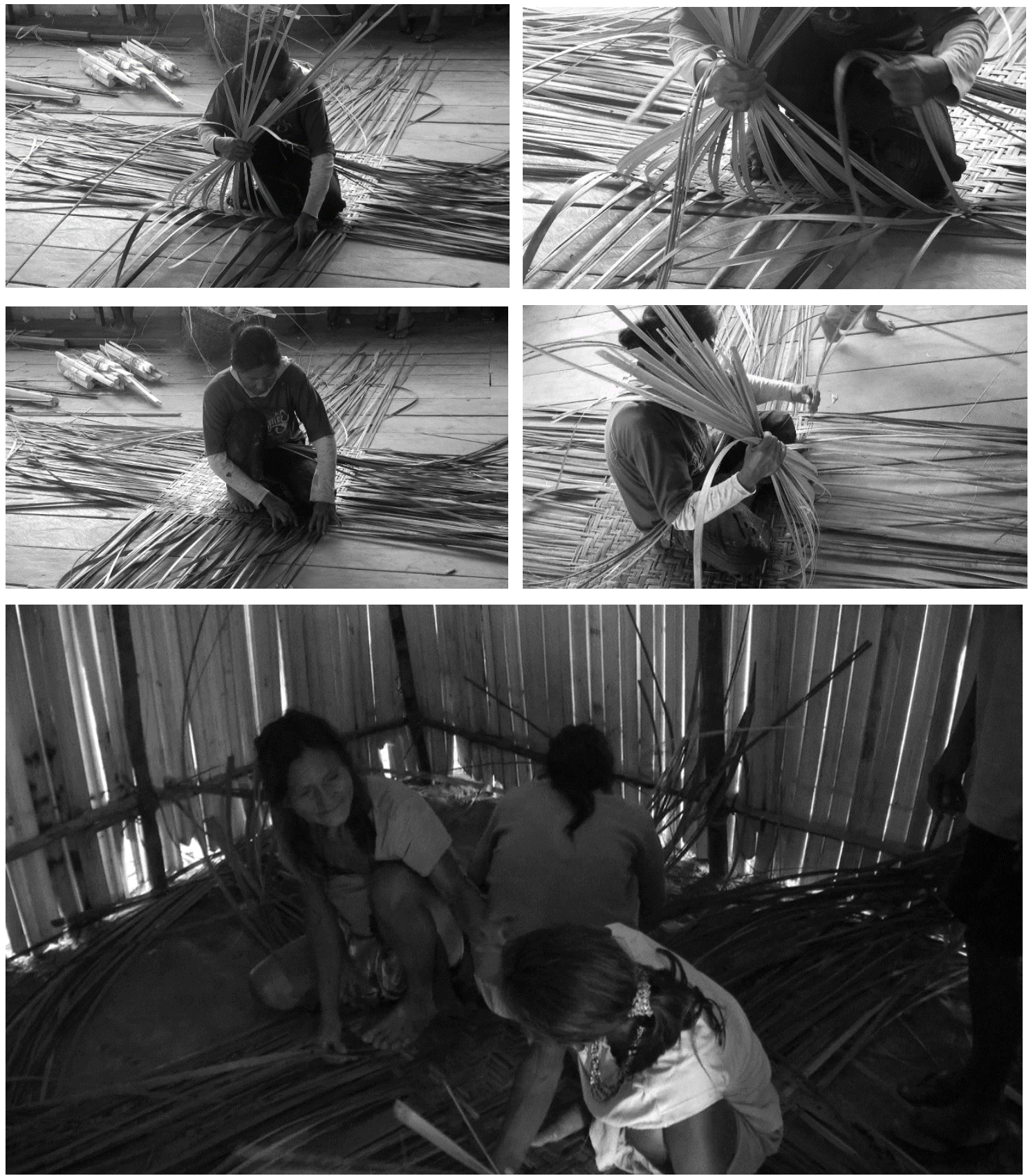

Figuras 78, 79, 80, 81, 82 - Fazendo a esteira para as moças novas 
Segundo Nimuendaju, antigamente o quarto de reclusão era feito em formato redondo. "Este pequeno retiro era circular, dois metros de diâmetro ou um pouco mais, e não tinha chão, uma vez que a worecü, dorme em sua rede ao longo de sua reclusão. (...) Muitas vezes, hoje o quarto de reclusão é quadrado e não é erguido onde deveria estar, porque a posição da casa nas margens do Solimões ou em igapó não permite isso" (1952: 75). Todos os quartos que pude ver foram feitos em formato quadrado. Como comenta o autor mencionado, a antiga regra do local onde deve ser construída a reclusão também é raramente obedecida. A regra diz que se a moça for de clã "com pena", o quarto será erguido na parte Leste da casa, se a moça for de clã "sem pena", a reclusão será orientada para o Oeste (Goulard, 2004: 90-91), como no exemplo fornecido por Faulhaber:

"A festa é organizada espacialmente conforme a oposição entre Ocidente e Oriente. No exemplo da festa de Tueguna, realizada no Enepü dia 29 de julho de 2002, a metade da moça (arara vermelha/pena/Leste) contrapunha-se à metade da criança (onça/ não pena/ Oeste). O curral da moça foi construído a Leste da casa. Os convidados da nação do pai da moça entravam na casa pelo Oriente, em direção ao Ocidente enquanto que os convidados da nação da criança entravam pelo Ocidente, em direção ao Oriente. O moquém (caça e peixe assado) foi preparado, guardado e trazido a partir do Oeste, enquanto em outra festa quando a moça era Woca [boi] (não pena), foi preparado, guardado e trazido a partir do Leste." (2003c)

$\mathrm{Na}$ parede frontal do quarto da moça nova são desenhados diversos elementos. Para iniciar a pintura do curral o bastão de ritmo dá um toque para o início. Nimuendaju faz o seguinte comentário sobre os desenhos:

“A superfície externa da parede da sala de reclusão (dentro da casa) é decorada com pinturas, ou seja, bandas ou desenhos cruzados compostos de triângulos, losangos e círculos. Em um desses quartos estava pintada a figura de um cervo, símbolo da vigilância. No topo, há sempre um sol com uma cara convencionada de humano, uma estrela e uma lua nova. Aparentemente, esses quatro desenhos foram os únicos pintados nos velhos tempos, mas hoje a parede está cheia de figuras menos tradicionais. Uma fotografia de uma tal parede, tomada por um missionário capuchinho, mostra um relógio, facões, uma barraca, um soldado, uma mulher, e assim por diante, que eu tenho observado pinturas de navios e aviões, porque hoje em dia qualquer convidado pode tirar proveito da parede branca e lisa para pintar o que vem em sua cabeça." (1952: 76). 

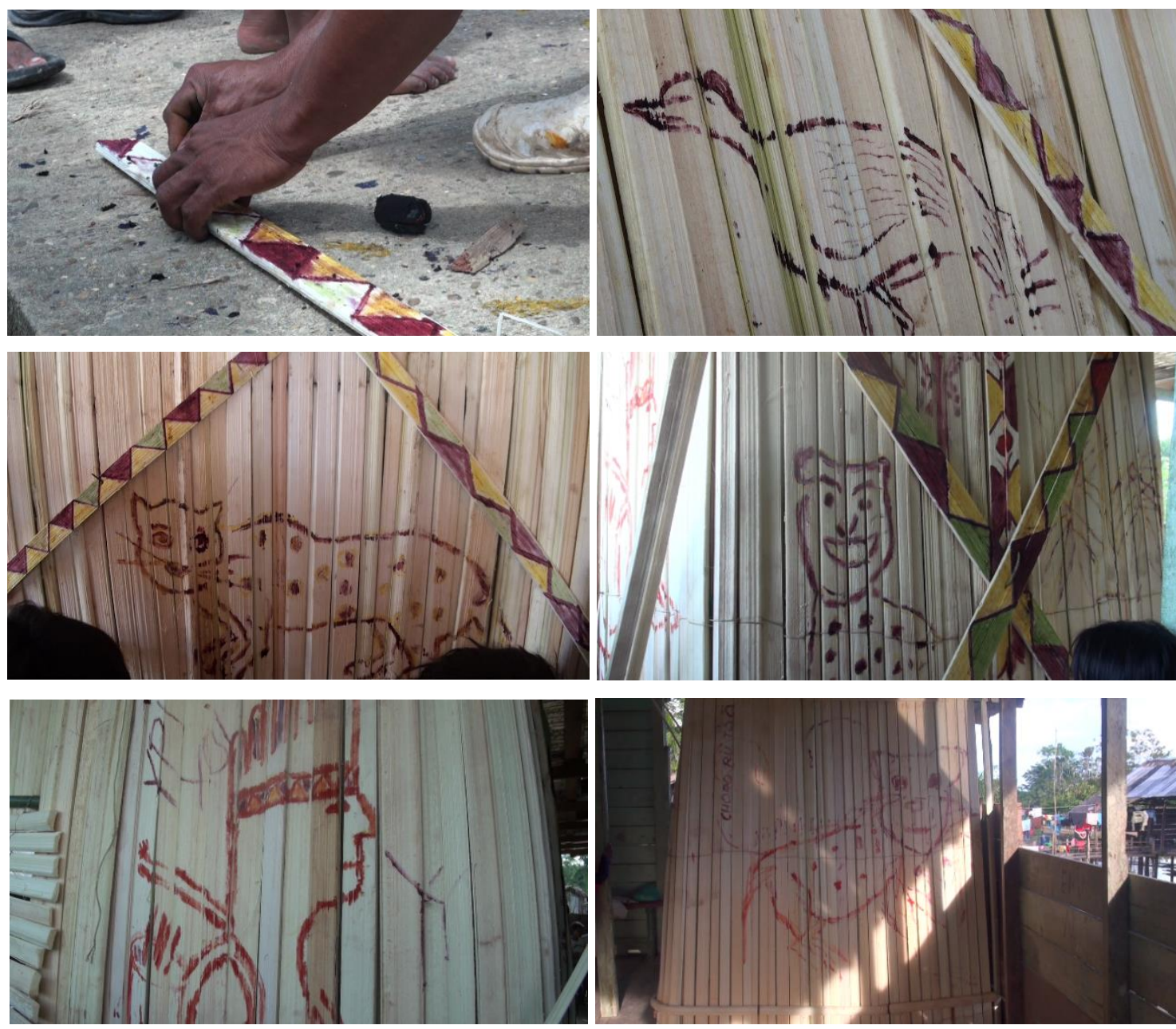

Figuras 83, 84, 85, 86, 87, 88 - Pinturas no quarto de reclusão (turi)

Dificilmente alguém irá repreender alguma pessoa que pinte algum elemento que não seja "tradicional" da cultura Ticuna. Interessa-nos aqui, no entanto, as figuras que são mais correntes nos desenhos. Vimos no Capítulo 5, tópico 5.3.2.2 - Canções de aconselhamento, que em algumas canções a moça é comparada ao sol. O desenho do sol é muito recorrente nas paredes da reclusão. Junto com outra figura frequente na parede, as duas ripas de buriti em " $\mathrm{X}$ " cruzando a parede, o sol, segundo Faulhaber, "representando a idéia de passagem do tempo no dia ou no ano" (2003a: 42). A passagem do tempo é desenhada de acordo com a posição do sol na parede do quarto. O sol posicionado “à esquerda representa eu'wa (manhã); acima, tocutchi (doze horas) e à direita yauanecü (seis da tarde). A ausência do Sol abaixo representa tchütacü (noite)" (ibdem). Um mito coletado por Nimuendaju, "A canoa do Sol", mostra o poder ressuscitador do sol. "Eles comeram o peixe inteiro. O Sol coletou as escamas e os ossos, juntou as partes do peixe novamente e jogou-o vivo na água.” (1952: 142). Os motivos 
da estrela e da lua também aparecem bastante. Quando uma estrela é desenhada numa Festa, está-se evocando o filho de Lua, ou seja, evoca-se o incesto com estas figuras ${ }^{472}$.

No quarto de reclusão da segunda Festa de Moça Nova que acompanhei em Vendaval foram desenhados uma onça, estrela, lua, um índio (Yoi?) e um mutum. Uma das moças que passaram pelo ritual era do clã do mutum. Perguntei na Festa anterior porque desenharam uma onça nas paredes da reclusão se as moças não eram deste clã (eram de arara e outros clãs de pena). Me disseram que era para ela arranjar um namorado de clã de onça.

Dentro da reclusão, atravessado na parte de cima, ficará um galho de taperebá (yomeru). O tronco fino desta planta é referido em algumas canções como o "poleiro" da moça nova, pois ela deverá segurá-lo durante boa parte da Festa evitando dormir. Na canção do quarto de reclusão da moça (turitchiga) que registrei em campo, podemos destacar o trecho:

Pa woware, wowarecü

"Moça nova, moça nova"

Turigu, turiguta cuaureün, aureün

"Lá no quarto [turi] você está guardada"

Marïgagu curutanĩ ya cupaweru

“Já vai ser seu, seu poleiro"

Contudo, notemos que há uma inversão aqui. Enquanto as aves ficam sobre o poleiro, a moça nova segura seu "poleiro" com a mão para cima. Enquanto estiver reclusa, ao longo da Festa, a menina deve ficar de pé o tempo todo, pois, segundo me disseram, se ela dormir dentro do "curral" o peito dela vai ficar caído muito cedo. Trata-se de uma evidente referência a um possível envelhecimento precoce da moça, caso ela não obedeça a esta importante regra do ritual. Um de meus colaboradores, em Santa Clara, me disse que o galho deve estar direcionado para o poente.

${ }^{472}$ Cf. Capítulo 1, tópico 1.11.1 - Incesto. 
Esta planta possui grande importância ritual para os Ticuna e reaparecerá em outros momentos da Festa ${ }^{473}$. O taperebá é afamado por seu poder de regeneração e crescimento, é uma planta que "pega fácil". De acordo com Nimuendaju, o cordão umbilical é colocado na casca da árvore de taperebá, pois é uma árvore que "não morre" ${ }^{\$ 74}$, Ondino me confirmou esta informação. Valenzuela o descreve de um ponto de vista ticuna, da seguinte maneira:

"Sus ramas retoñan de nuevo es longevo y por tanto es un símbolo de vida larga, de capacidad humana y espiritual de renovación. Cuando se quemó la tierra según el relato de J. Manduca, este árbol no se quemó. No es muy leñoso, carga mucha agua en su interior, es blando y flexible, siempre se encuentra cerca del agua, su fruto se come. También sirve como remedio para el dolor de cabeza, su cáscara en infusión sirve para el dolor de estómago, y pulverizada, se usa para curar las heridas en la boca." (2010: 123).

Valenzuela complementa ainda que o chão do interior do quarto de reclusão é recoberto com as folhas do taperebá (ibdem).

Mencionei que o umbigo do bêbe, quando cai, é colocado dentro da casca do taperebá. Isso serve para a criança ficar forte, para deixar ele mais resistente à doenças, sarar rápido. Sabemos que uma das funções do ritual é para que a moça tenha os males retirados do corpo (yunatüüne $=$ "males do corpo" - yunatü $=$ males $/ \ddot{u} n e=c o r p o){ }^{475} \mathrm{e}$

\footnotetext{
${ }^{473}$ Há um uso terapêutico do taperebá em algumas doenças. D. Lima nos mostra que ele é usado para os rins, durante o parto e no pós-parto: "Quando a mulher está de parto, pode tomar chá feito de casca de taperebá. A casca só pode ser tirada da direção onde o sol nasce. Podemos secar a casca para fazer o chá. (...) Quando a pessoa está rendida no rim pode-se fazer o chá com a casca misturada com remédio chamado gaivota. É colocado por três noites no sereno e três dias no sol para ser tomado depois. São três garrafadas e é muito bom para rendidura (...) Quando a barriga da mulher incha após o parto pode tomar o chá feito da casca. Já com as folhas pode-se fazer banho, para que a criança não fique doente, mas faz somente com a folha novinha, a folha do olhinho (...) Também após o parto pode fazer chá com o caroço, somente três caroços queimados e 14 folhas de cipó (um cipó especial, plantado pelo homem, um tipo de cipó apropriado para fazer remédio). Pode fazer quatro garrafadas para ficar bebendo durante o parto" (2006: 166).
}

474 “Uma vez que o cordão umbilical caiu, ele é empurrado entre as raízes de uma árvore de pupunheira, ou, melhor ainda, em uma fenda aberta pela ponta de um machado na casca do taperebá, já que esta árvore "não morre", mesmo quando cortado em pedaços." (Nimuendaju, 1952: 70).

${ }^{475}$ A palavra yunatü é traduzida por Ondino também como "pecado original", como se fosse algo que todo mundo já nascesse com ele. Yunatüta é usado para referir-se aos mortais, o contrário de ü'üne (imortal), ou traduzido como pecadores. 
esta planta atua nesta função. A razão do uso do taperebá em vários momentos do ritual

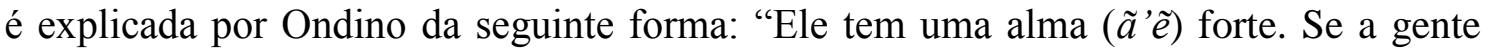
derrubar ela, ela cai e nasce de novo. Onde finca o galho dela nasce". O cabelo da menina, após ser arrancado ou cortado, é enterrado ao lado do tronco do taperebá. Mas sempre há o risco de pegarem o cabelo para fazerem feitiço. Ondino comentou que hoje se faz feitiço com as roupas da pessoa também.

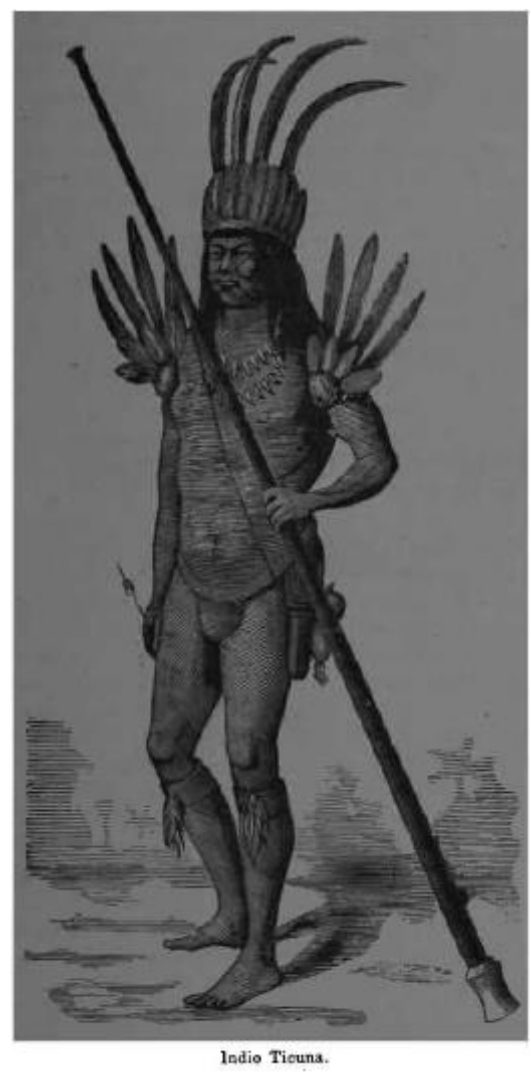

Figura 89 - Ticuna Adornado

A imagem ao lado, de um índio ticuna adornado para uma Festa, recebe a seguinte descrição de Barbosa Rodrigues:

"Os homens usam grandes collares de dentes de porco, ligas largas de tecidos de algodão, suspensórios do mesmo tecido, com que encobrem as partes sexuaes, e, nos dias de festa, de umas braçadeiras, feitas de pennas de arara, sendo a braçadeira propriamente de pennas miúdas da arara encarnada e o seu enfeite de pennas azues e amarellas da cauda da arara canindê"

"Ornam a cabeça com uma grande testeira de pennas das azas da mesma arara, orlada de pennas miúdas, vermelhas, e rematada por quatro ou cinco, na frente, das longas da cauda da arara vermelha." (1882: 53)

Alguns destes elementos que adornam o homem da figura, especialmente o cocar e as braçadeiras, são usados pela moça quando ela sai da reclusão. A confecção dos adornos pode acontecer no fim da tarde de sábado ou no domingo pela manhã.

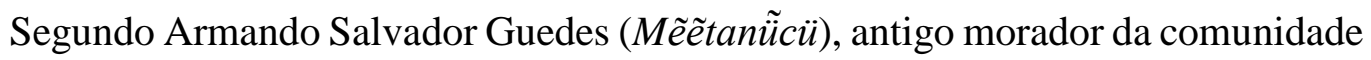
de Santa Clara, os adornos e as danças da festa são do herói mítico Yoi e todos estariam vestidos de Yoi. Com o olho ${ }^{476}$ da palmeira muru-muru (too - Astrocaryum murumuru) se faz um adorno (ngaiyanü) que é carregado nos ombros do dançarino que vai à frente na fileira de tamborins. Numa das Festa de Vendaval, o muru-muru e o buriti, para a

${ }^{476}$ A folha ainda verdinha que fica entre as folhas mais velhas. 
confecção dos adornos, foram buscados coordenadamente com o "copeiro". Um grupo de homens foi com ele até o bosque mais próximo para buscarem folhas de muru-muru e um olho de buriti. Voltaram para o cercado dos instrumentos com o material e abriram as folhas de muru-muru ao sinal do "copeiro" com o bastão de ritmo (aru). Retiraram então fibras do olho de buriti para fazerem os adornos que são pendurados no pescoço. Ao sinal do aru sairam do cercado dos instrumentos, deram voltas na casa e entraram para dançar. Tudo isso foi feito sem o tracajá. Depois de dançarem os ramos de muru-muru foram colocados nos esteios da casa, alguns ficam espetados no quarto de reclusão. As voltas que se dá fora da casa é algo que se repete inúmeras vezes no ritual. Em geral, estão trazendo algum elemento da Festa ou estão levando alguma coisa para fora da casa. Com o olho do buriti é feito o adorno (tchaiwaẽ) que fica em torno do pescoço. São tiras longas que enlaçam a parte da frente do pescoço e pendem para trás, nas costas, até o chão. Segundo Ondino, estes dois adornos corporais são feitos dentro do cercado do to 'cü e eles devem ser feitos por volta do final da tarde do sábado da festa. De acordo com este mesmo informante, o adorno de muru-muru deve ser usado só por homens e o de buriti só por mulheres.
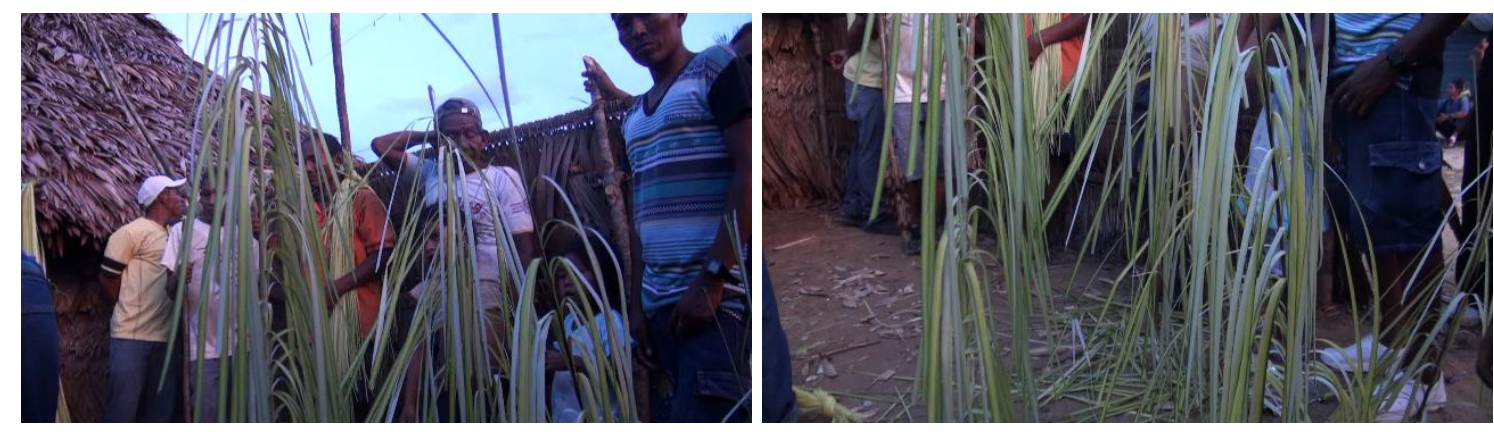

Figura 90 e 91 - Adornos de muru-muru 

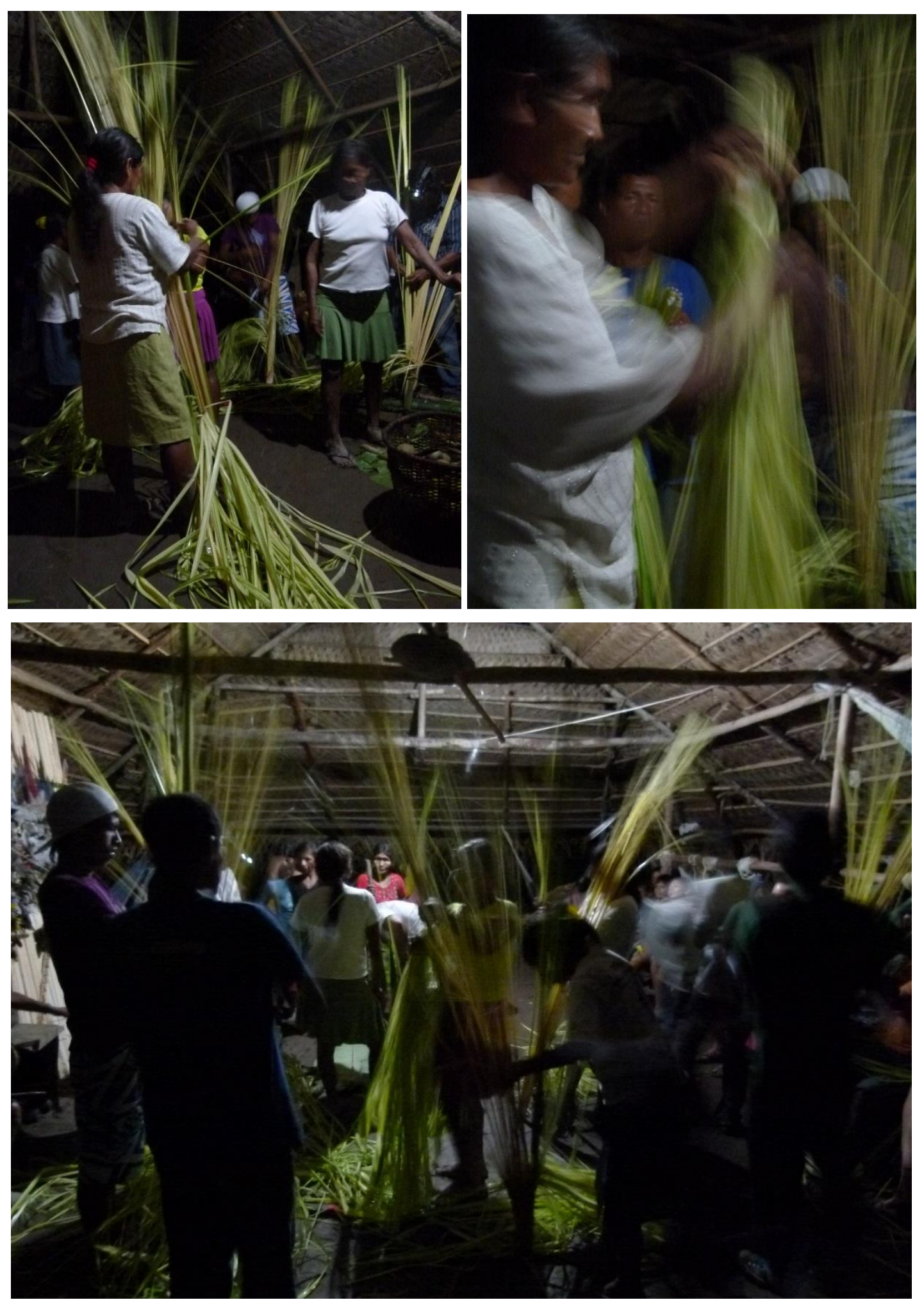


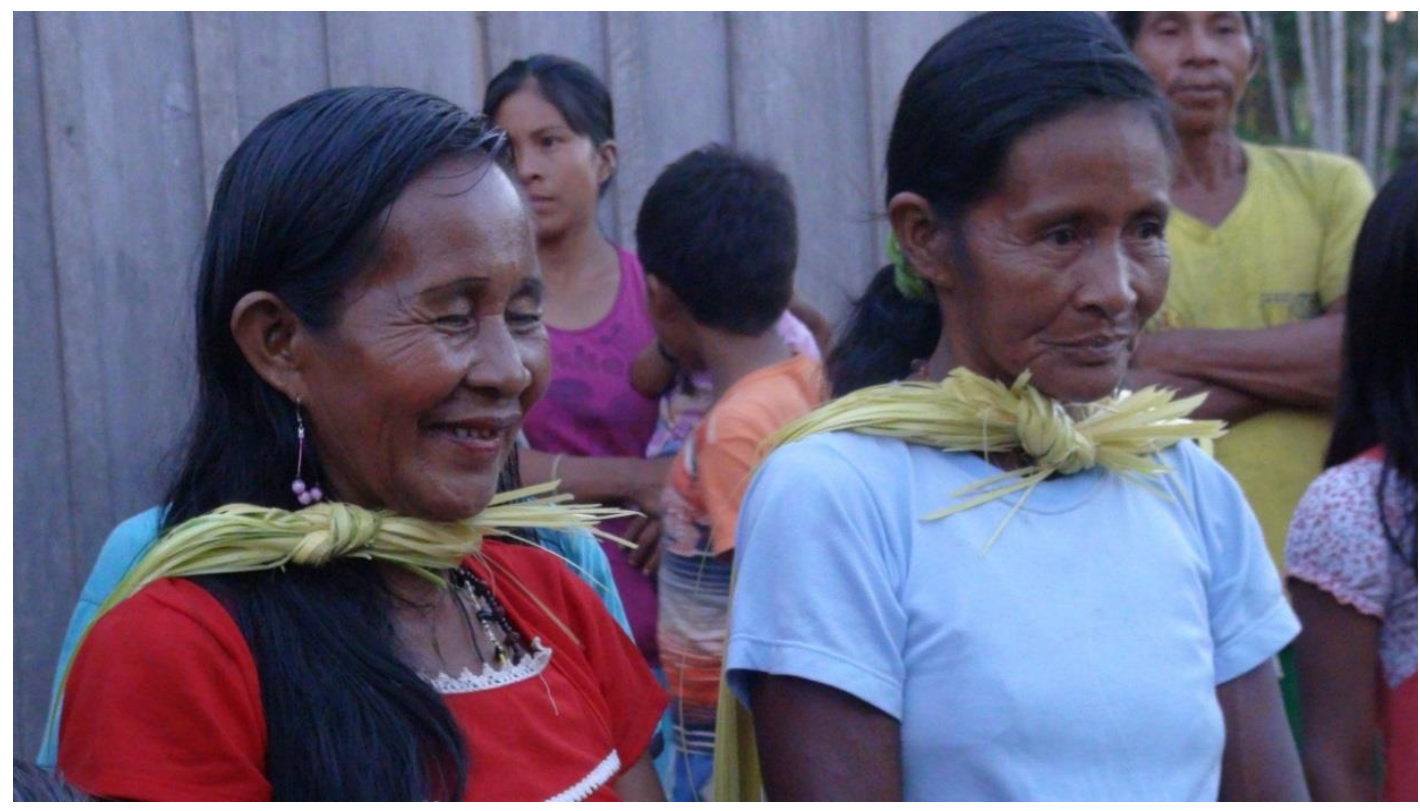

Figura 92, 93, 94, 95 - Adornos de olho de buriti

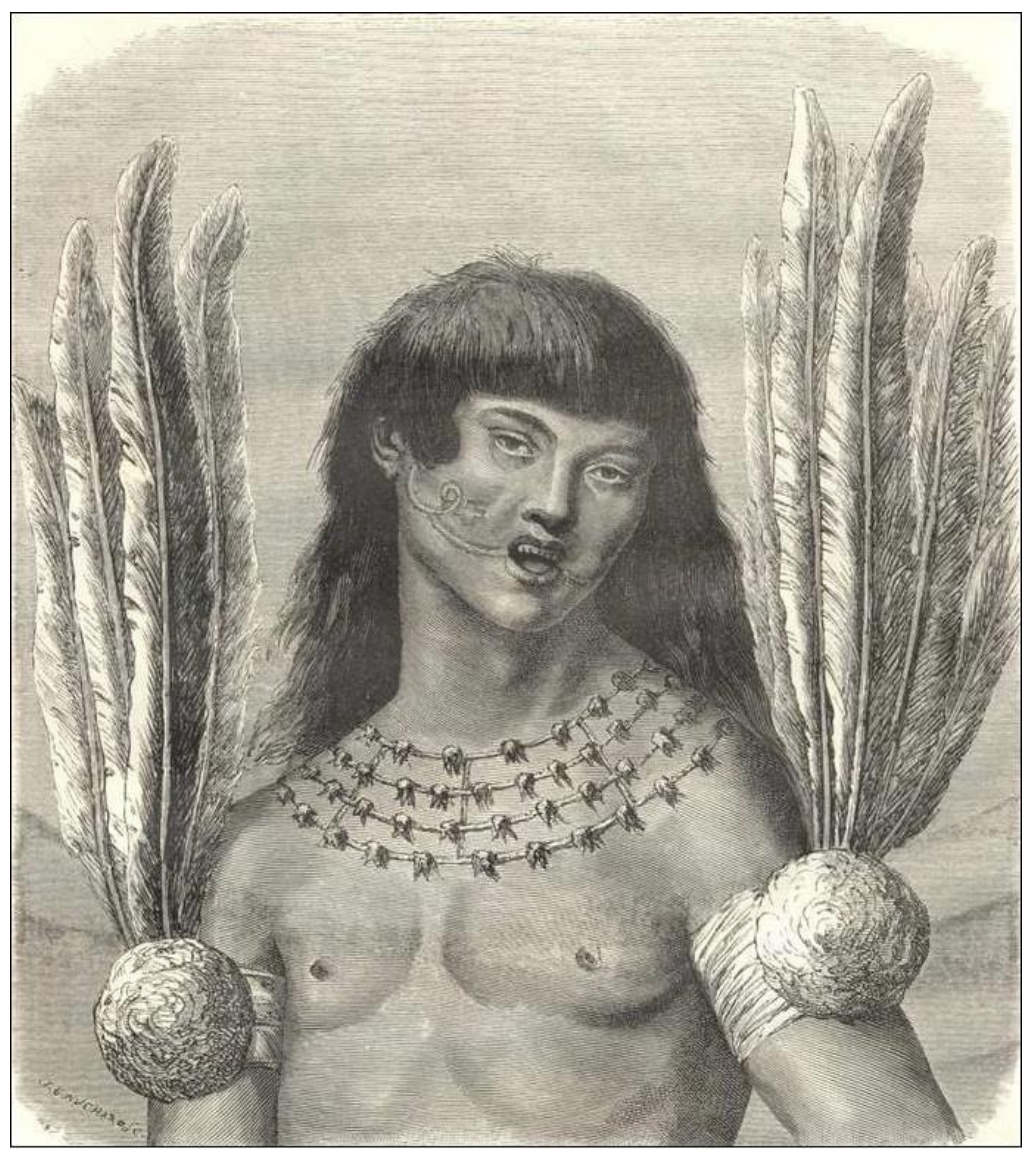

Figura 96 - No "Retrato de um índio Ticuna", gravura feita por Marcoy

(2001[1869]: 29) em sua passagem pelo Alto Rio Solimões em 1847, podemos ver os antigos braceletes ticuna. 
$\mathrm{Na}$ parede da frente do quarto reclusão ficam os adornos que a moça vestirá quando for sair da reclusão. São feitos de penas de maguari (cowa - Ciconia maguari), mutum, arara, mergulhão, gavião (iinjü), pato do mato (patú - Sarkidiornis sylvicola), além de cascas de caracóis (meerú). Laelsio, ticuna morador de Nazaré, me falou que o caracol (meru), cuja casca é usada como enfeite da moça nova, não morre nunca. "Só se alguém matar, porque de velho ele não morre. Tem passarinho que come ele". Vamos notando, com isso, que muitos elementos da Festa remetem à vida longa, ou mesmo à vida eterna, à imortalidade. Tününü é nome ticuna dado ao guiso. Este enfeite fica pendurado junto com a casca de caracol. O tururi (entrecasca de árvore) que se usa para fazer os braceletes da moça nova e a base de seu cocar são tirados da árvore naĩtchi ${ }^{477}$. Goulard (2010: 118) afirma que os braceletes entre os ticuna do interfluvio no Perú, usados pelas mulheres nos antebraços, eram confeccionados de cabelo humano. Atualmente são feitos de fibras de tucumã (Astrocaryum sp.) e pintados de vermelho e branco.

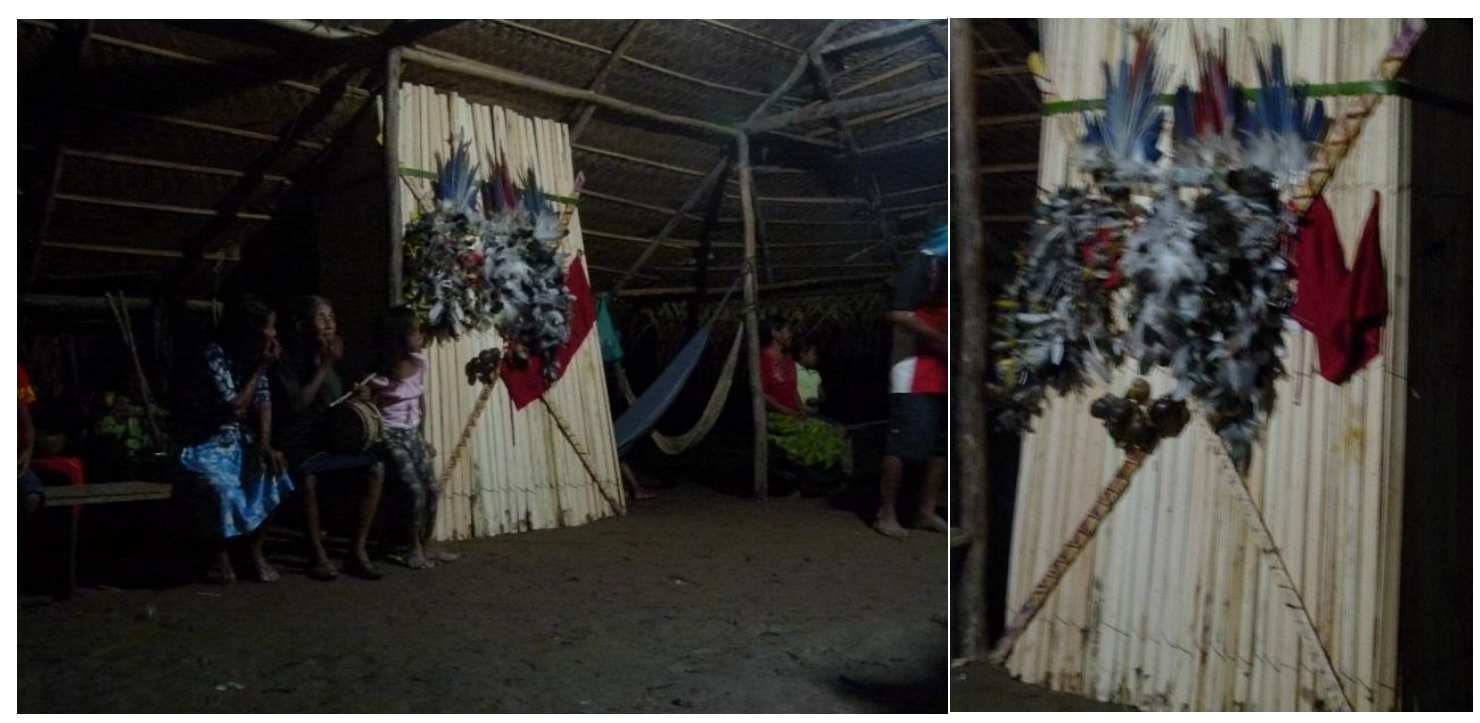

Figuras 97 e 98 - Adornos na parte da frente do quarto de reclusão

\footnotetext{
477 Me contaram que existe uma canção que é entoada durante a retirada deste tururi, naĩtchitchiga, "canção do naĩtchi". A canção menciona sobre o pênis do macaco-prego. Fala para esfolar mais rápido o galho da planta naĩtchi, assim como o macaco-prego "esfola" o pênis dele.
} 


\section{5 - A reclusão na Festa}

"Há relatos os mais fantásticos e imprecisos desta fase de reclusão"

Nimuendaju, The Tukuna, p. 73

Antes de pegarem a moça na casa dela para colocarem no quarto que foi construído, o "lixo", os restos do material usado para fazer a reclusão e os adornos, é levado para o igarapé. Neste momento vão buscar a moça. Os momentos de sair com o "lixo" e jogar no igarapé são coordenados pelo som do aru. Enquanto isso, a moça está em sua casa, ou numa casa próxima à casa de Festas, esperando para ser levada à sua reclusão. Ao mesmo tempo em que o "lixo" é levado para o rio, um grupo de mulheres vai buscar a moça nova. Isso é feito para despistar, para não acompanharem as pessoas que buscarão a moça. Tudo indica que a moça deve ser colocada na reclusão do modo mais discreto possível. Contudo, quando percebem que a moça está sendo levada, há um grande alvoroço e todo mundo quer olhar o que está acontecendo. A ação é bem rápida, a moça passa envolta em lençóis ou cobertores, acompanhada por algumas mulheres, enquanto a multidão seguiu o toque dos instrumentos que levam o "lixo" para o rio. 

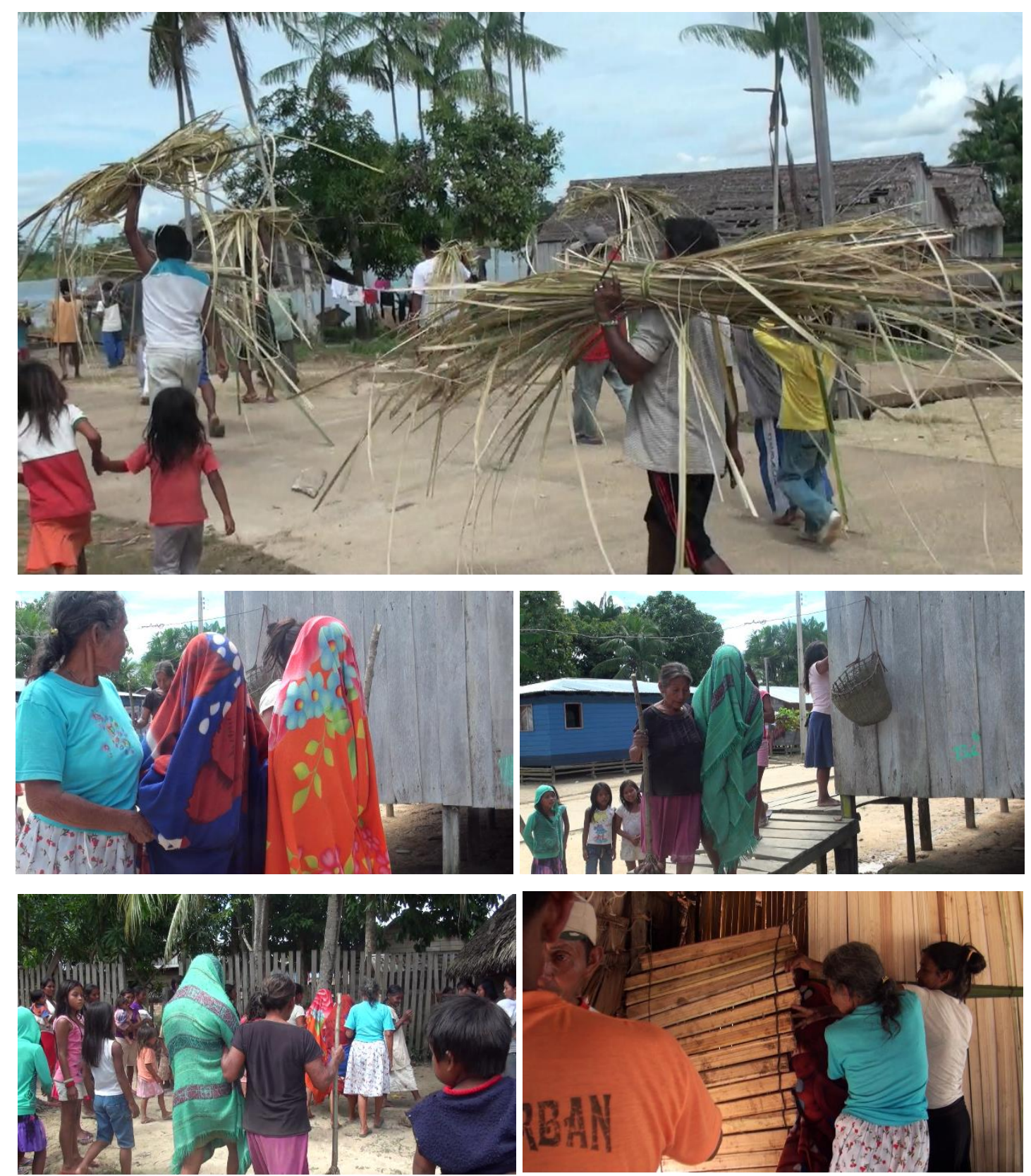

Figuras 99, 100, 101, 102 e 103 - Moças entrando no quarto de reclusão

Vejo uma oposição neste ato de levar a moça escondida e disfarçadamente para a reclusão e a ação, que descreverei agora, de buscar a carne moqueada. Nas duas Festas que presenciei em Vendaval, isso aconteceu pouco depois que a moça foi colocada no quarto de reclusão. Contudo, para buscarem a carne todos são convidados a acompanhar o casco de tracajá (tori), o bastão de ritmo (aru) e os tamborins (tutu), que seguem tocando até a casa do dono(a) da Festa. Ao contrário do que acontece com a moça nova, neste transporte é tudo feito publicamente. Cada um recebe um espeto com um pedaço de carne moqueada e trazem - com os espetos levantados para cima, bem à mostra - 
acompanhando os instrumentos. Depois de contornar a casa de Festas dançando entram e entregam o moqueado ao copeiro que coloca tudo no jirau da casa ${ }^{478}$.
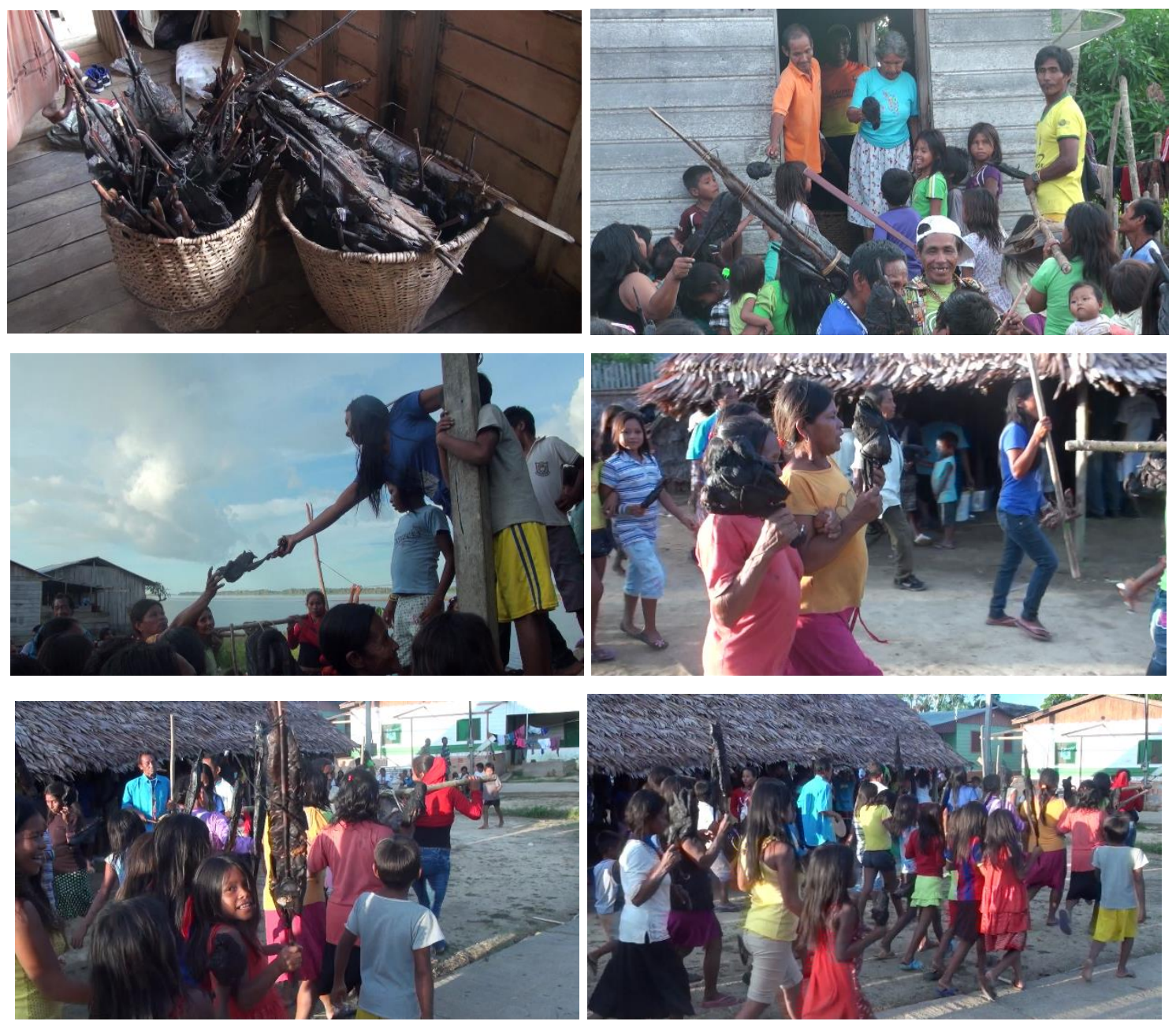

Figuras 104, 105, 106, 107, 108 e 109 - Buscando a carne moqueada

${ }^{478}$ Nimuendaju fornece uma descrição muito próxima do que eu presenciei nas Festas de Moça Nova de Vendaval. "Indo um a um em fila indiana para a cozinha, os convidados recebem do tio, que fica ao lado da plataforma segurando a carne defumada, um pedaço de carne, que cada hóspede coloca em seu ombro. Então, sempre com o anfitrião na frente, eles novamente circundam a casa três ou quatro vezes; quando entram, o tio já está esperando pela outra plataforma próxima ao quarto de isolamento. Um a um, entregam-Ihe os pedaços de carne que receberam, e estes são colocados em seus lugares novos. Depois da procissão, fazendo algumas voltas em torno da casa ao som de tambores, passam novamente antes do tio, os convidados entregando-lhe os feixes de tucum previamente solicitados, e ele trava estes em um feixe perto do quarto de isolamento. As corridas dos mascarados costumam começar a esta hora, grupos de cinco a dez pessoas, ou mesmo indivíduos, participando." (1952: 87). 
É importante destacar aqui que a carne moqueada é estocada no jirau que fica próximo ao telhado da casa de Festas e foi construído ao mesmo tempo que o quarto de reclusão. Este mesmo jirau é referido, em mitos e em relatos, como um local onde a moça nova fica reclusa também. $O$ trecho de Bates abaixo comenta sobre a reclusão das moças, baseado em observações feitas no séc. XIX. Relata principalmente onde elas eram colocadas assim que menstruavam: no jirau da casa.

\begin{abstract}
"Os Tucuna tem o singular costume - juntamente com os Colinas e os Maués de tratar as mocinhas da tribo, no momento em que se tornam púberes, como se elas tivessem cometido um crime. Elas são levadas para o jirau, junto ao teto sujo e fumarento da choupana, e mantidas ali às vezes durante um mês, em regime de fome. Contaram-me que uma pobre moça morreu ao ser submetida a esse tratamento" (1975: 294).
\end{abstract}

Pondo-se de lado os exageros e juízos de valor de Bates, a informação do autor é valiosa. Meus colaboradores ticuna também confirmaram que a menina pré-púbere tem sua cama no jirau que fica na parte superior da casa. Esta é uma medida de segurança com relação à moça. Isso nos leva a formular a hipótese de que a carne moqueada, que será entregue a alguns convidados e aos mascarados, é uma espécie de substituto da moça nova. Os mascarados vêm para a Festa para pegarem a moça, mas recebem a carne moqueada e bebida fermentada. 

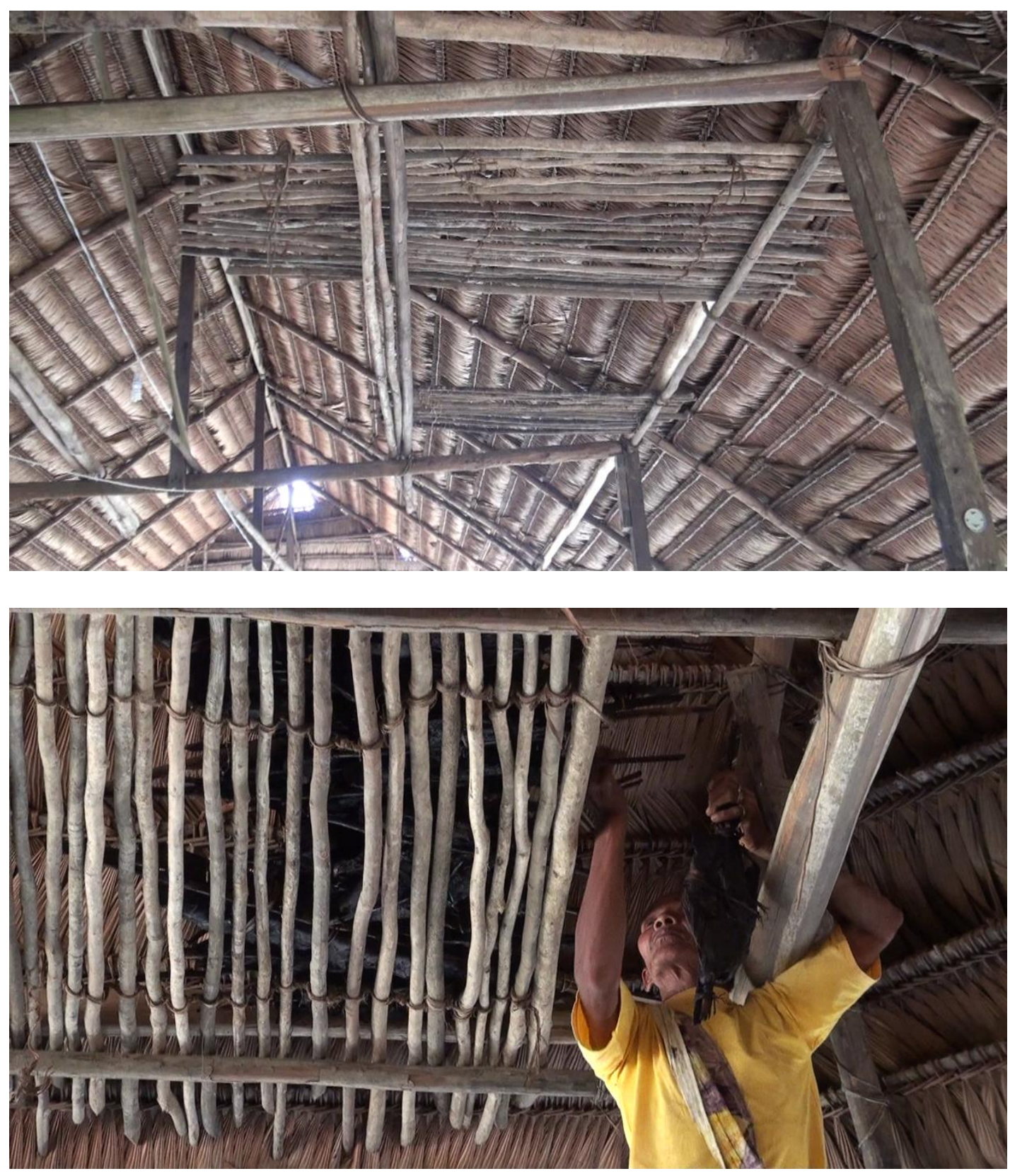

Figuras 110 e 111 - Jirau próximo ao teto da casa de Festa

Enquanto está na reclusão, a moça deve permanecer "completamente invisível e inaudível para todos, exceto sua mãe e tia paterna" (Nimuendaju, 1952: 73). Ou seja, está escondida, mas ao mesmo tempo é uma "isca" de mascarados e imortais, o que implica em formas de relações opostas no mesmo ritual. Devo salientar também que o ritual alterna momentos em que a moça é escondida com momentos de superexposição dela quando ela segura os mascarados, p.ex. Estes modos antagônicos de relação acontecendo em um mesmo ritual é chamado por Houseman \& Severi (1998) de “condensação ritual". 
Veremos mais detidamente algumas "condensações" que acontecem na Festa da Moça Nova nas Considerações Finais desta tese.

O comentário de Viveiros de Castro sobre o que significa a experiência da solidão entre os ameríndios pode nos ajudar a compreender esta situação pela qual a moça deve passar.

\footnotetext{
"A estratégia indígena é, em primeiro lugar, colocar um monte de parente na sua frente, não ficar sozinho. A solidão é uma experiência não só psicologicamente, mas metafisicamente arriscada no mundo indígena. Em suma, a solidão é patológica e patogênica. Ela cria situações de perigo, de doença, de roubo da alma e de invasão do corpo, de defecção e de infecção. Você passa para o outro lado, vira o outro. Perda de controle: você passa a ser controlado pela alteridade." (2008: 238)
}

A meu ver, a Festa da Moça Nova dos Ticuna usa este perigoso recurso da solidão para realizar a transformação da moça. Ao colocar a moça numa situação solitária, está-se pretendendo atrair os seres, principalmente os imortais. Contudo, a Festa deve estar preparada para os convidado nocivos também: os mascarados. Ou seja, os jovens púberes, especialmente as moças novas, estão sujeitos ao contato benéfico com os imortais (ü'üne) ou perigoso com os bichos (ngo'o).

\section{6 - Madrugada adentro - Trompete de Bambu, Jenipapo e Tururi}

Na madrugada as danças continuam e a maioria dos participantes são os jovens e adultos. As redes estão penduradas nas laterais da casa de Festa. Deste modo, quem estiver com sono pode se retirar para dormir no próprio local da Festa. Neste período os trompetes to'cü e iburi são tocados no cercado dos instrumentos, atrás do quarto de reclusão da moça, longe dos olhos das mulheres e crianças. Alguns mascarados aparecem de noite também. No meio da madrugada, as danças são interrompidas por um instante para que o centro da casa seja o local da confecção de alguns objetos rituais. Neste momento são fabricados os trompetes de bambu (coĩri), é tirado o tururi para fazer o 
cocar e outros adornos da moça, e o jenipapo é ralado ${ }^{479}$. Já vimos um pouco sobre os trompetes de bambu dos Ticuna ${ }^{480}$, o que pretendo mostrar agora é a performance feita com estes instrumentos antes deles serem distribuídos para os tocadores.

Os materiais, em geral, já foram buscados de tarde por um grupo com o "copeiro" à frente. Gruber descreve como são buscados os bambus para se fazer os instrumentos.

"No primeiro dia da festa, à tarde, uma comitiva formada por homens e

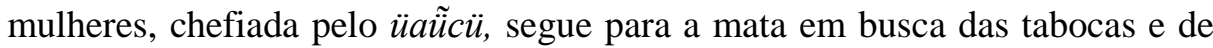
outros materiais, levando também alguns tamborins e chocalhos de vara. Antes de tirar as tabocas é preciso balançá-las para se ter certeza da presença de liquido em seu interior. Estas, então, são selecionadas e cortadas embaixo. Esse trabalho é feito ao som dos tamborins e chocalhos, que também são tocados durante o percurso de volta a casa." (1999: 19)

Uma grande quantidade de jenipapo e algumas varas de tururi são trazidos juntos com os bambus. Os bambus dos coĩri são medidos, cortados, afinados e os bocais são testados. Depois de prontos, eles são colocados juntos com as cascas de tururi, as flautas tchecü e um pajé faz o benzimento em cima deles, para que não façam mal a ninguém. $\mathrm{O}$ trompete coĩri imita o som da queixada, a voz da queixada. Os próprios instrumentos seriam a "sombra dos pés das queixadas" (coĩritchiru cutü). "Quando o pajé reza o coĩri, ele abre o caminho para a queixada vir para perto da casa", me disse um ticuna. Todo bando de queixadas possui um chefe (poratchata) e a avó (tawyana) deles, que é o animal maior do grupo. Os dois guiam o bando e é com eles que o pajé estabelece relações para atraí-los. Durante a performance das pessoas que imitam os queixadas, avançando sobre os instrumentos para tomarem o pajauaru, os trompetes são o próprio caminho dos

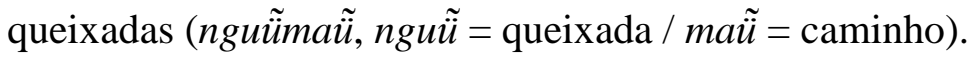

Em Santa Clara, os instrumentos e adornos foram confeccionados na manhã do penúltimo dia de festa. Quando os coĩri estavam prontos perguntei quem iria benzê-los. As pessoas diziam que não sabiam, pois naquele momento não havia pajés na comunidade. No final das contas, o filho do cacique da comunidade se encarregou de

\footnotetext{
479 A Festa da comunidade de Santa Clara foi uma exceção, como veremos nas fotos, a construção dos trompetes, a ralação do jenipapo e a retirada do tururi foi feita no sábado de tarde.

${ }^{480}$ Cf. Capítulo 6, tópico 6.3 - Demais instrumentos musicais.
} 
benzer os trompetes. Este tipo de "dúvida" sobre a existência de pajés na comunidade é bastante comum entre os Ticuna. Apenas com a convivência na aldeia que se descobre quem são os xamãs. Esta posição não costuma ser alardeada. Um xamã quando começa a se tornar muito poderoso/perigoso acaba se tornando um candidato a ser executado ${ }^{481}$.

Junto com os coĩri, o pajé também benze uma cuia de pajauaru e a água que saiu dos bambus (coirritüü) usados para fazer os trompetes. O efeito que a reza tem sobre os bandos de queixadas é descrito por Gruber como segue:

"O pajé reza demoradamente esses materiais, abrindo o "caminho" para que as queixadas se aproximem da aldeia. Assim, o "guia" das queixadas, aquela queixada maior que lidera o bando, perde o controle de seus animais que, desorientados e atraídos pelas rezas, encontram a "linha" (caminho) marcada pelo pajé, da aldeia até a mata, e através dela vão se aproximando. Segundo os ticunas, depois das festas muitas vezes aparecem queixadas até mesmo dentro da aldeia, deixando-se pegar com facilidade.” (1999: 19-20)

Depois dos benzimentos, com fumaça de tabaco e movimentos direcionados ao poente $^{482}$, acontece uma performance de alguns voluntários. Na frente da fileira de trompetes coĩri e flautas tchecü colocaram uma tigela cheia de pajauaru. A pessoa ia de quatro até a bebida, como se fosse um porco do mato ou alguma caça, passava por cima dos instrumentos, bebia um pouco sem colocar as mãos na cuia, corria de quatro, rolava no chão e parava como se tivesse sido alvejada por um disparo mortal. Tudo isso era acompanhado de gargalhadas da plateia. Como se o animal tivesse sido pego numa armadilha, uma emboscada. Parou para beber pajauaru e foi pego pelo caçador.

\footnotetext{
${ }^{481}$ Cf. Capítulo 4, tópico 4.1.6 - História do pajé Augusto - a execução do feiticeiro.

${ }^{482}$ Ao que parece o "caminho da caça" - especialmente os queixadas -, que é aberto pelo pajé que benze os instrumentos, vai neste sentido.
} 

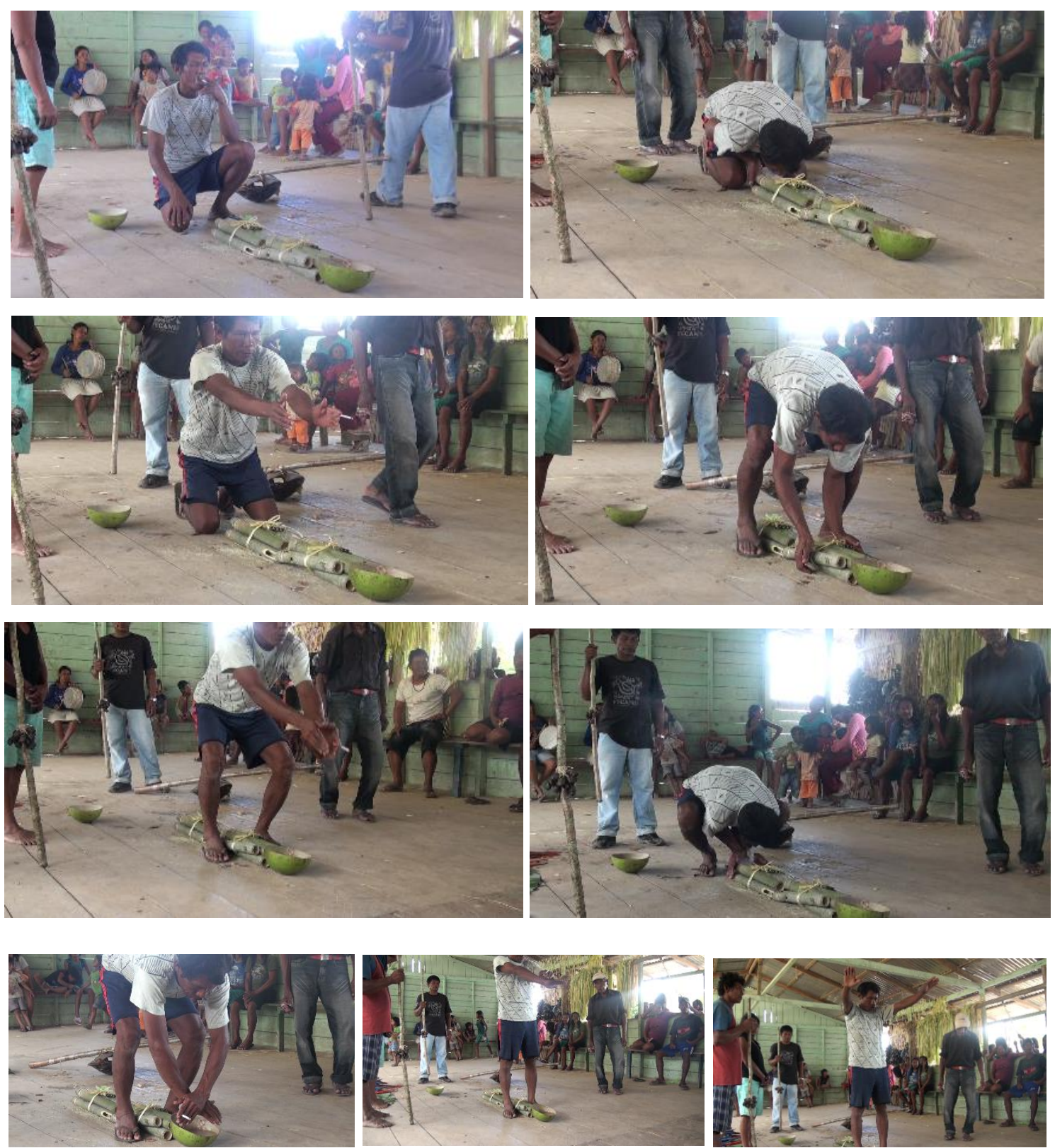

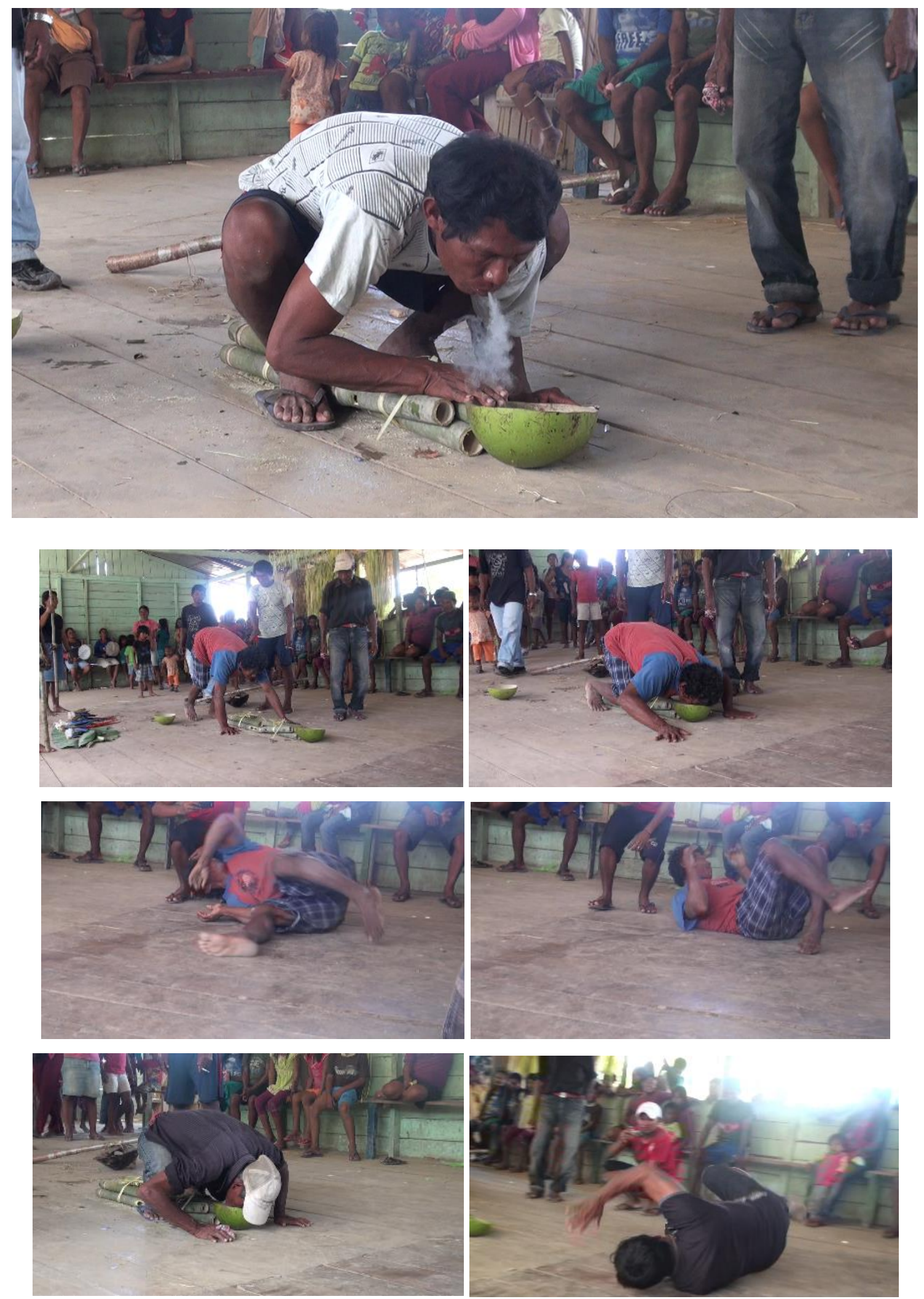

Figuras 112, 113, 114, 115, 116, 117, 118, 119, 120, 121, 122, 123, 124, 125, 126 e 127 - Benzimento dos trompetes de bambu e "queixadas" bebendo pajauaru e morrendo 
Sobre a imitação dos queixadas, um colaborador de Valenzuela comenta sobre o pajauaru que é bebido pelos "animais" e menciona não somente queixadas. Faz-se o caminho para que os animais não desapareçam.

“[E]l camino para que no se desapareció los animales (...) se está haciendo la imitación como salado y hacer imitación para que no se pierdan desapareció los animales (...) que vengan, que salgan, donde que están encerrado que vengan que no aparecen, todo clase de aves, garzas, paujiles, tentes, gavilanes, cóndor, mejor dicho todo, los pescados que no se hace falta, sigue llegando (...) el masato echan ahí, ese va a ser la imitación de cómo salado, hágale, puede beber ahí los churucos, cotudo, cerrillo, venados, guanganas, danta, tapir, borugo, guara, toda clase de animales usted puede hacer en la imitación; y mire, hay algunos con cría, algunos bebiendo, otros están como cazador" (2010: 120-21).

O que don Javier José refere como "salado" me foi referido pelos ticuna do Brasil como chavascal, uma espécie de lamaçal onde alguns animais vão beber água ou chafurdar na lama. Do nosso ponto de vista é um lamaçal, para os animais é o pajauaru que eles bebem e fazem Festa.

Esboço abaixo uma análise sobre esta encenação ritual de homens-queixadas. Para tanto, recorro principalmente ao artigo "A Gesta de Asdiwal", de Lévi-Strauss (2013[1958]). Publicado originalmente em 1958, este pode ser considerado um dos textos fundadores da análise estrutural da mitologia ameríndia, certamente é um dos mais didáticos neste tipo de análise. Em sua análise, Levi-Strauss não somente utiliza as quatro versões registradas deste mito dos índios Tsimshiam ${ }^{483}$, como também lança mão de informações sobre rituais deste povo. Segundo o autor, Os Tsimshiam "concebem a si mesmos como sub specie piscis", ou seja, como uma espécie de peixe. Isso implica que, durante o preparo destes animais para a alimentação, são observados vários ritos. Sobre estes ritos, Lévi-Strauss afirma o seguinte:

"Tais proibições e prescrições parecem traduzir uma mesma intenção, a de "imediatizar" a relação entre o peixe e o humano, tratando-o como se fosse um humano, ou pelo menos reduzindo ao máximo o emprego de objetos manufaturados, que são da ordem da cultura, ou seja, negando ou subestimando aquilo que faz com que os peixes não sejam humanos" (2013[1958]).

${ }^{483}$ Povo habitante da Columbia Britânica. 
A análise de Lévi-Strauss nos mostra que, para os Tsimshiam, por um lado, o ritual deve negar e subestimar "aquilo que faz com que os peixes não sejam humanos" (negação do não-ser ou consideração dos peixes como "nós" sujeitos, da mesma sub specie piscis). "Somos como vocês, continuem subindo o rio para que possamos matá-los e comê-los", pensaria um xamã tsinshiam, no sentido de negar a não-presença do alimento. Por outro lado, os mitos enfatizam o contrário. Desconsiderando a forma humana que vê os peixes, o príncipe transformado em peixe deve matá-los (negação do ser), ou seja, o que se nega aqui é a identificação abusiva do homem ao salmão, não sendo a identificação do salmão ao homem um problema. Pelo contrário, é desejada, como mostram os rituais (que provavelmente evitam uma vingança dos peixes: “...o herói consumiu as espinhas, visto que no final elas saem de seu estômago e provocam sua morte”, 2013[1958]: 201 nota 27) e como possibilita a posição reflexiva da humanidade.

Da mesma maneira a "identificação abusiva" dos Ticuna com os peixes é negada durante a pescaria de Yoi, no mito de origem. Ao pescá-los, Yoi transforma-os em gente e em caça, dependendo da isca que utiliza. Ou seja, trata-se, como vimos acima, de uma negação do ser, a própria especiação que podemos averiguar em diversos mitos. Contudo, o que ocorre no ritual é uma negação do não-ser, nas palavras de Lévi-Strauss. Não há apenas um estabelecimento de uma continuidade num âmbito onde o mito impõe uma ruptura. Não se trata de afirmar o ser, isto é, torna-se outro (peixe, queixada, etc). Ao tornar-se outro, esta identificação abusiva deve ser negada, a pessoa que performatiza o queixada no ritual é morta numa emboscada. Contudo, os queixadas, para serem atraídos para perto da Festa e para se evitar a vingança desta presa assim como dos peixes, devem se identificar aos humanos, algo que é desejado pelos humanos e que é possibilitado pela posição reflexiva da humanidade. Lembremos que as pessoas bebem o pajauaru sem usar as mãos, como fariam os queixadas em seus domínios. Fazendo isto, parafraseando o trecho acima de Lévi-Strauss, está-se subestimando aquilo que faz com que os queixadas não sejam humanos. Formalizando esta transformação com a ajuda da fórmula canônica do mito ${ }^{484}$, temos o que segue:

\footnotetext{
484 Utilizo aqui a fórmula como foi descrita originalmente em Lévi-Strauss (2012[1955]), Fx(a) : Fy(b) :: $\mathrm{Fx}(\mathrm{b}): \mathrm{Fa}^{-1}(\mathrm{y})$, existe outras variações possíveis. A forma como preenchi os termos da fórmula foi inspirada no texto de Kelly (2010) sobre a relação entre a fórmula canônica do mito e o perspectivismo multinaturalista.
} 
Fpresa (queixada) : Freflexividade(humano) $::$ Fpresa(humano) $:$ Fqueixada $^{-1}$ (reflexividade) $^{-}$

O lado esquerdo da fórmula representa a relação convencional entre humanos e queixadas. A transformação encontra-se no lado direito, em que é atribuída a capacidade reflexiva às queixadas (Fqueixada ${ }^{-1}$ (reflexividade)). Desta maneira, os Ticuna devem tornar-se presas durante o ritual - terceiro termo da formula acima (Fpresa(humano)) para que a posição reflexiva seja agenciada por outras gentes, suas futuras presas. Contudo, ao agenciarem a posição reflexiva, de humanos, os queixadas se invertem (-1), tornam-se predadores. A Festa ticuna, portanto, nega e subestima aquilo que faz com que os queixadas e peixes não sejam humanos (mais uma vez, nega o não-ser). Lembremos que na Festa da Moça Nova os trompetes coĩri são os próprios queixadas em suas festas, bebendo pajauaru.

Assim como a performance dos homens-queixada, é de madrugada que acontece a ralação ritual do jenipapo. Sabemos que o jenipapo é uma fruta muito importante na mitologia ticuna. Como vimos no Capítulo 2, tópico 2.1 - A passagem para a América do Norte, o jenipapo ralado por Ipi - na verdade, ele começa ralando um jenipapo, mas acaba se ralando todo no ralador - tem seu bagaço e caroço jogados na água, transformando-se em peixes que, depois de pescados transformaram-se no povo magüta, os Ticuna.
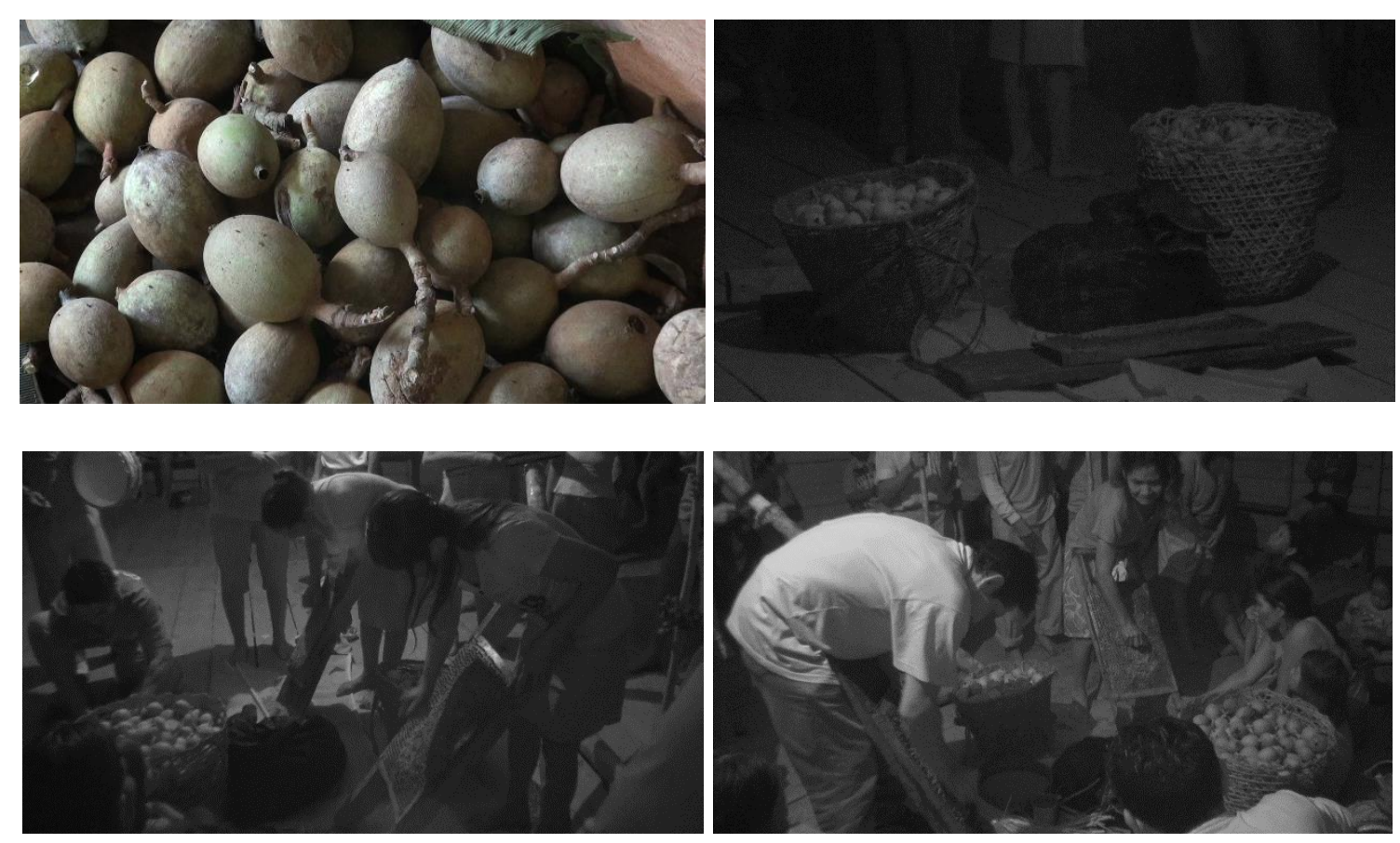

Figuras 128, 129, 130 e 131 - Ralando jenipapo 
Podemos notar um paralelo estrutural interessante entre a ralação ritual do jenipapo e a figura de Ipi se ralando no ralador. Enquanto este último começa ralando um jenipapo e acaba ralando o corpo todo, sobrando somente o caroço e o bagaço; no ritual a fruta só é esfregada no ralador uma única vez, num único sentido. Ou seja, aparentemente a ralação ritual repara um excesso cometido no mito. Contudo, passar o jenipapo apenas uma vez seria um excesso também, então, é necessário uma série de pessoas se revezando para ralar. A ralação do jenipapo começa, portanto, num processo lento. Alternadamente, uma pessoa de cada metade exogâmica - "com pena" e "sem pena" - deve passar o jenipapo pelo ralador, a princípio, uma única vez. As metades vão se alternando, pessoas da metade "sem pena" devem passar a fruta no ralador de baixo para cima, as pessoas da metade oposta, “com pena”, fazem o contrário, passam o jenipapo de cima para baixo ${ }^{485}$. Depois de um certo tempo, devido à grande quantidade de jenipapo, alguém acaba ralando todo o resto que está no cesto. No mito, Ipi, depois de todo ralado, seu corpo transformado em bagaço e caroço de jenipapo entra (ou é jogado) no rio e se transforma em peixe, que será pescado e virará gente magüta:

Jenipapo $\rightarrow$ excesso de ralação $\rightarrow$ caroço/bagaço $\rightarrow$ peixe $\rightarrow$ gente magüta

$\mathrm{Na}$ festa, o jenipapo é ralado e passado em todo o corpo da moça nova, transformando-a em mulher adulta, casável.

Jenipapo $\rightarrow$ ralação contida $\rightarrow$ sumo da fruta $\rightarrow$ pintura corporal e banho final no rio $\rightarrow$ adulta casável.

O jenipapo é ralado de madrugada, por volta das três horas da manhã começam a ralar até amanhecer. A retirada do tururi também é uma tarefa árdua e demorada. Devese bater no tronco com força para soltar a casca, mas com cuidado para não rasgar. O que

\footnotetext{
${ }^{485}$ Apesar de tratar da pintura das crianças e não mencionar a ralação do jenipapo para a moça nova, Goulard neste caso contradiz o que observei em campo com relação à ralação do jenipapo. Contudo, de acordo com minhas observações, a direção do movimento das mãos que seguram a fruta a ser ralada era determinada não pelo clã da moça que seria pintada - como informa Goulard com relação ao recémnascido que será pintado -, importa, neste caso, o clã a que pertence a pessoa que está ralando a fruta. O trecho de Goulard é o seguinte: "Outra prática é consistente com essa oposição: o fruto do jenipapo é ralado de maneira oposta, de acordo com a metade a qual pertence a criança a ser pintada após o seu nascimento. Se ela é de um clã Com penas, o movimento da mão vai de cima para baixo, ao passo que se ela for de um clã Sem pena, ele é invertido, ou de baixo para cima." (2004: 90-91). Cf. também Goulard, 2009: 120.
} 
é retirado é muito similar a um tecido. Quando terminam de ralar o jenipapo, tiram o sumo. Depois de ralar e espremer, os festeiros vão lavar o rosto no rio. Quando todo mundo sobe, vão pintar o corpo dela de jenipapo, só as pessoas do clã dela. O pajé tem que rezar sobre o jenipapo que será usado para pintar a moça nova, para que ela não sinta o cheiro da fruta. Se ela sentir o cheiro, pode morrer rapidamente. Se não sentir, terá vida longa. Como mencionei anteriormente ${ }^{486}$, Nimuendaju comenta que, antes de começarem a pintar a moça de jenipapo, "o tio paterno vai até a reclusão da garota para fechar suas narinas com um gesto mágico que consiste em torcer alguma coisa; se ela sentir o odor do jenipapo prematuramente, ela vai morrer" (1952: 86).

Quando já é de manhazinha, os "copeiros” dão banho na moça nova com água. Ela é trazida para a parte de traz do quarto de reclusão, no cercado dos instrumentos. Entre estes dois ambientes existe uma pequena passagem, a mesma pela qual a moça passa a bebida para os trompetes e os tocadores. Neste momento, pela manhã, os trompetes tabus já se retiraram da Festa. No cercado dos instrumentos (to 'cüpüü) ela é pintada de jenipapo da cabeça aos pés. Ela está completamente nua e "cobre os olhos com as mãos para protegê-los do sol" (Nimuendaju, 1952: 86). Além de não olhar para ninguém e evitar ser vista - exceto neste momento de super-exposição - a moça evita o sol.

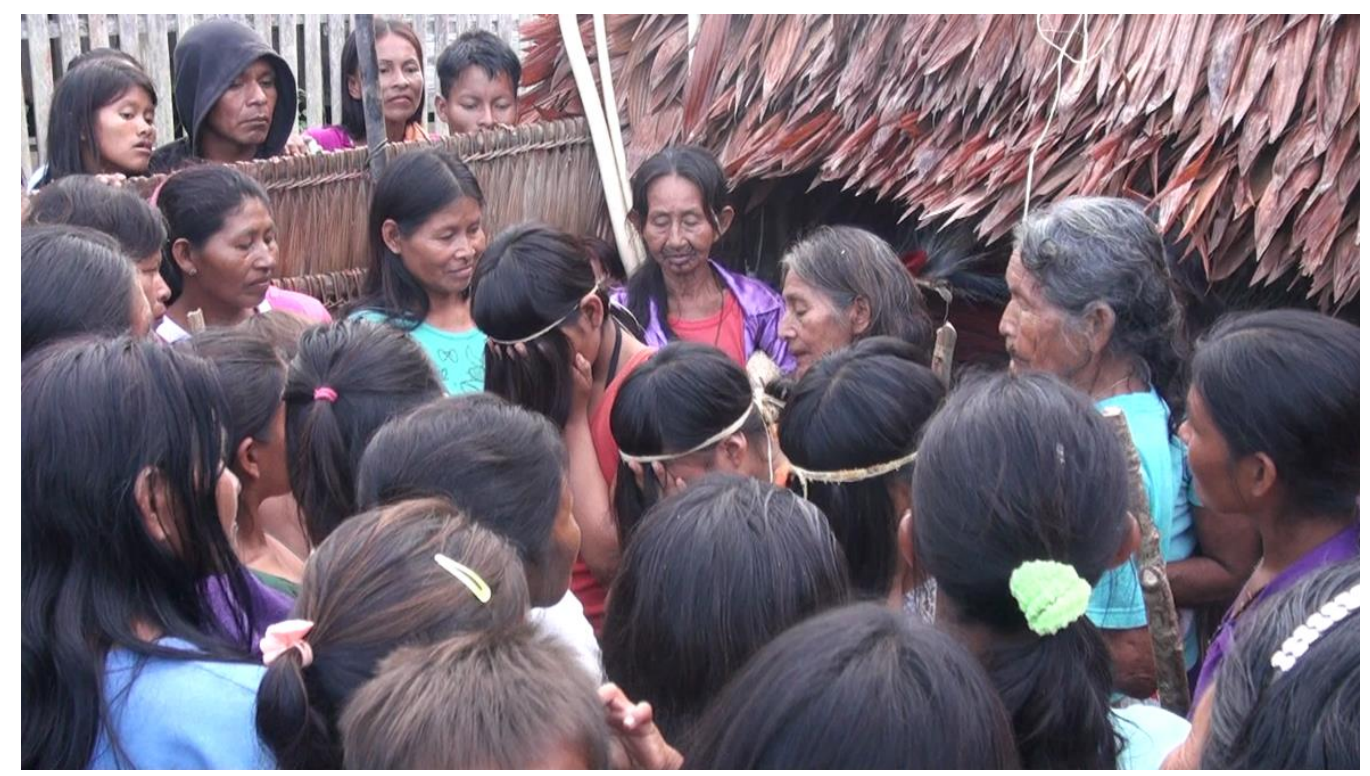

Figura 132 - Momento da pintura com jenipapo

\footnotetext{
${ }^{486}$ Introduzi um pouco sobre o jenipapo entre os Ticuna no Capítulo 4, tópico 4.3 - Jenipapo e Urucum.
} 
Durante a pintura da moça com jenipapo, muita gente se aglomera para ver o que está acontecendo. O bastão de ritmo ( $a r u)$ e o tamborim $(t u t u)$ estão tocando, mas a figura principal, além das moças, é o(a) cantor(a). Este é um momento em que a moça ouvirá um canto cheio de vitupérios, ensinando a ela não agir mal, especialmente com seus pais. Transcrevo abaixo alguns trechos em que isso aparece na "canção para pintar a moça com jenipapo":

Nama ga cu'ü̈ naeneta ga gunegü

"Com [o jenipapo] os convidados pintavam em ti"

Nha' $\ddot{u}$ i ngema ya cutchiga pa tchaurita pa woworecü

"Assim é a sua história, minha netinha/sobrinha, moça nova"

(...)

Ngegumata ga mamãe

Damatata ga tchigurü' ütaya

"Quando você age como aquela cotia com sua mãe"

(...)

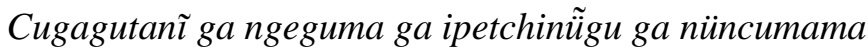

Ga utüne ga powopaweru cucatayeata ya wü̈̈tchi

"Antigamente você era culpada quando você estava lá na beira"

"O caniço foi fincado e sua ponta chegou do outro lado do Eware"

Ngegumatata ya cuĩya yeata ya cuaineta ga cugagu pa woworecü

"Você era culpada quando você ganhou uma surra porque estava lá [na beira], moça nova"

$(\ldots)$

Taüena ga aneё̈tchacua

"Não conheça a vergonha"

Rü ngemacani 'ĩ ga cutchigama yea caeatchi ga iraruwa

"É sim com sua história que eu estou cantando um pouquinho lá" 


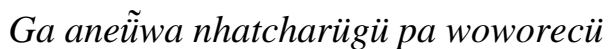

"Era vergonha, assim eu disse, moça nova"

Vimos no Capítulo 5, tópico 5.3.2.2 - Canções de aconselhamento, que a moça ao ser aconselhada é muitas vezes comparada à cotia. Durante a tradução da canção, o professor Darciano ${ }^{487}$, me explicou esta referência à cotia da seguinte maneira: "quando encontramos a cotia no mato ela briga com a gente. Quando a moça nova briga com a mãe, não obedece, ele está agindo como uma cotia". Daí as muitas comparações da moça com a cotia no momento do aconselhamento. Quando ela é pintada de jenipapo pela manhã é um deste momentos do que chamei de "canções de aconselhamento". Vemos nos excertos acima, como mostrei no referido tópico, o tema da vergonha. O cantor(a) insisite para que a moça não tenha vergonha, "não conheça a vergonha". O ponto alto deste aconselhamento, como veremos, é a saída do quarto de reclusão e o momento de arrancar os cabelos da moça. Ao final da pintura de jenipapo, a moça é abanada com ramos de folhas de taperebá pelas pessoas que a circundam. Depois de abaná-la, as folhas são jogadas em cima da casa, ao mesmo tempo, ao toque do bastão de ritmo (aru) e com o grito de "уӥӥӥ̈"488.

\footnotetext{
${ }^{487}$ Professor Darciano Manduca Bibiano, morador da comunidade de Campo Alegre.

${ }^{488}$ Nimuendaju descreve desta maneira esta parte do ritual: "todos caminham lentamente em volta dela e tocam-na levemente com as folhas, invertendo a direção da marcha várias vezes. Enfim todos gritam em coro: "dye!" e joguam as folhas em cima do telhado de palha." (1952: 88).
} 

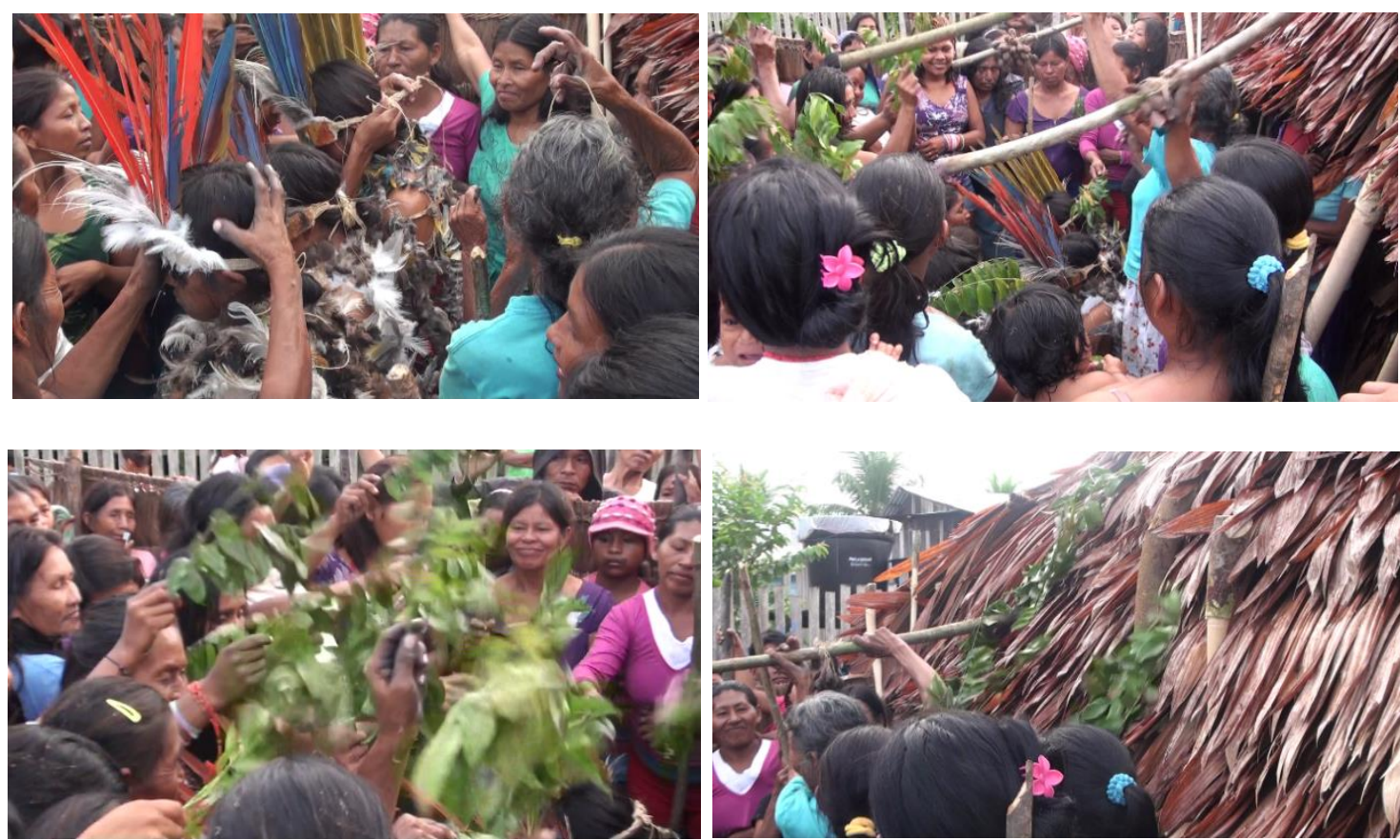

Figuras 133, 134, 135 e 136 - Adornamento das moças e abanação com taperebá

Além de ocultar o cheiro de sangue expelido pela moça nova (Valenzuela, 2010: 98), o jenipapo é uma substância que "troca" a pele da moça por uma pele nova. De acordo com a explicação de Adélia, "quando a criança nasce tem que pintar, para tirar aquela pele velha. E sai a pele. Por isso que pintam a moça nova também. Sempre pinta a moça nova porque protege a vida dela. O jenipapo renova a pele. E tira o cabelo para vir um cabelo novo". Começamos a antever aqui, na pintura da moça com jenipapo, um dos componentes do processo de troca de "pele" da moça, que envolve não somente a pele propriamente, mas também o sangramento da menstruação e os cabelos que são arrancados.

Feito o pequeno ritual da pintura de jenipapo, a moça retorna para o quarto de reclusão, enquanto o restante dos adornos é terminado, principalmente o cocar. As penas deste cocar representam o sol e ele começou a ser confeccionado logo após o nascente (Faulhaber, 2000: 105-107). Depois que o cocar está pronto, chega o momento de "apresentá-lo", uma das principais tarefas desempenhadas pelo "copeiro". Podemos considerar esta apresentação uma terceira dança da Festa da Moça Nova, além das danças do tracajá e do tamborim. É uma dança em que o "copeiro" apresentar os enfeites de pena da moça nova (worecüruane, worecü = moça nova $/$ ruane $=$ enfeite $)$, principalmente o cocar (ngoucüra) dela. Podemos denominar esta dança como naruametaanitchi (naruame 
$=$ enfeite de pena, taanitchi $=$ apresentar), a "apresentação dos enfeites de pena". Empunhando o bastão de ritmo (aru), com o cocar da moça na cabeça, o copeiro dança para frente e para trás com todos aglomerados atrás dele. Apesar do copeiro apresenta o cocar da moça vestindo-o, ele é usado apenas pelas moças, homens não usam.
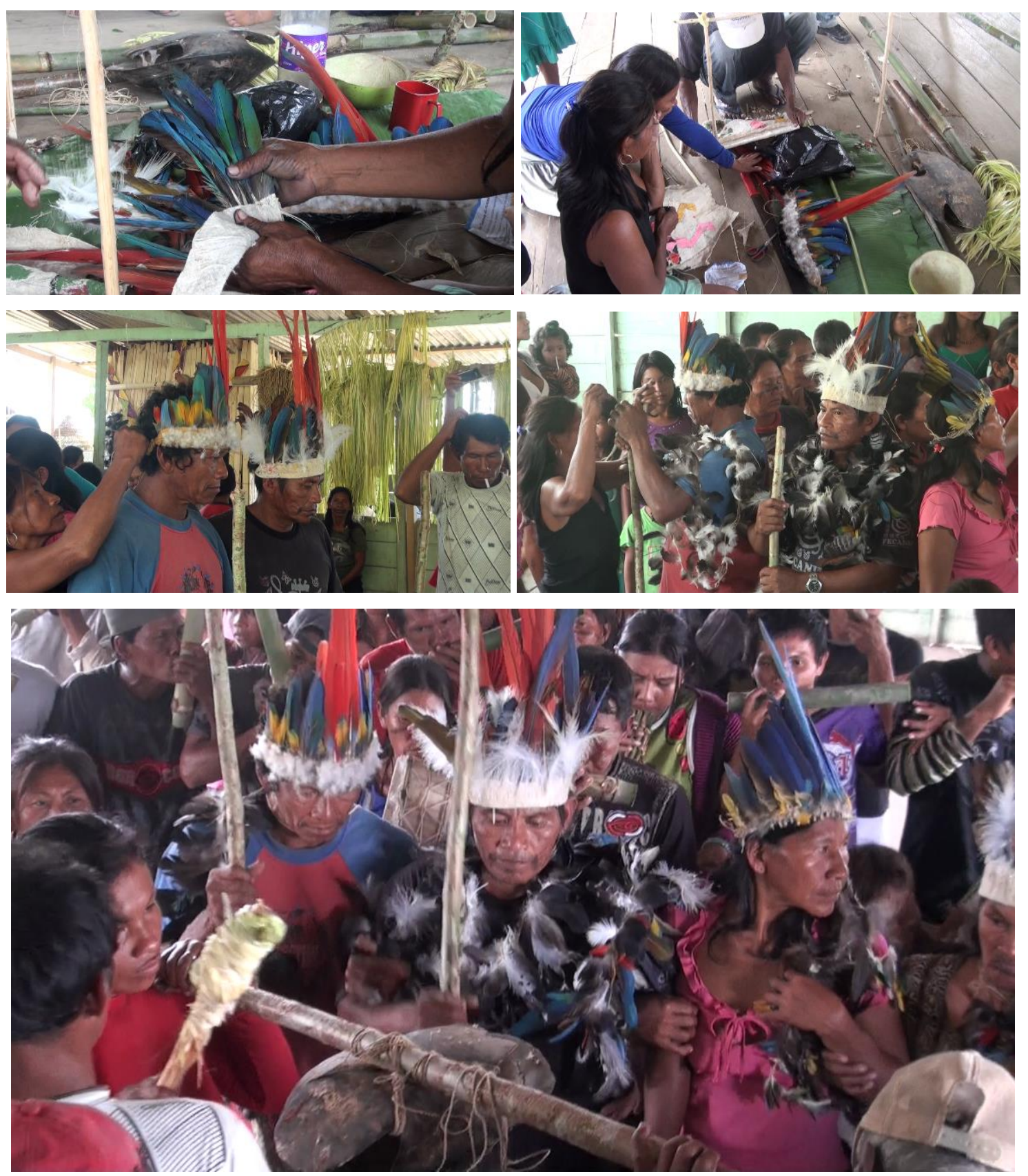

Figuras 137, 138, 139, 140 e 141 - Confecção do cocar e apresentação dos adornos das moças pelos "copeiros"

Interessante notar que o copeiro veste todos os trajes da moça nova e dança no centro da casa antes da moça ser vestida e sair da reclusão. A paramentarão é toda igual 
a da moça nova, com a diferença que o copeiro, em geral um tio paterno da moça, vai tocando o bastão de ritmo (aru). Pude observar isso em Santa Clara. Fica, portanto, a questão de porque o copeiro se veste de moça nova? Podemos estar diante de mais uma inversão de gênero presente nas Festas de Moça Nova, assim como vimos que os cantores cantam em falsete na Festa, ou seja, com voz de mulher ${ }^{489}$. Retomaremos esta questão nas Considerações Finais.

\section{7 - Mascarados}

Depois que o dia clareou, a moça e as crianças foram profilaticamente pintados de jenipapo, começam a chegar os primeiros mascarados da Festa. Segundo o colaborador de Valenzuela, o número de mascarados será limitado pela quantidade de carne moqueada que o "dono da Festa" tem para oferecer. O próprio dono convidará uma quantidade de mascarados condizente com a quantidade de moqueado que possui ${ }^{490}$. Todo mascarado receberá sua parte da caça e dos peixes defumados, além de beber muito pajauaru e seu caldo.

Os Ticuna possuem uma variedade grande de máscaras rituais. A fabricação destes trajes é um trabalho exclusivamente masculino (Goulard, 2011: 140). A matéria-prima principal utilizada para a confecção destas máscaras são as entrecascas de árvore, chamadas tururi, das quais existem diversos tipos. De acordo com o Dic. Houaiss, tururi é uma palavra de origem tupi. Entre os Ticuna ela é largamente utilizada para se referir à casca da árvore de que se fazem as máscaras e adornos da festa. Atualmente, muitos artesão e artistas plásticos ticuna utilizam o tururi para fazerem pinturas. São usados diversos tipos de tururi para se fazer máscaras. O tururi onecü, tirado da árvore onecütchi é o branquinho, usado para fazer a máscara do Mawü. Tem também o "tururi vermelho" (nawüri), “tururi cará” (tchunatchi), “tururi de cachimbomba” (pota), tiruri tchounã. O

\footnotetext{
${ }^{489} \mathrm{Na}$ verdade, existem "copeiros" e "copeiras" para a Festa, em geral a esposa do "copeiro" o auxilia em suas funções. A preferência, no entanto, como vimo, é que o "copeiro" seja o tio paterno da moça.

490 “¿Usted mandó a hacer esos cuatro no más? Eso no más cuatro ¿Por qué? Porque todo la comida que le he dado es bien. Cuando uno tiene harto de ahumado de animales pues uno invita bastantes, de toda clase de mascarados, harto, hasta los niños." [Plinio Vento] (Valenzuela, 2010: 129).
} 
tururi amakü recebe este nome, que é um termo de parentesco, porque a árvore deste tururi fica abraçada a outra árvore. Por isso ele se chama amacü (cunhado - WB), que pode ser traduzido como "tem mulher".

Na mitologia também estão presentes máscaras que saem prontas das árvores. No mito do "homem que matou as esposas dele" (Namatü dai'cü) ${ }^{491}$, o personagem que vingará a morte de suas irmãs, prepara as máscaras que ele levará para a Festa de seu cunhado inimigo apenas flechando a árvore de tururi. No momento em que ele flechava a árvore, imediatamente caía a máscara de tururi pronta. Enquanto traduzíamos esta história, Hilda comentou que "este tururi que o herói flecha é um tipo encantado. O nome deste tururi é tüerumaũ. Ele vira couro de onça. A onça yowarune que é a dona da árvore do tüerumaũ. Velho conta que quando a gente flecha esta árvore já cai pronta a máscara que queremos". De acordo com o Livro das Árvores dos Ticuna, os galhos desta árvore crescem para a esquerda e para a direita. As folhas que caem no chão pela direita se transformam em onças, as que caem pela esquerda se transformam em gaviões. Há aqui, portanto, uma divisão que remete de algum modo à divisão das metades exogâmicas dos Ticuna. De um lado temos onças, um animal "sem pena", e de outro, temos gaviões, "com pena". O Livro informa também que a árvore fornece máscaras de todos os tipos: "Yewae, O'ma, Mawü, To'ü e todas as outras. Quando alguém queria uma máscara para usar na festa, atirava uma flechinha com a zarabatana bem no tronco da árvore. Depois fazia o seu pedido. Na mesma hora a máscara aparecia, já pintada por si mesma, com desenhos de todo tipo, bonitos e coloridos." (Gruber, 1998: 42).

Lévi-Strauss, baseando-se nos dados da monografia de Nimuendaju sobre os Ticuna, aponta o tururi que se desprende magicamente da árvore quando ela é flechada como indicando que a casca da árvore é "caçada", como um animal:

“...a casca, matéria-prima da roupa, também pertence a uma categoria excepcional em seu gênero, já que foi obtida através de um meio mágico: "caçada", em vez de arrancada da árvore apresenta- se imediatamente sob a forma de tiras compridas, não sendo necessário desprendê-la laboriosamente do tronco (Nim. 1952: 81).” (2004[1967]: 343) $)^{492}$.

\footnotetext{
${ }^{491}$ Ver Firmino \& Gruber, 2010, vol. 2.

492 O autor se refere aqui ao mito $\mathrm{M}_{304}$, “A família que se transformou em jaguares" (Lévi-Strauss, 2004[1967]: 341-342, Nimuendaju, 1952: 147-48).
} 
A casca da árvore usada na confecção das máscaras, o tururi, pode ser terminologicamente equacionado à "pele", humana ou animal, e a própria màscara. Assim nos explica Goulard, "A máscara é nomeada chamu, termo que designa a pele, humana, animal, ou a casca da árvore. O chamu é a expressão física e visível de todo o existente [duügü]" (2011: 134).

O relato de origem das máscaras mais conhecido é o mito do Tchürüne, que examinamos no Capítulo 6, tópico 6.3 - Demais instrumentos musicais. Além dos instrumentos musicais que o Tchürüne traz com sua "turma", muitos motivos pictóricos das máscaras se originam nesta narrativa. Após a morte dos “bichos” (ngo ’o) que estavam dentro da montanha Decüãpü por asfixia com fumaça apimentada, "[o]s Tukuna contemplaram os corpos com cuidado, observando todos os detalhes, e depois copiaram os ngo'o em seus trajes." (Nimuendaju, 1952: 81) ${ }^{493}$. Na narrativa mítica apresentada por Goulard como a origem da fabricação das máscaras, o caçador que aprende a fazê-las levanta uma máscara e vê um corpo pintado de jenipapo (2011: 131). Mais adiante o autor detalha que se trata de uma pintura clânica. "Haveria, portanto, uma sobreposição de um corpo pintado de jenipapo (preto) e urucum (vermelho) e uma máscara coberta com pinturas policromadas, superposição necessária para a conclusão do processo metamórfico que seriam como "camadas de identidade", "porosas" entre elas (idêntico à Sibéria, Stépanoff, 2009: 2).” (2011: 132-133). Ao constatarem que não havia mais carne de caça durante uma Festa, um jovem caçador sai para caçar mais. Após matar alguns pássaros, ele se encontra com os mascarados na floresta que lhe ensinam a fazer as máscaras. Esta seria, segundo Goulard, a origem da proibição de caçar durante a Festa. “[A] adoção da máscara introduz novas relações entre os existentes [duügü]: seres sobrenaturais se misturam com os seres humanos através de representações mascaradas, novas condutas são adotadas, e assim, agora a caça não será mais praticada durante a celebração de rituais, o que viola a presença de seres sobrenaturais" (2011: 133).

Bueno apresenta uma reflexão interessante sobre o mito de Torama e o uso das máscaras. Retomando a análise de Goulard (2001: 77) sobre a origem das máscaras, a autora pensa a relação entre estas últimas com a pintura corporal. Na narrativa colhida por Bueno sobre a onça Torama, é a pintura com "barro aguado e açafroa” (2014: 94-97) que garante que a "pele" da máscara de onça não se fundirá a quem a veste para sempre,

${ }^{493}$ Cf. também Goulard, 2001: 77. 
transformando a pessoa em onça. Na versão do mito de Torama que traduzi junto com Hilda (Firmino \& Gruber, 2010, vol. 1), é um barro também (ota, tabatinga) o que faz com que o couro da onça solte da cabeça de quem o usa. Assim segue a reflexão de Bueno:

"Já no caso do mito trazido por Goulard (2001a, p. 77), o jovem que encontra os ü'üne nota que, por baixo de suas roupas, esses estão também pintados de jenipapo e outras substâncias, pois sem elas a roupa não teria eficácia alguma. No que diz respeito aos dois mitos [de origem das máscaras, registrado por Goulard e de Torama], é possível afirmar que é a pintura corporal sob a máscara que possibilita a transformação (temporária e reversível) corporal e o acesso a um estado sobrenatural, qual seja a transformação em ngo'o. $\mathrm{Na}$ reflexão proposta por Fausto (2012, p. 239-244), a eficácia da máscara ticuna seria função dos invólucros contidos no interior da máscara: a pele decorada. No entanto, a pintura é ela mesma uma outra pele (e uma outra máscara) que envolve uma imagem-alma, sem que se possa definir uma essência última que estaria presente sob todas essas camadas. Nesse sentido, é possível afirmar que com os imortais pôde-se aprender que é na pintura que reside o poder da transformação reversível e, especialmente, que é a capacidade de trocar de pele que possibilita o acesso à vida imortal." (2014: 97).

A pintura, portanto, proporciona a troca de pele e a transformação da pessoa em imortal, ou em "bicho". Deste modo, pintura, máscara e pele se confundiriam, ou formariam uma espécie de sistema, a manipulação de umas implicaria na alteração das outras.

A pintura é o que dá sentido às máscaras. Um informante diz a Goulard, "quando não tem pintura, ela [a máscara] não serve para nada" (2011: 134). Dentre os muitos motivos pintados nos trajes, alguns deles são sonhados pelos xamãs. É '́e é a figura de algum bicho que vive na montanha e que é desenhada na máscara. Os pajés sonham com ele antes da Festa e desenham, podem ser surubim, sucuriju, cobra-grande, etc. Um motivo pictórico bastante presente nas máscaras são os artrópodes. Estes animais são relacionados à imortalidade, assim como as cobras, pelo fato de trocarem de pele. "[O] escorpião tuchinawe, a centopéia epechi e outros invertebrados, (...) [s]ua presença nas máscaras significa compartilhar um mesmo estado com a menina, sempre mantida em isolamento e estão em um processo metamórfico." (Goulard, 2011: 144). Ao renovarem a pele, como acontece com a moça na Festa, eles rejuvenescem, começam um novo ciclo de vida. 


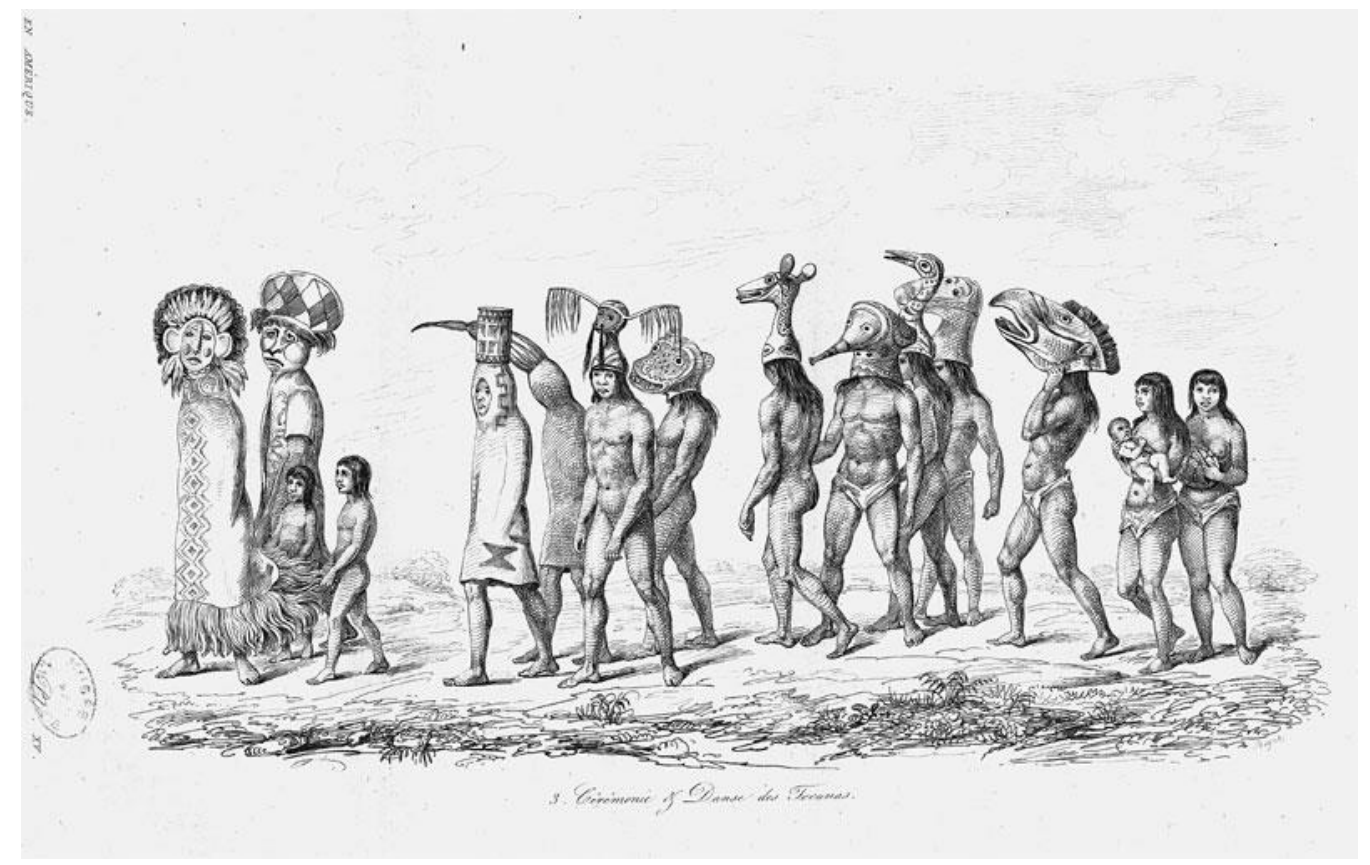

Figura 142 - Alguns mascarados na gravura feita por Spix (Spix \& Martius, 1981[1831]), "Préstito Festivo dos Tecunas”, entre 1819 e 1820, quando esteve no Alto Rio Solimões. Ver legenda da figura em nota.

Muitas destas máscaras são conhecidas de longa data, figurando em museus pelo mundo e em gravuras de cronistas $^{494}$. Uma delas é o personagem Mawü, a mãe das árvores e da mata. Este mascarado quando está dançando na Festa vai soprando um apito feito de talo de folha de mamoeiro. Na barra da máscara de tururi ficam pendurados caroços de avaí (aru), a mesma semente que está no bastão de ritmo (aru). Ondino me contou que antigamente o dono da Festa amarrava um cipó grosso na cumeeira da casa. O mascarado puxava e corria, se pendurava no cipó para testar a resistência da casa. O Mawü entra na festa junto com o Õma, o pai do vento.

Mawü é considerada também a mãe da planta macambo ${ }^{495}$. Alguns versos da canção do Mawü remetem à fruta desta árvore, vejamos um trecho:

\footnotetext{
${ }^{494}$ A legenda da gravura de Spix diz o seguinte: "Préstito festivo dos Tecunas. O nascimento de crianças dá-lhes oportunidade para uma estranha mascarada, na qual figuram o malvado demônio Jurupari, o tufão e as diferentes feras do mato, por meio de máscaras feitas com casca de árvore. Depila-se o recémnascido durante o préstito, enquanto ele é embalado lentamente pelas ruas do arraial, ao som de monótonas cantigas e aos estalidos feitos na carapaça de tartaruga. Não somente os Tecunas, porém igualmente os Passés e os Juris gostam de tais préstitos, também em outras oportunidades" (Spix \& Martius 1981[1831]: 192).

495 Nimuendaju identifica a planta do Mawü como sendo a araparirana (Macrolobium multijugum).
} 


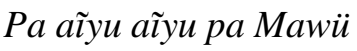

"Querido, querido, Mawü"496

Tchamarütawai üücamacü 'üntchao'otchi’ü

"Porque é amargo, eu também não gosto"

(...)

Oegacü yaocuti yatchiguricacu'ütchigu'üncuri

"Não serve para nada, somente a cotia vai te comer"

Pa aі̃уи аг̃yи ра Mawü

"Querido, querido, Mawü"

Yeayi ‘̃ iyaureru icacuricacu'üntchigu'üncuri

"Somente aquele gafanhoto e o papagaio vão te comer"

Pa aі̃yu aі̃yu pa Mawü

"Querido, querido, Mawü"

Guayayima wawüta yaopüya yanguünricacu'üntchigu'üncuri

"Só aquela queixada lá vai te comer"

Pa aи̃yu aи̃yu pa Mawü

"Querido, querido, Mawï"

Estas frases fazem referência à fruta homônima do mascarado Mawü. Ela é considerada bem amarga e venenosa, intragável. Interessante notar que a mãe da mata é representada justamente por uma fruta intragável. Ondino me explicou que esta fruta já foi comestível um dia. "Ipi, depois que foi embora, colocou o veneno ( gure) na fruta Mawü para ninguém comer mais. A fruta ficou amarga e venenosa, hoje ninguém come ela. Antigamente era igual castanha" ${ }^{497}$. Além da canção dizer que não gosta da fruta, ela enumera outros

\footnotetext{
${ }^{496}$ De acordo com Hilda a palavra aũyu é um jeito de chamar o mascarado e agradá-lo. Não se chama uma pessoa assim. Esta palavra aparece nas letras de canções de outros mascarados também, como o Õma e o To'ü, p. ex.

497 Há referências disto em Nimuendaju também: “Mawü, a árvore araparyrana [Macrolobium multijugum]. (PI. 18, b.) Os frutos desta árvore têm um odor e antigamente tinham um sabor agradável, mas perdeu porque o herói cultural Ipi deixou-os cair no curare antes de deixar a terra" (1952: 83).
} 
animais que a comem. De certa forma, o mascarado é desdenhado por ser dono de uma fruta que as pessoas não comem, mas ao mesmo tempo, Mawï é tratado por "aĩyu", uma palavra que designa um mascarado querido. Isso pode ser uma estratégia para evitar a vingança de Mawü.

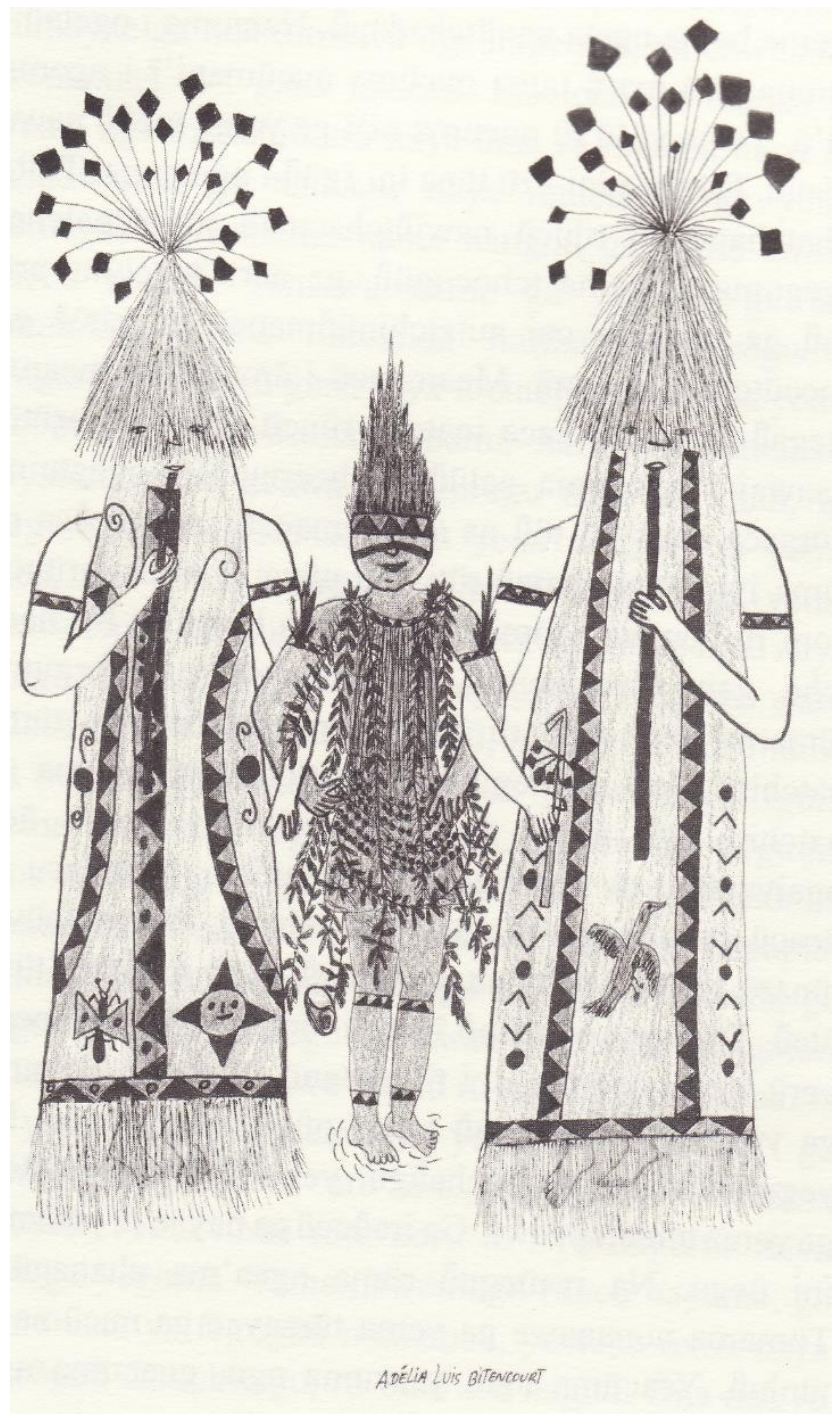

Figura 143 - Mascarados Mawü dançando com a moça nova, desenho de Adélia Luis Bitencourt (Firmino \& Gruber, 2010)

Mawü se apresenta na Festa junto com Õma, o "pai do vento" (buanecünatü). Eles costumam aparecer depois das seis horas da manhã ou depois que foi passado o suco de jenipapo na moça nova. O dono da festa segura nas costas de Mawü e do Õma para dançarem juntos. A canção do Õma é entoada quando se está puxando a máscara dele na 
festa. O mascarado é segurado pelo tururi das costas. Ele tem um pênis enorme que serve para derrubar as árvores, as casas, como um vendaval faz. $\mathrm{O}$ vento destruidor é evocado em muitas narrativas ticuna. Vimos no Capítulo 6, tópico 6.1 - Sopro, alguns significados que o "sopro" e o "vento" possuem para os Ticuna. No Livro dos Sapos dos Ticuna (Cururugü tchiga, OGPTB, 2002a), é mencionado que o sapo curepai "antigamente era gente ( $\left.d u^{\prime} \ddot{u}\right)$ e chamava o vento (buanec $\ddot{u}$ ) para matar os parentes dele". Na "História do caçador que só escutava vozes" ${ }^{\text {"498 }}$, os filhos de uma velha são um vento muito forte. A mãe deles é obrigada a esconder a heroína da história e a se amarrar para não se machucar quando eles entram em casa. Nimuendaju comenta a performance do mascarado Õma na Festa e como ele investe com seu pênis contra as pessoas:

"Especialmente quando a hora se aproxima para entregar a máscara, Õma ataca os espectadores com seu falo, especialmente os homens, já que as mulheres logo fogem, e tenta derrubá-los durante a perseguição. Se ele se volta contra as mulheres, pode acontecer que uma mais decidida, em meio a hilaridade geral, aproveitar e segurá-lo pelo falo" (1952: 82).

Ondino comenta que a moça nova dança com este mascarado, mas deve tomar cuidado. "A moça está no terreiro da casa de festa quando o Õma chega. Ele dança com ela enquanto ela segura no tururi nas costas do mascarado. Ela segura ele, mas tem que permanecer sempre nas suas costas, ele não pode ficar de frente para ela. O pênis dele é perigoso para ela". Notemos que a potência do mascarado é relacionada com seu pênis. Ou seja, o vento que derruba casas e árvores é o próprio pênis de Õma. Presenciei uma cena muito parecida com esta descrita por Ondino, em Festas nas comunidades de Santa Clara e Vendaval. A moça e a mãe dela seguravam a parte de trás da máscara do macaco caiarara/ macaco-prego (To' $\ddot{u}$ ). Este mascarado também segura seu pênis na frente, o que é perigoso para a moça nova. O que parece acontecer neste momento da Festa é uma espécie de disputa pelo acesso sexual à moça. Seres não-humanos visitam a Festa para tentarem roubá-la ou forçá-la a ter relações sexuais com eles. O efeito, contudo, é bastante cômico. A dança com os mascarados é um dos momentos mais esperados e animados da Festa.

498 “Feneẽcü ga wü’i ga nagaüninücü”, em Firmino \& Gruber, 2010, vol 3. 

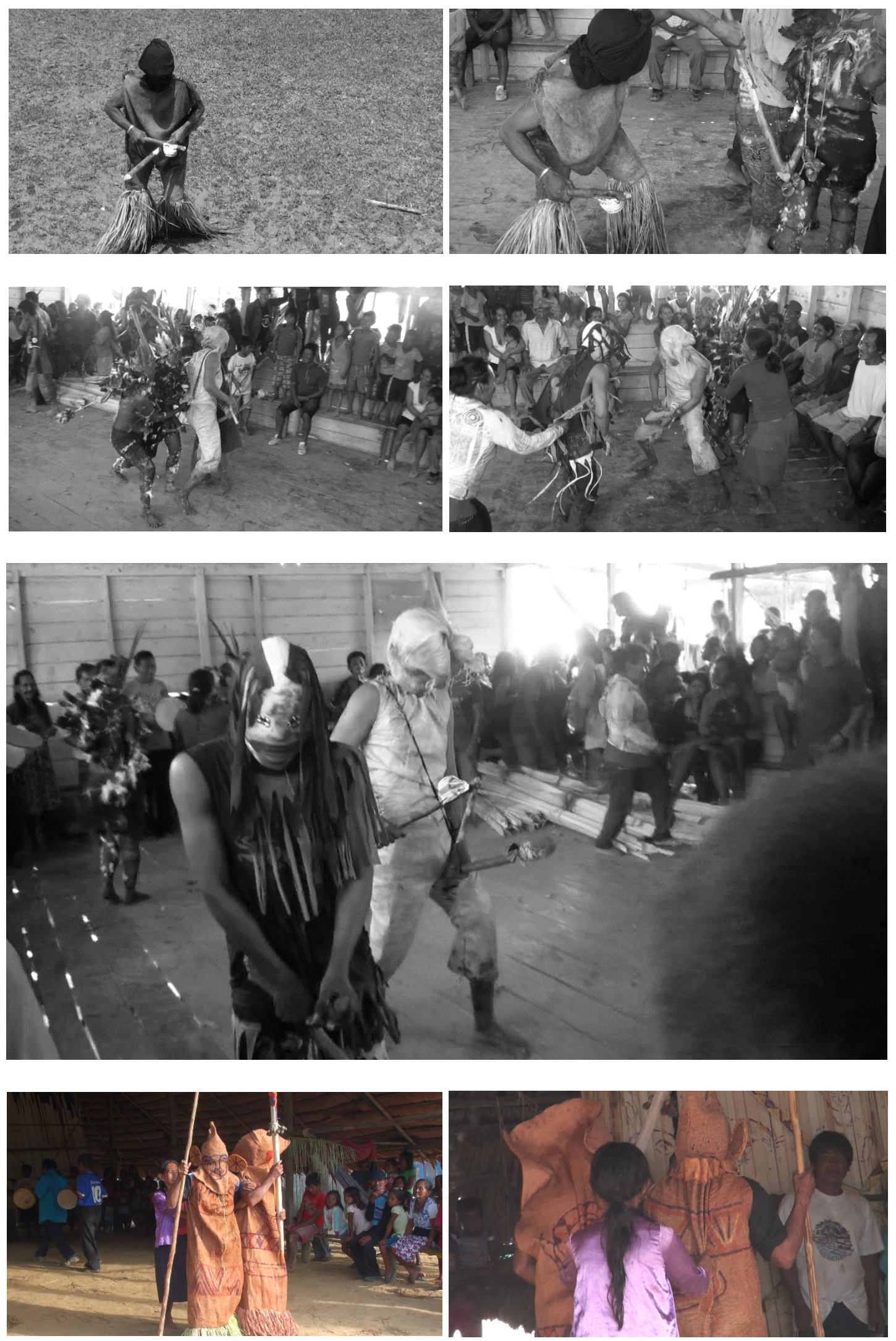

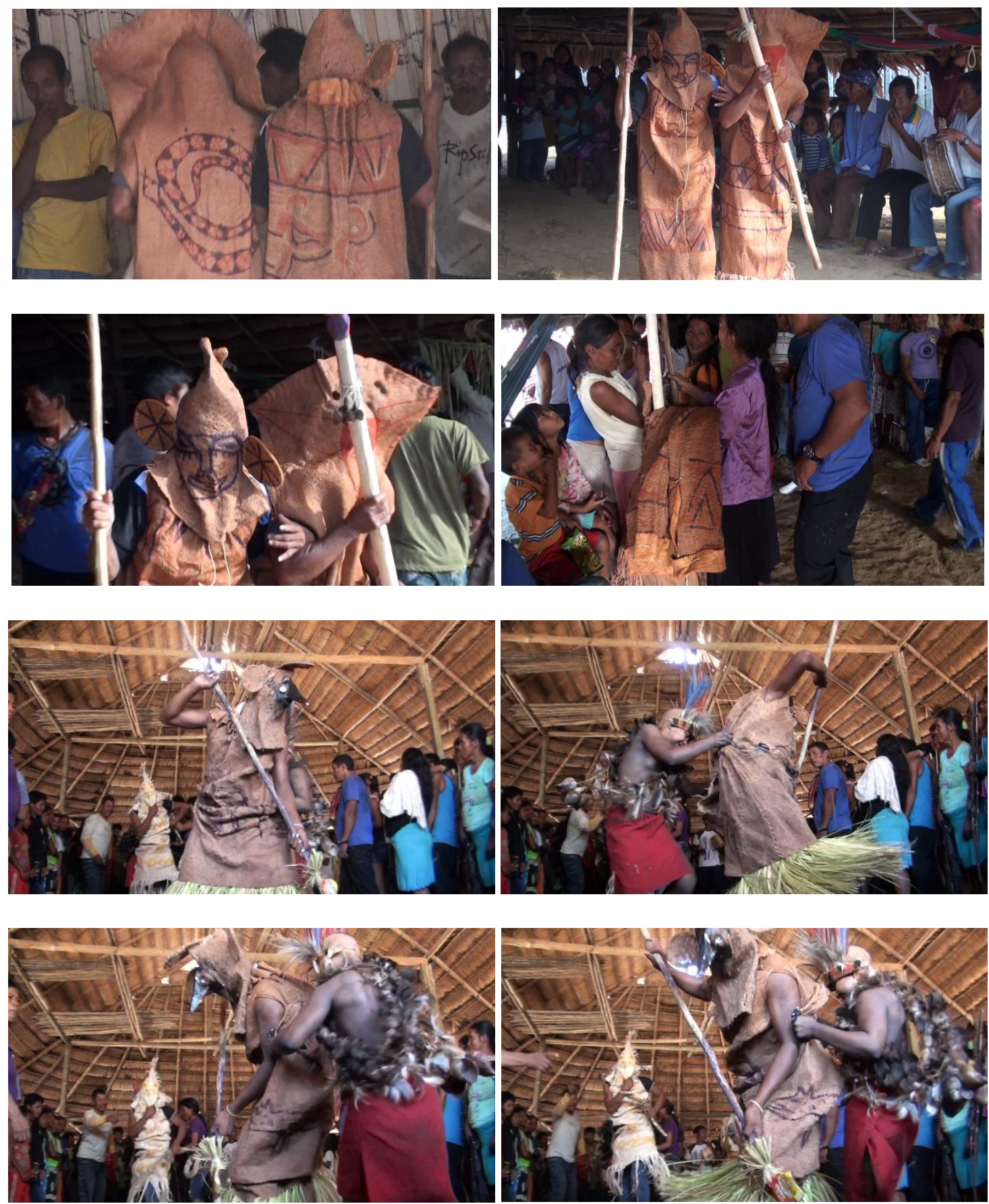

Figuras 144, 145, 146, 147, 148, 149, 150, 151, 152, 153, 154, 155, 156, 157 e 158 - Mascarados

Desta maneira, os mascarados, mesmo representando uma ameaça às pessoas da Festa, especialmente às moças novas, como bem mencionou Nimuendaju, são extremamente engraçados. Presenciei cenas em que a gargalhada era geral com a entrada dos mascarados To' ü nas Festas de Moça Nova de Santa Clara e Vendaval. Em uma das Festas que participei, em Santa Clara, não havia máscaras de tururi, eram mascaras improvisadas, que foram recebidas com uma efusividade incrível, principalmente pelas 
crianças. Eram dois mascarados, vestidos de macaco caiarara (To'ü), chegaram masturbando um pênis de madeira e batendo nele com um bastão com um chocalho na ponta. Ficavam saltando sem parar, correndo atrás das pessoas. Era uma gritaria geral. Dizem que a intenção deles é pegar a moça nova, então algumas pessoas seguram os macacos pelo rabo para eles não pegarem ninguém na Festa. Mas os mascarados não se dão por vencidos com facilidade. Muitas vezes se soltam e correm atrás de alguém, que sai correndo ao som das gargalhadas e gritos. Os mascarados têm prioridade, junto com os "copeiros", para receberem o moqueado que é distribuído para os convidados da Festa. Nimuendaju (1952: 83) identificou dois mascarados macacos, o que meus colaboradores confirmaram, o To’ü, macaco caiarara (Cebus albifrons), e o Taicüré, macaco-prego (Cebus fatuellus). Os dois são máscaras muito parecidas e são os mascarados mais comum nas Festas. Na canção do To 'ü, o cantor enumera as frutas que este macaco gosta de comer:
Аі̃уи аг̃уи ра Тоӥ
"Querido, querido Toü”

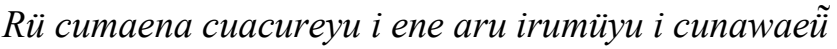
"Você quer banana amassada do periquitinho (ene), é o que você quer"
Ра Tоӥ riуи ра Тоӥ
“Toü, Той”
Аі̃уи аг̃уи ра Тоӥ
"Querido, querido Toü"
Rü cumaena i cowapua rü ngorũ̃ quĩ̃, pa Toü riyu pa Toü
"Você come cowapua, Toü, querido Toü" 499
Rü cumaena rü türüne aru daĩgüruü qui `̃ pa Toü riyu pa Toü
"Você é quebrador de castanha de macaco (türüne), Toü, querido Toü"500

\footnotetext{
${ }^{499}$ Cowapua = uma fruta que dá no igapó, que macaco gosta de comer, parece taquari

${ }^{500}$ Canção gravada, transcrita e traduzida com Hilda.
} 
A descrição feita por Nimuendaju da atitude destes mascarados na Festa é muito similar a que encontrei nas Festas que presenciei:

\begin{abstract}
“Outro [mascarado To'ü ou Taicüré] trazia um punhado de pequenas e apontadas varas de talos de anajá ou material similar, que ele jogou, duas ou três de cada vez, como azagaias, contra a parede do quarto de reclusão da menina, onde eles permaneceram espetados. Os espectadores gritaram para ele jogá-los na figura do cervo pintado na parede (...). Esses mascarados To' $\ddot{u}$ sempre se comportam de maneira muito impetuosa, arrogante, batendo na casa de palha antes de entrar, e galopando furiosamente para lá e para cá pelo centro da casa de festa, sem se importar com aqueles que podem estar dentro. Depois de um tempo eles se apresentam em uma atitude ameaçadora diante dos jarros, exigindo bebida, alguns dos To'ü dando em troca "seu filho" (il. 16, d), uma boneca de tururi com mais ou menos a forma humana e com um rosto de demônio, que é carregado suspenso nas costas e após a festa serve como um brinquedo das meninas (...). Assim que um dançarino mascarado, independentemente do seu tipo, entra na casa, algumas pessoas, às vezes até o dono [da festa] ou sua esposa, posicionam-se atrás dele e, segurando em seu traje, acompanham-no em sua carreira louca pela habitação; escoltar o Taicüré ou To'ü assim não é uma questão simples, mas constitui o entretenimento favorito das crianças de ambos os sexos...” (1952: 83).
\end{abstract}

Além destes mascarados que são mais frequentes nas Festas, há outros, muitos deles bastante raros de se encontrar. Apenas para mencionar alguns deles, Nutchi' $i$ e Popü são seres que saíram da montanha junto com o Tchürüne ${ }^{501}$. Batü é um mascarado que toca bastão de ritmo (aru) e vive no cipoal. A existência da máscara do Yureu ${ }^{502}$ deixa claro que existem mascarados que também são "bichos" (ngo'o). Neste caso, o mais perigoso de todos os "bichos" para a moça nova. Na mesma Festa, portanto, chegam para participar imortais, mortais e "demônios". Yewae, a cobra-grande, é um mascarado que também pode aparecer. No mito do "homem que matou suas esposas" (Namatü daí'cü) $)^{503}$ são referidas, além da máscara da aranha (pawii), outras duas máscaras, a do boto

\footnotetext{
${ }^{501}$ Cf Capítulo 6, tópico 6.3 - Demais instrumentos musicais, sobre a saída do Tchürüne da montanha e a origem de alguns elementos da Festa.

502 "Ele ainda tem a máscara yure-u, animal, um "demônio" que vive nas profundezas da floresta: de cor negra e pertencentes aos xamãs." (Goulard, 2011: 139).

${ }^{503}$ Ver Firmino \& Gruber, 2010, vol. 2.
} 
Tchoreruma, do qual já falamos ${ }^{504}$, e do Yotchiruma. Temos uma representação da máscara do boto que aparece na figura em Firmino \& Gruber (2010: 131), ao lado da máscara do Yotchiruma. No topo da máscara podemos ver a boca do boto com um peixe.

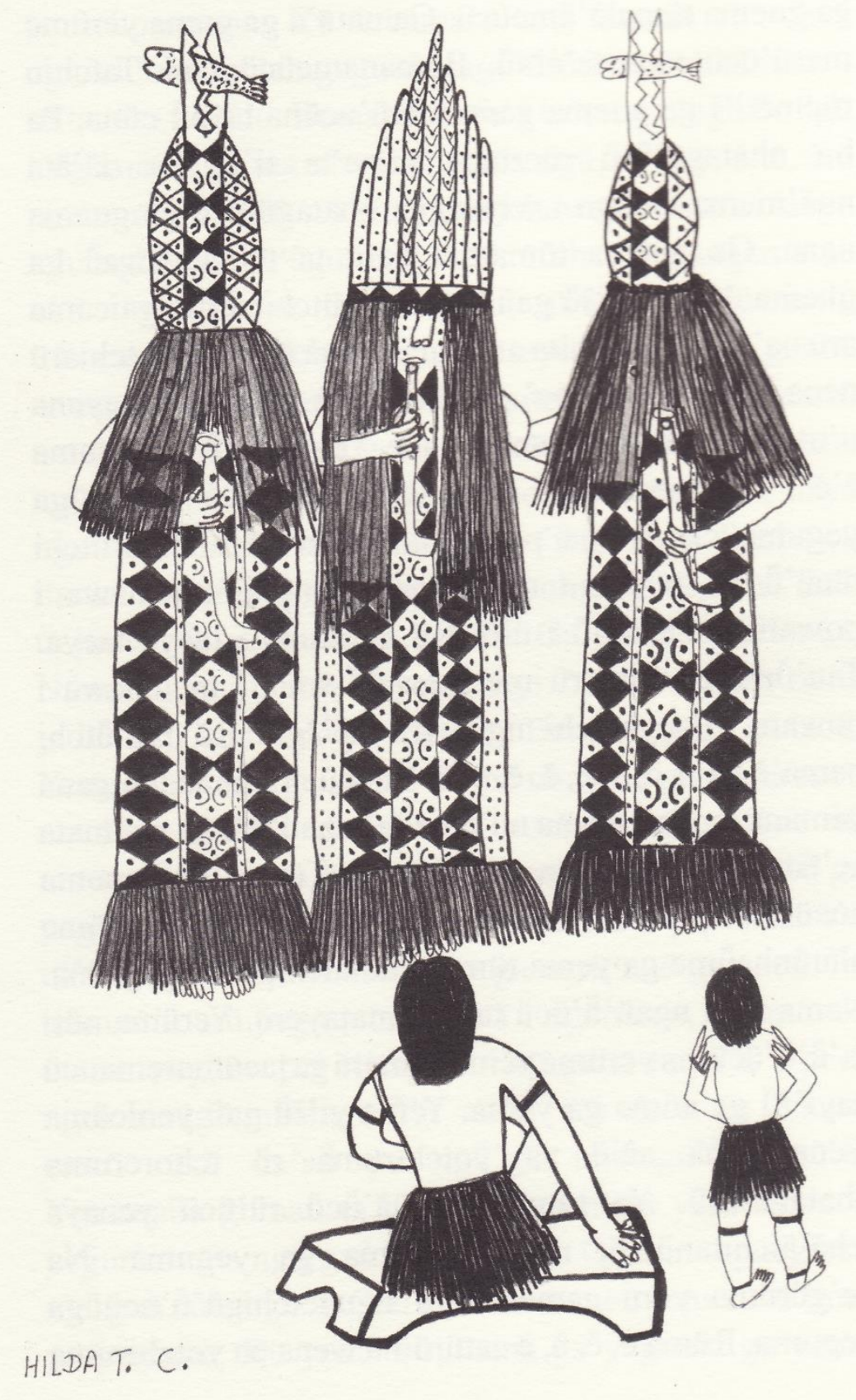

Figura 159 - Mascarados Tchoreruma e Yotchiruma, desenho de Hilda Tomás do Carmo (Firmino \& Gruber, 2010: 131)

${ }^{504}$ Ver Capítulo 6, tópico 6.2.1 - Batizado e Nomes dos trompetes. 
Um dos apetrechos que um mascarado pode portar são os grandes escudos (tchine). Mawü é um dos mascarados que podem aparecer com um escudo destes. Ouvi relatos de que numa Festa de Moça Nova ocorrida na comunidade de Umariaçu I, além dos mascarados, havia escudos. Mas eles são cada vez mais raros nas comunidades do Brasil. Valenzuela (2010: 167-70) mostra em sua dissertação algumas imagens de escudos, registradas na comunidade de Arara, na Colômbia. Reproduzo três fotografias deste autor abaixo.
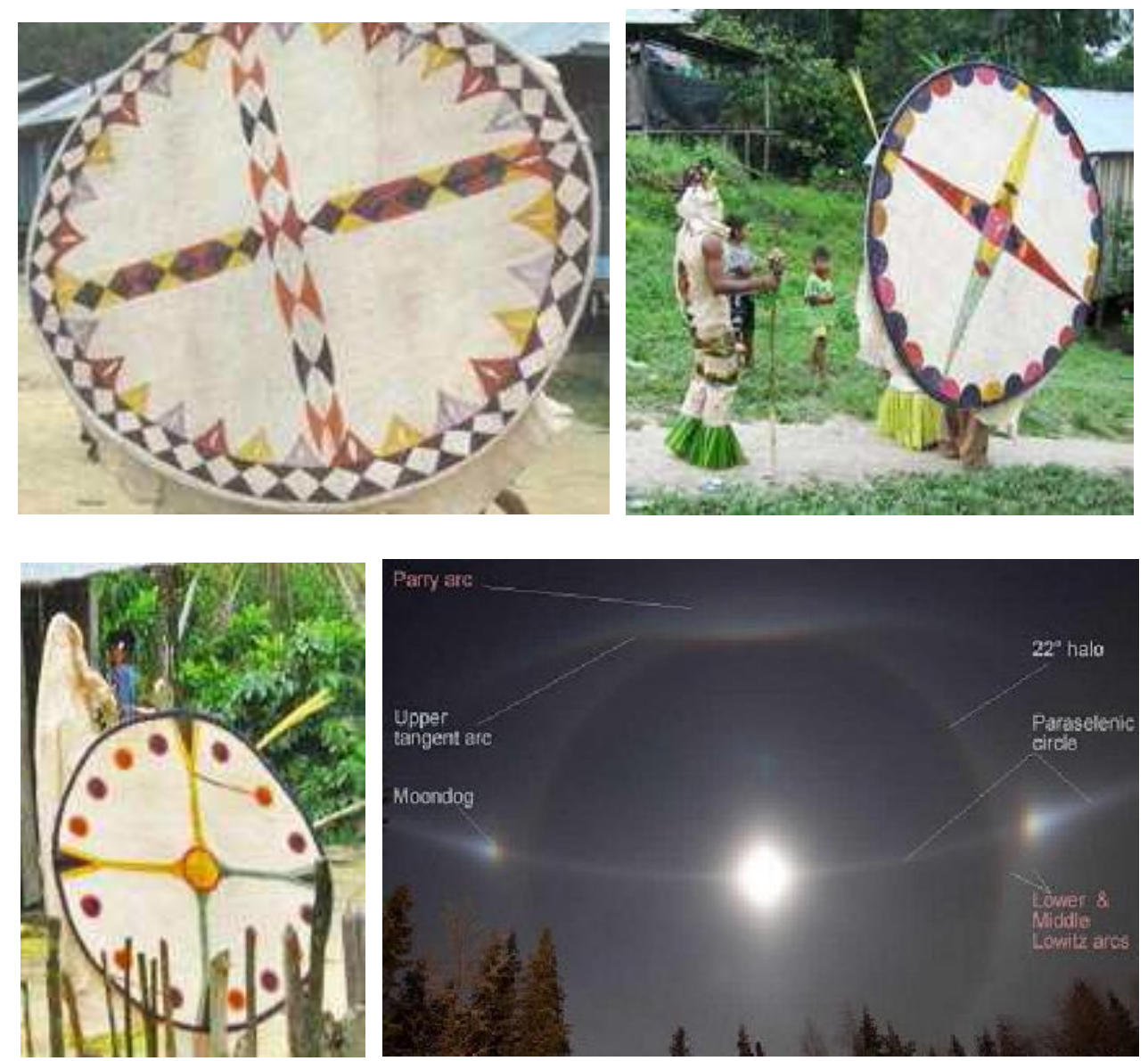

Figuras 160, 161, 162 e 163 - Fotografias de escudos (tchine) retiradas de Valenzuela (2010: 167-70) e fenômeno do parasselênio

Coloquei a última fotografia de Valenzuela ao lado de um evento astronômico denominado parasselênio. Segundo o dic. Houaiss, trata-se de um "halo luminoso que se observa, às vezes, em torno da Lua, semelhante ao para-hélio; parasselene". Pela semelhança das imagens, tudo leva a crer que alguns escudos de máscaras parecem representar o parasselênio. Se esta hipótese estiver correta, encontramos em alguns 
escudos, mais uma vez, uma referência ao mito de Lua e ao incesto primordial. Sobre um escudo destes que a moça pode ser carregada para o banho final no rio. Nas Festa que presenciei, ela foi levada em esteiras trançadas.

Assim como os grandes trompetes, que soaram durante a madrugada aconselhando as moças reclusas, as máscaras são uma forma de convidar os seres da floresta para que venham participar da Festa (Valenzuela, 2010: 128, nota 145). Os "bichos" (ngo'o) são, portanto, convidados. O fato de irem arrancar a macaxeira para fazer o payauaru tocando tamborim (tutu) e bastão de ritmo (aru) também indica que as plantas do roçado estão na Festa. Os seres do cosmos tanto vêm para a Festa, quanto a Festa vai até eles, as plantas da roça estão neste último caso. A roça feita para a produção do payauaru e a roça para o consumo cotidiano são distintas. Para arrancarem a macaxeira do payauaru são tocados os instrumentos, algo que não acontece nas colheitas ordinárias. O mesmo grito coletivo, “yü̈̈̈̈̈!”, usado para iniciar todas as atividades do ritual, é usado para marcar o momento de arrancar as raízes ${ }^{505}$. Valenzuela comenta também o uso do iburi no roçado para avisar aos "guardiões do território" que irão fazer a Festa: "Su uso es para comunicar, avisar e invitar, además es para que los guardianes del território escuchen que se está haciendo La pelazón, se usó en el momento en que empezaron a volver de la chagra." (2010: 151, nota 170).

A participação dos mascarados na Festa marca a presença de uma espécie de "aliança monstruosa" atuando no ritual. Este tipo de aliança - intensiva, "imanente ao devir", oposta àquela "interna ao socius e mesmo ao gênero masculino" (Viveiros de Castro, 2007: 119) -, é do tipo contra-natureza, se impõe do exterior e assume o valor do incesto (idem: 120). "Seu propósito não é o de gerir, mas o de "impedir a procriação": aliança antifiliativa." (ibdem). No caso ticuna, ela estabelece uma “"contiguidade absoluta" de tipo tangencial-diferencial" (idem: 119) entre humanos, "bichos" e imortais. Os "bichos" mascarados agem com um propósito, usando o termo de Viveiros de Castro, antifiliativo. Caso conseguissem roubar as moças para si, as alianças "internas ao socius" entrariam em colapso por falta de futuras esposas. "Não estamos aqui no elemento

\footnotetext{
505 “después llegamos a la chagra (...) Todo el tiempo está sonando el tambor, lo que le imprime cierta solemnidad a la actividad. (...) Luego de limpiar el terreno todos nos agachamos para coger el trozo del tallo cortado y halarlo, una actividad sincronizada marcada por un jubiloso grito colectivo iyüü! que indica el inicio de la extracción de la yuca." (Valenzuela, 2010: 150-51).
} 
místico-serial do sacrifício nem no elemento mítico-estrutural do totemismo, mas no elemento mágico-real do devir" (idem: 120).

A moça é uma isca para forçar os seres do cosmos a agir, forçá-los a aparecerem na Festa para que os humanos estabeleçam as regras da relação ${ }^{506}$. Convidar os "bichos" para a Festa é uma forma de "provocar uma resposta" deles, a sua maneira, como é esperado. É melhor um "bicho" que seja aliado do que um com o qual não se tenha qualquer relação. A aliança intensiva ticuna - que aparece no mito, principalmente com a fecundação dos joelhos de Ngutapa pela vespa, sua esposa Mapana ${ }^{507}$-, se concordarmos com a definição da aliança intensiva amazônica delineada por Viveiros de Castro, é uma aliança contra o Estado. Convidar os "bichos" e imortais para a Festa é impedir a "filiação de funcionar como germe de uma transcendência" 508 .

\section{8 - Saída da reclusão}

"Acredita-se que nesta hora a menina está exposta ao maior perigo..."

Nimuendaju, The Tukuna, pg. 89

No final da manhã de domingo chega o momento de a moça sair de sua reclusão. Dentro do quarto ela foi adornada pelas mulheres mais velhas, com urucum misturado com leite de tururi e plumas brancas. Depois de pintar todo o corpo, colocam enfeite de penas coloridas e casca de caracol $(m e r u)^{509}$. Por último, colocam o cocar e a tanga de miçangas. Quando terminam de enfeitar a moça, ela pode sair da reclusão.

\footnotetext{
506 “Os dons podem ser recíprocos; mas isso não faz de sua troca um movimento menos violento; todo o propósito do ato de donação é forçar o parceiro a agir, extrair um gesto do outro, provocar uma resposta: roubar sua alma. (A aliança como roubo recíproco de alma.)” (Viveiros de Castro, 2007: 121).

${ }^{507}$ Ver Capítulo 2, tópico 2.3 -O homem grávido - a questão de gênero como primeiro evento mítico.

508 “A aliança intensiva amazônica é uma aliança contra o Estado" (Viveiros de Castro, 2007: 123). "É esta aliança com o não-humano que define "as condições intensivas do sistema” na Amazônia." (idem: 124).

${ }^{509}$ O meru é usado atualmente, mas o melhor é outro tipo de caracol, teu.
} 
Se usarmos a terminologia de Van Gennep, podemos identificar aqui um tipo de ritual que este autor chamou de "ritos da soleira", em que o atravessar uma porta ou soleira confere a passagem do neófito:
““'[A]travessar a soleira” significa ingressar em um mundo novo. Tal é o motivo que confere a esse ato grande importância nas cerimônias do casamento, da adoção, da ordenação e dos funerais (...) Observaremos que os ritos realizados na própria soleira são ritos de margem" (2011[1909]: 37).

Mais adiante, Van Gennep ressalta a importância de se destruir o objeto pelo qual se passa. Desse modo, destrói-se ao mesmo tempo a vida anterior do(a) neófito(a), este deve sair do "mundo da infância" para entrar no "mundo da adolescência". Não por acaso, como veremos, depois que a moça sai da reclusão e mesmo durante a própria saída, o quarto é totalmente destruído:

"O rito [de saída da infância] essencial consiste ainda em passar por debaixo da porta artificial e neste caso é possível ou supor que a infância, considerada como uma qualidade positiva (tal como a doença), foi transferida para a porta e destruída, ou, e esta é a interpretação por mim preferida, que a porta é o limite entre dois períodos da existência, de tal sorte que passar por debaixo dela significa sair do mundo da infância para entrar no mundo da adolescência. A destruição do objeto que serviu para o rito pode explicar-se por este fato, encontrado, entre outros casos, na Austrália e na América do Sul” (idem: 6667)

A saída da reclusão é um dos momentos mais esperados da Festa. O quarto de reclusão das moças está cheio de gente. Todos vão saindo vagarosamente, balançando o corpo até ganharem ritmo ao som dos instrumentos. Ao longo da saída da reclusão, as meninas estão de olhos tapados por alguém que seja da mesma metade, no caso da Festa de Porto Lima, por exemplo, eram os irmãos das meninas. Eles tinham o rosto adornado de plumas brancas em torno da boca. As mulheres que acompanhavam as moças cantando, saindo do curral também, tinham tufos destas plumas coladas nas bochechas. Nimuendaju indica os seguintes parentes que saem da reclusão com a moça e a forma como devem fazê-lo:

“A remoção da garota da reclusão - O tio paterno, sua esposa, a mãe da worecü, seus parentes do sexo feminino, e algum irmão ou primo entram no quarto de reclusão pela porta lateral. Eles pegam a menina com muito cuidado 
em cada lado, puxam o cocar de penas para baixo sobre os olhos e começam a dançar com ela, tanto quanto o espaço permite, sempre de quatro passos para a frente, para a parede da frente, e quatro passos para trás. (...) Muito lentamente, sempre avançando e recuando, o grupo se aproxima da abertura, atrasando ainda mais a saída, movendo-se para frente e caindo para trás, e, finalmente, chegam ao lugar central na casa onde eles continuam a sua dança balançada, trocando de lugar lentamente na frente" (1952: 88-89).

Segundo Goulard (2010: 119), que fez seu trabalho de campo numa região do Perú onde os Ticuna ainda moram nas antigas casas comunais, "a entrada da casa é chamada de forma metafórica de "boca-vagina da casa", e as extremidades das folhas que se estendem para além do telhado são seus "pelos"”. Esta informação de Goulard é preciosa, pois notei que a saída da menina que está sendo iniciada da reclusão se dá como uma espécie de rompimento da placenta - que seria o próprio quarto de reclusão - pelo bebê. Afinal se a porta da casa é referida como uma vagina, seu interior seria o local onde a criança é gestada, o útero materno. Segundo meus informantes, durante a saída da moça nova do local da reclusão, não podem cortar todo o buriti da frente. "Tem que abrir só um buraco, sair apertadinho". O buriti deve ser rompido para a moça sair. Esta imagem evoca um parto, como se a moça estivesse saindo de um útero (natchimü) de ripas de buriti. Perguntei a Ondino se o quarto de reclusão (turi) poderia ser pensado como um útero, ele gostou da ideia ${ }^{510}$.

\footnotetext{
510 Uma frase um tanto enigmática de Goulard, em nota de rodapé pode indicar isto também: "Os Tikuna percebem o seu ambiente de acordo com as regularidades/ordenamentos [l'ordonnancement] do útero" (2010:128, nota 2). Além da forma como a moça sai da reclusão, como um parto ou ainda como a saída de uma borboleta de sua crisálida, lembremos que a moça também é aproximada da condição de um recém-nascido, na medida em que recebe a mesma pintura corporal de jenipapo do corpo todo, como um bebê poucos dias após o nascimento. $O$ fato de a moça ficar careca, como um bebê, também contribui para esta interpretação. Turner comenta a frequência com que estas imagens são evocadas em rituais de iniciação: "O outro aspecto que é o de não estar ainda classificado se expressa, com frequência, por meio de símbolos cujos modelos são os processos de gestação e parturição. Os neófitos são assimilados a, ou tratados como embriões, crianças recém-nascidas, lactantes, através de meios simbólicos que variam de cultura para cultura" (2005: 141).
} 

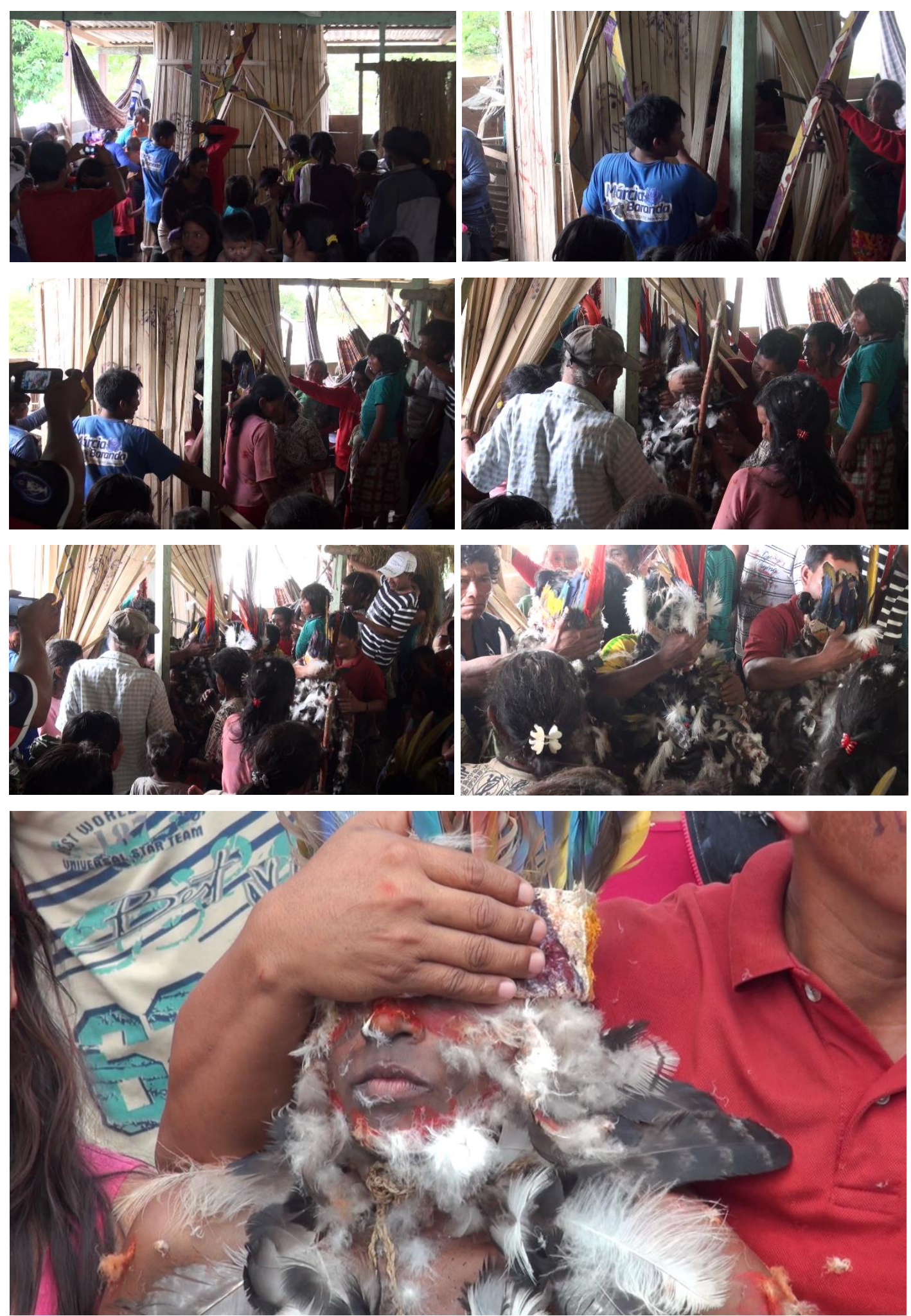

Figuras 164, 165, 166, 167, 168, 169 e 170 - Saída do quarto de reclusão

Outra possibilidade para se pensar a condição da reclusa é a da crisálida. Esta imagem não excluí a primeira, elas se sobrepõem. A moça estaria dentro de um casulo se preparando para sair transformada, mais madura. Nas palavras de Goulard, "[s]e utilizan, 
para significar la nueva situación, metáforas tomadas de los mundos vegetal y animal. Una de ellas compara su aislamiento con el de la larva del insecto que espera que le nazcan las alas para salir de su crisálida y convertirse en mariposa" (2009: 156). Nimuendaju nos apresenta alguns versos de uma canção que é entoada no momento em que a moça sai da reclusão. Nestes trechos, podemos notar a analogia da reclusão da moça com a crisálida da lagarta. Há também referências à comparação com a cotia, que também encontramos em outras canções. Nesta canção é frisada a "tagarelice" da cotia:

"1. Oh, o que foi isso agora que a nossa worecü veio entre nós, toda coberta com plumagem?"

“2. Oh, que fazes tu dizer agora de suas penas de tucano?"

“3. Como uma lagarta [em crisálida] nossa worecü foi colocada em isolamento por nós!"

“4. [Desafiando a pequena animação dos convidados]: Não estas tu absolutamente envergonha de tagarelar como cotias?"

“5. Que não deve tornar-se um formigueiro desagradável!” (1952: 89, eu grifo).

"A moça, quando sai do "curral" [quarto de reclusão], tem que ficar quieta, não pode nem rir. Ela tem que permanecer com os olhos fechados e a cabeça baixa", explica Ondino. Todas elas ficam com vergonha da situação. A timidez das meninas é um tema que também é cantado nas canções da Festa. Devemos ter em mente que estas meninas estão numa fase da vida que chamaríamos de pré-adolescência, saindo da infância. Muitas delas têm o hábito de circular pela cidade e já começam a estranhar as tradições de seus pais. Contudo, o que percebi de um modo geral, é que os jovens ticuna gostam mais de aparecer na Festa durante a noite. Em Porto Lima, por exemplo, notei que eles se reuniam em grupinhos fora da casa, algumas meninas tocando tutu e cantando ao mesmo tempo em que cantavam e tocavam dentro da casa. O ideal antigo, ressaltado pelo mito da primeira moça nova To'oena, diz que todos devem permanecer dentro da casa. Apesar de atualmente as casas não serem mais fechadas nas laterais, os mais velhos costumam permanecer dentro da cobertura de palha.

Após a lenta saída das moças de dentro da reclusão, elas permanecem sentadas nas esteiras no centro da casa de Festas. A todo momento elas permanecem com os olhos vendados pela tira de tururi do cocar. Permanecem imóveis, em silêncio e não podem ver nada. Vimos no Capítulo 3, tópico 3.1.4 - Festa e imortalidade, que neste momento o 
pajé intervém principalmente na fertilidade das moças. Ele coloca um contraceptivo mágico nelas, para retardar a gravidez das moças. A ação do xamã, feita com fumaça de tabaco (pori), é principalmente direcionada aos joelhos e aos pés das moças. Feito este tratamento nas moças é chegado o momento de a moça arremessar um tição em brasa no tronco do pé de taperebá (Spondias mombin).
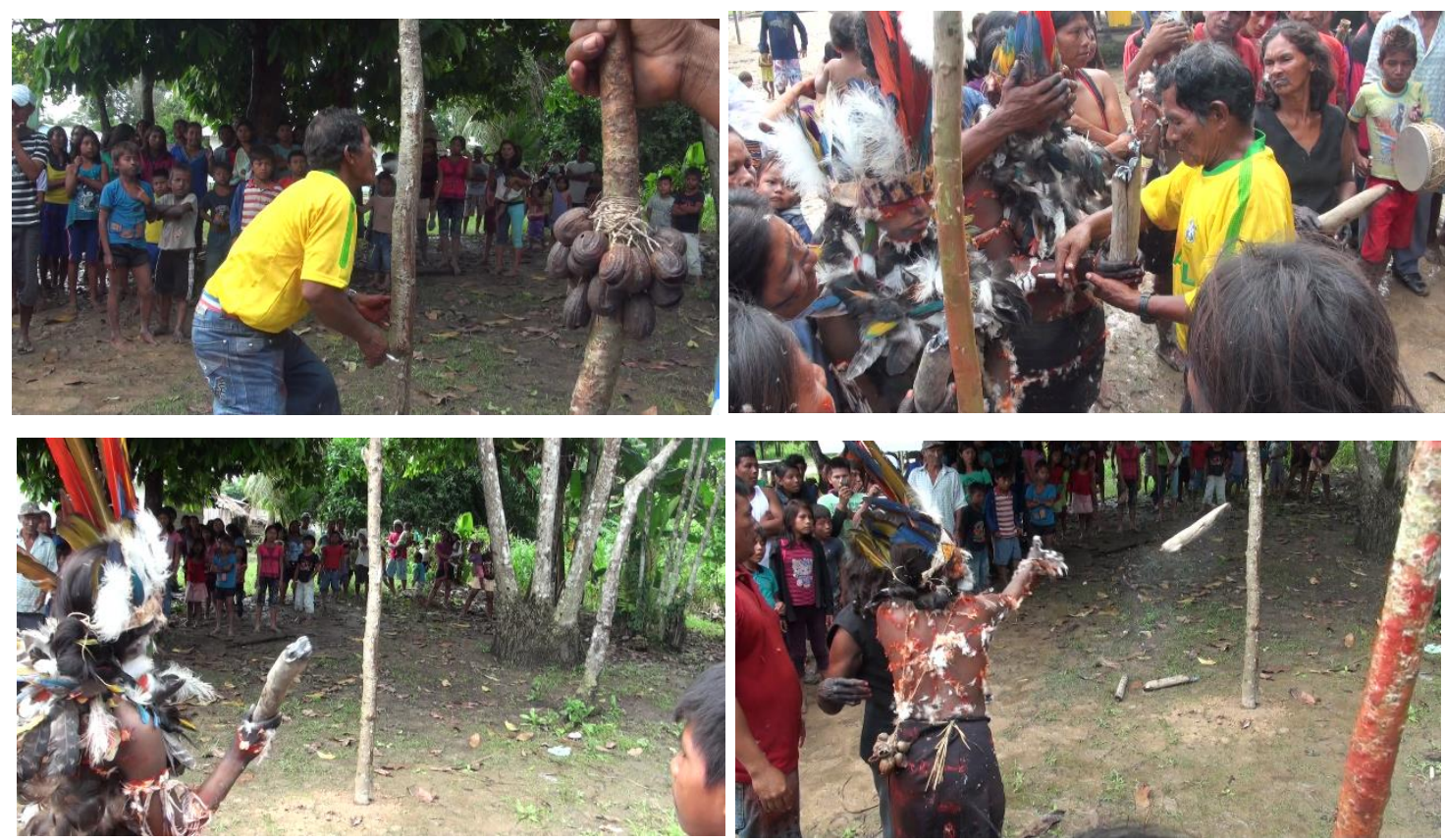

Figuras 171, 172, 173 e 174 - Jogando o tição no tronco do taperebá

Com o tição na mão, a uma distância de cerca de quatro metros, o desafio é acertar no tronco de uma árvore de taperebá. Outras árvores são referidas como possíveis alvos para o arremeço da moça. Adélia me disse que o tição pode ser lançado em um pé de tucumã ou numa pupunheira também. Nimuendaju menciona esta última árvore para este pequeno rito dentro da Festa. Vejamos a descrição que faz este autor deste momento do ritual:

"[O] cocar de pena é levantado dos olhos da worecü [moça nova], e seus braços são liberados. Um xamã coloca um tição atrás dela. Com movimentos rápidos dos dedos ele remove algum objeto invisível de sua própria cabeça e, com um gesto de enrolá-lo na frente de seu corpo, coloca-o no tição. Em seguida, entrega isso para a worecü e apontando-lhe uma pupunheira - ou, se não houver nenhuma, de qualquer outra árvore -, ele diz a ela: "Jogue-o em nosso inimigo!". Ela joga o tição contra a árvore, dizendo: “Tngng! tcha-rüu'anun , na ma dóó’n'ee” (?;tcha-rü-u'anun, “meu inimigo”; dóó’n'ëë, “não 
suporte, suporte"). A partir deste momento ela pode voltar a mover-se livremente sem a proteção de seus parentes; ela, então, geralmente coloca-se atrás de um dos mascarados para correr com ele, e então continua a dançar entre os outros, até a hora da depilação chegar, antes ou logo após o meiodia." (1952: 90).

As explicações de Nimuendaju ressaltam a capacidade que a moça tem de rogar pragas, especialmente para os inimigos. Este ataque à pupunheira é um ataque aos inimigos. Os comentários que obtive sobre este rito ressaltam a relação da Festa com a longevidade da moça e, no limite, com o tema da vida breve, que nos acompanha do começo a o fim desta tese. Segundo Hilda, o rito é feito "para [a moça] ter vida longa, porque dá sorte". O comentário de Adélia vai no mesmo sentido, "para a moça nova não morrer rápido". Outros comentários indicam que as moças que acertam a árvore terão abundância, casamento, roças fartas, muita sorte. As moças que erram a pontaria ficarão vagando solitárias pelo mundo, não serão boas esposas, passarão fome, terão vida curta. Errar a pontaria neste ritual significa também que a menina teve relações sexuais antes da Festa, o que é condenável. Todos os arremessos que pude observar foram exitosos. Caso a moça erre o arremeço ela pode tentar novamente, ou seja, o pequeno rito é feito para que ela necessariamente acerte.

\section{9 - Cabelos arrancados}

É chegado o momento mais aguardado da Festa. Depois que a moça já correu com os mascarados, dançou de braços dados com o(a) cantor(a) e ouviu seu aconselhamento, chega o momento do aconselhamento mais severo do ritual. Contudo, antes de abordarmos este ponto alto da Festa da Moça Nova, vejamos algumas possíveis referências ao cabelo arrancado na mitologia ticuna. 

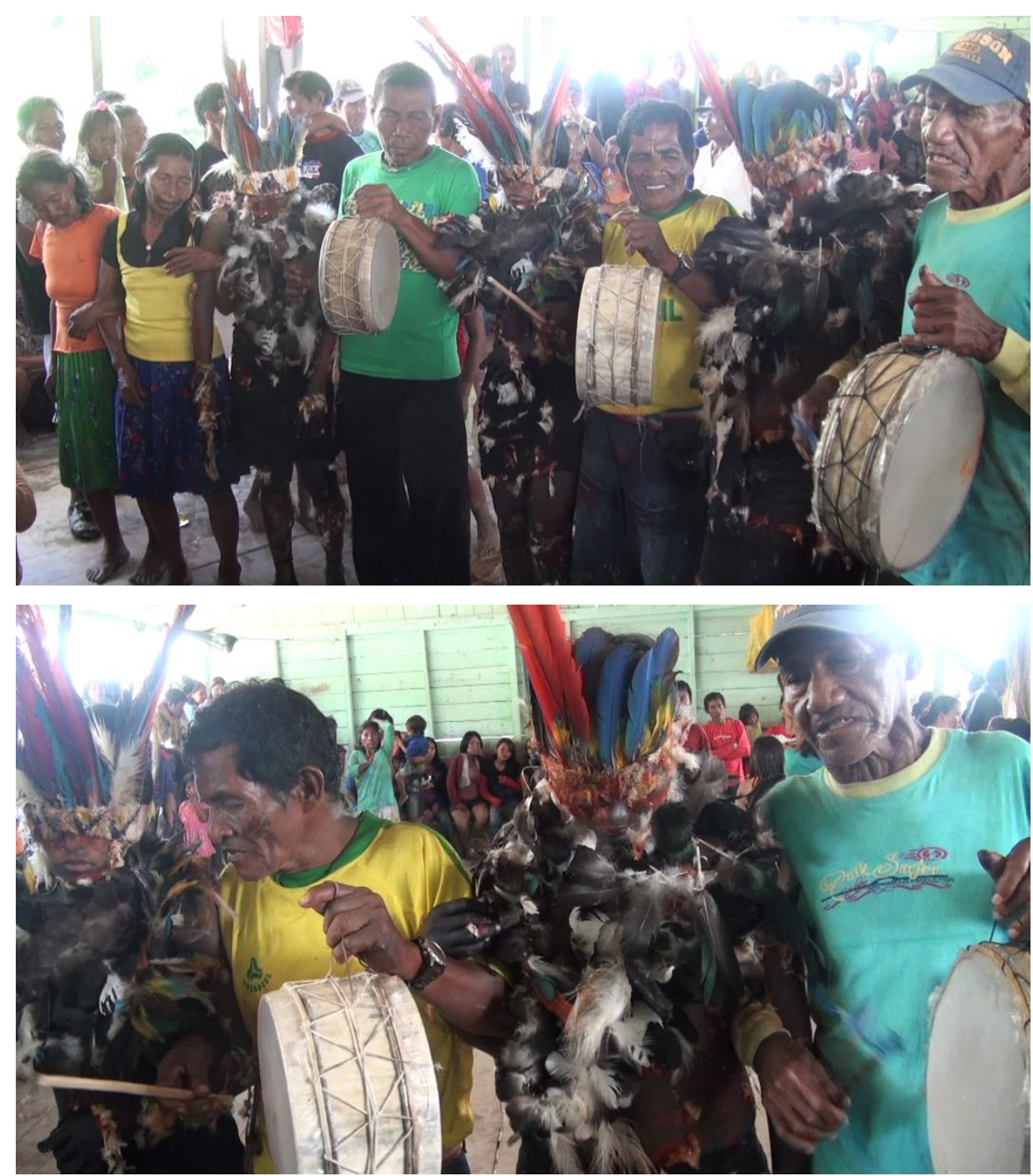

Figuras 175 e 176 - Cantores aconselham as moças

Há um trecho em que os gêmeos Yoi e Ipi estão procurando a onça que comeu o pai deles, Ngutapa. Para tanto, eles pegam o cabelo da irmã e amarram para "encurtar" o mundo. Deste modo, conseguem cercar todos os jaguares e encontrar Ngutapa na barriga de um deles. Numa das versões (Goulard, 2009), eles tecem um fio com os cabelos das irmãs. Em outra versão (Oliveira Filho, 1988), os gêmeos tiraram um único fỉo da cabeça de Mowatcha, a irmã que nasceu do mesmo joelho que Yoi, o joelho direito de Ngutapa. No segundo exemplo, fica claro que a quantidade de cabelo é exígua, além do fato de um fio de cabelo ser extremamente frágil para tal empreendimento. Contudo, os irmãos conseguem amarrar o "mundo" e encurtá-lo.

Temos aqui o que parece ser mais uma inversão que o ritual aplica ao mito, além daquelas mencionadas do horário de saída dos trompetes do rio e da ralação do jenipapo. 
Nesta última, o jenipapo é ralado apenas uma vez e num único sentido por pessoa, reparando o excesso de ralação feito por Ipi no mito. Durante o ritual, muitos fios são arrancados da cabeça da moça nova, ao contrário do que acontece no mito, em que um único fio é tirado da cabeça da irmã dos gêmeos. Ao mesmo tempo, como vimos no Capítulo 6, tópico 6.3-Demais instrumentos musicais, um dos motivos para a Festa ser realizada é a ampliação do mundo ${ }^{511}$. Isto aparece nas explicações sobre o mito do Tchürüne, referindo-se principalmente à dança do tracajá. Enquanto no mito o mundo é reduzido, no ritual ele é ampliado.

Outra referência importante é a feita à Mowatcha. Não se trata de qualquer cabelo capaz desta prova de força. Para estreitar o mundo usaram o cabelo da irmã que nasceu junto com Yoi, o mais valoroso herói cultural ticuna. Mowatcha muitas vezes é referida como a "bem aconselhada" (a-a-emaekiu) (Goulard, 2009: 394), justamente o que se pretende das moças que passam pelo ritual, serem bem aconselhadas pelas velhas.

O cabelo é algo que naturalmente cresce sem parar. Entre os imortais o crescimento se dá de maneira muito mais rápida. Quando um imortal nasce, ele cresce muito rapidamente. Os dias e noites na terra dos imortais passam num piscar de olhos ou num passar de uma nuvem. Com o cabelo não seria diferente. Mowatcha é uma imortal, portanto, seu cabelo cresce muito rápido, possibilitando abarcar o mundo com um fio ou com muitos fios. Valenzuela faz um comentario sobre este mito mostrando principalmente esta relação entre o cabelo e o crescimento ininterrupto: "Esto nos puede llevar a nociones semánticas de límite, o de crecimiento, pues la palabra para cabello Tayae significa "que crece", es entonces un elemento que no deja de crecer y por tanto es el instrumento ideal para lograr abarcar la totalidad del territorio" (2010: 132).

A mitologia ticuna está povoada de seres maléficos que são peludos e/ou cabeludos, como, p. ex., o ogro Beru ou o demônio Ucai. O ogro (ou ogra) Beru, possui

\footnotetext{
${ }^{511}$ O comentário do pajé Jorge Manduca, da comunidade de Arara, Colômbia, vai neste sentido. "[E]sa de encerrar la muchacha, es para agrandar el mundo, que agranda, que agranda" (Valenzuela, 2010: 110). Segundo o mesmo informante, a Festa é feita para que o inverno não seja tão intenso e para ampliar o mundo: "A ti, te dicen, te vas a envejecer y va pasando hasta llegar a mi edad, con esa historia de pelazón, eso de hacer la pelazón es bueno para nosotros, para que el invierno sea menor o no sea tan intenso, para que el mundo no se acabe em cima de nosotros, por eso hacemos la pelazón, para que..., ¿para qué esa pelazón? Esa pelazón es para ampliar (agrandar) el mundo, eso de hacer la pelazón, esa pelazón es para ampliar el mundo, para que nunca, nunca se dañe em cima de nosotros [Jorge Manduca]” (ídem: 73).
} 
uma vasta cabeleira e o corpo todo coberto de pelos. Algumas narrativas indicam que este personagem é uma mulher. Mas esta indicação não é unívoca. Ondino, conhecedor de mitos entre os Ticuna, afirma que o sexo de Beru não é bem estabelecido, "ninguém sabe ao certo se Beru é homem ou mulher". De acordo com meus colaboradores, Beru se transforma às vezes em homem, às vezes em mulher, às vezes em borboleta. Ou seja, trata-se de um ser andrógino. Se juntarmos esta informação com o fato de Beru ter o corpo coberto de pelos e uma vasta cabeleira, isso indica que o corte do cabelo - como temos tanto na primeira quanto na segunda Festa de iniciação das moças - é um dos principais fatores que estabelecem o gênero da pessoa ticuna.

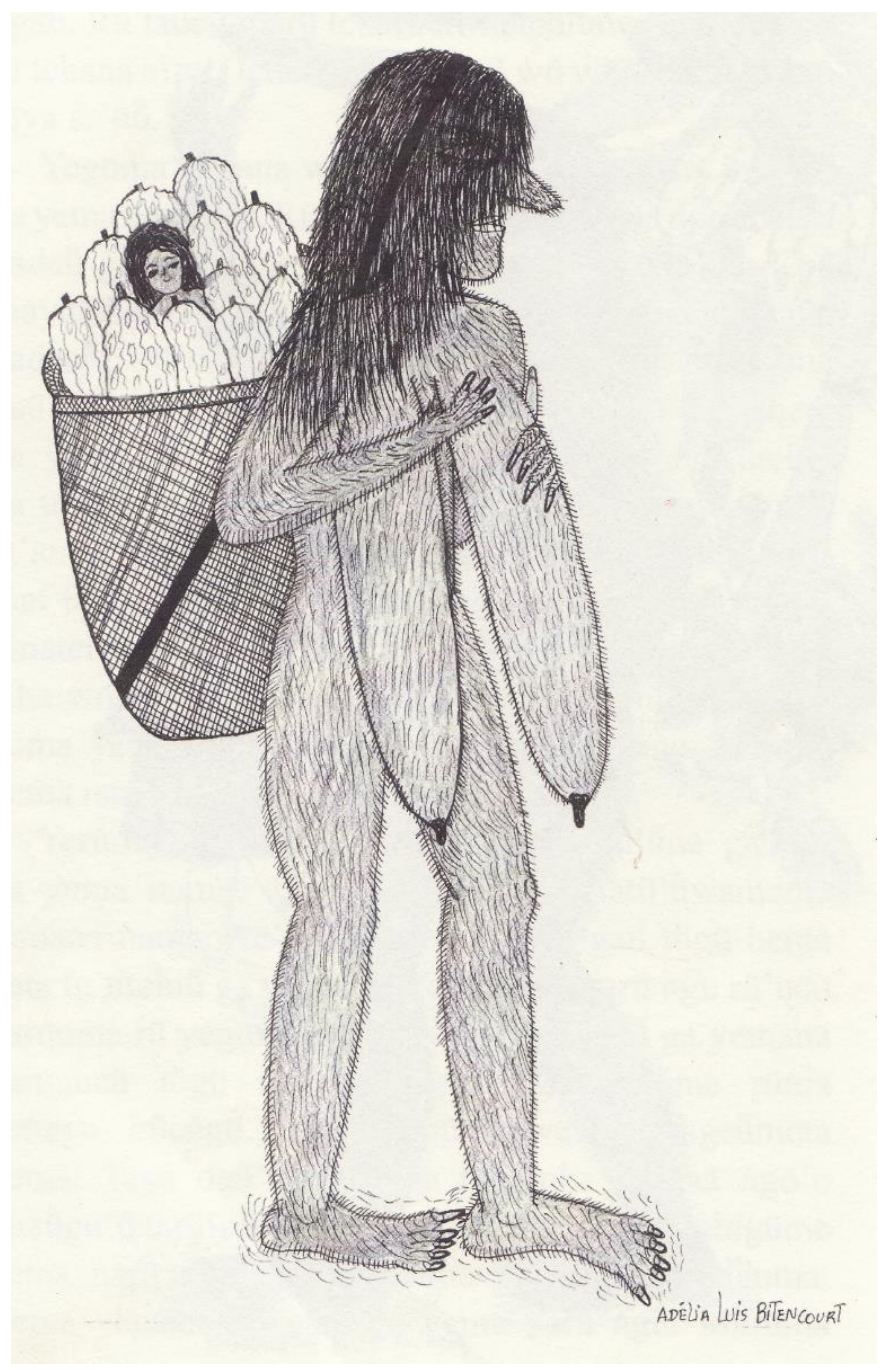




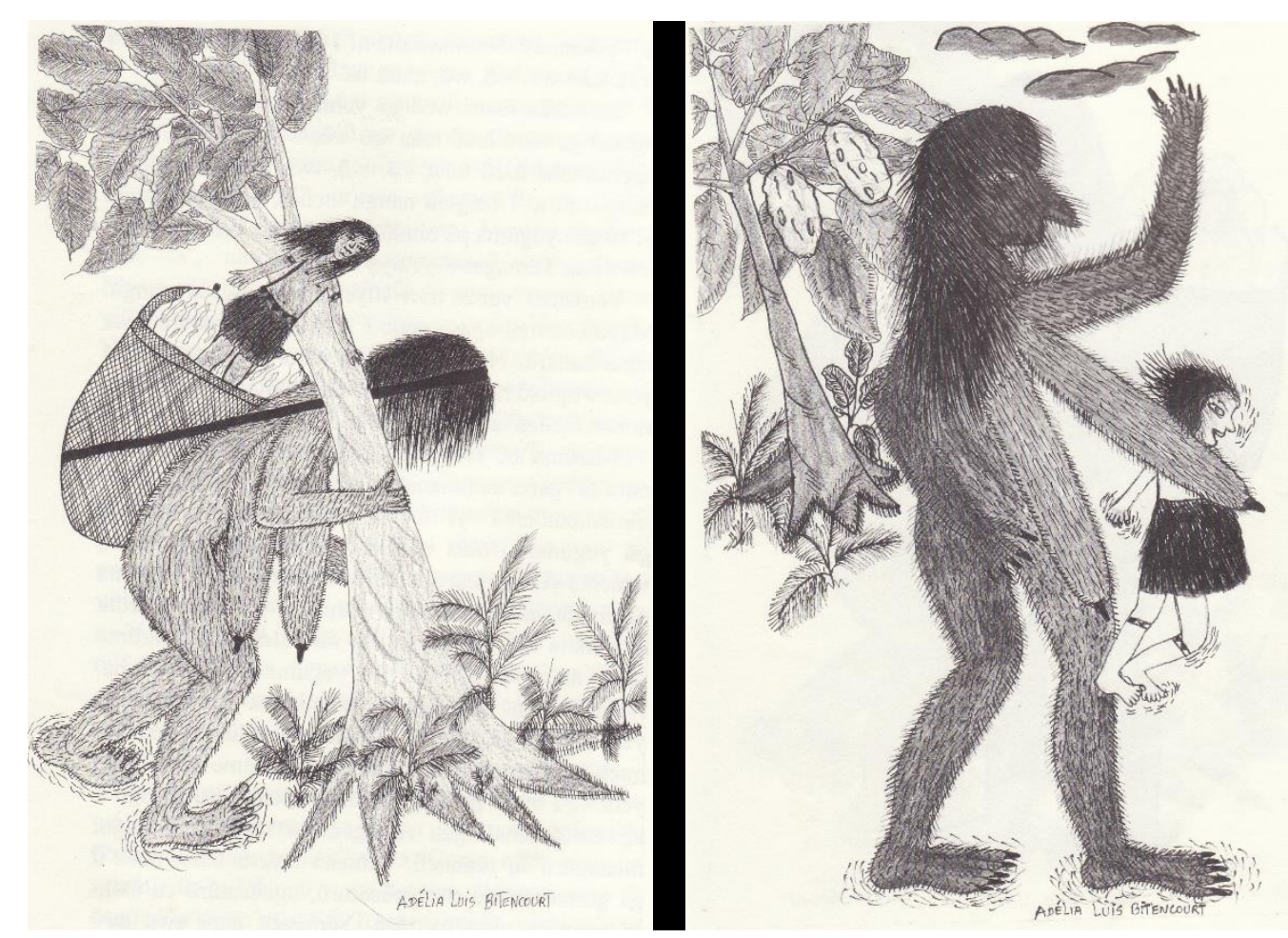

Figuras 177, 178 e 179 - Beru, desenhos de Adélia Luiz Bitencourt (Firmino \& Gruber, 2010)

A meu ver, Beru - um ser andrógino, coberto de pelos e com os seios caídos -, contrasta com o que se espera de uma moça que passa pelo ritual. Portanto, o fato de Beru ser caracterizado portando pelos/cabelos excessivos não é fortuito e se conecta com a depilação da cabeça da moça no ritual. Ao ter seus cabelo arrancados ocorre um afastamento da moça das características de Beru: 1) é reforçado o seu pertencimento ao mundo feminino, ela não é mais uma criança "andrógina", sua menstruação e o ritual a transformam em uma mulher que se casará em breve; 2) o ritual fará com que sua vida seja longa, aqui está o significado de Beru ter os seios caídos; em uma de suas explicações sobre a Festa, Ondino me disse que a moça deve passar pelo ritual para não ficar com os seios caídos, ou seja, não ficar velha tão logo.

Há outras referências ao excesso de pelos dos ogros (ngo'o) da floresta. O Wüwürü, dono do buritizal, é desenhado n'O Livro das Árvores (Gruber, 1998: 29) com o corpo coberto de pelos. O Curupira, dono da mata, que mora no sapopema da samaumeira, "[d]izem os velhos que ele tem os cabelos compridos, corpo peludo, olhos pretos e pés virados. Existem vários tipos de Curupira: o pai da samaumeira, o dono do jabuti, o dono dos outros animais, o Curupira macho e o Curupira fêmea" (idem: 30). Curupira, sabemos que é uma palavra do Tupi (dic. Houaiss). Parece-me uma tradução de Ucae, um tipo de ngo'o, que é dono e mora na samaumeira também. 
Em contraste com estes seres peludos, temos outro "bicho da floresta", o Daiyae. A descrição d'O Livro das Árvores o descreve como um ser "baixinho, com a cabeça quase pelada. Seus poucos fios de cabelo são muito procurados para dar sorte" (idem: 34). O professor ticuna Nailson Pissango Salvador me contou uma história do Daiyae (Anexo - 006). Trata-se de um ser que também é dono de árvore, o pé de jaboti, mas ao mesmo tempo inverte Beru na quantidade de cabelos. Enquanto Beru tem uma vasta cabeleira e pelos por todo o corpo, Daiyae tem apenas quatro fios de cabelo. Daiyae é descrito, como vimos, como um "bicho" baixinho, o que contrasta com Beru. Este último sempre é retratado como um ser bem alto. A relação de Daiyae com seu interlocutor, Caé, também é de troca. Eles trocam os fios de cabelo - e Daiyae demonstra ser bastante generoso, já que oferece um de seus únicos quatro fios de cabelo -, enquanto Beru é escalpelado pela mãe dos meninos ${ }^{512}$. No trecho de um dos mitos do Beru que registrei (Anexo - 007), abaixo, nota-se a vontade que este ser tem de cortar o cabelo como o da moça nova:

"Beru estava com dor de barriga e colocou sua rede fora da montanha. As crianças ficaram olhando. Beru viu as crianças e perguntou para elas "por que vocês estão com o corte de cabelo bonito?" (nunagueru = corte de cabelo da moça nova). As crianças responderam que a mãe (oe) delas que cortava. Ele achou bonito e queria cortar seu cabelo com ela também, usar o corte nunagueru."

Uma das intenções do ritual, como sabemos, é trocar a pele/cabelos da moça. A reclusão faz com que a pele da moça fique bem clara e o jenipapo promove uma "limpeza" da pele. Ao passar de uma pele escura para clara, além da ajuda do jenipapo, a moça é considerada como tendo trocado de pele. Quanto mais tempo a moça fica guardada, maior a eficácia na troca de pele. Um informante de Valenzuela deixa isso explícito: "[Don Camilo] [m]e contó que su hermana Rosa Ramos estuvo encerrada por dos años y "sale blanquita como gringo, está guardada, es como tigre, orina sólo de noche"." (2010:147). Arrancar os cabelos é trocar de pele e rejuvenescer. Um informante ticuna de Faulhaber nos diz o seguinte: "Quando chega o tempo de envelhecer, de ficar velho, troca-se de novo as peles e fica-se novo. À medida que o tempo passa, troca-se de novo, para nunca envelhecer. Por isso são arrancados os cabelos da moça nova" (2000: 115).

512 A terminação_yae do nome Daiyae remete, muito provavelmente, ao cabelo (yae). 
Nimuendaju nos apresenta uma descrição do momento em que as moças têm seus cabelos arrancados:

“A depilação - Interrompendo a dança, o tio paterno tira uma mecha de cabelo da worecü, em seguida, ela é levada para o centro da casa, onde ela fica sentada sobre uma pele de anta - hoje em dia isso é quase sempre substituído por um pano de tururi. Um jarro cheio de pajauaru e um pote menor contendo uma fermentação desta bebida são colocados à sua frente. $\mathrm{O}$ tio e uma outra pessoa com uma vara chocalho $[a r u]$ permanecem ao lado destes jarros. De três a seis mulheres $^{513}$ se sentam em um círculo em volta da worecü, sobre a pele, e começam imediatamente a arrancar os cabelos em pequenas amostras por rápidos e vigorosos puxões. De acordo com Tessmann, isto é feito "com o auxílio do leite de uma árvore"; na maioria das vezes, no entanto, nenhuma substância auxiliar é utilizada" (1952: 89-90).

Uma fruta que pode ser usada para facilitar o arrancamento dos cabelos é o cubiu (Solanum sessiliflorum). Segundo Adélia, “a mãe tem que curar com cubiu (bere). Tem que banhar de tarde com cubiu, enquanto está guardado. Cubiu é uma frutinha. A gente espreme e passa no cabelo. [Para que serve?]. Para ficar molinha a raiz, para soltar mais fácil”.

${ }^{513}$ Cardoso de Oliveira indica as tias paternas como responsáveis por arrancar os cabelos das meninas e cortar o cabelo dos meninos. Nas Festas que presenciei não havia esta especificação: "Procedeu-se a tosa no menino e o arrancamento dos cabelos da irmã, cerimônia denominada beru [be'eru]. Ambos eram tratados cerimonialmente pelas tias paternas. (...) [A moça f]oi tirada do curral e devidamente pintada e paramentada pelas tias paternas, portanto membros do mesmo clã, e demais velhas, provavelmente do mesmo clã (devo conferir oportunamente)" (2000: 7). 

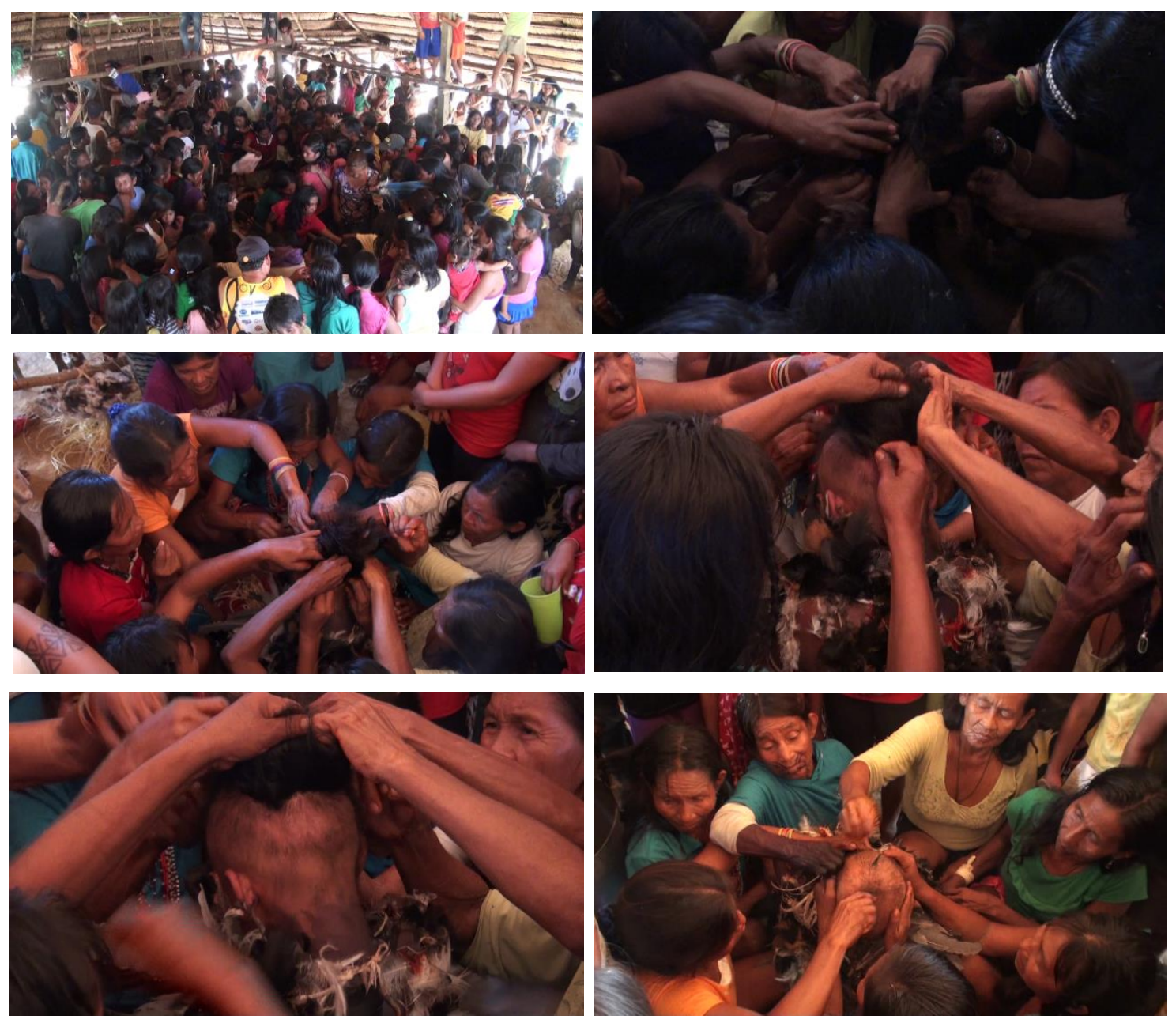

Figuras 180, 181, 182, 183, 184 e 185 - Arrancando os cabelos das moças

Às moças é oferecida bebida fermentada da mais alcoólica, o caldo do pajauaru. Muitas moças tomam um pouco para amenizar a dor da arrancação dos cabelos, mas isso não é uma regra. Algumas, como afirma Nimuendaju, "até mesmo rejeitam as bebidas que são oferecidas a elas" (1952: 90). Com a ajuda ou não da embriagues do álcool, o que mais impressiona é a impavidez das moças que passam pela depilação da cabeça, em geral não esboçam qualquer sinal de dor. "A maioria delas suportam a operação com calma evidente" (ibdem).

O final da arrancação dos cabelos das moças, que também pude presenciar, é descrito por Romualda Joaquim Costódio, na história "Como se cuida da moça nova" (Firmino \& Gruber, 2010, vol. 3), da seguinte maneira:

"Depois que terminam de puxar o cabelo, a moça senta em cima do escudo do [mascarado] Mawü. Pegam o enfeite da casa (ngaiyanü e tchaiwae, são os dois 
tipos de enfeite da casa) e colocam com a moça nova no meio da casa, em cima do escudo. Pegam um pouco de estopa ${ }^{514}$ da máscara e jogam no jirau da casa, para o próximo ano. Suspendem ela no escudo e colocam no ombro. Saem com ela ao redor da casa, andam com ela ao redor da casa, batendo tamborim. Deixam cinco fios de cabelo nela para puxar quando vai levantar. Depois de puxar o cabelo e correr entorno da casa, vão para o porto.”

Há um detalhe interessante no final desta descrição que merece atenção. Por que a autora se refere aos cinco fios que são deixados na cabeça da moça para serem puxados no momento em que ela é levantada? A meu ver a resposta é simples. As ações coletivas na Festa, como vimos, são todas coordenadas. Iniciam com o toque o bastão de ritmo $(a r u)$ e terminam com seu toque também. Isso tem uma grande importância. Não se pode fazer as atividades que compõem o ritual em qualquer momento ou cada pessoa isoladamente. Com o processo de arrancar os cabelos da moça se dá o mesmo. É uma atividade coletiva, realizada pelas senhoras mais velhas, e que começa com o sinal do "copeiro" com o aru. A moça deve ser levantada para dar as voltas na casa logo após ter os cabelos arrancados. Para coordenar as duas atividades, alguns fios são deixados sem arrancar. Assim, torna-se possível terminar de arrancar os cabelos - o que provoca uma imensa aglomeração de pessoa em torno da moça, todos querem ver os fios sendo arrancados - e, coordenadamente, inicia-se a corrida com ela suspensa sobre a esteira em torno da casa.

O momento em que os cabelos das moças são arrancados une os conselhos dos mais velhos com a dor física da moça. Vimos que os aconselhamentos feitos com vitupérios à moça acontecem em outros momentos da Festa. Agora, no entanto, ele adquire sua maior intensidade. Quando perguntei a Adélia e Hilda porque o cabelo da moça era arrancado na Festa, as respostas indicaram que as meninas precisam sofrer para que o ritual tenha sua eficácia. A moça será lembrada do quanto foi desobediente para seus pais:

“Adélia: Porque, quando a gente era pequena... Hilda: A gente teima... Adélia: A mãe da gente manda, "minha filha vai buscar água para... e a gente responde [feio], por isso que quando a gente está formada [teve a menarca] a gente leva castigo. [Porque desobedece, responde a mãe, não é?] Isso, nas cantorias fala...

\footnotetext{
${ }^{514}$ Estopa de mata-mata = turabunetchi, usada para fazer para fazer a saia do mascarado.
} 
Hilda: É para a menina sofrer (risos). Só para a gente jogar [fora] o cabelo também, para depois crescer outro. Adélia: joga o cabelo para nascer outro"

Conversei com Lorenzo, requisitado "copeiro" da comunidade de Belém do Solimões, sobre a reclusão da moça e ele ressaltou esta necessidade da moça sofrer na Festa:
"Dentro do curral [quarto de reclusão] a gente amarra um galho de taperebá para a menina segurar. Enquanto ela estiver dentro do curral, ela segura, não pode soltar, não pode dormir. Aí ela está sofrendo, moça nova sofre. [A moça nova tem que sofrer?]. Tem que sofrer, sim".

A moça passou a noite acordada segurando o galho de taperebá. Uma das funções do som dos trompetes na madrugada, além de aconselharem as moças, é impedir que ela pegue no sono. Gruber relata este fato:

\begin{abstract}
"Durante toda a noite, os tocadores se revezam e pedem bebida. Uma das funções do to 'cü é não deixar as jovens iniciadas dormirem. Como já foi visto anteriormente, a boca do instrumento fica bem junto à porta que dá acesso ao recinto de reclusão onde as moças permanecem em pé, segurando numa vara horizontal, de taperebá, colocada acima de suas cabeças. A “voz” do to 'cü passa a noite cantando, pedindo que as moças fiquem acordadas e em pé para que não lhes aconteça nenhum mal. Se não obedecerem, poderão ser punidas como a jovem To'oena, ou receber outros castigos, como o crescimento anormal dos seios. Seguem-se conselhos sobre seu procedimento em relação aos pais, ao trabalho, às responsabilidades que deverão assumir daí para frente em sua nova posição de pessoa adulta. Outros cantos falam de seus nomes pessoais e realçam os clãs." (1999: 35).
\end{abstract}

Vimos no Capítulo 5, tópico 5.3.2.2 - Canções de aconselhamento, algumas canções que são cantadas dentro do quarto de reclusão. Apresento abaixo alguns trechos de canções que podemos denominar be 'erutchiga, "canção para arrancar o cabelo" (be'e = puxar/ arrancar, tchiga $=$ história/ canção). Destaco principalmente os trechos em que o(a) cantor(a) falam sobre o sofrimento pelo qual a moça está passando (be 'erutchiga $1)^{515}$ :

\footnotetext{
${ }^{515}$ Assim como fiz com as Worecütchiga, como possuo três versões de canções para arrancar o cabelo das moças, intitulei-as be'erutchiga e enumerei-as de 1 a 3 . Canção 1, gravação e tradução de Ondino; canção
} 


\section{Nhumaruwai nawatürüwai dauũũ iri iri pa wowarecü}

"Contudo, neste momento, você vai sentir dor, moça nova"

Dentre os insultos que a moça recebe enquanto arrancam seus cabelos é sua comparação com aves depenadas (be'erutchiga 1):

Tacatürüwai poa'ãtchicüya noe noe ngocurü'ünwai cuũmayetarübecure

"Para nós você é igual à vovó bacurau depenada e pousada com as asas abertas".

Iri iri pa wowarecü

"Moça nova"

Há também versos das canções que fazem referência à pássaros que tem a pena mole. A canção pede para o cabelo ficar mais mole, para ser arrancado mais facilmente (be'erutchiga 1):

Nhumaruwai yeaĩyema ngoweamünrü 'ün tacatürüwai

"Neste momento, fique igual aquela surucuã para nós"

Cuyangoweamü'ün

"Teu cabelo igual a pena do surucuã"

Iri iri pa wowarecü

"Moça nova"

(be'erutchiga 2):

Ngemaücütü aи̃cümacü, aи̃cümacü, ya bunecüwa yepetchinüwa tacatürü buaãtchicü $i$ noe noe ngocurü'ũ ta nacatürü cudo'omü $i$ noegü $i$ cuma'atange rü totchitanü rü totchitanü

"Lá de onde ela vem, da beirinha (yepetchinü) do descampado (bunecü), voando para a gente a vovó bacurau (ngocu), assim como ela que tem as pluma molinhas (fáceis de arrancar) para as vovós que vão sentar junto com você."

O pássaro surucuã tem a pena bem molinha, não podemos pegar nela senão suas penas se soltam facilmente. Esta ave, designada pela palavra ngóweamã (pluma mole),

2, gravação Malvina, tradução de Hilda; canção 3, gravada por Clarícia, tradução Luscita. Participei de todas as traduções também. 
me foi identificado como diversas espécies do gênero Trogon ${ }^{516}$. O bacurau (ngocu, Lurocalis semitorquatus) é um pássaro noturno da pluma bem molinha. Segundo me disseram "é só puxar que a pena solta".

Como vimos, são frequentes as referências à forma mal-educada como ela tratou sua mãe (be'erutchiga 1):

Nhumaruwai nawatürüwai cudaũ̃' ũ

"Mas agora você vai sentir"

Erütürüwai curuwaiya otchameta õẽruwai cuüntürüwai

"Porque quando tua mãe manda em você"

Mucüraüngu cutchamatatürü oegacü

"Você responde a ela com raiva, com palavrão"

Norüoma 'ãyema imetü'ücü ocutiaraya tchigurü'ünwai

"Tua preguiça e tua canela fina igual a da cotia"

Cutchamatatürü nhiẽtügu cuyaporagü'ün curüotchametü

"Você quer ser mais do que tua mãe, fala com raiva em cima dela".

Pa iri iri wowarecü

"Moça nova"

(be'erutchiga 3):

Pa wowarecü

"Moça nova"

Rü cugaguni'

“É por sua culpa [cugaguni'î]

516 Yourucu - (ngóweamã = pluma mole/ sub. sp.) Surucuá-grande-de-barriga-amarela (Trogon viridis)/ cucunã (sub. sp.) = Surucuá-de-barriga-vermelha (Trogon curucui) / Surucuá-de-coleira (Trogon collaris) / Surucuá-pequeno (Trogon ramonianus) / Surucuá-mascarado (Trogon personatus) / Surucuá-de-caudapreta (Trogon melanurus) / Surucuá-de-barriga-amarela (Trogon rufus). 
Noriama ya mamae cu'üntürüyeya cu'ün ya uneta

"Que no início a sua mãe lhe guardou"

Nhemacani 'ĩ cu'üntürü taüneta

"Por isso ela the guardou"

Há momentos de consolo também, o(a) cantor(a) diz para a moça não chorar, pois o cabelo crescerá novamente (be'erutchiga 1 ):

Taüntürüwai nacamayecuya au'ün curuwai curungiyangiya

"Você não chore por causa do seu cabelo"

Cuyae iri iri pa wowarecü

"Teu cabelo, moça nova"

Marütatawai cu'ünnaya ãtchicu'ü

"Já vai crescer outro no lugar para você"

Ngemacaniwai taüntürüwai nacatürüwai cuya'au'ün

"Por isso, não adianta chorar por causa dele"

Curuwai curungiyangiya gacuyae iri iri pa wowarecü

"Teu, teu cabelo. Teu cabelo, moça nova"

(be'erutchiga 2):

Notürüta rü taũtamaü rü nacaicuau'ü, i cuyae, i cuyae,

"Não chore por causa dos seus cabelos, seus cabelos"

Nherütürüwai rü marümani 'î, rü marümani 'ĩ na yunatü' ũ̃ i cuyae

"Porque este seu cabelo já está de mortal"

O cabelo de mortal (yunatüyae) da moça nova tem "males" (puya), deve ser arrancado, pois ele pode atrair os “bichos” (ngo'o), como o Yureu (be'erutchiga 2):

Nhatürüye $i$ cuyae $i$ cuyae $i$ corugüyi rü yunatüyae nacatama rü cuawai na ẽaẽgü $i$ noegü

"Esse seu cabelo, cabelo, seus cabelos de mortal, por causa dele que as vovós estão te dando bebida" 
$(\ldots)$

Notürü ta taütamana nacaicuan cuauӥ $i$ cuyae i yunatü' ü, i yunatü'ü

"Não chore por causa do teu cabelo de mortal, mortal"

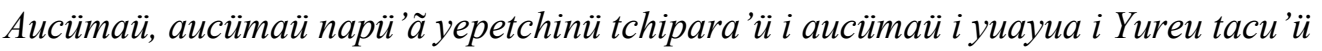

tatürü nacawa i yau'ü $i$ cuyae i yunatu'ü

“É perigosa, perigosa, a porta da montanha, na soleira fica de pé o perigoso Yureu. Por causa do seu cabelo de mortal que ele vai te pegar"

Em torno das moças e das velhas que arrancam os cabelos, forma-se uma enorme aglomeração de pessoas. As canções descrevem esta cena, comparando as pessoas às abelhas arapuá (acu - Trigona spinipes), conhecidas por se enroscarem nos cabelos das pessoas (be'erutchiga 3):

Yama acurü’üntürü ya gunegü ya cugutürüina wagütanün

"Os convidados estão pousando em cima de você como se fossem abelhas arapuá [acu]"

Taünwai nü'ün cuauamã

"Não chore com raiva deles [dos convidados]"

(be'erutchiga 2):

Damancütü, damancütü iguanecuya acurü' ü cucatürü rü cucatürü nibibimü i cuyae curügaye noetanücü

“Assim como a abelha $a c u$, para você, para você, em seus cabelos são como um enxame, suas vovós"

Após ter os cabelos arrancados, a moça pode levar um sermão de seu tio (FB). Pude observar isso na Festa e Porto Lima e pelo que me disseram, o tio estava sendo bem severo com as moças. Nimuendaju descreve um sermão destes:

““'Agora você pode deixar a reclusão e casar. Seja diligente! Uma menina preguiçosa também terá um marido preguiçoso, como ela mesma. Mantenha o respeito em suas palavras a seus pais e irmãos. Seja obediente a sua mãe, nunca indo contra seus desejos. Acima de tudo, você nunca deve abandoná-la! Mesmo depois que você estiver casada cuide dela.” E assim por diante.” (1952: 90).

Temos acima colocados em estreita relação o fim do ritual e o casamento. Os aconselhamentos que acontecem na Festa ensinam a moça a não ser preguiçosa, pois isso irá prejudicar seu casamento. "Uma menina preguiçosa também terá um marido 
preguiçoso, como ela mesma". A obediência e os cuidados com a mãe, como vimos, são algo recorrente nas canções. Os conselhos, portanto, vão na direção de formarem boa esposa e boa filha.

Numa das Festa que presenciei em Vendaval, a "pelação" da moça - modo como os ticuna chamam o processo de arrancar os cabelos da jovem - começou às onze horas da manhã do domingo, e prosseguiu por cerca de uma hora e meia, duas horas. É um processo demorado. Apesar de muitas mulheres arrancarem, uma pequena quantidade de fios é puxada por vez. Ao longo de todo o processo, são arrancados o máximo possível de fios.

\subsection{0 - Banho no rio - fim do ritual}

A Festa vai chegando ao final. A carne moqueada já foi distribuída aos convidados. Durante a manhã muitas crianças foram pintadas, adornadas e tiveram seus cabelos cortados. Neste sentido, em paraleleo ao ritual de passagem das moças, há uma Festa feita para as crianças, de ambos os sexos. Existem canções específicas para as crianças e, segundo me disseram, uma Festa pode ser feita só para elas. 

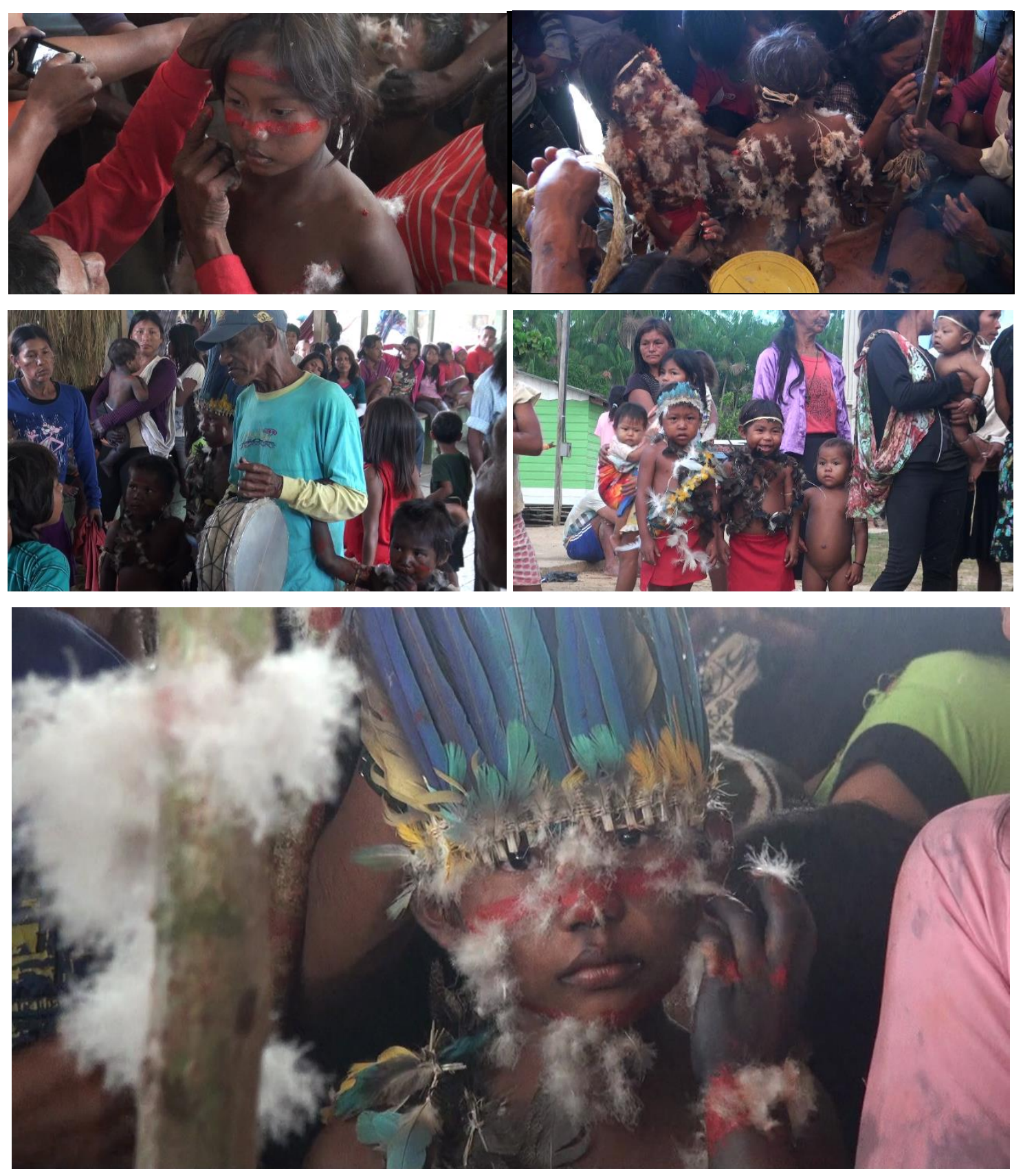

Figuras 186, 187, 188, 189 e 190 - Crianças adornadas na Festa

As moças ainda estão sentadas nas esteiras (tchepenü) após a "pelação". Antigamente usava-se o couro da anta ou os escudos (tchine) para esta finalidade. Nas Festa que presenciei, os homens ergueram as moças sobre esteiras. Deram voltas em torno da casa carregando as meninas em cima da esteira. Em Porto Lima, ao mesmo tempo em que levavam as moças, uma mulher foi cortando algumas pontas da palha do telhado da casa numa bacia segurada por um rapaz. Em Vendaval este corte das palhas da casa também aconteceu no domingo de manhã durante uma Festa da Moça Nova. Me disseram que este é o batizado da casa, como era recém-construída, tinha que ser batizada. "[O 
corte das pontas da palha de cobertura] é feito em casa nova, para batizá-la, ela também precisa de nome", afirma Ondino.
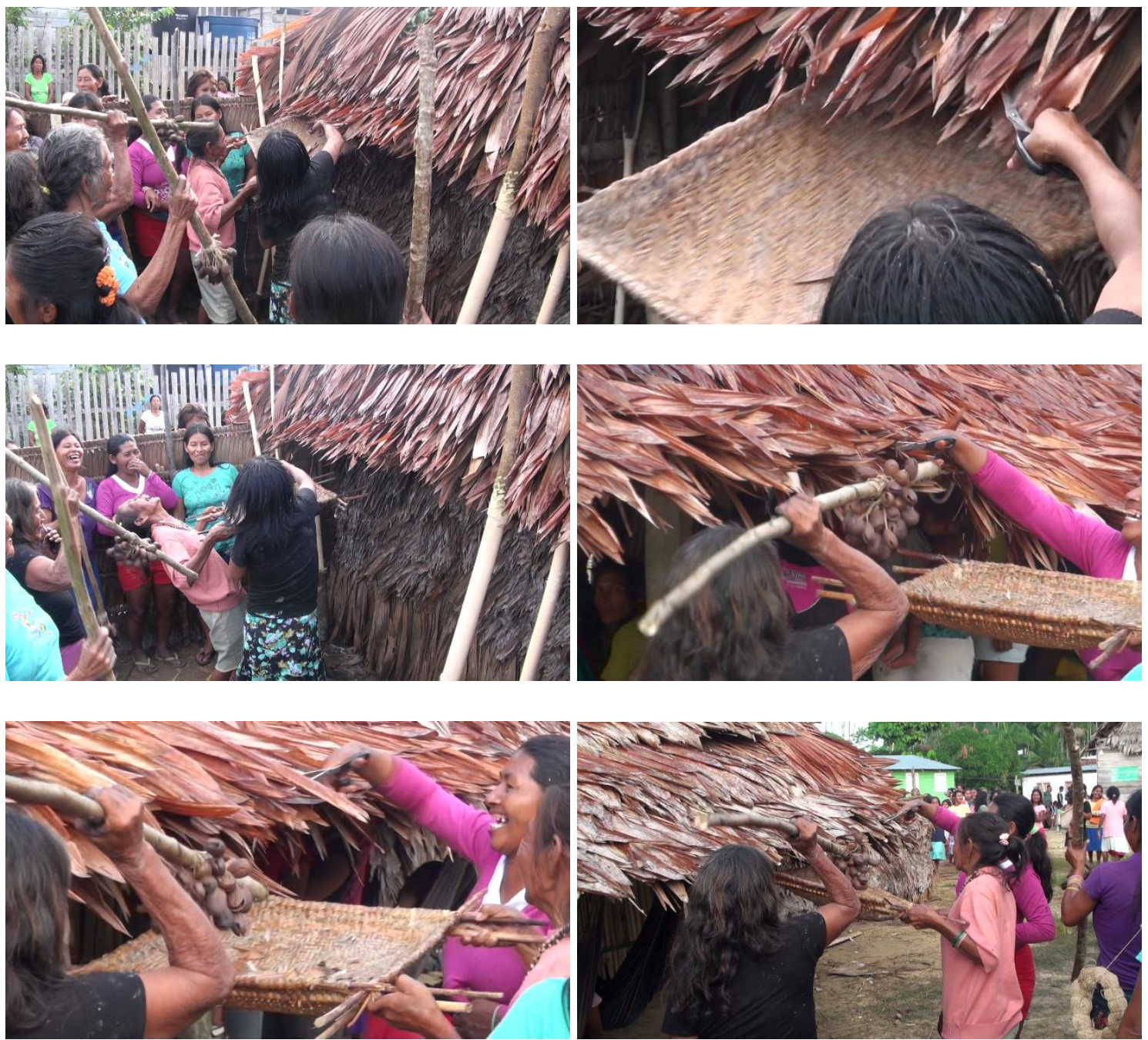

Figuras 191, 192, 193, 194, 195 e 196 - Corte do "cabelo" da casa de Festas

Goulard afirma que a moça é levada para o rio sobre os escudos de tururi. Levam ela porque ela não pode pisar o chão:

"Ela é levada para lá [o rio] sobre "escudos" de casca batida, porque ainda não pode colocar os pés em terra firme. Na verdade, ainda não é completamente mulher antes de seu banho, ela conserva uma parte de seu estado de imortalidade (ü'üne)." (Goulard, 2011: 149) ${ }^{517}$.

517 O fato de a moça não poder colocar os pés no chão parece ser recorrente em outras partes da América. "Em todo o oeste e noroeste da América do Norte, as meninas menstruadas pela primeira vez não podiam 
Isso pode ter relação com a temperatura do corpo. Assim como as cinzas protegem a moça do frio, levá-la suspensa do chão pode ser uma medida para prevenir seu "resfriamento", algo associado à floresta e aos seres que lá vivem. Uma das razõe para a Festa ser feita é para que o ventre da moça não se esfrie, não tenha "odor verde" 518 , ou seja, que adoece facilmente. Esta é a mesma explicação de ouvi de Ondino sobre o caminho de cinzas que é feito para que a moça ou a mãe no puerpério caminharem até o rio. Isso é feito para que seu corpo não esfrie, ou seja, mantenha-se saudável e fértil.

Todas as ripas de buriti do quarto de reclusão, os instrumentos de bambu, exceto os tamborins tutu, é tudo jogado no rio junto com as moças. Muita gente pula no igarapé junto com elas, outras tantas pessoas são jogadas na água. Depois disto termina a Festa. As meninas se lavam no rio e saem exaustas para suas casas. $\mathrm{O}$ banho no rio pode ser considerado a última etapa da sequência de pequenos ritos que compõem a Festa da Moça Nova.

Nimuendaju comentando sobre a importância da limpeza dos detritos ao final da Festa: "A menos que isso seja feito, todos os moradores da casa vão adoecer e morrer lentamente." (1952: 91). Esta informação sobre os danos acometidos aos moradores que não limpam a casa depois da Festa é bastante importante. É como se os restos da Festa estivesse infectados também, poluídos. Pardo sugere que os restos que são jogados no rio se transformam em peixes, assim como o bagaço de jenipapo do tempo mítico. "Las jóvenes de la pelazón y el médico tradicional encarnan la escena mítica, cuando los residuos de la fiesta se convierten en peces para ser pescados y convertidos por Yoi en el pueblo ticuna" (2010: 161). Neste sentido, os resíduos da Festa contribuiriam para a abundancia na pesca.

tocar no chão com os pés descalços nem olhar para o sol. Para evitar a primeira eventualidade, os Carrier exigiam que fosse carregada nos braços" (Lévi-Strauss, 2006 [1968]: 454).

518 “...el vientre, la matriz; que no se enferme, que no se enfríe que no entre frío, porque en ese momento para nosotros la mujer expide un olor, un olor como a verde, nosotros le decimos a verde, que si no se cuida se enferma fácilmente, esa es la parte más delicada donde va a formar nueva vida" (Valenzuela, 2010: 112). 

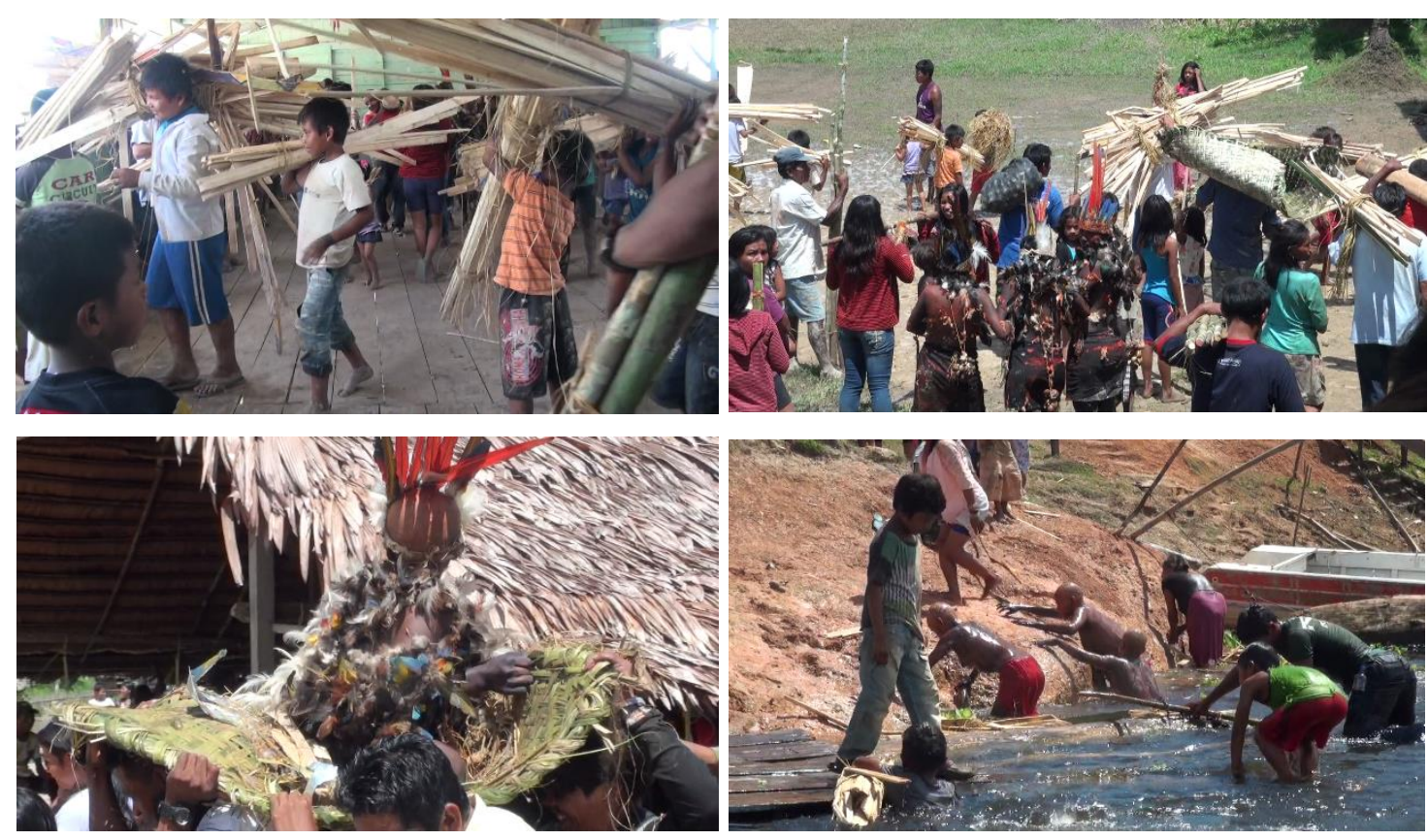

Figuras 197, 198, 199 e 200 - Levando as moças e o "lixo" para o rio

Os rituais que presenciei não elaboravam tanto o banho final no rio, a moça apenas era jogada ou entrava na água e muitas pessoas também se banhavam. Valenzuela, contudo, comenta sua elaboração, com benzeções do pajé. Enquanto estão na água, o pajé finca uma flecha dentro do rio e a moça deve dar três voltas em torno da flecha dentro d'água:

"Finalmente la llevan a bañar al río; ella [Blanca Ramos, uma moça nova] dice que durante el proceso se sintió temerosa y sentía que sus pies al caminar en la tierra eran como de bebé recién nacido, y en el río sentía cosquillas; durante el proceso, el chamán clava una flecha en el agua cerca de la orilla y ella debe dar tres vueltas alrededor de ésta nadando como acto final." (2010: 77)

O mesmo pequeno ritual dentro do rio é descrito por Nimuendaju:

"Um banho no rio fecha o ritual. Ela é conduzida até o rio por alguns homens, junto com a "roda" [o escudo, tchine] em que ela teve lugar anteriormente para puxarem seu cabelo. A seta (de yomeru? [taperebá]) do xamã, até então presa na entrada da casa onde o ritual foi celebrado, é plantada no leito do rio. Despida por sua mãe e a esposa de seu tio, a menina entra na água até os joelhos. O xamã a banha da cabeça aos pés para evitar a gravidez precoce que a tornaria estéril: "Assim você não vai engravidar tão logo, embora tenha um marido". O material é, então, destruído e lançado ao rio onde cada um por vez se banha. A menina, 
ainda no rio, é lavada com cipós ichtyotoxics [timbó], veneno de pesca para garantir futuras pescarias de sucesso." (1952: 126-27).

Despois de alguns meses, principalmente depois que o cabelo da moça já cresceu, uma última Festa é organizada para confirmar a passagem da moça. Esta Festa é chamada yopakechiga, nome que indica que somente a franja da moça será cortada ${ }^{519}$. As yopakechiga possuem menos elementos que as Festas de Moça Nova, diferem destas principalmente pelo fato de o cabelo não ser arrancado. As Festas que presenciei nas comunidades de Porto Lima e Santa Clara podem ser consideradas deste tipo.

Ao final da primeira Festa alguns itens são guardados no jirau da casa de Festas para serem queimados na ocasião da yopakechiga. De acordo com Gruber, "[t]erminado o ritual, os bastões $\left[d u^{\prime} p a\right]$ são colocados sobre o jirau da casa e aí permanecem à espera do yopaquee, quando então serão queimados junto com outros materiais" (1999: 12). A mesma autora menciona ainda os trompetes de bambu (coîri) e "as franjas que ornamentam as máscaras", que são guardados no jirau para serem queimados depois da Festa. O casco de tracajá também será destruído posteriormente.

Tentei mostrar neste capítulo o processo ritual da Festa da Moça Nova. Para alguns elementos do ritual já esbocei algumas análises e hipóteses. Para finalizar esta tese, gostaria ainda de expor algumas considerações finais: 1) uma consideração geral sobre rituais, em especial, rituais de iniciação à vida adulta; 2) uma hipótese que pretende ampliar a compreensão do fato de arrancarem os cabelos da moça; e 3) por fim, também a título de hipóteses, mostrar algumas possíveis "condensações rituais" que acontecem na Festa da Moça Nova descrita neste capítulo.

\footnotetext{
519 “Uma breve celebração complementar, chamada yopakechiga, ocorre alguns meses depois, o cabelo da menina, que já tornou a nascer em parte, é cortado em torno da testa. As cabeças das máscaras e as franjas que podem ser preservadas após o ritual, são queimadas e as cinzas espalhadas nos calcanhares dos participantes, para evitar os ataque de piolhos" (Nimuendaju, 1952: 127).
} 


\section{Considerações Finais}

As definições de ritual são abundantes na Antropologia. Encontramos definições que são tão amplas que fazem com que a noção acabe se enfraquecendo, perdendo sua capacidade analítica. Contudo, uma distinção que considero pertinente à análise do ritual em foco, a Festa da Moça Nova, é aquela entre ritual e cotidiano ${ }^{520}$. Enquanto nas relações da vida ordinária há espaço para "negociação de comportamento" de toda ordem, durante a ação ritual uma conduta exterior é prescrita aos participantes: "tem de se ajoelhar em momentos apropriados, derramar libações de uma forma particular, colocar certas máscaras e não outras, e assim por diante.” (Houseman, 2006: 413-414) ${ }^{521}$. Um desdobramento desta diferença, baseando-nos em Houseman, é que para o cotidiano, o que sentimos precede a ação, enquanto no caso do ritual, a ação precede o que se sente:

Podemos realmente dizer que, enquanto para a interação ordinária, a questão primordial é "dado o que eu sinto (e o que posso inferir sobre os sentimentos dos outros), o que devo fazer?", no caso do ritual é "dado o que eu estou fazendo (e que eu percebo os outros fazerem), o que devo estar sentindo?" (idem: $418)^{522}$.

Não que reavaliações e mudanças não possam surgir das interações cotidianas entre as pessoas, contudo, as atividades rituais possuem uma espécie de vocação para a "reavaliação convencional de conexões sociais existentes" (idem: 421).

"[A] mudança alcançada através do ritual implica uma ruptura definitiva: como já foi mencionado, uma das marcas registradas de ações rituais é que, para aqueles que as realizam, antes e depois não são os mesmos. Ao mesmo tempo, no entanto, na medida em que tal alteração implica uma confirmação de um conjunto prévio de interconexões entre as várias pessoas (e outras entidades)

\footnotetext{
520 Para um exemplo de consideração do ritual como não separado do cotidiano, ver Goffman (2011[1976]).

521 "Isso não significa que um determinado ritual é sempre executado exatamente da mesma maneira (...) ritual não é estranho à improvisação" (Houseman, 2006: 413-414).

522 “No entanto, a natureza exata desses estados [emocionais e intencionais dos participantes], enquanto informada pelo comportamento prescrito que eles prosseguem e regulamentado pelas (no momento conflitantes) pistas fornecidas pelas ações e discursos dos outros, permanece indeterminada." (Houseman, 2006: 419).
} 
envolvidos, corrobora a ordem pré-existente que pressupõe. Em suma, no tipo de recontextualização favorecido pela ação ritual, descontinuidades locais (por exemplo, a mudança de status social acarretado por se tornar marido e mulher) são sistematicamente incorporadas à predicação de continuidades mais amplas (por exemplo, o sistema de estatutos sociais, tal como definido por meio de conexões com e entre os membros da família, amigos, representantes do governo, etc.). Isso não quer dizer que tais reavaliações sistemáticas não possam ocorrer na ausência de ritual, mas apenas que o ritual é particularmente adequado para a sua realização." (ibdem).

O trecho acima já aponta o que examinaremos mais detidamente adiante: a natureza paradoxal do ritual, em especial os rituais de passagem. $\mathrm{O}$ "ritual implica uma ruptura definitiva" e, ao mesmo tempo, "corrobora a ordem pré-existente que pressupõe". Contudo, ressalta o autor, as descontinuidades locais, favorecidas pelos rituais, "são sistematicamente incorporadas à predicação de continuidades mais amplas". O processo se dá como numa espiral de transformações. As moças ticuna "formadas" na Festa tornam-se "outras" em sua "ruptura definitiva" com a infância. Ao mesmo tempo, estas moças se inserem na "continuidade mais ampla" das mulheres que passaram pela Festa e que iniciarão outras meninas. Este caráter cíclico das iniciações contribui também, como veremos, para a auto-referencialidade destes rituais.

Uma importante característica do ritual é seu caráter polissêmico ou multiplex (idem: 415 e 419). Ou seja, sua capacidade de conectar elementos que podem não ter qualquer relação no cotidiano. Ao ordenar fenômenos sociais que não tinham qualquer conexão no cotidiano, a ação ritual forma um novo todo ordenado, "o próprio desempenho ritual" (idem: 415). Neste novo contexto compartilhado, estes aspectos da vida social são imbuídos de mais significado. Desta maneira, e vimos exemplos disto ao longo desta tese, a ação ritual amplia a significação atribuída à determinada característica ou elemento da vida social $(\mathrm{ibdem})$.

\section{Iniciação}

Em seu pequeno verbete intitulado "Iniciação", Zempléni afirma que os etnólogos distinguem tradicionalmente três tipos de iniciação: 1) iniciação feminina e masculina à vida adulta, 2) as “iniciações religiosas eletivas dos vários intermediários entre o mundo 
humano e as potências invisíveis", 3) "iniciações opcionais e voluntárias às sociedades secretas". Como fica claro na leitura do clássico de Van Gennep, Os Ritos de Passagem, a iniciação é apenas um dos tipos de rituais de passagem. "Para a etnologia clássica", diz Zempléni, "a iniciação é o protótipo do rito de passagem cuja unidade formal e funcional foi estabelecida por A. Van Gennep (1909): invariavelmente estruturado em três fases separação, marginalização, agregação - sua função é marcar a transição de um estado ou condição social a outro (...) a iniciação não é uma variante, mas uma forma sintética dos ritos de passagem por meio dos quais ela opera." (1991: 375). A iniciação, portanto, não é uma mera variação dos rituais de passagem, ela é protótipo e síntese destes ritos. Neste sentido, ela seria uma espécie de "rito dos ritos" 523.

Contudo, este esquema demasiado genérico para os rituais de passagem não nos deixa ver a especificidade que possui a iniciação. Diferente de um simples ritual de passagem - que marca, por exemplo, o nascimento, a puberdade ou a morte -

"a iniciação consiste em engendrar uma identidade social através de um ritual e erigir este ritual como fundamento axiomático da identidade social que produz (...) [A]penas iniciados são habilitados e requeridos para executar a operação de iniciação. A iniciação é um rito identitário que contém o princípio de sua própria repetição (...) [torna-se um iniciado] em virtude de uma operação em que não se pode ser sujeito sem tornar-se agente, e vice-versa (...) Para o etnólogo, a iniciação não é nem um simples rito de passagem ou um processo de aprendizagem contínua, mas um rito de formação descontínuo e irreversível do indivíduo representante de uma categoria social, cujo principal atributo é a experiência transitiva comum desta transformação puramente cultural" (Zempléni, 1991: 375).

O ritual não cria nada ex nihilo, pelo contrário, reforça princípios de relacionamento ancorados na experiência irrefutável conferida pela própria performance ritual (Houseman, 2006: 420-421). Podemos encarar o ritual como "um modo distinto de transmissão cultural orientada para a organização da ação" (ibdem). Deste modo, a importância permanente de certos valores e ideias é veiculada "na forma de encenações relacionais altamente memoráveis" (ibdem). Aos participantes dos rituais são oferecidos

523 "Se ela [a iniciação] se parece com um "rito dos ritos" - e como uma forma sintética dos ritos de passagem através dos quais ela opera - é porque, ao contrário de outros rituais, ela define a identidade mesma de seus agentes como a condição ontológica de sua própria reprodução" (Zempléni, 1991: 377). 
os contextos auto-referenciais necessários para colocar estes valores e ideias em prática (ibdem).

Os Caribe do Rio Maroni, por exemplo, veem o rito de iniciação feminina como, em primeiro lugar, bom em si mesmo ${ }^{524}$. Esta postura com relação a estes rituais reflete a posição de Zempléni de que, no final das contas, estes ritos existem por si mesmos. Os ritos de iniciação, diz este autor, seriam portadores de uma recursividade própria das espécies naturais (1991: 377). Para Zempléni os rituais iniciáticos seriam auto-referentes:

"O caráter auto-referencial deste tipo de iniciação é um corolário de sua natureza antagonista (...). [A] eficácia desses ritos não está na ação não observável dos ancestrais ou espíritos, mas na sua simulação iniciática; apropriando-se, assim, dos seus próprios referentes invisíveis, o rito de iniciação toma o seu lugar como a causa eficiente da transformação iniciática. (...) Se essas ações rituais parecem "paradoxais" (M. Houseman) é porque elas materializam o caráter auto-referencial das operações de iniciação" (1991: 376).

A auto-referência mencionada pelo autor indica que, no limite, a iniciação tem um fim em si mesmo. O "conhecimento iniciático" está confinado ao mundo criado pelo próprio ritual. Neste trecho isso fica bem claro:

“...o conhecimento iniciático é caracterizado por, pelo menos, dois traços: 1) ele é inaplicável fora do campo da sua aquisição, a esfera fechada da iniciação (que não é uma "escola do mato" onde se ensina ou desenvolve o saber enciclopédico da "tribo"); 2) ele só é essencialmente válido pela ação transitiva de sua transmissão ritual, ou seja, pela reiteração da iniciação que o engendra. Somente tornando-se iniciador que nos tornamos totalmente iniciados." (1991: 376- 377).

Ou neste trecho:

"Ao se apartar assim de todo referente exterior e só se referir, explicitamente, a ela mesma, a iniciação induz nas mentes de seus atores que a sua eficácia é completamente imanente às operações que comporta. É através destas operações auto-referenciais que ela se afirma como o fundamento axiomático da identidade que produz" (1991: 377).

524 "Finalmente, como os Caribes explicam o rito? (...). Para eles, o rito é bom em si mesmo, em primeiro lugar. Em segundo lugar, é considerado como um meio para assegurar a realização da função de uma mulher adulta." (Kloos, 1969: 904) 
Por mais que existam atualmente mulheres ticuna que não passaram pela iniciação e nem por isso deixaram de se casar e ter filhos, não há como pertencer ao grupo das iniciadas sem ter passado pela Festa. No limite, a Festa também possui um valor em si mesmo, ela existe para se perpetuar. As mulheres são "formadas" por este ritual e, por terem passado por ele, "formarão" outras meninas.

No universo das iniciações, os estudos dos rituais femininos tem sua especificidade. Zempléni corrobora o que muitos outros etnólogos afirmam: os rituais de iniciação feminina mereceram menos atenção por parte dos etnólogos do que os ritos de passagem masculinos à vida adulta (1991: 375). Talvez a primeira a notar esta desproporção tenha sido Richards (1956), em um dos mais influentes estudos de iniciação feminina de uma sociedade africana, os Bemba, da Rodésia do Norte, atual Zâmbia ${ }^{525}$. Um compêndio relativamente mais recente sobre rituais iniciáticos femininos da Melanésia (Lutkehaus \& Roscoe, 1995) abre suas páginas afirmando o mesmo: a iniciação feminina é menos estudada que a masculina.

Não há como negar que o método estruturalista de análise dos mitos mostrou um extraordinário rendimento na análise dos mitos ameríndios. Talvez seja possível mesmo afirmar que a análise mítica empreendida por Lévi-Strauss nas Mitológicas seja uma das mais notáveis do mundo, comparável às dezenas de anos de estudos da mitologia grega. Contudo, se, por um lado, o rendimento da análise mítica se mostrou impar na América indígena, por outro lado, o estudo do ritual ainda espera por uma grande síntese teórica semelhante ${ }^{526}$. A literatura sobre rituais de iniciação entre os povos sul-ameríndios também apresenta muitas lacunas. Apesar de termos alguns registros etnográficos dispersos destes rituais ${ }^{527}$, pouco sabemos sobre suas semelhanças e diferenças. $\mathrm{O}$ fato de

\footnotetext{
525 O trabalho de Audrey Richards (1956), sobre a iniciação feminina dos Bemba, é considerado por Brown o mais notável e completo na área. Além disso, Brown destaca o pioneirismo de Richards afirmando que seu livro, Chisungu, "é provavelmente a descrição mais detalhada já feita de uma cerimônia de iniciação feminina" (1963: 837).

${ }^{526} \mathrm{Em}$ um recente congresso de antropologia, o GT responsável por reunir as comunicações sobre rituais indígenas, intitulado "Rituales: transformaciones cosmológicas y socio-históricas", dizia o seguinte em sua chamada: "A pesar de la abundante producción empírica de los últimos años, no se ha realizado hasta el momento un intento de articulación teórica de los temas más relevantes de la antropología del ritual en contextos amerindios de las Tierras Bajas Sudamericanas." (Gordon et al 2013: 1).

${ }^{527}$ Apenas para mencionar algumas referências: Kloos (1969), Maizza (2012), Miller (2007), Nimuendaju (1952), Hugh-Jones (2011[1979]), Matarezio Filho (2014[2010]), Metraux (1945, 1948), Matos (2014), Bonilla (2007), Spaolonse (2006), Falleiros (2010). Em Lévi-Strauss (2006 [1968]) há referências de rituais femininos para a América do Norte.
} 
a teoria sobre rituais de iniciação, feminina ou masculina, ter se desenvolvido fortemente para outras regiões do mundo, especialmente África e Melanésia, torna a comparação dos avanços teórico alcançados com os materiais destas áreas etnográficas bastante proveitosa para os estudos de rituais de iniciação na América indígena.

No prefácio da obra de Lutkehaus \& Roscoe (1995), mencionada acima, os autores relatam o motivo para as atenções voltadas, recentemente, para os rituais de iniciação feminina: o fato de alguns destes ritos envolverem a "mutilação genital feminina" (idem: xiii). Este tipo de mutilação ritual, dizem os editores do livro, apresenta aos antropólogos um dilema ético. Por um lado, "a prática é abominável para a tradição ocidental de onde a nossa disciplina surgiu" (ibdem). Por outro lado, a defesa da relatividade cultural promovida por antropólogos também defende as tradições não-ocidentais do etnocentrismo ocidental (ibdem). Neste sentido, propõem os autores, "[e]m um contexto em que a sensibilidade há muito tempo negligenciada para com as mulheres é agora exortada, no entanto, a "mutilação" genital feminina apresenta o dilema de tentar apoiar os direitos das mulheres ao mostrar respeito por essas mulheres que continuam a encontrar a sua dignidade através de tradições de iniciação" (ibdem). Muito do que alimenta este dilema está na falta de informações que possuímos sobre os mais diversos rituais de iniciação feminina que existem pelo mundo.

Existem duas diferenças centrais entre os rituais de iniciação masculinos e femininos. Enquanto a iniciação masculina costuma envolver grupos de neófitos, a iniciação feminina tende a focar em indivíduos (1995: xiv). Uma consequência disto, e a segunda diferença central entre os dois tipos de iniciação, é o fato de o ritual de iniciação para as mulheres serem geralmente em escala menor que os rituais masculinos (ibdem). Deste modo, devido à escala reduzida dos rituais femininos, focado mais em indivíduos do que em grupos, a "iniciação feminina necessariamente ocorre com mais frequência do que a iniciação masculina" (ibdem). Este dado pode fazer sentido para a Melanésia, contudo, a iniciação feminina dos Ticuna muito raramente acontece com apenas uma menina. Em geral, são duas ou mais moças que ficam juntas na reclusão e participam da mesma Festa.

O que contribuiu para a escassez de documentação sobre rituais femininos é apontado por Lutkehaus \& Roscoe como a "preponderância histórica de etnógrafos masculinos" (1995: xv). Além dos preconceitos carregados por muitos destes etnógrafos, que fecharam os olhos para os rituais femininos, existem, para os etnógrafos de sexo 
masculino nestes casos, "dificuldades pragmáticas significativas que, embora possam ser usadas também levianamente para desculpar a negligência dos reinos femininos, são reais, no entanto, e ajudam a explicar as nossas gastas informações em rituais do gênero feminino" (ibdem). Este é um ponto importante para o meu caso. Certamente o fato de ser homem teve influência sobre minha descrição da Festa. Principalmente, este fato pesou mais em minhas conversas com as mulheres ticuna. Minhas colaboradoras são, de modo geral, mulheres mais velhas que falavam bem o português. Senti muita resistência ou vergonha das mais jovens - ou mesmo as moças que haviam saído há pouco da reclusão - em conversarem comigo.

Com relação aos rituais de iniciação sul-americanos, gostaria ainda de esboçar alguns apontamentos gerais. Alguns autores que se debruçaram sobre estes rituais definiram linhas fundamentais presentes em todos eles. Assim como os mitos, os rituais de iniciação só fazem sentido internamente às culturas até certo ponto. Existe, assim como Lévi-Strauss demonstrou brilhantemente para os mitos ameríndios, um certo limiar de inteligibilidade nos rituais que exige a comparação com outros ritos de puberdade. Deste modo, assim como existe uma terceira ordem de código - que é o próprio pensamento mítico $^{528}$ - certamente existe, concordando com o psicanalista Bruno Bettelheim ${ }^{529}$, um fundamento comum entre tantos ritos pubertários distintos e talvez para além deles.

Em um artigo publicado em 1945, intitulado "Ritos de transito de los indios sudamericanos", Metraux indica a importância que têm estes ritos em toda América do Sul indígena e apresenta uma visão panorâmica dos rituais pubertários femininos na região. Podemos notar a atualidade das considerações gerais do etnólogo de origem suíça no excerto abaixo:

"En toda Sudamérica, la primera menstruación de una joven es considerada
como un acontecimiento de importancia, señalado por observaciones rituales, y
muy a menudo celebrado con grandes festividades. Los numerosos, y

\footnotetext{
${ }^{528}$ A primeira ordem de código são as línguas nas quais os mitos são relatados. A segunda ordem são as narrativas míticas. $O$ pensamento mítico, a terceira ordem, articularia as transformações entre as narrativas. Sobre isso, ver principalmente a Abertura de O Cru e o Cozido (Lévi-Strauss, 2004 [1964]).

529 “...creio que os ritos de puberdade se referem a algo tão primitivo que é compartilhado por todos os homens" (Bettelheim, 1974 [1954]: 12). Retomarei este ponto abaixo, quando for analisar o arrancamento dos cabelos das moças.
} 
frecuentemente rigurosos, tabús a que es sometida la joven púber, demuestran que el acontecimiento es visto con cierto temor, y que a la joven misma se la considera expuesta a peligros sobrenaturales. Las precauciones que en estas ocasiones se toman sirven no sólo para protegerla, sino también para impedir la corrupción de objetos o elementos que pueden ser adversamente afectados por la condición impura de la joven. La crisis fisiológica de la pubertad es generalmente considerada como la época en que se moldea el carácter de la joven, y el momento en que ella puede adquirir, por medios mágicos, las cualidades físicas y morales deseables que asegurarán su éxito como mujer, esposa y madre" (1945: 117-118).

Metraux mostra como o aconselhamento, tão presente na Festa dos Ticuna, é muito recorrente nos rituais de iniciação feminina sul-ameríndios:

“Educación moral. Durante el período de reclusión, la joven era ordinariamente instruida por su madre o por algún otro pariente femenino respecto de sus deberes como chica casadera, como mujer y como madre. Se le instaba a ser activa y diligente (Onas, Guaraníes, Caribes, etc.). La joven caribe, por ejemplo, era instruida por su madre en la mañana y en la tarde. Las admoniciones era luego repetidas por todos los que participaban en la fiesta, al final de su encierro" (1945: 127-128).

Estes aconselhamentos que pretendem "formar" uma moça que tenha "bons modos" - do mesmo modo que os regimes alimentares, talheres e utensílios de higiene são considerados por Lévi-Strauss "meios de mediação" que desempenham, portanto, "uma dupla função" (2006 [1968]: 459). Por um lado, e Lévi-Strauss atribui esta ideia a Frazer, cumprem um "papel de isolantes ou transformadores, suprimem ou baixam a tensão entre polos cujas cargas estavam anormalmente altas" (ibdem). Por outro lado, "servem também como padrões de medida" (ibdem). Neste último sentido, os aconselhamentos têm a mesma função da canoa do sol e da lua - função esta atribuível "a todo e qualquer objeto técnico, e à própria cultura que os engendra", diz Lévi-Strauss -, que é a de "ao mesmo tempo separar e unir seres que, se ficassem perto demais ou longe demais um do outro, deixariam o homem mergulhado na impotência ou na insensatez." (ibdem). Ou seja, olhando para esta formulação de Lévi-Strauss da perspectiva dos "bons modos" que se espera da moça após sua iniciação, estamos também diante de uma teoria ameríndia da maturidade. A moça ticuna sai da infância, se casa, respeita sua mãe, mas não deve abandoná-la, deve sempre residir próxima a ela e ampará- 
la até o fim de seus dias. Eis a boa distância - entre a menina, seus afins e consanguíneos - que se espera de uma moça que inicia sua vida adulta.

Algo muito semelhante ao aconselhamento da moça ticuna se passa com o que é falado para o cativo de guerra entre os antigos Iroqueses. Trata-se de uma vingança por suas (supostas) crueldades passadas, com relação aos parentes dos captores. A certa altura da tortura que é imposta ao cativo - quanto ele se mostra reticente em continuar a dança e o canto a que é forçado -, comenta Houseman que "ele é lembrado da maneira como ele e sua família tiveram de tratar seus cativos: 'Você não foi muito cruel onde estavam os prisioneiros? Conte-nos um pouco, você não se deleitou ao queimá-los? Você não achava que devíamos tratá-lo dessa forma, mas talvez você pensasse que havia matado todos os Hurons?'” (1999: 89). Na Festa da Moça Nova, como vimos, alguns cantos mostram que a moça é cobrada por todos os momentos em que tratou mal sua mãe, por isso ela estaria passando por aquele sofrimento. A tortura iroquesa era feita com a intenção de "obter a submissão de seus inimigos". Seria este também o caso do ritual da moça nova? A moça passaria por um processo de submissão, trata-se de submeter-se aos mais velhos para aceder ao status de mulher adulta?

Neste sentido, por meio da Festa, a moça é admitida na "sociedade" das mulheres maduras. Baseando-me nos estudos de Strathern sobre os povos da Melanésia, podemos desenvolver uma reflexão semelhante para os Ticuna. Segundo a autora, para os povos mencionados, os rituais de iniciação são uma espécie de lócus privilegiado para se pensar a relação entre "indivíduo" e "sociedade":

"Do modo como entendo os conceitos melanésios de socialidade, não há uma suposição nativa de uma sociedade que exista para além, ou acima, ou que seja englobante dos atos individuais e dos eventos singulares. Não há um domínio que represente a condensação de forças sociais controlando elementos inferiores ou resistentes a ele. Os problemas imaginados da existência social não são aqueles de um conjunto exteriorizado de normas, valores ou regras que precisam ser constantemente reforçados e mantidos contra realidades que constantemente parecem subvertê-los. As pessoas são subvertidas pelas ações de outras pessoas. Ou são atacadas por forças nãohumanas, para além do seu alcance. O mundo não está mapeado em esferas de influência, em impérios adjacentes e competitivos. As pessoas tampouco percebem uma hierarquia de níveis cujo campo de batalha final seja a subordinação do corpo humano. Consequentemente, os ritos de iniciação não 
são, creio, imaginados como uma apresentação do poder da sociedade/cultura, como uma força externa ao indivíduo, força que seja também um instrumento de poder mundano nas mãos masculinas e que os homens tenham a prerrogativa de exercer. As forças externas não são o problema, por assim dizer. Os melanésios se colocaram o problema da eficácia interna: como retirar do corpo aquilo do que ele é capaz. Os ritos constroem maneiras de entender quais são essas capacidades." (Strathern, 2006[1988]: 165).

Como alguns autores tem mostrado, tanto para os povos melanésios quanto para os ameríndios, as noções de indivíduo e sociedade não fazem muito sentido ${ }^{530}$, pensar os rituais de iniciação como o momento em que a sociedade apresenta seus poderes coercitivos aos indivíduos faz menos sentido ainda. A ideia da "existência social" como um "conjunto exteriorizado de normas, valores ou regras que precisam ser constantemente reforçados e mantidos contra realidades que constantemente parecem subvertê-los" (ver trecho acima) se aproxima, como veremos, da noção clastreana da finalidade do sofrimento no ritual de passagem, contudo, contradiz o próprio modo como estas sociedades se pensam. A questão não está, como afirma Strathern, nas forças externas à pessoa. A não ser na medida em que elas vêm de domínios externos à humanidade, "forças não-humanas", pois as relações internas e externas - as mesmas que conformariam a própria "sociedade" - à pessoa são a mesma coisa ${ }^{531}$. O problema colocado pelos melanésios, diz a antropóloga, é o "da eficácia interna: como retirar do corpo aquilo do que ele é capaz. Os ritos constroem maneiras de entender quais são essas capacidades" (ver trecho acima).

Seeger et al (1979: 2-3) já afirmavam que a grande contribuição da "etnologia dos grupos tribais brasileiros" à Antropologia de modo geral residiria em "uma elaboração particularmente rica da noção de pessoa" pelo viés da corporalidade. Estamos lidando aqui com a elaboração da pessoa da moça e as relações implicadas nesta elaboração. Tentei mostrar ao longo desta tese que - parafraseando o que os referidos autores defendiam em 1979 para as sociedades indígenas brasileiras de forma ampla - esta particular elaboração da pessoa ticuna durante a Festa da Moça Nova é o “caminho básico

\footnotetext{
530 Para os povos da Melanésia, ver Strathern, 1992, além de Wagner, 1991 e 2010[1974]. Para os desdobramentos destas teorias dos melanesistas entre os povos ameríndios, ver Kelly (2001)

531 "Whether external or internal, relations are intrinsic not extrinsic to the living person" (Wagner 1991). "One might say that relations are what animates the person..." (Strathern, 1992:83).
} 
para uma compreensão adequada da organização social e cosmologia" dos Ticuna (ibdem). Em outras palavras, através da Festa da Moça Nova dos Ticuna vai-se do controle e construção do corpo da pessoa ticuna, passando pelas relações entre os gêneros e pela organização social (as relações entre clãs e metades), às relações com os nãohumanos que povoam o cosmos.

\section{Por que os cabelos da moça são arrancados?}

Se há um traço muito presente nas iniciações entre os povos chamados primitivos são as operações que são realizadas sobre os corpos. Em especial, aquelas operações que causam um sofrimento nos neófitos ${ }^{532}$. Para Van Gennep, as provações físicas nos rituais de iniciação seriam equivalentes, sua única função seria criar uma marca comum aos ingressantes no ritual:

“Cortar o prepúcio equivale exatamente a arrancar um dente (Austrália, etc.), a cortar a última falange do dedo mínimo (África do Sul), a cortar o lobo da orelha ou a perfurar o lobo, o septo ou a praticar tatuagens e escarificações, ou a cortar os cabelos de certa maneira. Com estas práticas retira-se o indivíduo mutilado da humanidade comum mediante um rito de separação (ideia de secção, de perfuração, etc.) que automaticamente o agrega a um grupo determinado, e de tal maneira que a operação, deixando traços indeléveis, torna a agregação definitiva" (2011[1909]: 76).

Alguns autores se debruçaram sobre o tema do sofrimento imposto aos neófitos em rituais de iniciação ${ }^{533}$. Le Breton ressalta o caráter de educação para a dor de certos rituais iniciáticos. O sofrimento ritual seria tão intenso que depois disso nenhuma outra dor abalaria o iniciado. "Una mujer que describió su clitoridectomía subraya que ningún dolor en la existencia alcanza esa intensidad. Después de semejante experiencia, se siente capaz de soportar cualquier otro sufrimiento.” (1999: 263). Para o autor, o ritual prepara o jovem para as "vicissitudes da existência" (idem: 264). Habitando muitas vezes um meio

\footnotetext{
532 “... as iniciações tribais procedem quase universalmente as operações corporais, como o tamanho dos dentes, a circuncisão, subincisão, o piercing no nariz, as escarificações as mais diversificadas" (Zempléni, 1991: 377).

${ }^{533}$ Uma parte do texto que segue é uma revisão da discussão que se encontra em Matarezio Filho, 2014a.
} 
hostil, para o qual é necessária uma preparação do corpo, a iniciação seria fundamental para a própria sobrevivência do grupo.

"El dolor padecido es un antídoto que registra un recuerdo de la resistencia a la adversidad, la cual vuelve al iniciado menos vulnerable ante las pruebas inherentes a su condición. Apunta a forjar el carácter. Enfrentar al joven a un sufrimiento deliberado es una manera de poner a prueba los recursos que el grupo exige de él de manera perenne: resistencia, sangre fría y coraje.” (ibdem).

Esta consideração de Le Breton sobre a dor nos rituais de iniciação pode ser colocada junto com a de Clastres, como veremos, sob a rubrica de teorias que veem o ritual como uma espécie de mecanismo disciplinar. Uma forma de educar os jovens para as adversidades, para o sentimento de pertença ao grupo e para a igualdade dentro deste grupo. Nas palavras do próprio autor, "la resistencia al dolor es una especie de diploma entregado ante la mirada de todos" (1999: 264).

De acordo com Pierre Clastres, em seu texto "Da tortura nas sociedades primitivas", enquanto nós somos sujeitos à escolarização obrigatória e, por isso, nos é vedado o desconhecimento da lei ${ }^{534}$; a "dureza da lei” entre os primitivos se registra na carne do próprio corpo (P. Clastres, 2003[1973]), é indissociável da pessoa. A função da flagelação entre os povos ditos primitivos seria imprimir no corpo uma lei social. "A marca é um obstáculo ao esquecimento, o próprio corpo traz impresso em si os sulcos da lembrança - o corpo é uma memória" (idem: 201) ${ }^{535}$. Uma lei que se inscreve no corpo, nos dizeres de Clastres, não é uma lei a que simplesmente se submete; qualquer ato que escape a sua atualização é simplesmente impensado. "E essa lei não-separada só pode ser inscrita num espaço não-separado: o próprio corpo" (idem: 204).

Um ponto que pode ser desdobrado produtivamente do texto de Clastres, e que pretendo apenas esboçar aqui neste parêntese, é o negativo do que o autor coloca. Se ele aponta bem o fato da escolarização criar pessoas alfabetizadas e, por isso, vedadas ao desconhecimento da lei, para fazê-lo, o Estado deve retirar as crianças de casa, do seio da família. Muitas vezes, se pensamos em contextos extremamente urbanizados, são as primeiras relações mais marcantes e de maior duração que a criança terá fora de casa. $\mathrm{Ou}$ seja, entrar na escola é negar, ao menos em parte, a família, deixa-la em casa. O casamento

\footnotetext{
534 "A escrita existe em função da lei, a lei habita a escrita; e conhecer uma é não poder mais desconhecer a outra" (P. Clastres, 2003[1973]: 195).

535 Nos dizeres de Zempléni, trata-se da "“essência” nietzscheana da iniciação - crueldade que forjar a memória" (1991: 377).
} 
fará o mesmo, e de maneira mais definitiva, mas em outra etapa da vida desta pessoa. Portanto, o papel de socializador ${ }^{536}$ da criança exercido pela escola, no mundo ticuna é cumprido de modo mais radical pela Festa. Daí a relação inversamente proporcional que encontramos em muitas comunidades ticuna entre escolarização e frequência de execução de rituais ${ }^{537}$. A conta é simples, se a moça já participa de um processo que a retira do seio da família, que a torna uma mulher apta para o casamento, o rompimento operado pelo ritual torna-se acessório. Um tipo de ritual como este faz mais sentido num mundo em que a criança tem um apego e uma proximidade tal com os seus que somente uma Festa de iniciação poderá "formá-la" para se casar. Devo sublinhar que os tipos de rompimento com a família são distintos. No caso da escola, toda a complexidade do ritual é substituída por uma perspectiva de independência financeira proporcionada pela empregabilidade de uma pessoa que passou pela escolarização. Fechemos o parêntese e retomemos as considerações sobre o sofrimento ritual.

Ao contrário de Clastres, Houseman não considera adequado chamar de tortura o que se passa nos rituais iniciáticos. De um ponto de vista relacional, a dor crônica e a tortura são diferentes da dor infligida durante um ritual de iniciação pelas relações que são estabelecidas. A dor crônica seria a mais elementar, comportando apenas uma relação e meia, já que toda a pessoa que padece de dor crônica a entende como fruto de uma intencionalidade externa a si mesma. Assim como uma ilusão de ótica, a dor crônica geraria esta meia relação, que a pessoa mantém como um desdobramento de si mesma. Enquanto a tortura comportaria uma configuração relacional de "dois e meio" - ou seja, entre torturador, torturado e uma suposta terceira pessoa - a configuração do sofrimento no rito iniciático seria de ao menos três relações: o iniciando, o iniciador e o público. Neste sentido, conclui Houseman, quanto mais complexa é esta configuração relacional, mais a dor em questão contribui para a "construção de um mundo" (1999: 93). A função da violência no ritual é explicada da seguinte forma:

\footnotetext{
536 Uso aqui esta ideia, a "socialização", como negadora da família, muito próximo da definição de LéviStrauss da família. "Famílias na sociedade, pode dizer-se, como pausas na viagem, que são ao mesmo tempo a sua condição e a sua negação" (1983[1956]: 98). Da mesma maneira, os rituais de iniciação negam a "sociedade", mas são imprescindíveis para a sua continuidade.

${ }^{537}$ Na comunidade de Campo Alegre, por exemplo, encontramos uma grande escolarização em contraste com pouca atividade ritual. Enquanto que na comunidade de Vendaval os rituais são abundantes, mas a escolarização é baixa e até mesmo muitos professores são "importados" de Campo Alegre. Deve-se levar em conta também a forte influência da igreja batista na primeira comunidade, tanto incentivando a alfabetização, para a leitura da Bíblia, quanto coibindo as Festas de Moça Nova.
} 
"A violência que os iniciadores exercem sobre os iniciados intervém, ao mesmo tempo, para destacar os noviços dos não-iniciados, com os quais eles estavam até então identificados, e para intimidar e subordinar os não-iniciados (...) No entanto, na iniciação, as relações reunindo os três termos em presença (iniciador, noviços e não-iniciados) são atualizadas durante o ritual (...) Uma iniciação que não comportasse nem o concurso dos não-iniciados nas provas impostas aos noviços, nem a cumplicidade dos noviços na intimidação dos não-iniciados, perderia seu caráter iniciático" (1999: 86)

Tanto a dor crônica quanto a tortura, portanto, comportam um tipo de relação suposta, equivalentes aos "não-iniciados" presentes no ritual de iniciação. A relação entre a vítima e as pessoas ausentes, atuantes nos dois primeiros tipos de sofrimento, por ser simplesmente suposta e não atualizada, beneficia o torturado de uma grande margem de manobra e abre enormes possibilidades de especulação por parte do doente crônico sobre as causas de sua dor. De modo diferente, “durante a ação ritual, a dor é infligida no âmbito da interconexão sistemática de uma pluralidade de relações atualizadas" (1999: 94).

Enquanto a tortura proporcionaria uma "violência destrutiva", a iniciação seria a ocasião de um "sofrimento construtivo e honroso" (1999: 84). A tortura, diferente da iniciação, não comportaria qualquer aprendizado, já “a iniciação comporta a transmissão de um saber essencial" (idem: 77). Enquanto a tortura visa a destruição e degradação do indivíduo, operada pelo capricho de um outro indivíduo, o suplício iniciático, ao contrário, teria seu desenrolar estritamente codificado (Margarido et Panoff apud Hoseman, 1999: 78) $)^{538}$.

Deve-se enfatizar, portanto, que a imposição de dor é feita num contexto altamente ritualizado, ou seja, um contexto em que existem "restrições que governam a sua imposição." (Houseman, 1999: 93). Desta forma ela possui um potencial criador e de "transmissão de uma tradição (um "mundo")" (ibdem). As etnografias sobre os Ticuna são unânimes em afirmar que no cotidiano as crianças são tratadas com muito carinho, sem violência. Sobre as restrições em jogo na ritualização do sofrimento, Houseman afirma o seguinte: "Nestas condições, o desenvolvimento de dispositivos interativos e discursivos particularmente estáveis é altamente favorecido." (idem: 94). Daí o fato de cantos específicos aconselharem a moça ao mesmo tempo em que ela sofre com os

\footnotetext{
${ }^{538}$ Contudo, mostra Houseman (1999: 78), existem situações em ritos iniciáticos, especialmente em seus bastidores, em que a humilhação e a degradação dos neófitos é encorajada.
} 
cabelos arrancados. Todo o ritual é construído para que seu ápice seja o arrancamento dos cabelos das moças.

Outro importante autor que aborda o sofrimento nos rituais de iniciação é JeanLouis Siran. Logo no início do seu texto intitulado "Iniciação, por que a violência?" (2002) há uma crítica ao modelo de estudos de rituais de passagem de Van Gennep. O fundamento da formulação de Siran é a crítica ao "como se". "A iniciação, não é somente um como se. Não é só teatro para assustar as crianças e inquietar as mães! A violência é muito real, e a dor sofrida" (idem: 280). O esquema de Van Gennep nega a violência real que se passa nos ritos iniciáticos e transforma-a numa representação da morte, a "morte iniciática". Para Siran, e acredito que isto se aplica à Festa da Moça Nova também, as iniciações envolvem angustias reais que "liquefazem" algo nos neófitos (idem: 285) ${ }^{539}$. Algo é destruído para que a passagem possa ser feita.

Notemos que a angústia é evocada por Siran. O mesmo sentimento ${ }^{540}$ é destacado por Lévi-Strauss no capítulo Finale d'O Homem Nu (2011 [1971]) como traço distintivo do ritual de modo geral, como algo constitutivo da iniciação também. Os rituais podem ser motivados por estados de angústia/ansiedade ${ }^{541}$. Vejamos a definição de angústia feita por Lévi-Strauss por oposição ao riso:

"Entendido desse modo, o riso se opõe à angústia, sentimento que temos quando a função simbólica, longe de ser gratificada pela solução imprevista de um problema ao qual estava disposta a se dedicar com afinco, sente-se como que coagida pela necessidade, que as circunstâncias tornam vital, a operar entre campos operatórios ou semânticos, rapidamente, uma síntese cujos meios lhe escapam. E isso tanto para enfrentar a ameaça iminente de uma agressão como para restabelecer o equilíbrio de um sistema de vida que o desaparecimento de um ente querido, que nele tinha um papel insubstituível, destruiu. Em vez de

\footnotetext{
${ }^{539}$ Após citar um trecho de Van Gennep em que são enfileirados um exemplo após o outro de operações dolorosas nos neófitos, Siran conclui que: “A violência é, portanto, negada, pois é exatamente no mesmo movimento nomeada e removida: ela aparece apenas como um signo, ou melhor, como o significante (sem sentido em si) de um mesmo significado (separação / agregação)." (Siran, 2002: 280, nota 1). "A ideia de "morte iniciática" funciona bem no esquema de Van Gennep. Ela me parece, no entanto, infelizmente encorajar a crença que o neófito não é de fato levado a experimentar realmente essa angustia em que algo vacila, algo se "liquefaz" realmente nele." (idem: 285).

540 Lévi-Strauss refere-se à angústia - palavra que ele às vezes alterna com "ansiedade" - como um sentimento (2011 [1971]: 634-635). Lacan discordaria desta acepção: “Que é a angústia? Afastamos a ideia de que seja uma emoção. Para introduzi-la, direi que ela é um afeto." (2005: 23).

541 "Não deixo por isso de reconhecer a especificidade do ritual, nem tampouco os estados de ansiedade que - sem os exageros costumeiros - podem motivá-los" (Lévi-Strauss, 2011 [1971]: 646).
} 
um trajeto teoricamente laborioso ser evitado pelo atalho do cômico, nesses casos é a incapacidade de conceber um atalho que provoca aquela espécie de paralisia dolorosa, pressionando um espírito aterrorizado diante das dificuldades do trajeto que as vicissitudes da existência lhe impõem e das provações que cada etapa lhe reserva. (...) a emoção musical resulta de uma terceira eventualidade, que tem algo de ambos [do riso e da angústia]" (2011 [1971]: 634-635).

A situação liminar do neófito que passa pela iniciação é angustiante na medida em que ele ainda não restituiu o equilíbrio necessário em sua vida. A síntese entre os "campos operatórios ou semânticos", restauradora do "equilíbrio de um sistema de vida", é operada pelo ritual. Um funeral, por exemplo, pode ser pensado como um mecanismo social que visa a reestabelecer o equilíbrio num "sistema de vida" em que uma pessoa insubstituível não existe mais. No caso das iniciações à vida adulta, como a Festa da Moça Nova, podemos pensar que estes "campos operatórios ou semânticos" são a infância e a maturidade das moças. Arriscaria dizer que, em sociedades onde esta passagem não é ritualmente marcada, a tendência pode ser um aumento da angústia, pois os indivíduos têm que enfrentar sozinhos a saída da infância. Isto gera todo o tipo de "crises" de adolescência tão comuns em consultórios de psicólogos e psicanalistas.

Ao mesmo tempo, a Festa - composta de suas várias etapas mais ou menos angustiantes - se aproxima mais do que Lévi-Strauss chamou de "emoção musical", na medida em que é temperada por "atalhos cômicos". O ambiente criado no ritual pretende, retomando Siran, "liquefazer" a angústia, sentimento (ou afeto) este não só das moças, mas também de seus parentes e festeiros. A comicidade imprescindível no ritual ticunapensemos nas gargalhadas das pessoas ao verem os mascarados agitando seus pênis na Festa - desfaz a extrema tensão, também imprescindível, criada pela repressão sexual da moça: "não faça sexo antes da hora!". Como em muitas obras musicais, a tensão angustiante alcança seu ápice no final, no momento em que os cabelos são arrancados. Muito da tensão é desfeita ao final do ritual, com o banho no rio ${ }^{542}$.

\footnotetext{
542 Aproximo aqui "angústia" e "tensão musical" de uma forma talvez um tanto apressada ou imediata. Cumpre especificar aqui que na música tonal os acordes gravitam em torno do polo de atração gerado pelo acorde de tônica (Schoenberg, 1954). Um maior distanciamento deste centro é gerador de uma maior tensão, a convergência para esta nota principal resolve a tensão. Intuitivamente, a angústia remete mais à "tensão" do que a ao "relaxamento" ou "repouso". Para uma apreensão oposta da função da tônica na escala, ver Menezes Bastos: "Lembro que minha ideia de CT [centro tonal] não o apreende como local
} 
O sofrimento imposto aos jovens que estão sendo iniciados é uma constante nos rituais de iniciação. Entre os sul-ameríndios, apenas para mencionar alguns exemplos, como: a furação do nariz entre os Nambiquara (Miller, 2007); açoitamento das jovens púberes nos Jarawara (Maizza, 2012); as provações por que passam os meninos xavante (Spaolonse, 2006: 84; Falleiros, 2010: 204) ${ }^{543}$; açoitamento dos meninos waimiri-atroari, etc. Em meu livro, Ritual e Pessoa entre os Waimiri-Atroari (Matarezio Filho, 2014[2010]), passei em revista todos os sofrimentos por que passam os homens dos grupos indígenas de língua Caribe em rituais de iniciação: picadas de formigas, ardência de pimenta, açoitamento, dentre outros.

De fato, a Festa da Moça Nova cria um grupo de mulheres que passaram por ela. Contudo, apesar de estas provações físicas serem um forte candidato a um traço universal das iniciações, e por isso serem equivalentes neste plano, deve-se compreender o sentido de cada uma delas para determinado ritual. Uma importante questão que a Festa da Moça Nova nos coloca é: por que os cabelos da moça nova são arrancados? Por que o uso deste e não outro tipo de sofrimento físico é imposto a elas?

Há uma ação descrita por Nimuendaju, que pode acontecer no ritual ao final da depilação da cabeça das moças, mas que não apresentei até este momento, pois ela requer uma análise mais detida. $\mathrm{O}$ trecho é o seguinte:

"No final, resta apenas uma pequena mecha na parte superior da cabeça, que é ungida com urucu vermelho e torcida, finalmente, é arrancada pelo tio e levantada no ar, acompanhado por gritos de "dye!". Ato contínuo, a worecü recoloca o cocar de penas na cabeça e se levanta; os tios tomam-na por um braço, outro parente agarrando-a pelo outro; e eles galopam para fora enlouquecidamente ao redor da casa, gesticulando, com a última mecha de cabelo arrancada, em direção aos órgãos genitais dos espectadores." (1952: 90).

Pretendo formular aqui a hipótese de que esta ação realizada na Festa, de gesticular com a última mecha de cabelo da moça "em direção aos órgãos genitais dos

\footnotetext{
de repouso - como uma formulação consuetudinária da música ocidental o faz -, mas enquanto aquele que con-centra o tônus do sistema tonal, sua tônica." (2013: 203)

${ }^{543}$ Sobre o sofrimento ritual xavante, Falleiros nos diz o seguinte: "dadas as reclamações de alguns por estarmos ensaiando cantos debaixo do sol: "Paulinho" disse aos reclamantes que homem, para tornarse homem, datsiaibö, tem de sofrer nos rituais e no trabalho" (2010: 204).
} 
espectadores", equaciona, de alguma maneira, os cabelos da cabeça das moças com a região genital (pelos pubianos e órgão sexuais) ${ }^{544}$. Se esta primeira hipótese estiver correta, poderíamos desdobrar uma segunda ainda mais audaciosa. Caso os cabelos e os pelos pubianos estejam equacionados nesta ação descrita, poderíamos estar diante de uma castração simbólica da moça nova. Ou seja, a Festa da Moça Nova dos Ticuna seria um ritual em que a moça é castrada simbolicamente pelos festeiros. Vejamos estas hipóteses mais detidamente. Para tanto, me apoiarei principalmente num texto de Edmund Leach, “Cabelo Mágico”, publicado originalmente em 1958.

No entanto, antes de abordarmos a possível "castração simbólica" das moças no ritual, devemos ter em mente que mesmo a circuncisão masculina e feminina, que seria uma espécie de "castração de fato", não é desconhecida dos Ticuna de tempos pretéritos. Segundo Nimuendaju (1952: 9-10), dois cronistas comentam o costume dos Ticuna em realizarem a circuncisão, Padre Jose Monteiro de Noronha (1862) e Francisco Xavier Ribeiro de Sampaio (1825). Porém, ambos permaneceram por pouco tempo em área indígena - respectivamente, em 1768 e 1774 - e seus registros não são muito acurados. As informações registradas por estes cronistas são praticamente idênticas, o que levou Nimuendaju a concluir que "aparentemente usaram o mesmo informante" (1952: 10) $)^{545}$. De acordo com Noronha, a circuncisão, em ambos os sexos, ocorre da seguinte maneira:

\begin{abstract}
"Poucos dias depois de nascidos os filhos de um, e outro sexo, são circuncidádos pelas mães, que são ministras desta operação. Aos do sexo veril cortão a extremidade do prepúcio, e a ligadura inferior, que o prende a fava: E às do outro sexo a excrescência exterior, em cuja mais clara explicação seria menor o interesse da curiosidade, do que o prejuiso da modéstia. A esta ceremonia é conseqüente a de imporem nome aos filhos com festas..." (1862: 55-56)
\end{abstract}

Como bem nota Nimuendaju, apesar da descrição da circuncisão masculina ser bem clara, o cronista não define exatamente o que seria esta "excrescência exterior" do

\footnotetext{
${ }^{544}$ Vimos no Capítulo 1, tópico 1.3.1 - Nomes de Casas, que os Ticuna do Perú associam a cobertura das casas, também chamada "cabeleira" da casa, com os pelos pubianos. A entrada é chamada "boca-vagina da casa".

545 “Na minha opinião, todas as referências a esse costume [a circuncisão] são baseados no relato de Ribeiro de Sampaio, que viu os Tukuna brevemente em 1774 e repete um resumo dos dados obtidos pelo Padre Monteiro Noronha em 1768" (Nimuendaju, 1952: 40).
} 
sexo feminino que é circuncidada. Nimuendaju se questiona se seria uma clitorectomia ${ }^{546}$. Entretanto, com base em relatos de seu trabalho de campo, o etnógrafo afirma que provavelmente trata-se de "uma excisão dos pequenos lábios [labia minora], feita por razões de higiene, como me indicaram, logo depois que a criança nasce" (1952: 40). O etnógrafo alemão, no entanto, se contentou com as "razões de higiene" fornecidas pelos índios. Passemos aos dados fornecidos por Leach, ao que tudo indica, a Festa realizada nos dias de hoje pode fornecer outras "razões" para a antiga excisão feitas nas meninas ${ }^{547}$.

Podemos concordar com Leach quando ele afirma que frequentemente os psicanalistas "extraem do material etnográfico o apoio para suas observações clínicas" (1983[1958]: 142). Isso fica evidente, diz Leach, no clássico Totem e Tabu, de Freud. Mais próximo do objeto de estudo em foco nesta tese, p. ex., Bruno Bettelheim, um aluno de Freud, fez o mesmo uso de materiais etnográficos para seus estudos da relação entre alguns rituais de iniciação, especialmente os masculinos, com a psicanálise. Em seu artigo, Leach se dedica especialmente a um livro do psicanalista Dr. Charles Berg, em que "o autor usa material antropológico para provar conclusões de tipo psicanalítico, de maneira muito semelhante à de Freud.” (idem: 143). Partindo desta constatação, Leach propõe que a afirmativa de Freud, de que o material etnográfico tem significado para a teoria psicanalítica, seria "muito falaciosa" (ibdem). Contudo, a proposição inversa talvez renda frutos. "Pode ser que o material psicanalítico tenha significado para a teoria antropológica" (ibdem).

Para elaborar sua crítica, Leach parte da seguinte constatação feita pelo Dr. Charles Berg:

"Baseando-se, em primeiro lugar, em material clínico, o Dr. Berg conclui que o cabelo da cabeça é um símbolo universal dos órgãos genitais. O corte de

\footnotetext{
546 Entre os Cocama, povo também habitante do Alto Rio Solimões, apesar de Metraux afirmar que o "confinamento Cocama é menos rigoroso", a moça sofre uma excisão de seu clitóris (clitorectomia): "O confinamento das meninas Cocama é menos rigoroso. No final do período, é celebrada uma festa durante a qual a menina se embebeda até um estado de estupor. Ela é então levada para um compartimento construído acima do solo, onde uma velha corta a extremidade de seu clitóris. Cinzas são friccionadas na ferida para parar o sangue. Este rito foi obviamente emprestado das tribos Pano do rio Ucayali" (1948: 699).

${ }^{547}$ Segundo Brown, os rituais que envolvem mutilação genital, apesar de extremamente raros, são os que mais atraem a atenção dos estudos psicanalíticos: "Outro grupo de escritores estudou os ritos de iniciação femininos de um ponto de vista psicanalítico. É curioso que as suas obras geralmente tratam apenas dos ritos que envolvem alguma forma de mutilação genital, tais cerimônias são extremamente raras" (1963: 837).
} 
cabelo e o ato de fazer a barba devem, assim, ser entendidos como "castração" simbólica." (ibdem).

O argumento do Dr. Berg é de que o cabelo é um deslocamento genital. Portanto, ao termos os cabelos cortados/arrancados teríamos uma ação simbólica de castração. Mais adiante, este argumento, apesar de visto com certo ceticismo por Leach, é reforçado pela contribuição de materiais etnográficos, como no trecho:

“...os relatórios de trabalhos de campo mais recentes usualmente apontam na mesma direção. (...) os rituais de cabelo podem adquirir um significado claramente sexual." (idem: 145$)^{548}$.

Não temos dúvida que a Festa da Moça Nova é um ritual que marca a maturidade sexual das meninas que passam por ele. Uma das principais intensões da Festa é "formar" moças que se casarão muito em breve. Este seria, digamos, um ganho que as moças têm ao passar pelo ritual. Contudo, ao que parece, para atingir esta conquista, haveria necessariamente uma perda. Neste sentido, poderíamos afirmar que os cabelos arrancados das moças é uma "castração simbólica"? Pelo que vimos até aqui, algo se inverte depois da Festa. A moça não é mais uma criança ${ }^{549}$, ao invés dela ser alvo dos cuidados de sua mãe, agora ela é responsável por cuidar desta última.

Temos, portanto, duas faces da mesma moeda. A "castração" simbólica proporcionada por arrancar os cabelos da moça é a face disciplinadora da sexualidade da

\footnotetext{
${ }^{548}$ Apesar de todo o cuidado em não generalizar apressadamente a proposição do Dr. Charles Berg, Leach afirma que a hipótese deve ser considerada: “...estamos considerando a possibilidade de que, onde o cabelo é usado em ritual formal, ele tem sempre um significado fálico. Isto é uma proposição geral e, se fosse nula, poder-se-ia supor que os exemplos que a negassem seriam fáceis de demonstrar. Mas não é este o caso. Quando o indício é examinado de maneira realmente cuidadosa, levando-se em consideração os menores detalhes, o resultado é que o simbolismo do cabelo se aplica de maneira muito mais consistente do que poderia, em princípio, parecer. A maioria das "exceções" parece ser de "exceções que confirmam a regra" (...) tenho conhecimento de um pequeno número de casos em que o cabelo é usado como um símbolo ritual sem qualquer significado libidinoso aparente." (1983[1958]:151). No entanto, os antropólogos não teriam condições de explicar "por que a simbolização deveria tomar a forma que toma", para tanto seria necessário recorrer à psicanálise: "A etnografia indica uma relação persistente entre o cabelo como um símbolo e o falo como um símbolo e, neste ponto, é apropriado que o cabelo seja proeminente em ritos que denotam uma mudança no status socio-sexual; mas os antropólogos sozinhos não têm uma teoria que explique por que a simbolização deveria tomar a forma que toma. (...) Os argumentos psicanalíticos do Dr. Berg realmente fornecem tal explicação." (idem: 163).
}

${ }^{549}$ Leach comenta a recorrência da manipulação dos cabelos em ritos de passagem: "...é precisamente porque o comportamento do cabelo abrange um conjunto ritualmente compreendido de simbolizações sexuais conscientes que ele desempenha um papel tão importante em rituais do tipo rites de passage que envolvem a transferência formal de um indivíduo de um status sócio-sexual para outro." (1983[1958]: 158). 
moça, uma forma de assegurar que ela se case com a pessoa certa. Isso em vários sentidos, mas principalmente que seja um homem da metade exogâmica oposta a dela. Do ponto de vista dos presentes no ritual, esta moça irá se casar em breve. Ela já não pertence mais ao mundo da proteção materna, pelo contrário, é ela que será cobrada para cuidar de sua mãe. Seus tempos de criança que desrespeita os pais acabaram.

Ao longo da descrição da Festa fica evidente que ela é farta em simbolismos fálicos explícitos ou, nas palavras de Leach, conscientes (1983[1958]: 164), desde os grandes trompetes (to 'cü e iburi) até os mascarados que trazem seus pênis à mostra. De acordo com o antropólogo britânico, este tipo de simbolismo é "repetidamente recorrente em rituais dramáticos e religiosos" devido ao fato de que

"o ritual torna explícito e consciente aqueles pensamentos poderosos e perigosos que são passíveis de se tornarem reprimidos. A energia libidinosa é agressiva. Ipso facto, se assuntos de significação libidinosa são abertamente trazidos para o contexto da vida diária, há perigo para a sociedade. Mas no contexto do ritual religioso, onde tudo é formalizado de acordo com expectativas de grupo, as implicações agressivas da ação simbólica estão sob controle. O falicismo no ritual é, assim, uma forma de profilaxia catártica; não é uma expressão do inconsciente reprimido do indivíduo coletivo, mas um processo social que serve para evitar que o indivíduo desenvolva repressões sexuais." (ibdem).

A moça é preparada para o casamento ${ }^{550}$, mas espera-se que não tenha relações sexuais tão logo. A cabeça sem cabelos dela é um sinal de celibato entre os Ticuna, o que também é recorrente em uma "proporção assustadoramente alta da documentação etnográfica" ${ }^{551}$. Podemos pensar que uma das questões colocadas pela Festa da Moça Nova é: como proporcionar um período de abstinência sexual, sem que isso se torne a causa de consequentes repressões, ao mesmo tempo em que se prepara uma menina para

550 Isso é algo recorrente em outros rituais de iniciação feminina ameríndios. Entre os Mamaindê (Nambiquara), por exemplo, "de um modo geral, as descrições do ritual de puberdade feminina enfatizam a mudança no estatuto social da menina púbere, que se torna, ao fim do ritual, uma mulher "casável"." (Miller, 2007: 268).

551 “[U]ma proporção assustadoramente alta da documentação etnográfica se ajusta de maneira bastante óbvia ao modelo que se segue. Em situações rituais: cabelo longo = sexualidade não restringida; cabelo curto, cabeça parcialmente raspada ou cabelo bem amarrado = sexualidade restringida; cabeça totalmente raspada = celibato." (Leach, 1983[1958]: 152). 
seu casamento? O ritual, por meio de uma "profilaxia catártica" ocasionada pelo excesso de símbolos fálicos, prepara a moça para um curto período celibatário ao mesmo tempo em que, pela mesma via, evita o desenvolvimento de "repressões sexuais".

Esta é uma das chaves para se entender a função sofrimento no ritual da moça nova e porque ela se dá pelo arrancamento dos cabelos. No trecho citado acima, Leach se apoia nas conclusões dos psicanalistas, ou seja, a "energia libidinosa é agressiva". Conforme a moça cresce - e as canções e conselhos que ocorrem na Festa são bem explícitos com relação a isso -, começa a enfrentar sua mãe. Não respeita mais suas ordens, como dizem os Ticuna, "começa a responder em cima dela". A entrada da moça em sua puberdade implica numa potencialização de sua libido, portanto, aumenta sua agressividade em relação as pessoas mais próximas. Entre os Ticuna, a mãe da moça é que sente mais estas mudanças de humor e o aumento da agressividade da menina pubescente. Dois fenômenos que caminham pari passu, libido e agressividade, e possuem mecanismos de controle em qualquer sociedade. Ou seja, todas as sociedades possuem regras de matrimônio, que também direcionam a libido das pessoas, e possuem uma gestão de controle da violência. As conotações sexuais do arrancamento de cabelos da moça são, portanto, evidentes. Seu primeiro período fértil e, possivelmente, o momento e em que encontrará seu parceiro de casamento está diretamente relacionado com sua cabeça sem cabelos. Não é cena rara numa comunidade ticuna ver uma moça casada recentemente e com os cabelos bem curtos, ainda crescendo depois de sua Festa.

\section{Condensações rituais ${ }^{552}$}

Muitos dos principais autores que se debruçaram sobre a análise de rituais de iniciação - dos clássicos Van Gennep (2013) e Victor Turner (2005, 2013) aos mais contemporâneos, como Severi (2002), Houseman (1984, 2003, 2006) Houseman \& Severi (1998), Casajus (1993) e Zempléni (1991) - indicam a natureza paradoxal destes eventos. Este fato é bem destacado por Da Matta com relação aos valores e sentimentos que são impostos e negados ao mesmo tempo nestes ritos. "[As] iniciações e os períodos liminares", diz este autor, "são formas paradoxais. Ao mesmo tempo que inculcam valores e reprimem sentimentos, elas também apontam na direção de sistemas de

\footnotetext{
552 Faço aqui uma revisão e ampliação da reflexão que publiquei em Matarezio Filho, 2014c.
} 
comportamento alternativos" (2011: 18). Neste mesmo sentido, Zempléni destaca a relação antagônica da iniciação com o "mundo exterior", a iniciação "cria seu próprio mundo"553.

Em seu esquema "dinâmico hegeliano-sheakspeareano" dos momentos sucessivos da iniciação, Siran nos mostra um aspecto importante e aparentemente paradoxal da iniciação. Em todas as iniciações há uma espécie de desejo obrigatório de passar pelo rito. "Engajando-se no rito de iniciação, o neófito expressa um desejo de reconhecimento pelo Outro. (...) Estes dois componentes, o "desejo" e "obrigação", vão sempre então um com o outro, mas em proporções variáveis, no entanto, de acordo com as sociedades." (2002: 284). Temos neste primeiro item do esquema de Siran algo que contribui para a paradoxalidade da iniciação. Ela é ao mesmo tempo imposta, obrigatória, mas é sempre feita com o consentimento do neófito, ou, mais ainda, é alvo do desejo deste.

Além desta relação paradoxal entre "valores e sentimentos", apontada por Da Matta e por Siran, o ritual da moça nova aponta para uma espécie de paradoxo cosmológico. Ou seja, apesar de não desejarem a morte - uma das vias para torna-se imortal -, os Ticuna empreendem seus rituais com a intenção de se imortalizar. A conjunção com um imortal, principalmente o contato visual com eles, mas nem tanto o ato de ouvir um deles, é algo que - apesar de benéfico, porque traz sabedoria - pode ser um indicativo de que a pessoa morreu. Deste modo, ou se imortaliza morrendo ou se imortaliza através do ritual, sem passar pela morte. Tudo indica que este paradoxo ritual ticuna se dá de uma forma específica, da forma como Houseman define a "condensação ritual" 554 .

De acordo com Houseman, "condensação ritual" seria "a atuação simultânea de modos de relação formalmente contrários: afirmações de identidade são ao mesmo tempo

\footnotetext{
553 “A iniciação, enquanto ritual, não pode, portanto, realizar seus propósitos - gerar uma identidade social - a não ser em relação antagônica com o mundo exterior. Ela cria seu próprio mundo: a sua substância, o seu simbolismo e seus "conhecimentos" próprios, suas ações e palavras que subvertem a função referencial da linguagem para conferir às palavras e as coisas um sentido iniciático" (Zempléni, 1991: 377). Poderíamos seguir com os exemplos de paradoxos presentes nos rituais de iniciação. Houseman, por exemplo, destaca que a "transformação de iniciação" é "contínua" e "descontínua", produzindo o "mesmo" e o "diferente" a um só tempo (Houseman, 1984: 41).

554 Cf. Houseman \& Severi, 1998: 44-45 e passim, Houseman, 2003: 80 e passim; 2006: 415 e passim; Severi, 2002: 25; 2004: 818. É importante destacar que, apesar de a noção de "condensação ritual" ter sido desenvolvida principalmente em solos africanos e melanésios, no livro que deu origem à noção há exemplos de análise de rituais xamânicos ameríndios (Houseman \& Severi 1998: 271). Ver também Severi, 2002.
} 
testemunhos de diferença; exibições de autoridade são também demonstrações de subordinação; a presença de pessoas ou outros seres é ao mesmo tempo corroborada e negada; segredos são simultaneamente dissimulados e revelados e assim por diante" (2003: 80). Em outras palavras, o contexto ritual reúne características díspares articuladas de forma aparentemente paradoxal, "elas geralmente envolvem uma condensação de modos nominalmente incompatíveis de relacionamento." (Houseman 2006: 415). A principal "condensação ritual” da Festa da Moça Nova, como veremos, é a própria participação dos imortais numa Festa de mortais, mas também a entrada de homens e mulheres em domínios que seriam exclusivos de cada gênero. Examinemos primeiro este último caso.

De acordo com Zempléni, as "flautas sagradas" seriam uma característica marcante de alguns rituais masculinos. Contudo, se no caso Ticuna estas "flautas" estão associadas a um ritual feminino e podemos também considerar que os homens que cantam no ritual o fazem imitando mulheres, em falsete. Trata-se nitidamente de uma imitação da voz feminina, o que chamo, inspirado nos estudos de rituais melanésios ${ }^{555}$, de "travestismo vocal". Mimeticamente o cantor adota a voz feminina, como um japiim que canta o canto de outros pássaros. Podemos dizer que há, em certo sentido, uma "inveja da vagina" (Bettelheim, 1974 [1954]), um desejo em se apropriar mimeticamente "de propriedades ou capacidades naturais do outro sexo" (Zempléni, 1991: 376).

De acordo com Strathern, estes rituais são analisados no sentido de que as mulheres possuem uma "superioridade natural ou real em suas funções biológicas" (2006[1988]: 162) e os homens teriam de lidar com isso de alguma maneira. No ritual esse poder pode ser cobiçado pelos homens, que tentam se apropriar deles, ou, no mínimo, expressam sua inveja com relação aos poderes femininos. No mito das "flautas sagradas" dos Ticuna a história de To'oena, apesar de não apresentar a passagem do roubo e sua consequente inversão -, as mulheres são colocadas na posição de inimigas. Contudo, "se as mulheres eram "inimigas" elas, não obstante, eram inimigas "tão necessárias para o ideal de força masculina quanto as inimizades tradicionais entre grupos tribais adjacentes" (Read, 1984,

555 Certamente o pioneiro nestes estudos do travestismo melanésio foi Bateson (2006) em sua monografia sobre o Naven, ritual de travestimento dos latmul da Papua Nova Guiné, diversos outros se seguiram a ele. 
p. 233; Tuzín, 1980, p. 313).” (idem: 167). Daí a importância do controle sobre estes "seres periódicos", que podem pôr em risco a ordem do universo.

O "travestismo vocal" dos Ticuna e a capacidade de algumas mulheres na pósmenopausa de tocarem trompetes me parece um exemplo de um atributo que Strathern percebeu entre os Gimi da Papua Nova Guiné, ou seja, "a capacidade de transacionar com o que veríamos como atributos sexuais. Estes são trocados entre homens e mulheres..." (2006: 177). De acordo com Strathern, as afirmações dos homens sobre o antagonismo sexual nas Terras Altas de Papua-Nova Guiné "são vistas como expressão das ansiedades masculinas sobre seu controle "real" dos poderes femininos" (2006: 159). Desta maneira, quando os homens se recolhem a suas tarefas exclusivamente masculinas, fica suposto "o poder do sexo excluído". Ou seja, enquanto não invadem o terreno das atividades femininas, o poder feminino está garantido, ao menos nestas esferas.

Contudo, o caso Ticuna nos leva a inverter a declaração de Strathern, para ver no que dá. Quando os homens começam a imitar as mulheres no cantar e nas atividades produtivas, estariam se apropriando de seus "poderes"? Seria isto uma forma de controle dos "poderes femininos"? No ritual esse poder pode ser cobiçado pelos homens, que tentam se apropriar deles, ou, no mínimo, expressam sua inveja com relação aos poderes femininos. Contudo, a questão se complica quando sabemos que algumas mulheres, como a mãe de Francisco, também desejam tocar os trompetes, domínio supostamente masculino. Se os mitos que tratam da origem das "flautas sagradas", de um modo geral, mostram como as mulheres perderam para os homens o domínio exclusivo destas "flautas", no mito ticuna este domínio exclusivo masculino já é dado de início. As apropriações entre os domínios exclusivos de cada gênero se darão, portanto, ao longo do ritual de iniciação feminina.

Deste modo, os trompetes seriam um domínio exclusivamente masculino nos rituais, caso as mulheres na pós-menopausa não tivessem acesso a eles. Assim, não há uma só função fundamental no ritual que uma mulher não possa executar. Desta maneira, ao cantarem em falsete nos rituais - apropriando-se de uma característica eminentemente feminina - os homens ticuna impedem a afirmação de auto-reprodução das mulheres. $\mathrm{O}$ "travestismo vocal" ticuna, portanto, é um recurso para equilibrar os poderes de produção de pessoas entre os Ticuna.

Além deste "travestismo figurado", que estou chamando de "travestismo vocal", há um travestismo de fato durante a Festa. Lembremos que, após a confecção do cocar da 
moça nova, o "copeiro" é adornado como uma moça que sairá da reclusão. Neste sentido, temos um dos principais personagens da Festa vestido de moça nova, o que reforça a entrada dos homens nos domínios das mulheres. Passemos a outras condensações que ocorrem na Festa.

Não somente os imortais tocam os trompetes rituais. No recinto de execução destes instrumentos outra condensação ritual está em curso, aquela entre os chamados "bichos" (ngo'o) e os imortais (ü'üne) que tocam os trompetes. Ou seja, dois tipos de seres que no cotidiano mantém relações opostas com os Ticuna, durante a execução dos trompetes nas Festas são condensados na voz emitida pelos instrumentos ${ }^{556}$. As vozes ( $g a$ ) do veado (kowü), do Tchoreruma (o boto celeste), do Tchenawa (pajé da anta), de To'oena (primeira moça nova), de diversos ngo'o são entoadas pelos trompetes, mas também os próprios imortais tocam estes instrumentos ${ }^{557}$. Não fica claro nas etnografias e nas respostas de meus informantes se o som dos trompetes é a voz de um ngo'o ou se é um imortal quem está tocando. Seria difícil precisar justamente porque é mais provável que se trate dos dois tipos de seres tocando os trompetes

Quando a pessoa manifesta que estabeleceu uma comunicação com os imortais, nunca se sabe com certeza se a relação foi estabelecida com os imortais, seres puros, ou com "bichos" ou demônios. Portanto, a "condensação" entre demônios e encantados, que permeia o cotidiano de relações dos Ticuna com o sobrenatural, alcança seu ápice nos rituais. Os relatos sobre as visões de Ngorane, um ticuna que liderou um movimento messiânico, são emblemáticos neste sentido: "a reação dos pais e parentes era bastante cautelosa em face das visões de Ngorane. A sua mãe teria sugerido que podia tratar-se não de um imortal, mas de um demônio (...). Os seus parentes hesitavam em caracterizálo como "enfeitiçado" ou alguém que merecia ser consultado e ouvido, um "homem sábio". Ambas as alternativas de entendimento estavam apoiadas na tradição" (Oliveira Filho 1988: 159).

O contexto ritual é o momento de os imortais aparecerem. O momento dos nãohumanos, de um modo geral, serem aceitos e domesticados nas comunidades. A atração

\footnotetext{
556 Como descreve Goulard (2009) a noção de imortalidade dos Ticuna é mais condizente com um estado - que, por exemplo, pode ser perdido - do que com um traço permanente do ser. Por este motivo que ressalto aqui que a oposição é com relação às atitudes dos Ticuna com relação aos ngo'o e ü'üne.

${ }^{557}$ Ver Capítulo 6, tópico 6.2 - Aerofones.
} 
que a moça exerce sobre os imortais também é exercida sobre seres perigosos que aparecem na Festa. Os mascarados são esperados na Festa, mas as pessoas devem defender a moça de suas investidas, segurando-os e oferecendo bebida e carne moqueada ${ }^{558}$. Neste momento, os seres e estados que são antagônicos no cotidiano ticuna se juntam numa mesma Festa. E a condensação entre mortais e imortais em curso no ritual ticuna encontra seu epicentro nas próprias moças novas.

Nas situações liminares os neófitos são muitas vezes, segundo Turner, "tratados como se não fossem nem machos nem fêmeas" (2005: 143) - distinção fundamental para uma estrutura de clãs patrilineares como a ticuna. No ritual em questão, esta fronteira entre os gêneros, como vimos, é borrada pelo canto em falsete dos homens e a execução dos trompetes rituais por algumas mulheres. Contudo, na Festa da Moça Nova parece-me que desaparece uma distinção ainda mais fundamental. Durante a Festa, a moça é, por alguns momentos, considerada imortal, encantada ${ }^{559}$. Deste modo, a própria distinção entre mortais e imortais é abolida na persona liminar das moças que estão sendo iniciadas.

Existe um conceito já bem aclimatado da filosofia para as análises etnológicas dos ameríndios que nos ajuda a tornar mais complexo o conceito de "condensação ritual". Trata-se da ideia desenvolvida por Deleuze \& Guattari de "devir" (1997). Como vimos, a "condensação ritual" que acontece na Festa permite que a moça nova seja mortal e imortal ao mesmo tempo. Contudo, devemos considerar que a imortalidade do cantor e das moças que são iniciadas no ritual é diferente daquela dos imortais (ü'üne). Assim como a "metamorfose" xamânica desterritorializa os termos transformados "para associálos através de uma nova “conexão parcial"”, (Viveiros de Castro 2007: 116) - p.ex., como nos explica Viveiros de Castro sobre o devir xamânico, "tão logo o homem se torna um jaguar, o jaguar não está mais lá" (ibdem $)^{560}$-, quando um mortal se torna imortal durante

\footnotetext{
558 "O objeto-máscara é principalmente um dispositivo comemorativo da metamorfose, mas como sujeito, é também o instrumento da permanência da separação dos estados, promovendo por um curto período de tempo, a reunião dos mortais e imortais na forma e na sua essência" (Goulard, 2011: 153).

559 "A moça que não respeitar os ensinamentos [transmitidos durante a Festa] ficará encantada, sujeita aos seres invisíveis que habitam a mata" (Faulhaber, 2000: 106).

560 "Nem metáfora, nem metamorfose, um devir é um movimento que desterritorializa ambos os termos da relação que ele estabelece, extraindo-os das relações que os definiam anteriormente para associá-los através de uma nova "conexão parcial". O verbo devir, neste sentido, não designa uma operação predicativa ou uma ação transitiva: estar implicado em um devir-onça não é a mesma coisa que virar uma onça. É o devir ele próprio que é felino, não seu "objeto". Pois tão logo o homem se torna um jaguar, o jaguar não está mais lá." (Viveiros de Castro 2007:116).
} 
a Festa, na verdade, ele se transforma num mortal-imortal. Daí o paradoxo ou a condensação, trata-se de uma imortalidade-mortalidade ${ }^{561}$.

Aos imortais resta questionar, como no refrão da canção dos imortais, cujo eu lírico é um imortal falando para os mortais: “Por que? Por que?”. Por que não atenderam ao chamado constante? Estávamos sempre por perto e vocês não percebiam, fizemos barulho no buritizal e vocês não percebiam, não agiam da maneira correta, não jejuavam para subirem com a gente para o céu. A voz de um imortal entoada por um cantor mortal, ao ser enunciada no contexto ritual, faz do cantor também um mortal-imortal, condensando identidades contraditórias ${ }^{562}$.

A moça deve permanecer invisível ${ }^{563}$ e inaudível, ou seja, está escondida, mas ao mesmo tempo é uma "isca" para a aparição de mascarados e imortais, a "condensação" de seres sobrenaturais, o que implica em formas de relações opostas e uma "série de "verdades" contraditórias (...) em uma única sequência de ações." (Houseman \& Severi 1998: 40). Portanto, a "fusão sistemática de revelação e dissimulação, uma das marcas do processo de iniciação" (Houseman 2003: 89), marca a presença da moça nova e participação dos imortais na Festa. Eles estão lá e não se revelam ao mesmo tempo. A presença dos imortais na Festa é esperada, contudo, dissimulada. Eles estão na Festa, mas somente se revelarão se a Festa for realizada a contento ${ }^{564}$.

A oposição entre homens e mulheres, no entanto, é mais complexa do que aparenta, pois os meninos não iniciados aos trompetes, em virtude da interdição, neste

561 “Essa coincidência de processos e noções opostas em uma única representação caracteriza a peculiar unidade do liminar; o que não é nem isso, nem aquilo, e, no entanto, é ambos" (Turner, 2005: 143-144).

562 “...enunciação ritual envolve sempre a metamorfose (ou definição em termos rituais) de seu enunciador (...) Isso faz do enunciador uma figura complexa, formada pela condensação de identidades contraditórias" (Severi 2002: 37).

563 Trata-se de uma característica bastante comum em rituais de passagem. "O sujeito submetido ao ritual de passagem fica, no decorrer do período liminar, estruturalmente, ou mesmo fisicamente, "invisível" (...) As definições seculares de uma sociedade não consideram a existência de um nem-menino-nem-homem, o que vem a ser justamente o neófito de um rito de puberdade masculino (se é que se pode dizer que ele é algo (...) o estruturalmente indefinível “ser-transicional”” (Turner, 2005:139-140).

564 O que nos evoca o imperativo de o ritual ser executado corretamente apesar das vontades individuais: "[O ritual] prescreve sequências de atos de seus protagonistas, independentemente das suas intenções pessoais. Tudo o que a tradição exige deles é que realizem o ritual corretamente." (Houseman \& Severi 1998: 37). 
plano, estão assimilados às mulheres férteis. Ao mesmo tempo, as mulheres na pósmenopausa são assimiladas ao grupo de homens mais velhos que tocam os trompetes. Um esquema destas oposições poderia ser: mulheres férteis: meninos não iniciados :: homens mais velhos : mulheres na pós-menopausa. Em outros termos - levando em conta que os meninos estão "poluídos” (puya), assim como as mulheres menstruadas, e o rapé (cawü) os "desintoxica" 565 , ao passo que os homens e as mulheres velhos não possuem mais esta poluição. Desta relação, podemos passar a uma outra proporção: poluição: não-poluição (pureza) :: mortais : imortais. Na verdade, esta oposição entre mortais (seres poluídos) e imortais (seres sem "males no corpo") existe num plano cosmológico. Num plano, digamos, sociológico, entre os mortais existem seres mais e menos poluídos. Lembremos também que a despoluição dos meninos, com a rapé (cawü), é feita na Festa junto com a iniciação feminina. Ou seja, neste plano do ritual os meninos são assimilados ao grupo feminino, deste modo, este grupo todo (meninos e meninas) se opõem aos imortais, seres puros, ou ao estado de imortalidade.

Mencionei que eu estava em campo quando o filho temporão de Ondino e Raissa nasceu. Como ela não podia trabalhar, como em seus dias antes do parto - seu corpo estava coberto de sangue invisível -, então Ondino assumiu as tarefas dela, algo comum entre alguns sul-ameríndios ${ }^{566}$. Deste modo, assim como acontece com os domínios da mortalidade e da imortalidade, o sangramento feminino provoca a permeabilidade dos gêneros. A figura da moça, neste sentido, torna-se absolutamente paradoxal, pois, apesar de estar menstruando pela primeira vez e estar imbuída de todo o perigo e poluição que isto acarreta, a moça é considerada, como vimos, uma imortal (ü üne), ou seja, desprovida dos "males do corpo". No corpo da moça nova estão condensados a pureza e o perigo, mortalidade e imortalidade.

Não passar pelo ritual é não "renascer”, na metáfora de Eliade (1958), ou não sair do estado liminar, para usarmos um termo caro aos estudos de rituais de passagem, cunhado por Turner. Este estado implica em uma ambiguidade em vários níveis. Por um

\footnotetext{
565 Lembrando que antigamente alguns homens ficavam próximos aos trompetes durante o ritual para assoprarem rapé (cawü) nas crianças que se aproximassem. Ao passar pelo tratamento com o rapé - que causa intensos vômito, incontinência urinária e fecal - a pessoa estaria liberada para se aproximar dos instrumentos tabu. Ver Capítulo 6, tópico 6.2.2-Rapé, iniciação aos trompetes.

${ }^{566}$ Ver Capítulo 4, tópico 4.2.2 - Gravidez, nascimento, parto e pós-parto.
} 
lado, num plano sociológico, a moça ainda não é adulta e não saiu da infância. Por outro lado, num plano cosmológico, há um indiferenciação interna à própria moça entre um estado de mortal (yunatü) e um estado de imortalidade (ü'üne). A moça pode ser considerada uma criança-mulher, mortal-imortal. Enquanto a moça não cumpriu todo o processo ritual ela "flutua entre dois mundos" (Van Gennep, 2011[1909]: 35). Passar pela Festa, portanto, é definir-se como mulher mortal.

O que a Festa da Moça Nova faz é explicitar algumas tensões criados no tempo do mito - a separação de atributos masculinos e femininos, entre mortais e imortais - e não tanto resolvê-la, apesar dos esforços no sentido da imortalização. Semelhante ao que acontece nos rituais naven, entre os Iatmul da Nova Guiné, a Festa da Moça Nova deve ser encarada "não como uma resposta a questões levantadas pela sociedade, mas sim como uma réplica condensada de tais questões" (Houseman \& Severi 1998: 46). De acordo com Lévi-Strauss, no capítulo Final de O Homem Nu (2011 [1971]), o mito efetuaria a passagem do continuo ao descontinuo, enquanto o ritual operaria uma reversão disto, transformaria o descontinuo em continuo. Mas trata-se de uma continuidade sempre aproximativa, como a tangente criada num sacrifício. Nas palavras de Viveiros de Castro, “imagine-se a morte da vítima [do sacrifício] como o traçar de uma tangente, a melhor aproximação à curva da divindade..." (Viveiros de Castro 2008). O sacrifício cria uma quase-continuidade entre a vítima sacrifical e a divindade, uma tangente que (quase) une os dois (ibdem). A mesma lógica do sacrifício atua na Festa da Moça Nova. Assim como a vítima do sacrifício, a moça nova é a responsável por traçar esta tangente de melhor aproximação com a imortalidade.

O outro lado da moeda desta quase-continuidade sacrificial é a quase-extinção do próprio pensamento. Nos termos de Lévi-Strauss:

"Em suma, a oposição entre rito e mito é a oposição entre viver e pensar, e o ritual representa um abastardamento do pensamento, que se sujeita às servidões da vida. Reduz, ou antes tenta em vão reduzir, as exigências do pensamento a um valor-limite, que nunca consegue atingir, ou o próprio pensamento seria abolido. Essa tentativa arrebatada, sempre fadada ao fracasso, de restabelecer a continuidade de um vivido desmantelado sob efeito do esquematismo pelo qual a especulação mítica o substitui constitui a essência do ritual e dá conta das características distintivas que lhe foram reconhecidas nas análises acima" (LéviStrauss, 2011 [1971]: 651). 
Reduzir as exigências do pensamento a um valor-limite, "que nunca consegue atingir, ou o próprio pensamento seria abolido". Ou seja, a essência do ritual para LéviStrauss seria o seu fracasso ("tenta em vão reduzir"). Caso o ritual reestabelecesse as continuidades fracionadas pelo mito, seria a própria abolição do pensamento. 


\title{
Bibliografia
}

\author{
ALMEIDA, Mauro
}

2008 - “A Fórmula Canônica do Mito", in: Lévi-Strauss. Leituras Brasileiras. Queiroz, Ruben C. de \& Nobre, Renarde F. (eds.). Belo Horizonte, Editora da Universidade Federal de Minas Gerais, 2008, pp. 147-182. Artigo revisto pelo autor em 2009 disponível em: http://mwba.files.wordpress.com/2010/03/almeida2009-a-formula-canonica-do-mito-_corrigida.pdf

ANDRADE, Mário.

1980 - Pequena História da Música. 8ªed. São Paulo, Livraria Martins Editora, Belo Horizonte: Editora Itatiaia.

2002 - O Turista Aprendiz. Belo Horizonte: Itatiaia.

ANGARITA, Abel Antonio Santos (Wachiäükü)

2008 - "Territorio - Cuerpo - Agua”, in: Lenguas y tradición oral - IX Encuentro para la Promoción y Difusión del Patrimonio Inmaterial de Países Iberoamericanos. Tello, Carlos (ed.). Colômbia, ISBN: 978-958-98841-0-2.

2010 - "Narración tikuna del origen del territorio y de los humanos". En: Echeverri Juan Álvaro (Ed.) Mundo Amazónico. Revista anual, volumen 1, Instituto Amazónico de Investigación (IMANI). Universidad Nacional de Colombia, Sede Amazonia. Leticia Amazonas Colombia.

2013 - Percepción tikuna de Naane y Naüne: territorio y cuerpo, Tesis presentada para optar por el grado de: MAGÍSTER EN ESTUDIOS AMAZÓNICOS, Línea de investigación en Lingüística y Etnología Amazónica Maestría en Estudios Amazónicos, Universidad Nacional de Colombia, Sede Amazonia, Leticia.

ARGAÑARAZ, Silvina Bustos

2004 - Das trevas da floresta. Práticas missionárias dos capuchinhos da Úmbria no Alto Solimões (1910-1960). Dissertação de mestrado apresentada ao PPGAS/MN/UFRJ.

2006 - "Modalidades missionárias de conhecimento: o os capuchinhos da Úmbria no Alto Solimões, 1910-1960”, GT48 - Saberes Coloniais sobre os Indígenas em 
Exame Relatos de Viagem, Mapas, Censos e Iconografia, 25a Reunião Brasileira de Antropologia, Goiânia.

BARBOSA RODRIGUES, João

1882 - "Tribu dos Ticunas", in: Revista da Exposição Anthropológica Brazileira.

Rio de Janeiro: Typographia de Pinheiro \& Cia, p. 52-55.

BATES, $\underline{\text { Henry Walter }}$

1979[1863] - Um Naturalista no Rio Amazonas, Editora: Itatiaia / Edusp, São Paulo.

BATESON, Gregory

2006 - Naven: um esboço dos problemas sugeridos por um retrato compósito, realizado a partir de três perspectivas, da cultura de uma tribo da Nova Guiné I Gregory Bateson; tradução Magda Lopes. - 2. ed. - São Paulo: Editora da Universidade de São Paulo.

BELAUNDE, Luisa Elvira.

2006 - "A força dos pensamentos, o fedor do sangue: hematologia e gênero na Amazônia”. Revista de Antropologia, São Paulo, v. 49, n. 1, June.

BETTELHEIM, Bruno

1974 [1954] - Heridas simbólicas: los ritos de la pubertad y el macho envidioso.

Barcelona: Seix Barral.

BLACKING, John

2000[1973] - "Humanly Organized Sound", in: How Musical is Man? Seattle: University of Washingon Press.

BONILLA, Lydie Oiara

2007 - Des proies si desirables - Soumission et prédation pour les Paumari d'Amazonie brésilienne, Ph.D. diss., École des Hautes Etudes en Sciences Sociales, Paris

BORGES, Jorge Luis

1999 - “O Imortal”, in: O Aleph, Obras Completas de Jorge Luis Borges, volume 1, São Paulo: Globo.

BRASIL, Kátia. 
2009 - "PF investiga elo das Farc com milícias de indígenas no AM". Folha

Online.

Disponível

em:

<http://www1.folha.uol.com.br/folha/brasil/ult96u652675.shtml>. 15 nov. Acessada em 13 de novembro de 2014.

BRÊTAS, J.R.S.; TADINI, A.C.; FREITAS, M.J.D.; GOELLNER M.B.

2012 - "Significado da menarca segundo adolescentes". Acta paulista de enfermagem. [online], vol.25, n.2, pp. 249-255. ISSN 0103-2100.

BUENO, Maria Isabel Cardozo da Silva

2012 - “Algumas reflexões sobre feitiçaria entre os Ticuna (Alto Solimões-AM)”, GT23, $36^{\circ}$ Encontro Anual da Anpocs.

2014 - Sobre encantamento e terror: imagens das relações entre humanos e sobrenaturais numa comunidade Ticuna (Alto Solimões, Amazonas, Brasil), Tese de Doutorado, PPGSA-UFRJ, Rio de Janeiro, 252f: il.

BUENO, Ana Cecilia Venci

2008 - Os Irantxe e Myky do Mato Grosso: um estudo do parentesco. Dissertação de Mestrado, USP-São Paulo.

CAMACHO, Hugo A.

2000 - Historias de los abuelos de Moruapü. Imprenta Nacional de Colombia, Bogotá.

\section{CARDOSO DE OLIVEIRA, ROBERTO}

1964 - O Índio no Mundo dos Brancos: a Situação dos Tukúna do Alto Solimões. Difusão Européia do Livro, Coleção Corpo e Alma do Brasil, São Paulo, 143 p. 1983a [1961] - “Aliança inter-clânica no sociedade Tükúna". In: Enigmas $e$ soluções: exercícios de etnologia e de crítica. Rio de Janeiro: Tempo Brasileiro; Fortaleza: UFCE. p. 54-75. (Biblioteca Tempo Universitário, 68)

1983b [1964] - “Totemismo Tükúna?”, In: Enigmas e soluções: exercícios de etnologia e de crítica. Rio de Janeiro: Tempo Brasileiro; Fortaleza: UFCE (Biblioteca Tempo Universitário, 68).

2000 - “Tükúna, 1959: excertos de um diário de campo", In: Os Ticuna Hoje. Amazônia em Cadernos, n5. Manaus: Editora da Universidade do AMAZONAS. 
2009 - ““Cultura” e cultura: conhecimentos tradicionais e direitos intelectuais", in: Cultura com aspas e outros ensaios, São Paulo: Cosac Naify.

CASAJUS, Dominique

1993 - "Figures paradoxales dans quelques analyses de rituels", Cahiers Du CREA (Centre de recherches em épistémologie appliquée, École polytechnique), $\mathrm{n}^{\circ} 16,1993: 141-155$. Paris.

CHAUMEIL, Jean-Pierre

2011 - "Speaking Tubes: The Sonorous Language of the Yagua Flutes", in: Burst of breath : indigenous ritual wind instruments in lowland South America, edited by Jonathan David Hill and Jean-Pierre Chaumeil. Lincoln: University of Nebraska Press.

CLASTRES, Hélène.

1978 - A Terra sem Mal, São Paulo, Brasiliense.

CLASTRES, Pierre

2003[1962] - "Troca e poder: filosofia da chefia indígena", in: A Sociedade Contra o Estado - pesquisas de antropologia política, São Paulo, Cosac \& Naify. 2003[1973] - "Da tortura nas sociedades primitivas", in: A Sociedade Contra o Estado - pesquisas de antropologia política, São Paulo, Cosac \& Naify.

DA MATTA, Roberto

2011 - “Apresentação”, in: Ritos de passagem. Petrópolis: Vozes, 2a edição.

DAL POZ, JOÃO \& SILVA, MARCIO

2009 - "Pequeno guia de referência da Máquina do Parentesco", mimeo, 22p. Versão atualizada em inglês: "MaqPar: A Homemade Tool for the Study of Kinship Networks". in: Vibrant - Virtual Brazilian Anthropology, v. 6, n. 2. July to December 2009. Brasília, ABA. Available at http://www.vibrant.org.br/issues/v6n2/joao-dal-poz-neto-marcio-ferreira-dasilva-maqpar/

DAL POZ, João

1991 - No País Dos Cinta Larga: uma etnografia do ritual. Dissertação de Mestrado, São Paulo: USP.

DAHLHAUS, Carl 
2009. "Que é a música?”, Que é a música?, DAHLHAUS, Carl \& EGGEBRECHT, Hans Heinrich. Edições Texto \& Grafia, Ltda, Lisboa.

DO VALE, MARIA C. R.

2002 - Waimiri-Atroari em festa é Maryba na floresta. Dissertação de Mestrado, Universidade Federal do Amazonas - UFAM, Manaus.

ELIADE, Mircea

1958 - Rites and Symbols of Initiation (Birth and Rebirth), translated: W. Trask, London: Harvill Press.

FALLEIROS, Guilherme L. J.

2011 - Datsi'a'uwẽdzé. Vir a ser e não ser gente no Brasil Central. PPGAS-USP, São Paulo, Tese de Doutorado.

FAJARDO, Gloria.

1986 - "Visión etnografica de los Ticuna de San Martin de Amacayacu”. Trabajo semestre de campo. Universidad Nacional de Colombia. Bogota.

FARABEE, Willian. C.

1924 - "The Central Caribs". University of Pennsylvania, the University Museum Anthropological Publications Volume X.

FAULHABER, Priscila

2000 - "A Festa de To'oena relatos, performance e etnografia ticuna", In: Os Ticuna Hoje. Amazônia em Cadernos, n5. Manaus: Editora da Universidade do AMAZONAS.

2003a - "Descrições da Indumentária Ritual De Dança Da Coleção Ticuna Do

Acervo Curt Nimuendaju Do Museu Paraense Emílio Goeldi.”, in: FAULHABER, Priscila (org.) Magüta Arü Inü. Jogo de Memória - Pensamento Magüta. (CD-Rom).

2003b - "Giro do Céu, Constelações Ticuna e Sazonalidade”, in: FAULHABER, Priscila (org.) Magüta Arü Inü. Jogo de Memória - Pensamento Magüta. (CDRom).

2003c - "Metades Ticuna", in: FAULHABER, Priscila (org.) Magüta Arü Inü. Jogo de Memória - Pensamento Magüta. (CD-Rom). 
2004 - "“"As estrelas eram terrenas": antropologia do clima, da iconografia e das constelações Ticuna", Revista de antropologia, São Paulo, vol.47 n.2, p. 379-426. 2007 - "Interpretando os artefatos rituais Ticuna". Revista do Museu de Arqueologia e Etnologia, São Paulo, 17: 345-363.

FAUSTO, Carlos

2007 - "Feasting on People: Cannibalism and Commensality in Amazonia", Current Anthropology 28(4): 497-530.

FIRMINO, Lucinda S. \& GRUBER, Jussara G.

2010 - Ore i nucümaügü̈̈: Histórias Antigas, volumes 1, 2 e 3, Benjamin Constant, Amazonas: Organização Geral dos Professores Ticunas Bilíngues OGPTB, (Coleção Eware).

FLORIDO, Marcelo Pedro

2013 - Os Deni do Cuniuá: um estudo do parentesco. Tese (Doutorado em Antropologia Social) - Faculdade de Filosofia, Letras e Ciências Humanas, Universidade de São Paulo, São Paulo.

FRAZER, James

1913 - "Balder The Beautiful", The Golden Bough, vol. 10, London The Macmillan Press LTD.

GOFFMAN, Erving.

2011[1976] - Ritual de interação: ensaios sobre o comportamento face a face. Tradução Fábio Rodrigues Ribeiro da Silva. Petrópolis: Vozes, 255 p.

GÓMEZ, Ángela Marcela Cogua

2009 - Análisis de dos textos narrativos Tikuna, Trabajo de grado para optar el título de lingüista, Universidad Nacional de Colombia Facultad de Ciencias Humanas Departamento de Lingüística Bogotá D.C.

GONÇALVES, Marco Antonio

2001 - O mundo inacabado. Ação e criação em uma cosmologia amazônica. Etnografia Pirahã, Rio de Janeiro, UFRJ.

GONZALEZ, JORGE L. \& JAIME, RIVAS

1990. "Program a de generación y transferencia de tecnologia en comunidades indigenas: Coayare (Guainia), San Sebastian (Amazonas), Mitu-Cauchivera 
(Vaupes)". Universidad Nacional de Colombia, Facultad de Ciencias Humanas, Centro de Estudios Sociales. Bogotá. Manuscrito.

GORDON, C.; WILDE, G.; NAVEIRA, M.

2013 - "Propuesta de Grupo de Trabajo - Rituales: transformaciones cosmológicas y sociohistóricas", X Reunión de Antropología del Mercosur, Córdoba, Argentina. Retirado do site no dia 18 de fevereiro de 2015: http://www.xram.com.ar/gt/GT\%2066.pdf

GOULARD, Jean-Pierre

1992 - "Les Tikuna n'ont pas de loi ou le motif de la 'Tête Coupée”", Journal de la Société des Américanistes, Année 1992, Volume 78, Numéro 2, p. 8 - 24

1995. "La parole voilée ou les beaux-frères inévitables chez les Tikuna". Bulletin Societe Suisse des Americanistes (BSSA) 57/58: 139-146

2001 - "Le costume-masque”. Bulletin Société Suisse des Américanistes, Genève, v. $64-65$, p. $75-82$.

2002 - "Le temps du passage: exister pour vivre : l'entre-deux chez les Ticuna d'Amazonie", Autre : cliniques, cultures et sociétés : Revue Transculturelle, vol. 3, n. 1. Paris.

2004 - "Du héron cendré au jaguar ou comment l'identité clanique fait le corps chez les Ticuna", in: Corps et Affects, Héritier, Françoise \& Xanthakou, Margarita (ed.). Odile Jacob.

2009 - Entre Mortales e Inmortales - El Ser según los Ticuna de la Amazonía. CAAAP, CNRS-MAEE-IFEA, Lima.

2010 - "Le sens du poil chez les Tikuna (Amazonie)", in : Cahier d'anthropologie sociale No 6: Polis et Sang, L'Herne.

2011 - "La sur-face du masque: perpétuation et métamorphose chez les Tikuna", in Visages des Dieux, Masques des Hommes, Regards d'Amazonie (J-P Goulard et D. Karadimas eds.), CNRS-Editions, Paris, p. 129-153.

2012 - "La metamorfosis ritual: la identidad religiosa en la Amazonia", in: Revista Colombiana de Antropología, Volumen 48 (2), julio-diciembre, pp. 15-37.

GOULARD, Jean-Pierre \& BARRY, Laurent S.

1998 - "Un mode de composition de l'alliance : le "mariage oblique" ticuna", Journal de la Société des Américanistes, Volume 84, Numéro 1, p. 219 - 236. 
GOULARD, Jean-Pierre \& MONTES RODRÍGUEZ, Maria Emilia 2013 - "Los yurí/juri-tikuna en el complejo socio-lingüístico del Noroeste Amazónico", Revista LIAMES 13 - pp. 07-65.

GOW, Peter.

2001 - An Amazonian Myth and its History. Oxford: Oxford University Press. 338 pp.

GREGOR, T. A. \& TUZIN, D. (eds.)

2001 - Gender in Amazonia and Melanesia: An Exploration of the Comparative Method. Berkeley: University of California Press.

GREIMAS, A. J.

1973 - Semântica Estrutural. Tradução de Haquira Osakabe e Izidoro Blikstein. São Paulo: Cultrix: Edusp.

2002 - Da imperfeição. São Paulo: Hacker Editores. Trad.: Ana Cláudia Oliveira.

GREIMAS, A. J. \& FONTANILLE, J.

1993 - Semiótica das paixões. São Paulo: Ática.

GRUBER, Jussara Gomes

1999 - Instrumentos Musicais Ticunas, apostila manuscrita. Publicado também no volume organizado por Antonio Alexandre Bispo: Die Musikkulturen der Indianer Brasiliens - II, em Musices Aptatio-1996/97-Jahrbuch, Roma: Consociatio lntemationalis Musicae Sacrae.

GRUBER, Jussara Gomes (org.)

1998 - O Livro das Árvores. Organização Geral Dos Professores Ticuna Bilíngues. Benjamin Constant. Amazonas Brasil.

HENLEY, Paul

2001 - "Inside and Out: Alterity and the Ceremonial Construction of the Person in the Guianas", in Rival, L. and Whitehead, N. (eds.), Beyond the Visible and the Material: the Amerindianization of Society in the Work of Peter Rivière, Oxford, Oxford University Press.

HERZOG, George 
1940 - Book Reviews, sobre o livro de Izikowitz, K. G., Muscial and other Sound Instruments of the South American Indians-A comparative ethnographical study, in: AMERICAN ANTHROPOLOGIST, New Series, n. 42.

HILL, J. D. \& CHAUMEIL, J. P. (eds.)

2011a - Burst of breath: indigenous ritual wind instruments in lowland South America. Lincoln: University of Nebraska Press.

2011 b - "Overture", in: Burst of breath : indigenous ritual wind instruments in lowland South America, edited by Jonathan David Hill and Jean-Pierre Chaumeil. Lincoln: University of Nebraska Press.

HORNBOSTEL, Erich Von \& SACHS, Curt.

1961[1914] - "Classification of musical instrument". Tradução de Waschmann e Baines. The Galpin Society Journal. Vol. 14, p. 3-29.

HOUSEMAN, Michael \& WHITE, Douglas R.

1998 - "Taking Sides: Marriage Networks and Dravidian Kinship in Lowland South America". In: Maurice Godelier, Thomas Trautmann e Franklin Tjon Sie Fat (eds.). Transformations on Kinship. Washington \& London: Smithsonian Institution Press. pp. 214-243.

HOUSEMAN, M. \& SEVERI, C.

1998 - Naven or the Other Self: A Relational Approach to Ritual Action. Leiden: Brill. xvi, 325 pp., photos and illustrations.

HOUSEMAN, M.

1984 - "Les artifices de la logique initiatique". In: Journal des Africanistes, tome 54 fascicule 1. pp. 41-65.

1999 - "Quelques configurations relationnelles de la douleur”, in F. Héritier, De la violence II, Paris, Editions Odile Jacob, pp.77-112.

2003 - "O Vermelho e o Negro: um experimento para pensar o ritual”, in: MANA 9(2):79-107. Rio de Janeiro. http://www.scielo.br/pdf/mana/v9n2/17933.pdf 2006 - "Relationality", in: J. Kreinath, J. Snoek and M. Stausberg (eds.) Theorizing Rituals. Classical Topics, Theoretical Approaches, Analytical Concepts, Annotated Bibliography. Leiden: Brill, pp. 413-428.

HOWARD, C. 
1993 - "Pawana: a farsa dos visitantes entre os Waiwai da Amazônia", em: Amazônia: etnologia e história indígena. Viveiros de Castro, E. \& Carneiro da Cunha, M. (orgs.). São Paulo, Núcleo de História Indígena e do Indigenismo USP/FAPESP, p. 229-264.

HUGH-JONES, Stephen

2011[1979] - La palma y las Pléyades. Iniciación y cosmología en la Amazonia noroccidental. Bogotá: Ediciones Universidad Central.

IBGE

2010 - Censo Demográfico 2010 - Características gerais dos indígenas Resultados do universo, Instituto Brasileiro de Geografia e Estatística - IBGE, ISSN 0104-3145, Censo demográfico, Rio de Janeiro, p.1-245. Disponível em: ftp://ftp.ibge.gov.br/Censos/Censo_Demografico_2010/Caracteristicas_Gerais_d os_Indigenas/pdf/Publicacao_completa.pdf

IZIKOWITZ, Karl Gustav

1931 - "Le tambour à membrane au Pérou". In: Journal de la Société des Américanistes. Tome $23 \mathrm{n}^{\circ} 1, \mathrm{pp} .163-175$.

1935 - Musical and other Sound Instruments of the South American Indians - A comparative ethnographical study, Göteborg, Elanders boktr. xii, 433 p. illus. 25 $\mathrm{cm}$.

JOLKESKY, Marcelo

2009 - Macro-Daha: reconstrução de um tronco lingüístico do noroeste amazônico, ROSAE - I Congresso Internacional de Lingüística Histórica; manuscrito não publicado.

KELLY, J. A.

2001 - "Fractalidade e Troca de Perspectiva", in: Mana Estudos de Antropologia Social v.7 n.2 Rio de Janeiro.

2010 - "Perspectivismo multinatural como transformação estrutural". Ilha. Revista de Antropologia (Florianópolis), v. 12, p. 137-160.

KLOOS, Peter.

1969 - "Female Initiation Among the Maroni River Caribs", in: American Anthropologist. 71.5 (1969): 898-905. 
LACAN, Jacques

2005 - O Seminário - Livro 10 - A Angústia, Rio de Janeiro, Jorge Zahar Edit.

LAGROU, E. \& BELAUNDE, L. E.

2011 - "Do mito grego ao mito ameríndio: uma entrevista sobre Lévi-Strauss com

Eduardo Viveiros De Castro”, In: Sociologia \& Antropologia, V.01.02: 09-33.

LANA, Feliciano Pimentel

2009 - A Origem da Noite \& Como As Mulheres Roubaram as Flautas Sagradas.

2. ed. Manaus, AM: EDUA, Editora da Universidade Federal do Amazonas.

LARAIA, Roque de Barros

1988 - “A morte e as mortes de Nimuendajú", Série Antropologia n. 64. Unb, Brasília. Disponível em http://biblio.etnolinguistica.org/laraia_1988_curt

LE BRETON, David

1999 - Antropología del dolor, Barcelona, Seix Barral, 287 págs.

\section{LÉVI-STRAUSS, C.}

1969[1965] - "O Futuro dos Estudos de Parentesco", in: Organização Social, R.B. Laraia (org.), Zahar Editores, Rio de Janeiro.

1976 [1949] - As Estruturas Elementares do Parentesco. Petrópolis, Vozes; São Paulo, EDUSP.

1983 [1956] - “A Família”, in: O Olhar Distanciado (cap.3). Edições 70, Lisboa, Portugal.

1986 - A Oleira Ciumenta, São Paulo: Editora Brasiliense.

1989 [1962] - O pensamento selvagem. Campinas: Papirus.

2004 [1964] - O cru e o cozido. São Paulo: Cosac \& Naify.

2004[1967] - Do mel às cinzas. São Paulo: Cosac \& Naify.

2006[1968] - A Origem dos Modos à Mesa. São Paulo: Cosac \& Naify.

2008[1955] - “A Estrutura dos Mitos”. Em: Antropologia Estrutural, São Paulo:

Cosac Naify. 
2011 [1971] - O Homem Nu. São Paulo: Cosac \& Naify.

2013[1958] - “A gesta de Asdiwal”. In: Antropologia estrutural dois. São Paulo: Cosac \& Naify.

LIMA, Oswaldo Gonçalves de 1975 - Pulque, balchê e pajauaru: na etnobiologia das bebidas e dos alimentos fermentados. 1. ed. Recife: Universidade Federal de Pernambuco.

LIMA, TÂNIA STOLZE

1996 - “O Dois e seu Múltiplo: Reflexões sobre o Perspectivismo em uma Cosmologia Tupi”, Mana 2(2): 21-47.

2005 - Um peixe olhou para mim: o povo Yudjá e a perspectiva. São Paulo: Ed. UNESP: ISA; Rio de Janeiro: NuTI.

LIMA, Debora (org.)

2006 - Ngiã nüna tadaugü $i$ torü naãne = Vamos cuidar da nossa terral [Clóves Mariano Fernandes et al.] - Belo Horizonte: Editora UFMG, 216p.: Il.

LOLLI, Pedro.

2010 - As redes de trocas rituais dos Yuhupdeh no igarapé Castanha, através dos benzimentos (mihdïid) e das flautas jurupari (Ti') 206 f. Tese (Doutorado em Antropologia Social) - Universidade de São Paulo, São Paulo.

LOUNSBURY, F. G.

1964 - "The Structural Analysis of Kinship Semantics". In Bohannan, P. \& Middleton, J. (Eds.) Kinship and Social Organization. The Natural History Press: 125-148.

LOWIE, ROBERT

1952 - "Preface", in: The Tukuna. American Archeology. Berkeley \& Los Angeles University of California Press.

LUTKEHAUS, Nancy C. \& ROSCOE, Paul B. (eds.)

1995 - Gender rituals: female initiation in Melanesia, New York : Routledge, 265 p.

MACEDO, Guilherme Martins de. 
1996 - Negociando a identidade com os brancos: religião e política em um núcleo urbano Tikúna. Dissertação (Mestrado em Antropologia Social) - Programa de Pós-Graduação em Antropologia Social, Museu Nacional, Universidade Federal do Rio de Janeiro, Rio de Janeiro.

1999 - “A conversão cristã e a identidade Ticuna: a trajetória de Campo Alegre". Amazônia em Cadernos, Manaus, v. 5, p. 175-193.

MACHADO, Silvia de Ambrosis Pinheiro

2012 - Canção de Ninar Brasileira: Aproximações. Tese de Doutorado, FFLCH/USP, São Paulo.

MAIZZA, Fabiana

2012 - Cosmografia de um Mundo Perigoso: Espaço e Relações de Afinidade entre os Jarawara da Amazonia, EDUSP, São Paulo.

MARCOY, Paul

2001[1869] - Viagem pelo rio Amazonas. Trad., intr., e notas Antonio Porro. Manaus: Edua.

\section{MATAREZIO FILHO, Edson Tosta.}

2013 - “Trompetes Ticuna da Festa da Moça Nova", em: Anais do VI Encontro Nacional da Associação Brasileira de Etnomusicologia, 27-31 maio, 2013, João Pessoa, Paraíba / organizadores: Carlos Sandroni e Alice Lumi Satomi. - João Pessoa: UFPB. Disponível em: http://abetmusica.org.br/dld.php?dld_id=168

2014[2010] - Ritual e pessoa entre os Waimiri-Atroari. Prefácio de Márnio Teixeira-Pinto. Posfácio de Stephen G. Baines. São Paulo: Annablume/FAPESP. 2014a - Para crescer é preciso sofrer A Festa da Moça Nova dos Ticuna. In: Anais do II Seminário Infância Criança Indígena. São Carlos: Universidade Federal de São Carlos, v. 1. p. 1-10. Disponível em: http://https://infanciaindigena.files.wordpress.com/2014/10/paracrescerc3a9pre cisosofrere28093afestadamoc3a7anovadosticunaedsonmatarezio.pdf 2014 b - "Desafios de tradução em uma língua indígena - Ticuna". In: Álvaro Faleiros; Mário Ramos Francisco; Gisele Marion Rosa; Vanice Ribeiro Dias Latorre. (Org.). Jornada TRADUSP: tradução e poética. 1ed.Rio de Janeiro: Vermelho Marinho, 2014, v. 1, p. 73-86. Disponível em: 
http://citrat.fflch.usp.br/sites/citrat.fflch.usp.br/files/u13/JornadaTRADUSP2013 . .pdf

2014c - "Do corpo ao cosmos - condensações rituais dos Ticuna". Periferia (Bellaterra), v. 19, p. 28-54. Disponível em: http://ddd.uab.cat/pub/periferia/periferia_a2014m6v19n1/periferia_a2014m6v19 n1p28.pdf 2015 - "Trompetas Ticuna de la Fiesta de la Moça Nova", in Mundos audibles de América. Cosmologías y prácticas sonoras de los pueblos indígenas (Estudios Indiana 8). Brabec de Mori, Bernd; Matthias Lewy y Miguel A. García (eds.): Berlin: Iberoamerikanisches Institut / Gebr. Mann Verlag.

MATOS, Beatriz de Almeida

2014 - A Vista dos Espíritos: ritual, história e transformação entre os Matses da Amazônia brasileira, Tese (Doutorado em Antropologia Social) - Universidade Federal de Rio de Janeiro, Museu Nacional, PPGAS. Rio de Janeiro.

MEIGS, Anna S.

1976 - "Male Pregnancy and the Reduction of Sexual Opposition in a New Guinea Highlands Society". Ethnology 15: 393-407.

MENEZES BASTOS, Rafael

1999[1978] - A musicológica kamayurá: para uma antropologia da comunicação no Alto-Xingu. Florianópolis: Editora da Universidade Federal de Santa Catarina. 2006 - "Leonardo, a flauta: uns sentimentos selvagens", Revista de Antropologia, São Paulo, USP, 2006, V. 49 Nº 2.

2007 - "Música nas Sociedades Indígenas das Terras Baixas da América do Sul: Estado da Arte", MANA 13(2): 293-316.

2013 - A Festa da Jaguatirica: Uma Partitura Crítico-Interpretativa. Florianópolis: Editora UFSC, 525 páginas.

METRAUX, Alfred

1945 - "Ritos de transito de los indios sudamericanos". Anales del Instituto de Etnografia Americana, 6:117-128; 7:149-160. Mendoza.

1948 - "Tribes of the Middle and Upper Amazon River". Handbook of South American Indians, vol. 3. Washington D.C. 


\section{MILLER, Joana}

2007 - As Coisas: Os enfeites corporais e a noção de pessoa entre os Mamaindê (Nambiquara). Rio de Janeiro, PPGAS-MN/UFRJ.

MONTES RODRÍGUEZ, María Emilia

2000 - "Fonología de la lengua ticuna". En: M.S. González de Pérez \& M.E. Montes Rodríguez (eds.), Lenguas indígenas de Colombia. Una visión descriptiva. Bogotá: ICC.

MORAES, Melo

1882 - “Tribu dos Ticunas”, in: Revista da Exposição Anthropológica Brazileira. Rio de Janeiro: Typographia de Pinheiro \& Cia, p. 52-55.

MURA, Claudia

2007 - “Uma 'Tradição de Glória': o papel da experiência para capuchinhos e leigos úmbrios na Amazônia". Rio de Janeiro, UFRJ. Dissertação (mestrado) UFRJ / Museu Nacional / Programa de Pós-Graduação em Antropologia Social. NIMUENDAJU, Curt 1982[1929] - “Os índios Tukuna”, In: SUESS, Paulo (Coord.). Textos indigenistas: relatórios, monografias, cartas. Introdução de Carlos de Araújo Moreira Neto. São Paulo: Loyola. (Coleção Missão Aberta, 6). p. 192-208.

1952 - The Tukuna. American Archeology. Berkeley \& Los Angeles University of California Press.

NORONHA, Jose Monteiro de

1862 - Roteiro da viagem da cidade do Para até as últimas colônias dos domínios Portuguezes em os Rios Amazonas e Negro. [1768.]. Belém, Typ. de Santos \& Irmãos.

OGPTB

2002a - Cururugü tchiga [Livro dos Sapos], Organização Geral dos Professores Ticuna Bilíngues. Brasília, Ministério da Educação. 61p.: il.

2002b - Werigü arü ae [Livro dos Pássaros], Organização Geral dos Professores Ticuna Bilíngues - Brasília: Ministério da Educação. 48 : il.

OLIVEIRA FILHO, J. P. (org.) 


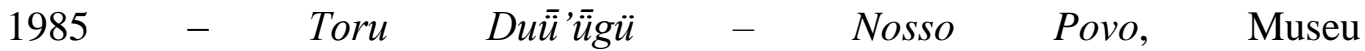
Nacional/UFRJ/SEC/MEC/SEPS/FNDE, Memórias Futuras Edições. Rio de Janeiro.

OLIVEIRA FILHO, J. P.

1988 - “O Nosso Governo”: os Ticuna e o regime tutelar. São Paulo: Marco Zero. 316p.

1999 - “A Busca da Salvação: Ação Indigenista e Etnopolítica entre os Ticuna”, Ensaios em Antropologia Histórica, Rio de Janeiro, Editora UFRJ, 21-59.

2000 - "Sobre Índios, Macacos, Peixes: Narrativas e Memórias de Intolerância na Amazônia Contemporânea”, Etnográfica, Vol. IV (2), pp. 285-310.

OLIVEIRA PINTO, Tiago

2001 - "Som e música. Questões de uma Antropologia Sonora". Revista de Antropologia, São Paulo, USP, V. 44 nº 1.

ORO, Ari Pedro

1977 - Tükúna: vida ou morte. Porto Alegre: Escola Superior de Teologia; Caxias do Sul: Univers. de Caxias do Sul. 130 p.

1989 - Na Amazônia um messias de índios e brancos: para uma antropologia do messianismo. Petrópolis: Vozes; Porto Alegre: EdiPUCRS. 208 p.

OVERING, Joanna

2006 - "O fétido odor da morte e os aromas da vida. Poética dos saberes e processo sensorial entre os Piaroa da Bacia do Orinoco", in: Revista de Antropologia, SÃO PAULO, USP, V. $49 \mathrm{~N}^{\circ} 1$.

OYUELA-CAYCEDO, A. \& ALBARRACIN, J. J. V.

1999 - "Aproximación cuantitativa a 1a organización social de los ticuna del trapecio amazónico colómbiano", in: Revista Colombiana de Antropologia, Volumen 35, enero-diciembre 1999, pp. 146-179.

PARDO, Camilo Alejandro Vargas

2008 - DEL YAJÉ AL MITO DE GÚTAPA Relación de una experiencia en la selva amazónica. Trabajo de grado presentado como requisito parcial para optar por el título de Magister en Literatura. PONTIFICIA UNIVERSIDAD 
JAVERIANA FACULTAD DE CIENCIAS SOCIALES MAESTRÍA EN LITERATURA BOGOTÁ, D.C. ENERO.

PORRO, Antônio

2007 - "Dicionário Etno-Histórico da Amazônia Colonial”, in: Cadernos do IEB, USP. São Paulo.

RAMOS, Danilo Paiva

2013 - Círculos de coca e fumaça. Encontros noturnos e caminhos vividos pelos Hupd'äh (Maku), Tese de Doutorado em Antropologia Social - Universidade de São Paulo, São Paulo.

RIBEIRO DE SAMPAIO, Francisco Xavier

1825 - Diário da viagem que em visita e correição povoações da capitania de São José do Rio Negro no anno de 1774 e 1775. Lisbon.

RICHARDS, Audrey.

1956 - Chisungu: a girl's initiation ceremony among the Bemba of Northern Rhodesia. London: Faber.

RIVET, Paul

1912 - “Affinités du Tikuna”. JSAP 9: 83-110.

ROSA, Patrícia Carvalho

2013 - "Romance de primas com primas e o problema dos afetos. Parentesco e micropolítica de relacionamentos entre interlocutores tikuna, sudoeste amazônico", Cadernos Pagu (41), julho-dezembro de 2013:77-85.

ROTH, Walter Edmund 1925 - An Introductory Study of the Arts, Crafts and the Customs of the Guiana Indians, in Annual Report of the Bureal of American Etnology, Washington, 38.

SAHLINS, Mashall

1990 [1987] - Ilhas de história, Rio de Janeiro, Jorge Zahar.

1997 - “O "pessimismo sentimental” e a experiência etnográfica: por que a cultura não é um "objeto" em via de extinção (parte I)". Mana, Rio de Janeiro , v. 3, n. 1, Apr.

SCHVARTSMAN, S.

1979 - Plantas Venenosas. Sarvier, São Paulo.

SEEGER, Anthony 
1980 - "O que podemos aprender quando eles cantam? Gêneros vocais do Brasil Central", in: Os índios e nós: estudos sobre sociedades tribais brasileiras. Rio de Janeiro: Campus.

1987. Why Suyá sing: a musical anthropology of an amazonian people. Cambridge: Cambridge University Press.

SEEGER, A., DA MATTA, R. \& VIVEIROS DE CASTRO, E.B.

1979 - “A construção da pessoa nas sociedades indígenas brasileiras”, Boletim do Museu Nacional, 32:2-19, Rio de Janeiro.

SEVERI, Carlo

2002 - "Memory, reflexivity and belief: reflections on the ritual use of language". Social Anthropology, Cambridge, v. 10, n. 1, p. 23-40.

SCHEFFLER, H. W.

1971 - "Dravidian-Iroquois: The Melanesian evidence", Anthropology in Oceania. Edited by L. R. Hiatt and E. Jayawardena, pp. 231-54. Sydney: Angus and Robertson.

SCHOENBERG, Arnold

1954 - Structural Functions of Harmony, London: Faber \& Faber.

SICK, Helmut

1997 - Ornitologia Brasileira. Rio de Janeiro, Ed. Nova Fronteira.

SIGRIST, Tomas

2008 - GUIA DE CAMPO - AVES DA AMAZONIA BRASILEIRA, Editora Avis Brasilis.

SILVA, Marcio Ferreira da

2010 - "Um pequeno mas espinhoso problema do parentesco". Ilha. Revista de Antropologia (Florianópolis), v. 12, n. 1,2, p. 163-207.

2012 - Liga dos Enawene-Nawe: um estudo da aliança de casamento na Amazônia Meridional. Tese (Livre Docência em Antropologia Social) - Faculdade de Filosofia, Letras e Ciências Humanas, Universidade de São Paulo, São Paulo. 
SIRAN, Jean-Louis

2002 - “Initiation: pourquoi la violence?”, in: L'HOMME 162, pp. 279 à 290.

SOARES, M. Facó.

2000 - O supra-segmental em Tikuna e a teoria fonológica. Volume I: Investigação de aspectos da sintaxe Tikuna. Campinas, Editora da UNICAMP.

SPIX, J.B.V. \& MARTIUS, C.F. Ph. 1981[1831] - Viagem pelo Brasil 1817-1820, São Paulo, EDUSP, vol. 3.

SPAOLONSE, Marcelo Barbosa

2006 - Uma "Tradição" em Performance: Corporalidade, Expressividade e Intercontextualidade Num Rito De Iniciação Social Entre Os Xavante De Sangradouro, Dissertação apresentada ao Programa de Pós-Graduação em Antropologia Social da UFSC.

SPARING, Margarethe et all.

2008[1976] - "Ticuna", in: Instrumentos musicales tradicionales de varios grupos de la selva Peruana. Datos Etno-Lingüísticos: Colección de los archivos del ILV, 36. Lima, Peru: Instituto Lingüístico de Verano, p. 113-16. http://www.sil.org/americas/peru/show_work.asp?id=52312

STRATHERN, Marilyn.

1992 - "Parts and wholes: refiguring relationships in a post-plural world", in A. Kuper (org.), Conceptualizing society, Londres/Nova York, Routledge, pp. 74104.

1999 - "No limite de uma certa linguagem". Revista Mana, Rio de Janeiro, v. 5, n. 2, Oct.

2006[1988] - O Gênero da Dádiva: problemas com as mulheres e problemas com a sociedade na Melanésia, Campinas, SP: Editora da Unicamp.

SZTUTMAN, Renato

2009 - "Ética e profética nas Mitológicas de Lévi-Strauss", in: Horizontes Antropológicos, Porto Alegre, ano 15, n. 31, p. 293-319, jan./jun.

TAMBIAH, S. J.

1968 - "The Magical Power of Words", in: Man, New Series, Vol. 3, No. 2 (Jun., 1968), pp. 175-208. http://www.jstor.org/stable/2798500 .

TATIT, Luiz 
1994 - Semiótica da Canção: Melodia e Letra. São Paulo: ESCUTA.

(2002[1996]) - O Cancionista. São Paulo: Edusp.

2011[1997] - "Tempo e tensividade na análise da canção", in: Musicando a Semiótica: Ensaios. São Paulo, AnnaBlume, 163p.

TEIXEIRA-PINTO, Márnio

1997 - Iepari. Sacrifício e Vida Social entre os Índios Arara, Eds. Hicitec/ANPOCS, UFPR, São Paulo/SP.

TRAUTMANN, Thomas R.

1981 - Dravidian Kinship. Cambridge: Cambridge University Press.

TURNER, Victor.

2005 - "Betwixt and Between: o período liminar nos "ritos de passagem", in: Floresta de Símbolos: aspectos do ritual Ndembu. Tradução de Paulo Gabriel Hilu da Rocha Pinto. Niterói: Editora da Universidade Federal Fluminense.

2013[1969] - O processo ritual: estrutura e antiestrutura. Petrópolis: Vozes.

VALDIVIESO, Salima Cure

2005 - "Cuidado te mochan la cabeza. Circulación y construcción de un rumor en la frontera amazónica de Colombia, Perú y Brasil”, Universidad Nacional de Colombia, sede Leticia.

2007 - "De gringos y cortacabezas", En: Amazonia Desde Adentro: Aportes A La Investigación De La Amazonia Colombiana. Colombia. Editora Guadalupe Ltda , v. , p. $100-127$.

VALENZUELA, Hugo Ramos.

2010 - El Ritual Tikuna de da pelazón en la Comunidad de Arara, sur del trapecio amazónico. Una Experiencia Etnográfica. Tesis de maestría en Estudios Amazónicos/Universidad Nacional De Colombia, Sede Amazonía.

VAN GENNEP, A.

2011[1909] - Os ritos de passagem. 2. ed., Trad. Mariano Ferreira. Petrópolis: Vozes.

VAN VELTHEM, LÚCIA H. 
1995 - O Belo é a Fera. A Estética da Produção e da Predação entre os Wayana. Tese de Doutorado, PPGAS/FFLCH/USP.

VASQUES, Anita Fermin

2010 - Análise Linguística de um Livro Tikúna, Dissertação de Mestrado, Programa de Pós-Graduação em Linguística, Instituto de Letras, Universidade de Brasília, Brasília.

VIVEIROS DE CASTRO, Eduardo.

1986 - Araweté: os deuses canibais, Rio de Janeiro: J. Zahar Ed. ANPOCS.

2002a - "Perspectivismo e multinaturalismo na América indígena", in: $A$ Inconstância da Alma Selvagem e outros ensaios de antropologia. São Paulo, Cosac \& Naify.

2002 b - "Atualização e conta-efetuação do virtual: o processo do parentesco", in: A Inconstância da Alma Selvagem - e outros ensaios de antropologia, São Paulo; Cosac \& Naify.

2007 - "Filiação Intensiva e Aliança Demoníaca", in: Novos Estudos CEBRAP, 77, pp. 91-126.

2008 - “Uma boa política é aquela que multiplica os possíveis", entrevista in: Entrevistas Eduardo Viveiros de Castro, Renato Sztutman (org.). RJ, Ed. Beco do Azougue.

WAGNER, Roy.

1991 - “The Fractal Person”. In: Marilyn Strathern e Maurice Godelier (org.). Big Men and Great Men: Personifications of Power in Melanesia. Cambridge: Cambridge University Press.

2010 - A invenção da cultura. São Paulo, Cosac Naify. 256 p.

2010[1974] - “Existem grupos sociais nas terras altas da Nova Guiné?”, in Cadernos de Campo, São Paulo, n. 19, p. 1-384.

WERLANG, Guilherme

2008 - "Musicalidade marubo, musicologia amazônica: tempo histórico e temporalidade mítica", Revista USP - Etnomusicologia, São Paulo, n. 77, 34-65.

WISNIK, José Miguel. 
1978 - “Onde não há pecado nem perdão”. In: Almanaque Cadernos de Literatura e Ensaio, São Paulo, v. 06, p. 11-16.

1989 - O som e o sentido. Uma outra história das músicas. São Paulo, Companhia das Letras.

ZEMPLÉNI, Andras.

1991 - "Initiation." Pp. 375-77 in Dictionnaire de l'ethnologie et de l'anthropologie, ed. P. Bonte and M. Izard. Paris: Presses Universitaires de France.

ZILBERBERG, Claude

2006. Razão e poética do sentido. São Paulo: Edusp.

\section{Referências Fonográficas:}

PEREIRA, E. M. M.; PACHECO, G.; OLIVEIRA, J. P.

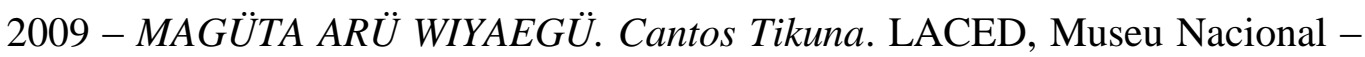
UFRJ.

\section{Filmografia}

DESCOLA, P. \& MATAREZIO Filho, E.

2013 - O que Lévi-Strauss deve aos Ameríndios [Filme], Entrevista concedida a Edson Tosta Matarezio Filho, Produção e Direção de Edson Tosta Matarezio Filho. São Paulo, Laboratório de Imagem e Som em Antropologia da Universidade de São Paulo (LISA-USP), 1 DVD/ NTSC, 50 min. color. son.

\section{MATAREZIO FILHO, Edson Tosta}

2014 - IBURI Trompete dos Ticuna, Filme documentário, São Paulo de Olivença (AM), São Paulo (SP), LISA-USP, FAPESP, DVD, NTSC, 14 min., color, som. 


\section{Anexos}

\section{Anexo 001 - Transcrição da Canção do Wiwirutcha. Gravação Ondino, tradução}

\section{Luscita Bibiano Ezequiel.}

Wiwiwi, wiwiwirutcha\} Refrão / Mama ta rü tóü ama / "A nossa mãe" / Nüünama ta oo ’ama / "Não quis" / Ya toriüna a wiwirutcha / "O nosso "filhinho" wiwirutcha" [üna= palavra usada pela mãe chamar o filho ou filha carinhosamente] / Waiama arü ngaünmawa / "No meio do caminho do Waia" / Toünama na'apaweru / "A gente que foi fisgado" [porque a mãe não quis; na'apaweru = fisgado] / Waiama arü ngaümawa / "No meio do caminho do Waia" / Toünama na'apaweru / "A gente que foi fisgado" / Ya toriüna ya wiwirutcha / "O nosso "filhinho" wiwirutcha".

\section{Anexo 002 - Canção do Boi (Woca). Acalanto gravado por Catarina Maria Basílio da Silva (Waigeremunã), tradução Luscita Bibiano Ezequiel.}

Wawawa.....wawa......wawawawa/ [wawae = cantar] / Taũ $i$ rü aü̈n pa mĩ / "Não chore, neném" / Nhemataã pa mĩ / "Lá vem, neném" / Ye i woca pa mĩ / "Aquele boi, neném" / Campo arü yecutüwa / "Do outro lado do campo" / Cuca i na nha / "Ele está vindo correndo para você" / I ye woca pa mĩ / "Lá está o boi, neném" / I tão i rü auün / "Então, não chore" / Tão i rü аü̈n аo рiu рiu / "Não chore, neném [piu]" [piu = neném, filhinho, mais carinhoso do que mĩ] / Tão $i$ aü̈n rü campo arü yecutüwa cuca $i$ tchaitche paratchigui pa mĩ / "Não chore, porque ele está vindo do outro lado do campo, correndo com as pernas dele batendo na água, neném" [tchaitche = "batendo na água"] / Woca pa mĩ / "Boi, neném" / Nheguma cucuigu ta / "Se você chorar agora" / Woca cucüi ma' pa

$m \tilde{\imath}$ / "O boi vai matar você" / Rü tão na aü̈n / "Então, não chore" / Nheguma campo arü / "Do outro lado do campo" / Yecutü wa taca i na nhagu pa mĩ / "Ele vem correndo na nossa direção neném" / Nhema i ya woca pa mĩ / "Aquele boi, neném” / Nheguma ta ta'ca i na nha papü na pe pa mĩ / "Ele vem na nossa direção, neném” / Rü taün i cu auün / “Então, não chore" / Na pe pa mĩ / "Dorme, neném" / Nheguma ta woca tama / "Lá vem o boi, neném" / Nuã i ũ pa mĩ / "Ele está vindo, neném" / Cu augui, woca ta yuraãcu ta nuã $i$ ün / "Se você chorar, o boi vai vir te pegar".

Anexo 003 - Canção dos Imortais (Uũnnetchiga). Gravação e tradução de Ondino. 
Tücüena, tücüena / "Por que, Por que?" / Pa yui, yui, pa yunatüta \} 2X [Refrão sublinhado]/ "Mortais, mortais, mortais" / Tau'ũnmani, rü tau'ũturü / Não, Não / Pefaega'ũ, Pefaega'ũ, (tücüena)Pefaega'ũ / "Vocês não estão sabendo" / Marütchiré, Marütchiré / "Já, Já” / Rü pepewa, pepewa, pepewa / "E na sua frente" / Rü bubuetü, bubuetü / "No descampado, descampado" / Rü temanecüma, rü temanecüma / "E no meio do buritizal” / Rü nga' únecüwa / "No meio" / Rü nga' ũwama / "No meio" / Rü pepewa, pepewa / "Na sua frente” [para muitas pessoas] / Tadudue'ũ, Tadudue'ũ / "Batendo" / Refrão 2X / Duwaucü, duwaucü, pemaucü, tauãtchiã \} 2X / "Eu tenho pena de vocês" / Rü tücüena, tücüena / "Por que, por que" / Rü tau'ũtürü rü tau'ũtürüwai / “Não, vocês não nos conheciam" / Dauega'ú, dauega'ũ / "Vocês não nos viam" / Erüwai, erüwai / "Por que, por que" / Aũriũtchi peyunatugü \} 2 / "Muitos mortais" / Tücüena, rü tücüena / "Por que, porque" / Tau'ütürüwai, tocatürü, pe aure' ú, pe aure 'ũ / "Vocês não nos conheciam, não jejuavam para nós" / Pe aure'ũ, pe aure'ũ / Refrão $2 \mathrm{X} /$ Tocatürü pe auregutchi / "Se vocês tivessem jejuado para nós" / Tocatürü, pedawama / "Vocês veriam a gente" / Refrão 2X / Guaniya'ĩ, guaniya'ĩ / "Aquela, aquela" / Rü totchĩ'ũ / "Nossa casa" / Ya Morugünẽ, morugünẽ, ya Tchuegünẽ / "A casa de Yoi vira no ar e some” [Este é o sobrenome da casa] / Totchĩ '́u \} 2X / "Nossa casa" / Pe tocatürü, pe auregutchi \} 2X / "Se vocês tivessem jejuado para nós" / Nawaücü rü pe útürü / tagagücüra'ũ \} 2X / “A gente teria levado vocês naquela casa" / Ngemaũcü \} 2X / "Lá [naquela casa]" / Düawacü rü naane rü taetünameegü, taetünameegü / "Pode ser que acabe o mundo, naquela casa vocês se salvarão" / Ngemaũcü \} 2X / "Lá [naquela casa]" / Rü Taurüpe'ũ / "Não vai acontecer nada com vocês / nunca vão morrer" / Nawaücü ya Morugünẽ" / "Lá na casa Morugünẽ” / Rü Taurüpeü / "Não vai acontecer nada com vocês / nunca vão morrer".

\section{Anexo 004 - História da Samaumeira e a origem do dia, contada por Severino}

"Quando derrubaram uma samaumeira (wõnê) grande mesmo, aí deu para ver o céu, amanheceu. A samaumeira era tão grande que seus galhos viraram igarapés. Ipi desceu o rio e Yoi subiu (Peru). Ipi viu muito ouro. Yoi e Ngutapa dormiram e inverteram as direções. O rio girou, Yoi veio para o Brasil, mas Ngutapa ficou no Peru. O tronco virou o rio Solimões, os galhos mais finos viraram os pequenos igarapés, as folhas viraram lagos. Aí amanheceu, antes era só noite. Ninguém tinha roupa, só tanga.” 


\section{Anexo 005 - História de To’oena, tradução feita com Ondino}

FIRMINO, Lucinda S. \& GRUBER, Jussara G

2010 - “To'oena", in: Ore i nucümaügüü: Histórias Antigas, volume 1, Benjamin Constant, Amazonas: Organização Geral dos Professores Ticunas Bilíngues OGPTB, (Coleção Eware).

Vão dançar com ela, por isso que ela está guardada. Mas, até então ninguém sabia se ela estava mesmo guardada. Naquele tempo, To ’oena era moça nova. Então, seus tios, Yoi e Ipi, começaram a tocar o to'cü. Depois que eles viram o povo poponari [pato], começaram a tocar música bonita. Eles ficaram fazendo barulho. Lá longe eles estavam fazendo e experimentando os instrumentos. A mãe de To'oena já sabia que ela era moça nova, mas naquela época ainda não recolhiam a moça. To 'oena ouviu e ficou curiosa para ver (ngutchaüngü) o que estava fazendo barulho lá.

Eles estavam na beira do igarapé Eware, o lugar de Ngutapa. Nesta época, o Eware ainda não estava cheio de sangue de To'oena. Então ela falou, "vamos ver onde os tios (oe - MB) estão cantando". Mas a amiga (mucü) dela, a pata poponari, falou para ela não ir porque eles podem matar. "É uma cantoria (cagü 'ün) mortal (daitchiga) o que eles estão cantando. Eles já sabem que nós não estamos bem guardadas (i'itchaeün)". To'oena pensou, então, em subir num ingazeiro e olhar para lá. Ela falou para sua amiga, a patinha poponari: “ainda não nos viram. Eu já vi, mas eles nunca vão nos ver”. Já a patinha respondeu o que era mais certo a fazer: "eu não vou subir em nenhuma árvore, agora mesmo eu vou me guardar/cuidar/esconder (ngu'ün). Depois de dizer isso, a patinha poponari se escondeu num lugar fechado e não se mexeu ${ }^{567}$.

Então, os tios (oe - MB) da moça nova chegaram por ali andando. [To'oena é nata'a (sobrinha/neta) de Yoi)]. Eles vinham tocando as trompas e batendo com os paus em quem estivesse na frente.

[O narrador diz que já viu este acontecimento. As pessoas mais antigas faziam isso, traziam os instrumentos e cacetavam qualquer um que estivesse na frente. Quem estivesse dentro da casa não podia sair. Ele conta que na infância dele a festa era mais rígida (ye'era) que agora].

${ }^{567}$ Comentário do tradutor: este tipo de pato gosta de se esconder no meio das folhagens. 
E To'oena estava no ingazeiro olhando para lá. De cima da árvore ela estava olhando para baixo para ver o to 'cü. Os antigos/velhinhos (yaguãta) contam que quando se olha para aquele trompete a vista se apaga. Quando To'oena olhou para o instrumento e viu os olhos dele brilhando (naiẽ'tü'ün). Por isso, as pessoas não podem ver.

Os que tocavam vinham andando e se enfrentavam para ver quem tocava melhor, ninguém mais mexia naquele trompete. Eles cantavam e sopravam: "vamos lá cantar sobre onde a gente está indo", e vinham subindo. Neste momento era de dia, muito cedo. Em cima do ingazeiro ela se espantou (Baia'tchiün). Então, o calor (naũün) vindo dos instrumentos chegou/pousou/tocou (tü'ünwagumema - p. ex. quando um pássaro pousa) nela. Neste momento, ela se urinou (wiyaünmaũ) de medo (mu'ũ). Então, eles viram o vermelho da urina dela e perceberam que lá tinha gente. Mas já não era mais gente que estava lá naquele momento. Pode ser que era um bicho que estava lá, em forma de pessoa. Como a urina já era sangue, ninguém sabia se era gente. Alguns dos que estavam tocando eram bons/normais/gente (meĩgü'üncü), outros eram parecidos com preguiças (wõeraügün'ün - wõẽ: preguiça; raügün'ün: parecido) e outros tipos de bichos. Eles vinham cantando com os instrumentos: "onde que vou colocar/enganchar meu tüwi nge, $n g e, n g e, e, e, e, e, e, e \ldots . . " 568$. Não era uma preguiça, mas um bicho (ngo'o) em forma de uma preguiça.

E vinham cantando "nge, nge, e,e,e,e,e,e,...", os bichos em forma de preguiça $(\text { wõerraürü })^{569}$. Eles sopravam a nge'cutü, uma flauta embolo feita de um cipó grosso (yowaru). Com o som do sopro, To'oena assustou, caiu e cacetaram ela. Naquele momento, os instrumentos voltaram, não seguiram para a festa, voltaram para a beira do Eware $^{570}$. Em virtude da morte dela, eles não podiam mais subir para a Festa. Todos ficaram interditados ( utü'ün) de subir para a Festa, inclusive os tios da moça. Com isso, Yoi e Ipi ficaram desanimados (tama = não, nata 'á ${ }^{\prime} \tilde{e}=$ animado $)^{571}$.

\footnotetext{
568 Tüwi é o gavião-tesoura (Elanoides forficatus), contudo, neste caso me disseram que não se trata do pássaro. Esta pode ser a voz da preguiça que está vindo. Tchaicure é a capa dos encantados. Quando os encantados vestem esta capa, eles se transformam em tüwi.

${ }^{569}$ Wõ̃ = preguiça; _raü = forma, foi-me dado o seguinte exemplo, “Edsonraü tem forma de Edson, mas não é Edson".

${ }^{570}$ Rio de onde os Ticuna foram pescados.

${ }^{571}$ Esta palavra tem como raiz a palavra que designa alma/espírito = _a áẽ.
} 
Depois disso, todo esse pessoal - Yoi, Ipi, os bichos preguiça e os instrumentos não apareceram mais. Só Yoi sabia o que ele queria, no pensamento dele. Depois destes acontecimentos, ninguém mais viu Yoi, ele ficou invisível (utü). Ele não pôde mais viver com o pessoal. A sobrinha ( $\left.t t^{\prime} a\right)$ de Yoi tinha morrido cacetada pela turma e tinha se transformado em jacaré (coya), mas foi comida só uma banda dele. Eles pegaram ela e levaram para o lugar onde eles tinha feito os instrumentos. Lá fizeram fogo (ün) e tiraram as tripas do jacaré (tchauna = estripar). Ninguém sabe se Yoi comeu a carne dela. Depois que estriparam e lavaram as carnes dela no igarapé Tunetü, afluente do Eware, a água do igarapé ficou avermelhada (dutchiii) com o sangue dela. Ipi comentou com Yoi, "irmão, com o sangue da nossa sobrinha que o rio ficou avermelhado". Yoi respondeu, "cuguta" ["não diga isso", “você está doido?”, “quer saber mais do que eu?”]. Neste momento, a água ficou mais avermelhada ainda.

Yoi subiu para a casa de sua irmã, mãe de To'oena e fez um discurso para ela: "se você respeitar seus festeiros (a'etanü'ün), você vai chamar todo mundo para entrar na sua casa. Agora vão subir os xerimbabos (_ünna) de To'oena. Todos devem ficar dentro da casa porque ela foi morta. Os xerimbabos já caíram na proibição. Eles não subiram antes, então, tome cuidado. Você já está sabendo. Aquela sua filha, que era moça nova, está morta. Não quero que você chore. Agora vamos subir os xerimbabos dela. Eles vão cantas a música dela. Não chore de jeito nenhum. Se você chorar vai sobrar para você, vai acontecer com você o mesmo que com To'oena. É tudo culpa sua, porque você não aconselhou (исие̃) sua filha. Era Festa dela, aconteceu isso porque você não juntou tudo que precisava antes, e To'oena ficou procurando alguma coisa. Por isso, eu nunca mais vou estar com vocês". To'oena caiu na proibição (utu'üngü) porque ela endoidou (_ecüna) e não obedeceu a sua mãe.

Yoi foi, então, na direção do aguidá (buetare), raspou a fuligem grudada na parte queimada pelo fogo e passou na cara de sua irmã. Ele passou esse pó preto na cara de sua irmã para saber se ela não estava chorando. Se ela chorasse, o pó cairia. "Se cair o pó preto vai sobrar para você, você será culpada também. Não quero que você chore”, avisou Yoi. E continuou falando, "Pense no que aconteceu com sua filha. Senão vai acontecer com você o que aconteceu com sua filha. Se você chorar, eu vou te matar e a água do igarapé ficará ainda mais avermelhada", assim ele dizia enquanto passava o pó na cara de sua irmã. "Agora está tudo bem. Eu vou onde está o xerimbabo dela, mas eu volto rapidamente para ver se você está chorando. Aqui estão seus festeiros, avise a eles que 
fiquem dentro da casa. Agora, como já quebraram a proibição, os xerimbabos não irão respeitar (nãgetchaün) mais ninguém”. Depois de dizer isto para sua irmã, Yoi foi lá onde os xerimbabos estavam. Demorou um pouquinho e voltaram cantando.

Então o soprador (fe'güru'ün) de nge'cutü - a flauta embolo de cipó - veio soprando, mas não soprava bem, soprava com raiva e cacetava para todo lado. Se alguém estivesse por perto, de pé, certamente ele mataria. O soprador vinha fazendo barulho com o pau que estava cacetando. Neste momento ele foi ver a irmã dele, mãe de To'oena. Ela se aguentou, não chorou e o pó não caiu de seu rosto. Por isso, Yoi não fez nada com ela.

A alma de To'one disse: "Mamãe [pa õ], quando eu estava viva, eu andava na sua frente, no meio da chuva, com meu cabelo esvoaçando (tchingeayaetchigü' $\ddot{u}$ - mexendo o cabelo quando ela estava andando)". Yoi falou: "agora você já fez o que não devia ter feito". A alma de To'oena dizia assim, dentro do to 'cü: "como fizeram para me derrubar do ingazeiro?". E Yoi mandou que ela cantasse assim dentro do instrumento: "Mamãe, quando eu estava lá com você, na sua frente, meu cabelo esvoaçava (tchingeayaetchigü)"”. Sua alma continuava cantando dentro do to 'cü: "Mamãe, não recebe a coxa do veado vermelho. Mamãe, se ele der a coxa do veado vermelho, não receba, pois essa é a minha coxa". Neste momento, Yoi olhou para a cara de sua irmã e viu que ainda não tinha escorrido o pó preto.

Então Yoi não fez nada com sua irmã, porque o pó preto não caiu de seu rosto. Deixou ela viver em paz e falou: "se vocês fizerem festa o to'cü não vai subir mais de

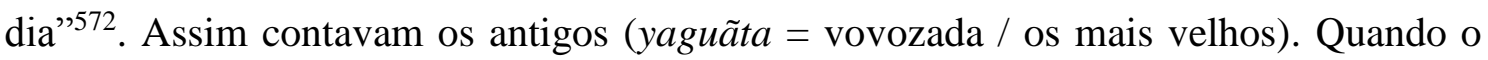
to 'cü estava subindo eles diziam: "vamos entra na casa e tomar cuidado (itarü unüaẽ)". Naquela Festa estavam todas as histórias deles e como vão cantar nas próximas Festas. Antigamente as pessoas eram boas e os mais velhos (yaguãta) eram bons.

Yoi avisou para os que estavam lá: “depois de mim, vocês vão dizer como será o nome dele. Vocês vão colocar o seguinte nome: o dente vermelho de sangue do $\underline{\text { Tchoreruma }}$ [boto gigantesco que vive no rio celeste, Tchowatü,], durutchte'e ya tchoreruma". Depois que ele pediu para batizar o to'cü, Yoi se afastou, não ficou mais

\footnotetext{
572 O narrador explica que hoje em dia o to'cü é retirado da água e sobe para a festa às $18 \mathrm{hs}$ e $30 \mathrm{~min}$, $19 \mathrm{hs}$. Só volta para o igarapé às $5 \mathrm{hs}$ da manhã, antes de amanhecer. Não é como agora, antigamente demorava mais para subir e chegavam cantando. Atualmente não trazem ele cantando, só cantam no curral dele.
} 
com o pessoal. Ele se afastou porque tinha comido a carne dela em forma de jacaré (coyaucü ti 'î). Os festeiros perguntaram para ele onde eles tinham matado o jacaré. Yoi respondeu com raiva: "lá, lá, lá, no meio do arumã (depenecügü), no meio do arumã, no meio do arumã”. E repetiu, com raiva: “lá que matamos nosso jacaré”. Quando chegou a madrugada, Yoi cantou de novo a música de To 'oena dentro do to 'cü. Yoi cantava pedindo a flor de sua sobrinha ${ }^{573}$, cantava pedindo para ela ficar de pé na frente dele para entregarlhe o caldo. Quando o dia estava clareando, ele cantou a música para todo mundo e disse: “aqui está a música para vocês. Eu vou sair de pé daqui, andando". Assim ele aconselhou (исиё̈̈n) com o xcerimbabo (ünna) dela, o to 'cü'.

O narrador comenta que se ele não tivesse matado sua sobrinha, a música da moça nova seria diferente. Agora já é diferente, não é mais como a música que ele cantou. Até então, ninguém conhecia a música que ele tinha cantado. Depois que passou o tempo de Yoi, a Festa ficou meio bagunçada. As pessoas ficam fora da casa, namorando, não fazem mais os instrumentos, etc. Se conhecem bem a história de Yoi, fazem bem a Festa, como ele fez com a gente. O que se faz agora já não é mais como antigamente, é uma Festa mais empobrecida. Antigamente, no tempo de Yoi, a Festa era sagrada. Ninguém saia da casa, a casa saía voando, se encantava, ia para Morugune, um lugar no Eware e o nome da casa de Yoi.

Depois da Festa da To’oena, ninguém mais viu Yoi. Antes, ele andava no meio das pessoas, depois disto ele não apareceu mais para ninguém. Após comer a carne do jacaré, ele ficou invisível. O narrador da história comenta que não sabe ao certo se Yoi comeu mesmo a carne a sobrinha, mas as pessoas que estavam com ele comeram. Quando amanheceu o dia, os xerimbabos de To'oena - os instrumentos que ficam dentro do "curral" ao lado do "curral" de reclusão da moça - foram embora fazendo barulho (yenaya cucumütanügü = "se barulhando"). Foram embora falando/barulhando que não iam mais aparecer para ninguém. Os velhos contam que, onde fabricaram o to 'cü, lá mesmo eles ficaram, Yoi não levou eles. Quando chega o dia que eles querem, eles cantam a música da To’oena. Cantam sozinhos a música do dia que mataram To’oena.

Outro dia, as pessoas foram ver escondidas e viram que era o to 'cü mesmo que estava cantando. Então o pessoal viu que ele é feito de paxiubinha ( $\left.e^{\prime} t a\right)$, que ele tem

\footnotetext{
${ }^{573}$ Segundo o tradutor, pode ser um jeito de pedir o caldo do pajauaru.
} 
boca, tem dente, olhos piscando/brilhando (naigüetütanücü' $\ddot{u}=$ como a luz de um vagalume ou o um espelho mexendo, balançando). Colocaram ele na água do Eware, por isso que os olhos dele ficaram avermelhados (dauae'tü).

\section{Anexo 006 - História do Daiyae (dono do pé de jaboti), contada por Nailson Pissango}

Salvador.

Antigamente existia somente um pé de jaboti (tütchi). Daiyae era bem baixinho. Um dia, dois irmãos saíram para pegar as frutas de jaboti, mas nunca encontravam, porque o dono sempre pegava todas as frutas. Então um dos irmãos subiu na árvore para dormir e esperar pelo dono. O menino se chamava Caé. Ele já tinha juntado todo o jaboti. Quando o dono chegou já não tinha mais nada.

Daiyae chegou e o menino jogou uma fruta na cabeça dele. Ele só tinha quatro fios de cabelo. Ele pensava que era um maracanã que estava jogando as frutas. $\mathrm{O}$ rapaz jogou de novo. Daiyae falava, "para, Marianita", pensando que estava falando com o maracanã. O menino ouviu aquilo e deu risada. Daiyae mandou Caé descer da árvore de jaboti. Mas Caé não queria descer. "Desce, Caé, senão eu vou mandar tucandeira aí em cima". "Se você mandar tucandeira eu mato ela", respondeu Caé. E Daiyae retrucou, "ei vou mandar uma cobra para te pegar". Caé respondeu, "eu vou matar a cobra". Quando Daiyae ameaçou mandar uma onça, Caé ficou com medo e desceu.

Quando ele chegou no chão, Daiyae avançou em Caé e começou a fazer cócegas (ngaianï) em Caé. O menino se mijou e se cagou de tanta cócega. Enfim, ele desmaiou de tanta cócega. Quando ele acordou, Daiyae estava ao redor dele, andando, circulando. Daiyae falou para Caé, “o que você quer comigo afinal?". E Caé disse, "eu quero te conhecer, como você é. Você é bem baixinho". Daiyae respondeu, "eu sou baixinho, mas ninguém pode comigo. Nenhum homem pode comigo". Daiyae perguntou, "você quer alguma coisa?". Caé respondeu, “será que você tem algo importante para me dar?”. Daiyae disse, "sim, Caé, eu vou te dar um dos meus fios de cabelo e você terá muita sorte, tanto no amor, na doença, no dinheiro, no perigo"

Caé deu um fio de seu cabelo para Daiyae e este deu um dos seus poucos fios para Caé. Daiyae e Caé foram embora, cada um para sua casa. Daiyae falou para ele não falar nada para ninguém, esse cabelo era segredo. Qualquer coisa que ele desejasse ele teria. As coisas que ele imaginasse ele teria, Daiyae daria para ele. 
As pessoas começaram a comentar, "Caé era um menino pobre, como ele está rico?". Um dia, o pessoal fez uma roça num ajuri. Fizeram um pajauaru forte para ele contar como ele consegue as coisas dele. Perguntaram então para ele, "onde você encontrou dinheiro?". Caé respondeu, “eu pesco, caço e vendo para ter as minhas coisas". Caé tinha esposa e roupas bonitas. Tudo isso o pessoal perguntava, mas ele falava outra coisa.

As pessoas estavam chateadas, queriam matá-lo com o terçado, mas não acertavam ele. Caé tinha um poder por causa do cabelo do Daiyae. Passavam o terçado bem perto, mas não acertavam. Caé foi para a guerra e todos os seus colegas foram mortos, menos ele. Caé derrotou todos os seus inimigos e voltou para a casa sozinho. Quando iam cortar ele, as próprias pessoas se cortavam, se matavam. Assim Caé venceu a guerra.

\section{Anexo 007 - História de Beru - contada por Nailson Pissango Salvador e traduzida por Firmario Olesio Macário.}

Beru é borboleta e é também o dono do macambo. Vamos contar a história do Beru, que existia na montanha antigamente. Beru vivia dentro da montanha, ele era dono da montanha do Beru. Existia uma árvore de macambo, um macambeiro perto desta montanha. As pessoas tiravam macambo desta montanha.

Toda vez que Beru ia pegar macambo não tinha mais, as pessoas tinham pegado tudo. Ele era dono do macambeiro mas não conseguia pegar a fruta. Beru às vezes se transformava em borboleta, às vezes em gente. Até que um dia ele pegou uma senhora grávida e bateu com seu peito nela. A grávida desmaiou. Ela estava pegando o macambo junto com os outros. Quando ela desmaiou, Beru colocou ela no paneiro. Ele jogou o paneiro nas costas e foi jogando macambo em cima. A mulher foi amarrada com cipó, os braços, as pernas. Ele levou para a casa dele.

Perto da casa dele, no caminho, havia uma árvore caída que todos os dias ele passava debaixo. Quando ele passou debaixo dessa árvore a grávida acordou, pegou na árvore e escapou do paneiro. Beru chegou na casa dele, o lugar onde ele comia gente, foi olhar no paneiro, mas a mulher não estava mais lá.

O macambo que ele levava para a casa dele era só para acompanhar a refeição principal, que eram as pessoas que ele comia. Quando ele viu que a mulher não estava 
mais no paneiro, ficou com raiva e gritou com a voz bem alta: "aaaaahhhhhh! Cadê minha comida? Wawawa!" Ele falava assim porque ela estava grávida. Depois disso, já que não tinha mais nada para comer, ele chamou as cobras verdes (cura) dele e comeu elas.

Então, um dia, ele encontrou um pajé, matou e comeu a carne do pajé. A carne fez mal para ele. Naquele local tinham crianças que pescavam por ali. Beru estava com dor de barriga e colocou sua rede fora da montanha. As crianças ficaram olhando. Beru viu as crianças perguntou para elas "por que vocês estão com o corte de cabelo bonito?" (nunagueru $=$ corte de cabelo da moça nova). As crianças responderam que a mãe (oe) delas que cortava. Ele achou bonito e queria cortar seu cabelo com ela também, usar o corte nunagueru.

Beru foi até a mãe das crianças ao meio-dia. A mãe delas preparou um panelão de breu (owii) bem quente para jogar no cabelo do Beru. Já estava preparado o dente de piranha que seria o pente do Beru. Beru sentiu a dor do penteado e perguntou, "por que dói o penteado?". A mulher respondeu "é assim mesmo o corte de cabelo. Sente-se sem se mexer". E a mulher continuou penteando com o dente de piranha. O pente arranhava ele.

A mulher foi pegar o breu quente que já estava no ponto. Ela mandou que ele fechasse o olho e jogou o breu quente na cabeça dele. Beru gritou, mas aguentou. $\mathrm{O}$ breu quente acabou matando Beru. Onde ele estava sentado a terra se abriu e Beru caiu. Quando ele caiu, a terra se fechou de novo. 


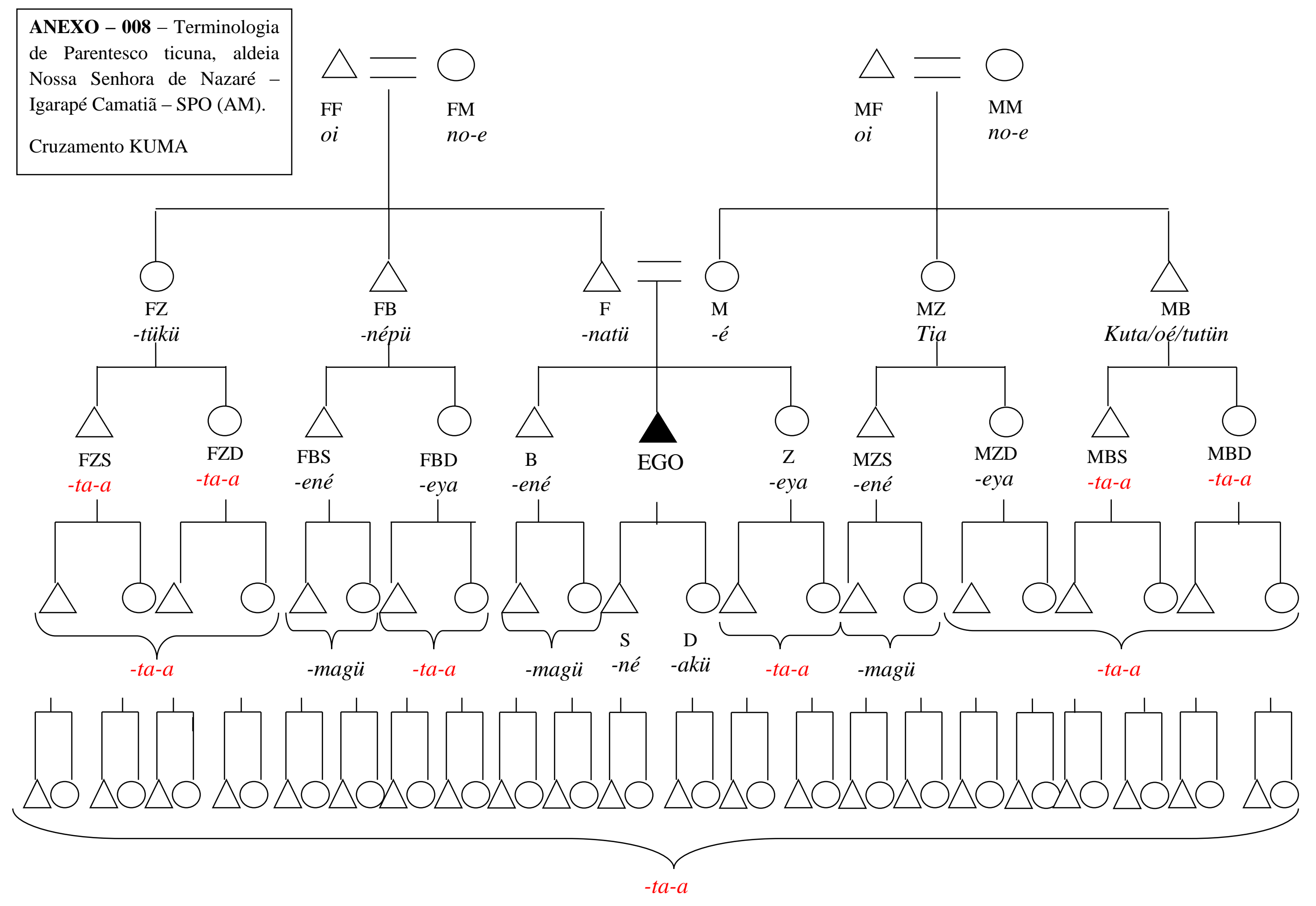



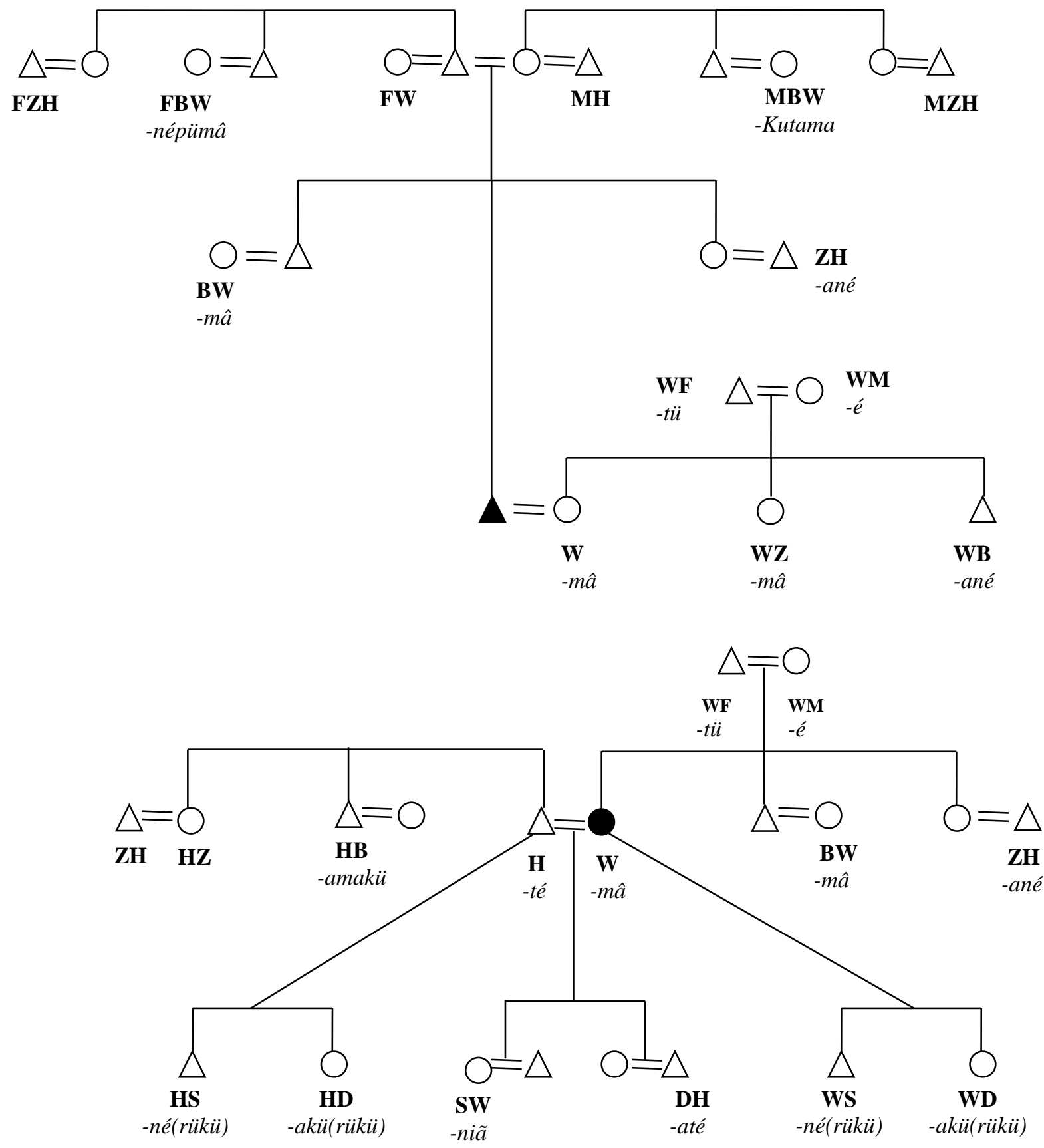


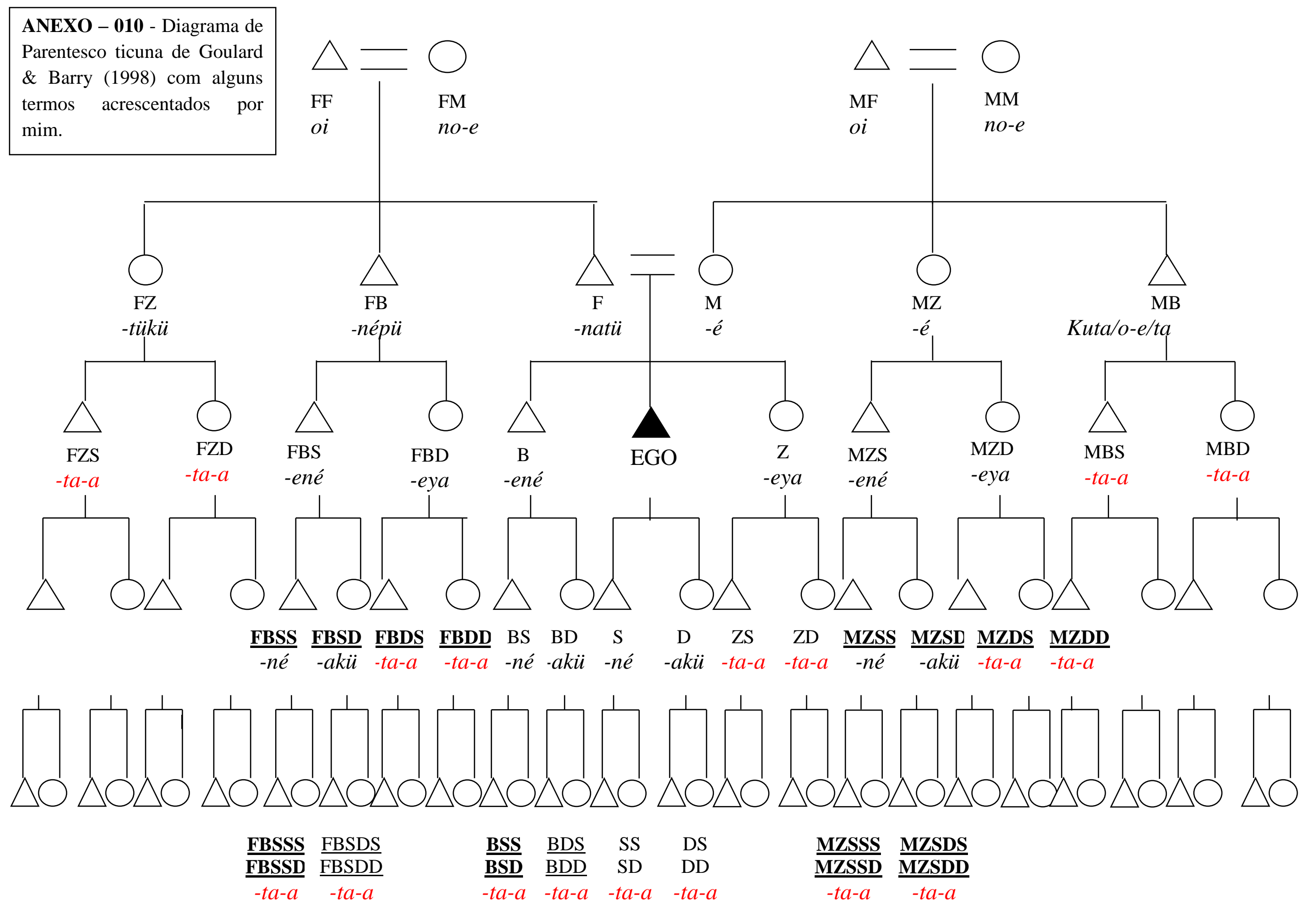


ANEXO - 011 - Transcrição da canção dos imortais. Cada linha corresponde a aproximadamente um semitom. A linha vertical indica uma duração maior da nota.
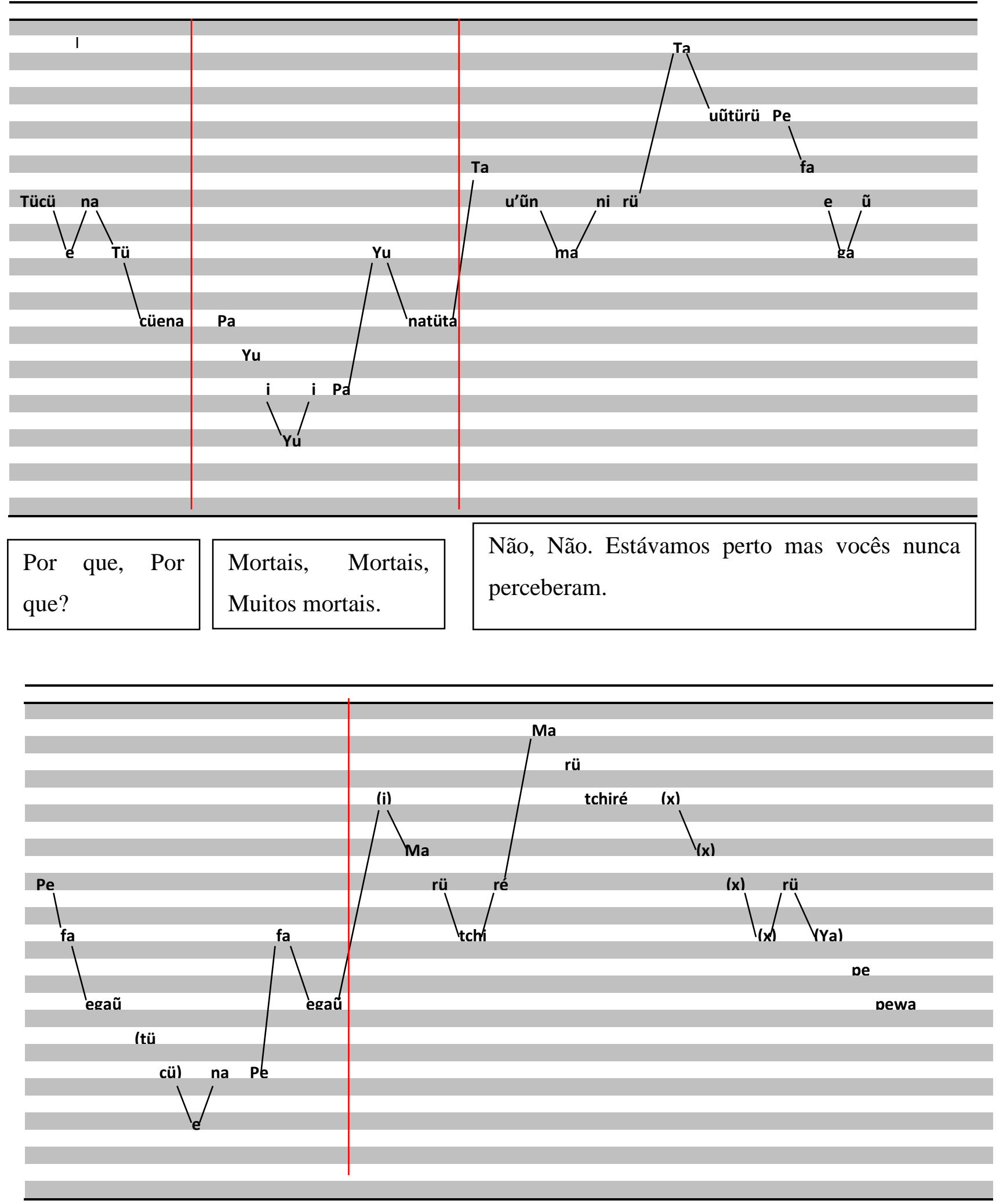

Já, Já.

E na sua frente 


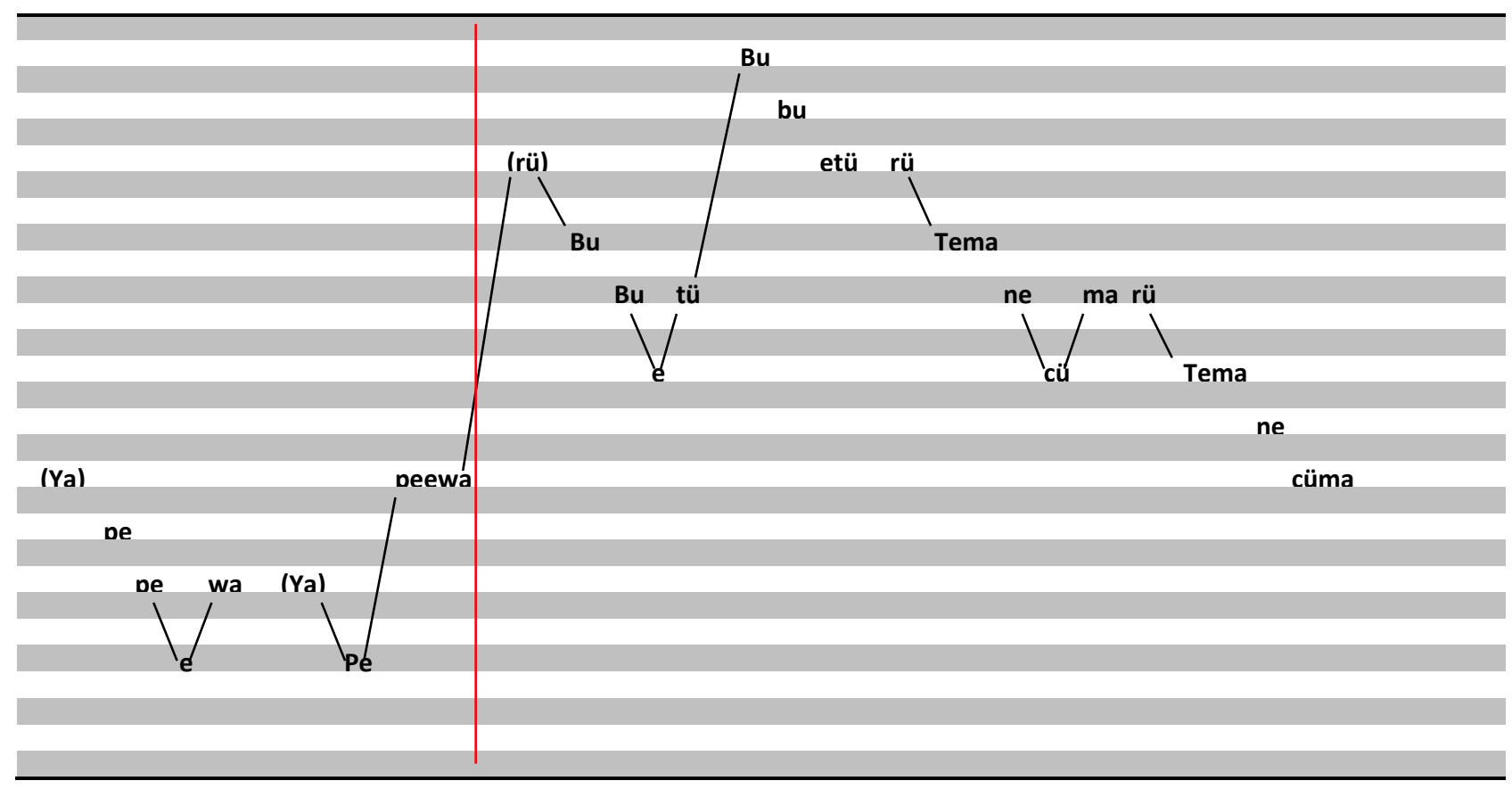

Um grande lugar descampado, com mato baixo. E no meio do buritizal

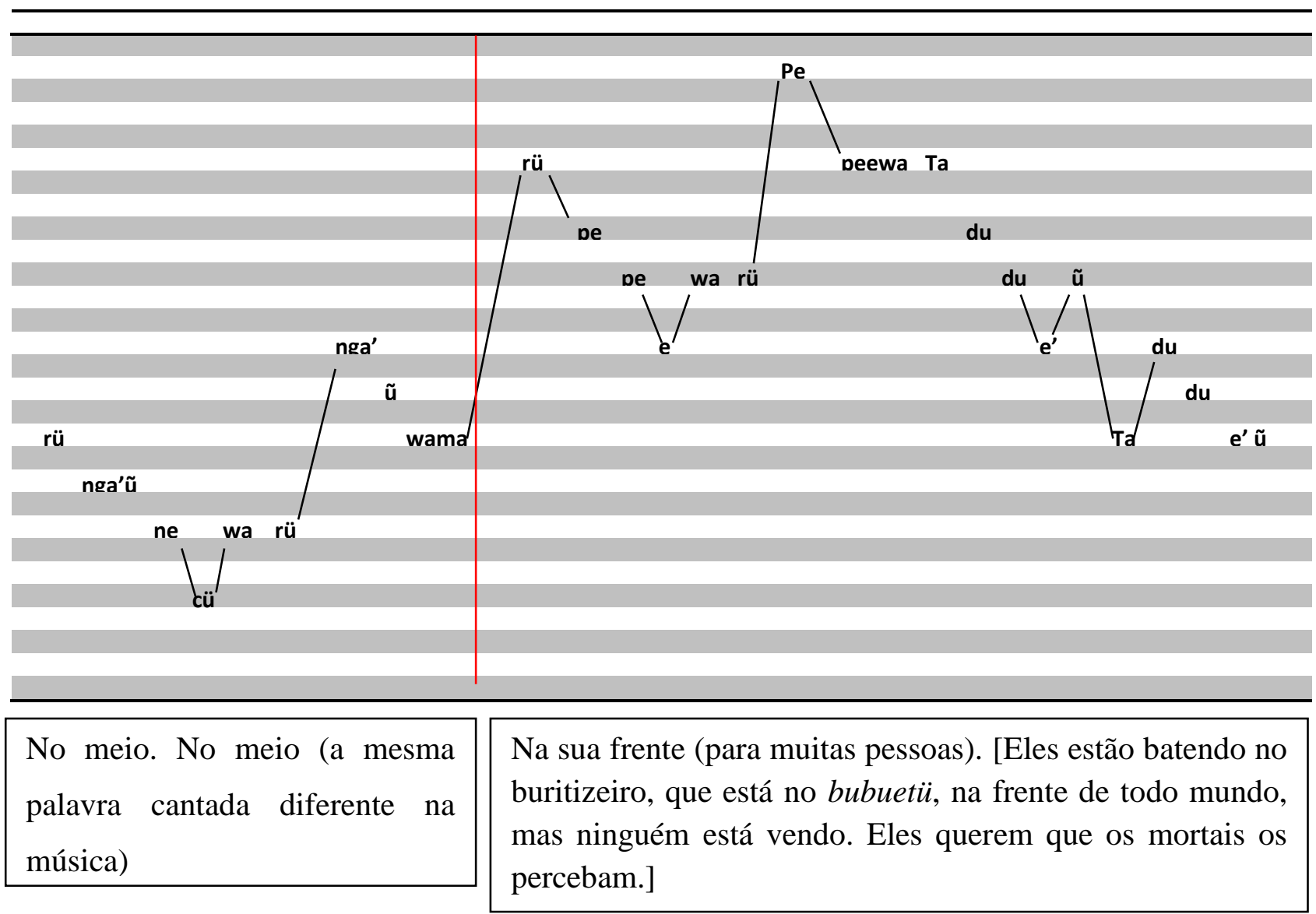



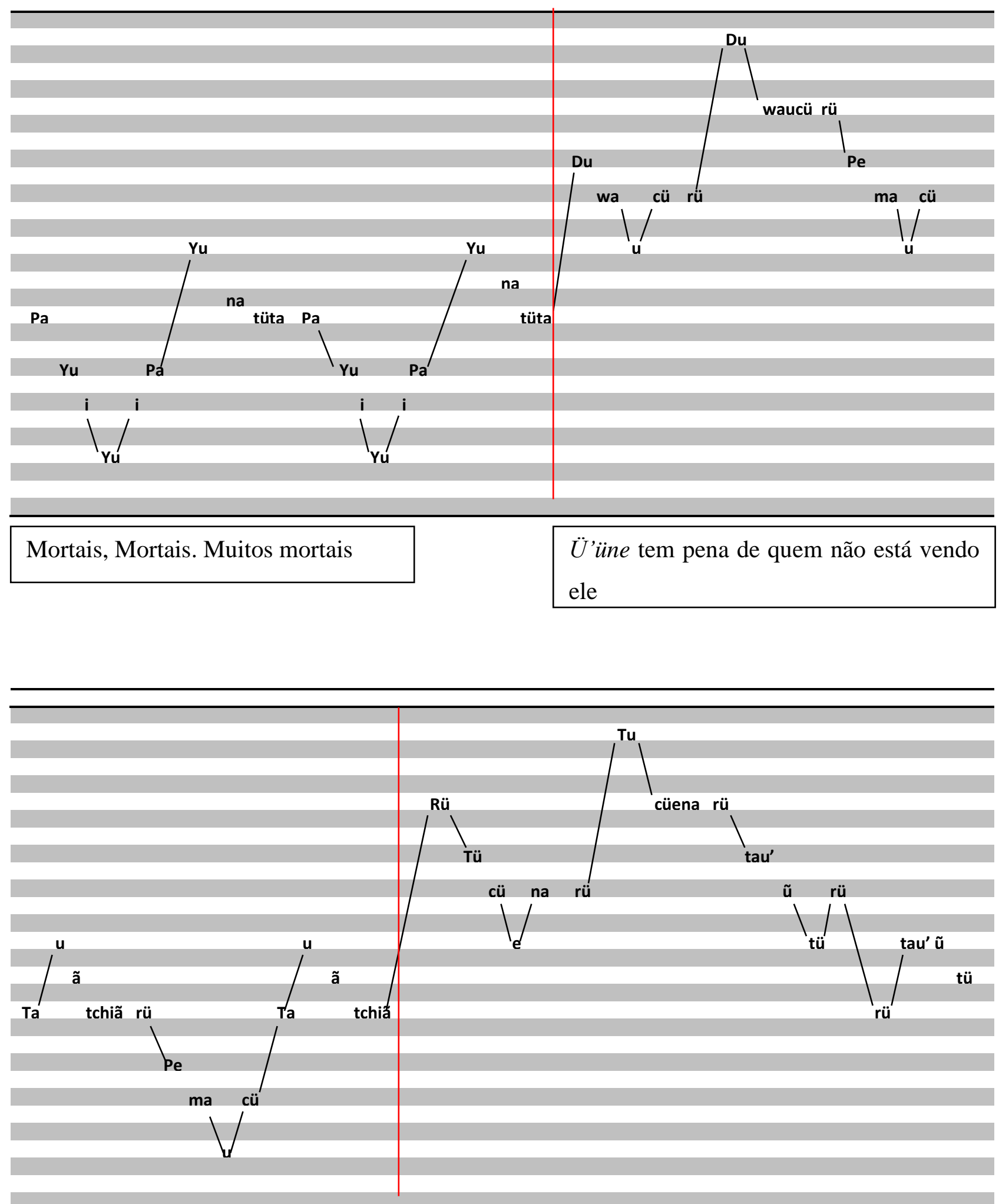

"Eu tenho pena de vocês"

Por que, por que? Não, vocês não nos conheciam. 


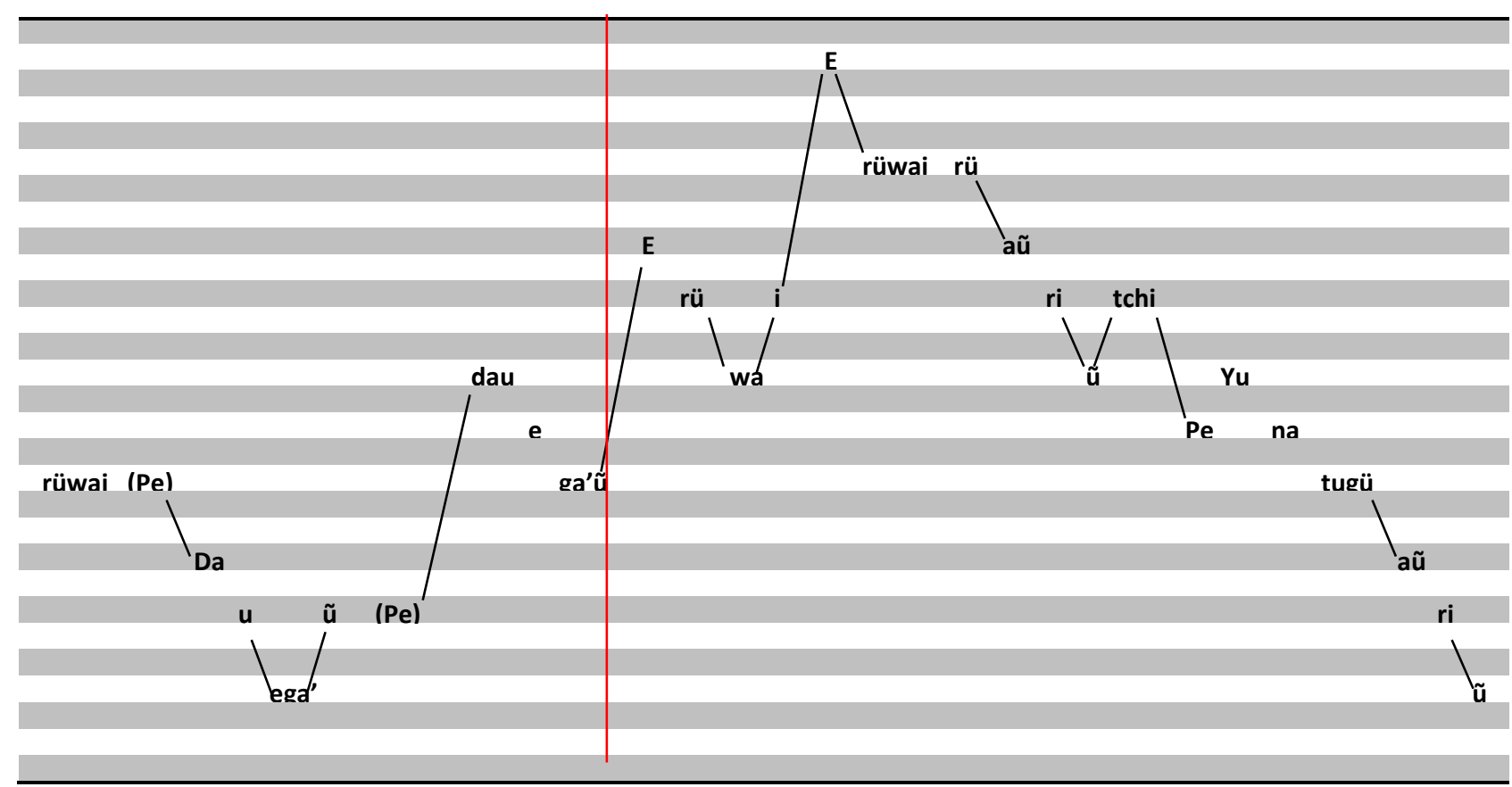

Vocês não nos viam

Por que, por que? Muitos Mortais.

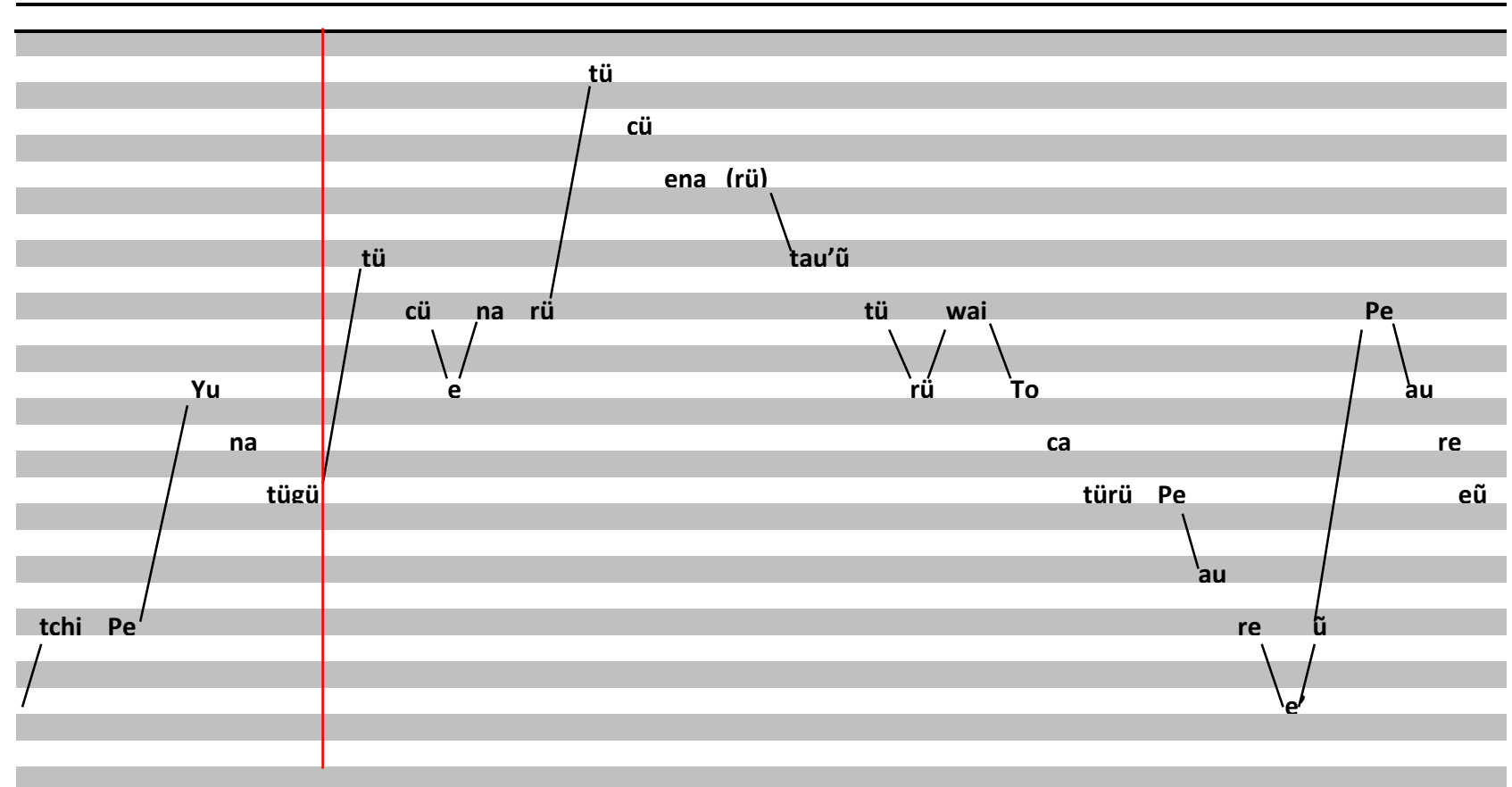

Por que, por que? Vocês não nos conheciam, para nós (refere-se ao jejum, abaixo). 


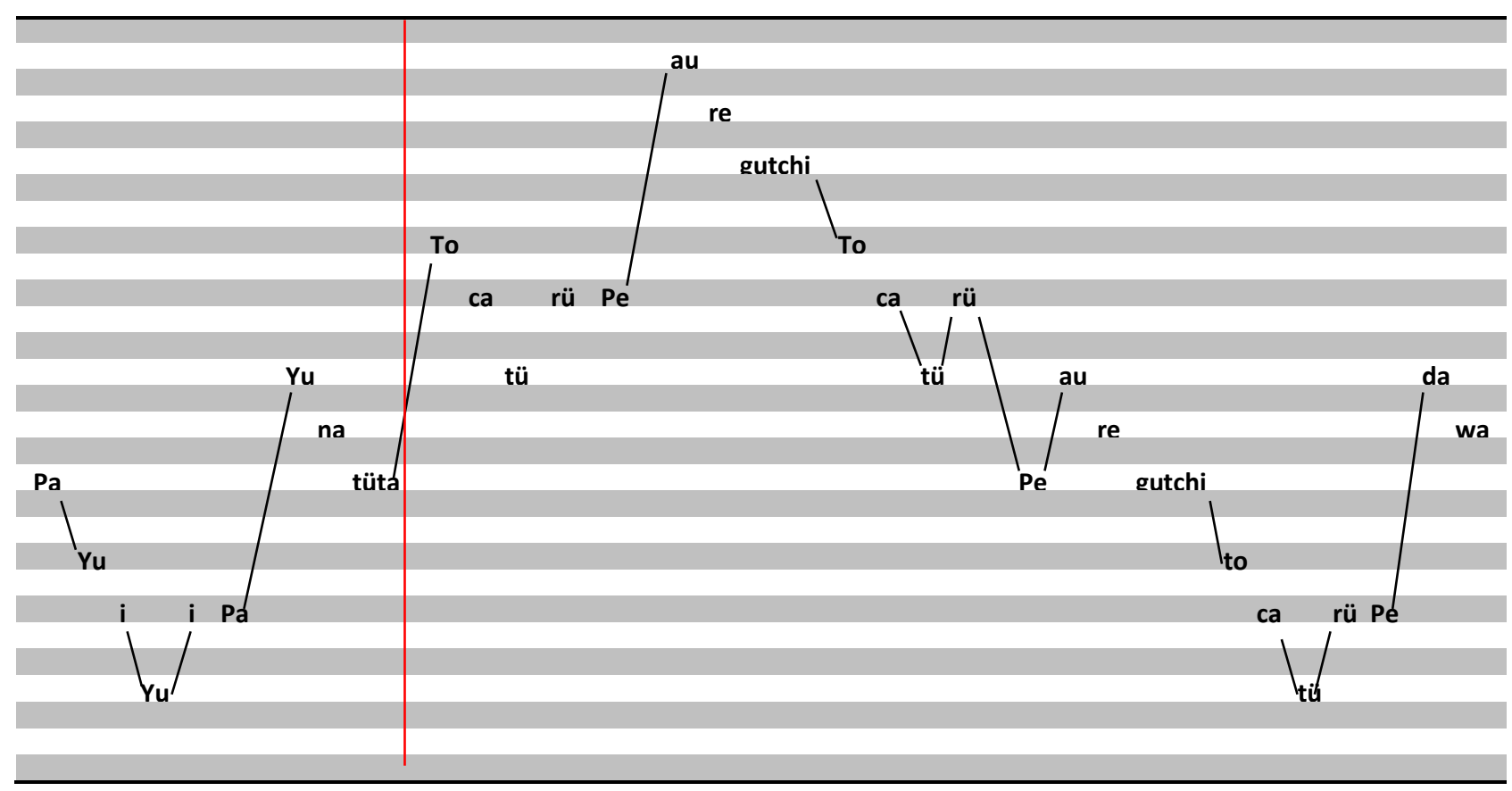

Mortais,mortais.

Se vocês tivessem jejuado para nós. "Vocês veriam a gente"

Muitos mortais

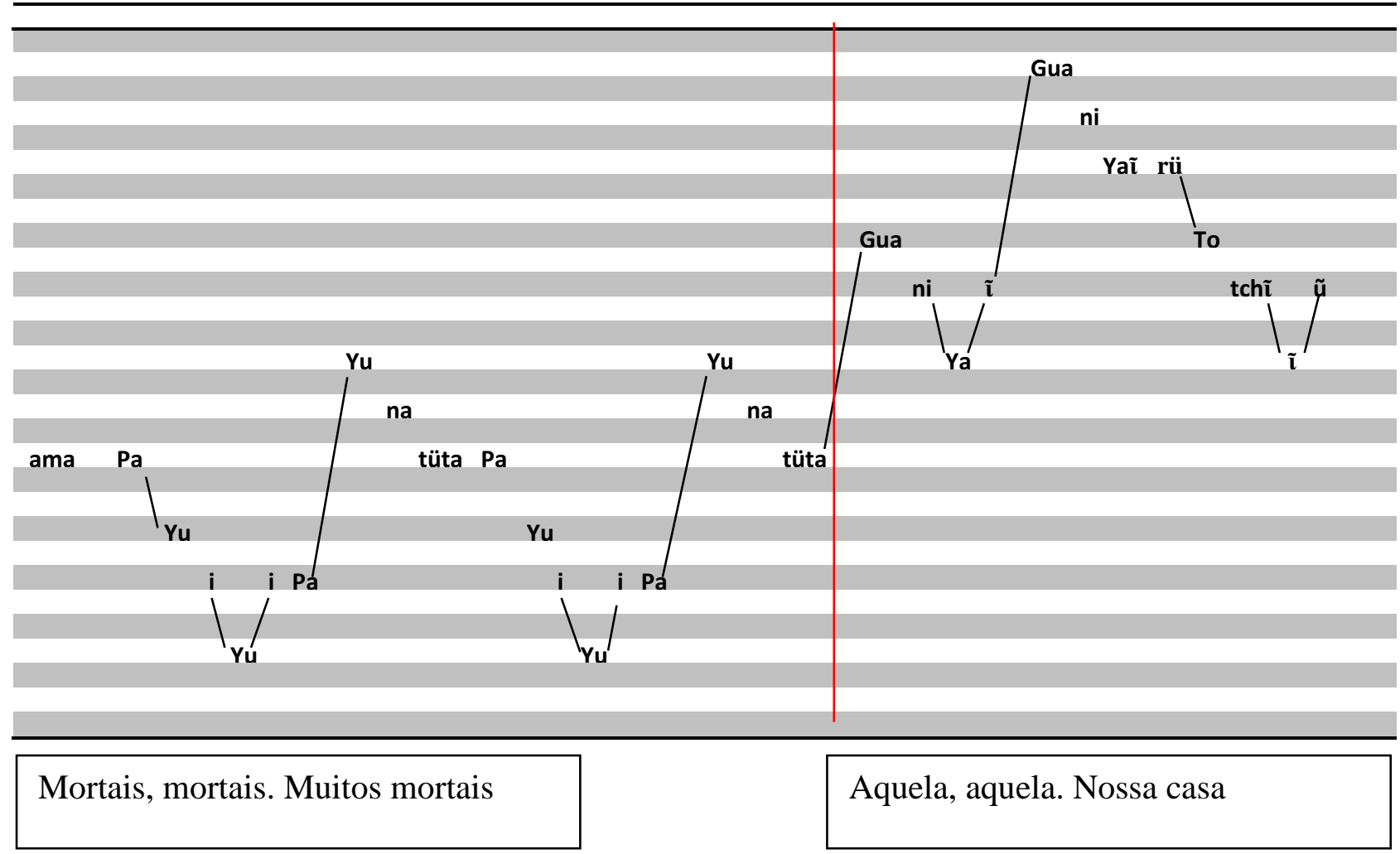




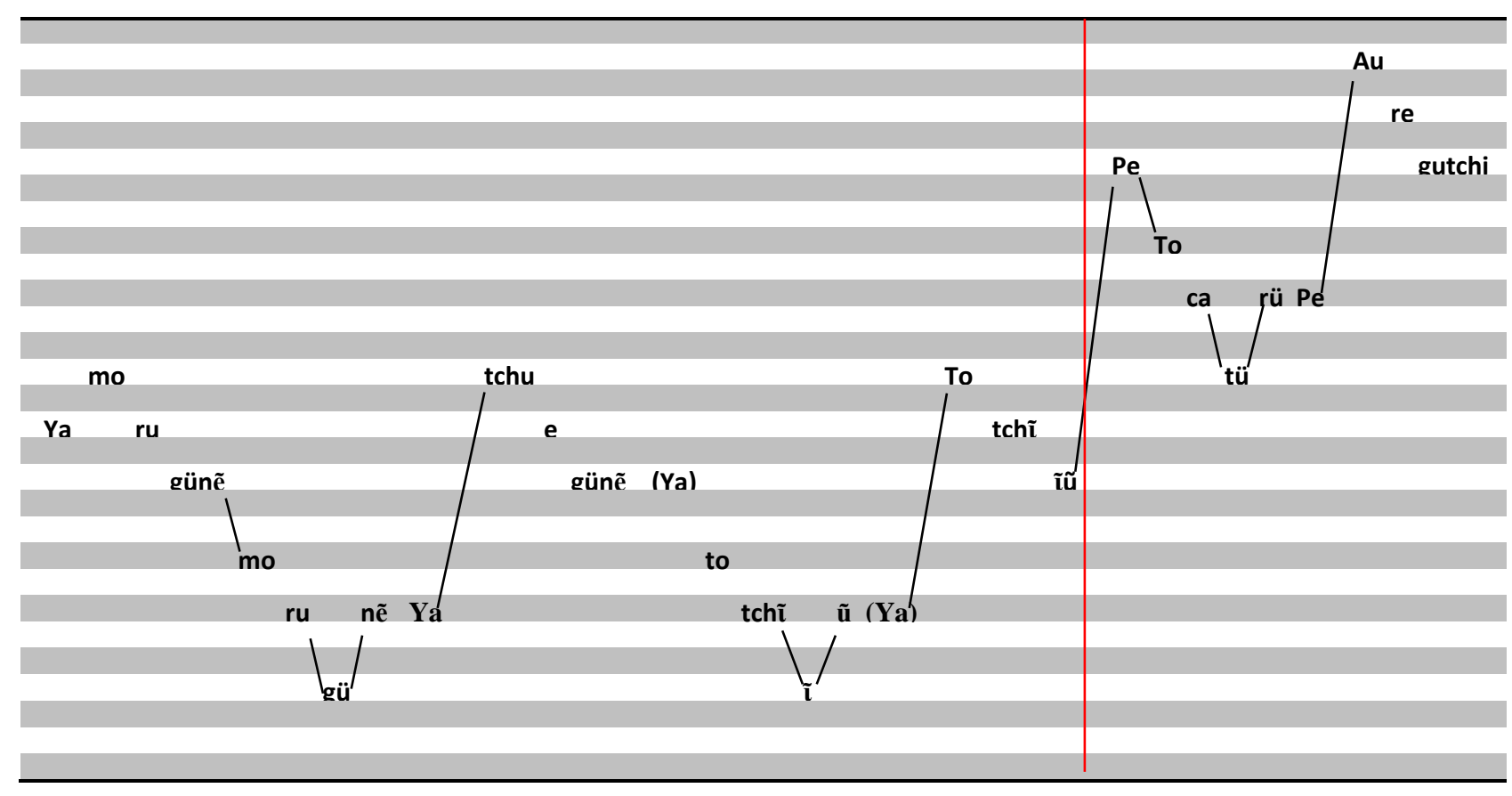

Morugünẽ [Nome da casa dos ü'üne, onde Yoi morava e fazia festa com To'oena, a moça que ele matou. "A casa vira no ar e some" (Este é o sobrenome da casa)]. Nossa casa (2X)

"Se vocês tivessem jejuado para nós"

$$
\text { (Esté o sobrenome da casa) Nossa casa (2X) }
$$

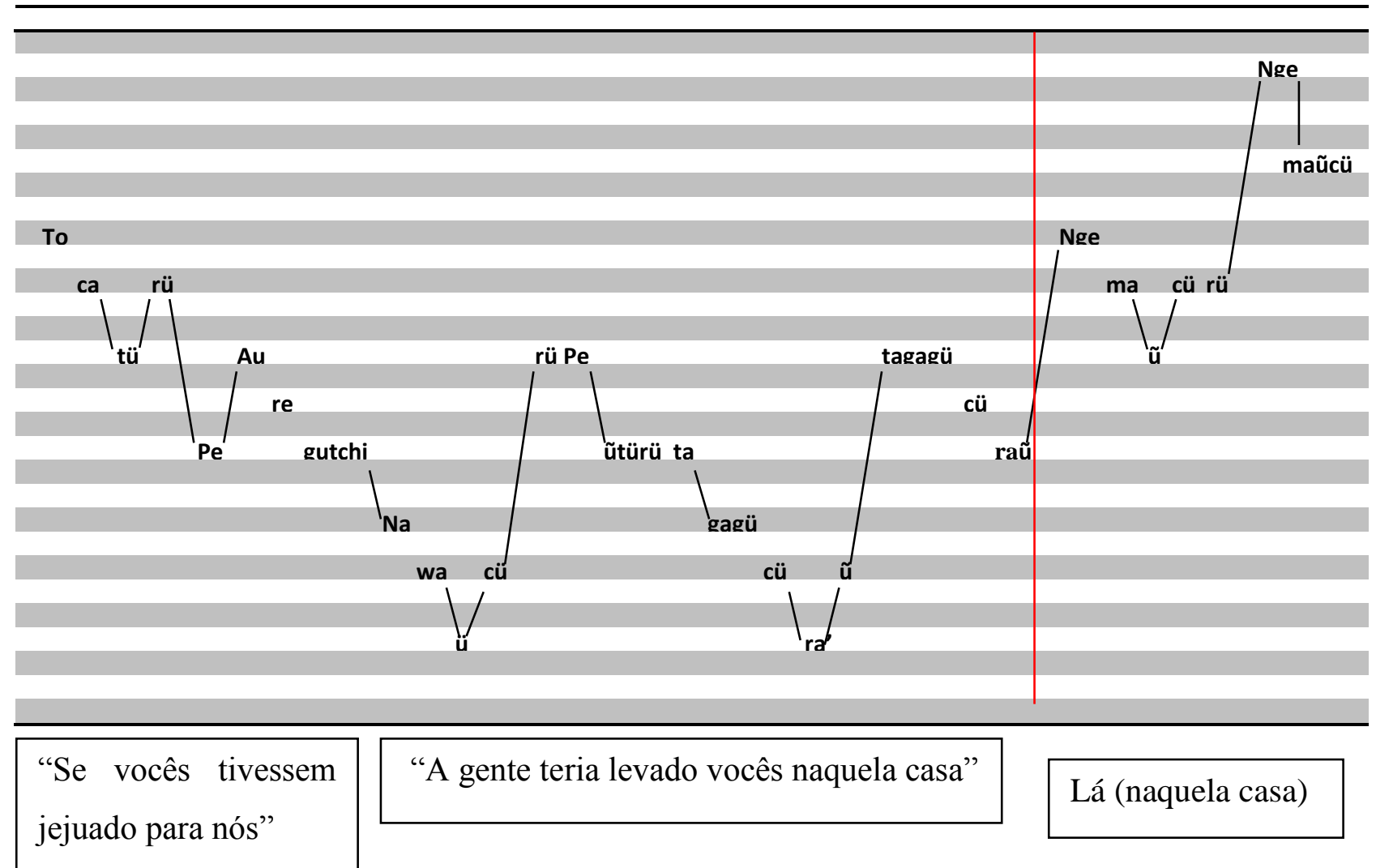




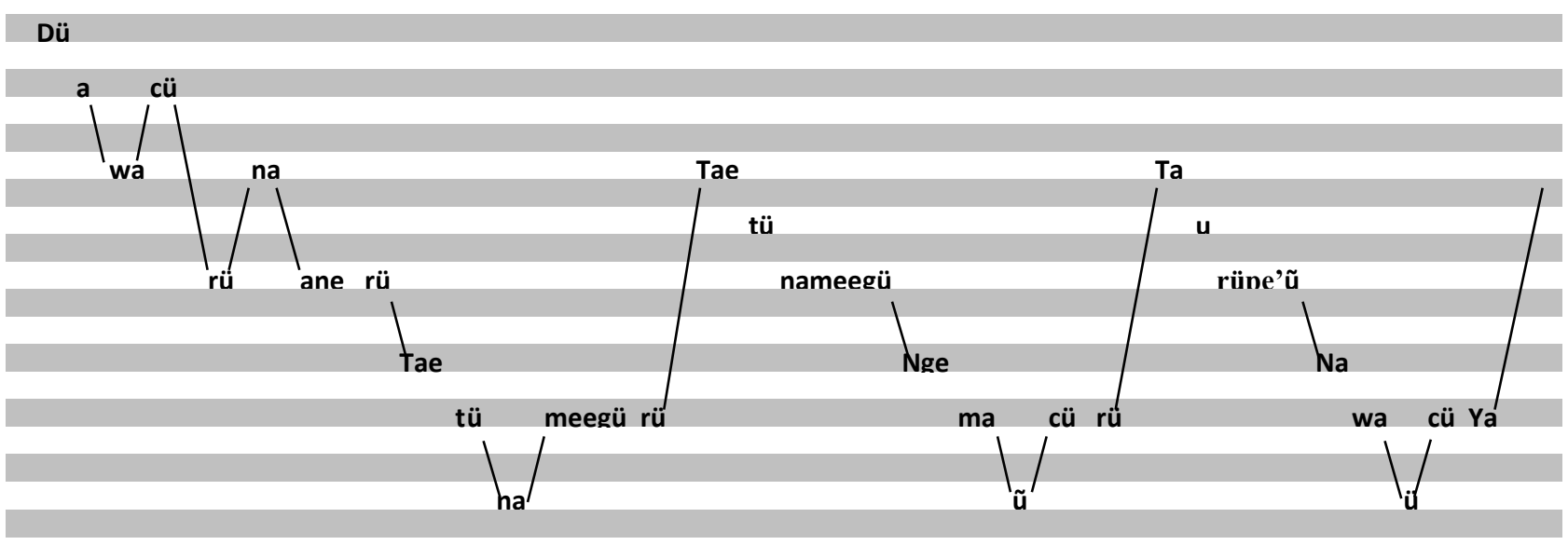

"Pode ser que acabe o mundo, naquela casa vocês se salvarão (salvariam?)"

Lá (naquela casa). Não vai acontecer nada com vocês, nunca vão morrer

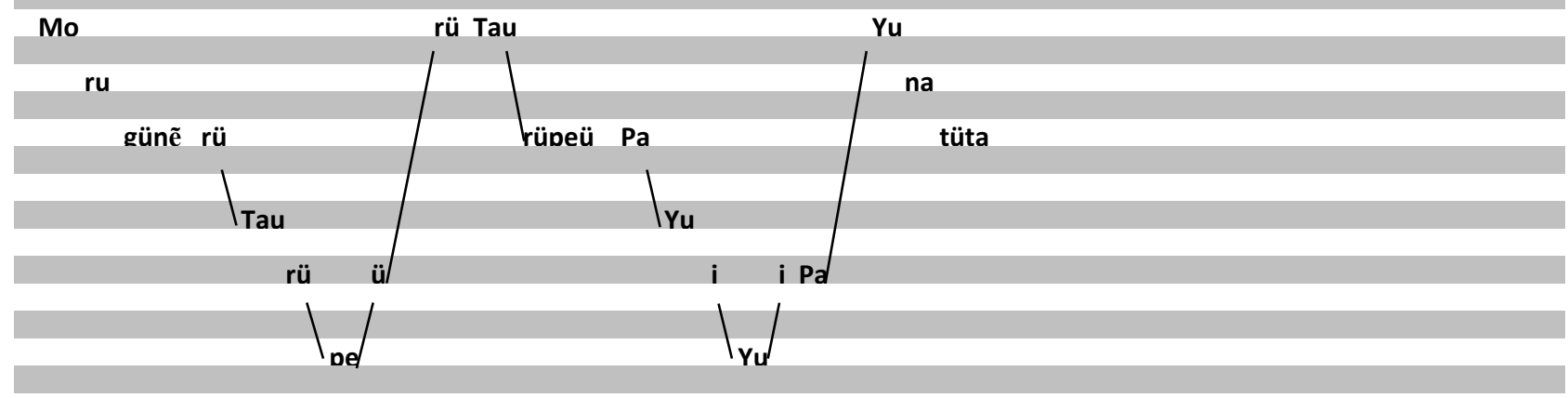

\begin{tabular}{|c|c|c|}
\hline $\begin{array}{l}\text { Lá na casa } \\
\text { Morugünẽ }\end{array}$ & $\begin{array}{l}\text { Não vai acontecer } \\
\text { nada com vocês, }\end{array}$ & $\begin{array}{l}\text { Mortais, mortais. } \\
\text { Muitos mortais }\end{array}$ \\
\hline & nunca vão morrer & \\
\hline
\end{tabular}

